Universidade de São Paulo

Escola de Comunicação e Artes

Maria Cecilia Costacurta de Sá Porto

"À sombra das cerejeiras tropicais"

O projeto comunicacional do Bunkyo e a construção

da narrativa nipo-brasileira

São Paulo

2018 


\author{
Universidade de São Paulo \\ Escola de Comunicação e Artes
}

Maria Cecilia Costacurta de Sá Porto

\title{
"À sombra das cerejeiras tropicais" \\ O projeto comunicacional do Bunkyo e a construção \\ da narrativa nipo-brasileira
}

Tese apresentada ao Programa de PósGraduação em Ciências da Comunicação, Área de Concentração: Teoria e Pesquisa em Comunicação, Linha de Pesquisa Epistemologia, Teoria e Metodologia da Comunicação, da Escola de Comunicação e Artes da Universidade de São Paulo, como exigência para a obtenção do Título de Doutora em Ciências da Comunicação.

Orientação: Profa. Dra. Maria Immacolata Vassallo de Lopes. 


\section{Maria Cecilia Costacurta de Sá Porto}

"À sombra das cerejeiras tropicais": o projeto comunicacional do Bunkyo e a construção da narrativa nipo-brasileira

\section{Banca examinadora}

\section{Presidente:}

Profa. Dra. Maria Immacolata Vassallo de Lopes

\section{Membros:}

Prof. Dr. Eugênio Bucci

Profa. Dra. Roseli Aparecida Fígaro Paulino

Profa. Dra. Shirlei Lica Ishisato Hashimoto

Profa. Dra. Madalena Natsuko Hashimoto Cordaro

Profa. Dra. Célia Sakurai

São Paulo, de de 2018 


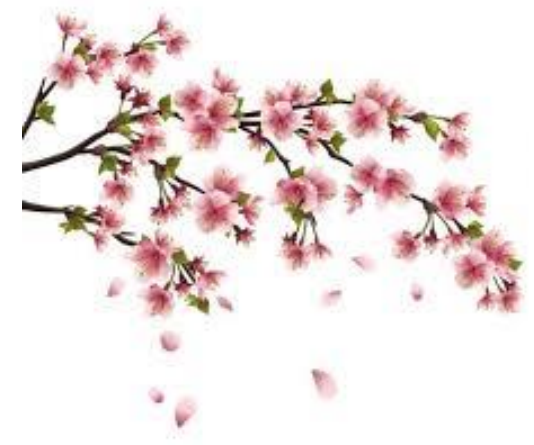

“Quantas memórias Me trazem à mente

Cerejeiras em flor"

(Bashô) 
Dedico este trabalho ao meu pai José de Sá Porto, in memoriam, e à minha mãe Maria Alice Balbar, exemplos de amor e trabalho. 


\section{Agradecimentos}

Agradeço a minha orientadora Maria Immacolata Vassalo de Lopes por te me dado esta oportunidade, por ter cedido generosamente o seu precioso tempo, por me ensinar os caminhos da disciplina e do método, por ter dividido comigo suas ideias inteligentes e seu conhecimento impressionante, e pelo exemplo de vida, de mulher forte e realizadora.

Agradeço a minha família pelo apoio e amor incondicional apesar da minha constante ausência: minha mãe Alice, meus irmãos Eliana, Paulo e Patrícia, meus filhos Lavinia, Natalia e Daniel, meus amados "necos" Ana Lívia, João Pedro, Beatriz e Manuela, meus genros André e Aldo e nora Chloe. Agradeço o carinho das minhas filhinhas caninas Satie, Milou e Fulô, cuja beleza e doçura inspiraram a minha vida de todas as formas e proporcionaram um ambiente de paz e alegria para que pudesse escrever esta tese, apesar de terem partido tão prematuramente. E também o Sammy, meu querido e corajoso sobrevivente.

Agradeço os meus amigos pelo incentivo e paciência exemplar, principalmente as amigas queridas Kátia e Beth, que com resignação amorosa "vêm tecendo os tapetes, desmanchando-os e começando tudo de novo, infinitas vezes". Agradeço o professor Rogério Dezem pelas explicações didáticas e interessantes, pelas sugestões de leitura, pelas aulas inesquecíveis, mesmo vivendo do outro lado do planeta.

Agradeço o pessoal do Bunkyo pelo acolhimento carinhoso e pelos inúmeros favores, especialmente a Célia Oi, Kênia Gomes e Eduardo Goo Nakashima. Agradeço ainda os meus professores e colegas da ECA e da FFLCH por tudo o que aprendi nestes anos. Agradeço também a minha Sensee, Maria Massae Makuta, pela assessoria linguística e cultural e pela amizade.

Agradeço a minha amiga Célia, mestra, provedora de lanternas, mapas e bússolas, de livros preciosos e de palavras secretas que abrem até as paredes de pedra. Sem você, esta tese não teria acontecido.

E agradeço especialmente ao Carlos Eduardo, amigo, mestre e amoroso companheiro. 


\section{Resumo:}

O objetivo desta pesquisa é demonstrar que as identidades coletivas são um fenômeno performático em constante redefinição e rearticulação (BUTLER, 1990), cujas dimensões simbólicas são construídas no espaço-chave da Comunicação (LOPES, 2004). Estes processos envolvem falas, textos, espaços, montagens e performances que renovam as narrativas delineadoras de "comunidades imaginadas" (ANDERSON, 2011). Como objetivo específico, a pesquisa focalizou a relação entre o projeto comunicacional do Bunkyo (Sociedade Brasileira de Cultura Japonesa e Assistência Social) - fundado em 1955 no bairro da Liberdade, na cidade de São Paulo - e a construção de uma visão da identidade e da comunidade nipo-brasileira, como resultado dos esforços da entidade em cumprir a missão atribuída a si mesma de representar os imigrantes japoneses e seus descendentes, e de preservar o seu legado no Brasil. Buscando autoridade institucional nos elos com o governo e a família imperial do Japão, e legitimidade moral no "dever" e no "direito" de administrar a memória dos ancestrais, o Bunkyo exerce uma "política de identidade" com base na "verdade da tradição" e nas "raízes da história" (RONSINI e OLIVEIRA, 2007). O projeto comunicacional analisado se constitui em um vasto aparato de mídia impressa, audiovisual e online, presença em redes sociais e a promoção de eventos, celebrações e festividades em que se falam e dramatizam questões referentes ao universo social, cultural, político, religioso e memorial da comunidade nipo-brasileira, abrangendo um arco de tempo que inclui aspectos da vida destes indivíduos no presente, suas referências do passado e perspectivas para o futuro. Pela natureza do objeto analisado, o quadro teórico abrange autores de várias disciplinas, o que implica entender a comunicação como área de convergência entre diversos saberes sociais, "sem negar a especificidade do campo da comunicação" (LOPES, 2009). Assim, são utilizados recursos teóricos como os aspectos performáticos e discursivos da identidade em Butler (1990), Canclini (1997) e Hall (1995), a memória como "tradição seletiva" em Williams (1979) e como "elo vivido no eterno presente" em Nora (1993). Quanto ao aspecto metodológico, a análise de narrativa é fundamentada em leituras de Bruner (2001), Ricoeur (1980) e Motta (2005), entre outros. Apesar das grandes transformações por que têm passado o Brasil e o Japão - as duas referências da comunidade nipo-brasileira - e do impacto da hibridização sobre as culturas nacionais (CANCLINI, 2012), a amplitude e o vigor do projeto comunicacional do Bunkyo revelam que a percepção da distinção cultural e o desejo de mantê-la permanecem, inspirando um tipo de militância identitária e memorial que mobiliza energia e recursos em favor da criação de territórios físicos e virtuais onde a socialização e as trocas simbólicas podem ocorrer.

Palavras-chave: comunicação; identidade; memória; narrativa; comunidade nipobrasileira. 


\section{Abstract}

The aim of this research is to demonstrate that collective identities are a performative phenomenon in constant redefinition and re-articulation (BUTLER, 1990), whose symbolic dimensions are constructed in the key-space of communication (LOPES, 2004). These processes involve speeches, texts, spaces, stage settings and performances which renovate the delineating narratives of "imagined communities" (ANDERSON, 2011). As an specific aim, this research focused on the relationship between the communication project of Bunkyo (Brazilian Society of Japanese Culture and Social Welfare) - founded in 1955 in the Liberdade district, in São Paulo city - and the construction of a Japanese-Brazilian identity and community, as the result of its efforts of fulfilling the mission (given by and to itself) of representing the Japanese immigrants and their descendants, and to preserve their cultural legacy in Brazil. Searching for institutional authority in its bonds with the Japanese government and imperial family, and for moral legitimacy in its "duty" and "right" to control their ancestors' memory, Bunkyo carries out a "politics of identity" based on the "truth of tradition" and on the "history's roots" (RONSINI and OLIVEIRA, 2007). The communication project analyzed here consists of a vast apparatus with print, internet and audiovisual media, the Bunkyo's presence in the social media, and its constant promotion of festivities, celebrations and events where aspects of the social, cultural, religious, political and memorial universe of the Japanese-Brazilian community are spoken and dramatized, embracing an arch of time that encompasses the individuals' lives in the present, their references in the past, and perspectives for their future. Taking into account the nature of the object of this analysis, the theoretical framework used here is comprised of authors from many disciplines, which implies understanding communication as a field of convergence of many social knowledges, "without denying the specificity of the communication field" (LOPES, 2009). Hence, theoretical resources such as discursive and performative aspects of identity in Butler (1990), Canclini (1997) and Hall (1995); memory as "selective tradition" in Williams (1979) and as "the living bond with the eternal present" in Nora (1993) were used, among others. As for the methodological approach, the narrative analysis used here was founded on authors such as Bruner (2001), Ricoeur (1980) and Motta (2005). In spite of the great transformations that Brazil and Japan had been through, and the impact of hybridization on national cultures (CANCLINI, 2012), the vastness and vigor of Bunkyo's communication project reveal that its perception of cultural distinctness and its desire to maintain it still persist, inspiring some kind of memorial and identity's militancy that mobilizes energy and resources for the creation of physical and virtual territories where socialization and symbolic exchanges can happen.

Key words: communication; identity; memory; narrative; Japanese-Brazilian community 


\section{Sumário}

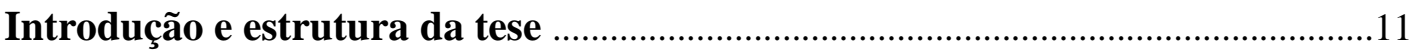

Capítulo 1 - Considerações teóricas, epistemológicas e metodológicas ……………...... 18

1. Apresentação do problema de pesquisa .............................................................18

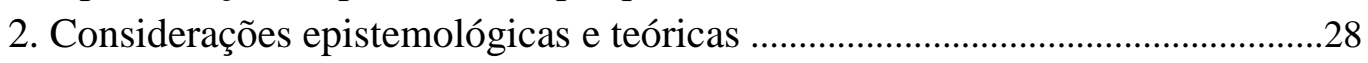

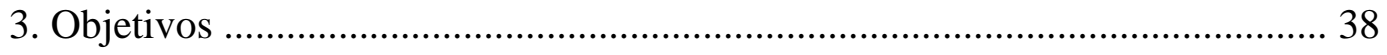

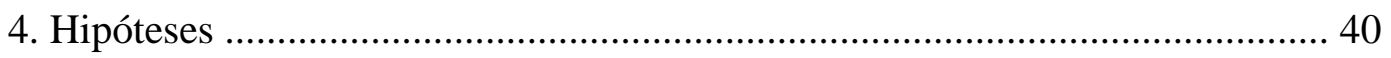

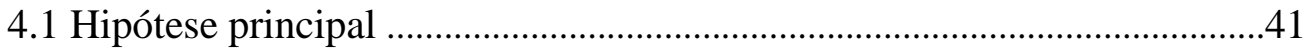

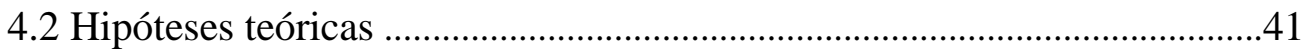

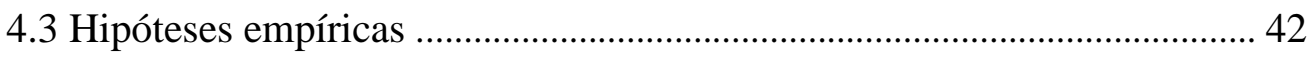

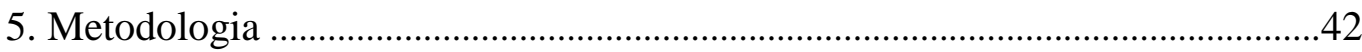

5.1 Apresentação das técnicas de coleta e descrição.......................................... 44

5.2 Apresentação da análise de narrativa.....................................................50

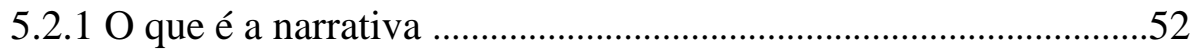

5.2.2 A interpretação da narrativa.........................................................55

5.2.3 A aplicação da análise narrativa................................................58

Capítulo 2 - O Japão e os japoneses do Brasil .........................................................63

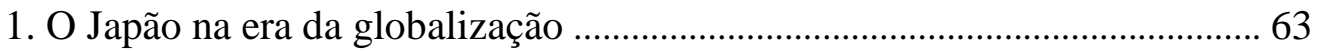

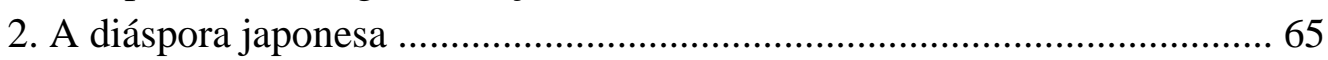

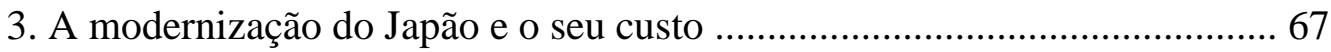

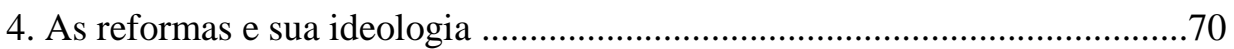

5. O “caráter japonês” e a emigração .........................................................73

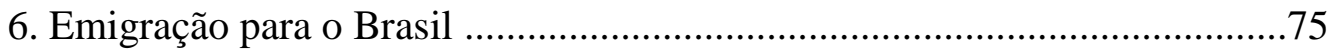

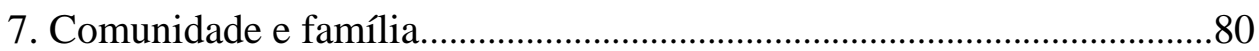

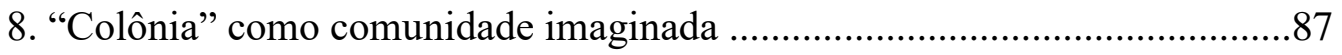

9. Assimilação e sobrevivência da "colônia" .................................................. 100

10. O Japão pop e as novas referências identitárias ........................................106

11. Mídia étnica e a coesão da comunidade.................................................. 109

Capítulo 3 - Bunkyo: histórico, missão, estrutura e funcionamento .................... 126

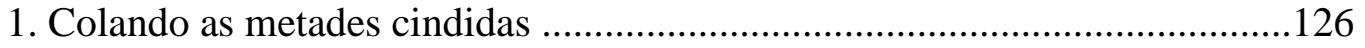

1.1 A consolidação da entidade ......................................................138

1.2 A crise e a comissão de renovação ..................................................164

2. Estrutura e funcionamento da entidade ..........................................................184

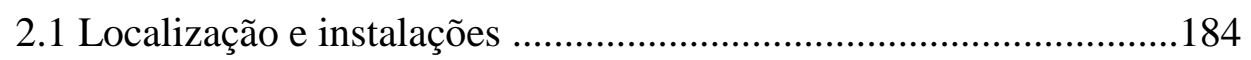

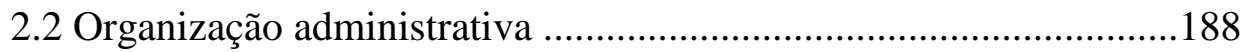

2.3 As comissões e a missão do Bunkyo .............................................191

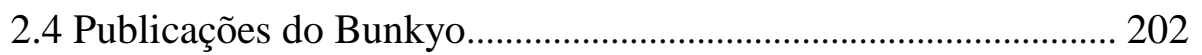

2.5 A mídia do Bunkyo ....................................................................... 206

2.5.1 A página do Bunkyo na Internet .................................. 206

2.5.2 Revistas e boletins ...................................................... 212 
Capítulo 4 - O Bunkyo e as narrativas da imigração japonesa e da comunidade

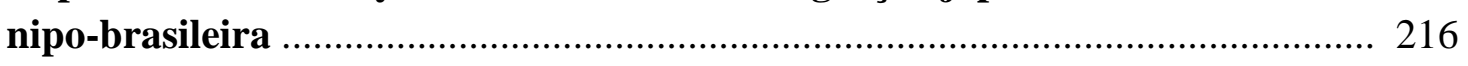

1. Primeiro cenário narrativo: o cenário discursivo-performático do IX FIB ......... 216

1.1. Pioneiros e "virtudes japonesas" ............................................ 219

$1.2 \mathrm{Na}$ "linha de frente" .............................................................. 227

1.3 A narrativa da integração e da renovação ................................... 242

2. Segundo cenário narrativo: o cenário espacial-visual do edifício-sede ............... 250

2.1 Bunkyo: lugar de memória ........................................................ 252

$2.2 \mathrm{O}$ que dizem os espaços, imagens e objetos ............................... 256

2.3 Festas e celebrações como dramas e ritualizações ..........................261

$2.4 \mathrm{O}$ poder evocativo do museu .................................................. 264

2.4.1 Um catálogo onde se visualizam as narrativas ..........................268

2.5 Um itinerário com cinema e leituras........................................... 271

2.6 As narrativas do espaço e da cultura material ............................. 274

3. Terceiro cenário narrativo: o discurso midiático na Internet .................................. 280

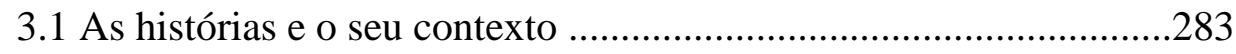

3.1.1 O cônsul Nakamae ........................................................286

3.1.2 Gueinosai: a arte de palco ...........................................288

3.1.3 Junho, tempo de lembrar ............................................291

3.1.4 Condecorados da primavera ......................................... 300

3.2 A mídia digital do Bunkyo e a narrativa nipo-brasileira ............... 304

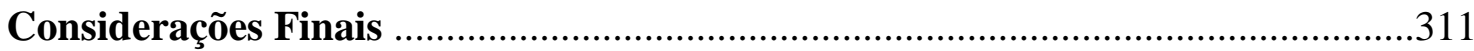

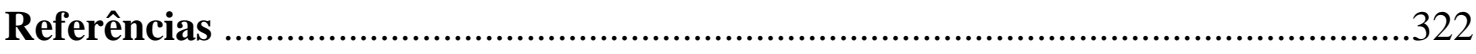

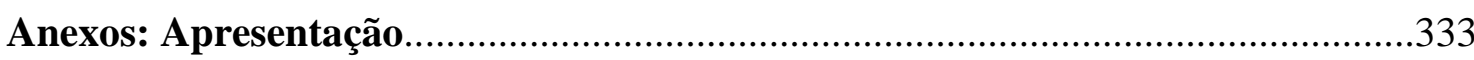

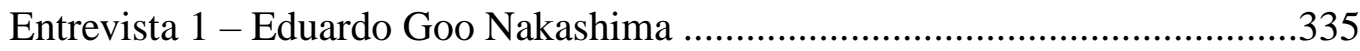

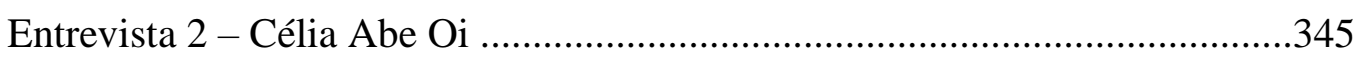

Entrevista 3 - Masato Ninomiya _......................................................................353

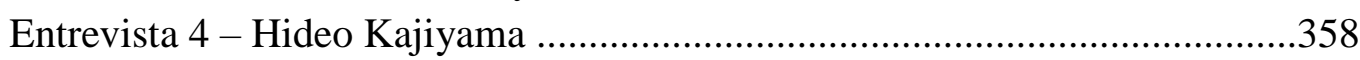

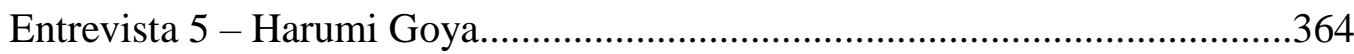




\title{
INTRODUÇÃO
}

\author{
"Porque é afetiva e mágica, a memória não se acomoda a \\ detalhes que a confortam; ela se alimenta de lembranças \\ vagas, telescópicas, globais ou flutuantes, particulares ou \\ simbólicas, sensivel a todas as transferências, cenas, \\ censura ou projeções" (NORA, 1993, p.9).
}

Ao buscar textos sobre a memória, em uma primeira fase de exploração dos temas que me levaram de volta aos bancos da universidade, eu mesma me vi perdida em lembranças vagas e flutuantes, pontuadas por cenas e visões que ora expunham faces familiares, ora desapareciam sem deixar vestígios. Certo dia consegui agarrar uma destas imagens da memória antes que ela fugisse novamente, e logo a reconheci: era o rosto simpático do professor Egon Schaden, meu querido mestre por dois semestres na ECA, no início da década de 1980.

Por que sua imagem me aparecia naquele momento, sem que eu tivesse evocado qualquer pensamento sobre aqueles anos? Embora aparentemente isso não tivesse nada a ver, lembrei que Schaden tinha um dom peculiar, que assim como sua impressionante inteligência, saltava aos olhos: ele transferia aos interlocutores seu enorme entusiasmo pela Antropologia. Impossível não se apaixonar perdidamente pela Antropologia quando era Schaden quem falava em seu nome. Eu iniciava o meu Mestrado em Ciências da Comunicação - depois de me formar em Jornalismo e exercer por uns anos a profissão - então aquele súbito fascínio pela Antropologia foi um tanto perturbador. Achei que não sabia o que queria, ou ainda pior, que estava sendo desleal para com a área da minha própria formação e escolha, a Comunicação.

Até que ele próprio nos apresentou um de seus textos, datilografado, intitulado "Antropologia da Comunicação", um trabalho no qual exercitava outro de seus dons: o de observar (ou promover) o encontro entre áreas e abordagens separadas, mas afins. Assim, me senti mais confiante: apaixonar-me pela Antropologia não significava que minha paixão pela Comunicação se havia evaporado. Esse pequeno artigo foi a primeira experiência de descoberta da minha afinidade com os estudos interdisciplinares. As análises comparativas de Schaden também celebravam este contato entre objetos cujos pontos em comum tinham muito a revelar sobre cada um deles. Um destes estudos, particularmente, me veio à memória enquanto me lembrava do mestre: sua comparação 
entre imigrantes alemães e japoneses ${ }^{1}$, que inspirou um de meus artigos jornalísticos sobre a presença japonesa em Santos, minha cidade natal.

Os anos se passaram e, levada por dificuldades intransponíveis naquele momento, acabei por deixar o Mestrado na ECA pouco antes de conclui-lo. Mudei-me para os Estados Unidos onde retomei o Mestrado, desta vez na área da Antropologia Cultural. Mas o tema de minha pesquisa foi "identidade e usos da língua materna" entre imigrantes brasileiros no país. Estava aí o tripé que me acompanharia ao Doutorado (comunicação, identidade e imigração). Sem que eu me desse conta, o mestre continuava a me apontar o caminho. Novos desvios me aguardavam na volta ao Brasil, e mais uma vez os planos de pesquisa acadêmica tiveram que esperar. Mas enquanto isto, as leituras e as reflexões prosseguiam, conspirando para que meu tema um dia se delineasse dentro daquele tripé organizador. No nível da consciência, só sabia que meu interesse pelos estudos da Comunicação cresciam cada vez mais, principalmente onde se encontravam com as reflexões sobre a memória - que parecem vicejar na França mais que em outros lugares, a julgar pelo trio de virtuosos que dominam o tema, Halbwachs, Nora e Ricoeur - e a identidade.

Um novo encontro foi o fator detonador dos projetos acadêmicos que, enfim, foram retomados. Um colega de trabalho, o historiador Rogério Dezem, especialista e apaixonado pela cultura japonesa, me ajudou a redescobrir os filmes de Ozu, Mizoguchi e Kurosawa, em conversas sem fim sobre este e outros temas correlatos. A partir daí, a aproximação foi muito rápida: fui fazer aulas de japonês e passei a frequentar uma entidade que promovia eventos interessantes de cultura japonesa, o Bunkyo. As conversas com Dezem e as novas experiências me levaram a pensar não mais no Japão, mas nos japoneses do Brasil, e assim consegui esboçar um rascunho do que viria a ser o meu projeto de tese sobre "a mídia do Bunkyo e a narrativa da comunidade nipobrasileira”. Mas ao levá-lo à professora Maria Immacolata Vassallo de Lopes - que mais tarde me aceitaria como sua orientanda - fui surpreendida por uma pergunta que me jogou novamente no labirinto das memórias longínquas. Ela me perguntou: "Por que você quer estudar a comunidade nipo-brasileira? Você tem parentes japoneses? Já se perguntou o que está por trás da sua motivação?”

\footnotetext{
${ }^{1}$ SCHADEN, E. Imigrantes alemães e japoneses: uma visão comparativa. In: SAITO, H. (ed.) A presença japonesa no Brasil. São Paulo: T.A.Queiroz/Edusp, 1980
} 
Ela esclareceu que esta era uma pergunta metodológica, pois a presença do pesquisador no campo nunca é neutra e exige reflexividade contínua, sempre fundamentada nas teorias que dão respaldo à pesquisa como um todo. Ao me confrontar com a questão do pertencimento, já que iria estudar uma comunidade da qual não faço parte, a pergunta da Immacolata me fez recuar longe no tempo, até encontrar o que Nora chama de imagens telescópicas, pois quase não as vemos a olho nu, de tão distantes. Se é que existe uma "arqueologia da memória", esta foi uma experiência do tipo. De repente, revi o Japão das folhinhas penduradas na parede da lavanderia que pertencia a uma família de "japoneses" nascidos na minha cidade, que eu visitava constantemente quando criança; vi de novo as cenas de um filme que adorei, "Casa de chá luar de agosto", cujo personagem principal era um "japonês" que se chamava, na vida real, Marlon Brando; vi o desenho divertido de Urashima Tarô, no jingle da Varig que celebrava, na TV, a inauguração do voo Brasil-Japão, cuja letra e melodia memorizei rapidamente e até hoje sei de cor; trouxe de volta o rosto belo e triste de Josui que imaginei, ao ler, na adolescência, "A Flor Oculta", romance de Pearl Buck sobre o amor impossível entre uma japonesa e um americano no Japão pós-guerra.

Tanto o Japão como os japoneses que eu conheci pela mídia ou por contatos diretos, na minha infância e juventude, tinham esse ar de familiaridade e mistério, de coisa genuína e estereótipo, e de beleza singular e "híbrida" - conceito que muito mais tarde viria me ajudar a entender estas misturas e os processos que as engendram no mundo globalizado em que vivemos hoje. E cheguei à conclusão de que embora seja verdade que eu não pertenço ao mundo nipo-brasileiro, por não ter ascendência japonesa, ele, de certa forma, me pertence, por fazer parte das minhas memórias afetivas da infância. Não me tornei menos gaijin ${ }^{2}$ por causa disso, nem minhas dificuldades foram menores durante a pesquisa de campo, conforme explico no Capítulo 1. Mas este primeiro passo na "reflexividade metodológica" que um pesquisador deve realizar, antes de entrar em campo, me colocou em uma posição mais consciente sobre os limites e as potencialidades da afetividade e do desejo de conhecer que estão por trás de toda motivação, inclusive a acadêmica.

Passo agora a expor a estrutura da pesquisa de doutorado.

\footnotetext{
${ }^{2}$ Como os japoneses chamam os não japoneses, conforme será explicado em mais detalhes no capítulo
} 1. 


\section{Estrutura da tese}

A tese está dividida em quatro capítulos com subdivisões internas.

O capítulo 1, intitulado "Considerações teóricas, epistemológicas e metodológicas", faz uma apresentação do problema de pesquisa, que definiu como questão principal a seguinte indagação: existe uma relação constitutiva entre o projeto comunicacional do Bunkyo e a definição de uma determinada visão do que venha a ser a identidade nipo-brasileira, ou seja, os contornos da comunidade e seu "verdadeiro" legado cultural? A partir daí, apresento os primeiros passos e as etapas seguintes da elaboração de um quadro teórico que fundamenta os principais conceitos utilizados na pesquisa e os caminhos da reflexão desenvolvida nos capítulos seguintes até as considerações finais. A abordagem epistemológica adotada na tese define a Comunicação como área de convergência entre várias disciplinas das Ciências Sociais, devido à multidimensionalidade dos seus objetos de estudo, mas sem perder a especificidade do campo comunicacional. Esta abordagem também reflete sobre o papel central das Ciências da Comunicação na compreensão das novas configurações socioculturais dos mundos contemporâneos.

Neste primeiro capítulo desenvolvo também os objetivos teóricos e práticos da tese, os gerais e os específicos. Discuto em seguida as funções das hipóteses e seu papel organizador e norteador da pesquisa. As hipóteses são então apresentadas a partir de uma principal, sendo duas teóricas e duas empíricas. A metodologia da pesquisa usada neste trabalho é apresentada em seguida, desde a formulação do objeto, até as técnicas de coleta, descrição e interpretação. Uma extensa reflexão sobre a análise de narrativa finaliza este capítulo, apresentando os autores e os métodos utilizados para a análise de todo o material coletado, teórico e empírico, e a verificação das hipóteses.

O capítulo 2, intitulado “O Japão e os japoneses do Brasil”, tem por objetivo apresentar o contexto histórico e cultural em que o objeto da tese está localizado. Inicia com uma reflexão sobre a diáspora japonesa e a conjuntura de grandes transformações desencadeadas na Ásia pela presença das potências ocidentais. No Japão, esta presença foi marcada pela exibição da força militar dos Estados Unidos, que Kitahara (1986) descreve como um ato típico da "dramaturgia do poder", ou seja, com a utilização, pela potência hegemônica, de signos e performances de grande visibilidade que induzem à intimidação sem necessidade de qualquer ameaça explícita. 
A partir de autores como Adachi (2006) e Hall (2016), o texto apresenta uma discussão em torno da utilização do conceito de "diáspora" e de sua eficácia na descrição de situações de deslocamento de populações em contextos históricos e culturais muito diversos. Neste capítulo, apresento também uma discussão sobre a construção e desenvolvimento de uma ideologia do "espírito japonês", disseminada entre a população e que repercutiu inclusive entre os emigrantes, encorajados a verem a si próprios como os "pequenos embaixadores do Japão" (DEZEM, 2005).

Esse capítulo discute também as desventuras dos primeiros imigrantes no Brasil, devido às más condições de vida e de trabalho, e o empenho do governo japonês em melhorar estas condições com a criação de uma estrutura de participação direta que Sakurai (1998) descreve em seu estudo sobre a "imigração tutelada". Em seguida, são discutidas as formas de organização social dos japoneses no Brasil através de comunidades que Handa (1987) chamava de "sociedades igualitárias" pelo nivelamento das diferenças de classe e predomínio das relações de solidariedade. Entre os fatores organizadores destas comunidades estão a etnicidade - discutida no contexto da imigração japonesa por Maeyama (1979), e como produto do contato interétnico por Oliveira (2003) - e o parentesco, baseado na estrutura do Ie (família tradicional japonesa), reproduzido no Brasil apesar de muitas adaptações impostas pelas condições locais.

O capítulo segue apresentando a noção de colônia japonesa desenvolvida por Wawzyniac (2008) que a considera não um território ou espaço físico de contornos delimitados, mas sim uma forma de representação simbólica fundada em redes de comunicação interna e em rotas de solidariedade. A transformação das colônias fechadas em comunidades abertas para a sociedade mais ampla; a mudança para as cidades e a reinvenção das redes e rotas de comunicação e solidariedade; o contato com as novas referências culturais do Japão moderno, e o papel da mídia nikkei na preservação e na atualização da comunidade são os demais assuntos abordados neste capítulo.

O capítulo 3, intitulado "Bunkyo: histórico, missão, estrutura e funcionamento" tem por objetivo apresentar em detalhes a entidade que foi objeto de análise desta tese, desde as circunstâncias anteriores à sua fundação até as que levaram à sua criação, e os rumos que a entidade foi tomando com a passagem do tempo. Mostra como o fim da guerra e os esforços de superação dos graves problemas econômicos 
decorrentes dela levaram o Japão a investir diplomaticamente nos países onde vivia um grande número de cidadãos japoneses, o que beneficiou direta e indiretamente os planos do Bunkyo de constituir-se na entidade representativa central dos imigrantes e seus descendentes no Brasil, o que pode ser ilustrado pela presença no país do príncipe Mikasa - em visita de grande importância simbólica - na cerimônia de lançamento da pedra fundamental do edifício-sede do Bunkyo, em 1958.

Neste capítulo também é discutida a fundação dos primeiros órgãos de comunicação do Bunkyo, que tinham por objetivo divulgar as notícias e os debates em torno de assuntos "referentes à comunidade", o que já demonstra a existência, desde o início, de um projeto comunicacional voltado a um público imaginado e que ao mesmo tempo delimitava o perfil do seu representado. Discute ainda o crescimento e a expansão da entidade, e a criação do Museu Histórico da Imigração Japonesa, em 1978, o ponto alto da realização da sua missão de "preservar o legado" dos ancestrais, alçando o Bunkyo à condição de "lugar de memória" da comunidade nipo-brasileira.

No capítulo 4, intitulado O Bunkyo e as narrativas da imigração japonesa e da comunidade nipo-brasileira, realizo a análise de narrativa, em três cenários, do corpus selecionado de modo a explorar aspectos do projeto comunicacional (textos, falas, espaços e performances) do Bunkyo conforme o objetivo da tese. O primeiro cenário narrativo é o cenário "discursivo-performático" do IX FIB (Fórum de Integração Bunkyo), um evento anual de intensas trocas simbólicas em que são ritualizadas várias das relações hierárquicas, políticas e afetivas entre os membros do Bunkyo e de outras entidades nipo-brasileiras. As falas e textos compartilhados, a montagem dos espaços e as performances dos personagens compõem um enredo e uma dinâmica de interação que revelam aspectos importantes dos valores e significados que estão sendo renovados nesta ocasião.

O segundo cenário narrativo é o cenário "espacial-visual", composto pelos espaços, imagens e objetos que participam das montagens de ambientes no edifício-sede do Bunkyo, participando de forma concreta das narrativas da entidade. E o terceiro cenário narrativo é o "discursivo midiático" do Bunkyo na Internet, em especial uma página do seu site, em que analiso os textos e seus significados, além do impacto que a tecnologia digital exerce sobre os formatos e conteúdos das narrativas.

As considerações finais apresentam uma avaliação sobre os objetivos da tese e seus resultados. Tal avaliação demonstra que o Bunkyo defende a distinção da 
comunidade nipo-brasileira enquanto segmento da sociedade brasileira, ao mesmo tempo em que procura garantir e manter a hegemonia sobre os significados desta identidade e da memória dos ancestrais. Demonstra ainda que o projeto comunicacional do Bunkyo faz a mediação desses processos de significação, com a produção de formas e conteúdos que se referem e se dirigem ao seu público e à sua cultura. Esta produção delimita, na visão da entidade, o perfil da comunidade nipo-brasileira, do legado dos imigrantes japoneses no Brasil e dos elos da comunidade com o Japão de hoje e do passado. Também a metodologia é avaliada, demonstrando que a análise de narrativa utilizada foi capaz de revelar as dinâmicas de construção e de compartilhamento das histórias e práticas que atualizam os valores éticos e estéticos distintivos da comunidade nipo-brasileira, segundo o Bunkyo.

E, finalmente, há um anexo que contém cinco entrevistas precedidas por um texto de apresentação do método utilizado, a entrevista semiestruturada. Estas entrevistas foram escolhidas e publicadas de modo que as "vozes" destes personagens todos ligados ao Bunkyo - pudessem ser "ouvidas" diretamente pelo leitor da tese, com a menor interferência possível da minha parte. A escolha destes nomes se deu em função do critério de que cada um deles era um "informante-chave", ou seja, alguém capaz de proporcionar o entendimento não apenas de suas próprias práticas e maneiras de pensar, mas também dos diversos componentes de sua sociedade e sobre seus diferentes meios de pertencimento, por serem "representativos" de seu grupo, como indica Poupart (2008). 


\section{Capítulo 1: Considerações teóricas, epistemológicas e metodológicas.}

\section{Apresentação do problema de pesquisa}

Diante de um panorama cultural tão complexo como o da sociedade brasileira, que em plena segunda década do século XXI ainda ostenta impressionante diversidade, é quase certo que aquela questão já tantas vezes levantada pela academia - e até pelo senso comum - ressurja com algum aspecto novo a considerar: como sobrevivem as culturas nacionais e locais nestes tempos de globalização, que Hall (1995) já definia como uma força capaz de erodir, gradualmente, as claras distinções entre o que é "de dentro" de cada cultura e o que é "de fora"? E o que os estudos da Comunicação têm revelado, mais recentemente, acerca dos processos de perda e/ou transformação cultural, sobretudo em sociedades abertas, que se desenvolvem sob o impacto da expansão da mídia transnacional e dos fluxos culturais globais?

As distinções culturais nacionais ou locais - como objeto de questionamento acadêmico - vêm quase sempre acompanhadas pela questão da identidade, uma ideia que, segundo Zygmunt Bauman, "nasceu da crise do pertencimento", ou seja, da preocupação com a "lenta desintegração e a redução do poder de aglutinação das vizinhanças" (2004, p. 24-26). O conceito de identidade tem servido há décadas às Ciências Sociais em seu esforço de delimitação e de descrição dos grupos humanos que conseguiram preservar - ou reinventar - suas distinções apesar das forças da desintegração, até que este mesmo esforço de delimitação passou a sofrer críticas de alguns estudiosos da cultura, que o consideram responsável pela incapacidade do conceito de representar a diversidade interna "transbordante" dos grupos que delimita (MACHADO, 2011).

Mas, apesar da relevância das críticas, o conceito de identidade seguiu sendo um instrumento teórico fundamental, sobretudo para a análise de questões interculturais do mundo contemporâneo, como as tensões entre a identidade nacional e a identidade diaspórica - e ainda a etnicidade transnacional -, conceitos que foram cunhados justamente para dar conta dos encontros culturais intensificados pelos fluxos migratórios, um dos efeitos da globalização. O tema desta tese de Doutorado nasceu de 
um ponto de intersecção entre o meu interesse pelos estudos de Comunicação e Cultura e a minha curiosidade em relação à presença cultural dos imigrantes no Brasil, em especial pelos modos de ser e pela resiliência da comunidade nipo-brasileira, que, apesar de dispersa pelas cidades brasileiras e totalmente integrada à sociedade nacional, me deu sempre a impressão de manter grande apego às múltiplas leituras de suas próprias tradições.

Esta impressão surgiu da observação de diversos eventos, celebrações, apresentações e cursos dos quais participei, de forma mais constante desde 2011, em espaços variados na Liberdade - o "bairro oriental" de São Paulo - e na Casa da Cultura Japonesa da USP. A questão da identidade e da comunidade nipo-brasileira, como um tema de estudo, foi se delineando aos poucos, ao observar as maneiras com que o grupo nomeava a si próprio em público, sobretudo nas ocasiões solenes e festivas. Ouvi diversas vezes líderes de entidades e membros dessas associações, em ocasiões variadas, usarem indistintamente os termos "Nikkei"3, "comunidade nipo-brasileira", "colônia" e até mesmo "japoneses" para se referirem a si mesmos. Embora o significado desses termos já tenha sido bastante explorado pela historiografia e etnografia da imigração japonesa no Brasil, a dinâmica da construção e atualização das ideias de identidade e comunidade como significados atribuídos e vivenciados pelas pessoas que se consideram parte desse segmento específico e distinto da sociedade brasileira, para mim ainda não havia se revelado satisfatoriamente.

Afinal, o que é ser um nipo-brasileiro, ou um "japonês” no Brasil hoje, em um mundo em que o próprio Japão passa por mudanças estruturais que abalam suas referências culturais e seu projeto de futuro? E se é verdade que esse apego às tradições (ainda que inventadas ou reinventadas) de fato persiste e é difundido pelo país, o que isto significa em termos da relação desses indivíduos com a sociedade nacional e ainda sob as forças da globalização? A busca pela dinâmica de atualização desses significados da identidade, obviamente, não me levou ao encontro de uma "essência natural" dos japoneses e seus descendentes no país, pré-determinada por qualidades supostamente inerentes a esses indivíduos que os induziriam a perceber o mundo desta ou daquela maneira. Em texto que se tornou referência nos estudos da identidade, Judith Butler

\footnotetext{
${ }^{3}$ A palavra Nikkei, em japonês, se refere aos descendentes dos imigrantes japoneses. Segundo Sakurai (1993), a palavra Nikkei "está sendo utilizada desde a Convenção Panamericana Nikkei ocorrida em 1985, em São Paulo, que adotou a terminologia para todos os descendentes de japoneses nas Américas" (1993, p.21).
} 
(1990) ressalta a natureza performática - portanto não essencialista - de seus significados, constantemente determinados e atualizados pelo desempenho cotidiano das pessoas. Ainda que seu foco fossem os estudos de gênero, ela demonstrava que os significados da identidade, em geral, não são moldados por circunstâncias préexistentes, mas pela performance dos membros de uma sociedade em suas trocas reais, sempre sujeitas a tensões, estímulos, mudanças e negociações.

Garcia Canclini (1997) também reforça a ideia de que a identidade é posta em cena, dramatizada nos rituais cotidianos, que seriam os encontros em situações sociais cujos formatos e significados são sempre atualizados pela cultura. Por sua vez, Hall (2004) aponta para o aspecto discursivo do processo de construção da identidade. Ou seja, para ele, é por meio dos dispositivos discursivos - levando-se em conta não apenas as interpelações orais e escritas diretas entre os sujeitos, mas todas as demais mediações comunicativas da cultura - que os significados e as concepções que os indivíduos têm de si mesmos são construídos, negociados e atualizados. Estando claro desde o início, então, que os significados da identidade e da comunidade nipo-brasileira que eu buscava não estavam em supostas qualidades inerentes dos imigrantes e seus descendentes, mas sim nas performances e nos discursos em que esses indivíduos evocam e representam a si mesmos como membros de uma comunidade distinta, o próximo passo foi identificar as situações, formatos, tempos e espaços em que essas evocações e representações se realizam.

São muitas as entidades culturais, esportivas, assistenciais e educacionais que reúnem imigrantes e seus descendentes ${ }^{4}$ a partir de algum tema, como áreas de atividade, recreação e serviços oferecidos aos membros da comunidade, além das associações de províncias japonesas de origem, situadas em diferentes bairros da capital e cidades do estado e do país. Todas essas entidades, e ainda outros lugares de encontro como igrejas e templos, clubes, estabelecimentos comerciais, feiras, festivais e residências, são espaços em que aquelas evocações e representações se concretizam. Para que se possa viabilizar uma pesquisa acadêmica, porém, é preciso delimitar o seu universo de análise, desde que a amostragem obtida possa ser considerada representativa.

\footnotetext{
${ }^{4}$ A Nikkeypedia tem uma página com a lista de 200 entidades ligadas à comunidade nipo-brasileira, além de outras 47 classificadas na categoria "Kenjinkais", que são as associações de províncias do Japão no Brasil, todas unificadas na Federações das Associações das Províncias do Japão no Brasil - o Kenren (com exceção de duas).
} 
Uma dessas entidades havia chamado a minha atenção mais do que as outras: a Sociedade Brasileira de Cultura Japonesa e Assistência Social, ou - como é mais conhecida na comunidade - o Bunkyo ${ }^{5}$. As circunstâncias especiais de sua fundação (que serão explicadas no Capítulo 2), a quantidade e diversidade dos eventos e atividades que promove regularmente, sempre com grande afluência de público, sua complexa estrutura institucional e protagonismo nas relações oficiais Brasil-Japão e, sobretudo, a amplitude de seu projeto comunicacional deixaram claro para mim que o Bunkyo não era apenas mais uma entre as entidades nipo-brasileiras. Devotado - como veremos - a fazer de si próprio um ponto de referência da comunidade de origem japonesa no Brasil, o Bunkyo construiu itinerários, espaços e circunstâncias de encontros capazes de aglutinar várias gerações de descendentes, de diferentes áreas de interesse, onde os rituais da comunidade nipo-brasileira são praticados, proporcionando assim uma constante ressignificação e atualização dos seus conteúdos.

O texto da "missão" do Bunkyo, que consta na ata de fundação da entidade e pode ser lido tanto no seu site como (em versão resumida) em um quadro pendurado com destaque na parede da secretaria de seu edifício-sede, na Liberdade, define como suas tarefas essenciais: "representar" a comunidade nipo-brasileira e "preservar" o legado dos imigrantes japoneses no Brasil. Partindo, então, do pressuposto de que a intenção de representar e de preservar implica, necessariamente, a definição do representado e do legado que se quer preservar, encontrei no texto da missão do Bunkyo o ponto de partida para a elaboração do problema de pesquisa da minha tese de Doutorado.

Os significados da identidade (e, por decorrência, da comunidade) nipobrasileira não estão dados a priori; não existem como resultado natural dos fatos históricos referentes à imigração japonesa e da cultura trazida pelos imigrantes ao Brasil. Dependem de um dinâmico processo de definição da identidade do representado e da natureza de seu legado, que decorre da seleção e reconstituição permanente de traços culturais e fatos do passado, a partir das conveniências e repertórios de leitura no presente. Este é o processo que Raymond Williams (1979) chama de "tradição seletiva", que une uma ordem contemporânea a um passado modelador.

\footnotetext{
${ }^{5}$ Abreviatura do nome japonês: Burajiru Nihon Bunka Fukushi Kyôkai. Embora a grafia devesse ser Bunkyô, já que se trata de fusão das duas sílabas, Bun (de Bunka) e kyô (de Kyôkai), neste trabalho utilizo a grafia que a entidade definiu como razão social e com a qual se refere a si própria há décadas em todas as suas publicações..
} 
Esse procedimento de definição pelo Bunkyo do representado e do legado a preservar é o que delimita o perfil de seu público, um público imaginado que ganha, nesse procedimento, um conteúdo e uma substância que, no entanto, são sempre mutantes, instáveis e não necessariamente consensuais. Levando em conta, então, a constatação de Butler (1990), Garcia Canclini (1997) e Hall (1995) de que as identidades decorrem de processos performáticos e discursivos, e também a de Lopes (2004), para quem "as identidades coletivas são sistemas de reconhecimento e diferenciação simbólicos das classes e dos grupos sociais e a comunicação emerge como espaço-chave na construção/reconstrução dessas identidades" (2004, p.126), estabeleci como principal pergunta-problema desta tese de Doutorado a seguinte indagação: existe uma relação constitutiva entre o projeto comunicacional do Bunkyo e a definição de uma determinada visão do que venha a ser a identidade nipo-brasileira, ou seja, os contornos da comunidade e seu "verdadeiro" legado cultural?

Refiro-me a "uma determinada visão" do que venha a ser a identidade nipobrasileira, da comunidade e seu legado porque o objetivo da minha tese não é confirmar a existência dessa identidade, comunidade e legado, nem descobrir quais as suas "reais" características, mas sim demonstrar que é nos espaços-chave de seu vasto aparato comunicacional que o Bunkyo define - a partir de seu próprio ponto de vista (intencionalmente ou não) - o seu representado (a identidade, ou a comunidade nipobrasileira imaginada) e o legado que se propôs a preservar (o que considera o verdadeiro patrimônio histórico e cultural dos imigrantes japoneses no Brasil).

Ou seja, minha tese procura demonstrar que é esse projeto comunicacional que delineia os contornos da comunidade ao estabelecer um repertório de temas, modos de abordagem e referências simbólicas com os quais interpela o seu público - um público que é previamente imaginado, mas que é também construído durante esse processo de interpelação. Esses repertórios se organizam na forma de narrativas que assumem (na medida do possível) o controle das memórias atribuídas aos ancestrais comuns e dos registros de acontecimentos e percursos desse grupo no presente e no passado, e também da sobrevivência deste legado no futuro. Embora Lopes (2004), em seu estudo, se refira à relação entre os processos formadores das culturas nacionais e a mídia em geral (e em especial a televisão) quando pensa a construção das identidades coletivas no espaço-chave da Comunicação, acredito que essa reflexão possa se estender aos meios 
de comunicação de uma entidade, por fazerem parte do processo gerador de significados referentes a essa comunidade específica.

Considero esse trabalho do Bunkyo um projeto comunicacional - e não um mero conjunto de mídias e publicações - porque se constitui em um vasto aparato que inclui meios de comunicação impressos, audiovisuais e on-line, presença em redes sociais e promoção de eventos, atividades, celebrações e festividades em que se falam e dramatizam questões referentes ao universo social, cultural, político, religioso e memorial da comunidade nipo-brasileira, abrangendo um arco de tempo que inclui aspectos da vida desses indivíduos no presente, suas referências do passado e suas perspectivas para o futuro.

Ao contrário de outras entidades nipo-brasileiras que se limitam a promover atividades específicas e usam poucos e intermitentes recursos de divulgação, o Bunkyo mantém um amplo leque de atividades e meios de comunicação, que permanecem ativos ao longo dos anos, com regularidade e continuidade, e atingem pessoas de diversos perfis sociais, faixas etárias, focos de interesse e localidades de residência. Não tive a preocupação de investigar se esse projeto comunicacional foi intencionalmente elaborado, nem quais são os objetivos implícitos que estão por trás de sua elaboração, porque, no meu ponto de vista, a existência, a continuidade (há 62 anos) e a amplitude do projeto são evidências suficientes da sua importância para a entidade. Quanto aos objetivos declarados das pessoas que dirigem hoje a entidade, eles importam menos do que o trabalho em si, pois é o trabalho que define e revela os contornos do público a que se destina e a tradição que lhe serve de referência, o que é o foco desta pesquisa.

A segunda indagação que esta tese se propõe a responder é complementar à primeira: os formatos e conteúdos desse projeto comunicacional refletem a percepção, pelo Bunkyo, de uma identidade e de um legado comunitário em crise? Lembrando que um dos dois aspectos centrais da missão do Bunkyo é a preservação da cultura japonesa no Brasil, pode-se dizer que a utilização da palavra já implica a percepção de que esse legado precisa ser protegido, ou seja, defendido de circunstâncias que podem levar ao seu desaparecimento. Com os inevitáveis envelhecimento e morte das velhas gerações, guardiãs das lembranças da imigração, pode haver um receio de que as referências morais, estéticas e materiais que distinguem o grupo se percam, o que justificaria esses esforços de defesa do legado. 
O Bunkyo se proporia, neste caso, a ser o lugar onde a comunidade, como disse Pierre Nora (1993), pode "ancorar a sua memória", que assim permanece um "fenômeno sempre atual, um elo vivido no eterno presente" (1993, p. 9). O que não exclui, como veremos, o esquecimento deliberado de certos aspectos da história (e da memória) como parte do processo de construção do legado a ser preservado, e da identidade que se quer representar. Os eventos e objetos que celebram a língua, os valores e outros aspectos culturais japoneses que devem ser rememorados têm, nos vários espaços da entidade, principalmente no Museu Histórico da Imigração Japonesa, os novos "territórios" disponíveis que as populações deslocadas pela imigração, assim como seus descendentes, podem frequentar não apenas como oportunidades de encontro e lazer, mas como verdadeiros pontos de referência comunitários.

Neste sentido, as atividades do Bunkyo podem ser consideradas um tipo de militância a favor da sobrevivência da história e da cultura que a entidade colocou sob sua custódia. A celebração do patrimônio histórico, como observa Garcia Canclini (2007, p. 163), é o tipo de momento em que acontecimentos fundadores, seus heróis e os "objetos fetichizados que os evocam" são colocados no centro de uma dramatização que encena a repetição e a perpetuação de uma certa ordem. Às dinâmicas de um contexto nacional e mundial que joga a todos na roda-viva dos deslocamentos e da hibridização diluidora, o Bunkyo contrapõe sua própria dinâmica militante, que resgata a estabilidade e a distinção. Portanto, considero as atividades do Bunkyo uma forma de ativismo, ou um trabalho consciente e consistente a favor da preservação da sua cultura, a partir de uma política de identidade que, em certo sentido, se assemelha à descrita por Ronsini e Oliveira (2007) em sua reflexão sobre movimentos de populações negras no Rio Grande do Sul:

A identidade conformada pelos movimentos sociais é essencializada na "verdade da tradição" e nas raízes da história, fazendo um apelo à realidade de um passado possivelmente reprimido e obscurecido, no qual a identidade que vem à tona no presente é revelada como um produto da história. (...) Consideramos, portanto, a política de identidade a partir do movimento social e da etnia. (2007, p. 3)

Apesar das diferenças entre os dois segmentos sociais, com participações diversas na história e na formação da sociedade brasileira, tanto os descendentes dos 
imigrantes japoneses (aqui representados pelo Bunkyo) como as populações negras estudadas pelas autoras têm em comum o fato de associarem suas distinções identitárias com a etnia, a tradição e as "raízes da história", as quais são evocadas na luta pelo reconhecimento e contra a dissolução de seu legado em um presente nivelador.

Assim, os meios de comunicação do Bunkyo operam concomitantemente à mídia nacional e internacional - que ignora a existência da comunidade nipo-brasileira ou a insere dentro de uma ordem ampla e diversa que a dilui dentro da sociedade nacional -, constituindo-se em espaço exclusivo de construção e ritualização dos seus próprios significados. Ou seja, os meios do Bunkyo não se opõem nem competem com a grande mídia, mas se apresentam como o espaço gerador de uma ordem paralela em que os fatos e os personagens do mundo nipo-brasileiro estão no centro do universo, em todas as edições, e em todos os meios e situações de comunicação.

Essa ordem paralela, é claro, não se constrói de forma independente e isolada do resto do mundo. Primeiro, porque os meios do Bunkyo não deixam de estar conectados a uma cultura midiática global que está permanentemente impactando os seus próprios significados, formatos e formas de organização. E, segundo, porque o próprio Bunkyo não é um bloco uniforme e homogêneo, mas sim um grupo de lideranças, dirigentes e membros mais e menos ativos - de várias origens, faixas etárias, ocupações, histórias de vida, posições políticas etc. - que vêm interagindo com a comunidade da qual fazem parte, através dos anos, de diversas formas e perspectivas, o que compõe um cenário propício para disputas, desentendimentos, confrontos e até mesmo lutas pela hegemonia das significações, ocultos sob uma aparência eterna de paz e cordialidade (para quem os vê de fora, claro).

Quanto a isto, Bourdieu (1989) lembrava que o processo de construção da identidade implica uma luta pela "propriedade de estigmas ou emblemas (o lugar de origem e seus sinais duradouros)", uma "luta pelo monopólio das definições legítimas, que impõem uma determinada visão de mundo e um consenso sobre os significados, em especial sobre a identidade e a unidade do grupo" (BOURDIEU, 1989, p.113). Essa luta interna pela hegemonia dos significados, no caso do Bunkyo, é discreta e confinada aos círculos de discussão das lideranças. Seus resultados, porém, devem ser observados no próprio critério de seleção da tradição e dos ritos a serem mantidos, no consequente silêncio sobre outros aspectos da história e, sobretudo, na manutenção das aparências de uma comunidade nipo-brasileira "unida", o que é sempre contestado em outros cenários. 
A percepção de uma identidade e um legado em crise também tem a ver com o fato de que a comunidade nipo-brasileira, com o tempo, se tornou mais afluente ${ }^{6}$ e urbana, o que levou à gradual diminuição da necessidade de ajuda mútua e à dispersão das famílias nas grandes cidades do país. A inserção das novas gerações de descendentes de imigrantes na sociedade brasileira, seu domínio cada vez menor da língua japonesa e a sua exposição a um maior contato intercultural, nas relações pessoais e através da mídia nacional e internacional, são os outros fatores de possível crise da identidade nipo-brasileira, a que, no entanto, o projeto comunicacional do Bunkyo se contrapõe ao construir novas oportunidades de identificação com um contexto atualizado de necessidades e expectativas de ajuda recíproca, e também de visibilidade de uma cultura própria que resiste às ameaças de dissolução total na sociedade nacional.

Se a colônia japonesa do passado tinha, no meio rural, seus limites delineados pelas trocas e ajuda mútua dos agricultores em um ambiente estranho e hostil, hoje a comunidade nipo-brasileira pode encontrar nos meios de comunicação e nos espaços do Bunkyo (não apenas neles, claro) os textos, imagens e falas que tecem novas redes de solidariedade, como a associação de assistência aos idosos Ikoi-no-Sono ${ }^{7}$, a Associação Pró-Excepcionais Kodomo-no-Sono ${ }^{8}$, o centro de apoio aos decasséguis de partida para o Japão ou de volta ao Brasil $(C I A T E)^{9}$ e as campanhas às vítimas dos desastres naturais no Japão. Assim, embora a ajuda mútua não seja mais essencial à sobrevivência da comunidade, ela se renova como fator agregador na assistência sempre necessária aos seus membros (ou aos flagelados no Japão) que estão em condição de vulnerabilidade, temporária ou permanente.

\footnotetext{
${ }^{6}$ Um número elevado de brasileiros de origem japonesa se tornou decasségui, a partir dos anos 1980, o que demonstra por si só que os problemas econômicos não desapareceram nesse segmento da sociedade brasileira, mas me refiro - na afirmação acima - ao fato de que já não estão na situação de pobreza em que a maioria dos imigrantes japoneses chegou ao Brasil.

${ }^{7}$ Em japonês, Jardim de Repouso. Teve origem no trabalho da Comissão Católica Japonesa de São Paulo, em 1942. Ver: http://ikoinosono.org.br/wordpress/, acesso em 08/08/2017.

${ }^{8}$ Em japonês, Jardim das Crianças. Fundado em 1950, com o objetivo de dar assistência às crianças com necessidades especiais da comunidade nipo-brasileira; hoje os residentes têm idade entre 22 e 60 anos. Ver em http://www.kodomonosono.org.br/, acesso em 08/08/2017.

${ }^{9}$ Centro de Apoio e Informação ao Trabalhador no Exterior. Fundado em 1992, oferece informações e orientação sobre condições de trabalho no Japão para os "nipo-brasileiros, a seus cônjuges e filhos", em três fases: "antes da sua ida, no período de sua permanência, e após o seu retorno" Ver em http://www.ciate.org.br/, acesso em 08/08/2017.
} 
Quanto às novas gerações, o Bunkyo criou a sua Comissão de Jovens $\left(\right.$ Seinenkai $\left.{ }^{10}\right)$, que tem participação na produção de eventos, falas, imagens e narrativas cuja questão central é o futuro da comunidade nipo-brasileira, sobretudo no que se refere à formação de novas lideranças, capazes de avaliar as condições do presente, mantendo como referência o legado dos seus antepassados. Integrando as novas tecnologias à causa da representação e da preservação, os jovens do Bunkyo exploram mais confortavelmente as redes sociais e os novíssimos dispositivos comunicacionais que falam a linguagem dos jovens e estabelecem os espaços virtuais de encontros, discussão e trocas. A agenda da Comissão de Jovens reflete as preocupações majoritárias do Bunkyo, como se pode depreender do texto da sua missão: "preservar, valorizar e divulgar a cultura nipo-brasileira através da integração e desenvolvimento dos jovens das entidades em prol da sociedade brasileira"11.

A questão da integração das entidades nipo-brasileiras está no topo da lista de prioridades do Bunkyo, como estratégia de contraposição à dispersão da comunidade. Mas como a dispersão é real e irreversível, as novas tecnologias da comunicação proporcionam a criação de territórios substitutivos de socialização e de troca, cujo comando está em boa parte a cargo dos jovens do Bunkyo. Hine (2000) ressalta esse aspecto da comunicação on-line, que possibilita a criação de páginas que são "vistas também como território, uma forma de espaço que enfatiza as fronteiras em vez de conexões" ${ }^{, 12}$ (2000, p.114). As páginas do Seinen no Facebook, por exemplo, refletem essa construção de fronteiras do mundo dos jovens nipo-brasileiros, embora sempre flexíveis e até convidativas à "invasão" de não descendentes, desde que apreciadores da cultura japonesa, tradicional ou pop.

Embora a integração dos descendentes de imigrantes japoneses na sociedade nacional seja uma realidade incontestável desde a segunda geração (os nisseis), a presença ativa da Comissão de Jovens nos espaços físicos e on-line do Bunkyo mostra que o interesse em manter, de alguma forma, as fronteiras da comunidade permanece ainda que abertas a conexões externas (a participação de não descendentes) -, e mostra também, mais uma vez, que essas linhas demarcatórias se delineiam (ou estão

\footnotetext{
${ }^{10}$ Em japonês, Associação da Juventude. Fundada em 1997, seu "ideal é a integração das entidades jovens e a valorização da cultura nipo-brasileira”. Ver em https://www.facebook.com/cjb.seinenBunkyo/, acesso em 10/10/2017

${ }^{11}$ Ver em "Sobre": facebook.com/cjb.seinenBunkyo, acesso em 10/09/2017.

12 No original, em inglês: "web pages are, however, also viewed as territory, a form of space which stresses boundaries rather than connections" (Tradução da autora).
} 
representadas) no espaço da comunicação. A autoridade das falas, a prioridade nos ritos, a ocupação dos espaços privilegiados, o controle dos recursos e o poder de decisões continuam nas mãos dos mais velhos, mas é inegável que os mais jovens exercem com discrição um tipo de soft power, fundamentado no seu poder inerente sobre o futuro e a continuidade do projeto do Bunkyo, como será discutido mais à frente, nos capítulos $2 \mathrm{e}$ 3.

\section{Considerações epistemológicas e teóricas}

Esta tese de Doutorado tem como foco a produção da estratégia comunicacional do Bunkyo, que constrói e delimita as formas e o conteúdo de um público-alvo previamente imaginado, constituindo assim os contornos da identidade desse público (a comunidade nipo-brasileira) e de seu legado (a cultura dos imigrantes japoneses no Brasil), em um processo de apropriação e recriação das narrativas da imigração e de outras histórias a elas relacionadas. Exploro, neste trabalho, as relações entre comunicação e identidade, que Nilda Jacks (2013, p.15) define como "íntimas, profundas e delicadas" em seu estudo sobre os meios de comunicação como criadores, renovadores e ou consolidadores de identidades culturais. Também Blanco (2004) reforça essa relação ao afirmar que os meios de comunicação são "os verdadeiros gestores" das identidades públicas contemporâneas, apresentando os "coletivos sociais em termos de igualdade ou diferença, exibindo marcas identitárias inclusivas (para os membros da comunidade) e excludentes (para o 'de fora', considerado como 'alheio')"13 (2004, p. 136).

O conceito de identidade utilizado nesta tese apoia-se também - conforme mencionado antes - na teoria de performance de Judith Butler (1990), que postula que identidades não possuem essência nem estabilidade, mas significados e conteúdos vivenciados e atualizados pelas pessoas na prática do seu cotidiano. O conceito de identidades coletivas, que Lopes (2004) define como sistemas de reconhecimento e diferenciação simbólicos que têm na comunicação seu espaço-chave de construção, é igualmente essencial na construção dos argumentos da tese.

\footnotetext{
${ }^{13}$ No original, em espanhol: "Y los medios presentan a los colectivos sociales en términos de igualdad o diferencia, exhibiendo marcas identitarias incluyentes (para los miembros de la comunidad) y excluyentes (para el extranjero, considerado como 'ajeno')". Tradução minha para o português.
} 
Estas reflexões se dão a partir de uma abordagem epistemológica, teórica e metodológica alinhada com a perspectiva da Comunicação como área de convergência entre várias disciplinas das Ciências Sociais - dada a multidimensionalidade do seu objeto - sem perder, no entanto, a especificidade do campo comunicacional.

Esta perspectiva aponta para o papel central das Ciências da Comunicação na compreensão das "novas configurações socioculturais dos mundos contemporâneos", como ressalta Sandra Valdettaro (2013, p. 29), ao mesmo tempo em que reconhece a pertinência, "para o desenvolvimento do saber comunicacional, dos estudos disciplinares que de dentro de sua especificidade teórica, abordem problemas do campo comunicativo", como lembra Muniz Sodré (2007, p. 25). Esta perspectiva implica, portanto, o reconhecimento da especificidade do campo da Comunicação como gerador de conhecimento e, concomitantemente, sua abertura aos recursos teóricos e metodológicos de outras Ciências Sociais e humanas, o que a predispõe a uma constante renovação como disciplina.

A questão dos prefixos "inter", "multi" e "trans" na questão da relação entre disciplinas se refere às discussões - iniciadas há décadas em diversas áreas da ciência sobre a necessidade de se recuperar um conhecimento baseado em uma visão holística da realidade humana, deixada de lado pelo prevalecimento do paradigma das especializações de cada área científica. No caso da Comunicação, em vez de ter suas especificidades dissolvidas pela sua permanente relação teórica e metodológica com as outras disciplinas, ela revela uma qualidade unificadora que reflete, na verdade, a "profunda unidade do real" (KOSIK apud LOPES, 2009, p.107).

Neste sentido, Lopes (2009) afirma que entender a Comunicação como área de convergência ou de intersecção entre os diversos saberes sociais não significa negar a especificidade da Comunicação, mas entendê-la como "um novo campo de problemas interdisciplinares". Essa interdisciplinaridade, como ressalta Lopes (2009), não se propõe a apresentar uma "visão integrada de todo conhecimento social", mas propõe uma forma renovada de pensamento que busque uma "nova síntese disciplinar" (2009, pp. 107-108). Essa visão está de acordo com a proposta de Morin (2015), que sugere uma nova forma de conhecimento, produzido a partir de um "paradigma da complexidade", capaz de apreender a multiplicidade de aspectos interligados entre os fatos no mundo contemporâneo (que não expõem sua dinâmica interna quando verificados isoladamente) e da rapidez com que se modificam. Assim, o campo da 
Comunicação deve situar-se em uma área de convergência entre as várias disciplinas das Ciências Sociais, compartilhando métodos e teorias, mas sem perder de vista a especificidade de seu objeto (a comunicação e o comunicacional nas interações humanas). Deve manter também uma abordagem que combine uma atitude crítica em relação a seu legado teórico-metodológico e inovadora em relação aos novos desafios da tecnologia e da globalização.

Assim, minha tese está fundamentada nesta linha de pesquisa que utiliza, de forma geral, as teorias e metodologias que dão conta da "multidimensionalidade do fenômeno comunicacional" (LOPES, 2009, p.106), e também das características específicas do meu objeto, que a todo o momento requer a "transgressão das fronteiras" - usando a expressão de Williams (1979) - entre Comunicação, História, Literatura e Antropologia. Esse compartilhamento teórico-metodológico possibilitou uma análise ampla e relacional dos aspectos históricos e culturais da imigração japonesa no Brasil; a formação das colônias rurais e a gradual migração dessas populações para centros urbanos, onde recriaram seus espaços de memória; os depoimentos e os poemas que revelam os pontos de vista, a ética e a estética de homens e mulheres de diferentes gerações; o surgimento de uma mídia nikkei e seu papel na coesão da comunidade em diferentes momentos históricos; o protagonismo político e institucional do Bunkyo no cenário nacional e internacional e a criação do seu projeto comunicacional, com suas narrativas sobre e para a comunidade nipo-brasileira.

Acrescento como contribuição a este trabalho as reflexões de Charaudeau (2012), que aborda questões centrais para o entendimento das mídias como prática social que "constrói um certo saber" à medida que constitui representações sobre seu público. As mídias, que, segundo Charaudeau, definem "o que é preciso saber" e se apresentam como instância com "competência para informar", mobilizam ao mesmo tempo o "imaginário do saber" e o "do poder", pela autoridade que esse saber lhes confere (2012, pp. 34-72). Sem esquecer que a era digital modificou bastante essas místicas do saber e do poder sobre o conhecimento, essas citações, no entanto, sintetizam pontos cruciais da relação que pretendo estabelecer entre a produção midiática do Bunkyo - que reivindica para si a legitimidade para representar e preservar - e a construção do seu público.

Embora as reflexões de Charaudeau se refiram, sobretudo, às grandes mídias nacionais e internacionais, penso que as dinâmicas que descreve se reproduzem em 
meios de comunicação de circulação menor e mais específica, como é o caso da mídia étnica em geral, e das mídias de entidades como o Bunkyo, em particular, que produzem "situações de comunicação" como num "palco, com suas restrições de espaço, de tempo, de relações e de palavras, no qual se encenam as trocas sociais e aquilo que constitui o seu valor simbólico" (2012, p. 67).

Essa "situação de comunicação" é justamente o modo como vejo meu objeto de pesquisa: as formas e o "palco" em que as narrativas do Bunkyo são compartilhadas, não só nos momentos especiais em que aqueles valores simbólicos selecionados pela entidade são dramatizados, como também em todos os momentos em que se dirige a seu público, seja na montagem de uma instalação no Museu Histórico da Imigração Japonesa, na decoração das paredes e das estantes com objetos e artefatos significativos, seja nas falas, textos e imagens que veicula em seus boletins e redes sociais, isto é, na produção e compartilhamento das narrativas que constroem seu próprio público.

Nesses momentos de compartilhamento, em que a narrativa é falada, dramatizada para um público (na forma de danças, cantos, declamações e outros tipos de apresentação) ou construída na forma de uma instalação presencial (como as visitas guiadas às montagens do museu e dos demais espaços do edifício do Bunkyo), o conceito de performance é novamente essencial para a análise dos significantes e significados que estão em jogo. A contribuição de dois outros autores é parte da fundamentação teórica desses pontos: um deles é Paul Zumthor (2000), que ressalta os aspectos simbólicos materializados na voz e nos gestos em um momento de performance culturalmente significativo.

Zumthor afirma que o texto (cantado, falado, declamado, ou interpretado) promove uma situação real de interação junto ao público, ou seja, transforma-se em um "texto em situação" (o que tem a ver com contexto e materialidade). O tempo da performance, diz o autor, é "corporalizado", é um tempo "vivido no corpo". Assim, a performance "se situa num contexto ao mesmo tempo cultural e situacional: nesse contexto ela aparece como uma 'emergência', um fenômeno que sai desse contexto ao mesmo tempo em que nele encontra lugar" (2000, p.31). Nesse sentido, o Bunkyo tem se dedicado a promover as situações e os contextos em que essas performances ocorrem, e as trocas simbólicas se estabelecem, como demonstro mais à frente. 
O outro autor é John L. Austin (1979), que aponta os aspectos performativos da fala em si, quando por meio dela o falante está fazendo algo em vez de simplesmente dizendo ou descrevendo alguma coisa. Quem diz, por exemplo, "eu aposto que nosso futuro está garantido!" não descreve, mas faz uma aposta. É nesse sentido que Austin considera essas formas de expressão como "falas performativas"14. O fazer é um ato que procura ter consequências mais concretas que o falar, pois implica uma intervenção direta na realidade. No caso do Bunkyo, cuja militância a favor da construção da identidade nipo-brasileira e da preservação da cultura japonesa no Brasil tem um inegável aspecto proativo, de intervenção direta sobre esse segmento da sociedade nacional, as falas performativas têm grande força simbólica e concreta, como veremos nos capítulos à frente.

No que se refere às relações comunicacionais do universo cultural nipobrasileiro, o Bunkyo se constitui em uma instância de produção, o que Charaudeau (2012) define como entidade composta de diferentes atores (de organização, programação, redação e operações técnicas), empenhados na construção de um "discurso midiático" unificado e representativo da "ideologia do organismo de informação" (2012, p. 73). A totalidade dessa produção midiática (as diversas situações de comunicação produzidas e efetuadas pelo Bunkyo) representa os pontos de vista hegemônicos da entidade quanto ao seu representado (seu público-alvo) e aos assuntos que "lhe dizem respeito".

Embora seja evidente, como ressalta Martín-Barbero (2008), que os significados das mensagens não dependem somente da intencionalidade de um dos polos da comunicação, o emissor (a instância da produção), mas inclui com igual importância os significados atribuídos pelo receptor (o público-alvo), de acordo com suas próprias competências interpretativas, não estou incluindo neste trabalho uma análise de recepção, dada a enormidade de um projeto que abarcasse ambas as perspectivas. A questão da recepção (o acolhimento e repercussão das mensagens do Bunkyo e as diversas formas de ressignificação dessas mensagens recebidas pelas pessoas reais que compõem a imaginada comunidade nipo-brasileira) permanece em aberto, como tema a ser explorado em minha próxima pesquisa, quem sabe de pós-doutorado.

A noção de comunidade nipo-brasileira é explorada nesta tese com base em uma ideia de espaço público que, segundo Patrick Charaudeau (2012), não pode ser

\footnotetext{
14 "Performative utterances", no original em inglês.
} 
universal, mas sim dependente das especificidades culturais de cada grupo. Charaudeau lembra que os territórios e fronteiras dos espaços públicos - que são múltiplos - têm sua atualização dependente, em grande parte, da atuação midiática. O espaço público forma e é formado pelo "discurso circulante", que o autor explica como uma soma empírica de enunciados através dos quais uma comunidade se reconhece. Desse discurso circulante fazem parte as palavras de autoridade dos líderes, e as narrativas que atualizam os valores e as normas e que registram o percurso do grupo e os assuntos "de seu interesse".

Esse espaço público - que se estabelece nos lugares físicos da entidade onde se montam cenários e se dramatizam eventos em torno de montagens, falas e narrativas que evocam a identidade e o legado nipo-brasileiros, e nas suas mídias, onde esses mesmos textos são produzidos em outras linguagens - inclui o espaço virtual da entidade, elaborado no uso regular dos meios digitais, que ampliam o alcance das mensagens e potencializam as possibilidades de interação e compartilhamento. Inserida em outros espaços mais amplos - da sociedade local, nacional e global -, a comunidade nipo-brasileira é, então, analisada neste trabalho como um espaço público, cujo discurso circulante o Bunkyo se empenha em constituir, atualizar e manter em atividade constante.

Isto não quer dizer que outros discursos - opostos ao do Bunkyo - não circulem. Um deles se organizou, por exemplo, em torno de um projeto teatral que mobilizou membros da população nipo-brasileira que não se identificam com a ideia de fazerem parte de uma "comunidade", muito menos esta das narrativas do Bunkyo. Trata-se do Núcleo Hana de Pesquisa Teatral, dirigido por Alice Kiyomi Yagyu, que concebeu o projeto "Travessias em conflito", prefere contar outras histórias, sobre a tensão que predominou entre os imigrantes que tiveram que se virar no Brasil, sobre as tristezas, a dor, o abandono, os antagonismos e tudo o mais que, segundo seus integrantes, ficou de fora dos relatos otimistas que prevaleceram nas festividades do centenário da imigração e nas demais narrativas que se dedicam à construção da imagem positiva de comunidade que se deu bem, apesar das adversidades no passado.

Esse embate pela hegemonia dos significados (referente aos "valores e conceitos") e significantes (os "paradigmas de representação, expressão e narração") é

\footnotetext{
${ }^{15}$ Ver em http://www.portalnikkei.com.br/tag/travessias-em-conflito/, acesso em 17/11/2017.
} 
exatamente o que define o espaço público, segundo Bucci (2005). Embora o autor se refira ao enfrentamento das grandes instituições da sociedade (a mídia, o Estado, a Igreja, a escola e a família), considero esse modelo de análise valioso para a compreensão do que ocorre no interior de um grupo "étnico"16. Acredito que assim como o processo de enfrentamento das instituições pelos significados e significantes se realiza na macroestrutura da sociedade nacional (e nas demais sociedades capitalistas do mundo), ele também ocorre na microestrutura dos segmentos sociais que se veem como distintos, ainda que integrados, reproduzindo dinâmicas semelhantes. Isto porque a distinção não é algo que exista em si mesmo, mas é construída por meio de algum discurso (quanto ao conteúdo e a forma) que nunca é absoluto, mas sempre desafiado por versões alternativas.

Nessa reflexão, Bucci (2005) elabora uma ideia de espaço público que traz a questão comunicacional para o centro das definições: "a função de dar a última palavra (ou a última imagem) para o estabelecimento dos significados, aquela que decide a interpretação do mundo, coube à mídia como instituição". Assim, "o papel 'dirigente' dos meios de comunicação, da instituição mediática, sobre as demais instituições e sobre as racionalidades sistêmicas é uma das marcas registradas do espaço público atual nas sociedades ditas ocidentais". Ainda que "precário e instável", diz o autor, o resultado dos embates se constitui em uma "combinação de equilíbrio", ou seja, em "uma forma de hegemonia" (2005, p. 92).

Assim, o espaço público da comunidade nipo-brasileira reflete a hierarquia de valores e conceitos e o idioma disseminados pelas narrativas do Bunkyo - cujas linguagens incluem falas, textos impressos e on-line, imagens, performances e montagens espaciais - em sua luta pela gestão da memória e da identidade desse segmento da população brasileira. Como pretendo demonstrar nos capítulos seguintes, apesar das contestações e disputas, o Bunkyo tem conseguido reunir meios institucionais e políticos para manter a hegemonia de seus significados e significantes, ainda que esta seja sempre precária e instável. As disputas sobre as representações da comunidade se dão hoje não só entre entidades diferentes, mas dentro do próprio Bunkyo, envolvendo

\footnotetext{
${ }^{16}$ Explicando as aspas: a comunidade nipo-brasileira já se assumiu, no passado, como uma comunidade étnica, mas hoje o discurso (como o do próprio Bunkyo) é diferente: fundamenta-se na herança cultural, e não mais nos vínculos de sangue. Mesmo assim, a etnicidade está longe de ser uma questão superada, como pretendo abordar nos capítulos seguintes.
} 
as várias gerações de descendentes, e pessoas com perspectivas diversas em relação ao que vem a ser o "verdadeiro" legado dos japoneses no Brasil e o que deve ser feito dele.

A noção de comunidade é central neste trabalho pelo fato de as lideranças e membros do Bunkyo se referirem à população de origem japonesa como "comunidade nipo-brasileira", apesar de serem usados também outros termos, como "colônia", ou simplesmente "nós, os japoneses" (incluindo aí os descendentes). Embora o senso comum utilize vocábulos e expressões sem preocupação com os seus contextos sociológicos, o sentido histórico de certas palavras - como parece ser o caso de "comunidade" - foi apropriado (ou assimilado) por camadas amplas da população, ainda que não necessariamente de forma reflexiva.

Em um artigo sobre o tema, Albuquerque (1999) lembra que os termos "comunidade" e "sociedade" são formas opostas de representação simbólica "que povoam o imaginário moderno". Se no século XVIII a ideia de sociedade surge como sinônimo de racionalismo, e "exorcismo da comunidade arcaica, medieval e tradicional", nos séculos seguintes a noção de comunidade retorna no discurso crítico dos chamados "utópicos" - que denunciam as "relações impessoais, anônimas e fracionadas" impostas pela sociedade industrial - passando a representar "as formas de relacionamento caracterizadas por intimidade, profundeza emocional, engajamento moral e continuidade no tempo" (1999, p.51).

Segundo a autora, enquanto a sociedade é marcada pelas relações secundárias, especialização profissional e individualismo, o espírito de comunidade é evocado para restabelecer os laços de parentesco, as redes de solidariedade e a orientação para o comportamento. No caso da comunidade nipo-brasileira, ela só se constitui em determinadas circunstâncias e lugares, já que os indivíduos que a compõem estão integrados à sociedade nacional, e não mais isolados em colônias agrícolas como no passado. A tarefa atribuída a si mesmo pelo Bunkyo é justamente a de constituir o espaço público através do qual a comunidade nipo-brasileira passa a existir como oportunidade de engajamento, reconhecimento e continuidade temporal. Como vimos acima, esse espaço público não é um território ou lugar físico, mas o resultado de um embate entre diferentes representações pela hegemonia dos significados da identidade e do legado, e das maneiras de narrá-los.

A comunidade nipo-brasileira é analisada também como uma comunidade imaginada, uma noção criada por Benedict Anderson (2011), em obra sobre a origem e 
a difusão histórica do nacionalismo na Europa. Para Anderson, a ideia de comunidade se refere às fronteiras que um grupo delineia em torno de si, ainda que elásticas. E é "imaginada" porque a grande maioria de seus membros nunca se conheceu pessoalmente, mas se reconhece como parte de um todo. Esse reconhecimento, segundo o autor, é um ato da imaginação, o que não tem nada a ver com "falsidade versus autenticidade", mas com o modo com que o grupo imagina a si mesmo como totalidade, com base em traços e histórias em comum.

Embora a construção da comunidade nipo-brasileira pelo Bunkyo se refira a laços com o Brasil e com o Japão, não é em relação à história dessas duas nações que a comunidade nipo-brasileira é imaginada, mas sim quanto ao percurso particular dos imigrantes japoneses e seus descendentes no Brasil, que tem na chegada do navio Kasato Maru, em 1908, seu marco inaugural. Assim, utilizo o conceito de comunidade imaginada para definir um grupo de pessoas que tiveram fronteiras desenhadas em torno de si, por meio de narrativas que descrevem as circunstâncias históricas e os traços culturais definidores dessa comunidade e de sua consequente distinção dos demais segmentos da sociedade brasileira.

O Brasil e o Japão - as duas referências nacionais da comunidade nipo-brasileira - são países modernos, ambos inseridos, desde bem antes da chegada ao Brasil dos primeiros imigrantes japoneses, no mundo globalizado e, portanto, afetados pelos processos de transformação que hibridizam suas culturas nacionais a partir de matrizes de várias origens. Por isso, os processos de construção das identidades nestes e em quaisquer outros países são constantemente levados a forjar novas formas de interpretação de si próprios, de retomar suas "culturas traduzidas", como diz Stuart Hall (2004), referindo-se à própria raiz etimológica da palavra "tradução", do latim: "transferir, transportar entre fronteiras" (2004, p. 89).

Conectada como está no passado e na atualidade aos países de outras partes do mundo pelo consumo, pela educação e pelos meios de comunicação, a comunidade nipo-brasileira traz em si mesma a indagação do que vem a ser cada uma de suas partes, a "nipo" e a "brasileira", ambas hibridizadas (e em perene processo de mudanças). Essa referência identitária dupla é o que Jeffrey Lesser (2000) chama de "identidade hifenizada", que, no caso da comunidade nipo-brasileira, se refere à adesão dos imigrantes que desistiram do seu projeto inicial de voltar ao Japão e de seus 
descendentes a uma identidade múltipla, que assimilou "muitos dos elementos da cultura majoritária, mesmo permanecendo distintos" (2000, p. 22).

A noção de hibridização cultural, essencial para situar essa questão das identidades coletivas na sociedade contemporânea, é utilizada neste trabalho com referência ao conceito desenvolvido por Garcia Canclini (2012) em sua análise das circunstâncias econômicas, políticas e sociais que há séculos favorecem os encontros multiculturais, potencializados pelo capitalismo multinacional e seus fluxos globais de deslocamentos humanos, temporários e permanentes. A hibridização cultural define-se como um fenômeno que "se materializa em cenários multideterminados onde diversos sistemas se cruzam e interpenetram" (2012, p.113). Fenômeno que ocorre desde a antiguidade com as migrações e o encontro de várias culturas em decorrência desses deslocamentos, a hibridização cultural foi acelerada pela rápida expansão dos meios de comunicação, das redes sociais e da ampliação do acesso à educação e ao consumo, sobretudo a partir da segunda metade do século XX.

O conceito de globalização, por sua vez essencial para situar a questão das culturas híbridas na atualidade, é entendido neste trabalho no sentido apresentado por Martín-Barbero (2009), como uma "nova realidade histórico-social de interdependência mundial" motivada, sobretudo, pelo "novo capitalismo financeiro" (2009, p. 149). A globalização, então, é um complexo de processos e forças de mudança do mundo contemporâneo que, entre outras coisas, tensionam as culturas nacionais, afetando de forma especialmente aguda as comunidades diaspóricas.

Para que se possa entender essas "novas dimensões simbólicas da construção do coletivo" no mundo globalizado, Martín-Barbero (2009) propõe que se reconheça o novo papel dos meios de comunicação, que devem ser vistos não como meros aparatos, mas como "instituições sociais" que fazem a mediação de todas "as formas da vida cultural e social dos povos” (2009, p. 153). A questão da imigração japonesa no Brasil, portanto, é analisada nesse contexto de globalização e hibridização cultural, em que os meios de comunicação do Bunkyo se inserem, participando como protagonistas, e também como coadjuvantes, na constituição de uma narrativa sobre a identidade e a comunidade nipo-brasileira, e de seu legado histórico e cultural.

Sintetizando o que foi exposto acima, considero que a produção comunicacional do Bunkyo deva ser abordada a partir de uma proposta holística, como a explicitada por Luís Carlos Lopes (2003), que enfatiza não os fragmentos (cada uma de suas 
manifestações isoladas), mas o modo integral de sua representação. $\mathrm{O}$ autor ressalta que os atos e situações comunicacionais, no seu conjunto, são muito mais amplos do que a fala e a escrita:

A fala e o texto até mesmo podem não existir ou serem secundários diante da gestualidade, da imagem, do som, da ambiência, da motricidade e do contexto cênico onde a comunicação se processa. Mesmo quando a fala e o texto são centrais, há de se considerar os demais elementos não-linguísticos que acompanham ambos (LOPES, 2003, p. 167).

Essa proposta está em consonância com a ideia de "pensamento complexo", de Morin (2015), que sugere exatamente essa postura diante de um objeto de estudo, que é a que escolhi para abordar o projeto comunicacional do Bunkyo. Assim, a produção midiática da entidade (as notícias e comentários impressos e on-line) é considerada em conjunto com as performances (as falas solenes e as apresentações), a produção material dos espaços da entidade e as montagens (no museu e em demais locais administrados pelo Bunkyo), cujos elementos também fazem parte das narrativas sobre a identidade e o patrimônio cultural da comunidade nipo-brasileira.

Desta forma, defino o projeto comunicacional do Bunkyo como o conjunto de mídias produzidas por ele, e também as situações de comunicação organizadas e montadas pela entidade em seus diversos espaços. Procuro com isto dar conta da multidimensionalidade do fenômeno comunicacional reconhecendo a diversidade das mídias e das situações de comunicação, e sua integração em um sistema único que produz saberes e significados.

\section{Objetivos}

O objetivo teórico desta pesquisa é demonstrar que as identidades coletivas são um fenômeno comunicacional e performático em constante redefinição e rearticulação por meio de processos que envolvem discursos, performances e narrativas que são, na verdade, os espaços constitutivos das representações sociais que delineiam as fronteiras 
físicas e virtuais de uma comunidade imaginada, além de envolverem atores sociais que exercem estratégias de uma política da identidade, que neste caso é a representação da distinção social e cultural com base na "verdade da tradição" e nas "raízes da história" (RONSINI e OLIVEIRA, 2007).

O objetivo prático da pesquisa é demonstrar a relação entre o projeto comunicacional do Bunkyo e a construção de uma versão da identidade e da comunidade nipo-brasileira, versão esta que a entidade busca legitimar de diversas formas. Analiso especificamente como o esforço do Bunkyo em representar os imigrantes japoneses e seus descendentes, e em preservar o seu legado, inspira a construção e o compartilhamento de narrativas que definem o perfil social e cultural do seu público (a comunidade nipo-brasileira) e selecionam os fatos considerados relevantes da sua história (seu patrimônio cultural), construindo assim a sua versão da identidade nipo-brasileira e do legado da comunidade dos descendentes japoneses no Brasil.

A pesquisa apresenta ainda, como objetivos específicos:

1) Analisar os eventos, espaços e mídias do Bunkyo que recompõem os territórios de uma comunidade antes concentrada em colônias rurais e hoje dispersa pelas áreas urbanas do país, construindo novas redes de identificação e de solidariedade entre os imigrantes e seus descendentes, e mantendo suas conexões com o Japão do passado e do presente.

2) Analisar como as salas temáticas, jardins, espaços físicos e acervos de material simbólico participam do projeto comunicacional do Bunkyo, em sua tentativa de construir espaços de memória que reconstituem territórios e referências identitárias da comunidade nipo-brasileira, incorporando esses espaços e objetos à grande narrativa da "saga da imigração japonesa no Brasil" e a outras histórias relevantes para a comunidade;

3) Analisar a relação entre gerações dentro do Bunkyo com a finalidade de observar o papel destinado aos jovens nas decisões e na realização do projeto comunicacional da entidade e no encaminhamento da narrativa da imigração japonesa no Brasil em direção ao futuro. 


\section{Hipóteses}

Sendo uma forma de articulação das indagações da pesquisa, a partir das leituras e observação dos fatos que deram origem ao objeto de estudo, as hipóteses têm a função de "fornecer a conexão necessária entre teoria e investigação, teoria e fato" (LOPES, 2009, p.140). Assim, as hipóteses não são simples perguntas que a tese vai tentar responder, mas sim um sistema organizador e norteador da pesquisa, definindo os caminhos a percorrer e a fundamentação teórica de cada passo que é dado, nesta ou naquela direção.

Nos primeiros estágios da construção do problema de pesquisa, a seguinte pergunta foi se articulando como indagação principal da tese: há relação entre o cumprimento da missão do Bunkyo (representar a comunidade nipo-brasileira e preservar o seu patrimônio) e o seu projeto comunicacional? A partir desta pergunta, as leituras de vários autores - em especial de Lopes (2003, 2004, 2010); Bourdieu (1987); Jacks (2013), Valdettaro (2013), Charaudeau (2012) e Martín-Barbero (2009) - me levaram ao esboço de uma ideia: de que o Bunkyo seleciona e constrói (o que não seria “inventar", mas sim "elaborar" a partir de uma seleção e de uma perspectiva particular) fatos do passado referentes à imigração japonesa no Brasil e a várias outras histórias relacionadas ao mundo nipo-brasileiro, que por sua vez se articulam em forma de narrativas tendo em vista um público-alvo imaginado.

Como veremos no desenrolar desta pesquisa, as teorias e os métodos de abordagem do objeto serão utilizados para nortear e, no final, para verificar não a "veracidade" (pois só as religiões pretendem encontrar a "verdade"), mas a utilidade e a adequação das hipóteses. Embora a sua validade em pesquisas empíricas, como é o caso desta, possa ter "o marco de um universo restrito" e por isso se abstenha de "proceder a generalizações" (LOPES, 2009, p.142), ainda assim acredito que estas que norteiam a análise do projeto do Bunkyo possam inspirar a formulação de novas indagações sobre a relação entre as mídias e a atualização da identidade, da sociedade como um todo ou de outros segmentos dela.

Como um sistema de hipóteses deve estabelecer diretrizes entre aquelas que são mais amplas e as outras que são mais específicas (LOPES, 2009 p.140), a partir da hipótese principal, procedi ao desdobramento das hipóteses em principal, teóricas e 
empíricas, sendo a primeira e as segundas derivadas diretamente do quadro teórico que fundamenta tanto as reflexões como a aplicação destas teorias ao entendimento e explicação do objeto; e as terceiras as "hipóteses de trabalho", que orientam os métodos utilizados no campo, tanto quanto à maneira de abordá-lo, como na de interpretá-lo. Assim, o conjunto das hipóteses que orientaram o desenrolar desta pesquisa ficou assim organizado:

\subsection{Hipótese principal}

O projeto comunicacional do Bunkyo é o espaço e é também o tempo em que são construídas e compartilhadas as narrativas que proporcionam à comunidade nipobrasileira a oportunidade de ver a si própria no presente (sua identidade) como um segmento distinto da sociedade nacional, tendo o passado como referência (sua memória).

\subsection{Hipóteses teóricas}

a) o Bunkyo como discurso de uma comunidade imaginada.

Pressuponho que o objetivo de representar a comunidade nipo-brasileira e de preservar o legado dos imigrantes japoneses no Brasil - missão atribuída a si mesmo pelo Bunkyo - implica, necessariamente, a definição do representado e do legado que se quer preservar, sendo que esse esforço de definição resulta, na prática, na construção de narrativas que refletem um público imaginado ao mesmo tempo em que o constroem.

b) A comunicação como espaço-chave da construção e reconstrução identitárias pelo Bunkyo.

Pressuponho que as identidades coletivas são sistemas simbólicos de reconhecimento e diferenciação que têm na Comunicação seu espaço-chave de construção e atualização; assim, a estratégia comunicacional do Bunkyo é um espaço onde são construídas narrativas que delineiam as fronteiras que distinguem os "de dentro" (os descendentes dos japoneses no Brasil) dos "de fora" (os demais brasileiros) - e também as novas redes de solidariedade que mantêm ligados os membros dessa comunidade imaginada, mesmo levando em conta a abertura à participação dos "de fora" no território nipobrasileiro constituído pelo Bunkyo. 


\subsection{Hipóteses empíricas}

a) O Bunkyo atualiza a história da comunidade, desde imagens da saga do passado até as do Japão pop.

Presumo que os esforços do Bunkyo em reconstituir fatos do passado e elementos culturais japoneses trazidos ao Brasil pelos imigrantes refletem uma luta contra forças externas percebidas como causadoras de "esquecimento" e de perda das tradições que a entidade busca preservar. Como, porém, a diáspora japonesa, desde o início, esteve integrada ao fenômeno amplo da globalização, o que tem resultado na hibridização das populações deslocadas, presumo que o legado a ser preservado, considerado legítimo, na verdade é uma mistura de vários elementos culturais, antigos e recentes, inclusive do próprio Japão, já que imigrantes de províncias diversas conviveram no Brasil e misturaram aqui suas culturas de origem.

b) A estratégia de comunicação midiática do Bunkyo (jornais, revistas, filmes, televisão, rádio, internet) mescla memória e fatos do passado e do presente e estende a temporalidade identitária para o tempo futuro.

Presumo que as falas, imagens, objetos, espaços e textos da mídia do Bunkyo sejam partes de uma grande narrativa (a saga da imigração japonesa) que integra fatos e lembranças do passado ao presente da comunidade nipo-brasileira, restabelecendo a sua continuidade no tempo e constituindo assim um conjunto que dá unidade e relevância aos temas, e constrói seu projeto de futuro. Consiste em um trabalho de seleção de notícias, fatos, objetos e testemunhos considerados verdadeiros e relevantes para a reconstituição da história da comunidade, em uma prática que recorta, cola e reconstrói os significados do passado, a partir das necessidades e pontos de vista do presente.

\section{Metodologia}

A abordagem metodológica desta pesquisa reflete acima de tudo a amplitude do objeto que construí: o projeto comunicacional do Bunkyo, que é aqui entendido não como uma somatória de meios de comunicação produzidos pela entidade, mas como um conjunto amplo de "situações de comunicação", conforme definição de Charaudeau 
(2012), que as narrativas são constituídas por diversas histórias interligadas. Assim, foram analisadas as mídias em si - boletins impressos e on-line, o site da entidade, documentos e catálogos - e também os espaços e situações em que se falam e dramatizam aspectos selecionados como de interesse do seu público-alvo. Juntas, essas situações de comunicação compõem a totalidade do projeto comunicacional do Bunkyo, em que os limites e contornos da identidade, da cultura e do legado da comunidade nipo-brasileira são constituídos.

Uma das primeiras questões metodológicas enfrentadas durante o trabalho, conforme já mencionei na introdução, referiu-se às estratégias de superação das esperadas barreiras impostas à minha presença no campo pelo fato de eu ser uma gaijin, ou seja, uma pessoa de fora da comunidade nipo-brasileira ${ }^{17}$, e, portanto, não portadora das senhas de acesso aos lugares-chave, aos significados deliberadamente guardados e à intimidade das histórias reservadas apenas a seus personagens. Deparei-me com essas barreiras desde o início da pesquisa, embora os membros do Bunkyo com quem me relacionei tenham sido sempre polidos e, na maior parte das vezes, acolhedores.

O método de pesquisa etnográfica - também utilizada neste trabalho - construiuse historicamente na prática de superação de obstáculos desse tipo, e até muito mais difíceis, já que a pesquisa de campo colocou desde o início o pesquisador em contato com comunidades de culturas muito diferentes da sua. E os desafios dessa experiência da diferença inspiraram as reflexões epistemológicas e a construção de métodos e técnicas de coleta que até hoje nos servem de referência, em todas as áreas das Ciências Humanas e Sociais.

Esses métodos e técnicas, entretanto, não colocam o pesquisador a salvo das armadilhas da subjetividade na construção e abordagem do objeto de estudo, seja ele qual for, já que "este é sempre construído pela razão de quem observa", sendo a permanente "objetivação da subjetividade", como Lopes nos diz, o pré-requisito para o conhecimento (2010, p. 36). As discussões epistemológicas sobre a autenticidade e relevância do conhecimento que produzimos e das condições de cientificidade das pesquisas que fazemos, também são a referência na qual buscamos os caminhos mais seguros para o conhecimento do outro.

\footnotetext{
17 "Pessoa de fora", em japonês. Pode significar "estrangeiro" no Japão (embora exista outra palavra mais específica), mas é utilizada pela comunidade nipo-brasileira no sentido de "não descendente", ou seja, pessoa que não tem origem japonesa.
} 
E esses caminhos não têm necessariamente que passar, segundo Poupart (2008), pelo "princípio da maior homologia possível" entre o sujeito e o objeto da pesquisa, caminho este em que se esperava que a familiaridade entre ambos garantisse uma pesquisa com risco reduzido de viés, etnocentrismo e incompreensão. $\mathrm{O}$ autor ressalta que a proximidade decorrente do pertencimento ao mesmo grupo social favorece uma boa compreensão do grupo pesquisado, mas, em contrapartida, pode "impedir o pesquisador de tomar a distância necessária para reconsiderar as evidências ou as racionalizações próprias ao grupo" (2008, p. 236). Desta forma, pode-se concluir que tanto um pesquisador de dentro da comunidade quanto um de fora enfrentam - por motivos opostos - limitações no exercício da pesquisa, mas podem, também, trazer contribuições diferentes - ou até complementares - ao estudo dos grupos sociais.

\subsection{Apresentação das técnicas de coleta e da descrição}

Thiollent (1980) recomenda que as técnicas de levantamento de informações sejam escolhidas a partir de uma avaliação das necessidades específicas da pesquisa, assim como as teorias que lhes dão respaldo, já que "cada técnica contém instrumentos particulares cujo uso envolve pressupostos teóricos" (1980, p. 44). A abordagem do conceito de identidade como fenômeno comunicacional (LOPES, 2004) e performático (BUTLER, 1990), utilizada neste trabalho, exigiu a inclusão da observação direta dos atores sociais nos locais onde a ação se desenrola, que neste caso são os eventos, festivais e demais atividades promovidas pelo Bunkyo. A observação direta permite que se verifique o desenvolvimento dos rituais da comunicação, como os agrupamentos, as encenações, as solenidades com suas formalidades, as nuances das falas e discursos, além dos aspectos simbólicos da comunicação visual presentes na composição dos espaços, nos cartazes, quadros e fotos, no vestuário, nos gestos, nas montagens e instalações.

Essa experiência direta no campo é, acima de tudo, segundo Lopes (2010), o “elemento fundante da pesquisa empírica. Trata-se de uma experiência insubstituível para o pesquisador, aquilo que 'só se aprende fazendo', quando ele entra em interação com os fenômenos sob estudo em seu contexto natural” (2010, p. 41). Esse contato direto com meu objeto foi realizado na forma de observação simples e participante, 
quando verifiquei in loco o desenrolar das atividades do Bunkyo, tanto no cotidiano quanto em ocasiões especiais - solenidades, celebrações e festivais. A observação simples - que desenvolvi de forma sistemática de 2014 a 2017 - foi uma experiência fundamental para o conhecimento das rotinas, personagens e composições espaciais do Bunkyo, e também para uma coleta de materiais de divulgação produzidos pela entidade e entregues ao público.

No segundo semestre de 2015 e no primeiro semestre de 2016, realizei uma experiência mais estruturada de observação participante, comparecendo aos eventos e a aulas de Ikebana ${ }^{18}$ com o objetivo de conhecer com mais detalhes as atividades, acontecimentos, trocas e aspectos operacionais do projeto comunicacional que foi objeto da minha análise. No segundo semestre de 2017 colhi mais material de pesquisa etnográfica, em visitas e participando ativamente de um evento, para complementar e confirmar dados durante várias situações diferentes.

Escolhi a pesquisa de campo tendo como base, entre outros autores, as reflexões de Lindlof (1995), para quem a observação participante é a maneira mais eficiente de experimentar e documentar eventos em situações sociais naturais (isto é, não arranjadas pelo próprio pesquisador), pois o pesquisador assume um papel ativo no campo, integrando-se às situações reais. A partir desse ponto privilegiado de observação, o pesquisador tem a oportunidade de desenvolver a "habilidade de se comportar dentro dos padrões apreciados pelo grupo e de produzir análises mais detalhadas, precisas e teoricamente bem fundamentadas" (1995, p.135).

Lindlof adverte, entretanto, que isso não impede que o pesquisador se veja, com frequência, em uma posição marginal em relação ao grupo que observa, já que estará sempre no limiar entre o mundo que observa e o seu próprio. Por isso, "a capacidade de tolerar o 'status marginal' e transformá-lo em um método de interpretação é essencial à eficiência no campo" (1995, p.136). Essa ponderação é ilustrada pela minha própria condição de não descendente de japoneses, conforme expus anteriormente, o que de fato restringiu o meu acesso a certos acontecimentos e espaços da entidade, mas por outro lado me levou a explorar o meu próprio distanciamento cultural como um ponto

\footnotetext{
${ }^{18}$ Prática cultural secular no Japão, de origem budista, que consiste em um arranjo de flores, folhas, sementes, raizes e galhos em um vaso com água, cujas combinações refletem valores estéticos e simbólicos.
} 
privilegiado de observação, já que a sensação de estranhamento ou de fascinação pelo diferente sempre instiga a curiosidade e aguça o olhar.

Outra possibilidade acessível ao observador participante, segundo Lindlof, é a de poder discernir, entre os fatos, aqueles que são "evidências" de algo, resultado do processo de inferência que atribui significado ao material observado à medida que ele se "refere significativamente a outras evidências, testemunhos e argumentos" (1995, p. 138). Para ilustrar essa questão, cito um desses momentos durante a pesquisa: a comemoração anual do aniversário do imperador - símbolo espiritual da unidade japonesa graças à sua "origem divina" (SAKURAI, 2007, p. 131), que se revelou uma evidência da adesão da comunidade nipo-brasileira idealizada pelo Bunkyo a um “espírito japonês" que transcende as distâncias espaciais e temporais, e permanece como referência de identidade até mesmo para os descendentes dos imigrantes que não falam japonês e nunca viveram no Japão. Embora outros elementos menos solenes do Japão contemporâneo também façam parte de diversos eventos, o culto ao imperador revela os elos dessa comunidade imaginada com um Japão também imaginado.

Malinowski (1976), o primeiro etnógrafo da história e criador do método da observação participante, apontou os três princípios essenciais da sua aplicação: o pesquisador deve guiar-se por objetivos verdadeiramente científicos, deve criar boas condições de trabalho de campo - que, para ele, era a imersão total na vida dos "nativos" - e recorrer a métodos especiais de coleta, manipulação e registro de provas (MALINOWSKI, 1976, p. 21). É evidente que, no caso da minha pesquisa, a situação é muito diferente.

Além de não serem "nativos", como aqueles que Malinowski observou nas ilhas Trobriand há quase cem anos, os membros da comunidade nipo-brasileira idealizada pelo Bunkyo são, na verdade, indivíduos que vivem há décadas nos centros urbanos do país, constituindo-se cidadãos brasileiros totalmente inseridos na sociedade nacional contemporânea. Mas a imersão no mundo nipo-brasileiro construído nos momentos de dramatização (solenidades, festivais, cerimônias etc.) da sua identidade distinta dos demais segmentos da sociedade brasileira proporcionou-me insights e elementos para reflexão que uma observação simples não teria proporcionado.

E quanto à aplicação de métodos etnográficos em contextos urbanos, Magnani (2009) lembra que um dos primeiros desafios do pesquisador é atender ao "pressuposto da totalidade" do objeto etnográfico, já que no meio urbano atual não existem as 
fronteiras bem delimitadas das comunidades tradicionais que foram objeto da Antropologia no passado (e ainda são, no caso de comunidades tribais e quilombolas isoladas). Para se constituir uma unidade de análise, então, o autor propõe que se considere os atores sociais não como elementos isolados e dispersos na grande cidade, mas como indivíduos ligados por padrões discerníveis de ação e de práticas compartilhadas em suas esferas de trabalho, religião, cultura, política e vida associativa, cujos "elementos estruturantes" podem ser reconhecidos em outros contextos (2009, p. 138). Na delimitação do meu objeto de pesquisa, considero os lugares de memória e os momentos aglutinadores criados e mantidos pelo Bunkyo como elementos estruturantes que constituem essa comunidade imaginada.

Outra ferramenta teórico-metodológica da etnografia utilizada nesta tese diz respeito ao conceito de "drama social”, concebido por Turner (1980), que eu considero crucial para a abordagem das dimensões comunicacionais das relações entre indivíduos de uma comunidade em circunstâncias especiais de troca e de reafirmação de seus valores sociais e culturais. Essas situações são como rituais em que certos valores essenciais do grupo são vivenciados através de performances que reafirmam esses valores, mas também os questionam e recriam. Os dramas analisados na minha tese são certos eventos organizados pelo Bunkyo, em que cenários são montados, personagens desempenham seus papéis e enredos se desenrolam enquanto momentos especiais da entidade são celebrados.

Quanto ao conceito de drama, também é levada em conta a reflexão de Assumpção (2010) sobre as relações entre ação dramática e narrativa, como, por exemplo, o que ela chama de "tempo dramático", cuja "duração dinâmica" é subordinada ao "aqui/ agora" cênico, no sentido em que o presente é função de um passado (ou futuro) a ser revelado durante a ação. Esses conceitos - eficientes na exploração de uma cultura comunitária que se atualiza evocando sua ancestralidade são expostos em mais detalhes e aplicados durante a análise do IX Fórum de Integração Bunkyo $(F I B)^{19}$, no Capítulo 3.

A minha pesquisa de campo também constou de coleta de material nos cenários em que se desenvolvem as atividades cotidianas do Bunkyo - o edifício-sede onde

\footnotetext{
${ }^{19}$ Encontro anual promovido pelo Bunkyo, em torno de temas que abordam questões de interesse da comunidade, com o objetivo principal de integrar as entidades nipo-brasileiras de São Paulo e de outras cidades do estado e do país.
} 
funcionam a secretaria, o auditório, o museu, a biblioteca, a sala de exibição de filmes, os espaços de aulas, de cerimônia do chá, de oficinas e de exposição de artes - e também das apresentações anuais de festivais de dança e música tradicionais (Bunka Matsuri e Gueinosai) ${ }^{20}$, da celebração do ano novo e do aniversário do imperador, e como mencionei acima - da realização do FIB. O modo de observação e de transcrição do material coletado tem como referência o método que Clifford Geertz (1978) chamou de "descrição densa", um método que busca conhecer um fato cultural na multiplicidade de aspectos, sutis e inapreensíveis ao olhar apressado, e que lhe confere significado.

A descrição - que neste tipo de investigação profunda já é uma forma de interpretação - é, para Geertz, o trabalho primordial do estudo das culturas, que ele vê como "teias de significados" cuja análise não tem "nada a ver com uma ciência experimental em busca de leis", mas sim com "uma ciência interpretativa, à procura do significado" (1978, p. 15). A descrição densa, mais do que um método, é uma atitude do pesquisador, que olha para o seu objeto de estudo como quem vê algo vasto e complexo, que o desafia a todo o momento a ir mais longe, mais fundo, e a estar sempre pronto para encontrar novos caminhos que estendem a teia de significados em direções inesperadas. Geertz não oferece regras que levam aos significados, mas sim uma série de reflexões que inspiram o pesquisador a buscá-los e a acreditar em sua capacidade de fazê-lo.

A descrição densa, então, é o trabalho do pesquisador que aceita o desafio de enfrentar "uma multiplicidade de estruturas conceptuais complexas, muitas delas sobrepostas ou amarradas umas às outras, que são simultaneamente estranhas, irregulares e inexplícitas, e que ele tem que, de alguma forma, primeiro apreender e depois apresentar" (GEERTZ, 1978, p. 20). Minha pesquisa de campo no Bunkyo, portanto, consiste em um trabalho etnográfico de coleta de dados e de reconhecimento dos espaços e tempos em que os significados das narrativas - presentes nos textos e também nos objetos, acontecimentos e rituais - são produzidos. Esse trabalho implica um encontro de subjetividades (entre o pesquisador e seu objeto), o que impõe um grande desafio quanto à autenticidade dos resultados obtidos. Mas o método da descrição densa, por tentar cercar o objeto de todas as formas possíveis e estabelecer e

\footnotetext{
${ }^{20}$ Bunka Matsuri: Festival da Cultura, realizado no mês de maio; Gueinosai: Festival de Música e Dança Folclórica Japonesa, realizado no mês de junho, ambos em vários espaços do edifício-sede do Bunkyo, na Liberdade.
} 
testar suas inter-relações explícitas e insinuadas, proporciona certo controle sobre os riscos, embora a porta esteja sempre aberta a outros possíveis significados.

Recorri também à técnica da entrevista semiestruturada descrita por Thiollent (1980) - organizada por seleção de temas previamente identificados na experiência de campo como relevantes, em que algumas perguntas orientam a conversa, que permanece aberta o suficiente às escolhas, aos ritmos e à livre expressão dos entrevistados - por proporcionar acesso às narrativas e às versões das histórias vividas por membros do Bunkyo. Os entrevistados foram selecionados entre os que considerei personagens-chave para o levantamento dessas falas e textos, embora muitos tenham ficado de fora por falta de oportunidade, de minha parte, de ouvi-los. As entrevistas não só serviram para revelar histórias que eu desconhecia como para esclarecer pontos e redefinir a pesquisa nesta ou naquela direção. Serviram, principalmente, para adicionar outras vozes ao texto, por isso os textos foram editados pelos próprios entrevistados. As entrevistas estão no anexo da tese.

Essas técnicas qualitativas de coleta de dados - pesquisa de campo e entrevista visam à construção de uma amostragem significativa ou de representatividade social da realidade estudada, como indica Lopes (2009, p. 145). E quanto à coleta do material que compõe o corpus a ser analisado, foram selecionados os itens que correspondem também ao critério principal de levantar uma amostra representativa das histórias produzidas e compartilhadas pelo Bunkyo. Para preservar a integridade desse processo que compõe as várias situações de comunicação, optei pela variedade das amostras, em detrimento da quantidade delas.

Considerei como pertinentes a produção comunicacional que implica investimento na periodicidade e no potencial de compartilhamento e que tenha, no ponto de vista da entidade, importância institucional. O material selecionado para uma análise de narrativa detalhada foi: um evento que vem sendo promovido há nove anos e que tem mobilizado jovens e idosos do Bunkyo e entidades parceiras, o FIB; a montagem do Museu Histórico de Imigração Japonesa, a partir do texto de um catálogo publicado recentemente, e uma página do site do Bunkyo. Mas mesmo antes disso, enquanto faço uma "descrição densa" do meu material observado, já realizo várias análises dos significados de aspectos variados das narrativas do Bunkyo, já que a descrição densa é em si mesma um trabalho de interpretação. 
O material colhido nas pesquisas de campo e nas mídias do Bunkyo foram submetidos a uma análise de narrativa, na tentativa de encontrar o nexo que faz de cada história, evento e notícia compartilhada pelo Bunkyo os elementos de uma totalidade, que por sua vez revela a visão da entidade do que vem a ser o seu público-alvo e o patrimônio que pretende "preservar", no contexto amplo das relações da entidade com outras entidades representativas da população de origem japonesa, no Brasil e no exterior. Em síntese, a metodologia da pesquisa proporcionou as ferramentas de observação e análise dos dispositivos e situações comunicacionais em que o Bunkyo cumpre sua missão, ou seja, define os contornos do seu representado (a comunidade nipo-brasileira) e do legado a ser preservado (o patrimônio cultural dos imigrantes), na forma de narrativas que revelam o conteúdo dessa comunidade e de sua herança cultural.

\subsection{Apresentação da análise de narrativa}

A narrativa da imigração japonesa, evidentemente, não teve início com a fundação do Bunkyo. Obras como o Estudo sobre a imigração japonesa no Brasil, de Kumao Takaoka, de 1925, e Os pioneiros da imigração japonesa no Brasil, de Teijiro Suzuki, de 1933, ambas escritas em japonês, e As colonias japonesas na zona do Ribeira do Iguape, de Jorge Midorikawa, de 1928, em português ${ }^{21}$, são exemplos de que essa história já começara a ser contada bem antes da fundação da entidade, em 1955. O nascimento do Bunkyo, entretanto, é concomitante ao surgimento de uma nova narrativa, a qual a entidade ajudou a produzir e foi por ela produzida: a história da cisão da comunidade nipo-brasileira, após a guerra, e de sua reunificação na grande festa do IV Centenário da cidade de São Paulo, sob a liderança das pessoas que conceberam o Bunkyo ${ }^{22}$.

A sua fundação é justificada e encorajada por essa reunificação, cuja história é inserida na narrativa principal com a celebração dali a três anos - a cargo da entidade recém-criada - do cinquentenário da imigração japonesa no Brasil. Dessa celebração

\footnotetext{
${ }^{21}$ Essas obras e muitas outras, de várias épocas, estão citadas na bibliografia de Tomoo Handa (1987), pp. 809-812.

${ }^{22}$ Essa história e outras que são mencionadas nesta apresentação serão discutidas detalhadamente nos capítulos seguintes.
} 
participou um membro da família imperial japonesa, um convidado de honra que foi crucial para conferir legitimidade aos protagonistas dessa nova história - as lideranças do Bunkyo, anfitriões da festa dos 50 anos - que passaram, a partir daí, a participar com destaque da produção, atualização e divulgação da saga da imigração japonesa no Brasil.

A história da imigração japonesa, objeto de pesquisas acadêmicas, se distingue da narrativa, ou seja, da "saga da imigração" - um trabalho de constituição da identidade cultural de uma comunidade que busca na "memória coletiva" sua fonte principal de identificação. Joël Candau (2011) lembra que a ideia de "memória coletiva" é uma representação que membros de um grupo vão produzir a respeito de lembranças percebidas (ou imaginadas) como comuns a todos. Essas narrativas dos acontecimentos, diz o autor, têm um efeito "performativo" sobre a memória, fazendo com que ela tenha uma existência concreta e compartilhada, o que não anula o fato de que sejam apenas representações, podendo haver, portanto, formas alternativas de se narrar o "passado comum".

Mas se é verdade que as narrativas compartilhadas pelo Bunkyo têm relevância e legitimidade, que narrativas são estas? Quais são os seus significados e como são atribuídos? Quais são os processos de reprodução das narrativas e de seu compartilhamento? Qual é o papel dessas narrativas na reformulação dos contornos e conteúdos da comunidade a que se destinam? O que elas têm a dizer sobre a construção da identidade nipo-brasileira e do seu legado?

Diante da evidência de que a partir de uma narrativa principal - a saga da imigração japonesa no Brasil - várias outras foram surgindo (ou sendo apropriadas e incorporadas) com o passar dos anos, formando com aquela uma totalidade, dinâmica e mutante, determinada não apenas pelos textos e discursos como também pelas ações e pela construção material do mundo onde circulam as pessoas envolvidas nessas histórias, considerei pertinente realizar uma análise de narrativa que responda e explique as questões formuladas acima. Antes de descrever como essa análise é realizada, porém, apresento uma rápida exposição de alguns aspectos do conceito de narrativa, que será desenvolvido em mais detalhes ao longo do trabalho. 


\subsubsection{O que é a narrativa}

Segundo Culler (1999), há um impulso humano básico de ouvir e narrar histórias, o que reflete algo ainda mais profundo: essas narrativas são referenciais para a percepção e atribuição de sentido aos acontecimentos do mundo e da própria vida. Como matéria acadêmica, diz o autor, a teoria da narrativa, ou "narratologia", é um ramo ativo da teoria literária, que analisa as características e variações da estrutura, das técnicas e da poética da narrativa. Mas sendo a narrativa uma forma de conhecer o mundo, mais do que uma análise estrutural de um texto literário, a teoria da narrativa poderia ser concebida como uma tentativa de explicar a competência narrativa do ser humano, ou seja, "pode ser concebida como uma exposição de uma compreensão ou conhecimento cultural intuitivo" $(1999$, p.85).

Com um ponto de vista semelhante, Bruner (2001) afirma que há uma forma "narrativa de construção da realidade", e que há "elementos universais nas realidades que elas constroem, sendo essenciais à vida em uma cultura" (2001, p.127). Para o autor, ainda que seja impossível distingui-los de maneira bem definida, há um "modo narrativo de pensamento" e um "texto ou discurso narrativo", que dão forma um ao outro, "do mesmo modo que o pensamento torna-se inextricável da linguagem que o expressa e que acaba moldando-o". Assim, "nossa experiência dos assuntos humanos passa a assumir a forma das narrativas que utilizamos ao contá-los” (2001, p. 129).

Mas se a narrativa é uma forma de pensamento e, portanto, uma referência de conhecimento do mundo, quais seriam, concretamente, suas características? Culler (1999) cita Aristóteles, para quem o enredo é o traço mais elementar da narrativa, e que "uma boa história deve ter começo, meio e fim". A partir desta ideia básica do filósofo, de que a narrativa é uma história que se define por um enredo sequencial, o autor explica como se organizariam então os elementos essenciais de uma narrativa: após uma situação inicial, os acontecimentos da história se desenrolam em uma determinada sequência, em que transformações desestabilizam o rumo das ocorrências em direção a um final, que deve indicar o que foi feito do "desejo que levou aos acontecimentos que a história narra" (1999, p. 86).

Usando o recurso do contraste para explorar a ideia do que vem a ser a narrativa, Motta (2004) contrapõe os conceitos de narração e descrição, sendo que o primeiro ele 
define como um "relato de eventos que configuram o desenvolvimento de uma ação temporal (cronológica) que estimula a imaginação (a diegese da história)", e o segundo como a representação de um momento único, estático, que "naturaliza" o discurso e cria "o efeito de real pelo excesso de informações geradoras de verossimilhança" (2004, p.3). Neste caso, as funções de temporalidade e de estímulo ao imaginário seriam cruciais à definição da narrativa. Outra oposição utilizada pelo autor é entre "mostrar e contar". Como exemplos do primeiro, ele cita o teatro e o cinema, que mais mostram do que narram, deixando ao expectador a configuração do enredo e da diegese da história. E o segundo "se distingue pelo esforço do narrador em conectar, juntar as partes, contar enfim" (2004, p.4). Neste caso, a narrativa se distinguiria pela maior ou menor presença do narrador.

Oferecendo uma perspectiva diferente, Martino (2016) pondera que a narrativa é um fenômeno social, responsável pela formação de vínculos e pela definição de identidades pessoais e comunitárias. Para o autor, o que define o "ato narrativo" é o compartilhamento deliberado de elementos simbólicos, através da história, entre pessoas de uma mesma cultura. Assim, a narrativa constrói um espaço comum entre narrador e público, que são participantes de um mesmo “ambiente narrativo". É na narrativa, com sua ênfase na criação de vínculos entre as pessoas, que se configura, para o autor, a dimensão estética da comunicação. $O$ aspecto mais saliente da narrativa, neste caso, seria o ato narrativo em si, ou seja, o compartilhamento das histórias, a qualidade afetiva da troca que enseja, e seu potencial de criação de um espírito comunitário.

Em sua reflexão sobre o "tempo da narrativa", Ricoeur (1980) afirma que a função narrativa e a experiência humana do tempo estão intimamente relacionadas. Para o autor, a "temporalidade é a estrutura da existência que se estende à linguagem na narratividade, e a narratividade é a estrutura da linguagem que tem a temporalidade como o seu referente máximo. A relação entre ambos é, portanto, de reciprocidade" ${ }^{23}$ (1980, p.165). A representação do tempo para as comunidades humanas difere do conceito de tempo explorado pela filosofia, que, segundo o autor, tem procurado em fontes como a cosmologia e a física as questões que um estudo das experiências da temporalidade nas narrativas - o "tempo humanamente relevante" - poderia elucidar. Da mesma forma, ele lamenta que tanto a história como a crítica literária não têm

\footnotetext{
${ }^{23}$ No original em inglês: "I take temporality to be that structure of existence that reaches language in narrativity and narrativity to be the language structure that has temporality as its ultimate referent. Their relationship is therefore reciprocal". Tradução da autora.
} 
avançado muito além de uma abordagem linear do tempo em seus estudos das narrativas.

Para Ricoeur, é no enredo - "a totalidade inteligível que governa a sucessão de eventos em uma história" - que a temporalidade da narrativa pode ser mais bem observada. Essa sucessão de eventos, a “dimensão episódica da narrativa”, é a dimensão propriamente "cronológica" dos eventos. Mas há uma segunda, "não cronológica", que é a "dimensão configuracional da narrativa", por meio da qual o enredo transforma eventos dispersos em totalidades significativas. Outro aspecto essencial é o caráter "público" do tempo da narrativa, que se expressa de duas formas: primeiro, "dentro" da história, ou seja, no tempo em que as ações se desenrolam envolvendo personagens que interagem, ou seja, em que os protagonistas estão "uns com os outros". E segundo, "fora" da história, ou seja, no tempo em que a história é contada (para uma audiência), pois é quando ela é narrada que "uma história é incorporada pela comunidade que ela $u^{24, "}(1980$, p.172). Ou seja, é em torno (ou em função) da narrativa que a comunidade se forma.

Quando as histórias se tornam bem conhecidas, diz o autor, o "contar uma história" dá lugar ao "recontar". Assim, quando as histórias são relembradas pelas pessoas (como totalidades, e não em sequências rígidas), elas podem subverter a ordem "natural" do tempo, pois quem lembra o faz de trás para frente, de frente para trás, em partes e recapitulações, e assim por diante, pois é a totalidade da história e seu nexo que estão na mente de quem lembra, e não a sequência na qual os acontecimentos ocorrem na narrativa original. Essa totalidade pode ser (e é constantemente) evocada em pequenos segmentos - ou fragmentos - que guardam o significado da história integral. Deste modo, o autor conclui que o enredo estabelece a ação humana não apenas dentro do tempo da história, mas também no tempo da recordação. Neste caso, então, o aspecto central da narrativa é a temporalidade, que elucida as formas de representação humana do tempo em toda a sua complexidade, e as maneiras com que as pessoas organizam o seu mundo ao recontá-lo umas às outras.

Sendo a narrativa um reflexo da experiência vivida, as melhores histórias escritas são aquelas que menos se distinguem da história oral, diz Benjamin em seu famoso ensaio sobre "o narrador" (1994, p. 198). Vem daí a sua natureza quase

\footnotetext{
${ }^{24}$ No original, em inglês: "Through its recitation, a story is incorporated into a community which it gathers together". Tradução da autora.
} 
utilitária, motivo pelo qual a narrativa sempre traz embutido no enredo um ensinamento moral, uma advertência, um conselho prático, ou uma norma de vida. Esse conhecimento vivido - a matéria-prima da narrativa - tem um nome, segundo Benjamin: "sabedoria", que é para ele "o lado épico da verdade". Épica é também a poesia que, como a narrativa, abarca a tradição oral, que só existe enquanto experiência compartilhada. Tanto a poesia épica como a narrativa têm como antítese o romance, cuja origem "é o indivíduo isolado, que não pode mais falar exemplarmente sobre suas preocupações mais importantes, e que não recebe conselhos nem sabe dá-los" (1994, p. 201).

A sabedoria contida na narrativa não reflete a experiência de vida do narrador, embora possa incluí-la. Como explica o autor, trata-se de um saber que vem de longe, "do longe espacial das terras estranhas, ou do longe temporal contido na tradição". Apropriar-se desse saber e conservá-lo pela narrativa é tarefa do narrador e de seu ouvinte, pois "o importante é assegurar a possibilidade da reprodução", o que faz da memória "a mais épica de todas as faculdades" (1994, p. 210). A relação entre memória, poesia épica e narrativa é representada pelo autor na ideia de "reminiscência", que inspira tanto a escrita da história como da tradição, "que transmite os acontecimentos de geração em geração". E é a reminiscência que tece a rede que articula todas as histórias, umas nas outras, através da figura "épica" do narrador, que "imagina uma nova história em cada passagem da história que está contando" (1994, p. 211). Neste caso, então, o aspecto essencial da narrativa é a figura do narrador e sua missão de levar adiante um saber que diz para o outro quem ele é e qual o sentido da existência.

\subsubsection{A interpretação da narrativa}

Expus acima alguns trechos dos textos que me ajudaram a pensar nas histórias da imigração japonesa, do Bunkyo e da comunidade nipo-brasileira como narrativas integradas. Procurei conhecê-las por meio de uma abordagem hermenêutica que indica os possíveis significados das falas, textos e ações dos personagens, isoladamente e em conjunto, e também da Antropologia interpretativa, que proporcionou a identificação dos valores éticos, estéticos e morais, além de outros aspectos culturais presentes nos 
ritos, eventos e composições de ambientes onde se realizam os atos narrativos e deles fazem parte.

A escolha do método interpretativo foi imposta pelo próprio objeto, que se revelou - pelo menos para mim, que o concebi - como vasto e variado demais para ser analisado a partir de apenas um de seus aspectos, e muito dinâmico na maneira com que suas partes interagem, para deixar de lado a relação entre os elementos que fazem parte do processo produtor de sentido. Como lembra Bruner, os significados de cada parte de uma história revelam o "todo", ao mesmo tempo em que o "todo" da história depende dos significados de cada uma de suas partes, por isso "a interpretação da história parece irremediavelmente hermenêutica" (2001, p.132). Essas tentativas de compreensão, porém, não esgotam as possibilidades alternativas de interpretação, e não há um "método empírico" que possibilite verificar se uma determinada leitura é a mais correta, motivo pelo qual, segundo Bruner, o objetivo da análise de narrativa não tem como oferecer mais do que "uma explicação convincente e não contraditória" dos seus significados.

Importante lembrar, por fim, que os textos submetidos à análise de narrativa nesta pesquisa correspondem a um conceito amplo de "texto", que Lindlof (1995) define como qualquer objeto de estudo (um ritual, canção, artefato, artigo impresso ou on-line, etc.) que represente "um conjunto coerente de significantes" (1995, p. 51). Assim, não apenas as notícias, histórias e falas são consideradas "textos" para fins de análise, mas também os espaços, objetos, montagens, rituais e imagens, cujos significados são interpretados nos seus próprios termos, à medida que ocorrem e na sua “inteireza", e também em relação ao contexto que os integra e lhes dá sentido.

As referências recíprocas entre os textos e a relação entre seus significados, como lembra o autor, revelam uma dinâmica de "intertextualidade" em que "a produção e uso de um texto depende da combinação criativa de partes de outros textos" (1995, p.52), o que determina a indispensabilidade de cada "texto" - no seu sentido amplo - e que faz dele uma parte essencial da totalidade que se procura reconstituir e entender. Esse objeto de estudo integra, portanto, as biografias e histórias que lhe conferem sentido, percepções do Brasil e do Japão, do passado e do presente, as figuras de destaque na comunidade que recebem prêmios e honrarias, as festas e solenidades, e também as montagens do edifício-sede do Bunkyo e do Museu Histórico da Imigração 
Japonesa, que nesse contexto não são observadas em uma abordagem museológica ou historiográfica, mas como lugar de memória.

Esses textos, isoladamente, têm significados restritos - aparentemente até irrelevantes -, mas, no conjunto, compõem o universo particular da comunidade nipobrasileira, segundo o Bunkyo. O método de análise de narrativa montado para realizar os objetivos desta tese expressa os recursos teóricos utilizados na composição das perguntas e hipóteses que orientaram todo o trabalho de pesquisa, e também na escolha das técnicas de coleta e descrição, conforme já mencionado. Os aspectos levantados por Jerome Bruner (2001) em A Interpretação Narrativa da Realidade e por Luiz Gonzaga Motta (2005) em A Análise Pragmática da Narrativa Jornalística são as duas referências principais do modelo de análise de narrativa montado por mim, a partir das necessidades específicas do meu objeto.

Foram principalmente importantes a abordagem de Bruner sobre "os elementos universais da construção narrativa dos fatos", que dá a eles sentido, ordem e coerência (2001, p.129), e a de Motta sobre o estudo das narrativas como uma "forma de análise e um campo de estudo antropológico porque remete à cultura da sociedade e não apenas às suas expressões ficcionais" (2005, p.3). A seleção das histórias, ambientes e eventos que são analisados baseou-se na minha própria percepção da relação entre eles, o que não é um processo arbitrário (pois utilizo metodologia para constituição e análise do meu objeto), mas é inevitavelmente subjetivo.

Como diz Motta, a reconstituição do enredo (que ele prefere chamar de "intriga") é um passo indutivo, que "se constitui em uma apropriação analítica do objeto", já que ao recompor a história, o analista "privilegia certos elementos da sua composição" (2005, p.5). Cada texto selecionado é analisado separadamente, na sua totalidade específica, na busca do enredo de cada um deles, e de seus pontos de contato com uma narrativa maior, a ser reconstituída no final da análise. Alguns desses textos são notícias publicadas no site do Bunkyo que isoladamente parecem fragmentos, mas que colocadas em contexto se "encaixam" a outras narrativas "em um enredo coerente", e o que "antes parecia desconectado vai ganhando continuidade e coesão", fazendo surgir "uma nova intriga complexa que confere ao objeto outra significação" (MOTTA, 2005, p.5). O enredo complexo, neste caso - a narrativa principal do Bunkyo em relação à identidade, à cultura e à comunidade nipo-brasileiras - é o produto final da análise. 
Dito isto, descrevo abaixo os procedimentos da análise de narrativa desenvolvidos na tese.

\subsubsection{A aplicação do método da análise de narrativa}

Seguindo as sugestões de Motta (2005) e Bruner (2001), são procurados no enredo de cada narrativa seus "elementos estruturantes", como as sequências (ou outros indicadores de temporalidade, como exemplifico abaixo), o conflito ou "problema" (formas de ruptura e desequilíbrio das situações narradas), os episódios (conjuntos de ações e situações que indicam as transformações ao longo da história), os personagens (e suas funções específicas na história), os cenários (composição e características dos lugares onde as histórias acontecem), os recursos de linguagem utilizados para a produção de "efeitos de real" (palavras, figuras e citações que conferem veracidade, rigor, precisão; autoridade das fontes; imagens que "comprovam" os fatos, etc.) e "efeitos de sentido" (recursos de linguagem que encorajam estados emocionais e uma troca afetiva entre narrador e público), o "foco narrativo" (quem narra: um narrador oculto ou alguém que se identifica ao narrar), e a fábula (a moral da história, ou os valores éticos que guiam a narrativa ou que ela "ensina").

Quanto à temporalidade, sendo esta uma coletânea de histórias contadas por pessoas que se consideram parte delas (a tradição da qual o próprio narrador faz parte, como lembrava Benjamin), e que têm na memória e no senso comunitário tanto os enredos quanto a motivação para contá-las, as representações do tempo estão no centro do "paradigma narrativo" que inspira as indagações levantadas pela pesquisa. Embora várias histórias que analiso tenham ocorrido em uma sequência cronológica - o navio Kasato Maru trouxe as primeiras levas de imigrantes, que foram para fazendas de café onde enfrentaram adversidades, depois foram para colônias e muitos trocaram, quando puderam, o campo pelas cidades, etc. -, as narrativas não estão presas à estrutura do tempo linear, pois, assim como a memória, elas podem intercalar os eventos, relatar em flashback, suprimir partes que depois retornam, etc., de acordo com a lógica inerente às recomposições dos fatos, cujas possibilidades são infinitas e ligadas às conveniências do momento. 
A temporalidade da narrativa também pode conter simultaneamente várias camadas de tempo, como ocorre no Museu Histórico da Imigração Japonesa, onde montagens que reúnem objetos, textos e imagens compartilham os espaços com outras de épocas diversas. Também os eventos, festivais e textos publicados nas mídias do Bunkyo justapõem partes de narrativas de tempos diferentes que seguem paralelas ou se encontram em algum ponto comum que lhes dá unidade. A temporalidade, portanto, é aspecto presente em todas as narrativas, mas não necessariamente na forma sequencial, que é apenas uma de suas possibilidades, como lembra Ricoeur. E quanto aos acontecimentos, às funções dos personagens e outros aspectos que envolvem eventos históricos e outros elementos factuais da narrativa, não é a veracidade ou grau de fidedignidade quanto à História oficial que importa para a minha análise, pois, como diz Motta, “nosso objeto é a versão, não a história” (2005, p.7).

Quanto ao gênero das narrativas, embora alguns autores não o considerem um atributo do texto em si, mas da maneira como os textos são classificados em relação uns aos outros, e ao contexto histórico e social de quem classifica (MITTEL, 2013), ele também pode ser atribuído ao texto - como uma forma convencional de contar e como um tipo de "representação" do mundo (BRUNER, 2001). Seja como for, os rótulos genéricos podem ser contestados e até subvertidos, já que uma narrativa pode ser contada e interpretada de várias maneiras. No que se refere às histórias da imigração, considerei algumas delas como pertencentes ao gênero épico, pela exaltação dos feitos heroicos dos pioneiros e dos sacrifícios que enfrentaram valendo-se apenas das "virtudes japonesas" (sendo elas determinação, coragem, perseverança e solidariedade, entre outras).

Da mesma forma, narrativas mais recentes remetem a valores semelhantes, como é o caso da história que relata uma exposição de Ikebana, no Bunkyo, cujo tema é tsumugu, palavra que no idioma japonês significa "fiar", e que reporta à ideia de "produzir algo com dedicação e paciência”, o que neste contexto se refere à "dedicação incessante de nossas alunas no caminho do 'kadô' (arranjos florais)",25. Ou seja, as alunas de Ikebana não estão simplesmente aprendendo a fazer buquês de flores, mas a trilhar um caminho que exige não só uma técnica, mas uma determinada atitude que diz respeito ao universo de valores morais do Japão tradicional, trazidos pelos imigrantes.

\footnotetext{
25 Texto de uma notícia publicada no site do Bunkyo, em 28 de setembro de 2017. Ver em: http://www.Bunkyo.org.br/pt-BR/noticias/157-2017/1304-exposicao-hana-wo-mederu, acesso em $17 / 11 / 2017$.
} 
Acontecimentos que ocorrem nas histórias, como desastres naturais, doenças, acidentes, perseguições e outras tragédias ou adversidades são o "contexto" e os fatores desencadeantes das ações dos protagonistas, que reagem com heroísmo, coragem, patriotismo, lealdade, senso de justiça, esforço, compaixão, resignação, paciência, discernimento, persistência e que revelam o que Bruner chama de "estados intencionais" dos personagens. A busca da narrativa, portanto, é pelas motivações que estão "por trás" das ações, as opções que foram feitas e o preço que foi pago por elas, pois o que importa, na história, não são as causas que produziram determinado efeito, mas os motivos que levam as pessoas a fazerem o que fazem.

Além das motivações, Bruner pondera que a interpretação dessas "realidades narradas" leva à indagação do por que uma história é narrada "desta" forma, e por "este narrador". A voz do narrador, assim como sua motivação - e dos personagens das histórias - são partes inerentes dos significados da narrativa, mesmo quando a voz está oculta e as motivações estão só subentendidas. Essa identificação do narrador é o que Motta chama de "foco narrativo". Como guardião do legado dos ancestrais e representante da comunidade nipo-brasileira, prestigiado pelas autoridades civis e imperiais do Japão, o Bunkyo exerce o direito e o dever de narrar as histórias dos imigrantes e de seus descendentes construindo-se como algo que transcende tanto as falas quanto as motivações de suas lideranças, pois o Bunkyo é uma missão, uma ideia maior - e mais longeva - do que os homens e mulheres que o dirigem temporariamente. Assim, minha análise tentou identificar as maneiras com que a voz e a motivação dessa entidade abstrata que é o Bunkyo se manifestam na narrativa. E como a narrativa, em si, o transforma ora em entidade abstrata e transcendente, ora na casa dos nikkeis e de todas as pessoas que estão ali porque amam a cultura japonesa.

Quanto ao "problema", ele se constrói como o centro da narrativa, sendo causado, como lembra Bruner, quase sempre por normas violadas ou por algum desequilíbrio na situação original dos personagens. Na compreensão do problema, porém, a análise da narrativa não deve levar em conta somente "aquilo que acontece", mas principalmente os aspectos de um drama que se tornou "epistemológico", como diz Bruner, no sentido de que os problemas "não existem apenas em um desencontro entre uma protagonista e seu ambiente, mas também na luta da protagonista para interpretar este ambiente" (2001, p.136). Os problemas em torno dos quais giram as primeiras narrativas reproduzidas pelo Bunkyo resultam de desequilíbrios de ordem econômica, 
política e social que levaram à saída dos imigrantes japoneses de sua terra natal, para onde planejavam voltar em poucos anos, e nos novos desequilíbrios que atrapalharam os planos de retorno ao Japão, obrigando os japoneses a abandoná-los definitivamente.

Outros "desequilíbrios", como a perseguição aos súditos do Eixo durante a Segunda Guerra, os conflitos que dividiram a comunidade entre "vitoristas" e "derrotistas" no pós-guerra, a dispersão da comunidade nos centros urbanos e, mais recentemente, as dificuldades financeiras que levaram os "decasséguis" a trilharem o mesmo caminho de seus ancestrais - mas no sentido oposto -, geraram novos problemas mantendo viva essa história, que não se esgota no acontecimento em si, mas se aprofunda com as tentativas dos protagonistas em interpretar esses eventos e a repercussão deles em suas vidas, dando a eles sentido e fazendo julgamentos de valor.

Quanto à dinâmica das histórias que se mantêm vivas através dos tempos, Bruner postula que há uma tendência humana de ver a continuidade, e mesmo uma causalidade entre as histórias, cujos detalhes parecem "advirem uns dos outros". Assim, em vez de histórias autônomas, narradas cada uma sobre sua própria base, o que temos são enredos, personagens e contextos que "parecem continuar a se expandir". Essas histórias continuadas, que giram em torno de "um panteão eterno de deuses" apesar das mudanças de contexto, seriam uma tentativa humana de impor "coerência sobre o passado". Essa "expansibilidade da história" é possível graças à percepção de que há certos "pontos decisivos de mudança", momentos-chave em que algo novo acontece e substitui o antigo, dando continuidade à narrativa (2005, p. 137-138).

Uma observação do "breve histórico" da seção "quem somos", no site do Bunkyo, permite que se conheçam alguns desses momentos decisivos em que acontecimentos especiais deflagram mudanças na vida da comunidade e do Bunkyo, na perspectiva da própria entidade. A sequência de fotografias dos presidentes do Bunkyo na sala da diretoria - que não chega a ser um "panteão de deuses", mas é certamente um "panteão de ilustres" colocados ali para serem lembrados e para inspirar o presente e o futuro - também traça uma linha do tempo que une personagens e enredos, em uma história continuada que dá coerência à narrativa da comunidade nipo-brasileira. É no Museu, no entanto, que o esforço máximo de constituição da saga dos japoneses no Brasil é realizado, cujo marco simbólico inicial é o Kasato Maru, e cujo "final" continua em expansão, com as histórias dos decasséguis e de sua complicada adaptação no Japão e problemático retorno ao Brasil, entre muitas outras histórias. 
E quanto aos espaços em que as histórias são contadas, lembro que para Martino (2016) o ato de narrar constrói o "ambiente narrativo", que une narradores e seus públicos, graças aos referenciais comuns que promovem e reforçam os laços de pertencimento à comunidade. Como pretendi demonstrar na minha análise de narrativa, esses espaços não são necessariamente físicos, mas são sempre simbólicos. Com o fim das antigas colônias, que eram o espaço físico da comunidade nipo-brasileira, essas localidades e as trajetórias percorridas por seus personagens são substituídas pelos espaços dos textos, das falas, dos rituais e das montagens, ou seja, os novos ambientes narrativos onde a comunidade "se reúne" (física ou virtualmente) e as histórias são compartilhadas. 


\section{Capítulo 2 - O Japão e os japoneses do Brasil}

\section{O Japão na era da globalização}

A imigração japonesa não foi um fenômeno em si mesmo, motivado apenas por razões domésticas, e nem um movimento espontâneo, largado à própria sorte, sob o olhar indiferente do governo, como ocorreu em outros países da Ásia que também tiveram uma intensa emigração de seus cidadãos no final do século XIX e começo (até meados) do século XX. Mesmo as primeiras levas - de homens jovens e solteiros para o Reino do Havaí - foram observadas de perto pelo novo regime japonês, que, desde 1868, com o fim do xogunato e a restauração do poder imperial, praticava mudanças estruturais no país. As levas seguintes - mais organizadas, e formadas por famílias selecionadas em suas províncias de origem - já faziam parte de um "projeto de emigração tutelado pelo Estado" (SAKURAI, 1998), que, se por um lado procurava atender às necessidades impostas pela nova conjuntura nacional, por outro agia de forma a adequar-se às fortes pressões vindas do exterior.

Como veremos neste capítulo, a inserção do Japão no mundo globalizado foi, de fato, acelerada pela intervenção direta de uma potência estrangeira. Mas isto não significa que a política interna já não estivesse há tempos sendo articulada em direção às grandes transformações que haveriam de tirar o Japão do isolamento imposto pelo xogunato desde o início do século XVII. Embora esse isolamento nunca tenha conseguido ser absoluto, ele foi restritivo o suficiente para irritar os estrangeiros impedidos de chegar aos portos japoneses ${ }^{26}$, sobretudo depois que a Revolução Industrial, na Europa e na América do Norte, inaugurara uma nova fase do capitalismo mundial, mais do que nunca ávido por mercados, mão de obra e matérias-primas.

A situação interna no Japão, logo após as modernizações realizadas com o intuito de viabilizar a participação do país no mercado internacional, atingiu em cheio a classe trabalhadora rural. Os que eram donos de pequenas porções de terra tiveram problemas para se adaptar à nova política tributária, com o pagamento de impostos agora em dinheiro e não mais em produtos. E um fator cultural também complicava a

\footnotetext{
${ }^{26}$ Durante a Era Tokugawa (1603-1868), somente navios holandeses e chineses tinham permissão de atracar no Japão, mesmo assim sob rígido controle, e apenas no porto de Nagasaki.
} 
situação de um expressivo contingente de pessoas no campo: na organização tradicional da família rural japonesa, o direito da primogenitura deixava os demais filhos sem nada a herdar. Como explica Hashimoto (2012), o $I e^{27}$ era a unidade familiar tradicional japonesa - cuja origem data do século XIII - e também um sistema básico de unidade produtiva:

...supunha não só a residência comum, sob a autoridade do pai, mas também a divisão dos papéis que cabiam a cada membro da família, segundo critérios de gênero e de idade: as mulheres e os mais jovens ocupavam uma posição inferior e deviam acatar com benevolência e lealdade, as relações hierárquicas e suas respectivas responsabilidades, virtudes pregadas pelo confucionismo. O primogênito (chônan), como futuro chefe da família, recebia, desde cedo, um tratamento diferenciado, para poder assumir a responsabilidade de prover o sustento material da família e cumprir as obrigações filiais de cuidar e zelar pelo bem estar dos pais. O direito consuetudinário confere ao primogênito o direito à herança familiar (2012, p. 81).

Uma família extensa, então, com tributos a pagar e a produção quase sempre insuficiente, não tinha como manter a todos em suas pequenas propriedades, e, com isso, os irmãos mais novos, com suas esposas e filhos, é que tinham que partir. $\mathrm{O}$ deslocamento de trabalhadores rurais no Japão não teve início com a modernização da Era Meiji ${ }^{28}$, mas com certeza o novo sistema gerou um contingente muito maior de pessoas que perderam suas terras para pagar dívidas tributárias, ou porque tiveram que deixar as famílias extensas, que migraram em massa para as cidades e, quando não mais puderam ser absorvidos por elas, passaram a ver a emigração como única saída. O capitalismo internacional, em meados do século XIX, embora muito longe ainda do nível de intensidade e velocidade dos fluxos de interação que haveria de atingir a partir do século seguinte, já havia gerado, em locais-chave, condições de produção que expulsavam de um lugar grandes massas humanas ao mesmo tempo em que as absorviam em outro.

Situações econômicas, políticas e sociais específicas, tanto nos países de origem dos emigrantes como nas nações de destino, determinaram as formas de deslocamento e também os planos de futuro daqueles que partiram, quanto à permanência na nova terra

\footnotetext{
27 "O termo ie significa lar, casa, moradia, habitação, família, residência e linhagem" (HASHIMOTO, nota de rodapé, p.81).

${ }^{28}$ Relativo ao período de governo do Imperador Meiji (1968-1912), que marcou o fim do xogunato e o retorno da figura do imperador como centro do poder no Japão.
} 
ou ao retorno à terra natal. O grande número de cidadãos japoneses que deixaram o país em direção a vários países das Américas e Sudeste Asiático desde a segunda metade do século XIX até o pós-guerra, certamente inscreveram o Japão na história mundial das grandes diásporas, ou seja, dos deslocamentos de milhares de pessoas que, a partir de um ponto comum, se dispersaram pelos diversos cantos do mundo onde se estabeleceram e reinventaram as suas próprias culturas.

\section{A diáspora japonesa}

Em seu estudo sobre a diáspora japonesa, Adachi (2006) reflete sobre a adequação do conceito de diáspora para abarcar a diversidade de experiências e de grupos de pessoas que deixaram o Japão, em épocas, rotas e circunstâncias tão diferentes. Embora o conceito de diáspora tenha sua própria história - cuja origem remonta à antiguidade grega e ao seu significado bíblico de "dispersão" do povo israelita -, sua utilização hoje nos estudos de globalização e imigração tem foco nos aspectos sociais, políticos e econômicos que motivam o deslocamento de populações que deixam seus países de origem, muitas vezes sem caminho de volta, e se estabelecem em outras regiões, impactando os países receptores e a si próprios, como comunidades diaspóricas, de várias maneiras. Mas além das condições históricas que motivaram a emigração dessas populações, a autora ressalta a importância de se levar em conta também a historicidade de cada uma dessas experiências nos países de destino, quanto às condições de marginalização social, política e econômica a que são submetidas, e, com igual importância, a natureza da identidade cultural que constroem com base em suas percepções da terra natal imaginada (2006, p.4).

Além dos fatores históricos que determinaram as razões e as condições que pesaram no momento de decisão dos emigrantes, há também as formas como essas histórias são percebidas e narradas, tanto pelos descendentes, que vêm os fatos "pelas lentes das gerações anteriores de imigrantes", como pelas sociedades que os receberam, que muitas vezes têm "o poder de impor uma visão privilegiada dos eventos históricos". Aquelas que se consideram, então, "as experiências compartilhadas” dos emigrantes de diferentes épocas e lugares, têm na verdade, segundo a autora, uma dinâmica interna que as coloca em permanente "estado de fluxo", ou seja, embora os fatos em si não 
mudem, a percepção deles e de seus significados estão em constante movimento de "expansão e contração" (ADACHI, 2006, p. 6).

Stuart Hall (2016), por outro lado, pondera que, apesar das especificidades históricas de cada caso, os grupos que migram - desde o início do processo de globalização até suas fases mais recentes - são diaspóricos no sentido de que estão em relação de "disseminação na dialética centro/periferia, colônia/metrópole", sendo por isso "sociedades de deslocamento e disjunção, separadas no tempo e no espaço de qualquer coisa que possa ser chamada de - ou construída como - seu lugar de origem" (2016, p.48). Esses grupos diaspóricos também têm, segundo o autor, a característica comum de terem suas histórias marcadas por "rupturas violentas e abruptas". Embora a imigração japonesa não tenha sido forçada, como no caso dos africanos escravizados a que Hall se refere, é preciso lembrar que na maioria dos casos a única alternativa a que os japoneses tinham acesso era permanecer na pobreza e com o futuro comprometido, já que não tinham terra nem trabalho. $\mathrm{E}$ os processos de adaptação a que foram submetidos, se não foram sempre violentos, com certeza foram abruptos e produziram rupturas violentas na estrutura das famílias e de seus modos de vida.

Portanto, apesar das limitações do conceito de diáspora para dar conta da diversidade e instabilidade inerentes aos grupos humanos que em diferentes momentos históricos deixaram sua terra natal com motivações diversas, mas sempre premidas pela necessidade de ir e pela impossibilidade de voltar, o seu uso como "construto teórico e ferramenta analítica" tem sido produtivo para a compreensão das circunstâncias históricas que desencadearam, no Japão, os grandes deslocamentos de pessoas em direção a diferentes partes do mundo. E tem sido útil também no entendimento das variadas estratégias de adaptação e integração às condições locais, de construção de sua cidadania e, ao mesmo tempo, de manutenção, em graus e significados variados, dos laços com a nação dos seus ancestrais. Adachi sugere ainda que os estudos da "diáspora japonesa" explorem o dinamismo dos registros sobre as experiências dos imigrantes e de seus descendentes espalhados pelo mundo, as formas híbridas que resultaram dos seus encontros interculturais, e como são recebidos, no Japão de hoje, os descendentes que "retornam" como mão de obra temporária à terra natal de seus ancestrais.

Mas para chegar a esse ponto - e às questões específicas a que esta tese se dedica - é preciso pegar uma ponta do fio dessa história e desenrolar o novelo para ver aonde ele nos leva. 


\section{A modernização do Japão e o seu custo}

Antes da abertura forçada dos seus portos ao Ocidente, por uma armada dos Estados Unidos em 1853, e da grande diáspora que inicia com os 153 primeiros emigrantes chegando em 1868 ao Reino do Havaí, o Japão tinha fama de ser uma nação literalmente "ilhada", ou seja, além da sua condição geográfica insular, estava política e comercialmente isolado do resto do mundo. Mas apesar da política de fechamento praticada de fato durante a Era Tokugawa ${ }^{29}$, que perdurou por mais de dois séculos, o processo de inclusão do país no panorama das inter-relações globais ${ }^{30}$ tem início muito antes disso tudo.

O Japão nunca deixou de ter algum contato com o mundo de fora, sobretudo por meio do comércio e intercâmbio cultural com China e Coreia, desde o século VI, e com outras nações próximas da Ásia e do Pacífico. A presença de europeus no Japão foi inaugurada pelos portugueses no início da década de 1540, que foram seguidos por espanhóis e ingleses. Mesmo depois da expulsão de todos os comerciantes estrangeiros, em 1639, navios holandeses continuaram a frequentar regularmente algumas cidades portuárias japonesas, ainda que sob estrito controle do regime.

Apesar de já estar preparando o país, aos poucos, para as grandes transformações que haveriam de acontecer mais tarde, esse contato com o mundo exterior não impediu, porém, que o regime feudal conseguisse excluir a maior parte da população camponesa da propriedade da terra e das oportunidades de ascensão social. A derrocada do xogunato e a radical modernização desencadeada na Era Meiji levaram esperança aos agricultores, com o fim dos grilhões que os prendiam aos senhores feudais e com a atribuição de direitos, como a permissão de comprar terras e de mandar os filhos para a escola $^{31}$. Mas com o direito de propriedade, vieram também a nova economia monetária e a legislação de taxação da terra, inspiradas nos modelos ocidentais, que foram um dos fatores desencadeadores do grande êxodo de trabalhadores rurais, primeiro em direção

\footnotetext{
${ }^{29}$ Tokugawa Ieyasu foi o primeiro xogun da família que governou o Japão de 1603 a 1868.

${ }^{30}$ Esse processo de contato econômico e cultural entre os povos do mundo, desde a Antiguidade, não se confunde, entretanto, com a definição de "globalização", conforme mencionado na Introdução desta tese, que se refere ao processo de interdependência entre as nações motivada pelo novo capitalismo financeiro (MARTÍN-BARBERO, 2009).

${ }^{31}$ A educação básica obrigatória, por um mínimo de quatro anos, foi instituída na Era Meiji seguindo o modelo dos países ocidentais. Se por um lado pode ser vista como um direito e uma oportunidade de ascensão social, por outro foi mais um fardo sobre os contribuintes, a maior parte do meio rural, que arcou com os custos da modernização (MASTERSON, 2004, p.8).
} 
às cidades e a outras regiões do país, e depois ao ultramar, dando início assim à diáspora japonesa.

Uma boa parte dessas imensas massas rurais deslocadas participou do projeto de colonização da ilha - até então praticamente desabitada - de Hokkaido, situada ao norte do arquipélago japonês e de "grande importância estratégica" para o novo governo, pela proximidade com a Rússia e a China (SAKURAI, 2007, p. 236). A ocupação de territórios na Coreia, Taiwan e Manchúria pelo Japão - a partir do final do século XIX e primeira década do século XX - também ofereceu oportunidades de relocação dessas populações excedentes do campo, só que agora com um objetivo adicional: o de garantir a presença japonesa nas terras conquistadas pelas forças imperiais. Mesmo com a anexação desses territórios adicionais e a colonização da ilha de Hokkaido (extremamente afetada por invernos rigorosos), um contingente expressivo da população deslocada ainda não tinha como ser absorvido.

A história da diáspora japonesa começa com os primeiros trabalhadores que chegaram ao Havaí em $1868^{32}$. Dez anos depois, o número de emigrantes aumentou rapidamente, agora também em direção aos Estados Unidos e Canadá. Antes da virada do século, cerca de duzentos mil emigrantes já tinham deixado o Japão em direção à América do Norte. Políticas racistas e um alegado receio do "perigo amarelo"33 motivado pela ascensão do poderio militar do Japão, com sua vitória nas guerras contra a China e a Rússia - fecharam o acesso de emigrantes japoneses à América do Norte, em 1908. Assim, a América Latina, que era até então o segundo destino mais importante de emigração, passou a ser a primeira opção ${ }^{34}$. Mesmo na ausência de uma tradição diplomática entre os países latino-americanos e o Japão, vários acordos foram firmados na primeira década do século XX, com grande empenho do governo japonês.

Masterson (2004) pondera que a Era Meiji inaugurou o expansionismo e a busca da imagem de potência mundial, o que motivou o governo a negociar tratados do interesse desses países, mas que incluíssem uma política de imigração favorável aos japoneses. Com isso, o país não correria o risco de ter "seu prestígio arruinado pelo mau

\footnotetext{
${ }^{32}$ Os 150 anos da emigração japonesa, e também da Restauração Meiji, serão comemorados no Havaí em 2018 com festividades promovidas pelo governo japonês com a promessa de presença de um membro da família imperial.

${ }^{33}$ Dezem argumenta que o "perigo amarelo" também incluía uma referência à questão da concorrência trabalhista, ou seja, o japonês também era uma ameaça por ser um imigrante "tão bom e eficiente" (2005, p. 182).

${ }^{34}$ A terceira área principal da diáspora ultramarina é o Sudeste Asiático (MASTERSON, 2004, p. 11)
} 
tratamento ou exclusão de seus imigrantes"35 (2004, p. 13). Assim, a proteção ao emigrante japonês foi regulamentada por decreto imperial em 1894, tornando-se lei dois anos depois. Com as medidas, o governo japonês pretendia não apenas proteger os emigrantes "de intermediários mal-intencionados" como também evitar um tipo de recrutamento de emigrantes que poderiam causar problemas que representariam a "perda da dignidade nacional" e até um "certo mal-estar diplomático"36.

A intervenção direta do governo, criando ou fiscalizando companhias especializadas para acompanhar a seleção, transporte e acomodação dos emigrantes japoneses nos países de destino, contrasta com o recrutamento em outros países da Ásia, como China, Índia e Filipinas, sem praticamente nenhuma política governamental de emigração, o que havia resultado em um tráfico de trabalhadores submetidos a trabalho escravo $^{37}$. Já no Japão, uma mudança na lei de proteção ao emigrante, de 1907, permitia até mesmo que empresas que tivessem o capital necessário comprassem e administrassem terras nos países hospedeiros para o assentamento dos trabalhadores japoneses, a quem, mais tarde, os lotes seriam vendidos.

No site da Biblioteca do Parlamento Japonês que celebra os cem anos de imigração japonesa no Brasil, é explicado que a compra de terras no exterior por empresas japonesas "nunca significou apoio, por parte do governo, à emigração de caráter colonizador", mas apenas "a intenção de coordenar as atividades das empresas e proteger os emigrantes" ${ }^{, 3}$. Essa observação é uma referência (apenas sugerida) à suspeita, disseminada entre os países que receberam, na época, imigrantes japoneses, de que eles seriam "enviados" do governo japonês para preparar o terreno para futuras invasões, o que está entre os motivos, durante a Segunda Guerra, do confinamento de imigrantes japoneses em campos de internamento nos Estados Unidos e até no Brasil (PERAZZO, 2009). Mesmo antes da guerra, essa presença marcante do governo japonês por meio de instituições de apoio aos seus cidadãos no exterior fez com que muitos achassem que o Japão tinha planos de introduzir nos países em que imigrantes japoneses

\footnotetext{
${ }^{35}$ No original, em inglês: “[...] Tokyo did not want its prestige undermined by the poor treatment or exclusion of its immigrants". (Ibid. p.13) Tradução da autora.

${ }^{36}$ Ver Cap. 1, "Os anos que precederam a imigração", em: http://www.ndl.go.jp/brasil/pt/s1/s1_2.html acesso em 02/02/2017.

37 A China tentou impedir o tráfico de seus cidadãos (conhecidos como coolies, um termo depreciativo referente a trabalhadores não especializados originários da China, Índia e outros países asiáticos), mas tornando-se o "epicentro" de vários conflitos que envolviam potências europeias, o país se transformou no início do século 20 "no que poderíamos chamar de "rebotalho de nação"” (DEZEM, 2005 p.150).

${ }^{38}$ Ibidem.
} 
se estabeleceram esquemas de colonização semelhantes aos da Coreia e da Manchúria (SAKURAI, 2007, p.252).

\section{As reformas e sua ideologia}

Quando a esquadra americana comandada pelo comodoro Matthew Calbraith Perry aportou na baía de $\operatorname{Edo}^{39}$ no dia 8 de julho de 1853, não deu a ninguém a impressão de que se tratava apenas de enviados do governo dos Estados Unidos com a mera intenção de "negociar" com as autoridades japonesas a abertura de seus portos ao comércio internacional. A exibição da força naval norte-americana fazia parte, como sustenta Kitahara (1986), de um ato típico da "dramaturgia do poder", em que a encenação dos termos de desigualdade entre as partes já definia por antecipação o resultado do encontro. Ou seja, o Japão não tinha mais a opção de permanecer de fora do grande jogo de interesses que já mantinha forte presença ocidental na Ásia desde o século XVII, e que se acentuara em tempos recentes, como é o caso, por exemplo, do episódio da Guerra do Ópio, em que a Inglaterra impôs humilhante derrota à China ${ }^{40}$.

Esse encontro radical com a evidente superioridade militar do Ocidente, em vez de provocar receio e encolhimento diante do poder do "inimigo", teve o efeito contrário de inspirar as lideranças japonesas a buscar rapidamente a modernização do país, para que os conhecimentos científicos e tecnológicos a serem adquiridos pudessem colocar o Japão em pé de igualdade com as potências europeias e norte-americanas. Essas ideias que já se articulavam antes mesmo da chegada de Perry - finalmente se tornaram hegemônicas e determinaram a queda definitiva do xogunato.

Como lembra Sakurai (2007), os movimentos por mudanças tiveram a participação não só de lideranças políticas e econômicas favoráveis à abertura ao exterior, mas também de líderes religiosos budistas que buscavam novos espaços para expandir, e de xintoístas, que pregavam a assimilação dos avanços tecnológicos para

\footnotetext{
39 Antigo nome da capital, Tóquio.

${ }^{40}$ As Guerras do Ópio (1939-1842 e 1856-1860) foram travadas na China para obrigar o governo imperial a permitir o tráfico irrestrito da droga pelas potências ocidentais, em especial a Inglaterra. À medida que as hostilidades foram se desenrolando, porém, foi ficando claro que o que estava em jogo era muito mais do que o ópio, mas os interesses da Europa na região. Ver em: PERDUE, P. The First Opium War. Cambridge: $\quad$ MIT, 2010. Disponível em: https://ocw.mit.edu/ans7870/21f/21f.027/opium_wars_01/ow1_essay.pdf. Acesso em 10/03/2017.
} 
consolidar a "superioridade inerente" do povo japonês. E quanto ao povo, "assediado pela fome e por desastres naturais", as mudanças também eram bem-vindas por significarem uma possibilidade de melhoria das condições de vida (2007, p. 131).

Assim, o fim do xogunato representou uma saída político-ideológica que envolvia muito mais do que uma solução pragmática de conciliação de interesses. $\mathrm{O}$ retorno do poder máximo ao imperador foi o restabelecimento de um poder simbólico que esteve, há séculos, ligado à ideia de superioridade do povo japonês, devido à crença na linhagem divina do imperador (o "grande pai") e na ancestralidade comum de todos os japoneses, descendentes distantes de Amaterasu, a deusa-mãe (SAKURAI, 2007, p. 332). Se no passado a autoridade do imperador esteve à sombra do poder real dos xoguns, que conseguiram pacificar o país e unificar os feudos em torno de si, agora era o poder transcendente do imperador que assumiria esse papel unificador, diante de uma pressão potencialmente arrasadora que não mais se revolvia no interior do país, mas se originava no exterior, ou seja, nas nações tecnologicamente superiores do Ocidente.

Masterson (2004) pondera que os ideólogos da nova nação logo perceberam que a modernização radical deveria reter os valores essenciais do Japão tradicional para garantir a estabilidade social. Ruth Benedict (2007) também não teve dúvidas, ao analisar "o caráter japonês" em sua famosa obra $O$ crisântemo e a espada, de que a Restauração Meiji foi extremamente conservadora, no sentido de que as lideranças do movimento mantiveram-se arraigadas às tradições. Apesar das grandes reformas estruturais levadas a cabo, não se cogitou, por exemplo, colocar um fim no hábito da hierarquia, um traço fundamental da cultura japonesa, profundamente instalado nas relações sociais e presente nos sistemas de deferência, na ética e na etiqueta (2007, p.77).

Benedict observa que as mudanças não depuseram a estrutura hierárquica em si, mas "deram-lhes nova localização", recolocando em seu ápice a figura divina do imperador. Com isso, o novo regime poderia reivindicar para si uma legitimidade baseada em sua alegada condição sagrada, ainda que secular na prática. Foi criado, assim, o Xintô de Estado, uma instituição vinculada ao xintoísmo ${ }^{41}$, mas que não se confundia com os seus rituais regulares, que pertenciam a outro departamento, propriamente religioso. O Xintô de Estado tinha sob sua jurisdição o culto que deveria

\footnotetext{
${ }^{41}$ Religião mais antiga do Japão, considerada autóctone.
} 
preservar os símbolos da unidade e da superioridade nacionais, como o emblema imperial, a nova bandeira e o hino nacionais.

A educação compulsória, que os ideólogos da Era Meiji adotaram como parte crucial das medidas modernizantes, foi centralizada pelo Estado, cabendo às municipalidades a sua aplicação, mas não seu planejamento e elaboração. A autora pondera que as transferências constantes dos professores para novos postos de trabalho tiveram por objetivo desenraizá-los de suas referências culturais locais, e também a criação de um material didático que deveria ser aplicado, ao mesmo tempo, em todas as escolas do país. Seu conteúdo - em sintonia com o Xintô de Estado - propagava "a história do Japão desde a era dos deuses e a veneração do Imperador, 'sempiterno governante"' (2007, p.78).

Como lembra Hashimoto (2012), a ausência de trabalho industrial infantil foi um fator determinante para que as crianças fossem direcionadas para o estudo (2012, p. 60). Diferente do que acontecia na Europa, nessa mesma época, com a cooptação massiva do trabalho infantil pela indústria, as crianças japonesas ajudavam apenas no trabalho agrícola, o que não impediu a sua escolarização. A obrigação dos pais de enviar as crianças para a escola incluía as meninas, o que não significou, porém, o fim da visão tradicional quanto ao papel "sublime" da mulher, ou a sua emancipação. Ela deveria continuar com a dedicação exclusiva à formação e cuidado da família (exceto as camponesas, claro, que deveriam fazer de tudo). Em sua pesquisa sobre as primeiras meninas japonesas enviadas aos Estados Unidos para serem educadas nos moldes ocidentais, na década de 1870, Nimura (2015) observa que os ideólogos da Era Meiji pretendiam que as meninas tivessem acesso à educação formal para que quando se tornassem mães, estivessem capacitadas para criar seus filhos para os desafios do Japão moderno. A educação feminina, então, não tinha uma finalidade em si, pois não se esperava que as mulheres se preparassem para o mercado de trabalho, ou para alguma carreira de sua escolha. Além de mães “sábias”, também poderiam se tornar professoras, embora muitas delas, de origem mais humilde, acabassem sendo recrutadas como operárias pela nascente indústria japonesa, ou se tornaram empregadas domésticas nos centros urbanos mais desenvolvidos. 


\section{O "caráter japonês" e a emigração}

A ideia de "caráter japonês" que emergiu durante a Era Meiji, como vimos, foi construída e disseminada através de uma consistente propaganda de Estado que, ao mesmo tempo em que promovia o desmonte e o "apagamento da velha ordem feudal" (Dezem, 2005), buscava nas fontes da tradição os valores necessários para a transformação. Em sua análise do Nihonjinron ${ }^{42}$, Befu (2001) pondera que uma ideia de si próprio como povo singular e de virtudes superiores começa a surgir mais consistentemente entre os intelectuais japoneses a partir do século XVIII, com a consolidação de certos valores neo-confucionistas, que realçava aspectos heroicos da história japonesa ${ }^{43}$ e o papel simbólico do imperador dentro dela. Essas ideias, entretanto, não ficaram confinadas nos círculos das elites, mas foram propagadas por folhetins, canções e peças teatrais populares, atingindo assim camadas mais amplas da população.

Befu compreende a ideologia do Nihonjinron como o conjunto dos valores éticos, estéticos e morais da população japonesa disseminados através dos séculos, por meio de autores de várias épocas, intelectuais ou não, e de mitos e contos populares que difundiram esses valores, transformando-os e adaptando-os a tradições locais. As qualidades "tipicamente japonesas", celebrizadas em expressões como Nihonjin no kokoro (coração do povo japonês) e Yamato damashii (espírito do Japão), são justificadas, segundo o autor, por meio de diversas teses (2001, p.17).

Entre essas teses, há uma "ecológica" que atribui a coesão comunitária e familiar, a arquitetura que privilegia o senso de coletividade em detrimento da privacidade e o temperamento persistente, disciplinado e resignado dos japoneses ao fato de serem afetados anualmente pelas monções, os ventos que trazem a seca e as inundações. Além disso, há também as baixas temperaturas no inverno e ainda os constantes desastres naturais - imprevisíveis, porém frequentes -, como terremotos, erupções vulcânicas e tsunamis, que teriam contribuído para determinar a resiliência e o caráter cooperativo e adaptável do povo japonês.

\footnotetext{
${ }^{42}$ Caráter nacional japonês (BEFU, 2001, p. 2).

${ }^{43}$ Essas "fontes históricas" incluíam o Kojiki (Crônica dos Acontecimentos Antigos), uma compilação de mitos, lendas e narrativas da tradição oral, que data do século VIII, sobre a fundação do Japão desde tempos imemoriais.
} 
Uma outra visão, baseada na "economia de subsistência", atribui ao cultivo do arroz - que demanda trabalho em conjunto para a construção e manutenção de complexo sistema de irrigação e de transplante de mudas - o agudo senso comunitário e corporativista que "chega a ser tirânico", pelo nível de exigência de consenso, conformidade e cooperativismo (2001, p. 19). Befu cita outro aspecto bastante difundido do "caráter japonês", a noção de "honra", associada à classe dos samurais, cujas qualidades típicas - de "coragem e lealdade" - se tornam referência de comportamento para todos os cidadãos.

$\mathrm{O}$ fato de que a maior parte dos emigrantes provinha do meio rural - onde a modernização nos estilos de vida da Era Meiji ainda estava longe de acontecer determinou um perfil do emigrante ligado aos valores tradicionais e emocionalmente apegado à terra natal, com planos de levantar recursos financeiros fora do país e retornar o mais rapidamente possível ao Japão (MASTERSON, 2004 p.5). Os valores tradicionais levados na bagagem incluíam as técnicas agrícolas e o tipo de organização familiar a que os emigrantes estavam acostumados. Além disso, o governo Meiji também investiu em um tipo de "treinamento" do emigrante japonês para que não fosse confundido com outros asiáticos, considerados povos de culturas inferiores, e que também não arrefecesse muito cedo, querendo voltar ao Japão antes de cumprida a sua missão.

Esse "treinamento" consistia em uma série de recomendações baseadas na ideologia do "caráter japonês", por meio de folhetos distribuídos aos emigrantes previamente selecionados pelos funcionários das suas respectivas províncias. Dezem (2005) comenta que essas ideias reforçavam a noção de que os emigrantes japoneses faziam parte de uma grande família, unida em torno da figura do imperador, considerado o "pai semidivino" e que deveriam manter "austeros padrões morais e culturais em terras estrangeiras". Assim, ao mesmo tempo em que resolvia o problema do excedente populacional, o governo transformava seus mais humildes cidadãos em "pequenos embaixadores do Japão" (2005, p.132), com a responsabilidade - e a honra de ajudar a construir para sua pátria, no exterior, a imagem de país civilizado. 


\section{Emigração para o Brasil}

Masterson (2004) relata que nas primeiras décadas da presença japonesa nas Américas, a grande maioria dos emigrantes que saíam do Japão preferia a América do Norte: entre os anos de 1899 e 1908, quando 155.772 japoneses entraram nos Estados Unidos e Canadá, 18.203 imigrantes optaram por se estabelecer no mesmo período em cinco países latino-americanos, principalmente no México e no Peru (2004, p. 11). Essa tendência se inverteu depois da assinatura, em 1907, do "Acordo de Cavalheiros" em que o Japão se comprometia a não mais emitir passaportes de emigrantes para os Estados Unidos, a não ser no caso de familiares ou futuras esposas dos japoneses que já residiam naquele país. As más condições de trabalho e a instabilidade econômica que prevaleciam nos países da América espanhola acabaram por redirecionar ao Brasil as expectativas de emigração para os japoneses.

Não que as condições no Brasil fossem muito melhores, mas notícias sobre a existência de grandes extensões de terras produtivas e infindáveis oportunidades de trabalho em fazendas de café - produto em alta no mercado mundial -, sobretudo no estado de São Paulo, atraíram a atenção dos responsáveis pelas empresas de emigração japonesas que procuravam alternativas aos destinos fechados ou que se provaram problemáticos. Os dois maiores fatores a retardar a chegada dos imigrantes japoneses ao Brasil foram a escravidão africana, recentemente abolida, e a preferência do governo brasileiro pela imigração europeia. Mesmo assim, algumas tentativas foram feitas, sendo que a primeira delas aconteceu em 1894, quando a empresa brasileira Prado Jordão tentou trazer, sem sucesso - por falta de relações comerciais entre os dois países -, imigrantes japoneses ao Brasil.

Tadashi Nemoto, enviado do governo japonês ao Brasil, escreveu um relato entusiasmado sobre as possibilidades abertas aos imigrantes "de construírem muitas cidades nesta vasta terra, aumentarem seus ganhos, tornarem-se proprietários, educarem seus filhos e viverem confortavelmente" (MASTERSON, 2004, p. 43). Com base nesse relatório, o governo japonês tomou a decisão de buscar um acordo comercial com o Brasil, que foi assinado em 1895. Dois anos depois, dois mil emigrantes se preparavam para embarcar no Tosa-Maru, no porto de Kobe, rumo ao Brasil, quando uma queda abrupta no preço do café levou os contratantes a cancelarem os acordos de trabalho, e a 
viagem foi abortada pouco antes da hora da partida. Circunstâncias desfavoráveis à emigração para o país persistiram, com a permanência dos baixos preços do café e a elaboração de novos relatórios, dessa vez por diplomatas da Legação Japonesa no Brasil, instituída em 1897, que não gostou do que viu e ouviu sobre as condições de trabalho nas fazendas paulistas e desaconselhou a vinda de seus cidadãos.

Um novo acordo - que previa a vinda de mil emigrantes japoneses para o país foi finalmente acertado entre o presidente paulista Jorge Tibiriçá e o representante da empresa de emigração japonesa, Ryo Mizuno, em 1907. Se por um lado os brasileiros consideravam a vinda de japoneses uma alternativa temporária à emigração europeia preferida pela elite preconceituosa e racista da época, que pretendia "embranquecer" o país -, o governo japonês tinha planos de permanência para seus cidadãos no exterior. Os emigrantes, porém, tinham seus próprios planos, quase sempre o de juntar dinheiro e retornar ao Japão (DEZEM, 2011, p. 5).

Apesar de o acordo prever o envio de mil emigrantes japoneses, a primeira leva que embarcou no Japão rumo ao Brasil, a bordo do Kasato Maru, era composta de 781 pessoas, originárias de várias províncias japonesas. O maior contingente era de Okinawa $^{44}$, província do sul do Japão, que representava quase a metade do grupo todo (MOTOYAMA, 2011, p. 100). Segundo o acordo, os emigrantes deveriam ser agricultores com experiência, em famílias de pelo menos "três enxadas", ou seja, três membros da mesma família em idade de trabalhar na lavoura. Não eram aceitos, portanto, os emigrantes "avulsos" - geralmente homens jovens -, que ambas as partes consideravam ser menos confiáveis quanto ao cumprimento dos contratos.

Essa exigência de famílias de no mínimo três pessoas em idade produtiva (o que incluía as mulheres, mas excluía os idosos e as crianças na contagem) fez com que se montassem, na hora da viagem, as "famílias confusas", ou seja, formadas por pessoas que se apresentavam como pai, mãe e filho, mas que não eram casadas, nem parentes e, em vários casos, nem sequer conhecidas umas das outras. Outra exigência do governo paulista que não foi cumprida era que todos os emigrantes fossem recrutados na área rural, sendo, portanto, agricultores com experiência. Pessoas de várias procedências e ocupações acabaram sendo recrutadas pela empresa japonesa de emigração, o que

\footnotetext{
${ }^{44}$ A ilha de Okinawa, uma das províncias do Japão, é situada cerca de 640 quilômetros ao sul do arquipélago japonês. Foi um reino com governo próprio até 1879, quando foi anexada pelo Japão. Tem língua e cultura própria, embora esteja cada vez mais integrada ao resto do país pela educação, legislação, economia, meios de comunicação, etc.
} 
acabaria sendo usado mais tarde como justificativa dos empregadores sobre o motivo pelo qual muitos recém-chegados deixaram as fazendas antes de cumprirem seus contratos (e não as péssimas condições de trabalho que ofereciam), indo trabalhar na estiva, em Santos, nas ferrovias em construção no interior do estado e em diversos tipos de prestação de serviço nas cidades.

O grande motivo das deserções em massa, claro, foi o descumprimento do contrato de trabalho nas fazendas de café paulistas, aonde a maioria dos imigrantes japoneses foram levados, e que contrastava com a propaganda divulgada no Japão pelas empresas de emigração, que davam a entender que seria fácil e rápido enriquecer no Brasil. Obrigados a se instalar em choças sem mobília e sem acesso a saneamento e água potável, e a trabalhar por longas horas sob a fiscalização de capatazes armados que os tratavam com rispidez, os imigrantes ainda tinham que se submeter a preços exorbitantes de produtos vendidos nos armazéns das fazendas, que no final do mês deixavam suas folhas de pagamento no vermelho, com dívidas impagáveis e nada a receber. Meses depois, havia greves, distúrbios e episódios de fugas em praticamente todas as fazendas, e mesmo com a intervenção da Legação Japonesa no Brasil, a maior parte dos imigrantes se dispersou pelo estado ou para fora do Brasil.

Os anos seguintes foram de grandes mudanças na direção e nas formas de atuação das empresas de emigração japonesas, com a produção de contratos com cláusulas mais específicas quanto aos direitos e deveres dos trabalhadores, numa tentativa de evitar os fracassos das levas anteriores. Apesar de muitos problemas terem se repetido, que também resultaram em fugas e dispersão, a avaliação da experiência foi se tornando mais positiva, tanto na perspectiva dos brasileiros quanto na dos japoneses. Os números crescentes de chegadas de navios do Japão mostram que, apesar das dificuldades, o Brasil era um destino atraente do ponto de vista do governo japonês, que se empenhou diretamente na solução dos problemas.

Quatro anos depois da chegada do primeiro navio, os japoneses já se espalhavam por várias regiões do estado de São Paulo, quase na divisa com Minas Gerais, e também no norte do Paraná. Motoyama (2011) lembra que a diversidade não se restringiu às localidades de assentamento, mas se estendeu também à variedade de cultivos, formas de produção e de arranjos com os empregadores, cuja flexibilidade, em alguns casos, possibilitava aos imigrantes o cultivo de produtos próprios em seus momentos de folga. Muitos imigrantes que conseguiram cumprir seus contratos tornavam-se arrendatários 
de lotes dentro das próprias fazendas, podendo assim juntar dinheiro para comprar mais tarde seus próprios pedaços de terra. A experiência pioneira aconteceu em 1911, quando seis famílias conseguiram ingressar no núcleo colonial federal Primeira Monção, em Cerqueira César. Três anos depois, mais dez famílias repetiram o feito, dessa vez comprando diretamente 50 alqueires no município paulista de Mairiporã e formando ali um pequeno núcleo de agricultores japoneses.

Se no primeiro período da imigração japonesa, de 1908 a 1923, a entrada de trabalhadores foi crescente, chegando até mesmo a ser expressiva (mais de $30 \mathrm{mil}$ pessoas), foi no segundo período, de 1924 a 1941, que os números deram um salto substancial, chegando a 137 mil imigrantes. A razão para esse aumento significativo está no que a pesquisadora Célia Sakurai (1998) chamou de "imigração tutelada", que foi o grande empenho do governo japonês em garantir o fluxo de emigrantes para o Brasil por meio de uma presença governamental intensa e abrangente, sem paralelo na história da imigração brasileira. Embora algum empenho do governo japonês se fizesse sentir desde o início da emigração, é a partir da década de 1920 que esses esforços se organizam de modo a se tornarem parte essencial não apenas da política emigratória, mas também dos projetos econômicos e de relações exteriores do Japão.

Um dos motivos foi a conjuntura internacional, desfavorável ao Japão, com o fechamento definitivo, em 1924, da emigração japonesa para os Estados Unidos, que continuava a acontecer via México e Havaí, embora o fluxo direto do Japão estivesse suspenso desde o Acordo de Cavalheiros de 1907. Canadá e outros destinos que antes recebiam japoneses também fecharam suas portas, restando como alternativa alguns países da América do Sul, cujas economias instáveis, porém, não tinham muito a oferecer. O Brasil, por outro lado, embora tivesse cancelado os subsídios naquele mesmo ano de 1924, continuava recebendo imigrantes sem restrições aos japoneses. Essa abertura do governo brasileiro e, mais importante ainda, a existência de grande extensão territorial inexplorada no país levaram as autoridades japonesas a concentrarem os seus esforços de emigração no Brasil.

Esses esforços se dirigiram, antes de tudo, ao estabelecimento de uma representação diplomática permanente - com a oficialização do Consulado Geral em São Paulo, em 1915, e a elevação da Legação Japonesa, no Rio de Janeiro, à categoria de Embaixada, em 1923 - e à reorganização das empresas japonesas de emigração e colonização, incumbidas de cuidar de todos os detalhes da emigração, desde o 
recrutamento até a instalação e fiscalização das condições de vida dos seus cidadãos no Brasil. Dezem (2011) aponta a fundação em 1924 da Colônia Aliança, no Noroeste Paulista, em lotes comprados pelo governo do Japão, como sendo o marco de uma nova disposição dos imigrantes japoneses no Brasil: pela primeira vez eles já chegavam ao país como proprietários, e - a maior de todas as mudanças! - com planos de permanência.

Antes deles, todos os imigrantes acalentavam sonhos de retorno à terra natal, mas muitos tiveram que despertar para a dura realidade da impossibilidade de se ganhar muito dinheiro em poucos anos, trabalhando como agricultores assalariados, e também para a difícil situação em seu próprio país, que por muitas décadas ainda haveria de enviar e manter seus cidadãos no exterior. Mesmo os que investiam suas poupanças na compra de lotes de terras achavam que isso retardaria, mas não impediria o retorno da família ao Japão. Com o tempo, porém, a maioria teve de aceitar a ideia de permanecer no Brasil. Com a ajuda do governo de seu país, entretanto, cada vez menos essa opção parecia ser tão ruim.

Com a presença maior e mais estruturada das agências japonesas de apoio ao imigrante, a qualidade de vida e também a da produção subiram significativamente. Sakurai (1998) ressalta que mesmo as colônias criadas por iniciativa dos próprios imigrantes, independentemente dos projetos oficiais, também recebiam ajuda do governo japonês, sobretudo por meio de seu consulado em São Paulo, o que revela "uma outra faceta da tutela japonesa" (1998, p.16). Esses pequenos núcleos, formados por pessoas da mesma província ou que se conheceram durante a viagem e se ajudaram no Brasil, tinham desenvolvimento mais lento, em comparação às colônias formadas por intervenção direta do Estado japonês. O planejamento incluía a escolha das terras, não só em função da adequação do solo, mas também quanto à localização. Sempre que possível eram compradas próximas às estradas de ferro, o que facilitava a mobilidade das pessoas e o escoamento da produção.

O planejamento também encorajou a formação técnica dos agricultores, com a criação, por exemplo, do Instituto de Prática Agrícola de São Paulo, pela empresa de colonização e imigração Kaikô ${ }^{45}$, além de toda uma infraestrutura de apoio aos trabalhadores, que incluía escolas em língua japonesa para seus filhos, filiais bancárias

\footnotetext{
${ }^{45}$ Forma abreviada de referência à KKKK: Kaigai Kogyo Kabushiki Kaisha (Companhia Ultramarina de Empreendimentos).
} 
para empréstimos a juros baixos e associações com finalidade social e esportiva. $\mathrm{O}$ investimento na área da saúde também foi essencial, sobretudo como tentativa de controle dos efeitos das doenças tropicais, como a malária, que vitimou um grande número de imigrantes. Enquanto isso, os imigrantes que optaram por morar na capital paulista - ou se mudaram para lá depois de concluídos seus contratos ou em fuga das fazendas onde eram explorados - também se organizavam em torno de atividades concentradas no entorno da rua Conde de Sarzedas, que se tornaria mais tarde o bairro da Liberdade, reduto da comunidade oriental de São Paulo.

Motoyama (2011, p.123) aponta como eventos marcantes nessa primeira fase de adaptação dos imigrantes japoneses no Brasil a criação do Clube Nihon, criado graças ao empenho pessoal do cônsul japonês em São Paulo; a criação da Taisho Shôgaku, primeira escola em língua japonesa, no estilo tradicional em que uns poucos alunos se reuniam em torno de um mestre; a fabricação e venda, em Santos, de um item fundamental da culinária japonesa, o shoyu (molho de soja); e a criação do primeiro órgão de imprensa em japonês, o Nambei (América do Sul), tudo isso antes de a imigração japonesa no Brasil completar a sua primeira década. Essas atividades, se não significavam ainda a disposição definitiva dos imigrantes de permanecerem no Brasil, já evidenciavam a adaptabilidade e a capacidade de organização dos japoneses e, principalmente, o efeito decisivo da presença governamental japonesa na integração dos imigrantes às diferentes tarefas a que se dedicaram no Brasil.

\section{Comunidade e família}

Em uma obra que se tornou referência nos estudos da imigração japonesa no Brasil, Tomoo Handa ${ }^{46}$ (1987) afirma que os primeiros imigrantes viviam em uma "sociedade igualitária", onde imperava o espírito de solidariedade. Tendo vindo ao

\footnotetext{
46 O escritor e artista plástico Tomoo Handa (1906-1996) é autor de várias obras sobre o tema da imigração japonesa no Brasil. Tendo sido ele próprio um imigrante (chegou em 1917), conheceu de perto a realidade que retrata. Ainda jovem, mudou-se para São Paulo, onde cursou a Escola de Belas Artes e esteve em contato com pesquisadores e artistas de várias áreas. Embora Handa não tenha tido formação em História, o fato de ter sentido "na pele o drama de ser imigrante" e ter sido um grande observador "da vida e dos costumes do povo nipônico na terra brasileira" faz com que o conjunto de sua obra tenha importante "papel social e histórico" (MOTOYAMA, 2011, ver "Notas biográficas"). Esse papel é confirmado pelo elevado "número de citações de sua obra em trabalhos acadêmicos" e "por revelar a maneira com que os japoneses da sua geração viam e compreendiam o que deveria ser a escrita da História" (DEZEM, em conversa com a autora em 11/03/2017).
} 
Brasil, na sua grande maioria, para "começar do nada", o trabalho braçal igualou a todos e, por esse motivo, "não se dava importância ao que faziam antes ou a que posição social pertenciam no Japão". Handa conta que os mutirões se baseavam no que se chamava, no Japão, de kassei (auxílio). Fosse para realizar uma atividade cotidiana como um roçado, colheita, queimada ou construção de uma casa, ou um evento extraordinário como um funeral, casamento ou aniversário, podia-se evocar o kassei. Também na colheita ou pescaria abundante, ou no abate de um animal maior, era hábito compartilhar entre os membros da comunidade (1987, pp. 560-561).

Embora esse "espírito solidário" possa não ter beneficiado a todos, ou perdurado todo o tempo, o fato é que os imigrantes tinham muitos motivos para se unir e se ajudar mutuamente. Desde a solução dos problemas cotidianos mais corriqueiros até as decisões mais importantes, mesmo contando com o apoio do governo japonês por meio do Consulado e das empresas de emigração, os imigrantes enfrentaram a maior parte dos seus desafios apoiando-se uns nos outros.

Muitos núcleos se formaram com base em amizades construídas durante a viagem para o Brasil, ou durante os tempos em que trabalharam juntos nas mesmas fazendas, ou ainda pelo fato de terem vindo das mesmas regiões do Japão. Mas essas afinidades entre as pessoas não foram, necessariamente, um fator essencial para a sua formação. Maeyama (1979) pondera que mesmo nos casos em que os grupos de imigrantes tinham muitas diferenças em termos de província de origem, ocupação ou dialeto, prevaleceu a "etnicidade" como fator crucial na construção da identidade. Neste caso, os gaijin (os não japoneses, em geral) eram o contraponto, ou a referência de distinção. A etnicidade, portanto, foi um fator agregador da comunidade japonesa no Brasil e critério suficiente de seleção de seus membros, mesmo quando as distinções de classe "se cristalizavam cada vez mais" (1979, p.593).

Neste sentido, é interessante lembrar o que diz Oliveira (2003) a respeito da identidade étnica: ela não é um valor em si mesmo, mas está fundada "numa autoapreensão de si em situação" (2003, p.120). Ou seja, a questão étnica não era, antes da emigração, um aspecto importante da identidade dos indivíduos que vieram para o Brasil, a não ser quando passam a vivenciar uma "situação" em que a etnicidade se torna saliente e passa a ter significado de distinção na relação "nós versus eles". Para o autor, esta é a peculiaridade da identidade étnica: o fato de que somente na situação de contato interétnico é que ela emerge e se torna um fator regulador de inclusão e de 
definição do grupo enquanto segmento social. A exacerbação desta "consciência de si" pode dar origem a uma forma de representação "etnocêntrica" da realidade, que no caso da imigração japonesa no Brasil, deu origem aos conflitos entre "vitoristas" e “derrotistas", logo após a Segunda Guerra Mundial, e ao surgimento do Shindô Renmei, cujo caso será discutido mais à frente, neste mesmo capítulo.

As relações pessoais se organizavam em primeiro lugar a partir dos laços de parentesco (real ou informal) e, em seguida, nas práticas cotidianas de trabalho e ajuda mútua. Com o tempo, formaram-se as associações, que organizavam as pessoas a partir de interesses mais ou menos específicos, ou em categorias de gênero e idade, como o seinenkai (de jovens), o shokokai (de mulheres) e as cooperativas agrícolas. Esses "canais de relacionamento interpessoal" integravam-se dentro de um grupo maior, o shokuminchi, que "significa, literalmente, colônia, mas que é, na prática, uma ‘comunidade japonesa local'” (1979, p. 593). Grande parte das famílias que emigraram para o Brasil era chefiada por homens que não eram os filhos primogênitos, que, segundo a tradição do $I e$, devem herdar as terras da família na sua terra natal e se responsabilizar pelo culto aos ancestrais.

Como as famílias dos não primogênitos não tinham obrigações religiosas relacionadas aos ancestrais, o culto ao imperador e os ritos funerários eram praticamente as únicas dramatizações comunitárias de fundo étnico e identitário observadas pelos japoneses no pré-guerra. Maeyama pondera que a participação nessas associações e nos ritos e cultos não era opcional para os imigrantes, que, se por algum motivo não quisessem integrá-las, se tornavam "socialmente invisíveis", ou até "deixavam de ser japoneses". Se a invisibilidade era uma possibilidade para um japonês (caso não observasse os ritos da comunidade), para seus vizinhos brasileiros já era uma condição inerente. Mas em se tratando de "figuras locais poderosas" era feita uma exceção, e poderiam se tornar "membros honorários" das associações (1979, p. 594).

As associações japonesas das respectivas colônias - quase sempre bem distantes umas das outras - estavam, porém, conectadas entre si e com o Japão, através das entidades representativas do governo japonês e pelas "práticas quase religiosas de culto ao imperador" (1979, p. 595). Essas evocações solenes à figura do imperador, como símbolo máximo do Japão e da identidade coletiva de seus súditos, é fruto "das inúmeras releituras" dos princípios éticos e políticos do confucionismo no período Meiji, que tinham por objetivo consolidar a figura do imperador e tornar central a 
questão da lealdade, como lembra Sakurai (2007, p. 148). Embora o culto ao imperador fosse uma celebração cívica - efetuada no dia 31 de outubro, que incluía o canto do hino nacional (Kimi ga yo ${ }^{47}$ ) e o hasteamento da bandeira japonesa - e não tivesse, portanto, uma conotação religiosa explícita, o imperador foi declarado "sagrado e inviolável” pela Constituição japonesa de 1889, que evocava sua hereditariedade divina, “desde épocas eternas” (SAKURAI, 2007, p.149).

Harumi Befu (2001) pondera que o culto ao imperador, sobretudo antes da Segunda Guerra, é a expressão de uma "religião civil" que celebra os "valores transcendentes" da sociedade e da nação japonesa. Ele explica que embora incluam aspectos do xintoísmo e budismo, esses rituais não têm um foco na reprodução de valores religiosos em si, mas nas atitudes e sentimentos nacionais. Assim, o imperador está colocado no centro desse sistema de valores "essencialmente japoneses", que se concretiza por meio de "uma orientação normativa e de uma visão de mundo idealizada" que os membros da comunidade devem acatar e seguir com todo esforço (2001, p. 115). Daí a importância, para os imigrantes no Brasil, de manter os elos com esses símbolos de identificação e orientação, incorporando nas suas práticas, além do aniversário do imperador, vários outros "rituais de religião civil" do calendário japonês, como a celebração do Oshougatsu (Ano Novo) e do Obon (Dia das almas dos antepassados).

As três entidades representativas do governo japonês - o consulado e as duas empresas "quase oficiais" (a agência de emigração KKKK, ou Kayô, e a cooperativa agrícola Bratac) - exerciam uma autoridade moral e paternalista sobre os imigrantes, que, segundo Maeyama (1979), as chamavam de go-sanke, que significa literalmente "as três famílias reais", em uma alusão às três famílias de conselheiros do clã Tokugawa, do Japão feudal. Embora os imigrantes contassem com a ajuda e intervenção dos go-sanke, em situações especiais de dificuldade, a estrutura não foi criada por inciativa deles, mas diretamente pelo governo japonês, que pretendia assim manter controle sobre o processo emigratório, tanto quanto às condições da saída no Japão como no assentamento e desenvolvimento das colônias no Brasil. O autor pondera que os imigrantes reverenciavam os go-sanke por reconhecerem neles uma verdadeira

\footnotetext{
${ }^{47}$ Kimi ga yo significa, em tradução livre, "Reino Imperial". A letra é baseada em um poema do período Heian (794-1185) e tornou-se hino oficial do Japão no período Meiji (1868-1912).
} 
condição de realeza e de sacralidade, por sua ligação simbólica com o imperador (1979, p. 595).

Esse espírito de coesão e de apego às raízes entre os membros da comunidade imigrante pré-guerra se expressa sobretudo na organização tradicional das famílias e das comunidades e associações - que reproduzem, dentro das possibilidades e circunstâncias locais, o modelo do mura (aldeia japonesa), assim como a prática de ajuda comunitária do tipo tanomoshi ${ }^{48}$. Para Woortmann (1995), embora as migrações tenham na maioria das vezes determinantes econômicos e políticos, não são estes os fatores que as organizam, mas sim a cultura. No caso da imigração japonesa no Brasil, a autora acredita que a sua organização se deu inteiramente "no âmbito de uma linguagem do parentesco que a reconstrói e ultrapassa, de acordo com as situações específicas enfrentadas pelos imigrantes" (1995, p.8). Assim, tanto a "seleção" daqueles que deveriam partir - os filhos não primogênitos sem direito à herança da terra e sem a responsabilidade de dar, na terra natal, continuidade ao $I e^{49}-$ como a forma com que os imigrantes se assentaram e se organizaram no Brasil, em famílias extensas e em comunidades, depois reunidas em colônias, foram determinadas pela ideologia do parentesco (1995, p. 13).

Wawzyniak (2008) também reforça essa linha de reflexão, ressaltando que após os primeiros anos em que prevaleceram as famílias de composição artificial, imposta pelas regras de imigração para o Brasil, as famílias japonesas foram aos poucos retomando a estrutura tradicional do $I e$. Embora haja vários registros de casamentos interétnicos, desde o início da imigração, o casamento fora da comunidade não era encorajado. A autora pondera que a preservação da estrutura familiar significava também a manutenção das redes de interesses comuns da comunidade e dos elos entre os membros que emigraram e aqueles que permaneceram no Japão, proprocionando, assim, os elementos para a construção e preservação da identidade cultural do imigrante japonês no Brasil. O casamento fora do grupo étnico poderia provocar, então, uma

\footnotetext{
${ }^{48}$ Prática tradicional de ajuda mútua existente no Japão desde o século XIII, reproduzida nas colônias japonesas no Brasil por quase um século (MOTOYAMA, 2011, p. 254).

49 Embora a emigração tenha sido descrita como fenômeno que dizia respeito somente aos expulsos estruturais (os filhos mais novos que não tinham direito à herança da terra), havia também um contingente de pessoas que migraram para manter a estrutura tradicional quando da sua volta, ou seja, os primogênitos que migraram temporariamente para assegurar a reprodução do $I e$, ameaçado por problemas financeiros (WOORTMANN, 1995, p. 10).
} 
ruptura não só da organização familiar e da comunidade como um todo, como também das ligações dos membros da família com a terra natal.

A manutenção dessa comunidade étnica com muito pouca miscigenação foi conseguida graças ao isolamento de grande parte das colônias - imposto pelas barreiras da cultura e da língua - e também ao apego às tradições, como é o caso da instituição do "casamento arranjado", uma prática comum na sociedade japonesa e que foi reproduzida nas colônias nipônicas no Brasil. A autoridade do pai sobre os filhos, inspirada no confucionismo, era parte de uma ideia muito mais ampla de harmonia universal: cada membro da família extensa aceitava seu papel e sua função, certo de que o sucesso da família era também o da comunidade e, por extensão, o da nação (SAKURAI, 2007, p. 150).

Assim, o "casamento arranjado" correspondia à percepção de que seria um instrumento legítimo e necessário para realização das alianças que garantiriam a cooperação entre os membros da comunidade e entre as colônias, consolidando assim o projeto social e econômico do grupo como um todo. Para realizar esse intento, foi comum no Brasil pré-guerra a prática do miai, ou "encontros marcados" entre noivos potenciais apresentados por intermediários, chamados nakoudo. Na sua versão original, no Japão, os arranjos matrimoniais incluíam pesquisas detalhadas, efetuadas pelos nakoudo, sobre as condições sociais, financeiras e de saúde dos noivos. No Brasil, os nakoudo tinham a grande responsabilidade de atender às expectativas das famílias dentro de um universo de opções muito menor, sobretudo quanto ao acesso aos antecedentes dos candidatos, mas com a idêntica atribuição de negociar os termos de um bom acordo, que contentasse a ambos os lados.

Sakurai (1993) também reforça a ideia de que a ideologia do parentesco está por trás das maneiras com que a imigração japonesa se organizou no Brasil, sobretudo graças à crença de que o povo japonês fazia parte de "uma grande família, onde o chefe era o imperador, e o pai, a autoridade mais próxima", crença esta divulgada pelos "manuais escolares de história e moral" que ensinavam "a ética da obediência, da lealdade e da fidelidade, resgatadas do confucionismo" (1993, p. 104). Nesse seu estudo, que analisa aspectos da vida cotidiana dos imigrantes relatados em romances escritos por eles próprios, Sakurai demonstra, em vários exemplos, que a estrutura familiar japonesa e sua ética se reproduziram no Brasil, oferecendo o modelo de ação dos indivíduos e de organização das comunidades, associações e colônias. 
Esse modelo é estruturado em torno da colaboração entre todos os membros da família, sob a autoridade paterna, que não deve ser contestada nem pela esposa, nem pelos filhos. O pai é o provedor, responsável pelo trabalho principal e pelas decisões que afetam a vida de todos, como também deve emitir a opinião e o voto da família nos assuntos da comunidade. A mulher deve ser a companheira forte, porém modesta, que tem como responsabilidade principal educar os filhos para os valores japoneses. Os filhos, por sua vez, devem acatar as decisões e escolhas do pai quanto a seu futuro e contribuir para o sucesso e dignidade do nome da família. Todos, porém, estão igualmente atados aos princípios éticos que devem diferenciar os súditos do imperador de todos os demais povos da terra, como o gambarê, por exemplo.

Segundo Sakurai (1993), o gambarê pode ser traduzido "como esforço com resignação, ou seja, a força para seguir adiante mesmo diante das dificuldades" (1993, p.52). Esse esforço inclui sacrifícios e renúncia, aceitação do sofrimento e das adversidades diante de um objetivo maior, que não se deve perder de vista. Inclui também o reconhecimento de que a finalidade de todo o esforço não é o indivíduo, mas a coletividade - não só a própria família, mas também a comunidade e, acima de tudo, a pátria. O princípio do gambarê está em sintonia com os mesmos valores tradicionais japoneses que inspiraram a "ética samurai", segundo a qual "a verdadeira vitória é aquela sobre si mesmo, numa sólida combinação entre físico e espiritual” (SAKURAI, 2007, p. 331).

Tanto o gambarê como a ética samurai decorrem de princípios derivados do confucionismo, xintoísmo e budismo, as três vertentes filosófico-religiosas que estão na base da cultura japonesa: o confucionismo reforçando o valor da obediência e do cumprimento dos deveres, o xintoísmo enfatizando a lealdade e a honra, e o budismo, o aprimoramento espiritual, cada qual dentro de seu contexto - muito mais complexo do que é resumido aqui -, mas resultando em princípios de vida que são simplificados pelo homem comum para sua utilização prática em todos os momentos do cotidiano.

Desde o início do processo emigratório, o princípio do gambarê foi evocado, quando os emigrantes eram instados a deixar o país como um sacrifício que faziam pela nação, lembrando que seus esforços e sucessos ajudariam a conquistar para o Japão um lugar entre as potências mundiais. Sakurai conta que no Brasil, o gambarê se materializou na "necessidade de trabalhar ao máximo para economizar também ao 
máximo, abrindo mão de luxos supérfluos, acalentando a esperança de uma vida melhor" (1993, p.52).

Assim, para os homens, o gambarê foi a aceitação do trabalho árduo até o limite da sua resistência, o esforço de suportar a vida em um ambiente cultural e natural completamente estranhos, o que exigia ânimo inabalável para vencer os obstáculos, e foi ainda a superação das desilusões quanto aos sonhos não realizados de juntar dinheiro e voltar, o mais rapidamente possível, à terra natal. Para as mulheres, o gambarê se expressou no enfrentamento diário das jornadas múltiplas - o trabalho na lavoura, os afazeres domésticos e o cuidado das crianças - e no esforço estoico de suportarem a dor do parto "sem emitirem um gemido" e no retorno rápido ao trabalho, "tão logo davam à luz” (SAKURAI, 1993, pp. 70-71). Para os filhos, o gambarê inspirou o esforço contínuo de atender as expectativas da família quanto ao trabalho e os estudos, a força para enfrentar todos os dias a contradição e o conflito de ser "brasileiro" fora de casa e "japonês" ao voltar, e ainda a capacidade de renúncia dos seus próprios planos de vida e de futuro em favor da vontade paterna.

\section{8. “Colônia” como comunidade imaginada}

Se, por um lado, a forma de organização dos japoneses no Brasil foi inspirada em valores culturais e hábitos sociais trazidos prontos na bagagem, por outro foi fortemente determinada pela experiência cotidiana dos imigrantes, em sua luta contra as barreiras da língua e da cultura local, em sua adaptação às imposições da legislação brasileira, à natureza tropical e às circunstâncias de sobrevivência social e econômica, e em seus esforços para manutenção (e depois para mudança) dos planos e sonhos que os moveram desde a saída do Japão. É evidente que esses dois aspectos se combinam, pois os fatores culturais e os hábitos com que foram socializados na terra natal estiveram sempre presentes nas estratégias com que os imigrantes enfrentaram as realidades específicas vividas no Brasil. Mas é importante levar em conta esses dois aspectos interdependentes, porém distintos - que se referem a certa autoimagem do que é "ser japonês" em qualquer lugar em que se esteja, e a experiência concreta de "ser japonês no Brasil" como fatores de construção dos discursos e do espírito de colônia. 
Embora praticamente toda experiência de imigração envolva, pelo menos por algum tempo, a formação de grupos ou comunidades de conterrâneos, principalmente em função das afinidades linguísticas e de costumes, as colônias japonesas no Brasil tiveram as suas peculiaridades. A começar pela atribuição patriótica de serem, como diz Dezem (2005), os "pequenos embaixadores" do seu país, os imigrantes japoneses deveriam não só cuidar de sua sobrevivência econômica, mas também mostrar ao mundo o verdadeiro "espírito do Japão". Esse "espírito", que havia sido resgatado na Era Meiji, com a restauração do poder do imperador e a evocação da origem divina de todo o povo japonês, foi reforçado pela ascensão das forças ultranacionalistas da Era Taisho $^{50}$, que pregavam a revalorização da "ética samurai" e das tradições milenares do povo japonês (SAKURAI, 2007, pp. 173-174). Essa ideia de nação japonesa, da qual os imigrantes sentiam-se parte, corresponde ao que Anderson (1991) define como "comunidade imaginada", pelo sentimento de pertencimento fundamentado em uma "legitimação emocional profunda" (1991, p.30).

Dada a diversidade das populações que se deslocaram para o Brasil, que vinham de diversas províncias do Japão e falavam dialetos diferentes, a representação de uma ideia de unidade teve que ser construída a partir de um esforço de superação (ou negação) dos aspectos que diferenciavam os indivíduos em favor do que era percebido como traços comuns de todo japonês. De todos os fatores de unificação, o que exerceu a "legitimação emocional (mais) profunda" foi por certo a sua condição de "súditos do imperador". Foi em torno da imagem meio humana, meio mística do imperador que o vínculo da "etnia" japonesa pôde ser costurado fora do Japão, já que sua figura representava não só o ponto de referência circunstancial - a terra natal de onde saíram os imigrantes e para onde pretendiam retornar um dia -, mas algo transcendente: a fundação do reino de Yamato e da ancestralidade que unia a todos os japoneses, vivos e mortos, dentro e fora do Japão, ao mesmo tempo em que os distinguia de todos os outros povos do mundo.

Mas se a comunidade imaginada japonesa - disseminada a partir das narrativas da nação divulgadas pela propaganda governamental - prevaleceu como referência na construção de uma consciência étnica capaz de transformar a diversidade em unidade, foi na experiência concreta da vida no Brasil que os imigrantes construíram as fundações de uma colônia japonesa que viria a dar origem, gradualmente, a uma

\footnotetext{
${ }^{50}$ Referente ao período de governo do Imperador Taisho, de 1912 a 1926.
} 
comunidade verdadeiramente nipo-brasileira, no sentido "hifenizado" a que Lesser (2001, p.221) se refere. Desde os primeiros núcleos, que congregaram imigrantes de diferentes origens provinciais no Japão - vindos das fazendas paulistas como fugitivos ou após cumprirem seus contratos -, as mudanças culturais começaram a ocorrer em função desses encontros e também da adaptação ao meio ambiente e às condições sociais locais. A própria forma de "associativismo" dos japoneses do Brasil, segundo Maeyama (1979), já é uma resposta à situação particular encontrada no Brasil ${ }^{51}$.

O isolamento dos imigrantes japoneses em seus núcleos e colônias agrícolas, como já foi comentado aqui, deveu-se sobretudo às dificuldades de entenderem a língua e a cultura locais, e também ao desinteresse em superar essas barreiras, já que a maioria tinha planos de retornar ao Japão em poucos anos. Outro motivo foi a necessidade de se diferenciar de seus vizinhos, os caboclos, o que "conduziu as famílias a um relacionamento mais estreito com os que consideravam seus iguais e a um contato somente necessário com os brasileiros" (SAKURAI, 1993, p.88). Isto não impediu, porém, que a vida no Brasil começasse a introduzir suas marcas na cultura dos imigrantes, a começar pela alimentação, que teve de ser adaptada aos produtos brasileiros, e à própria língua japonesa falada nas colônias, que, além de misturar-se aos dialetos dos residentes, assimilou também palavras e expressões do português, necessárias para nomear as coisas e situações do cotidiano sem equivalente em japonês.

A criação de escolas para o ensino do japonês e de semanários para divulgação de informações de interesse dos imigrantes, também em língua japonesa, além da preservação das práticas culturais - ainda que adaptadas - e de trabalho que garantiam a autossuficiência das comunidades, proporcionou o estabelecimento da "colônia" como entidade simbólica. Segundo Wawzyniak (2008), o conceito de colônia não se refere "a uma concentração populacional de imigrantes nem a um espaço geográfico determinado, mas a uma representação simbólica, construída e mapeada pelo imaginário coletivo dos nipônicos na terra estrangeira” (2008, p.185). A autora pondera que a colônia japonesa formou-se como um "campo de sinais e signos" construído e compartilhado por meio de uma rede de comunicação tecida pelos imigrantes durante as trajetórias percorridas por eles no exercício do seu trabalho e de suas trocas sociais.

\footnotetext{
${ }^{51}$ No original em inglês: "These associations may not be accounted for as something brought from their home country or something found in and learned from their host society (...). We can better account for these associations if we look at them as strategical devices for organizing social action in the particular situations encountered in Brazil" (Maeyama, 1979, p.590).
} 
Esse sistema de representação simbólica é como uma linha imaginária que alcança seus membros e traça em torno deles os limites do "espaço" que os contém enquanto entidade coletiva. Com a mudança de grande parte da população de origem japonesa para os centros urbanos, a partir da década de 1950, a "colônia" teve de reinventar suas rotas de solidariedade e redes de comunicação interna para seguir reproduzindo os valores culturais dos quais dependia a própria sobrevivência da comunidade, mantendo o "espírito de colônia" como referencial de ajuda mútua e como "uma possibilidade sempre aberta para o estreitamento de vínculos entre eles" (2008, p.186).

Embora o culto ao imperador, as formas tradicionais de organização familiar e comunitária, os hábitos culturais e a prática da língua japonesa continuassem a manter a coesão entre os imigrantes e seus descendentes sempre forte e dinâmica, cada vez mais a vida no Brasil foi impondo as suas marcas em uma "comunidade imaginada" fortemente apegada aos seus vínculos com a terra natal, e modificando seus referenciais de origem. Uma das evidências dessa modificação foi a decisão, ainda em 1929, dos editores do jornal Nippak Shimbun de publicar algumas páginas em português, pois já havia descendentes nascidos no Brasil que não eram capazes de ler em japonês (LESSER, 2003, p.6). E havia também as "evidências" baseadas na percepção dos observadores de fora: ainda na década de 1920, um enviado do governo japonês, ao visitar as colônias de imigrantes no estado de São Paulo, estranhou a aparência "feia" de seus compatriotas, que atribuiu ao "estilo de vida incivilizado" que levavam no Brasil (LESSER, 2001, p. 190).

Depois da Segunda Guerra, quando uma nova leva de imigrantes começou a chegar ao Brasil, o contraste entre os velhos imigrantes e esses recém-chegados chamados pelos antigos de "japões novos" - também tornou evidentes as mudanças na colônia japonesa no Brasil, na percepção dos observadores, agora de ambos os lados. Os imigrantes recentes chamavam os antigos de "Brasil-bokê", ou seja, "aqueles que caducaram, não por senilidade, mas por estarem vivendo no Brasil" (HANDA, 1987, p.715). Já os antigos se espantavam com os "maus modos" dos "japões-novos", a quem faltavam as "qualidades tipicamente japonesas". Para os recém-chegados, a língua japonesa falada pelos velhos colonos (e também seus descendentes) era “incompreensível", e criticavam principalmente o "senso e modo de agir brasileiros que tinham passado a ostentar" (1987, p.717). 
Mesmo antes da Segunda Guerra, mudanças no cenário político brasileiro impuseram novos desafios para a colônia japonesa no Brasil, que há tempos já reestruturavam a natureza dos seus vínculos com a terra natal, ora renovando-os - a partir de critérios já "contaminados" por suas experiências de vida fora do Japão - em favor de valores vindos das "fontes nipônicas originais", ora permitindo que se flexibilizassem ainda mais, em favor das influências culturais locais. O nacionalismo varguista - que combatia especificamente o "enquistamento" de imigrantes estrangeiros em suas próprias colônias e núcleos - primeiro dificultou e depois fechou jornais e escolas em língua japonesa, já no final da década de 1930 e início dos anos 1940. Essa medida, se por um lado abriu a comunidade japonesa para uma maior convivência com a sociedade brasileira, por outro estimulou a criação de publicações e escolas clandestinas, e também de práticas culturais que se configuravam como "atos de resistência" do espírito japonês, ameaçado pela assimilação forçada.

As formas tradicionais de organização adaptadas às condições locais, como a família (nuclear e extensa) e o associativismo, foram os espaços em que se desenvolveu a resistência cultural dos japoneses no Brasil, o que é exemplificado pelo relato de Teruko Oda (2008), filha de imigrantes japoneses praticantes da técnica do haicai ${ }^{52} \mathrm{e}$ discípulos de Nempuku Sato ${ }^{53}$, que, "imbuído da missão" de disseminar no Brasil essa forma poética tradicional do Japão, "percorria os núcleos agrícolas promovendo sessões de haicai e concursos" (2008, p.356). Além do haicai, o cinema itinerante também levava a cultura da terra natal às colônias rurais, em caminhões que projetavam para o público, em panos brancos que serviam como tela, filmes trazidos do Japão.

Da mesma forma, torneios esportivos e concursos de oratória entre as colônias, e apresentações de canções populares japonesas com acompanhamento de instrumentos tradicionais, eram realizados tanto nos palcos das associações como nas casas dos imigrantes (HANDA, 1987, p. 486-489). Até mesmo o teatro kabuki chegou a ser apresentado nas primeiras décadas da imigração, como foi o caso da Colônia São João,

\footnotetext{
${ }^{52}$ Chamado no Japão de haiku, essa técnica de poema foi desenvolvida pelo poeta Bashô, no final do século XVII, mas suas origens remontam ao tanka, forma poética surgida no período Heian (794-1185). No Brasil, o haicai passou por profundas adaptações: quanto ao conteúdo, teve de deixar de lado seu apego às estações do ano, como no original japonês (embora tenha preservado as referências constantes à Natureza), e quanto à forma, teve de desenvolver novas maneiras de síntese em três versos "sem os recursos dos ideogramas e do idioma japonês" (ODA, 2008, p.362).

${ }^{53}$ Haicaísta japonês, emigrou para o Brasil em 1927. Lançou colunas de haicai em revistas e jornais nipobrasileiros.
} 
na região noroeste do Estado de São Paulo, em que um dos imigrantes era especialista em joururi, narrativa acompanhada de shamisen (instrumento de cordas) ${ }^{54}$.

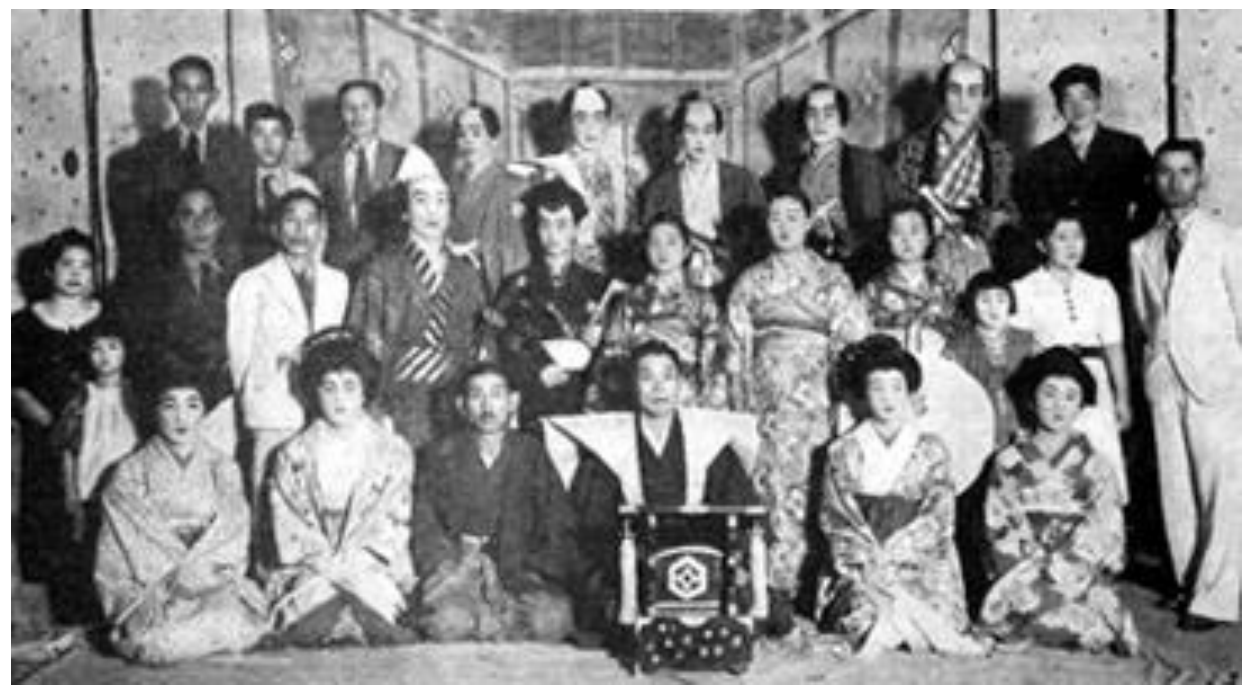

Foto 1: grupo de kabuki na Colônia São João, noroeste paulista, 1940. Fonte: Jornal Nippo-Brasil/Blog Cinema é Magia

Com a adesão do Brasil às forças aliadas, na Segunda Guerra, o cerco contra os imigrantes oriundos dos países do Eixo se fechou ainda mais, tornando a resistência pacífica dos movimentos culturais japoneses, difícil e arriscada. Até mesmo periódicos como a revista Transição, editada pela Liga Estudantina Nipo-Brasileira, que defendia uma "postura pró-abrasileiramento" da população japonesa no país, foi fechada pelas autoridades e a Liga, posta na ilegalidade (LESSER, 1999, p.235). Logo após o ataque de Pearl Harbor pela força aérea japonesa, os "súditos do Eixo" foram considerados "prisioneiros de guerra" e toda a infraestrutura e práticas comunitárias dos imigrantes japoneses foram suspensas, sendo que a desobediência a qualquer uma das proibições poderia implicar em detenção. Estabelecimentos prisionais, que na época receberam "a alcunha de campos de concentração", tiveram internos de origem japonesa, acusados de envolvimento em espionagem ou sabotagem (PERAZZO, 2009, p.95).

Essa situação de repressão propiciou o surgimento, sobretudo (mas não apenas) no estado de São Paulo, de sociedades secretas, "cujo nacionalismo ultrajaponês mesclava-se ao desejo de reforçar o espaço da identidade nipo-brasileira" (LESSER,

\footnotetext{
${ }^{54}$ Ver em https://cinemagia.wordpress.com/2009/01/18/lembrancas-de-um-ator-de-kabuki/ Acesso em $11 / 03 / 2017$.
} 
2001, p.239). Essas sociedades produziam clandestinamente informações sobre a guerra e o Japão, que os periódicos em língua japonesa já não podiam divulgar, e foram - para aqueles agricultores que não sabiam ler em português e estavam isolados em seus núcleos - praticamente a única fonte de notícias sobre os acontecimentos na terra natal.

Reproduzindo as formas de associativismo desenvolvidas no Brasil, as sociedades secretas tentavam reconstituir as redes de comunicação entre os imigrantes, desfeitas pelas autoridades brasileiras, e atribuíam a si próprias a missão de manter viva a tradição japonesa e a lealdade dos imigrantes ao imperador. A diferença é que agora assumiam posturas agressivas e às vezes fora da lei, cujas vítimas eram seus próprios conterrâneos que se dedicavam ao cultivo de produtos considerados "antipatrióticos", como a hortelã e o bicho da seda, ambos alegadamente utilizados para fins militares pelo inimigo (os Estados Unidos) ${ }^{55}$.

Com a derrota do Japão na Guerra, surgiu a "mais poderosa" das sociedades secretas, a Shindô Renmei (Caminho dos Súditos da Liga do Imperador), que conseguiu manter o monopólio da informação para a colônia japonesa no Brasil, por meio de seus sessenta e quatro escritórios distritais, e tentava reforçar, com notícias inventadas e distorcidas, a crença, entre os imigrantes, "na superioridade e invencibilidade do Japão" (LESSER, 2001, p. 241). O que viria a acontecer em seguida traumatizou profundamente a comunidade japonesa no Brasil, com a divisão entre aqueles que acreditavam na vitória do Japão (os kachigumi, ou "vitoristas") e os que reconheciam a derrota (os makegumi, ou "derrotistas"). A divisão dos imigrantes e seus descendentes em dois grupos antagônicos e hostis entre si alterou de forma definitiva a dinâmica de construção da colônia japonesa como comunidade imaginada, dando origem a novas narrativas separadas: a dos patriotas que já não consideravam os traidores como parte da colônia e a dos esclarecidos que queriam renovar profundamente as relações da colônia com o Brasil e com o Japão, como explica Maeyama (1979).

Para o autor, a luta entre as facções levou esses imigrantes chamados de "derrotistas" a construir uma nova "identidade étnica", agora voltada à sua condição de imigrantes permanentes no Brasil, ainda que mantendo os elos com seu país de origem. A trajetória dessa facção foi pontuada pela tentativa de persuasão de seus oponentes através do ninshiki undô (movimento de esclarecimento) e por formas de organização que iam além do nível local. Rompendo com a condição de dekasegi imin (trabalhadores

\footnotetext{
${ }^{55}$ A seda era usada na fabricação de paraquedas, e a hortelã (mentol), na de nitroglicerina.
} 
imigrantes), esses grupos promoviam a ideia de que deveriam ver a si mesmos como colônia-jin ou Nikkei-jin, duas expressões que enfatizam uma ligação renovada com sua origem nipônica, mas "finalmente distinguindo a si próprios dos japoneses no Japão" (1979, p. 602).

Já os que aderiram à posição "vitorista", mesmo não apoiando a violência de alguns de seus membros, apegavam-se aos valores e ensinamentos disseminados pela educação e propaganda governamental japonesa das eras Meiji e Taisho, período em que havia saído um expressivo número de imigrantes presentes no Brasil à época da Segunda Guerra ${ }^{56}$. A grande maioria dessas pessoas vivia no meio rural ou em pequenas cidades, distantes dos grandes centros urbanos, e, sem ter acesso a notícias confiáveis sobre o desenrolar dos acontecimentos no mundo, apegou-se às suas convicções de lealdade ao Japão. Maeyama (1979) pondera que mesmo depois da prisão dos líderes "vitoristas" envolvidos em crimes, as redes de comunicação informal desse grupo se mantiveram, dando origem a associações religiosas japonesas, que passaram a oferecer “aos imigrantes perdidos, os 'reais significados' dos valores e símbolos japoneses e o caminho para se tornarem 'japoneses de verdade"' (1979, p.603-4). Além das experiências religiosas bem sucedidas, como a Seicho-no-Ie, por exemplo, que chegou a congregar milhares de pessoas de origem nipônica, os "vitoristas" também se organizaram em outros tipos de associações sociais, esportivas e políticas, que com o tempo foram sendo absorvidas pela estrutura do antigo grupo "derrotista".

A ascensão econômica dos imigrantes japoneses implicou naturalmente a sua gradual mudança do meio rural para as cidades, com a perspectiva de proporcionarem educação de melhor qualidade para seus filhos e a adesão destes a carreiras urbanas. A dispersão cada vez maior das famílias japonesas nas cidades foi um novo desafio para a colônia como "comunidade imaginada" - ainda traumatizada pela cisão de "vitoristas e derrotistas" - que passou a desenvolver nas cidades novas rotas de solidariedade, trajetos e redes de comunicação. Uma das iniciativas concebidas com essa finalidade foi a criação do "Comitê de socorro às vítimas de guerra do Japão", sob a liderança de ex"derrotistas" que tentavam mobilizar a comunidade em torno de um objetivo comum,

\footnotetext{
${ }^{56}$ É estimado que entre 1908 e 1923 (incluindo, portanto, as duas eras mencionadas), 32.266 imigrantes japoneses chegaram ao Brasil. Porém, foi no período entre 1924 e 1935, já entrando na Era Showa (19261989), que o número maior de imigrantes japoneses entrou no país: 141.732 pessoas (Fonte: Hiroshi Saito, apud LESSER, 2003, p. 7).
} 
procurando assim retraçar os limites da colônia, passando uma borracha nas mágoas e ressentimentos de um passado recente que precisava ser superado.

Uma nova oportunidade para a "re-união" da comunidade foi a visita em 1949, ao Brasil, dos "peixes voadores", como eram chamados os nadadores olímpicos japoneses que foram recebidos como heróis por milhares de membros da colônia, na capital paulista e em cidades do interior. Voltando a hastear a bandeira japonesa em público, sem medo, os imigrantes e seus descendentes puderam ritualizar mais uma vez suas referências identitárias em torno dos símbolos da nação. Nem todos os japoneses do Brasil, entretanto, se entusiasmaram com a presença dos "peixes voadores": quando estes se mostraram chocados com um comentário de que o Japão havia ganhado a guerra, “a Shindô Renmei e a Zenpaku Seinen Renmei (Liga dos Moços de Todo o Brasil) lançaram uma campanha contra os nadadores, espalhando cartazes que diziam que eles eram coreanos fingindo-se de japoneses" (LESSER, 2001, p.250). Mas uma nova oportunidade haveria de se oferecer em breve, dessa vez por meio da prefeitura paulistana, que organizava a celebração do IV Centenário de fundação da cidade de São Paulo e queria a participação dos imigrantes nas festividades, a se realizarem em janeiro de 1954.

O comitê que havia se formado anos antes para envio de ajuda ao Japão assumiu a liderança da organização desse grande evento mobilizando as pequenas associações espalhadas pelo estado de São Paulo. A visibilidade proporcionada pela participação dos imigrantes japoneses nos eventos do IV Centenário - com seus duzentos carros alegóricos de várias regiões do estado, que desfilaram seus produtos e equipamentos, artes japonesas e danças folclóricas em trajes típicos - teve o efeito duplo de apresentar à sociedade nacional uma comunidade nipo-brasileira legitimada por sua contribuição ao estado e ao país, e de expor à comunidade os seus próprios contornos, evidenciando aquilo que os unia e que tinham de melhor.

E esses contornos indicavam a formação de uma nova identidade, que já não era apenas a do "japonês transplantado", mas uma identidade nipo-brasileira em desenvolvimento, pois o que se apresentava ali não era apenas o legado japonês - a herança cultural trazida na bagagem - mas o produto da vivência e da adaptação do imigrante japonês no Brasil. Esse fenômeno é o que Lesser (2001) chama de identidade "hifenizada", isto é, a do nipo-brasileiro que, ao desistir do projeto de voltar ao Japão, 
aderiu a uma identidade múltipla, assimilando "muitos dos elementos da cultura majoritária, mesmo permanecendo distintos" (LESSER, 2001, p.22).

O sucesso do evento e a perspectiva de construir um espaço de referência para a "colônia nipo-brasileira" que se constituía a partir de novas circunstâncias sociais (a crescente urbanização e maior identificação dos descendentes de imigrantes com o país em que nasceram) e históricas (os efeitos da Segunda Guerra sobre o Japão e sobre os japoneses no Brasil) inspiraram as lideranças do movimento a manter a comunidade unida em torno de um novo projeto, com potencial igual ou até maior de mobilização: a comemoração dos 50 anos da imigração japonesa, dali a quatro anos.

Esse espaço de referência foi a Sociedade Paulista de Cultura Japonesa, ou Bunkyo, fundado no ano seguinte, e que anos mais tarde mudaria o termo "Sociedade Paulista" para "Sociedade Brasileira", devido ao seu interesse de abranger as populações nipo-brasileiras de todo o país. Handa (1987) lembra que a entidade já nasceu com a aspiração de se tornar um ponto de convergência para os japoneses e seus descendentes, tanto no aspecto social - proporcionando lazer e confraternização aos membros da comunidade como um todo - como no aspecto cultural, já que se propunha a promover "o desenvolvimento cultural da colônia" e atividades de "intercâmbio cultural entre o Brasil e o Japão" (1987, p. 763). Para o autor, foi a organização do cinquentenário da imigração - que contou com a histórica visita de membros da família imperial para as comemorações, o príncipe Mikasa e sua esposa - e, anos depois, a recepção ao futuro imperador Akihito, que o Bunkyô consolidou sua posição de "órgão central de contato da colônia japonesa radicada no Brasil” (1987, p. 764).

Essa tentativa do Bunkyo de reunir a comunidade japonesa em torno de si, porém, não significa que o movimento de dispersão e diversificação da colônia tivesse, de alguma forma, mudado de rumo. Como ressalta Maeyama (1979), um número considerável de associações continuou sendo criado dentro da perspectiva étnica, congregando mulheres, jovens, naturais de cada província japonesa, praticantes de determinado esporte, hobby, atividade cultural ou crença religiosa, a partir de suas crescentes diferenças, não só quanto a áreas de interesse, mas de divisões mais profundas de visão de mundo, refletindo questões de classe social e sua maior ou menor identificação com a cultura do Brasil e do Japão (1979, p. 606). A narrativa da representatividade do Bunkyo, entretanto, já começara a ser construída e compartilhada, 
apesar da falta de consenso entre os membros da heterogênea população nipo-brasileira sobre as reais condições da entidade de representá-los.

Portanto, as duas décadas que se seguiram ao final da Segunda Guerra foram um período de acontecimentos transformadores tanto para a comunidade nipo-brasileira que construía uma identidade coletiva a partir de cisões recentes e antigas, mais aberta às influências da cultura brasileira, mas sem se desapegar do conjunto de sinais e signos que constituía a colônia como campo de representação simbólica - quanto para o Japão, que se reerguia dos escombros da guerra e tentava apresentar ao mundo uma nova versão de nação vitoriosa, agora em sua guerra contra o tempo, com uma rápida recuperação da economia e da sua paisagem devastada. Mas será que esse novo Japão que emergia, ocidentalizado à força, humilhado e destituído de sua origem divina ${ }^{57}$, poderia continuar sendo a referência de terra natal dos imigrantes japoneses e seus descendentes no Brasil, a caminho de se tornar a maior população de origem nipônica fora do Japão?

O encontro dos antigos imigrantes que há décadas viviam no país com uma nova leva que chegou logo após a guerra ilustra a experiência traumatizante que foi esse encontro entre o velho e o novo Japão. Conforme mencionado aqui antes, esses "japõesnovos" estranharam os japoneses que encontraram no Brasil, a quem chamaram de "Brasil-bokêe", como também eles foram objeto de estranhamento pelos antigos que, decepcionados, não podiam acreditar que fossem mesmo japoneses. Para os velhos imigrantes, "era inimaginável a mudança de vida que ocorrera no Japão, país que passara pela guerra e pela derrota" (HANDA,1987, p. 772). Para os novos imigrantes, por outro lado, foi surpreendente e difícil conviver com conterrâneos que veementemente se recusavam a acreditar nas histórias de fome e destruição que tinham para contar sobre seu país, muito menos na humilhante ocupação estrangeira que se seguiu ao reconhecimento pelo Japão de que havia perdido a guerra. Já estes eram vistos, por alguns dos velhos imigrantes, como culpados pela derrota do país, pois, se tivessem lutado como verdadeiros heróis, claro que o Japão teria vencido a guerra.

O espanto profundo e o sentimento de perda irreparável desses velhos japoneses em relação ao Japão transformado inspiraram uma interessante comparação de si

\footnotetext{
${ }^{57}$ Em 1946, sob ocupação americana, o Japão promulgou uma nova Constituição, de inspiração ocidental, em que o imperador renunciava à sua condição divina e passava a ser "símbolo do Estado e da unidade do povo" (SAKURAI, 2007, p.199).
} 
próprios com o personagem lendário Urashima Tarô ${ }^{58}$, feita por imigrantes que visitaram o Japão pela primeira vez depois de décadas de ausência, e que foram objeto de uma pesquisa acadêmica (ROTH, 2003, p.110). Segundo a lenda, Urashima Tarô é levado a um reino submarino, o Ryûgh, onde vive durante séculos sem que perceba a passagem do tempo; ao sentir saudades da terra natal, retorna, mas já não reconhece nada e nem ninguém; desesperado, contraria instruções recebidas e abre um baú mágico, tornando-se imediatamente um homem muito velho, sem recuperar, porém, a aldeia e a família que tinha ao partir.

Para o autor do estudo, a identificação dos imigrantes com a lenda aponta para uma questão de ambiguidade fundamental daqueles que deixaram o Japão e tentaram, sem sucesso, reconhecê-lo muitos anos depois como sendo ainda sua terra natal: se por um lado sua associação com o personagem de uma lenda tipicamente japonesa indica identificação com a cultura do seu país de origem, por outro a percepção de que sua história de vida coincide com o conteúdo da lenda assinala o reconhecimento de que seu país já não existe mais. O cerne da ambiguidade, então, seria que "a história de Urashima Tarô permite aos imigrantes japoneses que reconheçam seu distanciamento do Japão ao mesmo tempo em que se identificam com ele" (2003, p. 113).

Essa ambiguidade, de certa maneira, ilustra uma reflexão de Hall (2016) sobre "hibridismo", que nada tem a ver, para o autor, com uma "composição de mistura racial", mas sim com o estado de uma cultura já significativamente misturada, mesmo que os indivíduos possam "traçar, em outro lugar, uma linha direta de descendência". O produto dessa cultura hibridizada, lembra Hall, jamais poderá ter seus elementos originais desagregados, o que em termos práticos significa que nunca poderão voltar novamente "para casa" (2016, p. 50-51). Este foi, portanto, o caso dos japoneses que pensavam estar "retornando" para a terra natal, depois de décadas no Brasil, e ao chegarem ao Japão descobriram que haviam se transformado no "Brasil-bokêe". Difuso, “o senso de perda” é como um pássaro perdido que não tem onde pousar. Diz Hall:

\footnotetext{
${ }^{58}$ Esse conto, no Japão, faz parte da categoria dos mukashi banashi ("contos antigos"), difundidos pela tradição oral e adaptados para literatura infantil. Sua primeira versão data do século oitavo e é encontrada na coletânea Fudoki (713 D.C.), que é considerada uma das primeiras obras literárias do Japão (NAMEKATA, 1998, p. 73).
} 
A fantasia de uma origem final, assim como a de um início "verdadeiro", permanece assombrada pela "falta" ou pelo "excesso", sendo de qualquer forma inapreensível na plenitude de sua presença para si mesma ${ }^{59}$ (2016, p. 51).

Voltando à lenda de Urashima Tarô, uma outra apropriação interessante relacionada à experiência dos imigrantes japoneses no Brasil aconteceu quando a companhia aérea Varig lançou em 1968 - ano do sexagésimo aniversário da imigração uma vinheta comemorativa da inauguração da sua linha aérea Brasil-Japão, amplamente reproduzida nas redes de televisão da época. Nessa adaptação do autor da vinheta, Urashima Tarô representa o imigrante que, em vez de ser levado ao reino de Ryûgh, chega à "terra encantada" do Brasil, pela qual "se apaixonou", e "por aqui ficou"60. Na animação, sua longa permanência é representada pelo envelhecimento do viajante, que desenvolve compridas barbas brancas.

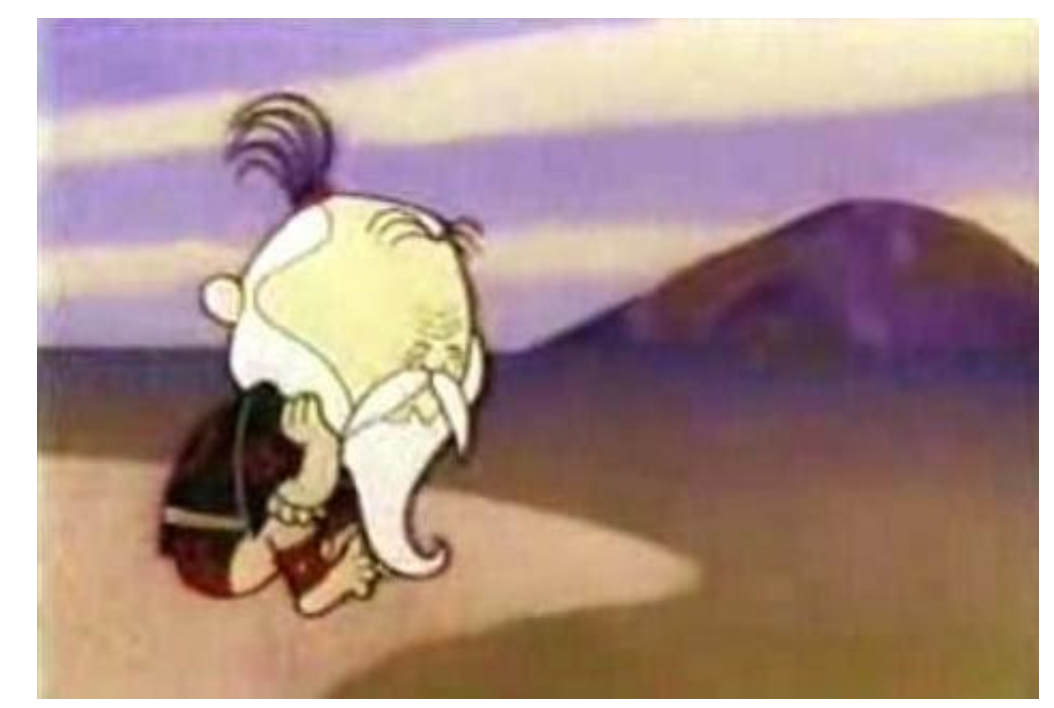

Figura 1: vinheta da Varig, Urashima Tarô.

Fonte: https://www.youtube.com/watch?v=K6MiR1WM8Tk Acesso em 12/03/2017

Nessa versão, o lado triste da história original - a decepção do japonês que, ao voltar, não reconhece sua terra natal e que, ao abrir o baú mágico, se transforma em homem muito idoso - é substituído por um desfecho oposto e feliz: o velho japonês, ao abrir o baú, encontra passagens aéreas para o Japão, e essa visão tem o poder mágico de

\footnotetext{
${ }^{59}$ No original em inglês: "The fantasy of a final origin, like a 'true' beginning, remains haunted by 'lack' or by 'excess', but is anyhow never graspable in the plenitude of its presence to itself". (Tradução da autora).

${ }^{60}$ Esse é o "desenho divertido" da Varig que assisti na infância pela TV, mencionado na introdução.
} 
rejuvenescê-lo, pela alegria de poder retornar à terra natal, da qual sentia tantas saudades ${ }^{61}$. O fato de ter sido uma lenda bastante difundida entre os imigrantes japoneses do Brasil, como relata Namekata (1998, p. 72), pode ter contado na escolha do tema pelo autor da vinheta. Na sua versão, porém, o potencial de comparação da lenda com o verdadeiro dilema do imigrante japonês que perdera suas referências de terra natal ficou esvaziado, até porque o objetivo da vinheta da Varig era celebrar a nova linha aérea que possibilitava o reencontro dos imigrantes com o Japão, e não explorar as consequências sociais e psicológicas dessa experiência.

\section{Assimilação e sobrevivência da "colônia"}

Um dos pilares de sustentação da etnicidade japonesa tradicional na colônia, como vimos, foi a família, que reproduzia - ainda que adaptados às realidades locais os valores e práticas do antigo Ie trazidos da terra natal. Mesmo com a mudança para os meios urbanos, a estrutura familiar continuou a manter esse papel de sustentação das características mais essenciais do "modo de viver japonês" tradicional, pois a família permaneceu sendo, por bom tempo, não só a referência da vida pessoal como também da vida do trabalho, como havia sido antes nos sítios e núcleos rurais. Handa (1987) relata que com a transição da agricultura para o comércio e prestação de serviços, nas cidades, os negócios continuaram fortemente dependentes dos membros da família. Seja na "quitanda, tinturaria, bar, empório, farmácia", as atividades fluíam sem interferências de fora, e sem "problemas de comunicação" (1987, p. 774). Com a graduação dos filhos no curso superior, as coisas começariam a mudar, pois a esfera de influência direta dos valores e práticas do Ie foi sendo substituída pela dinâmica do mercado de trabalho e da necessária convivência social com os brasileiros.

O papel da família na reprodução dos valores japoneses foi também discutido por Miyao ${ }^{62}$ (2006), em sua reflexão sobre o "processo de assimilação" dos

\footnotetext{
${ }^{61}$ A vinheta - de autoria de José Carlos Galerani Diniz, com música de Archimedes Messina e interpretação da cantora Rosa Miyake - foi criada em 1968 e voltou ao ar em 1988, na celebração dos 80 anos da imigração japonesa no Brasil, podendo ser vista em: https://www.youtube.com/watch?v=WLyaPAmMMfM acesso em 04/04/2017.

${ }^{62}$ Susumu Miyao foi um dos fundadores do Jinmonken, ou Centro de Estudos Nipo-Brasileiros (CENB), entidade dedicada à pesquisa da imigração japonesa no Brasil, que teve colaboradores como Hiroshi Saitô e Teichii Susuki, da USP. Foi diretor-executivo da entidade de 1991 a 2003, e um de seus conselheiros até
} 
descendentes de imigrantes japoneses no Brasil. Segundo o autor, a população nipobrasileira que possui escolaridade de nível superior - o que em 1990, de acordo com sua pesquisa, atingia $40 \%$ do total da comunidade - não costuma frequentar as associações nem coloca "seus filhos nas escolas de língua japonesa. Em resumo, são pessoas que se situam fora da "colônia"” (2006, p. 84). A "colônia nikkei", segundo o autor, é hoje um conjunto de entidades regionais organizadas por agricultores e comerciantes cuja "consciência" de pertencimento à comunidade nipo-brasileira é que define a maneira de ser e de pensar da própria "colônia"63.

Essas famílias teriam um papel essencial na manutenção do legado cultural dos seus ancestrais, principalmente porque "fazem os seus filhos estudarem a língua japonesa e fazem questão de que o ensino da língua japonesa seja direcionado no sentido da formação de moral japonesa, que deve ser incutida nas crianças” (MIYAO, 2006, p. 84). Essa "moral japonesa", no pensamento do autor, não se refere necessariamente aos valores que se praticam hoje no Japão, mas às "coisas boas da cultura japonesa" que foram trazidas e conservadas pelos imigrantes - e transmitidas aos filhos pelos exemplos dos pais e pela educação familiar - inclusive "aquelas desaparecidas no próprio Japão" (2006, p. 181).

Esse espírito de colônia, porém, está fadado à extinção, segundo a opinião do autor, publicada na forma de reflexões e análises datadas de 1969 a 2005 e reunidas na obra citada. Pesquisas conduzidas pelo Centro de Estudos Nipo-Brasileiro (CENB) são mencionadas como evidência de que embora a população nipo-brasileira esteja crescendo numericamente, a "consciência de pertencimento" dessas pessoas a uma comunidade de origem japonesa é cada vez menor, à medida que as novas gerações de descendentes vão deixando "de possuir a consciência familiar, a consciência de identidade para com a "colônia"” (MIYAO, 2006, p.121). O declínio da importância dada pelas novas gerações à manutenção da família japonesa é ilustrado, segundo Miyao, por pesquisa de 1986 sobre casamento na população Nikkei.

Segundo essa pesquisa, ao serem questionados sobre os pontos aos quais atribuíam maior importância na escolha do parceiro, apenas 4,8\% dos entrevistados

sua morte, em 2016. Nascido em 1930 na Colônia Aliança, no Brasil, Miyao viveu dos 9 aos 23 anos de idade no Japão, onde se formou em Filosofia.

${ }^{63}$ Segundo pesquisa do $C E N B$ de $1986,39,8 \%$ dos participantes de entidades nipo-brasileiras - culturais, beneficentes ou esportivas - eram nisseis (segunda geração) nascidos antes da Segunda Guerra; 28,3\% de nisseis nascidos no pós-guerra, e 9,2\% eram sanseis (terceira geração). "Com o avançar das gerações, o grau de participação vai diminuindo" (MIYAO, 2006, p. 49) 
solteiros escolheram o quesito "ser nikkei". Nessa mesma pesquisa, ao serem perguntados se possuíam irmã ou irmão casado com não-nikkei, 45,7\% dos entrevistados "responderam positivamente, indicando o avanço dos casamentos interétnicos” (2006, p.47). A “miscigenação", para o autor, é um dado que confirma a tendência à dissolução da "colônia japonesa" do Brasil, embora a questão racial não seja o foco da sua observação, mas sim a transmissão cultural dos "valores japoneses". Estes desapareceriam à medida que a constituição familiar deixa de ter como referência a forma de organização tradicional da família japonesa, mesmo nas suas formas adaptadas à realidade brasileira.

Discussões sobre o casamento interétnico e seu impacto na sobrevivência da “colônia japonesa" no Brasil estão presentes nos mais variados registros sobre a família japonesa e sua relação com os brasileiros, desde as primeiras décadas da imigração. Lesser (2001) relata que um estudo da Comissão de Recenseamento da Colônia Japonesa, publicado em 1964, afirmava que os casamentos interétnicos eram raros: “entre 1908 e 1942, o índice era de menos de 2\% entre os imigrantes e de menos de 6\% entre os nikkeis (todos os descendentes de japoneses)", e que os poucos casamentos entre japoneses e caboclos haviam "fracassado de forma abjeta" (2001, p.182). Já o Centro Nipônico de Cultura, em 1934, também citado por Lesser, publicava um relatório em sete páginas, intitulado "Cruzamento da etnia japonesa". Ilustrado por fotografias de homens japoneses com suas esposas brasileiras brancas (ou imigrantes europeias) e seus filhos mestiços, em cenas familiares bem compostas, o relatório afirmava que "as crianças nascidas de pais japoneses continuavam a ser geneticamente japonesas, independentemente de sua fisionomia" (2001, p.184).

Handa (1987) observa que os imigrantes de primeira geração não desejavam de forma alguma ver seus filhos se casando com pessoas sem ascendência japonesa, e quando isso acontecia mesmo contra sua vontade, sentiam-se "envergonhados diante da sociedade" ou "culpados perante os ancestrais". Com o tempo, as famílias de origem japonesa no Brasil tiveram que enfrentar a abertura cada vez maior das novas gerações em relação ao casamento fora da colônia e, embora tivessem que acabar aceitando a opção dos filhos, não podiam deixar de sentir "um pouco de inconformismo" (1987, p. 794). E quanto ao sucesso desse tipo de "casamento misto", Handa acreditava ser mais provável que desse certo o casamento de mulheres do que de homens de ascendência japonesa com não descendentes, porque "as mulheres nisseis se adaptam ao estilo de 
vida do marido", enquanto que os homens não conseguem livrar-se de seus “sentimentos japoneses" (1987, p.795).

A questão da avaliação de indivíduos "mestiços", frutos desses "casamentos mistos", é discutida em estudo de Hatugai (2015), que revelou que, diferente do que ocorre no Japão - onde os "mestiços" são chamados de hafu (da palavra half, que quer dizer "metade" em inglês), portanto "divididos em duas partes" -, no Brasil, "além da bipartição do 'mestiço', há ainda uma composição pensada em níveis". Nos casos examinados pela autora, enquanto os filhos miscigenados de pai descendente com mãe não descendente possuíam o estatuto de japoneses - por sua incorporação no sistema patrilinear da família tradicional nipônica -, os filhos de mãe descendente com pai não descendente eram considerados "mestiços", por estarem fora desse sistema de incorporação $(2015$, p.3). Mas os níveis de pertencimento do "mestiço" à comunidade nipo-brasileira, segundo o estudo da autora, não se referem apenas a questões relativas ao "sangue japonês" e sua localização no sistema de linearidade do parentesco, mas também à educação e à prática de costumes considerados essenciais para sua identificação com a cultura japonesa.

Assim, um mestiço pode ser considerado mais ou menos "japonês" de acordo com seu nível de adesão aos hábitos familiares, às regras de etiqueta e às técnicas da culinária japonesa. A questão da comida é crucial na produção de indivíduos identificados com a cultura japonesa, segundo a autora, pois "a ausência desse alimento na vida de um sujeito o afasta das referências nipônicas e revela um perfil familiar onde os elementos da tradição estão ausentes" (2015, p.11). Nesse sentido, há uma situação inversa à relatada acima: na família "mista" onde a mãe é que é a descendente, há maior expectativa de que sejam mantidos os costumes alimentares japoneses - já que o gerenciamento da casa e da família é atribuição feminina -, e se a mãe é brasileira, ocorreria maior (ou total) afastamento das tradições. Segundo esse estudo de Hatugai, mesmo hoje o casamento entre descendentes pode permanecer como "um modelo ideal e desejável" para muitas famílias, não por apego ao passado ou por desejo de manter a comunidade fechada em si mesma, mas pela percepção de que quando ambas as partes compartilham os mesmos valores, "não há grandes choques entre a herança cultural e a educação familiar" (2015, p.12).

O fato de os descendentes de japoneses já estarem há várias gerações completamente introduzidos na sociedade brasileira, em seus ambientes de estudo, lazer 
e trabalho, faz com que a escolha do "parceiro afetivo" seja cada vez menos determinada pelo fator étnico, por maior que seja o empenho da família nesse sentido. Um dos ambientes que proporcionariam uma socialização que inclui o fator étnico sem excluir os demais - é uma igreja como a Metodista Livre ${ }^{64}$, que, segundo o estudo de Hatugai, é "marcada pela forte presença nipônica". A autora observou que além dessa presença massiva, a Igreja promove eventos em que não faltam a "comida japonesa e costumes nipônicos", proporcionando assim oportunidades de identificação desses indivíduos uns com os outros e com sua cultura de origem. $\mathrm{O}$ namoro entre descendentes, e com mestiços, que se conheceram na igreja levou a autora a considerar que as sociabilidades religiosas e étnicas se combinam, em alguns casos, para “aproximar as pessoas por similaridades étnicas e ou religiosas atualizando a noção de casamento preferencial entre descendentes de nipônicos” (2015, pp. 11-12).

O papel das igrejas, templos e seitas religiosas na construção de espaços de socialização que promovem a identidade étnica e a disseminação de valores japoneses no Brasil é ressaltado também no estudo de Tomita (2004) sobre as Novas Religiões Japonesas $(N R J)^{65}$. Essas religiões - fundadas por imigrantes e seus descendentes, ou por missionários que vieram do Japão - passaram por processos de transformação, sobretudo a partir da década de 1970, quando se abriram à sociedade mais ampla, deixando assim de ser "religiões étnicas" para se tornarem "religiões de características universais" (2004, p. 89).

Segundo a autora, essa abertura implicou uma "tradução" não só dos conteúdos em japonês, mas também das práticas mesmas, que se baseavam em valores difíceis de serem assimilados por brasileiros (incluindo aí as gerações mais jovens de nikkeis) como, por exemplo, a obediência a preceitos e submissão a hierarquias, sem discussão nem explicação. Por outro lado, mesmo "traduzidas", essas religiões proporcionam a criação de espaços em que o universo cultural japonês - como a cerimônia do chá, o

64 “A Igreja Metodista Livre - Concílio Nikkei foi iniciada em 1936 pelo missionário japonês Daniel Nishizumi. Naquela época, a língua falada da Igreja, tanto na evangelização como nas atividades eclesiásticas, era o japonês. Em 1964, alguns jovens da IMel Saúde entenderam que havia chegado o momento de se formar uma igreja em novos paradigmas. Orientados pelo então missionário no Brasil, Dr. James Mannoia, formaram a Igreja Metodista Livre Nissei. Seu público alvo eram os descendentes de japoneses, com suas características e necessidades peculiares”. Disponível em: https://www.imel.org.br/diadema-1, acesso em: 20/04/2017.

${ }^{65}$ Segundo dados do IBGE do ano 2000, as NRJ com maior número de adeptos no Brasil são, em ordem decrescente: Igreja Messiânica Mundial, Seicho-no-Ie, Perfect Liberty, Tenrikyo e Mahicari, todas elas com mais adeptos nas regiões Sudeste e Sul, mas presentes também nas demais regiões do país (em: TOMITA, 2004, p.90). 
ikebana, o judô, a culinária e até mesmo palavras e expressões da língua japonesa pôde ser cultivado e disseminado, tendo em vista não só a comunidade nipo-brasileira, mas também os adeptos não descendentes.

As novas associações e seitas religiosas japonesas que surgiram no Brasil, a partir da Segunda Guerra, acompanharam uma tendência que ocorria na mesma época no Japão, com o fim do predomínio do Budismo e Xintoísmo como religiões oficiais de Estado. Handa (1987) relata que nos primeiros anos da imigração, os imigrantes japoneses não formalizaram suas práticas religiosas no Brasil, dedicando-se a atividades privadas, dentro da própria família, sobretudo nos matrimônios e ocasiões fúnebres. Sem tempo de folga nem condições materiais para construção de templos ou santuários, os imigrantes, porém, conseguiam promover "alguma atividade religiosa", ainda que fosse apenas "ler em voz alta orações budistas ou xintoístas". Igrejas cristãs e evangélicas também surgiram, ainda nas décadas de 1920 e 1930, nos núcleos de imigrantes, geralmente propagadas "pelos próprios compatriotas". Mas se antes da guerra a ideia de comunidade japonesa referia-se basicamente à convivência e socialização no interior dos "núcleos de colonização" e do "bairro japonês" da cidade de São Paulo (o entorno da Rua Conde de Sarzedas), depois da guerra a religião firmou-se como "o princípio da união étnico-racial dos japoneses radicados no Brasil" (HANDA, 1987, pp. 735-736).

Embora as igrejas, seitas e templos se dediquem declaradamente a atividades ligadas à devoção e à espiritualidade, a experiência de socialização e de construção do sentimento de pertencimento reafirma, portanto, o papel da religião na "construção de sentidos", cujo compartilhamento pelos fiéis faz com que vejam a si mesmos como parte de um todo. Em seu estudo sobre a religião como "agente de socialização", Setton (2008) afirma que "a religião e suas estratégias de convencimento, sociabilidade e controle seriam práticas e ou estratégias pelas quais os indivíduos e os grupos se mantêm coesos ou se dissociam a partir da comunhão ou da diferenciação de sentidos" (2008, p.18).

Com a transformação da "colônia japonesa" do Brasil em "comunidades nipobrasileiras", diversas e abertas a constantes transformações, a religião foi, assim como a família, uma instituição que garantiu um espaço para a cultura japonesa continuar funcionando como fator de coesão e de construção de sentido, ainda que "traduzida" para exprimir as mudanças no interior da própria comunidade e também para permitir a 
inclusão de não descendentes. Os estudos mencionados acima sugerem, portanto, que a dispersão e diversificação da comunidade nipo-brasileira não implicam necessariamente dissolução e desaparecimento da sua cultura de referência, embora uma constante dinâmica de modificação tanto da família como das religiões atualize as memórias do passado, misturando-as com as novas referências de um Japão moderno, também imaginado.

\section{O Japão pop e as novas referências identitárias}

Imagens e produtos desse Japão moderno foram disseminados pelo mundo a partir da década de 1960, mas ganharam maior intensidade a partir dos anos 1980, marco da recuperação econômica do país iniciada com os esforços de reconstrução do pós-guerra. E são exatamente esses produtos da indústria cultural japonesa - que chegam ao Brasil pela televisão e pelo cinema quando a maior parte dos imigrantes e seus descendentes já está dispersa pelas cidades - que vão preencher alguns dos espaços que a educação familiar e religiosa não conseguem alcançar, quanto à transmissão dos valores nipônicos para as novas gerações. Como afirmam Nakamura e Crippa (2014), é justamente "o afastamento do contato com as tradições e ensinamentos dos membros mais velhos da comunidade" que vai abrir caminho para "as mudanças na forma com que os nipo-descendentes se identificam com a cultura de origem” (2014, p. 373).

Embora a cultura pop japonesa não seja parte do legado tradicional dos imigrantes, ela se impõe gradualmente como referência de identificação do "ser japonês no Brasil" por três motivos: primeiro, pela sua enorme repercussão entre os jovens descendentes, graças aos meios de comunicação de massa e, mais tarde, às mídias digitais; segundo, pela oportunidade de renovação dos vínculos da comunidade nipobrasileira com o Japão; e terceiro, por ser motivo de orgulho - o que é uma poderosa força de coesão - para toda a comunidade de origem japonesa, já que representa um dos aspectos mais bem sucedidos da indústria cultural nipônica no mundo.

A estética da cultura pop japonesa tem suas raízes na arte tradicional, como ressalta Sonia Luyten (2014), que vê nos Hokusai Manga ${ }^{66}$ a origem dos temas e

\footnotetext{
${ }^{66}$ Segundo Luyten (2014), foi o artista japonês Katsushika Hokusai (1760-1849) que introduziu o termo manga. Hokusai Manga é uma série de estudos sobre movimentos e expressões cujos temas incluíam "a
} 
formatos desses "desenhos irreverentes". Tanto o próprio Hokusai como artistas de períodos posteriores se inspiraram nas imagens e no humor do Ocidente para criar uma arte com referências locais e de apelo popular, que com o tempo passou a ser publicada em um formato aproximado ao das histórias em quadrinhos, representando não apenas a realidade cotidiana das pessoas comuns, como também situações fantásticas e representações do imaginário. Assim, aspectos da cultura tradicional japonesa - como imagens de $u k i y o-\hat{e}^{67}$ e personagens de narrativas clássicas - foram sendo incorporados aos "novos mangás", em releituras dos padrões estéticos e éticos originais.

A partir dos anos 1920, o mercado editorial no Japão começou a se organizar para a produção do mangá separado por faixas etárias (para adultos, crianças e adolescentes) e mais tarde por sexo: os quadrinhos para meninas (shojo mangá) e para meninos (shonen mangá). Nas décadas subsequentes ao final da Segunda Guerra, surgiu um novo gênero que haveria de levar a estética do mangá para todos os cantos do mundo: o animê (do inglês animation), um tipo de desenho animado inspirado no mangá ${ }^{68}$, que se disseminou via seriados de televisão, filmes e games. Um dos primeiros personagens do animê a ganhar fama mundial foi Godzilla (ou Gojira, na pronúncia em japonês), um monstro criado pela radiação atômica, em clara alusão aos trágicos eventos de Hiroshima e Nagasaki.

Antes de ganharem notoriedade pelo mundo, os mangás já eram amplamente consumidos pelos descendentes de japoneses no Brasil. Eram importados do Japão e distribuídos por livrarias do bairro da Liberdade, que os enviava às cidades do interior de São Paulo e de outros Estados. Os filmes inspirados na estética do mangá também chegavam logo ao bairro da Liberdade, onde eram exibidos em salas de cinema especializadas em produções japonesas (como o Cine Niterói ${ }^{69}$ ), atraindo um público fiel e numeroso. Segundo Luyten (2014), esses elementos da indústria cultural nipônica tiveram a função dupla, no Brasil, de manter a fluência na língua japonesa e de atualizar

vida urbana, as classes sociais, a natureza fantástica e a personificação dos animais”. Esses desenhos, muitos em formato caricatural, deram ao termo mangá (ou histórias em quadrinhos) a conotação de "desenhos irreverentes".

${ }^{67}$ Em japonês, "desenhos do mundo flutuante", os ukiyo-e são gravuras ou pinturas do período Edo (1603-1868) que retratam aspectos da "vida mundana", como cenas eróticas, de lutas e de narrativas populares, rostos femininos, paisagens, animais, etc.

${ }^{68}$ No Japão, porém, animê se refere a todo tipo de desenho animado, de qualquer procedência, não apenas o inspirado no mangá japonês.

${ }^{69}$ Fundado em 1953, o Cine Niterói foi a primeira sala de cinema a se especializar em filmes japoneses. Era localizado na rua Galvão Bueno, mas em 1968 mudou-se para a avenida Liberdade, para dar lugar ao viaduto Osaka. Fechou as portas em 1988, como outros cinemas do bairro (KISHIMOTO, 2013, p. 37). 
o seu uso entre os imigrantes e seus descendentes, que podiam assim conhecer os novos termos em voga no Japão, em especial aqueles derivados do inglês, introduzidos no pósguerra.

A partir dos anos 1960, os seriados e desenhos animados passaram a ser transmitidos pela televisão, em audiência que já não se restringia à população nipobrasileira. No resto do mundo, ocorreu o mesmo fenômeno, o que coloca a cultura pop japonesa em uma posição ambígua, no que se refere à sua recepção pelos descendentes de imigrantes no Brasil: se por um lado a cultura japonesa se torna transnacional e por isso deixa de ser "japonesa", em um sentido estrito, mas parte de uma cultura pop mundial apropriada de diversas formas em países diferentes, por outro lado a acessibilidade dos meios de comunicação de massa possibilita a todos o contato com um produto cultural que é, de qualquer modo, de origem japonesa, o que oferece novas oportunidades de identificação - e de reconexão - dos jovens descendentes com a terra de seus ancestrais.

Foi com o advento da Internet, porém, que a cultura pop japonesa teve seu alcance significativamente ampliado, modificando também a relação dos consumidores com os mangás, animês, filmes e seriados, graças aos novos dispositivos de interatividade, apropriação e autoria. No ponto de vista da identificação dos jovens nipo-descendentes com a cultura japonesa, as novas mídias digitais possibilitaram, portanto, não só um acesso ao conteúdo, mas também a novas formas de sociabilidade, com a criação de grupos on-line que trocam material criativo, comentários e informações sobre festivais de cosplay ${ }^{70}$ e encontros informais de otakus ${ }^{71}$. Os meios digitais também abriram o leque das formas possíveis de contato e relação com outros aspectos da cultura japonesa, pois é possível acessar informações extras e variadas relacionadas aos produtos, personagens, autores e eventos relacionados à cultura pop e também ao próprio país, o que inclui a língua japonesa - que, segundo Luyten (2014), tem sido cada vez mais procurada como "segunda língua" graças à utilização da Internet como ferramenta de acesso.

\footnotetext{
${ }^{70} \mathrm{O}$ termo cosplay é uma junção de duas palavras em inglês: costume (fantasia) e play (representar, jogar ou brincar) que se refere a um tipo de performance em que os participantes se vestem como um personagem de uma história, geralmente da cultura pop japonesa ou outra. Segundo Luyten (2014), o Brasil foi bi-campeão no World Cosplay Summit, realizado em Tóquio, em 2008.

71 "Embora no Japão o termo otaku tenha um valor negativo e designe uma geração de jovens avessos às relações pessoais, no Brasil os otakus são os fãs de animês, mangás e outros ramos da cultura pop japonesa" (NAKAMURA e CRIPPA, 2014, p. 378, nota de rodapé).
} 
Os novos espaços e experiências vivenciados pelas novas gerações de nipobrasileiros graças ao acesso à cultura pop e à cultura japonesa em geral pelas mídias digitais e pelos meios de comunicação de massa são, como lembra Luyten (2014), um "ritual de identificação". Por meio desses rituais, são construídos (ou renovados) laços de pertencimento em nível local - com a participação real das pessoas em determinado evento ou encontro de cosplay ou de otakus - e em nível global - na inclusão virtual das pessoas no universo da cultura pop japonesa, por ser hoje um produto de consumo e de intercâmbio transnacional.

Embora todo o repertório icônico, gestual, idiomático e narrativo da cultura pop japonesa represente um Japão completamente diferente daquele que é referência da história e da memória dos imigrantes, a língua e a etnicidade japonesas - as "marcas de origem" - são o fator de identificação sempre presente, tecendo os fios da continuidade entre o que é antigo e o que é novo. Assim, a lógica do pertencimento e da identidade nipo-brasileira, para as novas gerações, é um complexo emaranhado de referências do passado - transmitidas pela família (em variados graus de adesão, já que cada família se relaciona mais ou menos com o legado dos seus ancestrais) e ritualizadas nas festas e eventos da comunidade (também em graus diferentes de adesão, já que cada família comparece mais ou menos a esses eventos) - e de novas referências do presente, mediadas pelas novas mídias digitais que oferecem, entre muitas outras experiências igualmente determinantes, a cultura pop japonesa e o Japão moderno como uma possibilidade de renovação do "ser japonês no Brasil".

\section{Mídia étnica e a coesão da comunidade}

O "ser japonês no Brasil” contou desde as primeiras fases da imigração com uma poderosa força de coesão: os jornais da comunidade. Consta que os primeiros exemplares dessa mídia produzida por e para imigrantes japoneses surgiram antes mesmo da chegada deles, com uma edição realizada e distribuída à bordo do Kasato Maru, o navio que trouxe a primeira leva de trabalhadores japoneses ao Brasil, em junho de 1908. Kinjô (2009, s/p) relata que esse "primeiro jornal da história dos cem anos da imigração" chamou-se Kokai Shimbun (Jornal da Travessia) e circulou em "três toscas edições", durante a viagem de 51 dias que trouxe os primeiros imigrantes da cidade 
portuária japonesa de Kobe ao porto de Santos, descrevendo e comentando o cotidiano a bordo:

Rokuro Koyama, um aventureiro de 23 anos, fazia tudo sozinho: entrevistava, redigia, ilustrava, tirava cópias, distribuía. Perdeu o gás quando o representante da companhia de imigração, Shuhei Uehara, chamou sua atenção: "Koyama, não escreva mal nem seja indelicado com tripulantes e passageiros". É que matéria sobre os carecas a bordo produziu desconforto e algumas reclamações de passageiros. A nascente trajetória jornalística de Koyama foi desse modo atropelada. Mas alguns anos depois ele voltaria à luta (KINJÔ, 2009, s/p).

Segundo Handa (1987), em todo lugar que houvesse uma concentração de japoneses era criada uma associação, que por sua vez publicava o jornalzinho da entidade, geralmente semanários ou mensários de pequenas tiragens, produzidos artesanalmente e entregues aos seus membros, que os passavam de mão em mão, ampliando assim seus raios de alcance. A mídia do imigrante japonês no Brasil - que teve início de forma mais articulada em 1916, oito anos após a chegada dos primeiros imigrantes, com o Nambei Shuho (Semanário da América do Sul) e o Nippak Shimbun (Jornal Nipo-Brasileiro) - foi um dos mais decisivos instrumentos de construção da identidade do grupo, ao circunscrever o universo de seu público, refletindo aspectos essenciais da sua cultura e de suas áreas de interesse.

Participou ativamente da vida dos imigrantes desde o início e ainda hoje embora já transformada - permanece como uma força empenhada em atualizar os laços da comunidade, fundada na ancestralidade comum e nas memórias da imigração. A seleção de assuntos, a linguagem e as formas de distribuição da antiga mídia japonesa do Brasil definiam o perfil do leitor: falante de japonês, capaz de ler kanjis e kanás ${ }^{72}$, interessado em narrativas e poesias japonesas, em notícias do Japão e do consulado geral japonês em São Paulo, e em informações sobre preço de terras, equipamentos e insumos agrícolas da região.

Por mais amplo que pareça, esse perfil na verdade revela um público muito específico, ou melhor, que buscava definir sua especificidade em um contexto temporal

\footnotetext{
${ }^{72}$ A escrita japonesa é composta por hiraganás, katakanás e kanjis - sendo que os dois primeiros são fonéticos e o terceiro é ideográfico (derivado do chinês, mas com diferente pronúncia e sentido).
} 
e espacial complexo e desafiador, e ainda por cima provisório, já que a imensa maioria dos imigrantes tinha planos de ficar no Brasil apenas o tempo suficiente para juntar dinheiro e voltar, o mais rápido possível, para o Japão. Esses periódicos, portanto, tiveram o papel fundamental de articular e organizar um discurso que unificasse uma comunidade composta por indivíduos de diversas procedências, dialetos, idades, ocupações e objetivos, mas que tinham em comum o fato de serem cidadãos japoneses vivendo no Brasil, na condição temporária de imigrantes, em um determinado momento histórico. Isto não exclui, porém, o fato de que apesar de seu papel unificador, algumas vezes esses veículos de comunicação buscassem preservar certas diferenças existentes dentro da comunidade mais ampla, como foi o caso, por exemplo, de jornais de comunidades em que a maioria era de imigrantes provenientes de Okinawa.

A intensa produção e consumo de jornais pelos imigrantes no Brasil reflete um hábito de leitura adquirido ainda no país de origem. As grandes transformações políticas e culturais na Era Meiji, que incluíram a educação obrigatória, haviam encorajado a formação de uma indústria editorial que se consolidou graças à existência de um público leitor interessado, sobretudo, em histórias em fascículos e notícias. Mizumura (2011) relata que os primeiros jornais produzidos pelos imigrantes japoneses no Brasil reproduziam o tipo de jornalismo que existia nessa época no Japão, quando já prevaleciam os grandes jornais, ou Oo Shimbun, que incluíam conteúdo opinativo (com frequência, censurado pelo Estado) e matérias de interesse popular. Esses veículos de informação circulavam diariamente com boa infraestrutura de impressão e distribuição, a mesma que editava novelas e peças de teatro.

Nos jornais editados pelos imigrantes, como no Japão, não faltavam as histórias em capítulos, geralmente publicadas na primeira página, que os leitores aguardavam com grande entusiasmo e comentavam entre si. Também eram populares os poemas clássicos japoneses, como os tanka e haiku, compostos em boa parte das vezes pelos próprios imigrantes. Para estes, os poemas eram uma forma de autoexpressão e de organização das experiências de adaptação e também dos sentimentos de tristeza, saudade e, sobretudo, de decepção, ao se darem conta de que o objetivo de juntar dinheiro rapidamente e voltar ao Japão não se realizaria ${ }^{73}$. E nesses jornais, distribuídos nas diversas regiões onde os japoneses haviam se assentado, também havia muita

\footnotetext{
${ }^{73}$ Um desses poemas, citado por Lesser (2001, p.168), é exemplar desse sentimento de decepção: "Dez anos de Brasil/ A pátria deixada para trás/ Sonhos de ouro desfeitos/ E eu me vejo na estaca zero/ Dias vagabundos voam em lágrimas e risos/ Vou dormir bêbado, amanhã será outro dia”.
} 
opinião, como relata Handa (1987). O autor conta que as divergências de opiniões muitas vezes transformavam-se em "debates acalorados entre pessoas de visões políticas opostas", tornando-se, assim, uma forma de "conscientização" dos imigrantes como membros de uma "comunidade nipônica brasileira" (1987, p. 602).

Esses jornais desempenharam um papel importante na formação e disseminação dos ideais de colonização, defendendo a venda de terras aos imigrantes e sugestões de como os núcleos deveriam ser organizados e administrados. Também proporcionaram informações essenciais sobre preços para que os imigrantes tivessem condições de negociar e vender bem os seus produtos. Fizeram a mediação entre os colonos e o governo japonês, publicando notícias do consulado, avisos de chegadas de pacotes e cartas do Japão e informações sobre remessas de dinheiro e emissão de documentos. Tiveram função integradora, juntando em uma mesma comunidade de leitores imigrantes dispersos em regiões distantes entre si. Investiram na manutenção desses laços comunitários patrocinando campeonatos esportivos como o undokai e o sumo $\hat{o}^{74}$, anunciando locais de venda de produtos da culinária japonesa e publicando notas de casamento, nascimento, falecimento e sobre pessoas solteiras disponíveis para matrimônio.

Fortaleceram os laços da comunidade de imigrantes com a terra natal promovendo edições especiais no aniversário do imperador, publicando notícias sobre o Japão - que por muito tempo ocuparam muito mais espaço do que as notícias regionais, o que reflete o interesse da maioria de ficar pouco tempo no Brasil - e promovendo campanhas para angariar fundos de auxílio às vítimas de catástrofes, como do grande terremoto de Tóquio de 1923. Foram educadores da comunidade de imigrantes, fornecendo material de leitura e reflexão, espaços de autoexpressão literária - conforme mencionado acima - e até mesmo aulas de português básico. Graças ao prestígio conquistado com toda essa prestação de serviços e ao seu poder de disseminar suas versões dos fatos, os jornais de imigrantes exerceram grande controle sobre o comportamento dos membros da comunidade, que temiam ser expostos em "notícias desonrosas" e virar assunto de fofoca.

Nos seus primórdios, os jornais da comunidade nipo-brasileira tinham como característica comum a simplicidade de recursos, que refletia a própria situação dos

\footnotetext{
${ }^{74}$ Undokai: gincana poliesportiva; sumô: luta entre dois atletas em que é derrotado o primeiro a tocar o chão com alguma parte do corpo (exceto os pés), ou a pisar fora do ringue.
} 
imigrantes japoneses no Brasil, instalados sob condições adversas, quase sempre no meio rural, embora vários deles também tenham se instalado logo nas cidades. Muitos desses jornais eram, na verdade, apenas boletins de duas ou quatro páginas, produzidos por amadores, com materiais e métodos improvisados, focados em questões específicas - como aspectos ligados à agricultura e à compra e venda de terra - e de curta duração. Com o estabelecimento dos imigrantes em núcleos de colonização e a criação de clubes e associações da comunidade, periódicos mais elaborados foram produzidos e distribuídos com maior regularidade, por pessoas mais experientes na produção de texto e até por jornalistas de profissão.

Mizumura (2011) descreve o perfil dos jornalistas pioneiros da imprensa nipobrasileira como o "imigrante com pretensões intelectuais", com habilidade "acima da média” de redigir em japonês, e com "pouca afinidade com a enxada" - sendo por isso, não raro, chamados de "vagabundos" pelos compatriotas agricultores (2011, p. 95). O sucesso desses jornalistas era proporcional à sua capacidade de reproduzir, em suas matérias, a "oralidade dos imigrantes", numa linguagem semelhante à utilizada em cartas e diários. Esses textos revelavam uma língua japonesa falada somente no Brasil, pela mistura do japonês com palavras e expressões em português, que resultou no "coronia-go" (língua da colônia), em que a maior parte das palavras pertencia ao vocabulário do imigrante refletindo, sobretudo, a sua vida no campo.

Em sua análise dos depoimentos de imigrantes que atuaram como jornalistas nas primeiras décadas de presença japonesa no Brasil, Mizumura (2011) comenta que, apesar da baixa (ou nenhuma) remuneração, esses pioneiros tinham "percepção da importância do jornalismo para a comunidade" e sentiam-se felizes - e até mesmo emocionados $^{75}$ - por terem escolhido esse ramo de atividade. Esses pioneiros não reclamavam da vida muito pobre que levavam, por terem a compensação dos "acalorados debates políticos" e da posição de destaque que acabavam assumindo, com o tempo, junto à colônia japonesa, como "orientadores" ou "formadores de opinião" (2011, p.96).

\footnotetext{
${ }^{75}$ Em sua tese, a autora transcreve trecho das memórias de Rokuro Koyama - o mesmo autor do Jornal da Travessia, produzido a bordo do Kasato Maru, conforme mencionado acima - em que ele narra a emoção que sentiu ao produzir edições extras, agora no Seishu Shinpo (conhecido em português como Novo Expresso São Paulo), sobre o grande terremoto de Tóquio, de 1923, e ao ver a repercussão de suas matérias junto à comunidade de imigrantes (MIZUMURA, 2011, p. 97).
} 
Os "acalorados debates políticos" promovidos pela imprensa dos imigrantes, nunca tiveram temperaturas tão elevadas como nos tempos de Saku Miura, que adquiriu em 1919 o Nippak Shimbun (Jornal Nipo-brasileiro), semanário de quatro páginas, fundado três anos antes por dois intérpretes de núcleos de imigrantes no estado de São Paulo. Miura tinha um estilo crítico e irreverente, com o qual questionava as autoridades japonesas no Brasil, que, segundo ele, não se mexiam o suficiente para atender às necessidades prementes dos imigrantes. De espírito livre e independente, a atitude de Miura atraiu inimigos que o acusaram de comunismo e de desacato à autoridade imperial. Esses desafetos articularam sua expulsão do país, que foi aprovada, depois suspensa, e finalmente executada em 1939, quando foi deportado para o Japão.

Um de seus principais antagonistas foi Seisaku Kuroishi, que em 1917 fundou o Brasil Jihô (Notícias do Brasil), cujo primeiro número foi dedicado ao aniversário do imperador. De estilo mais conciliador e moderado, o seu Jihô era um jornal com “tendências para a 'doutrina de esconder os podres' ou 'jornal partidário do governo"” (HANDA, 1987, p. 607). Os confrontos constantes entre os dois - cujo campo de batalha eram os editoriais de seus respectivos jornais - representavam a polarização de duas tendências da época, que, segundo Kinjô (2009, s/p), haveria de resistir às turbulências do mundo, incluída aí a Segunda Guerra: "preservar ou integrar? Fechar-se em gueto ou fundir-se no melting pot tropical?".

A tendência que defendia a preservação - mais forte e numerosa - era a dos imigrantes nacionalistas, com deveres de lealdade para com o Japão, sua terra natal e para onde pretendiam voltar um dia. A outra tendência - menos numerosa, mas bem articulada -, na verdade, estava longe de defender uma integração do tipo "dissolução total" no melting pot tropical, mas a essa altura já vislumbrava uma identidade independente para a colônia, formada por pessoas que, como diz Handa, "começavam a criar raízes no Brasil” (1987, p. 610). Essas duas tendências, mais tarde, teriam seus contornos mais claramente definidos com a trágica cisão, conforme analisado acima, da comunidade de imigrantes japoneses, após a Segunda Guerra, em "vitoristas" e "derrotistas".

Os anos 1930, década de maior fluxo de imigrantes japoneses no Brasil ${ }^{76}$, foram também, não por acaso, uma época de grande movimentação na indústria jornalística e

\footnotetext{
76 Mizumura (2011) lembra que nos primeiros anos da década de 1930, entraram cerca de 20 mil imigrantes japoneses no Brasil, que se juntaram a uma população já existente de 170 mil, num ritmo
} 
editorial nipo-brasileira. O surgimento de novos jornais, revistas e outros produtos editoriais, em japonês ou bilíngues, atendia a uma demanda crescente de uma comunidade que se tornava mais complexa e diversa, interessada em notícias do Japão e do Brasil, em literatura, entretenimento e anúncios de produtos e serviços variados. Grande parte dessa produção - como todos os outros jornais de comunidades estrangeiras do Brasil - passou em 1937 a ser observada de perto pelo governo nacionalista de Getúlio Vargas, que dois anos depois obrigava todos eles a publicarem somente em português, antes de fechá-los de uma vez em 1941.

Além da organização e prosperidade de boa parte dos imigrantes japoneses no meio rural $^{77}$, os anos 1930 também marcaram sua crescente presença nas cidades brasileiras (sobretudo do estado de São Paulo e Paraná), em uma época conturbada pela xenofobia e pela desaceleração forçada da imigração de japoneses ao Brasil (a partir de 1934), quando, segundo Lesser (2001), uma "multifacetada identidade nipo-brasileira" passaria a ser "constituída e contestada de muitas maneiras" (2001, p. 211). Mais uma vez, o jornalismo praticado pela comunidade proporcionou oportunidades de expressão e confronto que expuseram os impasses vividos por seus membros, nesse caso pela geração de descendentes, premidos entre as obrigações de lealdade à terra de seus pais e avós e uma identificação cada vez maior com o país onde viviam.

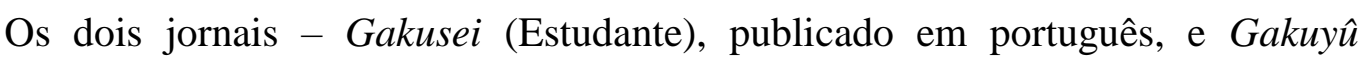
(Colega de escola), publicado em japonês - da Liga Estudantina Nipo-Brasileira, fundada em 1935 por estudantes da Faculdade de Direito do Largo de São Francisco, são emblemáticos desse momento de definição da identidade que Lesser chama de "hifenizada", por enfatizar "que a etnicidade e a nacionalidade eram dois itens separados, mas inter-relacionados" (2001, p. 221).

Os jornais foram criados com o intuito de patrocinar eventos culturais, esportivos e educacionais que promovessem "o lugar do nikkei na "raça brasileira"” (2001, idem), e também debates, através de seus editoriais, de questões referentes à integração dos descendentes na sociedade brasileira, um assunto potencialmente

acelerado de crescimento da população japonesa no país, interrompido abruptamente em 1934, quando ficou estabelecida uma cota de entrada de no máximo 3 mil imigrantes japoneses por ano.

${ }^{77}$ Um exemplo do nível de organização da comunidade nipo-brasileira no meio rural foi a criação da Cooperativa Agrícola de Cotia, em 1927, que no início atendia apenas ao escoamento da produção de batatas, mas logo incluiu os setores produtivos de vários outros vegetais, além de frutas, flores e até aves. A CAC tornou-se uma das maiores cooperativas agrícolas do país, até seu fechamento em 1994. 
explosivo que refletia não só a polarização dos próprios imigrantes, em si, como também as posições de personagens públicas e autoridades brasileiras, que divergiam quanto a aspectos biológicos e culturais do povo japonês e a sua suposta (segundo alguns) "incapacidade de assimilação".

Assim, os assuntos mais recorrentes nos editoriais dos jornais foram a integração dos japoneses - sobretudo dos descendentes - na sociedade nacional e a sua contribuição para a cultura do país. Um exemplo especialmente revelador de como os estudantes viam essa integração entre as duas culturas foi a aplicação extremamente ousada do conceito de "Yamato damashii" - fundamental na ideologia da autodefinição do povo japonês (Nihonjinron) e frequentemente associado, nesses tempos, à sua condição de súditos do imperador - neste texto de 1936: "Vocês devem defender a bandeira brasileira com o mesmo ardor e a mesma dedicação de um soldado japonês defendendo seu soberano. O que vocês não devem é interpretar o 'Yamato damashii' unicamente ligado ao Mikado (...) se vocês juram defender a integridade da Pátria Brasileira, suas instituições e a ordem (...) Eis a essência do 'Yamato damashii",78.

Defendendo a criação de uma mentalidade única, que condensasse as duas culturas, os editoriais dos jornais da Liga Estudantina Nipo-Brasileira tentaram interpretar e traduzir aspectos essenciais da cultura japonesa em um novo contexto cultural e político, propondo, assim, uma solução para o conflito de lealdades, que no caso deveriam ser dirigidas igualmente às duas nações de pertencimento do imigrante japonês: a terra de origem e da ancestralidade (o Japão) e a terra de acolhimento, onde a vida já começava a desenvolver raízes (o Brasil). Lesser (2001) chama atenção para o fato de que nem sempre a ideia de como essa integração deveria acontecer estava exposta claramente nos editoriais dos jornais. Defendia-se, por exemplo, uma ideia geral de "aculturação" dos japoneses que, no entanto, era interpretada de formas variadas.

Se por um lado alguns textos criticavam aqueles descendentes que adotavam os "costumes brasileiros" sem conhecer a cultura da "terra dos seus pais", por outro aplaudiam uma educação brasileira e o uso do português como língua de integração social. Essa proposta de integração também se podia detectar nos anúncios das revistas, que vendiam produtos e serviços que traçavam, ao mesmo tempo em que refletiam, o

\footnotetext{
${ }^{78}$ Texto do jornalista José Yamashiro, publicado na edição de abril de 1936 da Gakusei (apud LESSER, 2001, p.223). Mikado significa "porta sublime" em japonês antigo; refere-se ao poder divino do Imperador.
} 
perfil de um "mercado de consumo étnico voltado aos nascidos no Brasil", constituído de itens de origem japonesa, mas já desvinculado dos usos e significados de origem. Assim, serviços de uma escola de beleza nipo-brasileira vendiam um tipo específico de beleza "ensinada 'por nikkei e para nikkei"”, e lojas de produtos japoneses vendiam objetos religiosos e de decoração que eram usados mais como "ícones" do Japão, por aqueles que desejavam manter seus vínculos afetivos com a terra de seus ancestrais, do que como utilitários, já que esses “usos 'japoneses', jamais seriam reconhecidos no Japão" (LESSER, 2001, p. 224).

Com o cerco do Estado Novo às publicações de imigrantes estrangeiros no Brasil, a partir de abril de 1938, os jornais da Liga Estudantina deixaram de lado os assuntos "polêmicos sobre a identidade nipo-brasileira", e passaram a publicar apenas notícias de esportes e sobre eventos de interesse da comunidade até seu fechamento, em setembro do mesmo ano. Mas já no ano seguinte, uma nova publicação é lançada pela Liga, só que dessa vez com título em português: Transição, uma alusão ainda mais direta ao tema já levantado pelos jornais anteriores da entidade, ou seja, a passagem da condição de japoneses para a de brasileiros. No editorial do primeiro número, o texto conclamava a "harmonização de duas civilizações, aparentemente antagônicas", e exortava a utilização de "uma língua comum, a brasileira" (apud LESSER, 2001, p. 231).

Apesar de defender a brasilidade dos descendentes de segunda e terceira geração e de ser publicada em português, em 1941 a Transição foi considerada imprensa estrangeira e, assim, proibida de circular, juntamente com os demais jornais em língua japonesa, como os diários Nippak Shimbun, Brasil Jihô e Seishu Shimpô. Durante os anos da guerra, sem acesso a notícias em japonês, a maior parte das comunidades de origem nipônica teve apenas como alternativa a imprensa clandestina de entidades como a Shindô Renmei, que a partir de seus vários escritórios na capital e no interior paulista distribuía noticiários e panfletos de cunho ultranacionalista, pregando a lealdade irrestrita ao imperador e a fé na invencibilidade do Japão. Para Lesser, foi esse monopólio da informação no seio da comunidade nipo-brasileira que garantiu o crescimento do Shindô Renmei e o alastramento da versão de que a derrota do Japão era criação da propaganda americana com o aval da imprensa e do governo brasileiros.

Mais uma vez ficava clara, através das publicações destinadas à comunidade nipo-brasileira, a cisão entre as suas lideranças quanto ao futuro dos japoneses no 
Brasil: enquanto boa parte da geração dos isseis se via, permanentemente, como japoneses de corpo e alma - ainda que expatriados -, a dos nisseis e sanseis já tinha como certa a sua identidade "hifenizada", de nipo-brasileiros. Handa avalia que a atitude patriótica dos mais velhos só fazia acentuar a sua distância ideológica dos mais jovens, pois para estes "os isseis que tanto pregavam o sublime espírito japonês não passavam de pessoas obstinadas e impiedosas" (apud HANDA, 1987, p. 661). Essa divisão geracional, porém, não é o único fator de diferença ideológica entre os membros da comunidade à época da Segunda Guerra: o acesso à educação e a localidade de moradia - nas grandes cidades ou no meio rural - também eram fatores de diferenciação de posições mais liberais ou mais conservadoras quanto à integração dos japoneses na sociedade brasileira.

Ou seja, enquanto os trabalhadores tendiam a reproduzir modos de vida trazidos do Japão, que tentavam preservar no convívio quase que exclusivo com conterrâneos, os imigrantes e descendentes estabelecidos nas cidades estavam mais expostos ao contato com pessoas de fora da comunidade, embora isso não signifique uma ruptura com a ancestralidade e a tradição japonesa. A própria emergência de uma cultura "nikkei", impulsionada pelas discussões levantadas pela mídia nipo-brasileira - como é o caso, por exemplo, dos editoriais e artigos da Gakusei e da Transição -, era uma busca de conciliação, por membros da comunidade estabelecidos nas cidades, das duas tradições: a antiga (japonesa, ancestral) e a nova (brasileira, pátria de adoção).

Quando os jornais estrangeiros - entre eles os de língua japonesa - puderam novamente circular em 1946, a desinformação não desapareceu imediatamente do seio das comunidades nipônicas, em especial daquelas estabelecidas em localidades rurais ou em pequenas cidades do interior do estado. As publicações dos ultranacionalistas não só continuavam a pregar os mesmos valores de obediência e lealdade ao imperador, como condenavam ostensivamente seus conterrâneos que não acreditavam na vitória do Japão na guerra, divulgando listas de nomes de "infiéis" e exortando a comunidade a expulsálos de seu convívio. Vários assassinatos se sucederam ${ }^{79}$, com a radicalização das posições nacionalistas que transformaram trabalhadores em militantes de entidades secretas japonesas no Brasil.

\footnotetext{
${ }^{79}$ Segundo Handa, a maior parte dos assassinatos ocorreu no ano de 1946, sendo que o mês de julho desse ano teve o maior número de casos, sendo por isso chamado de "o mês trágico, manchado de sangue". Foram, no total, 16 mortos e 11 feridos graves, com vários feridos leves e outros que escaparam ilesos dos ataques (HANDA, 1987, pp. 668-671).
} 
Membros da imprensa nipo-brasileira que admitiam publicamente a derrota do Japão passaram a ser alvos de grupos radicais, como o tokkôtai ${ }^{80}$ do Shindô Renmei, por sua função formadora de opinião dentro da comunidade. Este foi o caso de Chuzaburo Nomura, ex-redator-chefe do Nippak Shimbun, cujo assassinato teve grande repercussão por ser uma figura bastante conhecida por suas atividades jornalísticas. Também o Paulista Shimbun - fundado em 1946 por dois jornalistas que haviam trabalhado juntos no Gakusei e na Transição - foi particularmente visado por ter criticado, em diversos números, a Shindô Renmei e seus partidários. Um repórter desse jornal, entrevistado décadas depois por Lesser, conta que, naquela época, eles guardavam armas na gaveta e estavam sempre de prontidão, preparados para um ataque (LESSER, 2001, p. 245).

Com a prisão dos responsáveis pelos atos violentos e o esvaziamento das sociedades secretas, o estado geral de ânimos foi pacificado, e os jornais e boletins da comunidade nipo-brasileira puderam iniciar, com mais tranquilidade, uma nova fase de organização dos seus discursos públicos, o que, em vez de expor uma comunidade em processo de reunificação, mostrou, ao contrário, que a polarização haveria de persistir ainda por mais tempo. Um exemplo disso foi a publicação, em 1952 (portanto, sete anos após o fim da guerra), de um extenso artigo no Brasil Jihô, em que o autor - assinando com pseudônimo - discorria sobre a "certeza de que a crença dos vitoristas estava correta" e que aqueles que acreditaram na derrota do Japão eram "japoneses degenerados, adeptos do liberalismo e do epicurismo, confundidos por artifícios tramados pelas forças aliadas" (apud HANDA, 1987, p.703).

Desde o reinício de suas atividades, no pós-guerra, a mídia nipo-brasileira buscou por diferentes caminhos reencontrar-se com aquilo que já perseguia antes: ser a "voz" da comunidade, o seu espelho mais fiel, e um espaço de confluência de assuntos, personalidades, eventos e notícias que "lhe dizem respeito". Assim, essas publicações mostram, segundo Koshiyama (2003), que "a relação de japoneses e seus descendentes com a explicitação de sua condição nikkei é um fato". Em 1946 foi fundado o São Paulo Shimbun; em 1947, o Jornal Paulista; em 1948, o Diário Nippak (que não tem nada a

\footnotetext{
${ }^{80}$ Segundo Handa, a palavra significa literalmente, "esquadrão suicida", em referência ao "grupo de jovens soldados da Marinha e do Exército japoneses, que atuaram durante a guerra do Pacífico. Iam atacar os inimigos com o avião abastecido só com o combustível de ida, ou seja, estavam dispostos a se sacrificar e morrer no momento do ataque". (HANDA, 1987, p.827). Lesser, entretanto, traduz a palavra como "equipe especial de ataque" e kesshitai como "esquadrão suicida" (LESSER, 2001, p.244). Ambos os autores referem-se ao grupo de militantes do Shindô Renmei que atacaram e assassinaram, logo após a guerra, pessoas rotuladas como "derrotistas" (makegumi), ou seja, contrárias à posição denominada "vitorista" (kachigumi).
} 
ver com o antigo Nippak Shimbun, de Saku Miura, criado em 1919). O Paulista e o Nippak se fundiram em 1997 dando origem ao Nikkey Shimbun (NS), que, juntamente com o São Paulo Shimbun (SPS), são hoje os maiores jornais de língua japonesa no Brasil. Ambos têm versões on-line nas duas línguas e versões impressas: o SPS circula de terça a sábado em português e japonês, e o NS é diário em japonês e semanal em português.

Como os jornais dos anos 1930, mencionados por Lesser (2001), que tratavam de definir uma identidade "hifenizada", também no SPS e no NS as colunas, sessões e notícias têm uma predominância quase total de assuntos relacionados ao mundo nipobrasileiro ou ao Japão, por exemplo: as dicas de beleza que levam em conta a maquiagem que cai bem "nos olhos orientais"; as novidades da indústria automobilística lançadas pela Nissan e Toyota; a venda da cervejaria Kirin do Brasil; o cinema japonês ao ar livre na Casa das Rosas; o "Japão que veio para ficar", com a inauguração da Japan House na Avenida Paulista; os campeonatos de judô e sumô; o envolvimento de deputados nikkeis no escândalo da distribuição de propina pela JBS, entre outros. As opiniões dos rivais São Paulo Shimbun e Nikkey Shimbun não são abertamente veiculadas em editoriais, embora reportagens ou textos de colunistas em ambos os jornais possam ter um tom crítico e/ou opinativo.

Nada que lembre, porém, as grandes polêmicas e embates ideológicos do passado, quando defensores da preservação do "espírito japonês" e partidários da integração à sociedade nacional fizeram da mídia nipo-brasileira a sua tribuna. Mas o fato de terem suas versões principais em japonês e publicarem assuntos quase totalmente referentes ao Japão ou à comunidade nipo-brasileira revela um compromisso com as raízes e, principalmente, a percepção de que a comunidade nipo-brasileira tem, sim, uma existência e um perfil específicos, por maior que tenha sido a sua dispersão nas grandes cidades nas últimas décadas. A construção desse perfil, entretanto, e da voz da comunidade - que a mídia busca representar - é determinada por essa seleção de assuntos, personagens e imagens que, reunidos por obra da mídia, dão àquele perfil um contorno e uma unidade.

Quanto à mídia televisiva, a primeira experiência mais efetiva de uma tentativa de elaboração da identidade nipo-brasileira se deu em 1970, quando o programa 
Imagens do Japão foi lançado na Rede Tupi ${ }^{81}$, tendo - a partir do segundo ano - a apresentadora e cantora Rosa Miyake à frente do projeto, que durou cerca de quatro décadas. Miyake já era bem conhecida na comunidade nipo-brasileira, e até fora dela, por sua participação em shows da Jovem Guarda e por diversas gravações de músicas japonesas no idioma original e em versões para o português, além de ter sido a personagem principal da telenovela Yoshico, um poema de amor ${ }^{82}$ também da TV Tupi. É de Miyake a voz da famosa vinheta comemorativa da primeira linha Brasil-Japão da Varig (comentada acima), que cantava a história de Urashima Tarô, de 1968, quando se celebravam também os sessenta anos da imigração japonesa no Brasil.

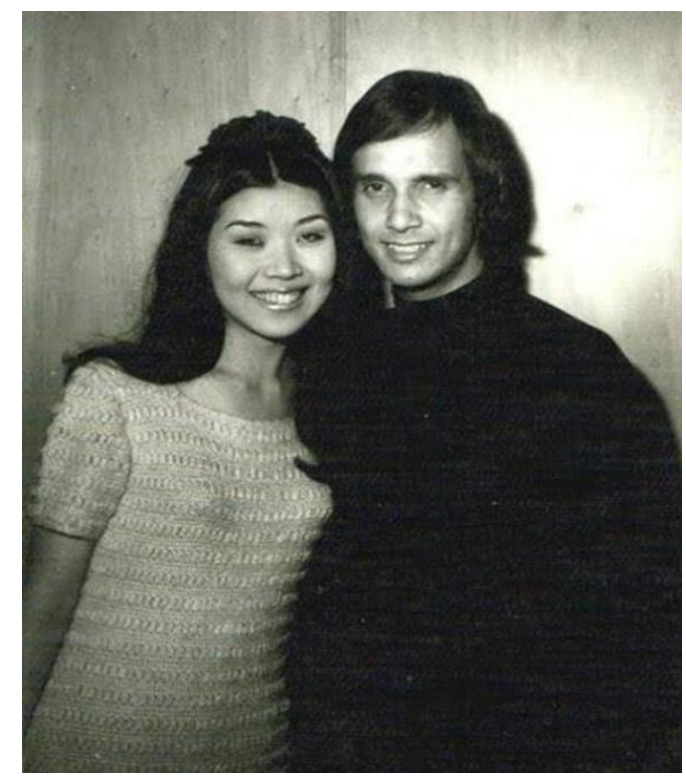

Foto 2: Rosa Miyake e Roberto Carlos, 1968

Fonte: http://sanduichemusical.blogspot.com.br/2011/07/rosa-miyake-em-toquio1968.html Acesso em 20/03/2017.

O título do programa evocava o país da ancestralidade como fator de distinção da comunidade que, no entanto, era representada no programa também pelos assuntos considerados próprios dela, como, por exemplo, o concurso de Miss Nissei, do qual participavam, como o nome já sugere, somente as moças brasileiras de origem japonesa. Assim, o programa Imagens do Japão - com suas reportagens, entrevistas e também muitos de seus anúncios comerciais - se estabeleceu como espaço de confluência de assuntos, personagens e valores éticos e estéticos dedicados a refletir e dar visibilidade

\footnotetext{
${ }^{81}$ Quando a Rede Tupi foi extinta, em 1980, o programa Imagens do Japão migrou para a TV Gazeta, onde ficou no ar até 2005. Foi então convidada para apresentar o quadro "Imagens Curiosas do Japão" no programa "Você é Curioso?" da Rádio Bandeirantes, criado em 2001, e que vai ao ar aos sábados das 10 às 12:00.

${ }^{82}$ A novela em 60 capítulos, de Lúcia Lambertini, foi transmitida de 9 de janeiro a 31 de março de 1967.
} 
ao universo identitário dos japoneses e seus descendentes no Brasil. Para isso, misturou dentro de um cardápio único aspectos da cultura japonesa contemporânea e tradicional aos temas da vida cotidiana dos imigrantes e seus descendentes no país, apresentados pela primeira vez por uma emissora aberta de televisão, para um público muito mais vasto que a própria comunidade.

Também nos programas radiofônicos a identidade nipo-brasileira encontrou um espaço de organização e divulgação, com iniciativas pioneiras como a Voz do Nissei, na Rádio Santo Amaro, que viria a sediar mais tarde a Rádio Nikkey, hoje apresentado pela Rádio Imprensa FM. Atualmente, essa rádio faz parte de um projeto midiático mais amplo, o RTV Nikkey, que a partir de 2004 passou a incluir um programa semanal pelas operadoras de TV a cabo Net e Vivo e pela tevê aberta TV 8, apresentado por Paulo Miyagui e Mieko Senaha, que falam em português (ele) e em japonês (ela) com os entrevistados e telespectadores. Além das televisões a cabo e aberta e das ondas de FM, esses programas também podem ser acessados on-line e pelo Youtube ${ }^{83}$, ampliando dessa forma um público que pode acompanhar os programas a partir do Brasil, do Japão ou de qualquer outro lugar do mundo. Apesar da acessibilidade ampliada, porém, a RTV Nikkey mantém uma programação e um corpo de anunciantes com foco no Brasil, priorizando os eventos e os personagens do país, mas com muitas notícias sobre o Japão também, repetindo assim a fórmula dos programas televisivos anteriores, que se consolidaram como espaço de definição e atualização da identidade nipo-brasileira tendo o país da ancestralidade como principal fonte de referência.

Esses espaços também são explorados por outras mídias produzidas pela e para a comunidade nipo-brasileira, como os inúmeros sites que se autodenominam "nipobrasileiros" ou "Nikkei", ou ainda de "cultura japonesa", todos em português, voltados para os descendentes de japoneses que vivem no Brasil ou são decasséguis no Japão. Esses sites ou portais - que quase sempre possuem páginas no Facebook, Instagram e Twitter, às quais se tem acesso a partir dos próprios sites - são geralmente independentes dos complexos midiáticos maiores (São Paulo Shimbun e Nikkey Shimbun, que possuem seus próprios portais on-line), ou das agências japonesas de fomento cultural, tecnológico e científico no Brasil, como a Fundação Japão, a JICA (Japan International Cooperation Agency) e a JSPS (Japan Society for the Promotion of

\footnotetext{
83 Ver em www.radioetvnikkey.com.br/ e www.youtube.com/watch? $\mathrm{v}=\mathrm{c} 5 \mathrm{~kJ} 8 \mathrm{yi} 15 \mathrm{lo}$, acesso em
} 05/05/2017. 
Science), que também divulgam assuntos referentes ao Japão que possam interessar aos brasileiros em geral e aos descendentes em particular.

Os sites são espaços de divulgação que refletem algum aspecto específico da cultura japonesa no Brasil, como os grupos de $\mathrm{Otaku}^{84}$ e segmento da comunidade nipobrasileira, como a comunidade okinawana ${ }^{85}$, ou que cobrem assuntos gerais, com um leque amplo de eventos, notícias e artigos sobre o Japão ou a cultura japonesa no Brasil $^{86}$. Além dos jornais diários, dos sites independentes e daqueles produzidos pelas agências de fomento citadas, há também as mídias das associações de imigrantes e de entidades culturais, como é o caso do Bunkyo, que é o objeto de estudo desta tese e que será analisado detalhadamente a partir do próximo capítulo.

Essas mídias buscam construir os seus públicos a partir do que Sato (2009) chama de "estratégias cognitivas", ou seja, opções editoriais que reconhecem a priori a capacidade de seus leitores de decodificar certos significados ou modos de expressão e de se identificar com os repertórios selecionados. O Japão e aspectos da cultura japonesa (como o mangá, a culinária e o festival das cerejeiras, por exemplo), e também assuntos relacionados à vida no Brasil (como os partidos políticos e questões econômicas e trabalhistas que afetam a todos), são os signos mais evidentes de identificação da comunidade, no ponto de vista do conteúdo. E quanto à linguagem utilizada, o uso da língua japonesa pode ser considerado como uma dessas "estratégias cognitivas", já que o japonês utilizado desde os primeiros jornais da comunidade costuma ser misturado com palavras derivadas do português, o que deixa de fora todos os demais falantes de japonês que não os do Brasil.

Assim, o repertório e as formas de expressão utilizadas não têm apenas uma função comunicativa direta, mas também uma força simbólica capaz de criar um "consenso" entre a mídia (incluindo aí os anunciantes) e seus leitores, fazendo com que todos se vejam como parte de uma mesma comunidade. Em diversos sites e jornais, entretanto, já há uma mudança de utilização de estrangeirismos, que são agora derivados do inglês, como no japonês falado no Japão desde o pós-guerra. Essa mudança, que sinaliza um distanciamento gradual do japonês falado pelos imigrantes no passado (o “coronia-go"), reflete o contato cada vez maior dos falantes de japonês do Brasil com

\footnotetext{
${ }^{84}$ Ver https://orgulhootaku.wordpress.com/, acesso em 05/05/2017.

${ }^{85}$ Ver www.utinapress.com.br/, acesso em 05/05/2017.

86 Ver, como exemplo: http://mundo-nipo.com/__www.nippobrasil.com.br/2 www.nikkeybrasil.com.br/index.php 2 www.japaoemfoco.com/, acesso em 05/05/2017.
} 
jornais e revistas on-line japonesas e também com a tevê a cabo a que já se tem acesso no país, como a $\mathrm{NHK}^{87}$. As mudanças de perfil das comunidades nipo-brasileiras introduzidas pelas novas tecnologias midiáticas acompanham uma tendência mundial de reconfiguração dos públicos, espalhados, como afirma Koshiyama (2003, s/p), por "novos territórios geográficos que transcendem as fronteiras nacionais e continentais".

A Revista Made in $\operatorname{Japan}^{88}$, analisada por Koshiyama (2003), foi um exemplo pioneiro de mídia nipo-brasileira que tentou refletir os novos contextos da comunidade com um projeto editorial de foco duplo e simultâneo nos leitores que vivem no Brasil e nos que emigraram para o Japão como decasséguis. A revista - sempre editada em português - teve versão impressa de 1997 a 2009, e hoje permanece apenas como portal on-line, mantendo o foco no público que se interessa tanto por assuntos da comunidade nipo-brasileira no Brasil como no Japão. A revista, segundo Koshiyama também foi inovadora quanto às novas controvérsias enfrentadas pela comunidade nipo-brasileira, incorporando o "debate sobre o que é realmente um Nikkei" com a crescente miscigenação da população de origem japonesa no Brasil. Fugindo das separações e definições excludentes, a revista buscou, com seus temas, linguagem e programações visuais, construir um território de encontro, sempre movediço, entre as duas culturas, "com uma perspectiva de integração daquilo que lembra o Japão no Brasil e o que nos lembra o Brasil no Japão" (KOSHIYAMA, 2003, s/p).

\footnotetext{
${ }^{87}$ NHK é a sigla de Nippon Hoso Kyokai (Companhia de Tele e Radiodifusão Japonesa).

${ }^{88}$ Ver em https://madeinjapan.com.br/ acesso em 02/04/2017.
} 


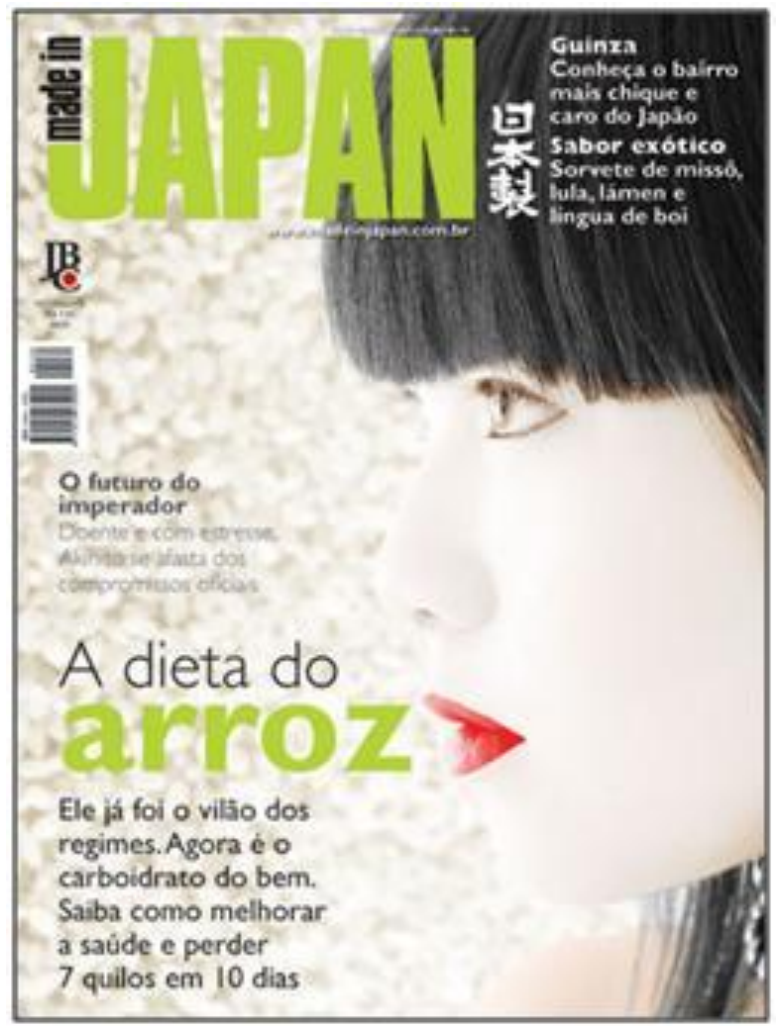

Foto 3: Revista Made in Japan, n.139, 2009.

Fonte: http://aacj-br.zip.net/arch2009-04-01_2009-04-30.html Acesso em 02/04/2017

Embora a mídia nipo-brasileira tenha assumido para si a função primordial de ser a "voz" da comunidade - no sentido de preencher as lacunas da mídia nacional quanto aos seus assuntos de interesse específico - e tenha se consolidado, dessa forma, como espaço de autodefinição e de visibilidade desse segmento da sociedade brasileira, cada vez mais as novas mídias (principalmente os sites, redes sociais e canais on-line) abrangem públicos que ultrapassam as fronteiras da comunidade, o que segundo Koshiyama (2003, s/p) tem aberto o caminho "para o questionamento do que é, exatamente, a comunidade Nikkei". Para a autora, a Made in Japan é um exemplo de mídia que "opera com a hipótese de que a comunidade nikkei deve ser mais ampla do que o conjunto das pessoas nikkeis". Assim, se a identidade nipo-brasileira não apenas está refletida na mídia da comunidade, como é por meio dela (re)organizada e definida, então estes novos tempos de integração midiática globalizada parecem apontar para um processo de atualização identitária muito mais complexo e dinâmico do que se pôde se observar até aqui. 


\section{Capítulo 3 - Bunkyo: histórico, missão, estrutura e funcionamento}

\section{Colando as metades cindidas}

O nascimento da Sociedade Brasileira de Cultura Japonesa e de Assistência Social, ou simplesmente Bunkyo ${ }^{89}$, é atribuído, nos textos em que a entidade narra as circunstâncias da sua fundação, à importância das associações para os imigrantes japoneses. Essas associações - que articularam as formas de cooperação entre os membros da colônia, estabelecida em áreas rurais distantes entre si, desde os primeiros anos da imigração - enfrentaram duras provas, durante a Segunda Guerra, quando o governo Vargas restringiu o agrupamento de estrangeiros no país. Mas o momento mais difícil ainda estava por vir: foi logo após a guerra, com as notícias da derrota do Japão, que - como já foi comentado no capítulo anterior - dividiram a comunidade japonesa em dois grupos antagônicos: o de pessoas que reconheciam e o das que não aceitavam as notícias de que o Japão havia sido derrotado. Essa cisão foi quase fatal para as associações, sacudidas pelos conflitos que se instalaram entre seus quadros no pósguerra.

Mas vejamos como esses fatos foram acontecendo e acabaram levando à fundação do Bunkyo.

A cisão interna da colônia foi grave e profunda, pois não se tratava apenas de mera discussão entre compatriotas com opiniões diferentes acerca de uma questão qualquer. De um lado, estavam aqueles que amavam a terra natal acima de qualquer coisa, e acreditavam que colocar em dúvida a sua invencibilidade era o mesmo que desonrá-la; de outro, aqueles que achavam que um patriota "esclarecido" deveria aceitar os fatos, mesmo que se tratasse de situação indesejável e de fato desonrosa. Assim, membros de um e de outro grupo passaram a se estranhar, os primeiros chamando os segundos de "traidores" e os segundos chamando os primeiros de "fanáticos". Embora os mais radicais não fossem muito numerosos, em pouco tempo a colônia japonesa quase inteira se viu premida pelo acirramento dos ânimos e pelo adensamento das

\footnotetext{
${ }^{89}$ Junção das primeiras sílabas das palavras japonesas: bunka (cultura) e kyôkai (associação). Apesar do som alongado do "o" (representado com circunflexo na palavra japonesa romanizada kyôkai), não utilizo acento na grafia de Bunkyo porque a entidade não o usa em nenhum de seus documentos, sites, jornais, livros, panfletos, cartazes etc.
} 
diferenças que os separavam. Falava-se em listas de nomes de "marcados para morrer", até que vários atentados - e mesmo assassinatos ${ }^{90}$ - ocorreram em vários pontos do estado de São Paulo. Muitos "derrotistas" foram hostilizados ou impedidos de circular em determinados locais e de entrar nas associações que antes frequentavam, sob a grave acusação de traição à pátria, impingida a eles pelos "vitoristas".

Enquanto isso, muitas famílias de imigrantes enterravam de vez os planos de voltar a viver um dia no Japão, que, arrasado pela guerra, já não tinha como receber de volta seus cidadãos que há tempos aguardavam a oportunidade de voltar para casa. Os nisseis e sanseis ${ }^{91}$ já não tinham a colônia como sua única referência de vida, o que deixava os isseis ${ }^{92}$ assustados com a perspectiva de assimilação, uma possibilidade que ameaçava concretizar-se naquela conjuntura de desunião e discórdia entre conterrâneos. Mas, entre os velhos imigrantes, segundo Handa (1987), crescia a sensação de que ainda havia "algumas tarefas a serem cumpridas", antes que a cultura japonesa que tentavam preservar no Brasil simplesmente se dissolvesse na sociedade nacional. A pacificação da colônia parecia ser a condição necessária para sua sobrevivência, e assim algumas lideranças puseram em prática, em 1949, a primeira grande estratégia para sua reunificação: a criação de uma comissão de ajuda às vítimas da guerra no Japão, um tema com boas chances de evidenciar os laços que todos os japoneses ainda tinham em comum.

Porém, apesar do esforço dos envolvidos, a iniciativa teve sucesso bem aquém do esperado. Foi então que algumas boas notícias começaram a acontecer e foram se sucedendo, preparando assim o terreno para que a oportunidade tão esperada pelas lideranças empenhadas na reunificação da colônia acabasse se apresentando. A primeira boa notícia foi o descongelamento, em 1950, dos bens dos imigrantes, que o governo brasileiro havia tornado indisponíveis durante a guerra ${ }^{93}$. E essa notícia pôde ser lida em japonês nos próprios órgãos voltados à colônia, entre eles o São Paulo Shimbun, o

\footnotetext{
${ }^{90}$ Conforme mencionado no capítulo anterior, Handa (1987) fala em 16 mortes que resultaram dos atentados. Já o Guia do Museu Histórico da Imigração Japonesa, publicado pelo Bunkyo em 2008, afirma que foram 23 mortes (ver p. 64).

${ }^{91}$ Segunda e terceira gerações nascidas no Brasil.

92 Primeira geração de imigrantes, nascida no Japão.

93 Durante a Segunda Guerra, um decreto-lei de 11 de março de 1942 confiscou bens e direitos dos cidadãos do Eixo (japoneses, alemães e italianos), colocando-os sob a custódia do Banco do Brasil. Cinco anos após o fim da guerra, outro decreto-lei, de 4 de novembro de 1950, autorizou a restituição dos bens a seus donos, embora decretos posteriores tenham adiado os prazos para devolução dos valores congelados. (Fonte: Ministério da Fazenda, Procuradoria-Geral da Fazenda Nacional. Disponível em: http://dados.pgfn.fazenda.gov.br/storage/f/2016-06-22T115358/parecer954.PDF, acesso em 27/06/17.)
} 
Jornal Paulista e o Diário Nippak, fundados após a guerra, com a suspensão da censura imposta às comunidades de "cidadãos do Eixo". Outra notícia que na mesma época também ajudou a trazer de volta o otimismo entre os membros da colônia foi a visita dos tobiuo $^{94}$, os nadadores olímpicos japoneses que atraíram ao Estádio do Pacaembu, em São Paulo, uma multidão de conterrâneos que não só pôde assistir às celebrações em homenagem aos festejados atletas como também a um espetáculo que há muito não se via no país: milhares de bandeirinhas do Japão juntas, tremulando pelo ar. O orgulho de ser japonês no Brasil já podia novamente ser expresso em público, sem medo.

Em 1951, Yukishigue Tamura, o primeiro deputado estadual nissei, tomou posse na Assembleia Legislativa de São Paulo, inaugurando uma nova era para a comunidade japonesa no país, que passou assim a ter representatividade política, com uma agenda totalmente voltada para os interesses da colônia. Tanto Tamura como os demais políticos de origem japonesa que surgem nessa década de 1950 têm como característica comum essa identificação com as questões específicas da comunidade, tendo por isso uma "base de apoio praticamente restrita à colônia" (SAKURAI, 1995, p. 129). O exemplo de Tamura - que também foi o primeiro vereador (eleito em 1947) e o primeiro deputado federal (eleito em 1954) da colônia - foi rapidamente seguido por outros, que se candidataram e se elegeram antes mesmo que a década terminasse ${ }^{95}$. Mais um grande motivo de otimismo foi a assinatura, em 1952, do reatamento da paz entre Brasil e Japão. Assim, as relações diplomáticas entre os dois países - rompidas em 1942, com a adesão do Brasil às Forças Aliadas, na Segunda Guerra - são finalmente restabelecidas, e projetos de cooperação mútua começam a ser gestados.

A vinda, nesse mesmo ano, do famoso escritor Yukio Mishima a São Paulo, Lins e Rio de Janeiro também contribuiu para o clima de otimismo que envolvia boa parte da colônia, pela importância do autor na cena literária mundial e pelo consequente sentimento de orgulho que seus conterrâneos podiam novamente ostentar com a visita de mais um japonês ilustre ao país. Mishima conheceu bem a comunidade japonesa do Brasil e chegou a escrever ensaios e peças de ficção inspiradas em suas impressões do país e da comunidade ${ }^{96}$. E já no ano seguinte, em 1953, como resultado do

\footnotetext{
${ }^{94}$ Peixe-voador, em japonês.

95 Sussumu Hirata e Yoshifumi Utiyama foram eleitos para a Assembleia Legislativa de São Paulo em 1958 (SAKURAI, 1995, p. 158).

${ }^{96}$ Yukio Mishima (1925-1970) chegou ao Brasil em janeiro de 1952 como convidado especial de Mituto Mizumoto, dono do jornal São Paulo Shimbun. Participou de rodas de conversas com membros da
} 
restabelecimento das relações bilaterais, teve início a retomada da imigração japonesa para o Brasil, e também a chegada das primeiras empresas japonesas e dos primeiros investimentos do governo japonês no país. Com tantas coisas positivas acontecendo em sucessão, para compensar as terríveis dificuldades vividas pela colônia na década anterior, só faltava mesmo um pequeno empurrão para que a tão esperada reconciliação dos membros da comunidade finalmente tivesse uma boa oportunidade para se concretizar.

E foi ainda no ano de 1952 que a oportunidade se apresentou, na forma de um convite da prefeitura paulistana para a participação dos membros da colônia japonesa na grande festa do IV Centenário da Cidade de São Paulo. Na verdade, a Prefeitura já se articulava há anos no planejamento de um grande acontecimento comemorativo, de repercussão nacional e internacional. Membros do comitê pró-IV Centenário e várias outras pessoas envolvidas de formas diversas na sua realização contataram governos estrangeiros na tentativa de conseguir adesões para uma grande exposição industrial, que deveria acontecer em um Pavilhão, ainda em construção, e que viria a ser, mais tarde, o prédio da Bienal, no futuro parque Ibirapuera, a ser inaugurado também como parte das celebrações.

O Japão foi um dos países visitados, e os emissários paulistanos voltaram para o Brasil já com várias propostas do governo japonês, sendo que uma delas era a de construir, não só para a festa do IV Centenário, mas em caráter definitivo, uma edificação em estilo tradicional japonês, a ser oferecida ao povo de São Paulo. O primeiro contato da prefeitura com a colônia japonesa no Brasil foi através da Câmara de Comércio Brasil-Japão, já que na época ainda não havia órgãos representativos da colônia japonesa que pudessem servir na interlocução junto às autoridades brasileiras.

intelectualidade nipo-brasileira e foi hóspede de um amigo de infância, o príncipe Toshihiko Tarama, que se mudara para o Brasil - como filho adotivo de uma rica senhora japonesa que emigrara anos antes - e vivia em Lins, no interior de São Paulo. De lá, Mishima escreveu cartas sobre sua experiência no Brasil para o amigo e também escritor Yasunari Kawabata (primeiro japonês a ganhar o Prêmio Nobel de Literatura, em 1968). Suas impressões de viagem ao Brasil foram reunidas no livro de crônicas Cálice de Apolo (1955), e também inspiraram a peça de teatro Toca de Cupins (1955), o conto "Mulheres Insatisfeitas" (1953) e a opereta Bom dia, Senhora (1954) (KUSANO, 2009). Apesar de sua importante relação com o país e com a história da comunidade nipo-brasileira, infelizmente essa obra "brasileira" de Mishima ainda não foi traduzida para o português. Porém, está acessível em japonês na biblioteca Teiiti Suzuki, do Centro de Estudos Japoneses da USP. 
As lideranças da comunidade que vinham se articulando desde a campanha de auxílio às vítimas da guerra no Japão ainda estavam mobilizadas, mas as desavenças resultantes dos conflitos do pós-guerra tornavam difícil a organização de uma comissão que pudesse assumir o início dos trabalhos e a definição de uma linha de ação. Segundo Handa (1987, p. 753), até mesmo a intervenção do cônsul do Japão foi convocada, e nem isso surtiu efeito imediato, pois o próprio consulado já não tinha mais o papel de centro de referência da colônia que tivera no passado. Depois de várias tentativas, finalmente uma comissão chefiada pelo engenheiro agrônomo Kiyoshi Yamamoto conseguiu formar um grupo de pessoas determinadas a agir.

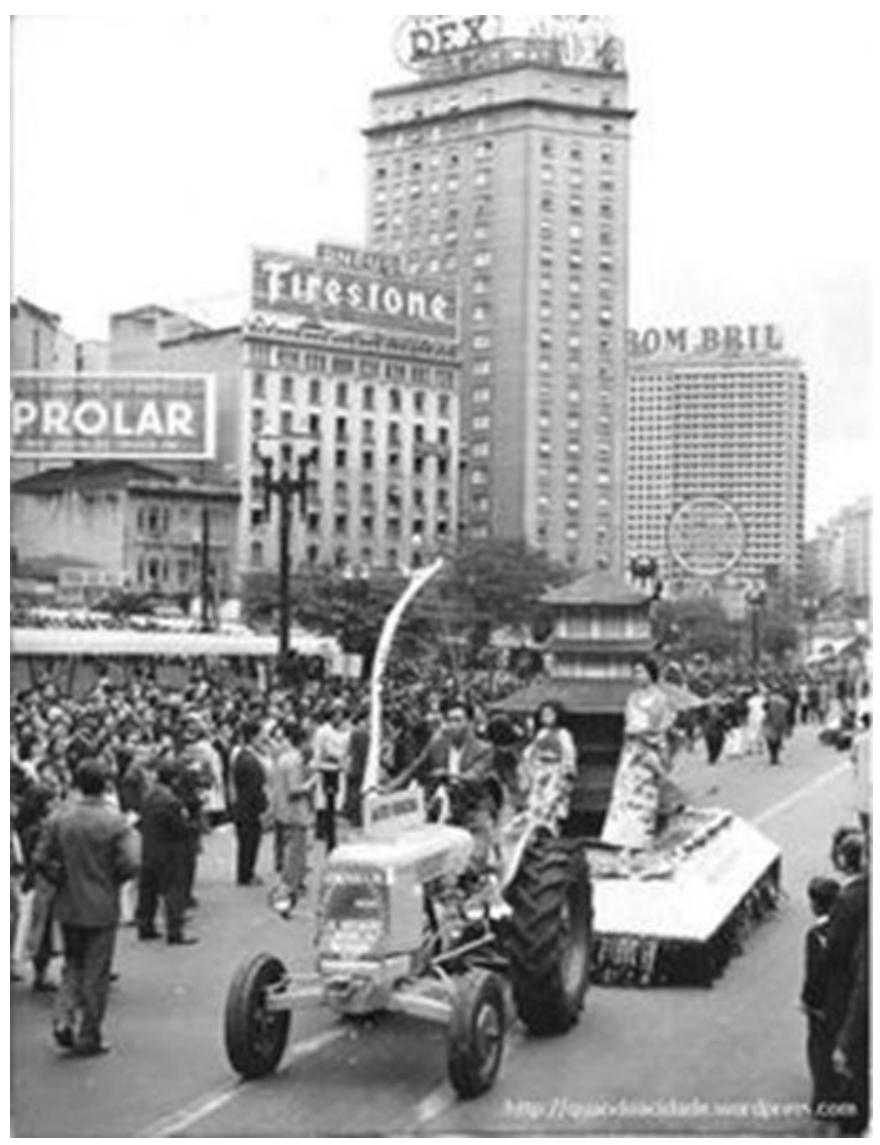

Foto 1: Carro alegórico dos imigrantes japoneses no IV Centenário.

Fonte: http://www.nippobrasil.com.br/4.imigracao_japonesa/index.php

\section{Acesso em 10/01/2017}

Essas pessoas já estavam bem estabelecidas em áreas como o comércio, o agronegócio, os órgãos de imprensa, os bancos e entidades financeiras e outras atividades que proporcionavam acesso aos recursos necessários para assumirem, com a ajuda da comunidade, os custos da sua participação no grande evento paulistano. Tão 
logo a "Comissão Colaboradora da Colônia Japonesa Pró IV Centenário de São Paulo" foi constituída, seus membros partiram para um grande esforço de envolvimento das cooperativas agrícolas, associações de províncias e entidades esportivas e culturais da comunidade japonesa espalhadas pela cidade e pelo interior. Era necessário conseguir a ajuda de todos para a construção do Pavilhão Japonês no futuro Parque Ibirapuera, pois, segundo cartas trocadas à época, e guardadas pelo Arquivo Histórico Municipal, a idealização do projeto foi do governo japonês (que também prestaria apoio às obras de construção), mas seu custeio ficaria a cargo da comunidade nipo-brasileira (CAMARGO, 2008).

O Pavilhão seria o monumento mais importante da presença nipônica no Brasil, não apenas por ser o primeiro centro de cultura japonesa em um espaço público no país, mas principalmente porque simbolizava - por ser construído com recursos da própria comunidade - a demonstração concreta dos sonhos de prosperidade que moveram os imigrantes ao deixarem sua terra natal, décadas atrás. Assim, o Pavilhão e as exposições da festa do IV Centenário dariam visibilidade às realizações dos japoneses no Brasil para os próprios imigrantes e seus descendentes, e também deveriam ajudar a dissipar o que ainda restasse do sentimento antijaponês que se disseminara em setores da sociedade brasileira desde o início da imigração japonesa e, sobretudo, durante e logo após a Segunda Guerra ${ }^{97}$.

Ao lado dessas metas de consequências imediatas, a comissão da colônia japonesa nas festas do IV Centenário ainda tinha o seu plano principal de longo prazo: a reorganização da comunidade nipo-brasileira, ainda separada por mágoas e ressentimentos desde a sua cisão em "vitoristas" e "derrotistas". Além dessa divisão ideológica do pós-guerra, a colônia japonesa daquele início dos anos 1950 já não era mais uma comunidade exclusiva de imigrantes, mas tinha muitos nisseis adultos e até sanseis, o que aumentava sua diversidade interna (que já era bem considerável) e, portanto, o desafio de quem tentava unificá-la.

\footnotetext{
97 O sentimento antinipônico no Brasil tem origem nas teses racistas europeias do século XIX que inspiraram a política de branqueamento das autoridades brasileiras da época. As formas de preconceito tiveram variações e atingiram o seu ápice durante a Segunda Guerra (1939-1945), quando a polícia política do país chegou a construir um prontuário intitulado "Niponismo", em que ideias de "perigo amarelo" - importadas dos EUA - legitimaram um quadro repressivo contra o imigrante japonês (DEZEM, 2005, pp. 29-32).
} 
Apesar das dificuldades, tão logo terminaram as celebrações, durante a assembleia de dissolução da comissão, seus membros decidiram manter a sua estrutura com uma nova proposta à frente: a comemoração dos 50 anos da imigração japonesa ao Brasil, a ser celebrada em 1958. O plano de unificação da colônia, portanto, teria como estratégia principal a evocação do passado mais recente - a imigração -, que era, afinal, o passado de todos os japoneses do Brasil, de qualquer geração ou posição ideológica. E também a exaltação da milenar cultura japonesa, cujo monumento principal acabava de ser inaugurado em momento histórico de grande significado para a população de São Paulo, o que não só ligava os imigrantes e seus descendentes entre si, mas também à história do país onde agora se estabeleciam definitivamente.

Aproveitando, então, esse momento propício em que o otimismo da comunidade estava intensificado pelas emoções recentes, e a perspectiva de mais motivos a festejar, com o cinquentenário da chegada dos primeiros imigrantes japoneses ao Brasil, a mesma comissão que se empenhara na festa do IV Centenário se reuniu em 15 de outubro de 1955 no Teatro Nambei, situado no bairro da Liberdade, para deliberar os regulamentos preliminares de fundação da Sociedade Paulista de Cultura Japonesa, que logo seria conhecida como Bunkyo, e que haveria de ser, nas palavras de Handa, "a entidade central da colônia japonesa no Brasil" (1987, p. 762). O número de participantes da assembleia convocada para o dia 17 de dezembro do mesmo ano, quando a entidade seria fundada formalmente, foi bem menor que o esperado. Mesmo assim, ao avaliar aquele momento, cinco décadas depois, a entidade considerou a sucessão de eventos significativos que culminaram na sua fundação como um marco para a comunidade japonesa no Brasil, que conseguia terminar a sua travessia por "longo e obscuro túnel” para sair, finalmente, “em direção ao alvorecer" (BUNKYO, 2008, p. 75).

No capítulo de seu livro em que descreve a fundação do Bunkyo, Handa (1987) ressalta alguns pontos que considerou inovadores da entidade recém-criada: o primeiro deles, a presença de nisseis no quadro da diretoria, o que, segundo o autor, contrastava com "as antigas associações japonesas de antes da guerra, maciçamente dominadas pelos isseis". Outra medida citada foi a inclusão de quotas para pessoas jurídicas, o que garantia uma arrecadação bem mais expressiva do que se receberia somente por meio de contribuições dos associados. Também a palavra "cultura" na denominação da entidade era fator "indicador dos novos tempos", segundo Handa, pela amplitude de objetivos 
abraçados pela nova entidade. Mesmo assim, o autor levantou questionamentos sobre sua real natureza: seria o Bunkyo "uma federação das antigas associações japonesas"? Ou um órgão promotor de lazer para a "confraternização de seus membros"? Ou ainda uma entidade devotada ao "desenvolvimento cultural dos japoneses e seus descentes no país"? Ao que ele mesmo respondeu: o Bunkyo é "uma entidade com todas estas aspirações", que, segundo ele, se concretizariam com o passar do tempo e o advento da maturidade (1987, p. 763).

Em uma transição direta para a etapa seguinte do esforço de mobilização, as lideranças que atuaram na comissão pró-IV Centenário assumiram postos de direção na estrutura da nova entidade, mantendo na chefia Kiyoshi Yamamoto, que se tornou assim o primeiro presidente do Bunkyo - de dezembro de 1955 até seu falecimento, em julho de 1963, pouco antes de inaugurar as obras da sede própria. Natural de Tóquio, onde se formou em Agronomia, Yamamoto chegou ao Brasil em 1926 para administrar a fazenda de café Tozan, na região de Campinas, estado de São Paulo.

Na Tozan, introduziu uma técnica nova de controle de pragas (trazendo abelhas da África) e um projeto de reflorestamento com eucaliptos, pioneiro na época. Também participou da transformação da Tozan em projeto de agroindústria, com foco na fabricação de produtos japoneses. Yamamoto tornou-se conhecido na colônia por seu espírito de iniciativa, não só quanto ao seu trabalho, mas, principalmente, no ativismo comunitário, assumindo a liderança de movimentos importantes como o de liberação dos bens congelados dos japoneses, a campanha de auxílio às vítimas da guerra no Japão e as complicadas negociações em busca de consenso para a participação da colônia japonesa na comemoração do IV Centenário. 


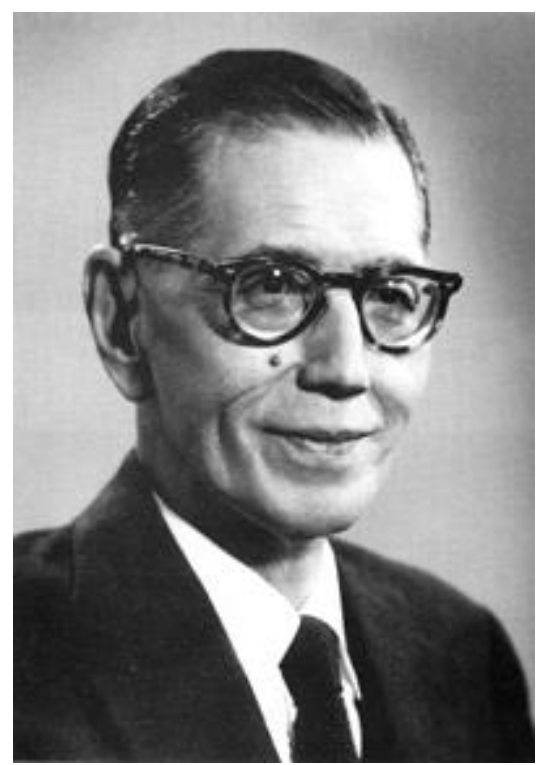

Foto 2: Kiyoshi Yamamoto, primeiro presidente do Bunkyo (1955-1963) Fonte: Bunkyo

O grande acontecimento da gestão de Yamamoto foi a comemoração do cinquentenário da imigração japonesa, em 1958. A consolidação do reatamento dos laços entre as duas metades cindidas da colônia japonesa foi o objetivo central da festa dos 50 anos, a primeira grande celebração exclusiva dos imigrantes e seus descendentes desde o final da guerra. Mais uma vez as lideranças se mobilizaram para conseguir apoio de associações, empresas e autoridades, no Brasil e no Japão, para a montagem de um grande espetáculo cuja atração maior seria a presença ilustre de um membro da família imperial, o que - graças a seu poder simbólico de unir todos os japoneses em torno de si - deveria contribuir para o apaziguamento definitivo dos ânimos e a recuperação do "sentimento de autoconfiança" dos imigrantes, que viviam em "estado de apatia em função do choque sofrido pela derrota japonesa, seguida pelo estado caótico da 'colônia"” (BUNKYO, 2008, p. 77).

Os esforços deram certo: a cerimônia de 18 de junho de 1958 contou com a presença do irmão caçula do imperador Hirohito, o príncipe Takahito Mikasa, e sua esposa, a princesa Yuriko, em visita que seria a primeira de uma série que membros da família imperial fariam ao país nas décadas seguintes, o que demonstrava a importância dada ao Brasil pelo Japão, não só quanto às relações diplomáticas e comerciais entre os dois países, mas também quanto ao fato de que o Brasil havia reaberto as portas aos imigrantes japoneses após o fim da guerra. Em relação a isto, as próprias lideranças que 
fundaram o Bunkyo se esforçaram pessoalmente para obter o empenho das autoridades de sua terra natal, como se depreende de um texto publicado pela entidade no início da década de 1960:

Para o Japão que perdeu toda a área além-mar, o Brasil com a maior colônia japonesa do mundo, tornou-se a única esperança. Tínhamos então que compenetrar deste fato, fazer com que o próprio Japão reconhecesse esta verdade e estabelecesse uma sólida política diplomática em relação ao Brasil e à Colônia ${ }^{98}$.

O reconhecimento do Japão foi confirmado pela presença inédita do irmão do imperador no Brasil e, sobretudo, pela amplitude da sua agenda no país. O casal de príncipes participou de extensa programação, que, além da grande cerimônia dos 50 anos da imigração, na atual sede da Bienal no Parque Ibirapuera, incluiu visita às obras de Brasília, na companhia do então presidente Juscelino Kubitschek, a cooperativas e empresas da comunidade japonesa em oito municípios dos estados de São Paulo e Paraná, e a eventos comemorativos variados, como a missa na Catedral da Sé e uma partida de beisebol entre a seleção brasileira e o time da universidade japonesa de Waseda. Mas, para o Bunkyo, o momento mais importante da visita foi o lançamento da pedra fundamental da sede da entidade pelas mãos do próprio príncipe Mikasa. Além de esse gesto possuir grande significado simbólico para uma entidade que buscava unificar a colônia japonesa no país, o local escolhido também tinha valor histórico, por abrigar a primeira escola de língua japonesa no Brasil, a Escola Taisho, fundada em $1915^{99}$.

A importância da sede própria, que seria levantada a partir da pedra fundamental lançada pelo príncipe Mikasa, foi motivo de longa reflexão dos líderes do Bunkyo, para quem não era suficiente a existência de uma entidade que se dedicasse apenas a atividades de rotina: “é necessário um lugar onde as pessoas se reúnam, expressem opiniões, troquem ideias e debatam os assuntos de interesse comum" ${ }^{100}$. Desses debates deveriam surgir medidas para resolver problemas específicos da comunidade e os

\footnotetext{
${ }^{98}$ SOCIEDADE PAULISTA DE CULTURA JAPONESA, Comissão Pró Construção do Centro Cultural Brasil-Japão. "O Porquê do Centro Cultural Brasil Japão" [1961].

${ }^{99}$ A Taisho Shogakko (Escola Primária Taisho) ocupou várias sedes, mas só se mudou para o local que abriga o edifício-sede do Bunkyo, na esquina da rua São Joaquim, em 1928, ou seja, exatamente trinta anos antes da cerimônia de lançamento da pedra fundamental pelo príncipe Mikasa.

${ }^{100}$ SOCIEDADE PAULISTA DE CULTURA JAPONESA, Comissão Pró Construção do Centro Cultural Brasil-Japão. "O Porquê do Centro Cultural Brasil-Japão" [1961].
} 
planos para o futuro, construindo assim a base da conciliação e da estabilidade entre os seus membros. Levando em conta o tamanho da colônia japonesa no país - que à época já contava com quase meio milhão de pessoas, ocupando terras que somavam cerca de um milhão de alqueires ${ }^{101}$, , os líderes do Bunkyo avaliavam que a harmonia entre seus membros era condição essencial para o bom funcionamento das relações entre Brasil e Japão e para a continuidade do fluxo de imigrantes japoneses que chegavam ao país.

Além do efeito direto sobre a estabilidade das relações entre os habitantes da colônia, a sede do Bunkyo também seria importante, segundo avaliação de seus líderes, para uma rápida elevação das condições intelectuais dos japoneses e seus descendentes no Brasil, que precisavam de investimentos na área cultural - caso contrário, jamais deixariam de ser "simples trabalhadores braçais"102. A entidade se empenharia em proporcionar aos membros da colônia oportunidades de informação e capacitação profissional, com a criação de biblioteca, sala de projeção de filmes, bolsas de estudos no Brasil e no Japão, cursos de japonês e de português, exposições de arte, eventos culturais no Pavilhão Japonês e até mesmo um balcão de empregos, para ajudar a colocação de conterrâneos no mercado de trabalho.

Ao mesmo tempo, seus líderes esperavam também que essas medidas de divulgação da cultura japonesa entre os brasileiros em geral trariam um maior conhecimento sobre o Japão, ajudando assim a terminar de vez com os resquícios de "má compreensão e sentimento antijaponês"103 que porventura ainda restassem na sociedade nacional. Outro argumento utilizado pelos líderes do Bunkyo era que outros países, como Inglaterra, Estados Unidos, França, Itália, Portugal e Síria, já possuíam centros culturais no Brasil, "desenvolvendo campanhas e expendendo fortuna para este fim"104, motivo pelo qual os japoneses também precisavam ter uma verdadeira sede para poder abrigar seu próprio centro cultural.

Um dos primeiros eventos importantes, na área científico-cultural, com repercussão sobre a imagem do Japão e da comunidade japonesa no Brasil foi a vinda em 1958 (ainda como parte das comemorações do cinquentenário da imigração), e com apoio do Bunkyo, do físico Hideki Yukawa, o primeiro japonês a ganhar um Prêmio

\footnotetext{
101 “(...) de acordo com o resultado apresentado pela Comissão de Recenseamento da Colônia Japonesa”. Idem.

102 Idem.

103 Idem

${ }^{104}$ Idem.
} 
Nobel, em 1949. Yukawa foi um dos responsáveis, anos mais tarde, pela criação da Colaboração Brasil-Japão (CBJ) - um grupo de pesquisa em física de partículas -, juntamente com o físico César Lattes e vários outros cientistas brasileiros e japoneses. $\mathrm{Na}$ verdade, Yukawa já havia sido convidado a vir ao Brasil anos antes, com recursos levantados pela comunidade nipo-brasileira, para ajudar a informar os "vitoristas" quanto ao real desfecho da Segunda Guerra.

Yukawa, entretanto, não pôde vir naquele momento, o que levou os líderes da colônia responsáveis pelo convite a doarem o dinheiro que seria usado na sua viagem para a universidade de Quioto, que passava por graves problemas de escassez de recursos desde o pós-guerra. Segundo cientistas dessa universidade, as pesquisas que desenvolviam só puderam sobreviver graças a esse gesto da colônia nipo-brasileira, o que motivou a criação de laços duradouros entre cientistas dos dois países (JUSTO, 2008, p. 14-15). A série de palestras de Yukawa, em 1958, teve como objetivo apresentar uma imagem favorável do Japão, junto à sociedade brasileira, e consolidar os laços entre os dois países, aproveitando esse especial momento de celebração da imigração japonesa ao país. Ao mesmo tempo, servia de inspiração às famílias nipobrasileiras, que na época já haviam começado a mandar seus filhos para as universidades, buscando justamente elevar a condição intelectual de seus membros.

Em 1956, um ano após a fundação do Bunkyo, foi criada a Aliança Cultural Brasil-Japão, com a finalidade de ser uma entidade especificamente voltada para a divulgação da cultura japonesa junto à sociedade brasileira. A sua criação foi inspirada na existência de centros culturais de outros países no Brasil, como a União Cultural Brasil-Estados Unidos, a União Cultural Brasil-Inglaterra, o Instituto Hans Staden, o Instituto Cultural Ítalo-Brasileiro, a Casa de Cervantes, o Clube Homs, a Sociedade Beneficente Nordlyset e o Centro Armênio. Na percepção dos líderes do Bunkyo, era necessário que a cultura japonesa, igualmente trazida por imigrantes, se fizesse representar por um centro difusor da língua e da cultura do Japão, porque já havia um atraso considerável a recuperar em relação às demais.

A criação da Aliança, a julgar pelo discurso dos líderes que a conceberam, reflete de certo modo o espírito de "pequenos embaixadores do Japão" difundido entre os imigrantes das primeiras levas, conforme explicado no Capítulo 1 desta tese. Mesmo depois de se radicarem definitivamente no país, os imigrantes japoneses continuavam a 
manter vivos seus laços com o Japão e o senso de obrigação quanto à manutenção de uma boa imagem da terra de seus ancestrais, como se isso, em grande medida, dependesse deles. Por isso, a criação da Aliança era justificada com a alegação de que, "sem a compreensão e intercâmbio cultural, as relações entre países nunca se darão de maneira satisfatória""105. Ponderavam ainda que intercâmbio é "via de mão dupla" e, portanto, não seria adequado ter apenas japoneses e seus descendentes na direção da nova entidade.

Foi então convidado à presidência da nova entidade o poeta e haicaísta Guilherme de Almeida, e, para o conselho deliberativo, foram chamados nipobrasileiros e não descendentes. Apesar de entidade independente, a Aliança ocupava três andares do edifício-sede do Bunkyo, e a indefinição jurídica dessa ocupação deu origem, anos depois, a graves desentendimentos que desembocaram em um impasse litigioso entre as partes, em 2011, até que uma solução amigável foi encontrada no ano seguinte. Além do curso de língua japonesa, com método encomendado do Japão e aberto a todos os brasileiros - mas especialmente dedicado aos "jovens da colônia” -, a Aliança manteve biblioteca, cursos de oratória (tradicionais no Japão), de cerimônia do chá, de ikebana, de música e dança japonesas, além de manter uma revista bimestral, com tiragem inicial de três mil exemplares, mantida por anúncios.

\subsection{A consolidação da entidade}

Os primeiros anos do Bunkyo foram dedicados ao crescimento da entidade, na dura tarefa de arregimentar associados. Em dezembro de 1960, portanto cinco anos após a sua fundação, o Bunkyo contava com 1.412 sócios, a grande maioria residente na cidade de São Paulo. A média de crescimento do número de sócios deveria ser de $10 \%$ ao ano, segundo estimativa da própria entidade, que tinha como estratégia principal o oferecimento de serviços - como as bolsas de estudos (no Brasil e no Japão) e a seção de empregos - e a utilização de enquetes para conhecer as expectativas dos membros da

\footnotetext{
${ }^{105}$ SOCIEDADE PAULISTA DE CULTURA JAPONESA, Comissão Pró Construção do Centro Cultural Brasil-Japão. "O Porquê do Centro Cultural Brasil-Japão" [1961]
} 
comunidade, o que resultou na criação de departamentos de música, cinema, leitura e passeios.

Com seus esforços de relacionamento com entidades, empresas e associações nipo-brasileiras espalhadas pelas áreas urbanas e rurais, e também com os serviços prestados aos sócios e à comunidade em geral, o Bunkyo procurava obter legitimidade para que pudesse atuar em outra frente prioritária: a consolidação da sua condição de interlocutor do governo japonês no Brasil. Assim como foi anfitrião do príncipe Mikasa, em 1958, quando um membro da família imperial japonesa vinha pela primeira vez ao Brasil, mais uma vez o Bunkyo conseguiu ser anfitrião na primeira visita de um primeiro-ministro japonês ao país, em 1959, oferecendo a Nobusuke Kishi "uma acolhida digna do seu cargo":

Como parte do programa de recepção ao ministro Kishi, realizamos uma exposição de produtos agrícolas e industriais da Colônia Japonesa. Contando com a participação de 41 firmas, foi uma demonstração da capacidade produtiva dos japoneses ${ }^{106}$.

Depois dele, vários outros membros do governo japonês - como, por exemplo, o neto de Kishi, Shinzo Abe, que 55 anos mais tarde visitaria o Brasil, também como primeiro-ministro - seriam igualmente recepcionados pelo Bunkyo. O bom trânsito da diretoria do Bunkyo junto às autoridades diplomáticas japonesas no Brasil e a membros do governo no Japão era um reflexo do fato de serem eles próprios parte da elite intelectual e econômica nipo-brasileira, que não só tinha acesso a diversos setores do governo japonês para negociar, por exemplo, alguma forma de ajuda financeira à construção da sua sede, como também teve muitas vezes a oportunidade de fazer o oposto, ou seja, de levantar recursos no Brasil para prestar ajuda financeira ao Japão, como foi o caso do auxílio enviado às vítimas da guerra e das catástrofes naturais, à reconstrução do país e às Olimpíadas de Tóquio de 1964.

Ao mesmo tempo em que se esforçavam para conseguir mais associados e para estabelecer a imagem do Bunkyo como interlocutor do Japão no Brasil, os líderes da entidade prosseguiam com os trabalhos de captação de recursos para a construção da

\footnotetext{
${ }^{106}$ SOCIEDADE PAULISTA DE CULTURA JAPONESA, Comissão Pró Construção do Centro Cultural Brasil-Japão. "O Porquê do Centro Cultural Brasil-Japão" [1961].
} 
sede própria da entidade. Uma estratégia eficiente para unir esses objetivos foi o envolvimento de empresas, jornais, emissoras de rádio e associações regionais em uma ampla campanha de divulgação dos objetivos e significados simbólicos da sede própria do Bunkyo, incluindo um concurso de lemas e logotipo do qual resultaram mais de 2.500 sugestões de lemas e 350 de logotipos, por concorrentes dos estados de São Paulo, Minas Gerais, Goiás, Mato Grosso e outros.

O lema vencedor, de um morador da cidade de Lins, foi "Juntos construiremos nosso templo"107, uma frase que sintetizava as três atitudes que se pretendia restabelecer na colônia japonesa, como um todo: união, trabalho e espírito. Embora no contexto cultural da comunidade a palavra "templo" pudesse remeter à religião budista - que, aliás, era a crença religiosa mais comum entre os japoneses, juntamente com o xintoísmo -, a expressão tinha uma força simbólica abrangente, capaz de transformar um mero edifício em local de congraçamento, memória e superação das dificuldades. E, de fato, em publicação comemorativa dos 60 anos da entidade, atribui-se ao "centro de cultura japonesa" não só a missão de abrigar a sede do Bunkyo, mas também de vir a ser "o refúgio espiritual de toda a comunidade" ${ }^{108}$. Flâmulas com o lema e o logotipo foram produzidas para divulgar a ideia e arrecadar recursos, em uma ampla campanha de mobilização que incluiu outras publicações da entidade.

A publicação Kaiho ("boletim informativo") do Bunkyo, em língua japonesa, foi fundada em 1956, com tiragem de dois mil exemplares e periodicidade bimestral, sendo distribuída gratuitamente entre os associados, órgãos governamentais e instituições particulares no Brasil, Japão e vários outros países das Américas. Após 1960, o nome do boletim passou a ser Coronia (Colônia), agora com periodicidade mensal e um título mais abrangente para uma publicação que tinha a missão de atingir, se possível, a "colônia japonesa" como um todo. Mantida por meio de anúncios e de orçamento da própria entidade, a revista tinha conteúdos "de caráter cultural”, com o objetivo de levar ao conhecimento dos leitores as atividades desenvolvidas pela entidade e de promover “o intercâmbio cultural” entre eles ${ }^{109}$.

\footnotetext{
${ }^{107}$ OI, C.A. A trajetória do Bunkyo e as comemorações da imigração japonesa no Brasil. Em: HARADA, K. (coord.). 60 anos de Bunkyo: Passado, Presente, Futuro. São Paulo: 2015, p. 54.

${ }^{108}$ BUNKYO - Sociedade Brasileira de Cultura Japonesa e de Assistência Social. Bunkyo: 60 anos. Sua trajetória. São Paulo, 2015, p. 11

${ }^{109}$ SOCIEDADE PAULISTA DE CULTURA JAPONESA, Comissão Pró Construção do Centro Cultural Brasil-Japão. "O Porquê do Centro Cultural Brasil-Japão" [1961]
} 


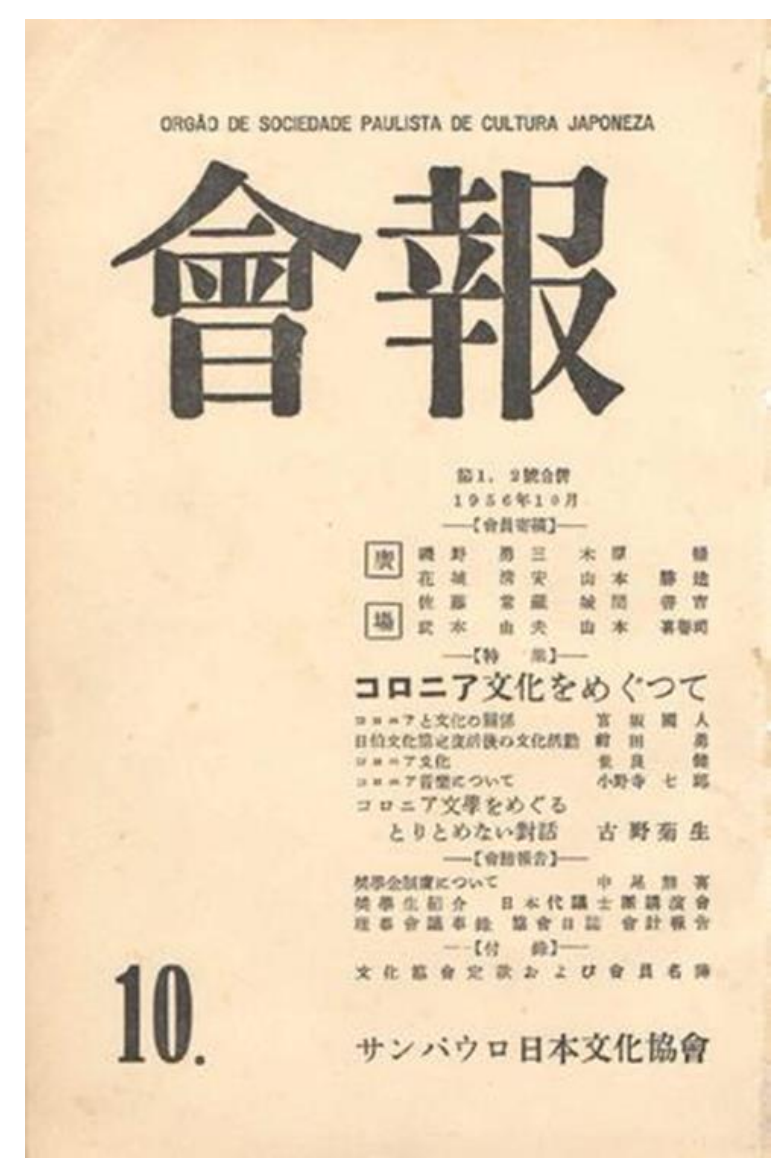

Figura 1. Capa da revista Kaiho, edição de outubro de 1956.

Fonte: Bunkyo.

Os veículos de comunicação do Bunkyo também registravam os debates e assuntos que, na perspectiva das lideranças da entidade, mobilizavam a comunidade nipo-brasileira, construindo já desde o início uma visão específica sobre a relevância e a natureza das questões consideradas de interesse do (e inerentes ao) seu público. Entre muitos outros exemplos, houve a publicação de artigos sobre mesas-redondas promovidas pela entidade que discutiam problemas referentes ao ensino da língua japonesa no país (assunto da primeira edição da nova revista Coronia) e a criação, junto à sede do Bunkyo, de um museu dedicado à preservação da memória da imigração. Assim, como veremos no decorrer desta tese, é nos seus espaços comunicacionais que o Bunkyo vai organizar e disseminar a sua própria narrativa, ou seja, suas metas e as justificativas e finalidades de seus projetos e atividades, ao mesmo tempo em que constrói a si próprio como "órgão central", refúgio espiritual e "coluna vertebral" da comunidade nipo-brasileira. 
A sede do Bunkyo foi finalmente inaugurada em abril de 1964, menos de um mês após o golpe militar que destituiu o presidente João Goulart. Apesar das grandes e recentíssimas transformações políticas no cenário nacional, o Bunkyo conseguiu contar com a presença de representantes dos três níveis de governo: o ministro da Agricultura Oscar Thompson Filho, o vice-governador Laudo Natel e o vice-prefeito da capital Freitas Nobre. Além das autoridades brasileiras, da mesma forma o governo japonês se fez representar pelo embaixador Keiichi Tatsuke e pelo cônsul-geral em São Paulo. Políticos nipo-brasileiros também estavam presentes nas solenidades de inauguração, como os pioneiros deputados nisseis Sussumu Hirata (à época deputado federal) e Yoshifumi Utiyama (deputado estadual), além de vários outros. Como parte da solenidade, o primeiro presidente do Bunkyo, Kiyoshi Yamamoto - falecido nove meses antes -, foi homenageado pelo governo do Japão, com a entrega à viúva Issoe Yamamoto da Medalha da Ordem do Sol Nascente, uma importante ordem honorífica japonesa $^{110}$.

Apenas três anos depois da inauguração do seu edifício-sede, o Bunkyo estava novamente envolvido em uma grande festividade. Mais uma vez a família imperial visitava o Brasil, só que agora o visitante ilustre era ninguém menos que o futuro imperador do Japão: o príncipe herdeiro Akihito e sua esposa, a princesa Michiko. Essa visita causou tanta comoção na comunidade nipo-brasileira que mereceu um capítulo exclusivo no livro de Handa (1987, pp. 776-780) e também manchetes entusiasmadas da grande imprensa, que cobriu a passagem do casal imperial pelo Vale do Anhangabaú, no dia 24 de maio de 1967: "100 mil aplaudem Akihito" (Folha de São Paulo); "O vale nunca viu uma festa igual” ( $O$ Estado de São Paulo); “Akihito levou a maior acolhida que São Paulo já deu" (Diário de São Paulo). Além da recepção calorosa no Vale do Anhangabaú - que ficava no meio do caminho entre o aeroporto e o hotel para onde o casal imperial foi levado ao chegar a São Paulo -, houve no dia seguinte uma outra, ainda maior, no Estádio do Pacaembu.

Foi no estádio que se registraram as maiores demonstrações de afeto, clamor e veneração por parte de uma multidão de japoneses que cantou o Kimi ga yo ("Reino Imperial”, hino do Japão) e Sakura, Sakura ("Cerejeira, cerejeira”, canção tradicional japonesa), muitos deles assistindo às solenidades em atitude de prece. Handa ficou tão

\footnotetext{
${ }^{110}$ OI, C. A. In: HARADA, Kiyoshi (coord.). 60 anos de Bunkyo. Passado, Presente e Futuro. São Paulo: Cadaris Comunicação, 2015 p. 59.
} 
perplexo com essa mobilização da comunidade nipo-brasileira, sobretudo dos velhos isseis vindos de partes distantes do país, que avaliou o episódio como único, "sem par na história da imigração japonesa no país", algo "tão grandioso e emocionante" que nunca mais poderia se repetir. Segundo o autor, para muitos japoneses que aqui viviam, aquele foi um momento de reencontro com sua "alma japonesa", que um jornal de Tóquio considerou ser o verdadeiro "espírito de Yamato", que sobrevivia somente no país: “devemos aprender o orgulho japonês dos japoneses e seus descendentes radicados no Brasil",111.

Embora o príncipe Akihito e a princesa Michiko tivessem uma extensa agenda de compromissos oficiais em Brasília, São Paulo e Rio de Janeiro, não deixaram de comparecer ao Bunkyo, onde foram recepcionados no salão nobre pela diretoria da entidade e pelos ilustres da comunidade. Além da presença do casal ilustre na sua sede, o Bunkyo ainda teve como prova de seu prestígio junto aos governos japonês e do estado de São Paulo o convite para seu presidente, Kunito Miyasaka, sentar-se ao lado dos homenageados na tribuna de honra, juntamente com o governador Abreu Sodré, o prefeito Faria Lima e o embaixador japonês Keiichi Tatsuke, durante as solenidades e o desfile de carros alegóricos no Estádio do Pacaembu.

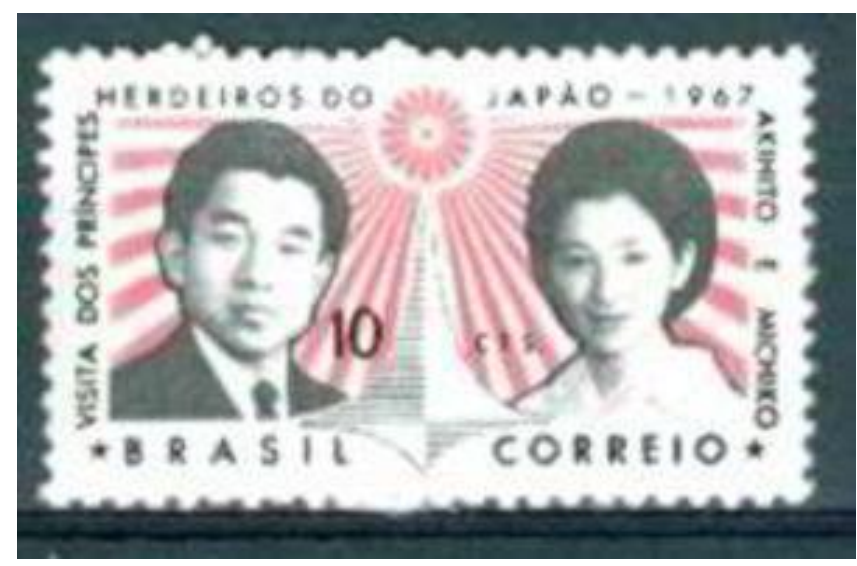

Foto 3. Selo comemorativo da visita dos príncipes herdeiros.

Fonte: Made in Japan

\footnotetext{
${ }^{111}$ Segundo Handa, o Paulista Shimbun (um dos jornais nipo-brasileiros de São Paulo, aberto em 1947 e fechado em 1998) noticiou no dia 30 de maio de 1967 o editorial publicado um dia antes pelo jornal Sankei, de Tóquio, em que este discorria "sobre a questão do espírito de Yamato, o espírito da Era Meiji”, presente nos japoneses que imigraram para o Brasil antes da guerra (1987, p. 780).
} 
A grande arrecadação conseguida entre entidades nipo-brasileiras e doadores particulares para a recepção aos príncipes herdeiros acabou deixando um bom saldo a ser gasto em alguma outra coisa importante. A apresentação de duas propostas de utilização dessa verba dividiu a entidade entre aqueles que preferiam usá-la para a construção de um grande auditório e ampliação de serviços na sede e os que achavam que deveria ser usada em bolsas de estudo. Em votação apertada, a primeira proposta saiu vencedora, o que levou o presidente da entidade a novas viagens ao Japão em busca de apoio financeiro complementar para as obras de construção do auditório. Assim, a década de 1960 terminava como começou: com acontecimentos auspiciosos e positivamente transformadores para o Bunkyo.

Em junho de 1968, como parte das comemorações dos 60 anos da imigração japonesa ao Brasil, foi lançada a pedra fundamental para a construção do grande auditório - uma adição ao edifício-sede que haveria de ampliar significativamente a atuação da entidade -; e no final desse mesmo ano, foi efetuada uma mudança de nome que consolidava simbolicamente o compromisso assumido pelo Bunkyo desde sua concepção, 14 anos antes: de Sociedade Paulista, a entidade passava a chamar-se Sociedade Brasileira de Cultura Japonesa. No ano seguinte, fechando a década, e de olho nos novos desafios que se apresentavam no horizonte, o Bunkyo promoveu grandes mudanças na direção, o que incluía maior espaço para os nisseis:

\footnotetext{
"Buscava-se, com isso, estabelecer um novo equilíbrio de poder na Sociedade e um rejuvenescimento da diretoria para dar andamento às transformações estruturais que atendessem às necessidades de um novo tempo" ${ }^{\prime 12}$.
}

A grande realização que abriu a nova década foi a inauguração do auditório, em setembro de 1970, dois anos e três meses após o lançamento da sua pedra fundamental. Mais do que um mero local de apresentações, o auditório do Bunkyo - com capacidade para 1.100 pessoas - era um espaço estratégico para a consolidação da sua proposta de representação nacional da comunidade nipo-brasileira. Esse auditório haveria de sediar, daquele momento em diante, recepções a governantes japoneses e autoridades

\footnotetext{
${ }^{112}$ OI, C. A. In: HARADA, Kiyoshi (coord.). 60 anos de Bunkyo. Passado, Presente e Futuro. São Paulo: Cadaris Comunicação, 2015, p. 67.
} 
brasileiras, cerimônias religiosas, homenagens aos pioneiros e condecoração de personalidades da colônia, conferências e palestras, espetáculos beneficentes, festivais da tradição folclórica e erudita do Japão e manifestações culturais do Japão contemporâneo. Na sua estreia, dois dias após a inauguração, o grande auditório abrigou o $5^{\circ}$ Gueinosai (artes de palco), ou Festival de Música e Dança Folclórica Japonesa. O Gueinosai, que atualmente é apresentado no mês de junho (como parte das comemorações da Imigração Japonesa ao Brasil), é considerado uma referência da cultura tradicional japonesa, pois boa parte das coreografias, canções, técnicas instrumentais e enredos trazidos pelos imigrantes - e até hoje praticados por eles ou seus discípulos - já se perderam no Japão.

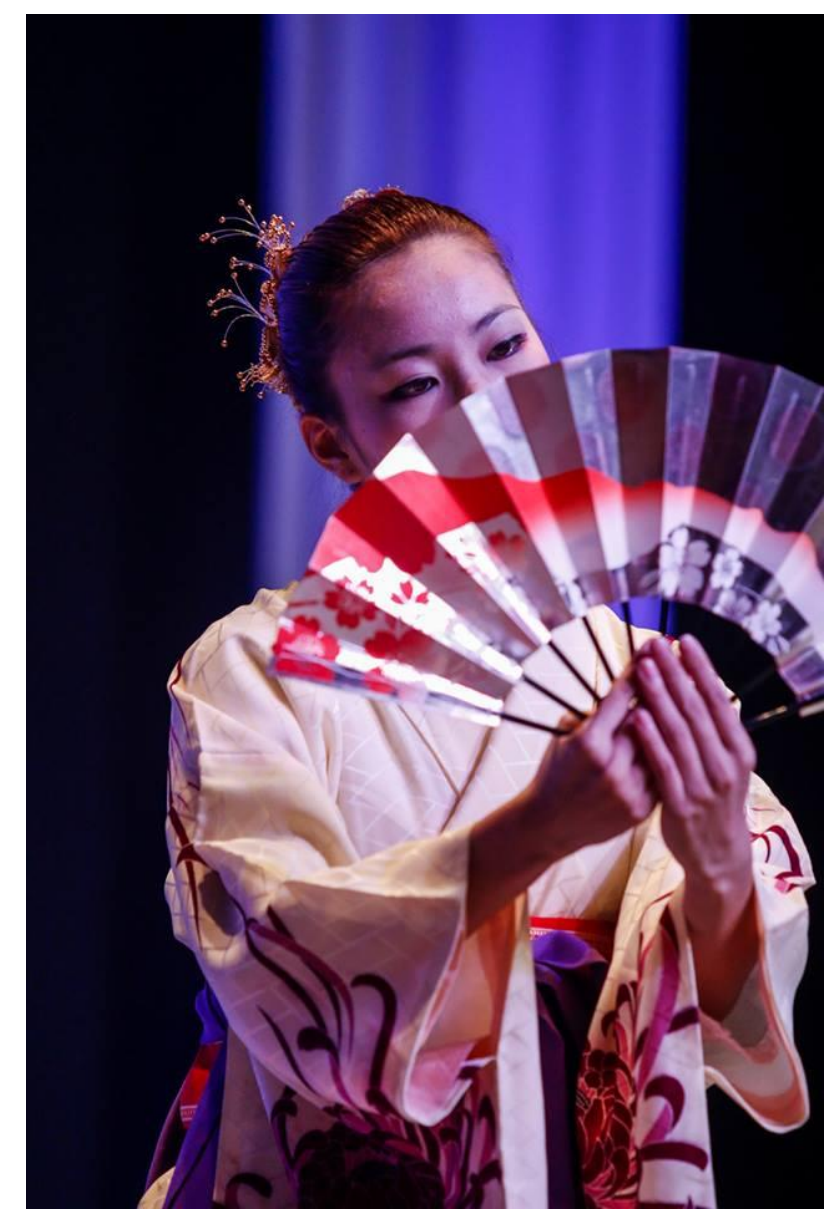

Foto 4. Dançarina em coreografia tradicional japonesa, no Gueinosai.

Fonte: fotografia de Gabriel Inamine/Bunkyo

Uma importante aquisição na área das artes plásticas também ajudou a fazer dos anos 1970 uma era de significativas ampliações culturais no Bunkyo: em 1972, o 
famoso Seibikai, ou Grupo Seibi ${ }^{113}$, se dissolvia, e sua proposta de arte nipo-brasileira foi logo absorvida pelo Salão Bunkyo, uma exposição de arte a ser montada anualmente, com foco nos artistas e no público nikkei, mas aberto a não descendentes. Embora o contexto histórico que tanto marcou as experiências de vida e as visões de mundo dos artistas que criaram o Seibikai já fosse outro, o Salão Bunkyo se ofereceu como espaço de convergência para as tentativas de divulgação de uma prática artística que conservasse a marca do olhar e da experiência dos imigrantes japoneses e seus descendentes no país.

Enquanto isso, a mobilização para captação de recursos continuava, dessa vez em benefício de outro projeto de grandes proporções e que teria um impacto ainda maior do que todos os realizados pelo Bunkyo até então: a criação de um museu para "abrigar a memória da imigração japonesa", um projeto que organizaria no plano material as ideias e discursos produzidos pelas lideranças do Bunkyo, desde a sua fundação, quanto às origens, as vicissitudes, o legado e as contribuições dos japoneses no Brasil. As práticas referentes ao presente e aos projetos de futuro da comunidade nipo-brasileira já eram o foco da atuação do Bunkyo, que começaria agora a construir o seu passado.

A criação do museu exigiria uma ampliação considerável dos espaços disponíveis na sede do Bunkyo; por isso, ao mesmo tempo em que lançavam uma campanha nacional para doação de material histórico, as lideranças da entidade iniciaram também uma nova fase de arrecadação de fundos para a construção de mais cinco andares no edifício-sede, sendo que dois deles seriam destinados às instalações do museu. Uma das ideias era a venda de espaços para outras entidades nipo-brasileiras, além, é claro, de pedir ajuda ao governo japonês. A mobilização da comunidade para a empreitada de resgate da memória dos imigrantes envolveu, sobretudo, intelectuais da colônia, como os membros do Centro de Estudos Nipo-Brasileiros, ou Jinmonken, do qual fizeram parte, entre outros, o escritor e artista plástico Tomoo Handa e os pesquisadores Teiichi Suzuki e Hiroshi Saito, ambos da Universidade de São Paulo.

\footnotetext{
${ }^{113}$ Em 1931, o Nihon Club de São Paulo promoveu a primeira exposição de pintura da colônia japonesa, cujo sucesso inspirou a fundação, quatro anos mais tarde, da São Paulo Bijutsu Kenkyukai (Associação de Estudos de Belas Artes de São Paulo, mais conhecida como Seibikai ou Grupo Seibi). As suas atividades foram interrompidas com o começo da Segunda Guerra e retomadas em 1947. Manabu Mabe e Tomie Ohtake se destacam entre os seus mais famosos integrantes. Ver: Sussumu Miyao, 1995. Disponível em: http://www.imigrantesjaponeses.com.br/PintoresConteporaneos.pdf, acesso em 11/07/2017.
} 
Este último, além de ter participado ativamente da busca por um modelo para o museu, visitando vários congêneres no Japão, foi o seu primeiro diretor, de 1978 a 1980.

A vinda em 1974 do primeiro-ministro japonês Kakuei Tanaka - 15 anos depois da histórica visita do premiê Nobusuke Kishi ao Brasil - ajudou a acelerar as negociações para o auxílio financeiro às obras do museu, motivando também a ida de líderes do Bunkyo ao Japão, onde percorreram museus etnográficos em busca de modelos de instalação e de técnicas museológicas adequadas ao que se imaginava para o projeto nipo-brasileiro. Com a liberação da verba, em 1977, foi contratada a empresa japonesa Tanseisha, especializada em obras desse tipo. Os trabalhos de construção foram acelerados para que pudesse estar tudo pronto no ano seguinte, quando se comemoraria - mais uma vez com a presença, possivelmente, de um membro da família imperial - o septuagésimo aniversário da imigração japonesa.

O Museu Histórico da Imigração Japonesa - instalado em dois dos cinco andares recém-construídos no edifício-sede do Bunkyo - foi inaugurado em 18 de junho de 1978, como parte das comemorações dos 70 anos da chegada do navio Kasato Maru ao Porto de Santos, trazendo a bordo os primeiros imigrantes japoneses. Mais uma vez, o Bunkyo conseguiu reforçar, junto à comunidade, a sua imagem de órgão central da população nipo-brasileira no país e de interlocutor principal junto às autoridades brasileiras e japonesas, ao conseguir a presença, na cerimônia de inauguração do museu, entre outros personagens importantes, das duas figuras políticas mais elevadas dos dois países: a do príncipe herdeiro Akihito - que voltava ao Brasil representando oficialmente seu pai, o imperador Hiroito, que não pôde aceitar o convite por motivo de doença - e a do então presidente da República, general Ernesto Geisel. 


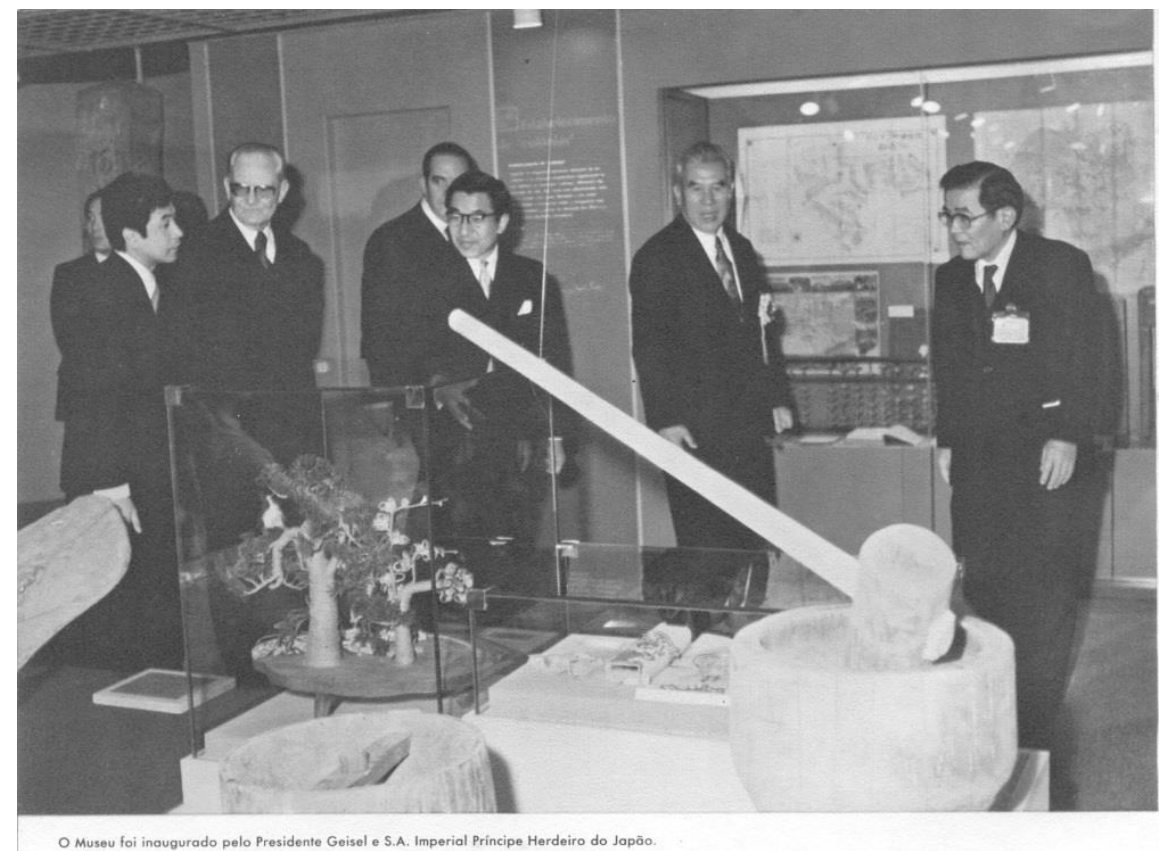

Foto 5: Príncipe herdeiro Akihito e presidente Geisel na inauguração do museu.

Fonte: http://www.imigracaojaponesa.com.br Acesso em 11/07/2017

No momento da inauguração, o museu contava com cerca de mil peças, distribuídas em uma área de 578 metros quadrados em cada andar, totalizando, portanto, 1.156 metros quadrados de instalações com fotografias e objetos montados em uma linha do tempo que construía uma narrativa sobre o percurso dos imigrantes, desde os preparativos para a primeira viagem, ainda no Japão, até a chegada das empresas japonesas ao Brasil, no pós-guerra. A construção da narrativa foi inspirada nas orientações de Tadao Umezano, antropólogo e museólogo de Osaka, para quem um museu não deveria ser uma mera exposição de objetos históricos, mas "um local de educação social". O centro da narrativa, então, seria o registro da contribuição do imigrante japonês que, ao levar consigo a cultura de sua terra natal, participava da "construção de um novo mundo",114.

A ideia era agrupar os objetos e imagens coletados, juntamente com outros produzidos para ajudar na reconstituição dos contextos narrados - como réplicas de navios, animais empalhados, maquetes etc. -, em três grandes temas: a travessia dos japoneses para o novo mundo, as produções dos imigrantes que contribuíram para o

\footnotetext{
${ }^{114}$ YAMASHITA, L.R. O Museu Histórico da Imigração Japonesa no Brasil. In HARADA, K. (coord.). 60 anos de Bunkyo. Passado, Presente e Futuro. São Paulo: Cadaris Comunicação, 2015, pp.159-176. Ver também o site do museu: http://www.museuBunkyo.org.br/ acesso em 11/07/2017.
} 
desenvolvimento do país e a procura por novos rumos. A narrativa foi se alongando com os anos, à medida que novas instalações foram adicionadas ao museu, e novas histórias se juntaram ao conjunto da saga. Modificações e adições também foram efetuadas com a possibilidade de incluir assuntos "sensíveis" que antes não se podiam expor abertamente (como, por exemplo, os assassinatos que traumatizaram a colônia, no pós-guerra, considerados verdadeiros "fratricídios") e com a disponibilidade de novas tecnologias que proporcionaram acesso maior e mais diverso aos assuntos referentes ao passado da comunidade. Hoje, o museu possui mais de 90 mil itens, distribuídos em três andares do edifício-sede do Bunkyo, além dos objetos de grande porte, que ficam expostos no Centro Esportivo Kokushikan Daigaku, localizado na área rural de São Roque.

A década de 1970 encerrou-se com muitos planos para novos projetos, entre eles a aquisição de terreno e a construção de um estacionamento exclusivo, uma necessidade cada vez mais premente com o aumento do tráfego local e da população moradora e lojista no bairro da Liberdade, e ainda com o considerável acréscimo de movimento no edifício, com as visitas ao novo museu. Também foi aprovado o início da fundação do ginásio esportivo, obra estratégica para atrair a presença dos jovens da comunidade, para quem outra providência de incentivo também seria destinada: a implementação das bolsas de estudo, estendidas agora a pesquisas acadêmicas. Os eventos desse fim de década também marcaram, segundo avaliação da entidade, o final de uma era para o Bunkyo: a era em que os grandes eventos foram idealizados e promovidos predominantemente por imigrantes da primeira geração, os isseis (japoneses natos). A partir de então, a presença cada vez maior de nisseis em cargos de direção levaria a entidade a uma gradual mudança de estilo e de perspectiva.

Embora as mudanças que ocorrem no seio de uma população como decorrência do envelhecimento de uma determinada geração e da consequente ascensão dos mais jovens não sejam, obviamente, um traço exclusivo da população nipo-brasileira, sobretudo em uma época de grandes transformações sociais - como foi o caso da segunda metade do século XX -, a troca (ainda que gradual) de "comando" no Bunkyo refletia as profundas alterações que aconteciam na comunidade nikkei. Ainda que o país dos ancestrais continuasse a ser uma referência significativa para nisseis e sanseis que já eram adultos no final dos anos 1970 e início dos 1980, ter nascido e vivido no Brasil produzira mudanças em aspectos cruciais da vida, a começar pela língua, que é um 
repositório poderoso das imagens e das experiências definidoras do sistema de valores e de visões de mundo. Quanto a essa relação entre subjetividade e língua nos contextos diaspóricos, Payer (2005, p. 5) afirma que:

(...) a tensão entre a língua nacional e a língua materna (...) atinge a constituição da linguagem e do sujeito, em seus processos de identificação em relação à língua. Trata-se de uma tensão que se apresenta no processo histórico de subjetivação do sujeito imigrante, processo ao longo do qual esse sujeito estrangeiro vai se tornando brasileiro.

A perda do japonês como língua falada em casa - e, bem antes disso, nos ambientes de trabalho e em encontros sociais fora da comunidade - foi um processo reforçado pela ação do Estado, nos anos de exacerbação do nacionalismo getulista, mas foi muito mais a decorrência natural de uma sucessão de mudanças no estilo de vida dos imigrantes e de seus descendentes, fazendo com que estes últimos se tornassem cada vez mais "brasileiros". Segundo avaliação do Bunkyo, esse "abrasileiramento" se dá com a maior escolaridade das novas gerações, que passaram a frequentar universidades brasileiras de ponta e a ocupar posições diversas no mercado de trabalho, verificandose, ao mesmo tempo, um aumento dos casamentos interétnicos e, consequentemente, do nascimento de indivíduos "mestiços", resultando em "uma delimitação cada vez menos nítida da comunidade nikkei"115.

O interesse por escolas de japonês, ainda segundo a entidade, permaneceu crescente entre os nikkeis até os anos 1990, quando o número começou a decrescer e o de alunos não descendentes a aumentar. Ao mesmo tempo em que a língua japonesa evanescia no seio das famílias, também os costumes tradicionais iam perdendo terreno. A autoridade paterna deixa de ter a ascendência indiscutível que tinha sobre os demais membros da família, que se tornam mais autônomos nas decisões quanto ao seu próprio futuro, incluindo aí as escolhas afetivas e profissionais. Desaparecem as "escolas formadoras de noivas, à moda da colônia japonesa", que delimitavam o mundo feminino aos cursos de corte e costura, culinária e economia doméstica, e surge a

\footnotetext{
${ }^{115}$ BUNKYO - Sociedade Brasileira de Cultura Japonesa e Assistência Social. Guia do Museu Histórico da Imigração Japonesa no Brasil. São Paulo, 2008, pp. 84-85.
} 
moderna mulher nikkei, inserida "na sociedade em todos os ramos de atividade profissional” ${ }^{116}$.

O fenômeno do envelhecimento das primeiras gerações de imigrantes, além de previsível, foi comprovado pela grande participação de isseis na Semana dos Idosos, promovida em 1970, em São Paulo, por várias entidades beneficentes nikkeis, tendo inspirado a criação de "clubes dos idosos" em várias localidades, além de programas mais estruturados de avaliação das condições de saúde dessa população. Anos mais tarde, a Beneficência Nipo-Brasileira de São Paulo fez um levantamento do total de consultas da instituição, verificando que o atendimento aos idosos chegava a $43 \%$ do total, o que significava um aumento considerável em relação ao levantado anteriormente.

Muitos desses casos envolviam pacientes com necessidades de cuidados permanentes, o que motivou a criação de entidades assistenciais da comunidade. Uma das pioneiras nesse ramo de atividade é a Ikoi-no-sono (Jardim de Repouso Dom José Gaspar), atualmente proprietária de duas salas no quarto andar do edifício-sede do Bunkyo. A entidade foi fundada no início da década de 1940, quando estendia seu raio de ação à assistência de qualquer pessoa que se enquadrasse no conceito de "necessitado", dentro da comunidade nipo-brasileira, que, na época, enfrentava violência política e destituição e congelamento de bens por serem "cidadãos do Eixo". Com o passar dos anos, a entidade passou a dedicar-se exclusivamente ao atendimento dos idosos.

A década de 1980 começou com novas articulações para renovação na entidade, dando prosseguimento a uma expectativa de "mudança de mentalidade" que já se discutia nos últimos anos da década anterior. O presidente do Bunkyo na época, Shinichi Aiba - issei que ascendeu da condição de agricultor à de dirigente em um dos setores do grupo financeiro América do Sul - via com preocupação a dispersão da comunidade japonesa, e a possibilidade de o legado dos imigrantes acabar sem herdeiros. Ele sugeria, como medida urgente para a revitalização da comunidade, que estivessem todos, sempre, envolvidos em algum grande projeto. Na sua gestão, o Bunkyo empenhou-se no projeto de construção de um centro poliesportivo, que incluiria desde

${ }^{116}$ Idem, p. 87. 
ginásio de esportes até piscina olímpica, quadra de tênis, campo de beisebol e pista de atletismo.

A inflação galopante que envolveu o país naqueles anos não permitiu que a ideia progredisse, mas pelo menos o ginásio de esportes, o estacionamento e o prédio anexo foram concretizados, já mais perto do final da década, com a ajuda do governo japonês. Apesar das limitações econômicas, o projeto de renovação continuou no plano institucional. Uma grande campanha para conquistar novos associados foi deflagrada, não só para aumentar a arrecadação, mas principalmente para que a entidade fizesse jus à sua condição de "órgão central" da comunidade nipo-brasileira.

Um levantamento do perfil dos associados, nessa época, revelou que aproximadamente $60 \%$ eram nisseis, e que a faixa etária predominante entre os novos sócios era de 30 a 40 anos de idade. Ao mudar novamente de direção, em 1983, a entidade definiu como meta assumir uma atitude que levasse em conta os interesses das gerações mais novas e que fosse "mais progressista" quanto às suas relações com a comunidade em geral, criando oportunidades para "intercâmbio de opiniões" e abrindo mais lugares na direção para nisseis e isseis pós-guerra ${ }^{117}$. Até mesmo a inclusão de mulheres em cargos de direção foi discutida, o que significava um grande passo à frente para uma entidade criada e gerida somente por homens da velha geração.

A percepção de que os modelos de gestão já davam sinais de fadiga era concomitante com a preocupação com a própria sobrevivência da colônia, o que levou o Bunkyo a promover um seminário e um concurso de monografias com o tema "O Futuro da Comunidade Japonesa e seu Desenvolvimento". Enquanto as discussões se concentravam no futuro, os trabalhos no presente reproduziam a mesma estratégia bem sucedida do passado: em 1982, o Bunkyo recebia em sua sede mais um membro da família imperial, dessa vez o príncipe Naruhito, filho primogênito do imperador, que vinha ao Brasil em sua primeira viagem oficial como herdeiro da Coroa japonesa. Além da associação do nome do Bunkyo com uma instituição "venerável” - a casa imperial -, também a cultura japonesa tradicional continuava sendo prestigiada, com a criação de

\footnotetext{
${ }^{117}$ Havia um estranhamento mútuo entre os imigrantes japoneses que vieram antes e depois da guerra, conforme foi explicado no capítulo anterior. A criação do Bunkyo foi obra dos isseis do primeiro grupo, que àquela altura já haviam conquistado posições econômicas e sociais elevadas, tanto na comunidade quanto na sociedade brasileira; os do segundo grupo, além de terem terminado mais tarde de percorrer esse caminho, ainda tinham um perfil cultural e de visão de mundo que refletia as grandes mudanças vividas pelo Japão durante e depois da guerra, bem diferente, portanto, do perfil dos japoneses do período anterior.
} 
cursos e exposições de Ikebana e Arte Kôguei ${ }^{118}$ na sede da entidade. Também a continuidade do programa de bolsas de estudo ao Japão ao mesmo tempo atendia às expectativas dos jovens de obterem ajuda para o seu aprimoramento educacional e profissional e reforçava o vínculo da comunidade com a terra dos ancestrais.

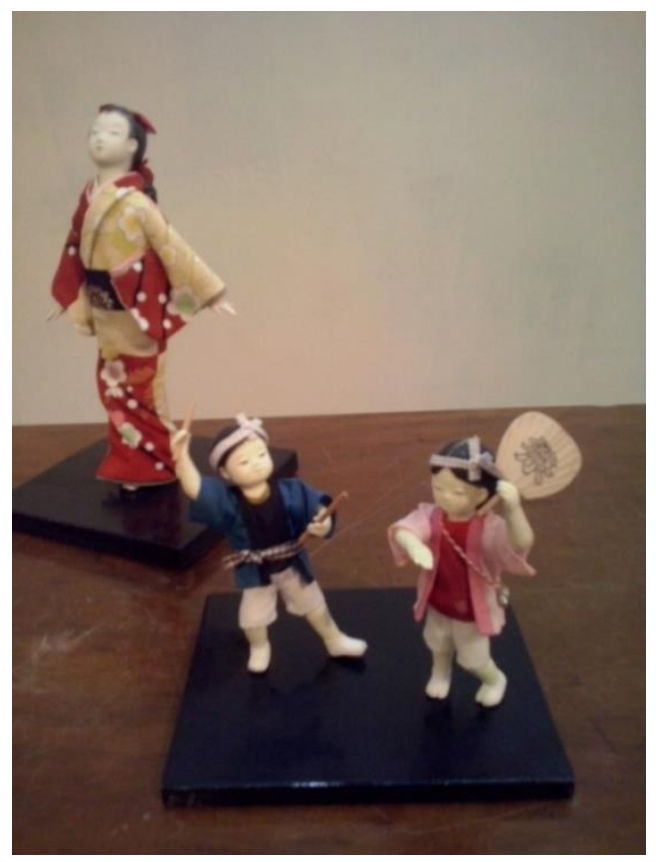

Foto 6: Arte Kôguei.

Fonte: fotografia da autora

Dois outros importantes acontecimentos, de repercussões opostas, também marcaram a década de 1980 para a entidade: por um lado, a grandiosa celebração do octogésimo aniversário da imigração japonesa, com nova concentração de milhares de pessoas no Pacaembu e a presença do príncipe Akishino, segundo filho do imperador Akihito - cuja presença garantiu novas promessas de apoio do governo japonês ao Bunkyo -; por outro, o início da emigração em massa de nipo-brasileiros para o Japão e a necessidade de "preencher o vazio deixado pelos decasséguis" ${ }^{119}$. Nesse final dos anos 1980, com o prolongamento da crise econômica no Brasil, a falta de empregos levou muitos trabalhadores a buscarem alternativas no exterior, o que foi o caso dos

\footnotetext{
${ }^{118}$ Trabalho artesanal pertencente à cultura popular tradicional japonesa; geralmente é feito à base de materiais naturais, como argila, água e madeira, mas engloba técnicas e materiais variados.

${ }^{119}$ BUNKYO - Sociedade Brasileira de Cultura Japonesa e de Assistência Social. Bunkyo: 60 anos. Sua trajetória. São Paulo, 2015, p. 18.
} 
brasileiros que, aproveitando o crescimento da economia no Japão, foram atrás das oportunidades oferecidas aos estrangeiros com ascendência japonesa ${ }^{120}$.

Para o Bunkyo, esse fenômeno "provocou, de certa forma, o esvaziamento das associações nipo-brasileiras"121. Esse "vazio" a ser preenchido era o mais recente dos muitos desafios enfrentados pelo Bunkyo, que nesse final de década buscava, com dificuldade, encontrar novas (ou mesmo antigas) lideranças que aceitassem assumir a presidência da entidade. A indicação de um nissei para o cargo registrou, nas narrativas sobre seu próprio percurso, as diferenças de visão entre os líderes do Bunkyo: enquanto uns acreditavam que já era hora de abrir espaço para a segunda geração, outros se apegavam à tradição e - 36 anos após a fundação da entidade - ainda defendiam a permanência de um issei no comando.

Os isseis perderam a batalha. Não só o nissei Atushi Yamauchi foi escolhido presidente, como, de todos os cinco vice-presidentes eleitos, nenhum era issei do período anterior à guerra, um fato inédito na história do Bunkyo. Com planos de grandes mudanças, a equipe recém-eleita criou novas comissões. Uma delas revelava a prioridade do presente: a Comissão de Planejamento Futuro. Com essa comissão, buscava-se encontrar, no presente, sinais que apontassem a direção a tomar desde já para garantir o futuro da entidade. Reunidos em congressos promovidos pelo Bunkyo, com o apoio da JICA ${ }^{122}$, representantes de diversas associações nipo-brasileiras traziam à mesa de discussão algumas de suas constatações mais prementes: a perda da língua e da cultura japonesas, a crise de liderança, o esvaziamento das associações nipobrasileiras em todo o país e a dificuldade de conciliar os interesses das diferentes gerações que conviviam nas entidades.

\footnotetext{
${ }^{120}$ Pelo menos por mais uma década, os números de saídas de brasileiros com visto de trabalho para o Japão só cresceram, até que, no final da primeira década dos anos 2000, a economia do Japão estagnou e os decasséguis começaram a retornar em massa. Atualmente, com a retomada gradual da economia japonesa, os números de interessados em trabalhar no Japão voltaram a crescer. Como reflexo disso, no site do Bunkyo, uma matéria publicada em 13 de julho de 2017 anuncia palestra de um deputado japonês sobre a concessão de visto de trabalho a yonseis (quarta geração). Ver em: http://www.Bunkyo.org.br/ptBR/noticias/157-2017/1257-deputado-japones-fala-sobre-concessao-de-visto-de-longa-permanencia-aosyonseis acesso em 11/07/2017.

${ }_{121}$ OI, Célia Abe. Em: HARADA, Kiyoshi (coord.). 60 anos de Bunkyo. Passado, Presente e Futuro. São Paulo: Cadaris Comunicação, 2015, p. 84.

122 JICA: Japan International Cooperation Agency. É um órgão governamental japonês de apoio técnico e financeiro aos países em desenvolvimento, estabelecido em 1974. O escritório da JICA no Brasil foi aberto em 1976, no Distrito Federal. Ver: https://www.jica.go.jp/brazil/portuguese/office/about/, acesso em 22/07/2017.
} 
Apesar da intensa mobilização da entidade, que contava agora com "sangue novo" disposto a buscar os caminhos da revitalização, a década de 1990, segundo avaliação do próprio Bunkyo, "representou um período de inquietação na comunidade nipo-brasileira", uma "era de incertezas" sobre o futuro da comunidade ${ }^{123}$. Uma evidência inquestionável da crise foi o levantamento, feito em 1991, que mostrava que boa parte dos associados deixara de pagar as suas contribuições, enquanto que os pagantes efetivos já eram em número consideravelmente inferior ao registrado em levantamento anterior. E, para agravar o quadro, houve uma sequência de fechamentos de instituições cruciais na história do Bunkyo: a Cooperativa Agrícola Central Cotia, em 1990, a Cooperativa Central Sul Brasil, em 1992, e o Banco América do Sul, em 1997, "que não só contribuíram financeiramente com o crescimento patrimonial do Bunkyo", como também foram fonte essencial de recursos humanos, de onde saíram muito dos dirigentes e voluntários da entidade ${ }^{124}$.

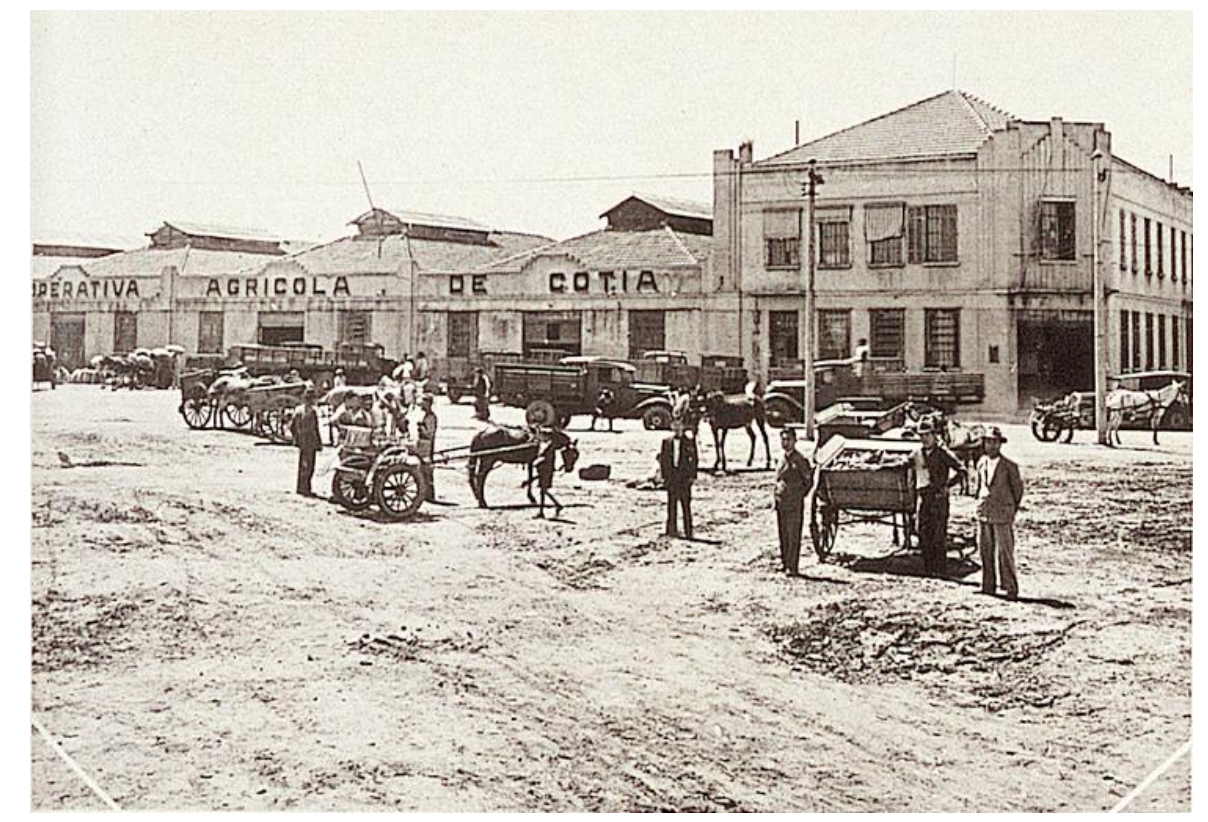

Foto 7: Cooperativa Agrícola de Cotia.

Fonte: site da Biblioteca da Dieta Nacional, Japão.

Uma ideia que surgiu com a promessa de revitalizar a comunidade nipobrasileira e de auxiliar o Bunkyo a cumprir melhor a sua missão acabou por dividir ainda

123 OHARA, Tuyoci. Uma inflexão nos rumos da entidade: renovação do Bunkyo. Em: HARADA, Kiyoshi (coord.). 60 anos de Bunkyo. Passado, Presente e Futuro. São Paulo: Cadaris Comunicação, 2015, p. 181.

${ }^{124}$ NAKASHIMA, Eduardo Goo. A luta pelos recursos financeiros. Em: HARADA, Kiyoshi (coord.). 60 anos de Bunkyo. Passado, Presente e Futuro. São Paulo: Cadaris Comunicação, 2015, p. 178. 
mais as lideranças da entidade. Durante reunião dos representantes de associações nikkeis, em 1996, foi lançada a ideia de se fundar uma nova entidade central, que funcionaria como uma federação de todas as entidades dispersas pelo país. O papel dessa nova entidade - a ser chamada de União Nacional das Entidades Nikkeis (UNEN) - seria identificar os problemas de cada associada e propor maneiras de revitalização, incentivando ainda a união de todas, o intercâmbio de ideias e a ajuda recíproca.

As lideranças contrárias a essa proposta argumentavam que o Bunkyo já cumpria esse papel de órgão representativo e central da comunidade nipo-brasileira, e que a criação de uma nova entidade com a mesma função só esvaziaria a entidade e desestabilizaria as relações com as autoridades do Japão e do Brasil, que já tinham há décadas o Bunkyo como seu interlocutor e como representante central da comunidade nipo-brasileira. Já os defensores da ideia - muitos deles dirigentes do próprio Bunkyo achavam que a entidade possuía uma estrutura de funcionamento e um calendário de atividades intensos demais, o que impedia a agilidade necessária para identificar e responder rapidamente às necessidades das entidades espalhadas pelo país. Ponderavam também que a população nipo-brasileira passara por grandes mudanças, e que uma nova entidade teria maior possibilidade de atender às expectativas das novas gerações. A falta de consenso arrastou as discussões pelo resto da década, até que, em março de 2000, a UNEN finalmente foi fundada. O desinteresse das entidades, porém, acabou esvaziando a entidade recém-criada, que nunca chegou a realizar nada de importante.

Enquanto isso, uma nova frente de atividades tomava forma no Bunkyo já no início da década de 1990. O chamado "fenômeno decasségui" começava a criar problemas de certa maneira inusitados, já que uma emigração com essas características era uma novidade tanto para o Japão como para a comunidade nipo-brasileira. Mais uma vez, o Bunkyo confirmava seu papel de interlocutor do governo japonês ao receber, em 1991, a visita do chefe do setor que seria mais tarde a Divisão da Política de Emprego aos Trabalhadores Estrangeiros do Ministério do Trabalho japonês, que pedia a ajuda da entidade na preparação dos decasséguis, que chegavam ao Japão "sem o conhecimento da língua e dos costumes do país" e causavam, por isso, “inúmeros conflitos" no ambiente de trabalho e na vida social ${ }^{125}$. Nesse mesmo ano, uma comissão especialmente constituída para examinar essa questão conseguiu juntar representantes

\footnotetext{
${ }^{125}$ Ver narrativa de Atushi Yamaushi, em Do Japão ao Brasil... Retornando à origem. CIATE - Vinte Anos de História. Coordenação de Helena Sanada. São Paulo: CIATE, 2012, pp.7-10.
} 
dos governos brasileiro e japonês, da Organização Internacional do Trabalho e do meio acadêmico em um simpósio que, após três dias de discussões, definiu - entre outras coisas - que seria criado um centro de orientação mantido por entidades representativas da comunidade nipo-brasileira, com o objetivo de preparar os emigrantes e impedir que fossem vítimas de falsas expectativas e recrutamento fraudulento.

Em abril do ano seguinte, o Bunkyo já abria provisoriamente o Centro de Informação, Orientação e Assistência aos Decasséguis, enquanto preparava a estrutura de um órgão definitivo, a ser inaugurado em outubro daquele mesmo ano e que contaria com ajuda financeira do governo japonês. Ficou acertado que esse órgão se chamaria CIATE (Centro de Informação e Apoio ao Trabalhador no Exterior), nome escolhido pelo presidente provisório (depois confirmado como presidente de fato, cargo em que permanece até hoje), o advogado e professor universitário Masato Ninomiya. A indicação do seu nome - pelos membros do Bunkyo e das demais entidades que auxiliaram na criação do novo centro - foi unânime, não só porque Masato já tinha à época formação acadêmica e experiência profissional nas áreas do Direito trabalhista e internacional, entre outras, mas também por suas boas relações com autoridades brasileiras e japonesas (inclusive com a família imperial, a quem acompanhou em suas visitas ao país, como assessor e tradutor), e por sua fluência nas duas línguas.

O CIATE teve muitos problemas a resolver, desde o início. A começar pela própria dificuldade em abordar a questão em certos círculos da comunidade nipobrasileira, "em razão do preconceito e de certo sentimento de vergonha que nutriam em relação a essa paradoxal situação de retorno dos decasséguis ao país de origem de seus pais e avós para conseguir melhores oportunidades de trabalho" ${ }^{126}$. O uso da expressão "retorno" dos decasséguis indica que, pelo menos durante um tempo, para alguns membros da comunidade nipo-brasileira, era como se os filhos e netos dos imigrantes os representassem em uma volta simbólica ao Japão. E "retornar" como trabalhadores não especializados - o que era o caso da grande maioria dos decasséguis - significava que seus pais e avós não teriam sido bem sucedidos no Brasil, já que seus filhos e netos repetiam igual destino, agora no sentido contrário da mesma viagem. Talvez por esse motivo, um ponto frequentemente enfatizado pelo CIATE é a questão da educação dos

\footnotetext{
${ }^{126}$ Ver narrativa de Kazuo Watanabe, membro do conselho deliberativo acadêmico do CIATE e um dos organizadores do simpósio de 1991, em: Do Japão ao Brasil... Retornando à origem. CIATE - Vinte Anos de História. Coordenação de Helena Sanada. São Paulo: CIATE, 2012, p. 13.
} 
filhos dos emigrantes - que muitas vezes têm problemas de adaptação na escola japonesa, ao chegar, e depois na escola brasileira, ao voltar - para que as dificuldades financeiras da família não se perpetuem nas próximas gerações.

Embora trabalhadores estrangeiros - sobretudo de países asiáticos vizinhos como Indonésia, Filipinas e Vietnã - tenham sido admitidos em números crescentes (com contratos temporários) no Japão, nas últimas décadas, com a necessidade premente de mão de obra nos picos de crescimento da economia, é sabido que o governo japonês está entre os países que mais dificultam, entre as potências industrializadas, a admissão de imigrantes estrangeiros. A autoimagem de país etnicamente coeso e homogêneo, conforme discutido no capítulo anterior, está por trás desse fenômeno e de suas consequências sociais, culturais e demográficas ${ }^{127}$.

A atribuição de "status especial de permanência" aos trabalhadores nikkeis reforça a percepção de que as autoridades japonesas valorizam, como política demográfica hegemônica, a manutenção das características étnicas da sua população, e que os "laços de sangue" são percebidos como um fator de "proximidade" a ligar os descendentes de japoneses ao Japão ${ }^{128}$. Mas isto não impediu que os nipo-brasileiros enfrentassem problemas graves de adaptação no país de seus ancestrais. $\mathrm{O}$ fato de terem o fenótipo igual ao dos cidadãos nativos - a "falsa imagem de japonês"129 - foi a fonte, muitas vezes, de uma expectativa de conformidade, por parte da população local, a que os nikkeis não tinham como corresponder.

Assim, o primeiro problema enfrentado pelos decasséguis já ao chegar ao Japão era o da língua, pois a maior parte deles não era fluente em japonês. Mesmo aqueles que aprenderam o idioma com pais e avós, e achavam que sabiam o suficiente para uma comunicação básica com a população local e no ambiente de trabalho, descobriram ao chegar que as línguas são dinâmicas e, portanto, mudam. Isto significa que o japonês

\footnotetext{
${ }^{127}$ Para uma perspectiva crítica desse tema, ver análise de um ex-embaixador britânico que serviu no Japão nos anos 1980: http://www.japantimes.co.jp/opinion/2015/11/19/commentary/japancommentary/japans-population-problem/\#.WW4bJIjyvIV acesso em: 18/07/2017. Para uma análise acadêmica do tema, ver a resenha da historiadora Jiyeoun Song do livro Fighting for Foreigners: Immigration and Its Impact on Japanese Democracy, de Apichai W. Shipper. Em Journal of East Asian Studies, Vol. 10, No. 2 (MAY-AUGUST 2010), Cambridge University Press, pp. 353-355.

${ }^{128}$ Ver narrativa de Mitsuaki Yoshimen, ex-diretor superintendente do Centro de Estabilização do Emprego nas Indústrias do Japão, em: SANADA, Helena (coord.) Do Japão ao Brasil... Retornando à origem. CIATE - Vinte Anos de História. São Paulo: CIATE, 2012, pp. 23-26.

${ }^{129}$ Ver narrativa de Ricardo Sasaki, consultor do CIATE entre 2000 e 2007, em: SANADA, Helena (coord.) Do Japão ao Brasil... Retornando à origem. CIATE - Vinte Anos de História. São Paulo: CIATE, 2012, p. 53.
} 
aprendido com familiares no Brasil - que era, na verdade, um japonês falado décadas atrás - não servia no Japão atual. Além disso, o japonês falado no Brasil era muitas vezes uma mistura de dialetos (o antigo coronia-go), com inclusão de palavras adaptadas do português, o que aumentava ainda mais a dificuldade de comunicação para os recém-chegados no Japão.

Assim, uma das necessidades prementes foi a montagem de um curso de japonês a ser oferecido pelo CIATE, cujo modelo foi inspirado nos cursos oferecidos pela Tokyo Nikkeis, uma organização mantida pela Fundação Centro de Estabilização de Emprego nas Indústrias do Japão. As aulas de idioma japonês do CIATE passaram por reformulações até a criação de um método que procura atender às necessidades específicas dos decasséguis brasileiros. Além das aulas de japonês, o CIATE organizou palestras com orientação sobre as normas trabalhistas, a tributação e a previdência social vigentes no Japão, e sobre aspectos essenciais da cultura japonesa, um conhecimento indispensável para a adaptação em qualquer país estrangeiro, quanto mais em uma situação em que as expectativas do país imaginado (a partir das histórias ouvidas de pais e avós desde a infância) não correspondiam à realidade encontrada.

Instalado no primeiro andar do edifício-sede do Bunkyo, o CIATE é uma entidade autônoma, embora algumas pessoas que participam do quadro dirigente de uma entidade também participem da outra, mantendo assim os vínculos que as unem desde a origem do projeto, em 1991. A presença constante de anúncios das atividades do CIATE no site do Bunkyo também sinaliza a disposição das duas entidades em preservar seus vínculos e se ajudar mutuamente. Sua estrutura de atendimento foi adicionando novas frentes de orientação e serviço, ao longo dos anos, à medida que a situação dos decasséguis se tornava mais conhecida e acessível àqueles que se propunham a ajudálos, e também em função das mudanças do fenômeno decasségui em si, com o passar do tempo, tanto no Japão como no Brasil. O logo da entidade, criado pela designer e coordenadora de cursos e palestras Helena Sanada, resume o espírito do CIATE e de sua clientela: uma rosa dos ventos estilizada, cujas agulhas lembram as asas de um grande pássaro alçando voo. 


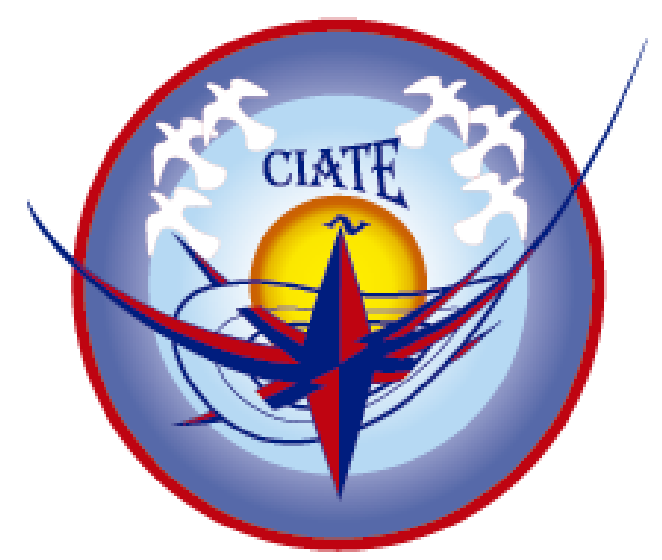

Figura 2: logo da entidade.

Fonte: CIATE

Hoje, a entidade tenta alcançar o seu público por meio de um sistema amplo de comunicação escrito e audiovisual, com site e presença nas redes sociais, e material impresso que é distribuído no Consulado do Japão, em entidades nipo-brasileiras e em órgãos da mídia nikkei. Mantém um quadro de auxiliares fixos e eventuais, como psicólogos que preparam os futuros decasséguis para o impacto emocional da jornada que vão realizar, e também os retornados para a difícil readaptação ao país. Outros profissionais focam em diversos outros aspectos, como a formação de atitudes que valorizam o trabalho e o trabalhador e de empreendedorismo para aqueles que retornam e pensam em aplicar suas economias em um projeto próprio.

A segunda metade da década de 1990 foi marcada por eventos e celebrações que mostram o Bunkyo ainda investindo para se manter à frente de trabalhos pela mobilização da comunidade nipo-brasileira. O primeiro deles foi o centenário do Tratado de Amizade Brasil-Japão, em 1995, que foi motivo de muitas festas e solenidades, com a presença de autoridades brasileiras e japonesas que evocaram os avanços e conquistas do intercâmbio tecnológico e científico entre os dois países e os elos afetivos que unem os dois povos, apesar de se situarem "praticamente em posições opostas na Terra" ${ }^{\prime 130}$. Como parte das celebrações, o Bunkyo recebeu a filha caçula do imperador Akihito, princesa Sayako, em visita ao museu da imigração, inaugurado por seus pais em 1978 e também visitado por seus irmãos mais velhos em 1982 (Naruhito) e 1988 (Akishino). Assim, a família imperial consolidava, agora com o registro da

\footnotetext{
${ }^{130}$ Ver texto do governo japonês sobre esse tema no site do Ministério das Relações Exteriores do Japão: http://www.mofa.go.jp/region/latin/brazil/centenary.html acesso em 20/07/2017.
} 
presença de todos os seus membros, a tradição iniciada pelo imperador em pessoa (na época, príncipe herdeiro) de visitar o museu da imigração, construído para ser o lugar de memória dos japoneses que deixaram a terra natal rumo ao Brasil.

Ainda como parte da comemoração dos cem anos do tratado de amizade, o Bunkyo promoveu o Simpósio Internacional sobre Preservação da Memória dos Imigrantes, com a presença de especialistas em museologia do Japão, do Peru, dos Estados Unidos e do Brasil, uma atividade que contribuiu para marcar a posição da entidade como centro de organização e disseminação da história da comunidade nikkei. E, aproveitando o momento comemorativo, um outro museu foi inaugurado nesse mesmo ano, depois de quase uma década de preparações: o Museu de Arte NipoBrasileira, que, herdando o espírito do antigo Seibikai, criava um espaço de registro do olhar específico do imigrante e de seus descendentes na arte brasileira.

O ano de 1996 foi marcado por pelo menos três eventos importantes para a reafirmação do Bunkyo como entidade central da comunidade nipo-brasileira, do ponto de vista das autoridades japonesas. O primeiro, em maio, foi a realização do Congresso de Jovens Líderes da Comunidade Nipo-Brasileira, um evento que refletia a preocupação do Bunkyo com o futuro da comunidade e cujo tema foi, justamente, o "presente e futuro de jovens nas entidades nikkeis". A razão de ser desse congresso focado na participação de sanseis e yonseis na faixa de vinte anos de idade - foi a retomada de uma discussão levantada dois anos antes, sobre a importância crucial da formação de novas lideranças para a revitalização das associações nipo-brasileiras.

O sinal evidente da importância desse tema foi o subsídio conferido pela JICA ao Bunkyo para a organização de um ciclo de debates sobre a revitalização das associações, do qual fez parte o congresso de jovens líderes. O Congresso, até hoje, mantém seu foco nos "projetos de integração entre os seinenkais" (grupos de jovens) e na promoção de debates sobre o perfil das novas lideranças, o papel dessas entidades na sociedade brasileira e formas de planejar e capacitar os seus membros ${ }^{131}$.

O segundo evento importante foi o encontro de membros do Bunkyo, além de representantes de outras entidades nipo-brasileiras, com o primeiro-ministro Ryutaro Hashimoto, que, em visita ao Brasil, quis ouvir as sugestões das pessoas de origem

\footnotetext{
${ }^{131}$ Ver texto sobre este tema no site do Bunkyo: http://www.Bunkyo.org.br/pt-BR/pt-br/noticias/86-
} 2014/455-revi-forum-nacional-dos-jovens-lideres-das-entidades acesso em: 24/07/2017. 
japonesa do Brasil quanto à sua disposição de incrementar a parceria entre os dois países. A proposta levada pelo Bunkyo - a construção de um colégio nipo-brasileiro foi aprovada pelo premiê, que, em conversa com o presidente brasileiro (na época, Fernando Henrique Cardoso), citou o interesse do governo japonês em auxiliar o projeto $^{132}$. O colégio nipo-brasileiro foi uma ideia que durante anos circulou entre as lideranças do Bunkyo, que consideravam importante que também os japoneses tivessem no Brasil o seu colégio, como os italianos tinham o Dante Alighieri, e os alemães, o Visconde de Porto Seguro (ambas em São Paulo), entre outras escolas bilíngues do país.

A proposta do colégio era incluir o ensino do japonês na grade curricular brasileira, o que atenderia não só à expectativa das famílias nipo-brasileiras de recuperar, entre as gerações mais jovens, a fluência no idioma dos antepassados, como também proporcionaria a alunos não descendentes o conhecimento da língua e da cultura do Japão - o que poderia, a médio e longo prazo, aumentar as chances de intercâmbio entre os dois países, o que era, justamente, a proposta do premiê Hashimoto. Apesar de ter tido alguns avanços no seu planejamento, o colégio nipobrasileiro nunca se concretizou, embora até hoje a ideia ressurja, de vez em quando, em conversas dentro e fora do Bunkyo.

O terceiro evento importante de 1996 foi a doação de um terreno de vinte e três alqueires pela Universidade Kokushikan, de Tóquio, ao Bunkyo, como parte das celebrações do seu quadragésimo aniversário. Situada na parte rural do município de São Roque, a cerca de setenta quilômetros da capital paulista, a área era utilizada há mais de dez anos por uma academia de artes marciais e educação física mantida pela universidade japonesa. Com a doação, o Bunkyo passou a planejar uma nova frente de atuação: a de proporcionar um grande espaço de convivência, lazer e prática de esportes, a ser desfrutado, sobretudo, nos finais de semana e outros momentos de folga dos associados. Criar um ambiente como esse, semelhante a um clube de campo, era uma velha ideia das lideranças pioneiras da entidade, que viam no tripé "cultura, esportes e lazer" uma fórmula eficiente para manter unidas todas as gerações da comunidade.

\footnotetext{
${ }^{132}$ OI, Célia Abe. Em: HARADA, Kiyoshi (coord.). 60 anos de Bunkyo. Passado, Presente e Futuro. São Paulo: Cadaris Comunicação, 2015, p. 89.
} 
Levou tempo para que o Centro Esportivo Kokushikan Daigaku se tornasse o que é hoje, uma área composta por um campo de mallet golf, um jardim típico japonês, uma grande área construída onde se realizam exposições e apresentações culturais, uma ampla "praça" onde toldos são montados para bazares, restaurantes e oficinas durante os festivais anuais das cerejeiras, plantadas em torno de um lago, e que recebe a visita de milhares de pessoas em uma versão brasileira do hanami, prática tradicional japonesa de contemplação das floradas (que no Japão acontecem de março a maio, e no Brasil geralmente no mês de julho). O Centro Kokushikan também passou a abrigar, mais recentemente, um encontro anual de jovens, ligado à comissão de revitalização das organizações, chamado por isso de REVI.

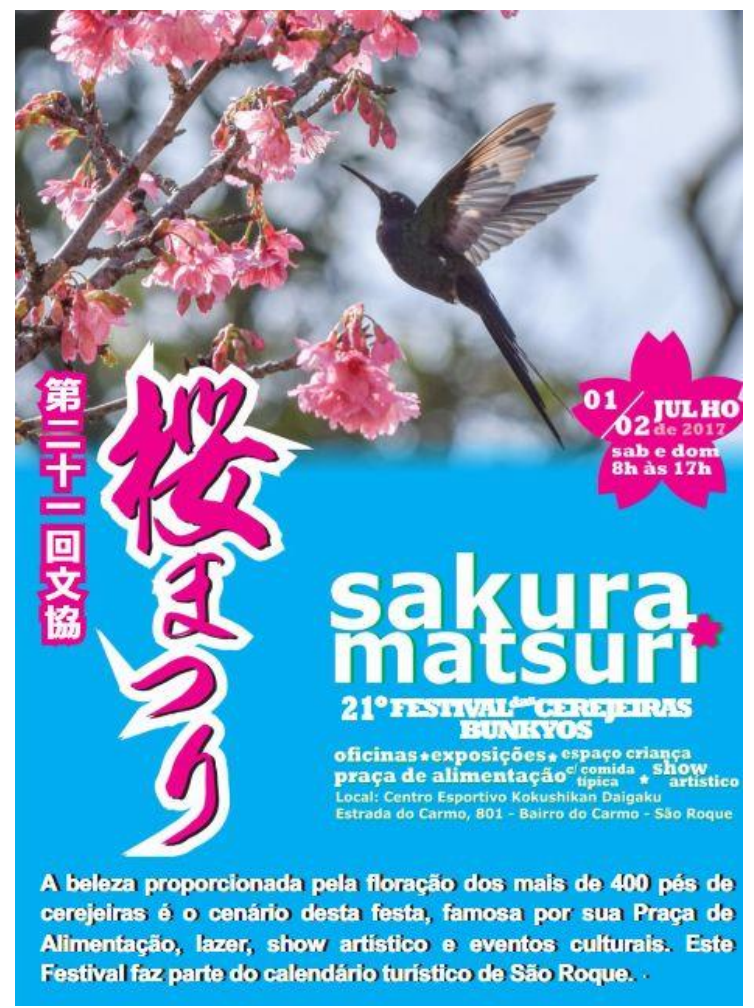

Foto 8: Cartaz de divulgação do Festival das Cerejeiras 2017 no Centro Esportivo Kokushikan Daigaku. Fonte: Bunkyo

Mais um acontecimento de grande relevância para o Bunkyo ainda estaria reservado para esse final de década: o retorno, em 1997, de Akihito ao Brasil já como 
imperador, "um fato inédito na diplomacia imperial do Japão"133. Recebido no Distrito Federal pelo então presidente Fernando Henrique Cardoso, o imperador e sua esposa estiveram em outras cidades brasileiras, além de São Paulo. No Bunkyo, foram recebidos no salão nobre por líderes da comunidade nipo-brasileira e visitaram uma exposição especial sobre a família imperial no Museu da Imigração Japonesa. Apesar do grande significado dessa visita do imperador ao Bunkyo, as comemorações dos 90 anos da imigração em São Paulo foram superadas pelas festas no Paraná, que contaram com a participação do presidente Fernando Henrique Cardoso. Embora as celebrações de 70 e 80 anos da imigração tenham lotado, em São Paulo, o Estádio do Pacaembu, a festa dos 90 anos reuniu um número bem menor de pessoas no centro de eventos Anhembi, o que refletia as desarticulações internas no Bunkyo e as dificuldades em lidar com os desafios do momento. Na avaliação dos líderes da entidade, porém, o fraco desempenho do Bunkyo nas comemorações do nonagésimo aniversário da imigração se deu por causa da “diminuição da população issei de imigrantes"134.

\subsection{A crise e a comissão de renovação}

O Bunkyo chegou ao século XXI em clima de reflexão profunda, com grande parte de seus próprios quadros pedindo por "renovação total". A falta de consenso em torno da questão da UNEN, a inegável diminuição do interesse dos associados e uma crescente percepção de que a comunidade nipo-brasileira como um todo passava por mudanças profundas, além de um grave problema interno que foi o estopim de uma crise com potencial devastador, levaram a diretoria do Bunkyo (o presidente e os cinco vice-presidentes) a anunciar, em outubro de 2002, que não se recandidataria às novas eleições, previstas para dali a cinco meses. A decisão foi acompanhada pela criação de uma comissão de "estudos de renovação"135, que ouviu vários segmentos da comunidade e promoveu um debate público, em fevereiro de 2003, sobre as questões mais essenciais quanto à sua missão e razão de ser: o seu papel na representação da

\footnotetext{
${ }^{133}$ Idem.

${ }^{134}$ BUNKYO - Sociedade Brasileira de Cultura Japonesa e Assistência Social. Guia do Museu Histórico da Imigração Japonesa no Brasil. São Paulo, 2008, p. 88.

135 A Comissão foi coordenada por Kazuo Watanabe, desembargador aposentado do Tribunal de Justiça de São Paulo, que à época não fazia parte da direção do Bunkyo. Os demais membros eram o presidente e seus vices, além de Kenitiro Suguio, presidente do Conselho Deliberativo.
} 
comunidade nipo-brasileira e na preservação do legado dos imigrantes japoneses no país.

O relatório final, assinado em 19 de março de 2003 e levado a público no ano seguinte na Revista Colônia, não deixou pedra sobre pedra. Como todos os seus signatários eram dirigentes ou lideranças muito próximas ao Bunkyo, o texto soava como uma autocrítica. Suas primeiras palavras, porém, colocavam a entidade acima dos problemas circunstanciais, ao assegurarem a existência de um "consenso geral” de que o Bunkyo era e deveria continuar sendo a "entidade central representativa da comunidade nipo-brasileira", e que, apesar das "eventuais falhas isoladas", sua atuação sempre foi "notável e abnegada"136. Mas, logo em seguida, o relatório apontava, sem rodeios, os outros pontos sobre os quais também havia consenso: de que, "em relação ao Bunkyo, a impressão é de que as decisões são tomadas em âmbito restrito, sem transparência"; de que a falta de comunicação faz com que "sócios e não sócios, principalmente os jovens" desconheçam as atividades desenvolvidas na entidade; e de que "o associado, no seu relacionamento com a entidade, não consegue ser ouvido"137.

Prosseguindo com sua "autocrítica", a comissão avaliava que, apesar de ter havido grandes mudanças no mundo, no Brasil e no Japão, e como consequência também na comunidade nipo-brasileira, o Bunkyo não conseguia acompanhar os novos tempos, tendo se fechado em torno dos isseis, que fundaram a entidade "com grande dedicação e sacrifício pessoal", mas deixando de fora os nisseis, sanseis e yonseis, que não sentiam, como decorrência disso, nenhuma atração pelas atividades promovidas pela entidade. Por isso, o Bunkyo era percebido como uma espécie de "nihonjin-kai", ou seja, uma associação japonesa semelhante às dos antigos imigrantes, fechadas em seu próprio mundo, acarretando assim o distanciamento dos jovens nikkeis e das pessoas de outras etnias $^{138}$. Este último ponto levantado no relatório representava um grande salto na mudança de perspectiva quanto aos novos significados que o Bunkyo deveria abraçar. Os autores do relatório pediam a renovação do próprio conceito de "comunidade nipobrasileira", afirmando que o critério de "laços de sangue", que prevaleceu no passado, não tinha mais razão de ser, com o aumento dos casamentos interétnicos e os

136 Sociedade Brasileira de Cultura Japonesa ("Bunkyo"), Comissão Provisória dos Estudos de Renovação, Relatório final, 19 de março de 2003, pp. 1 e 2.

${ }^{137}$ Idem.

${ }^{138}$ Idem. 
descendentes mestiços, e com a inserção dos cônjuges não descendentes dentro da comunidade japonesa do Brasil ${ }^{139}$.

Com a ampliação do conceito, a comunidade nipo-brasileira deixaria de ter um significado étnico, ligado apenas à ascendência japonesa, passando assim a ser considerada "um segmento da sociedade brasileira". A implicação desse conceito renovado de comunidade nipo-brasileira vai mais longe do que a mera inclusão de não descendentes com vínculos de casamento com nikkeis: deveriam ser vistos como parte da comunidade, também, todos os brasileiros que de alguma forma apreciam ou se identificam com a cultura japonesa, ou que desenvolveram laços "de estudos, amizades e relacionamentos pessoais" que os ligam a pessoas ou entidades nipo-brasileiras. Os autores do relatório recomendavam, então, que o "quadro social" do Bunkyo refletisse esse "amplo conceito de nipo-brasileiro", o que deveria incluir também, cada vez mais, "pessoas de gerações mais novas, com a ampliação da participação feminina" "140.

Quanto à participação feminina, passaram-se doze anos desde a assinatura desse relatório até que uma mulher assumisse o cargo mais alto dentro da entidade. Harumi Goya foi eleita presidente do Bunkyo para o biênio 2015/2017 e, em seguida, foi reconduzida para mais dois anos à frente da entidade. Antes da presidência, ela mesma e outras mulheres ocuparam funções e postos significativos nas comissões, nos órgãos institucionais e na coordenação de eventos ligados ao Bunkyo, mas, para se ter uma ideia, na diretoria atual (2017/2019), de 35 cargos, só dois são ocupados por mulheres: a própria presidente Harumi Goya e Teruco Kamitsuji (5 $5^{\text {a }}$ vice-presidente). Quanto aos jovens, desde a criação do Seinen em 1997, o Bunkyo já abria espaços para sua participação, embora - como destacou o texto do relatório - isso não tenha resultado na produção de eventos do interesse das novas gerações, que se mantiveram relativamente afastadas da entidade. A criação de novas frentes de atuação, como o Fórum Anual dos Jovens Líderes das Entidades (REVI) e o - também anual - Fórum de Integração Bunkyo (FIB), proporcionou maiores oportunidades de expressão para os mais jovens, que, no entanto, não conseguiram até hoje mudar de forma significativa o perfil da entidade quanto à distribuição do poder, que continua sendo uma atribuição dos mais velhos.

\footnotetext{
${ }^{139}$ Idem, pp. 2 e 3.

${ }^{140}$ Idem, p.3.
} 
Quanto à inclusão dos não descendentes no conceito de comunidade nipobrasileira, conforme sugeria o relatório, a situação atual pode ser observada pela presença de nomes de origem não japonesa nos quadros diretivos do Bunkyo: no biênio 2017-2019, de 74 cargos na diretoria e nos conselhos (deliberativo, superior de apoio e orientação, consultivo e fiscal), apenas duas pessoas com sobrenomes brasileiros participam da lista, ambas no conselho consultivo. Os demais 72 cargos são ocupados por pessoas cujos nomes indicam ascendência japonesa. A presença mais significativa de não descendentes no Bunkyo continua a ser notada nos eventos promovidos pelo Bunkyo: como palestrantes convidados, como participantes nos festivais (lutadores de artes marciais; praticantes de haicai, taikô, cerimônia do chá e ikebana; músicos, expositores e dançarinos, etc.) e no público do auditório e das oficinas, exposições, bazares e praças de alimentação, refletindo o interesse dos brasileiros em geral pela cultura japonesa.

O relatório de 2003 também toca no sensível ponto da real representatividade do Bunkyo, já que a entidade passara a se denominar Sociedade Brasileira de Cultura Japonesa - e não mais Sociedade Paulista - em 1968, "graças à sua abrangência nacional" ${ }^{\text {141 }}$. Com a crise de participação dos associados, reconhecida pelos signatários do relatório - que apontavam como razão principal desse esvaziamento a falta de "uma linha de atuação" e a "atual dispersão" da entidade -, uma nova abordagem seria essencial para o reconhecimento de que a entidade de fato cumpria a sua missão. Independente do fato de o Bunkyo conseguir ou não a adesão de associados de todas as partes do país, a sua representatividade como órgão de expressão nacional resultaria, segundo o relatório, de "sua capacidade de identificar e defender efetivamente os interesses e necessidades gerais da comunidade, agindo em benefício de todos" ${ }^{\text {"142 }}$.

A redefinição do "representado" do Bunkyo se torna, então, condição estratégica para obtenção da real representatividade nacional, com a inclusão dos imigrantes pré e pós-guerra, os decasséguis e suas famílias, os nikkeis de qualquer geração e também os não descendentes que se aproximaram da comunidade graças a seu "interesse pela cultura japonesa" ${ }^{\prime 143}$. O documento termina com uma lista de vinte recomendações,

\footnotetext{
${ }^{141}$ BUNKYO - Sociedade Brasileira de Cultura Japonesa e de Assistência Social. Bunkyo: 60 anos. Sua trajetória. São Paulo, 2015, p. 12.

${ }_{142}$ Sociedade Brasileira de Cultura Japonesa ("Bunkyo"), Comissão Provisória dos Estudos de Renovação, Relatório final, 19 de março de 2003, p. 5.

${ }^{143}$ Idem.
} 
referentes a aspectos técnicos, estruturais e filosóficos da entidade, marcando o momento em que o Bunkyo procura mudar para poder sobreviver, conciliando a integração definitiva da comunidade nipo-brasileira à sociedade nacional, mas sem perder sua distinção como minoria. Em praticamente todas as recomendações, a ênfase se divide entre a amplitude da representatividade - que deve atingir uma comunidade nipo-brasileira redefinida não apenas em termos de etnia, idade e gênero, mas também quanto a todas as necessidades e interesses geradores de inclusão - e a especificidade do seu fator distintivo: sua ligação com o Japão contemporâneo e o do passado, com a história da imigração e com a cultura e a língua japonesas.

Os trabalhos que preconizavam a maior reflexão interna já realizada pelo Bunkyo desde a sua fundação aconteciam ao mesmo tempo em que se preparava a celebração do centenário da imigração japonesa, a mais importante de todas as festas já promovidas pela comunidade nipo-brasileira. Outro motivo de intensa agitação, concomitante às reformas e aos preparativos dos cem anos da imigração, foram as eleições internas da entidade de 2005, que aconteceram em clima de disputa e até de confrontação, em parte pelo fato de ter sido um pleito direto, em obediência a uma mudança no código civil brasileiro que, aliás, teve curta duração.

Segundo avaliação da entidade, apesar das grandes dificuldades de ordem logística, as eleições diretas de 2005 contribuíram para "o despertar da consciência cívica dos associados", para a escolha de melhores dirigentes "tendo em vista o surgimento de vários candidatos", para o "combate ao imobilismo" e para a "democratização do sistema de escolha dos dirigentes" $" 144$. Embora outros pleitos tenham sido também disputados, essa foi a única eleição direta realizada pelo Bunkyo. O retorno das eleições diretas foi novamente considerado pela entidade, que até criou uma comissão de renovação do estatuto instituída em 2015, mas sem prosseguimento até os dias de hoje.

\footnotetext{
${ }^{144}$ HARADA, Kiyoshi (coord.). 60 anos de Bunkyo. Passado, Presente e Futuro. São Paulo: Cadaris Comunicação, 2015, p. 112.
} 


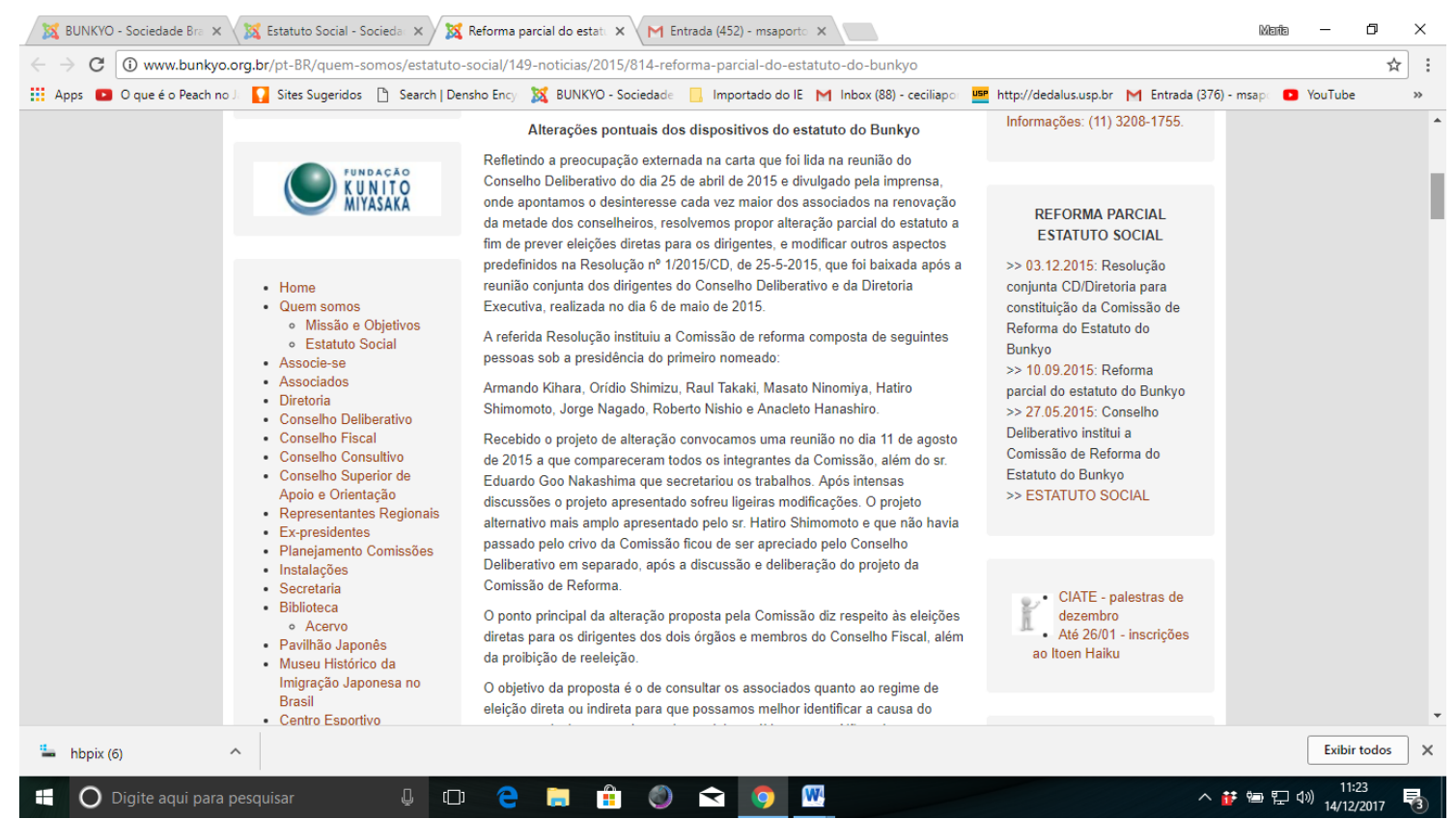

Texto da proposta de reforma do estatuto, em que são sugeridas eleições $\operatorname{diretas}^{145}$. Fonte: site do Bunkyo.

Utilizando recursos doados por empresas nipo-brasileiras e de fundos de comemorações anteriores, o Bunkyo promoveu reformas físicas no seu edifício-sede como parte dos preparativos para a grande festa, incluindo troca de elevadores e obras na fachada do prédio, no salão nobre e no grande auditório. Enquanto isso, uma comissão especial era montada para discutir e montar os planos de execução dos eventos do centenário, mobilizando praticamente todos os setores do Bunkyo. Além dos preparativos para o que ocorreria dentro das suas instalações, incluindo o Pavilhão, o Bunkyo ainda se transformou em central de informações e de consultoria para órgãos e instituições brasileiras e estrangeiras de cultura e de comunicação, que realizavam filmes, noticiário, cadernos especiais e outras produções culturais e educacionais sobre os cem anos da imigração japonesa no Brasil. Exemplo disso foi a integração do museu no projeto pedagógico de escolas públicas e privadas que levaram seus alunos em visitas monitoradas às exposições sobre a imigração japonesa. Um outro exemplo, que atingia público bem diverso, foi a participação do museu na produção de uma exposição de quimonos na São Paulo Fashion Week daquele ano.

\footnotetext{
${ }^{145}$ Ver em: http://www.Bunkyo.org.br/pt-BR/quem-somos/estatuto-social/149-noticias/2015/814-reformaparcial-do-estatuto-do-Bunkyo acesso em 14/8/2017.
} 
Sendo um dos setores mais requisitados naqueles tempos de grandes preparativos, o museu teve a missão de organizar as narrativas (que incluíam histórias, imagens, espaços e objetos) em um evento grandioso que não só contasse esses cem anos de história, mas que se tornasse, ele próprio, história. Como centro de convergência de boa parte das atividades e dos documentos memoriais dos imigrantes e seus descendentes, o museu foi o espaço da ritualização solene dessas lembranças, exercendo assim - em um momento de especial significado para o Bunkyo e para a comunidade nipo-brasileira como um todo - o seu papel de "lugar de memória", inaugurado no dia da sua fundação, trinta anos antes. Segundo os coordenadores do museu, o número de visitantes nesse ano de comemoração do centenário foi o maior já registrado na sua história: 33.868 pessoas, três vezes mais do que no ano anterior.

Mais uma vez, a família imperial referendou, com sua presença, o projeto do Bunkyo de representar a comunidade e de preservar o seu legado. Dessa vez, quem veio foi o príncipe herdeiro Naruhito (que já havia estado no Bunkyo em 1982), cuja participação foi considerada "o ápice do Centenário para a comunidade nipobrasileira" ${ }^{" 146}$. O futuro imperador japonês percorreu uma exposição de trinta e seis painéis fotográficos especialmente montada no museu para relatar a história da imigração, e que depois seria transformada em exposição itinerante, percorrendo associações nipo-brasileiras em vários pontos do país.

Um passo determinante para reunir toda a informação disponível sobre a vinda de imigrantes japoneses ao Brasil, desde o seu "marco zero" - a chegada do navio Kasato Maru ao porto de Santos, em 1908 -, foi a formação da Comissão Ashiato, um grupo de mais de cem voluntários japoneses e brasileiros que fizeram um grande trabalho de transcrição e digitalização de mais de três milhões de dados sobre 255 mil imigrantes japoneses que desembarcaram no Brasil ao longo de sete décadas. A palavra ashiato quer dizer "pegada" em japonês, o que inspirou a criação de um banco de dados, acessível em terminais eletrônicos, com a lista de passageiros de cada navio, as datas e portos de saída, as províncias de origem e as fazendas para onde se dirigiam essas pessoas.

\footnotetext{
146 YAMASHITA, Lidia Reiko, vice-presidente da Comissão do Museu. Em: HARADA, Kiyoshi
} (coord.). 60 anos de Bunkyo. Passado, Presente e Futuro. São Paulo: Cadaris Comunicação, 2015, p. 166. 
Assim, bastando digitar o nome da família (em kanji ou em grafia romanizada), qualquer pessoa passou a poder "traçar as pegadas" de seus ancestrais, desde o momento em que saíram do Japão até a chegada ao destino final. Esse projeto de digitalização levou à criação de outros, após as festividades dos cem anos, como a catalogação e o registro do acervo do museu, que em boa parte "permanecia na obscuridade" ou já estava em "processo de deterioração". Esse trabalho de salvamento e de organização dos objetos e documentos históricos, que tinha por objetivo o cumprimento, pelo Bunkyo, de uma de suas missões (preservação do legado dos imigrantes japoneses no Brasil), resultou na articulação de uma poderosa narrativa sobre a imigração, sob o controle da entidade, ao mesmo tempo em que consolidava seu edifício-sede como "lugar de memória" e ponto de referência de todos os eventos significativos referentes à comunidade nipo-brasileira.

\begin{tabular}{|c|c|c|c|c|}
\hline 1 - Sato & 2 - Suzuki & 3-Takahashi & 4 - Tanaka & 5-Watanabe \\
\hline 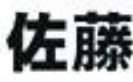 & 蜍來 & 高憣 & Bdy & 海记 \\
\hline 6 - Ito & 7 - Nakamura & 8 - Yamamoto & 9-Kobayashi & 10 - Saito \\
\hline
\end{tabular}

Sobrenomes japoneses em kanji e grafia romanizada correspondente.

\section{Fonte: Nippobrasil}

Esse status especial conquistado pelo Bunkyo foi confirmado pela presença massiva dos meios de comunicação do Brasil e de outros países, que fizeram da entidade uma de suas fontes mais importantes de informação e de entrevistas. Além dos grandes jornais impressos (como Folha e Estado de São Paulo), que dedicaram ao tema várias matérias e cadernos especiais, também as rádios e redes de televisão foram buscar nas salas e no museu do Bunkyo grande parte dos dados e das imagens de suas reportagens ao vivo e gravadas. A Rede Globo chegou a produzir uma série de DVDs com dez horas de gravação, que foram posteriormente doados ao museu. Também a Editora Abril deu uma contribuição especial: a confecção de um site interativo ${ }^{147}$ com ampla abordagem do mundo nipo-brasileiro, que após 2008 foi vinculado à homepage do museu. Quanto à mídia estrangeira, a NHK japonesa, a BBC inglesa, a CNN

\footnotetext{
${ }^{147}$ Ver o site original em: http://www.japao100.com.br acesso em 24/07/2017.
} 
americana e o Libération francês foram alguns dos órgãos que fizeram do Bunkyo um ponto de convergência para a obtenção de informações sobre o Centenário.

Acontecimentos importantes, alguns resultantes da intervenção do próprio Bunkyo e outros decorrentes de eventos inesperados, agitaram a rotina da entidade nos anos seguintes à celebração dos cem anos da imigração. Um desses acontecimentos foi a criação, ainda em 2008, da Comissão Bunkyo Rural, que no ano seguinte já promovia o Primeiro Encontro Bunkyo Rural, no município paulista de Pompeia, localizado em área que foi, no passado, um dos centros da colônia japonesa. Essa comissão teve por objetivo resgatar um aspecto crucial da memória da imigração: a sua origem agrícola, pois a grande maioria dos imigrantes japoneses, até a primeira metade do século XX, era formada por agricultores. Apesar do intenso êxodo rural a partir dos anos 1950, a presença de japoneses e de seus descendentes no campo ou em agronegócios continuou significativa, mantendo, até hoje, "uma participação elevada na produção agrícola do país" ${ }^{\text {"148 }}$. Os encontros do Bunkyo Rural, que continuam acontecendo anualmente, têm hoje um foco nas inovações tecnológicas e no intercâmbio Brasil-Japão, além de abrir espaço para a troca de ideias e propostas de gestão para o futuro da agricultura.

Ainda ecoando as recomendações do relatório de 2003 - que apontava graves falhas do sistema de divulgação do Bunkyo, feito "sem a utilização de mecanismos modernos de comunicação", o que deixava "muitos sócios e não sócios, principalmente os jovens" sem saber das "atividades desenvolvidas pelo Bunkyo""149 -, em 2009, foi implementado um novo sistema de comunicação com base em tecnologias digitais, ao mesmo tempo em que era mantida a produção de material impresso. O site do Bunkyo foi ampliado, permitindo uma navegação em direções variadas, desde as informações sobre a história, os serviços e a estrutura da entidade, até a programação dos eventos mais recentes e os links que redirecionam o visitante a uma seleção de outras entidades e instituições referentes ao mundo nipo-brasileiro, além de proporcionar acesso às páginas da entidade nas redes sociais (Facebook, Instagram, Twitter e TripAdvisor) e a vídeos do Bunkyo no YouTube. Também um boletim eletrônico foi criado, com as notícias dos principais acontecimentos da entidade, e que é enviado a todas as pessoas que fazem parte da sua lista de contatos. Mesmo não-sócios podem inscrever seus $e$ -

${ }^{148}$ KATSURAGAWA, Tomio, ex-presidente da Comissão do Bunkyo Rural. Em: HARADA, Kiyoshi (coord.). 60 anos de Bunkyo. Passado, Presente e Futuro. São Paulo: Cadaris Comunicação, 2015, p. 233. 149 Sociedade Brasileira de Cultura Japonesa ("Bunkyo"), Comissão Provisória dos Estudos de Renovação, Relatório final, 19 de março de 2003, p. 1. 
mails diretamente na secretaria e passam a receber o boletim, que tem periodicidade irregular. A versão impressa, Bunkyonews, também circulou durante um tempo ${ }^{150}$, com conteúdo similar (em português e japonês) à sua versão eletrônica, tendo sido distribuída na sede da entidade e em outros espaços públicos até que deixou de ser produzida por tempo indeterminado, por motivos financeiros.

Em 2010, uma disputa referente à ocupação da Aliança Cultural Brasil-Japão nas dependências do edifício-sede do Bunkyo jogou as duas entidades irmãs em um litígio desgastante para ambas as partes, e que levou dois longos anos, até que um acordo pôs fim às hostilidades. A origem da discórdia foi a diferente percepção das duas entidades quanto à ocupação gratuita da Aliança - garantida em carta de 1958 do governo japonês, que concedia ajuda financeira para a construção do edifício-sede do Bunkyo para que a Aliança pudesse "promover o intercâmbio cultural entre o Brasil e o Japão". Para o Bunkyo, a forma de pagamento dos gastos decorrentes da utilização do prédio para as aulas de japonês e demais atividades da Aliança, que fora estabelecida verbalmente, precisava ser definida formalmente, e seus valores recalculados, levando em conta o fato de que a cláusula de gratuidade de 1958 já havia perdido a validade.

Embora a tese da perda de validade tenha sido referendada pelo próprio governo japonês, em carta enviada pelo consulado-geral de São Paulo, segundo essa mesma carta a solução do impasse deveria caber às duas partes, "após esgotadas todas as discussões". A discordância levou as duas entidades a um confronto jurídico, em 2011, que só não chegou às vias de fato porque na "derradeira tentativa" uma solução intermediária apareceu - com a proposta de elaboração de um contrato semelhante ao de "locação" (que era o que o Bunkyo queria), mas sem o uso dessa palavra (que a Aliança não aceitava) - sem que se pudesse "falar em quem perdeu e quem ganhou a ação judicial, o que é muito importante para a preservação da amizade que une as duas entidades" ${ }^{\prime 151}$.

Em 2011, apresentou-se ao Bunkyo uma nova oportunidade de exercer "seu papel de entidade representativa da comunidade nikkei" e de "interlocutor junto aos órgãos japoneses": uma tragédia de proporções inéditas, causada por terremotos e tsunamis e o consequente vazamento radioativo de três usinas nucleares, abateu-se sobre

\footnotetext{
${ }^{150} \mathrm{O}$ Bunkyonews teve 13 edições, sendo que a última delas foi de janeiro/março de 2013. Todas as edições podem ser lidas on-line em: http://www.Bunkyo.org.br/pt-BR/publicacoes/249-Bunkyonews acesso em 28/8/2017.

${ }^{151}$ HARADA, Kiyoshi (coord.). 60 anos de Bunkyo. Passado, Presente e Futuro. São Paulo: Cadaris Comunicação, 2015, pp. 194-197.
} 
extensa área do litoral leste do Japão, deixando mais 30 mil vítimas, entre mortos, feridos e desabrigados. Assim que a notícia chegou ao Brasil, as lideranças do Bunkyo convocaram uma reunião de emergência para decidir qual seria a estratégia da entidade para elaborar uma resposta à altura da gravidade da situação. O Bunkyo, que nasceu dos esforços de união entre imigrantes cuja primeira estratégia foi o levantamento de recursos para auxílio às vítimas de guerra no Japão, já possuía experiência na organização dessas campanhas, tendo em vista a enorme frequência e variedade dos desastres naturais que assolam o arquipélago japonês.

Mas esse desastre, em particular - talvez pela grande cobertura da mídia, graças à extensão e a características inusitadas dos acontecimentos, causando comoção mundial - comprovou a eficiência dos meios de mobilização do Bunkyo e, sobretudo, a confiança da comunidade nipo-brasileira em usar a entidade como agente seguro de intermediação das doações. Embora os trabalhos tenham sido realizados em conjunto pelo grupo das chamadas "go-dantai","152 (cinco entidades), o Bunkyo centralizou boa parte das atividades de divulgação, captação de recursos e realização de cerimônias. As histórias que envolvem esse episódio até hoje circulam entre os membros da entidade, que se recordam dos homens e mulheres que chegavam de municípios distantes, após longas viagens, abraçados a pacotes de dinheiro vivo que só confiariam ao Bunkyo como remetente ${ }^{153}$. A maior parte das doações, porém, foi feita por meio de depósitos bancários, em valores que variaram de duzentos mil reais (o maior depósito individual, feito por doador anônimo) até dois reais, que tinham o valor simbólico de demonstração de kimoti (sentimento) ${ }^{154}$.

O envio de doações materiais - como cobertores, roupas e alimentos, por exemplo - foi desencorajado pelo Bunkyo e demais entidades parceiras, pela dificuldade de transporte até o Japão. Como ápice das ritualizações de atualização dos vínculos que ligam a comunidade nipo-brasileira e o Japão, patrocinadas pelo Bunkyo e as demais parceiras do go-dantai ${ }^{155}$, foi realizada no auditório da entidade uma grande cerimônia

152 "Go-dantai" são as "cinco entidades”, que geralmente atuam juntas em situações especiais; são elas: Sociedade Brasileira de Cultura Japonesa e de Assistência Social (Bunkyo), Federação das Associações de Províncias do Japão no Brasil (Kenren), Beneficência Nipo-Brasileira de São Paulo (Enkyo), Câmara de Comércio e Indústria Japonesa do Brasil e Aliança Cultural Brasil-Japão.

${ }^{153}$ Ver entrevista de Eduardo Goo Nakashima, no Anexo.

${ }^{154}$ KITA, Kihatiro, presidente do Bunkyo à época. Em: HARADA, Kiyoshi (coord.). 60 anos de Bunkyo. Passado, Presente e Futuro. São Paulo: Cadaris Comunicação, 2015, p. 272.

${ }^{155}$ Várias campanhas e eventos foram promovidos no Brasil por outras entidades ou empresas nipobrasileiras, e também por órgãos do governo brasileiro, em benefício das vítimas do "triplo desastre" 
ecumênica em memória das vítimas, celebrada por um padre católico, um pastor metodista e um monge budista, todos de instituições religiosas nikkeis. Além da revitalização dos vínculos entre as duas nações, a cerimônia ecumênica também contribuiu para reforçar a função de "lugar de memória" do edifício-sede do Bunkyo, que desde a fundação do museu da imigração - e a construção de outros espaços memoriais, espalhados pelo prédio - vem se consolidando como espaço de referência e de narração da memória coletiva dos japoneses e seus descendentes no Brasil.

No final de 2012, uma visita inesperada agitou o Bunkyo de uma forma alentadora. Minoru Otsuka, empresário japonês da área de peças para informática, quis conhecer as instalações da entidade e entender melhor as suas atividades. Recebido pelo presidente na época, Kihatiro Kita, o visitante percorreu várias salas, o auditório, a biblioteca, e se interessou especialmente pelo museu da imigração, por ser um "apreciador de obras culturais" realizadas por pessoas "de mesma origem que a sua". E, no final, o que parecia ser apenas uma visita simpática de um japonês que veio conhecer mais de perto a saga e o legado dos imigrantes que deixaram para trás sua terra natal para se instalarem em um país tão distante revelou-se um encontro muito especial, que deixou a todos com "taquicardia devido à excepcional notícia" que viera dar. Otsuka, na verdade, só queria ver de perto o que já conhecia de ouvir falar, e, ao confirmar suas expectativas, revelou a Kita sua intenção de doar cem milhões de ienes (o equivalente, na época, a dois milhões de reais) ao Bunkyo ${ }^{156}$.

A doação - que foi entregue por Otsuka ao presidente Kita na sede da embaixada brasileira em Tóquio, em março do ano seguinte - motivou a criação de uma comissão especial que deliberou a sua utilização em reformas do grande auditório, do Pavilhão Japonês, da sala de exposição, do ginásio de esportes e do museu da imigração. Essa doação, por parte de um japonês idoso que veio ver com seus próprios olhos como a cultura de seu país foi plantada há décadas no outro lado do planeta, pode ser entendida como mais uma demonstração do sucesso alcançado pelo projeto do Bunkyo de construir-se como referência e ponto de encontro entre o Japão de hoje e o do passado, criando e mantendo um espaço de continuidade da cultura e identidade japonesa pré e pós-guerra. Como a comunidade nipo-brasileira tem a sua própria

japonês de 2011, mas como o objetivo desta tese não é explorar o fato em si, restringi-me a analisar o papel desempenhado nele pelo Bunkyo e suas entidades parceiras.

${ }_{156}$ HANASHIRO, A. S., $3^{\mathrm{o}}$ vice-presidente do Bunkyo (2013/2014), em: HARADA, Kiyoshi (coord.). 60 anos de Bunkyo. Passado, Presente e Futuro. São Paulo: Cadaris Comunicação, 2015, p. 213. 
cultura, diversa e mutante, pelo fato de que a vida cotidiana de seus membros é uma resposta (desde os primeiros tempos da imigração) aos estímulos da realidade brasileira e não da japonesa, a construção da narrativa da continuidade - que justifica a preservação do legado - depende destas ações em ambos os lados do mundo.

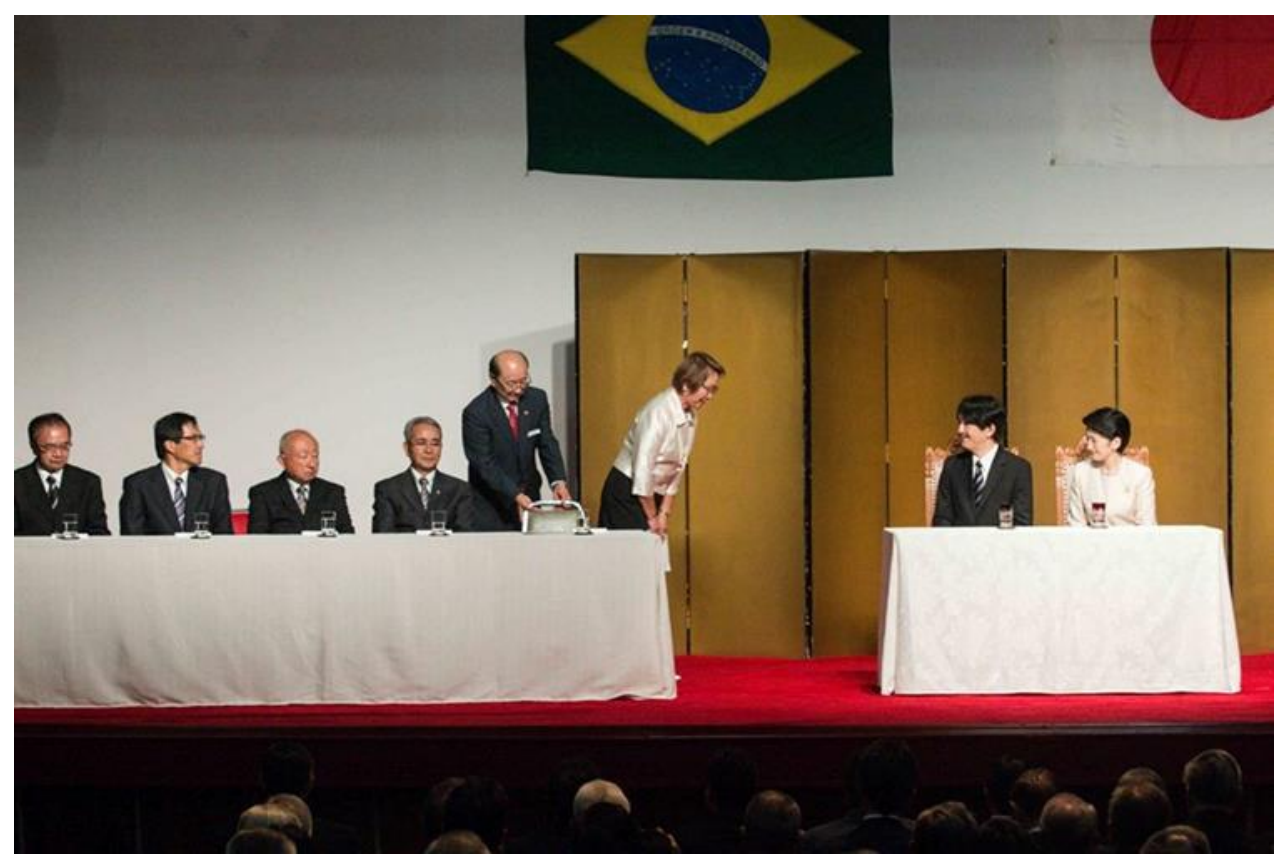

Foto 9. Presidente do Bunkyo Hiromi Goya reverencia o príncipe Akishino e a princesa Kiko, no grande auditório, em 2015. Foto de Gabriel Inamine/Bunkyo.

O sucesso do Bunkyo como referência e ponto de encontro entre Brasil e Japão sofreu um revés, porém, com o episódio da construção da Japan House, projeto do governo japonês inaugurado em São Paulo em maio de 2017. Tendo escolhido a capital paulista para receber a primeira Japan House (as duas outras em Los Angeles e Londres), o governo japonês sinalizou seu reconhecimento quanto à existência de laços especiais unindo Brasil e Japão graças à imigração (pré e pós-guerra) e à grande população de origem japonesa no país. Assim que o plano de construção da Japan House foi anunciado, em 2014, o Bunkyo se apresentou como candidato para sediar o projeto $^{157}$.

Os argumentos a favor de sua candidatura eram poderosos: a localização histórica da entidade, no bairro que recebeu os primeiros imigrantes japoneses na cidade de São Paulo; seu edifício-sede com amplas instalações ainda disponíveis para

\footnotetext{
${ }^{157}$ Ver em http://www.Bunkyo.org.br/pt-BR/noticias/149-2015/593-vice-ministro-sonoura-pr acesso em $05 / 08 / 2017$
} 
ocupação; sua história em prol da unificação da comunidade de origem japonesa no país; sua lista de festivais e eventos de cultura japonesa promovidos regularmente há décadas; suas campanhas de auxílio às vítimas de catástrofes no Japão; seu rol de frequentadores ilustres, a começar pela família imperial e primeiros-ministros japoneses; sua condição de mantenedor do Pavilhão Japonês, primeiro símbolo da amizade e intercâmbio entre os dois países e uma das duas primeiras edificações em estilo tradicional japonês a serem construídas fora do Japão ${ }^{158}$; e o fato de ter criado o maior Museu Histórico da Imigração Japonesa do mundo ${ }^{159}$.

Segundo as informações divulgadas na época (dezembro de 2014) pelo Consulado Geral do Japão em São Paulo, o projeto da Japan House tinha por objetivo estabelecer uma porta de entrada para se conhecer o "verdadeiro Japão"160. E, de acordo com o seu site, a Japan House "é um ponto de difusão de todos os elementos da genuína

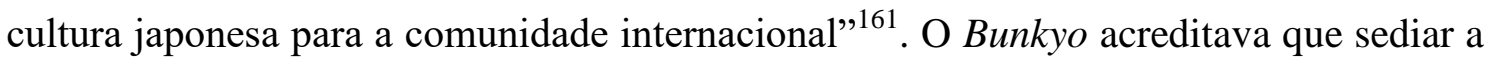
Japan House seria uma oportunidade de somar as suas propostas ao papel que a entidade já vinha cumprindo no Brasil há 60 anos, ampliando "sua atuação como entidade representativa dos nipo-brasileiros e do Japão no país”. Mas, por algum motivo, a ideia de "verdadeiro Japão" e de "genuína cultura japonesa" que a Japan House quer representar no Brasil passou reto pelo Bunkyo ${ }^{162}$, acabando por sediar-se em edifício próprio, na Avenida Paulista - antigo corredor simbólico da elite paulistana, cujos casarões foram substituídos pelas fachadas futuristas de grandes bancos e empresas multinacionais.

Em 2015, acontecia no edifício-sede da entidade a sétima edição de um encontro denominado Fórum de Integração Bunkyo (FIB), criado justamente para promover um

\footnotetext{
${ }^{158}$ A outra edificação, inaugurada apenas dois meses antes do Pavilhão Japonês brasileiro, é o Shofuso (solar do pinheiro e do vento), construído em Nova Iorque e depois transferido para Filadélfia, onde está até hoje. TAKASE, Hayahiko (arquiteto e um dos responsáveis pela obra do Pavilhão, em 1954). Em: HARADA, Kiyoshi (coord.). 60 anos de Bunkyo. Passado, Presente e Futuro. São Paulo: Cadaris Comunicação, 2015, p. 147.

${ }^{159}$ Com um acervo de 97.000 itens, “o Museu Histórico da Imigração Japonesa no Brasil é considerado o maior museu sobre a imigração japonesa, dentre aqueles de outros países que tiveram imigração japonesa, como o Peru e os Estados Unidos, sendo até mesmo maior que o do Japão". YAMASHITA, Lidia Reiko, vice-presidente da Comissão do Museu. Em: HARADA, Kiyoshi (coord.). 60 anos de Bunkyo. Passado, Presente e Futuro. São Paulo: Cadaris Comunicação, 2015, p. 163.

${ }_{160}$ Ver em http://www.sp.br.emb-japan.go.jp/pt/not_14_12 japan house_setsumeikai.htm acesso em 03/08/2017.

${ }^{161}$ Ver em http://www.japanhouse.jp/saopaulo/what/index.html acesso em 05/08/2017.

${ }^{162}$ O Bunkyo, entretanto, está de certa forma "representado" por Cláudio Kurita, ex-presidente do Seinen e ex-diretor da entidade, atualmente diretor operacional da Japan House. Ver sua apresentação no IX FIB, no Capítulo 3.
} 
espaço de troca de relatos e de ideias entre as associações e agremiações nipobrasileiras, com o objetivo geral de promover o fortalecimento mútuo para que a missão comum de todas elas - a divulgação da cultura japonesa no Brasil - possa ser cumprida efetivamente. A cada ano a comissão, responsável pela organização do FIB escolhe um tema, que dá origem a várias palestras, exposições, dinâmicas de grupo e apresentações que, no final, vão constituir um aprendizado a ser posto em prática no cotidiano de cada entidade e, com isso, enriquecê-la. O FIB também foi concebido para dar aos jovens a oportunidade de exercer a liderança durante os trabalhos e de ajudar a pensar os caminhos que a comunidade nipo-brasileira deve tomar em médio e longo prazo.

Esse encontro do FIB de 2015 foi especial por três motivos: primeiro, por fazer parte das comemorações do sexagésimo aniversário do Bunkyo; segundo, por participar da celebração dos 120 anos do Tratado de Amizade Brasil-Japão - o que garantiu a presença de várias autoridades, dirigentes e personalidades da população Nikkei mundial -; terceiro, pelo tema inusitado escolhido pela comissão organizadora: "O que é japonesar para você? A cultura nipo-brasileira atual”. A ideia por trás do neologismo "japonesar" era desafiar os participantes a pensar nos possíveis significados do "ser japonês" no Brasil, não como conceito abstrato, mas como forma de vida que incorpora velhas e novas práticas e perspectivas inspiradas pela cultura deixada no país pelos imigrantes japoneses. O uso da palavra "japonesar", uma corruptela de "japonizar" que por sua vez deriva do francês japoniser, na verdade tem pouco a ver com seu significado de dicionário ${ }^{163}$ : segundo os coordenadores do evento, a ideia de "japonesar" era explorar a diversidade da comunidade nipo-brasileira, dando voz a todos que têm algo a dizer sobre um "ser japonês" mais inclusivo, aceitando até mesmo não descendentes que compartilham a "paixão pela cultura japonesa".

\footnotetext{
${ }^{163}$ Dar ou adquirir feição ou características japonesas; niponizar(-se).

Ver em: http://michaelis.uol.com.br/busca?id=7mdyQ_acesso em: 06/08/2017.
} 


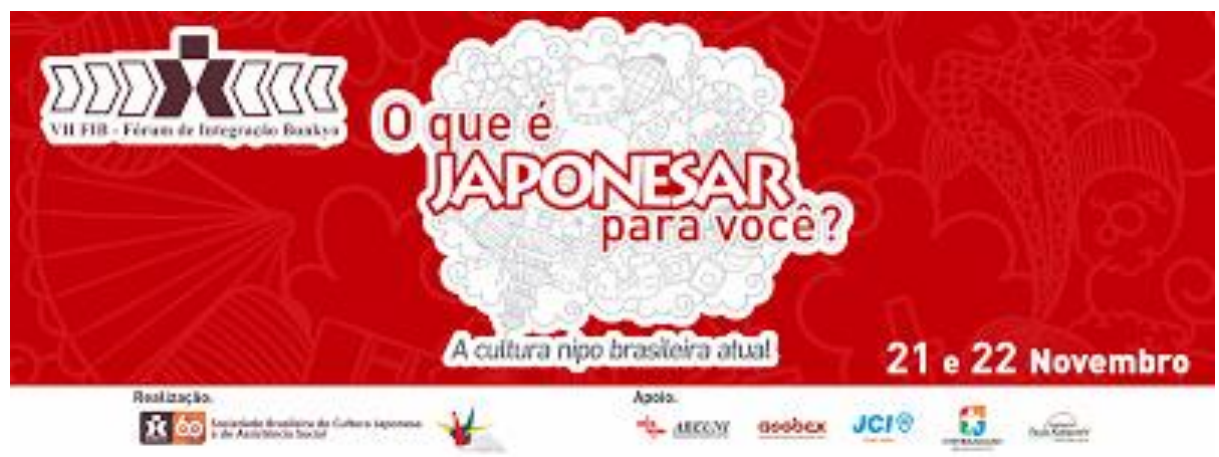

Fig.3 Pôster do VII Fórum de Integração Bunkyo.

Fonte: FIB, Bunkyo.

A busca pelos significados do que vem a ser "japonesar para você" ultrapassou os limites do evento e tem continuado através da Rede FIB, um grupo fechado no Facebook onde seus 213 membros ${ }^{164}$ compartilham mensagens, vídeos, fotos, links, curtidas e comentários sobre fatos, eventos e a questão da identidade nipo-brasileira na atualidade. Na lista dos membros, há a presença de entidades e pessoas físicas, sendo que, do total destas, apenas quinze não têm sobrenome japonês, o que mostra que, apesar da abertura para não descendentes, sua presença ainda é minoritária (cerca de 7\%). Os discursos e reflexões compartilhadas durante o evento se adaptaram às postagens breves e aos múltiplos recursos do Facebook, incluindo agora notícias de membros no Japão, nos Estados Unidos e no Brasil, links para diversos sites sobre aspectos da cultura japonesa, histórias sobre a guerra e os campos de concentração, trocas de notícias pessoais etc. A Rede FIB não tem chefias nem regras para participação, mas um novo participante só entra se for adicionado por um dos membros, o que garante o controle do perfil da comunidade, não por alguns indivíduos, mas pelo grupo. O FIB é tema de uma análise de narrativa no Capítulo 3.

\footnotetext{
${ }^{164}$ Com novas adesões e saídas, o número de membros se altera com o tempo. Esse número constava no site da Rede FIB no dia 07/08/2017.
} 


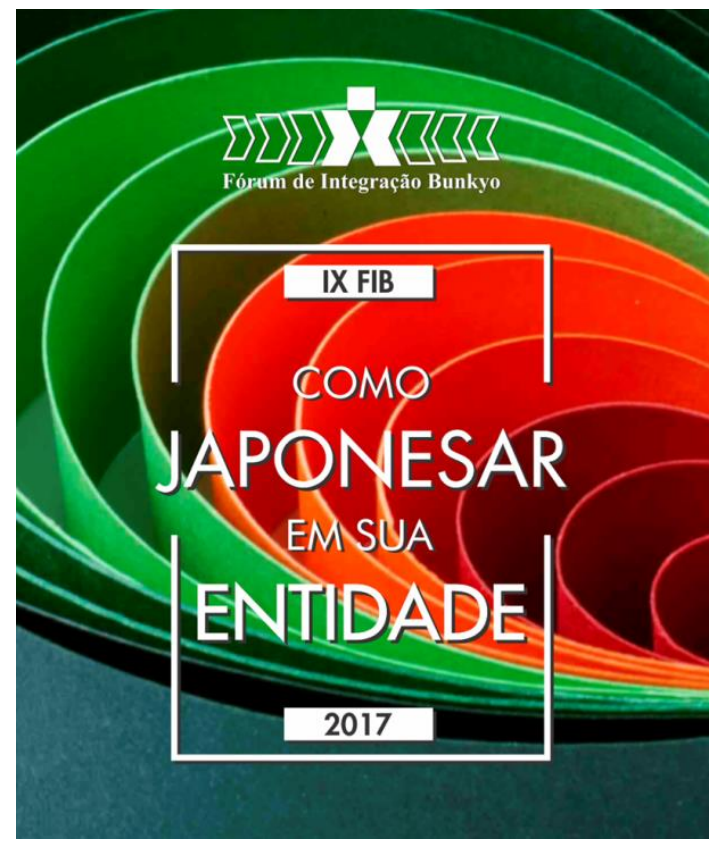

\section{Figura 4: Pôster do IX Fórum de Integração Bunkyo.}

\section{Fonte: Rede FIB}

As energias do Bunkyo, no ano de 2017, foram voltadas para a organização do próximo grande evento da comunidade nipo-brasileira: a comemoração dos 110 anos da imigração japonesa, em 2018. Assumindo seu posto de entidade central da comunidade, o Bunkyo formou a "comissão para comemoração dos 110 anos da imigração japonesa no Brasil", cujo presidente do comitê executivo, Yoshiharu Kikuchi, anunciou que a celebração dos 110 anos será parte do Festival do Japão ${ }^{165}$, “considerado o maior evento da cultura japonesa". Para manter a tradição de todas as grandes celebrações da comunidade iniciada pelo príncipe Mikasa, em 1958, o convidado de honra será um membro da família imperial japonesa, que terá nesse mesmo ano duas outras celebrações importantes sobre a emigração japonesa: o $150^{\circ}$ aniversário da primeira saída de trabalhadores do Japão, para o Havaí, e o centenário da emigração para o Equador.

O foco das apresentações, segundo a agenda de apresentações já definida pela comissão, privilegia a cultura folclórica japonesa, mantida viva no Brasil pelos imigrantes e seus descendentes, como as danças Awaodori e Eisa e os grupos de percussão Taikô. A cultura tradicional será o mote do ano, a começar pela festa do Ano

\footnotetext{
${ }^{165}$ O Festival do Japão é realizado anualmente - geralmente no mês de julho - pelo Kenren (Federação das Associações de Províncias do Japão no Brasil), com participação do Bunkyo e muitas outras entidades nipo-brasileiras, no São Paulo Exhibition \& Convention Center, na Rodovia dos Imigrantes.
} 
Novo (Oshôgatsu), tendo ainda no programa o cerimonial Hatsugama (primeira cerimônia do chá do ano) e a realização do Hatsuike (primeiro ikebana do ano). Para arcar com os custos das celebrações, o Bunkyo criou um "Livro de Ouro" para passar entre as organizações japonesas e nipo-brasileiras ${ }^{166}$. A comemoração do evento fundador da comunidade nipo-brasileira - a chegada da primeira leva de imigrantes japoneses a bordo do Kasato Maru, em 18 de junho de 1908 - será mais uma oportunidade de reflexões e debates sobre as suas reais possibilidades de sobrevivência como segmento integrado, porém distinto da sociedade brasileira.

Esse questionamento foi antecipado de forma bem direta no capítulo final do livro dos 60 anos do Bunkyo, em que o autor, Kiyoshi Harada, afirma que "hoje, no Brasil, não mais cabe falar em futuro da comunidade nikkei pois ela não está mais em construção"167. Assim como a expressão "colônia japonesa" já foi ultrapassada há mais de cinquenta anos, agora a "comunidade nikkei” também está superada, diz o autor. E, se não há mais futuro para a comunidade, que já em si mesma é uma expressão superada, então qual seria a perspectiva de sobrevivência para o Bunkyo, cuja missão é representá-la? O autor propõe uma regressão na história do próprio conceito de "nikkei" para ver se na sua trajetória - ou seja, na redefinição do "quem somos" - algo indica "se é possível projetar um futuro compartilhado" para os descendentes de japoneses no Brasil e, portanto, se há um futuro para a representatividade do Bunkyo.

Ser nikkei, para Harada, não é apenas uma questão de hereditariedade, mas um sentimento, um "sentir-se nikkei”. Mas é também um discurso que muda com o tempo, uma "construção dinâmica" sujeita às mudanças trazidas pelas novas gerações. Para o autor, o primeiro nikkei foi o próprio imigrante japonês, com as mudanças de estilo de vida impostas pela necessidade de adaptação aos costumes do Brasil, mudando de forma definitiva sua identidade japonesa. Harada acredita que o discurso da identidade nikkei mudou de novo - e de forma mais consciente - na geração nissei, que defendia abertamente a integração à sociedade brasileira, contra a vontade dos pais, que tentavam preservar seus laços com a cultura ancestral. Já sem a pressão dos pais, a terceira geração pôde mudar mais livremente o discurso do "ser nikkei", mantendo os laços com

\footnotetext{
166 Ver: http://www.Bunkyo.org.br/pt-BR/noticias/157-2017/1232-os-preparativos-aos-110-anos-daimigracao-japonesa-em-2018, acesso em 7/08/2017.

${ }^{167}$ HARADA, Kiyoshi, presidente do conselho deliberativo do Bunkyo (período 2011/2014). "O futuro do Bunkyo". Em: HARADA, Kiyoshi (coord.). 60 anos de Bunkyo. Passado, Presente e Futuro. São Paulo: Cadaris Comunicação, 2015, p. 323.
} 
a cultura japonesa do seu próprio jeito, e assim por diante, cada nova geração se apropriando da cultura dos ancestrais a partir de suas renovadas visões de mundo.

Com a integração irreversível dos nikkeis na sociedade brasileira e também com a miscigenação - quando até mesmo os traços fisionômicos das pessoas de origem japonesa tendem a se diluir e, por fim, a desaparecer -, não há mais como imaginar uma comunidade nikkei como "um núcleo étnico, com espaço próprio", diz o autor. Para Harada, somente a sociedade brasileira, como um todo, deverá evoluir, e, com ela, todos os segmentos sociais que a compõem, inclusive os nikkeis. A inclusão dos traços culturais japoneses na grande matriz brasileira, vasta e multicultural, é provavelmente o caminho da sobrevivência da contribuição do imigrante e de seus descendentes, segundo o autor. Ele cita a festa do centenário da imigração japonesa como um exemplo da integração efetiva das duas culturas, já que o público brasileiro participou ativamente da festa, demonstrando assim sua familiaridade e apreciação da cultura japonesa no Brasil, sentindo-a como sua também. Diante desse quadro de mudanças permanentes, o autor defende a ideia de que a palavra "nikkei" seja trocada pela expressão "nipo-brasileira", que, para ele, reflete muito mais a realidade atual, de apropriação da cultura de origem japonesa por todos os brasileiros, descendentes de imigrantes ou não.

Quanto ao Bunkyo, Harada vê grande potencial de sobrevivência no longo prazo por causa uma de suas características principais, que outras entidades não teriam: uma atuação permanente e simultânea em uma grande variedade de áreas. Dessa forma, por oferecer continuamente programas e serviços muito diferentes entre si, o Bunkyo consegue atender às expectativas de um público diverso e mutante, que seria, para o autor, o traço fundamental da "moderna sociedade nipo-brasileira". O outro motivo a favor do Bunkyo seria sua missão institucional de incentivar o intercâmbio social e cultural entre o Brasil e o Japão, com o objetivo de contribuir para o fortalecimento dos laços de amizade entre os dois países. Como o interesse de ambas as nações pelas oportunidades de intercâmbio não tem perspectiva de diminuição, pelo contrário, o Bunkyo teria garantida mais uma de suas razões de ser. Ou seja, somente o "rompimento dessa amizade entre o Brasil e o Japão" poderia ameaçar o futuro do Bunkyo, o que, pelo que tudo indica até o momento, não parece estar em cogitação para nenhuma das partes envolvidas. 
Os pontos principais da reflexão de Harada, jurista de prestígio e um dos protagonistas da história do Bunkyo, são endossados por outro personagem, também da direção da entidade, Jorge Yamashita ${ }^{168}$, que cita outra figura de destaque, Susumu Miyao, que desde 1998 já falava em um "anacronismo" dessa discussão ${ }^{169}$. Tudo isso indica que a questão do futuro da comunidade nipo-brasileira, ou nikkei, é um tema que preocupa a presente geração, que daqui a poucos anos estará se aposentando e deixando para os mais jovens as decisões que definirão os rumos da entidade. Quanto aos dois termos, nikkei e nipo-brasileiro, que têm sido usados indistintamente, na verdade têm uma diferença nada insignificante: enquanto o nipo-brasileiro refere-se apenas ao brasileiro de origem japonesa, o nikkei é um termo bem mais amplo, que unifica todos os descendentes da diáspora japonesa pelo mundo.

Os jovens do Bunkyo têm se envolvido nos eventos da Associação Panamericana Nikkei (APN), que a cada dois anos promove a Convenção Pan-americana Nikkei (COPANI) ${ }^{170}$. No FIB de 2015, o tema de um dos painéis abordava a questão da militância nikkei: "por que é importante o Brasil ser atuante no panorama Nikkei global?”. Essa abordagem defende implicitamente a existência de uma característica comum a todos os descendentes de japoneses pelo mundo, independentemente de seus países de origem e de suas histórias de vida. A construção desses novos "discursos" do "sentir-se nikkei”, como diz Harada, na busca pelas definições do que vem a ser esse patrimônio distinto dos imigrantes e a presença dele nos modos de ser dos seus descendentes, é o que alimenta a narrativa da imigração japonesa e de seu legado no Brasil e no mundo, cujos desdobramentos em diferentes histórias são compartilhados entre muitos espaços - no IX FIB, que é assunto, conforme mencionado, do Capítulo 3.

\footnotetext{
168 Jorge Yamashita é, atualmente (2017), presidente do Conselho Deliberativo do Bunkyo. O texto em que endossa a reflexão de Harada está em: YAMASHITA, J. "O Bunkyo como entidade central da comunidade nipo-brasileira”. Em: HARADA, Kiyoshi (coord.). 60 anos de Bunkyo. Passado, Presente e Futuro. São Paulo: Cadaris Comunicação, 2015, p. 315.

${ }^{169}$ Susumu Miyao (já citado no capítulo anterior) publicou o texto mencionado por Yamashita no jornal Nikkei Shimbun, edição de 29 de agosto de 1998. Ver em: YAMASHITA, J. "O Bunkyo como entidade central da comunidade nipo-brasileira". Em: HARADA, Kiyoshi (coord.). 60 anos de Bunkyo. Passado, Presente e Futuro. São Paulo: Cadaris Comunicação, 2015, p. 314.

170 Ver matéria que relata o evento de 2015, com participação do Seinen Bunkyo, em: http://www.Bunkyo.org.br/pt-BR/noticias/149-2015/805-copani-2015-a-participacao-dos-jovensbrasileiros-no-evento, acesso em 08/08/2017.
} 


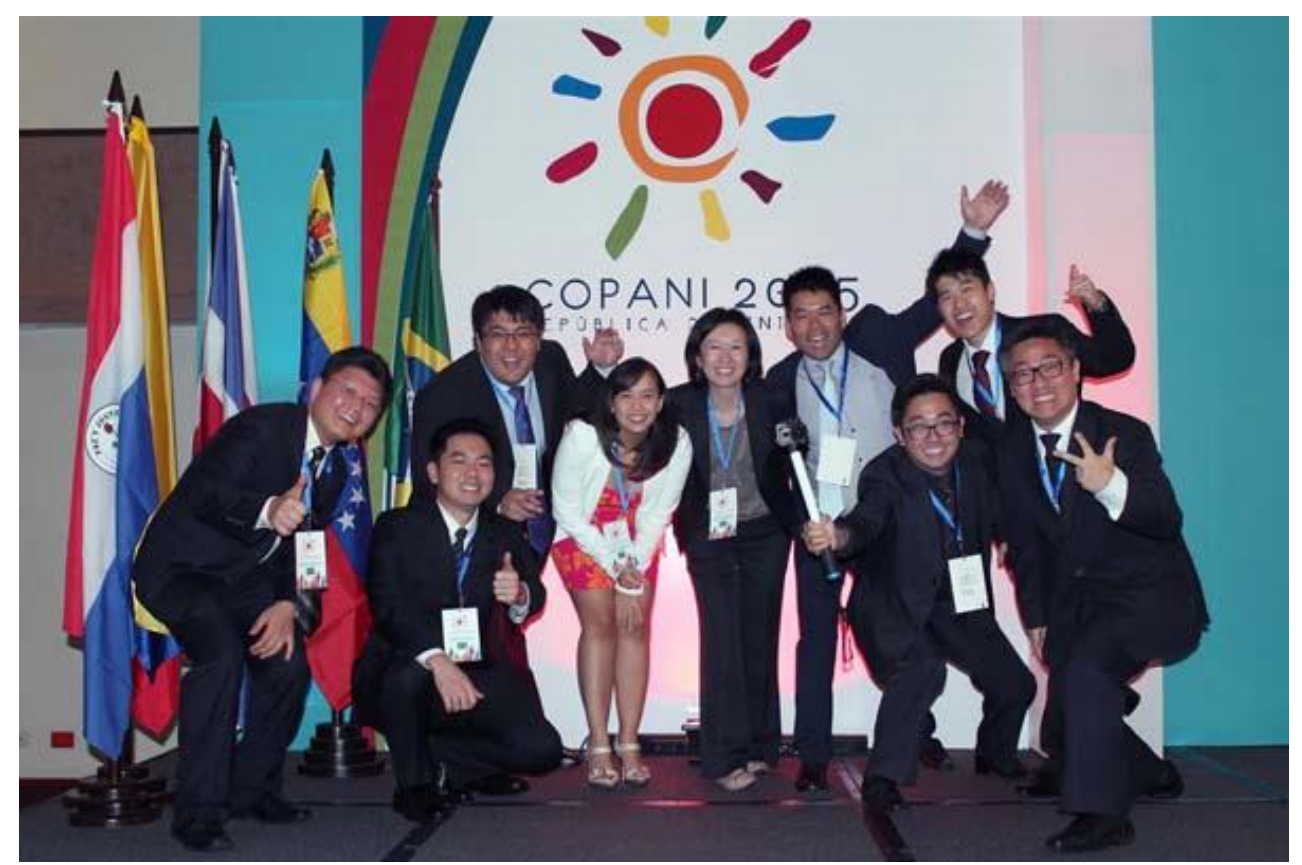

Foto 10: Copani 2015, República Dominicana.

Fonte: Bunkyo.

\section{Estrutura e funcionamento da entidade}

\subsection{Localização e instalações}

O edifício-sede do Bunkyo está localizado na rua São Joaquim, 381, esquina com Galvão Bueno, no bairro da Liberdade, cidade de São Paulo. A aparência comum do prédio de nove andares não revela sua origem nobre: o fato de que sua pedra fundamental foi lançada pelas mãos de um verdadeiro príncipe ${ }^{171}$, o primeiro de vários membros da família imperial japonesa que haveriam de pisar nesse mesmo edifício pelas décadas que se seguiram. O edifício foi inaugurado com quatro andares em 1963, aos quais foram acrescidos mais cinco, completando os nove andares atuais, em uma área total de 17 mil metros quadrados. Logo à entrada do edifício principal, há uma escadaria que dá acesso a um amplo saguão - onde são montados bazares e exposições e acontecem algumas solenidades -, e logo em seguida há o grande auditório, com capacidade para 1.300 pessoas.

\footnotetext{
${ }^{171}$ Referência ao príncipe Mikasa, irmão do imperador Hiroito, que lançou a pedra fundamental do Bunkyo, em 1958.
} 


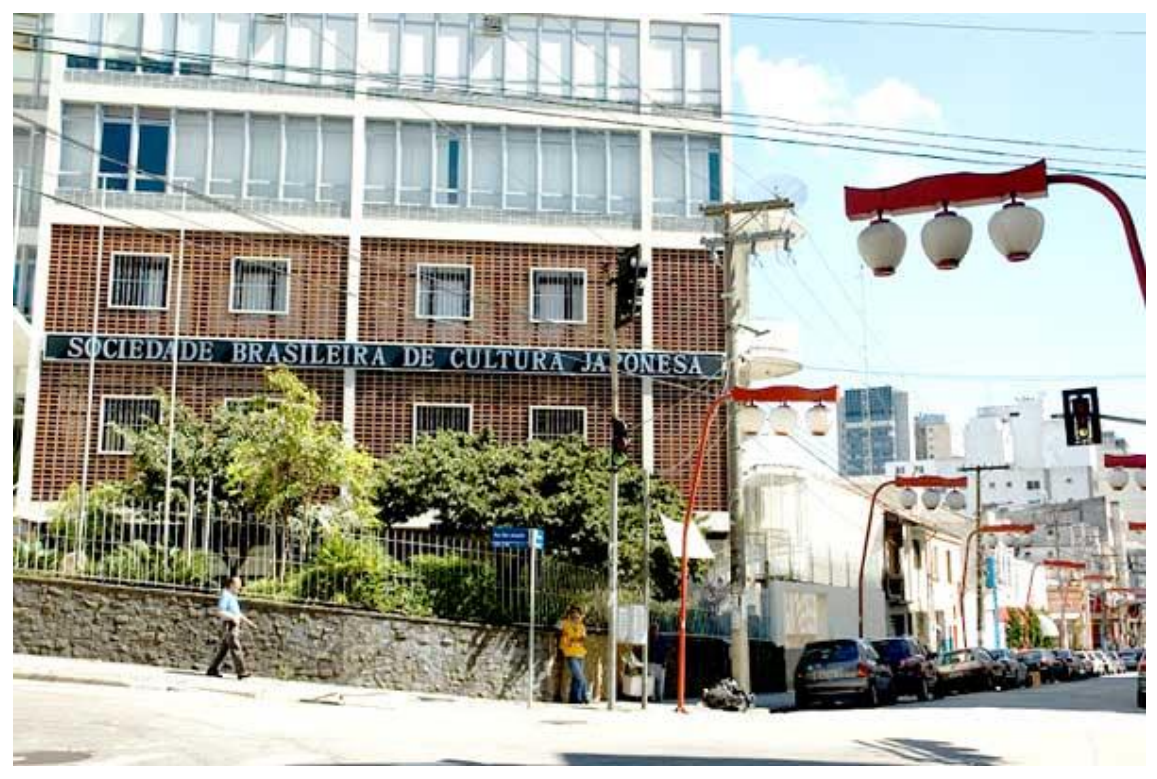

Foto 11: Edifício-sede do Bunkyo.

Fonte: Bunkyo.

Por um corredor lateral, tem-se acesso aos elevadores e escadarias que levam ao salão nobre, a duas salas de exposição, a salas de reunião e a diversas salas de trabalho, e às dependências do Museu Histórico da Imigração Japonesa, que ocupam o sétimo, oitavo e nono andares, além da área da reserva técnica do museu, no terceiro andar, e do Museu de Arte Nipo-Brasileiro, que fica no primeiro andar. Outras doze entidades (todas ligadas ao mundo nipo-brasileiro) alugam espaços no prédio, como é o caso, por exemplo, do CIATE, que fica no primeiro andar, do Centro de Cerimônia do Chá Urasenke do Brasil, no quarto, e da Aliança Brasil-Japão, no sexto. Em 1988 foi construído o prédio anexo, com ginásio esportivo, auditório de 180 lugares, biblioteca com 60 mil volumes (parte deles já digitalizados), espaço multiuso e estacionamento. Um jardim zen, situado do lado direito da entrada principal do edifício, é o único elemento do conjunto, visto pelo lado de fora, que dá um ar japonês à construção.

Além de seu próprio edifício-sede, o Bunkyo também possui uma grande área na zona rural de São Roque, município localizado a pouco mais de 50 quilômetros de São Paulo, onde foi construído o Centro Esportivo Kokushikan Daigaku. A área de 23 alqueires foi doada ao Bunkyo em 1997 pela universidade japonesa Kokushikan, que já mantinha ali uma escola de artes marciais. Além de um grande centro esportivo, a área tem um campo de mallet golf, quadras de tênis e cerca de 400 mil pés de cerejeiras. O evento mais importante do Kokushikan é o Sakura Matsuri (Festival das Cerejeiras), que ocorre anualmente no mês de julho, e que foi incorporado ao calendário oficial do 
município de São Roque. Além do festival, o Kokushikan também recebe anualmente o Fórum Nacional dos Jovens Líderes das Entidades, também conhecido por REVI, dedicado a discussões e trocas de ideias que buscam a revitalização das entidades nipobrasileiras. Como muitos associados e dirigentes reclamavam que a área era subaproveitada, foi criado em 2011 o Centro de Cultura Nipo-brasileira BunkyoKokushikan, com o objetivo de agilizar a ocupação do espaço e a sustentabilidade do local $^{172}$.

O Bunkyo também é responsável pela administração, manutenção e promoção de eventos do Pavilhão Japonês, localizado no Parque Ibirapuera. Construído em 1954 como parte das festividades do IV Centenário da cidade de São Paulo, o Pavilhão veio desmontado do Japão e foi remontado no Brasil por técnicos japoneses auxiliados por voluntários da comunidade nipo-brasileira. Além das estruturas de madeira da construção, os demais materiais utilizados no restante do complexo do Pavilhão, como as pedras vulcânicas do jardim e uma lama especial de Quioto, também vieram do Japão. O projeto do Pavilhão teve como referência o Palácio Katsura, construído no século XVII e que foi residência de verão da família imperial japonesa, em Quioto. O Pavilhão é composto por um salão nobre, com salas anexas e uma para exposições, sendo circundado pelo jardim e um lago de carpas, no estilo tradicional japonês.

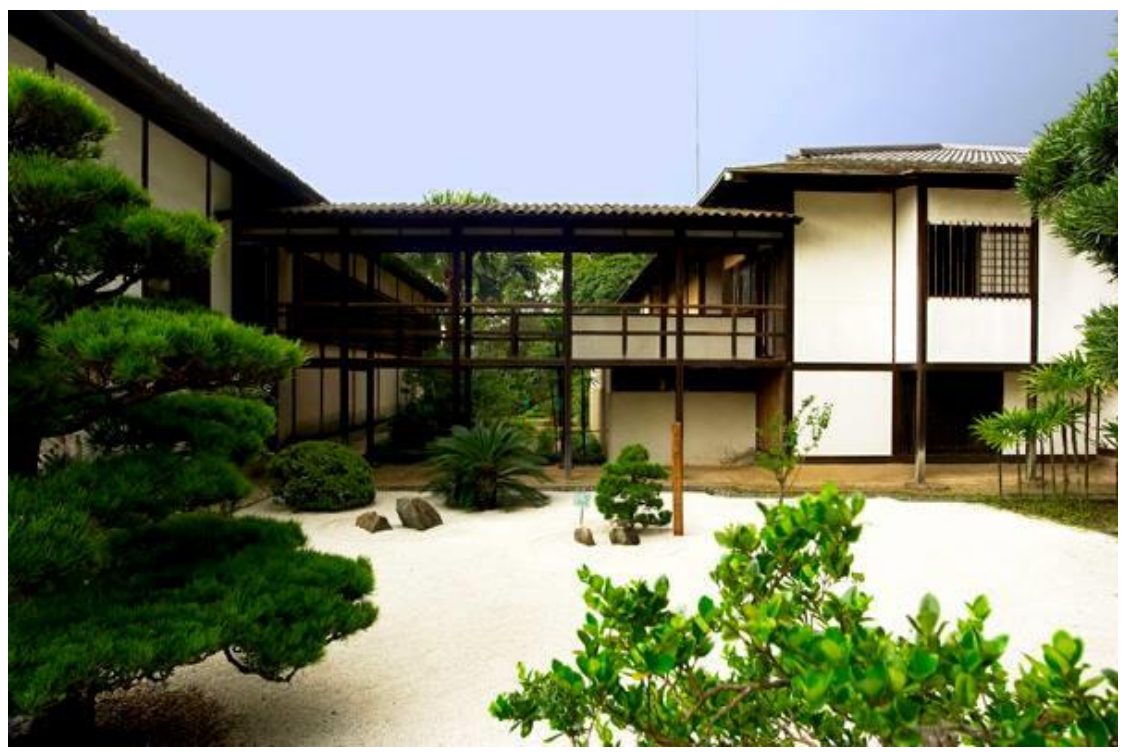

Foto 12: Pavilhão Japonês.

Fonte: Bunkyo.

\footnotetext{
${ }^{172}$ Ver em BUNKYO - Sociedade Brasileira de Cultura Japonesa e de Assistência Social. Bunkyo: 60 anos. Sua trajetória. São Paulo, 2015, p. 20.
} 
O Pavilhão é um dos principais "lugares de memória" da comunidade nipobrasileira, não só por ser um pedaço do Japão transplantado no Brasil, mas por ser um ponto de referência de vários tipos de eventos e celebrações que remetem ao universo nipônico, como, por exemplo, a vigília em homenagem às vítimas da bomba atômica em Hiroshima e Nagasaki, realizada no dia 6 de agosto de 2017. A visita do príncipe Akishino e de sua esposa Kiko, em 2015, também começou no Pavilhão Japonês e no Memorial aos Imigrantes Pioneiros, também no Parque Ibirapuera, em mais uma demonstração de que o Pavilhão é local de recordação e reconhecimento do legado dos japoneses no Brasil.

Várias outras personagens importantes passaram pelo Pavilhão como forma solene de homenagear a memória dos imigrantes, como foi o caso do primeiro-ministro Shinzo Abe, em 2014, e de seu avô, Nobusuke Kishi, que visitou o Pavilhão em 1959 também na condição de primeiro-ministro. Exposições de ikebana, de bonsai e das diversas formas de arte tradicional do Japão, além de concertos de música japonesa, fazem parte do programa regular do Pavilhão, que fica aberto ao público nas quartasfeiras, fins de semana e feriados, das 10 às 12 horas e das 13 às 17 horas.

Inaugurado em 1978, como parte das comemorações dos 70 anos da imigração, o Museu Histórico da Imigração Japonesa é mais um dos "lugares de memória" administrados pelo Bunkyo, sendo, talvez, o mais importante deles, por ter sido construído justamente com a intenção de "registrar e preservar tudo o que pudesse contar a vida dos imigrantes japoneses no Brasil" ${ }^{, 173}$. A importância do museu - e do que ele representa - foi reconhecida pelos governos do Japão e do Brasil, como se pode deduzir da presença do príncipe herdeiro Akihito (hoje imperador do Japão) e do então presidente brasileiro, general Ernesto Geisel, na inauguração. O acervo do museu está distribuído por três andares (sétimo, oitavo e nono) do prédio do Bunkyo, em uma área total de 1.592 metros quadrados.

\footnotetext{
${ }^{173}$ Ver em http://www.Bunkyo.org.br/pt-BR/museu-historico-da-imigracao-japonesa-no-brasil, acesso em
} 14/08/2017. 


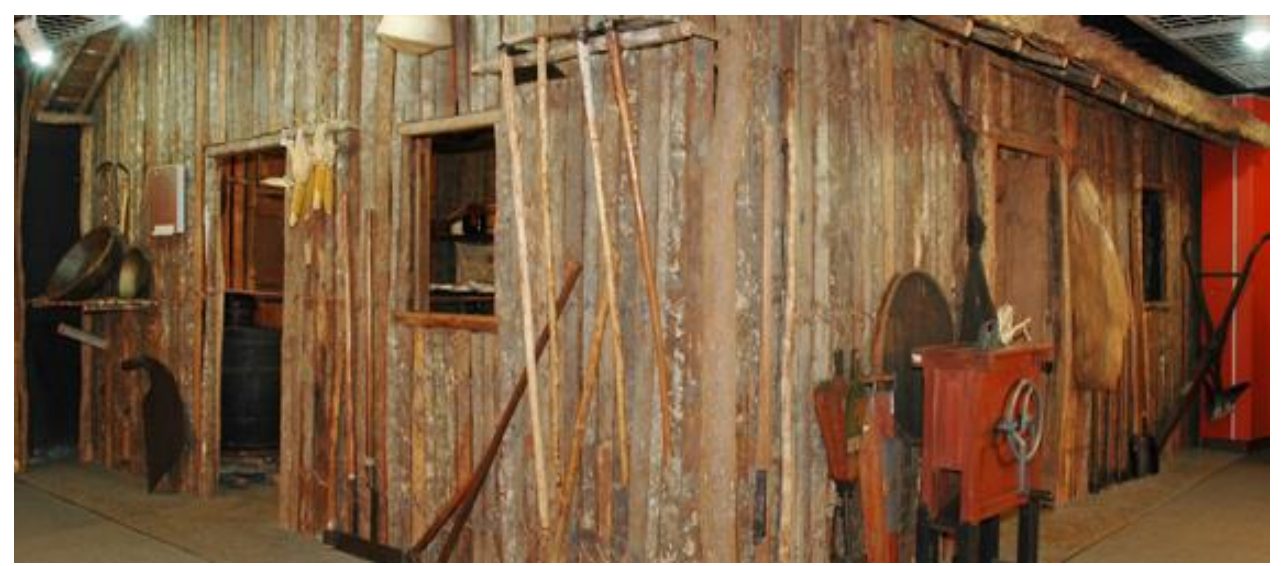

Foto 13: Cabana do imigrante pioneiro.

Fonte: Museu Histórico da Imigração Japonesa

Nos dois primeiros andares estão reunidos documentos, fotografias e objetos que contam a história da imigração desde a chegada do navio Kasato Maru, em 1908, até a vida nas colônias e suas atividades produtivas. As instalações do nono andar focalizam as transformações vividas pelos imigrantes e seus descendentes no Brasil desde o pósguerra até os dias de hoje. Finalmente, no terceiro andar está localizada a reserva técnica do museu, que inclui biblioteca, objetos, fotografias, diários, revistas, livros e jornais, todos relacionados ou pertencentes aos imigrantes japoneses. Em 2012 foi lançado o site específico do museu ${ }^{174}$, onde se pode acessar, entre outras coisas, o banco de dados sobre os navios e a lista de passageiros que vieram do Japão ao Brasil nos anos da imigração, e também o link para o site "100 anos de histórias", doado no Centenário da Imigração pela Editora Abril. O museu está aberto à visitação de terça-feira a domingo, das 13 h30 às 17 horas.

\subsection{Organização administrativa}

O Bunkyo é regido por um estatuto social, cujo texto em vigor foi assinado em 2006. Atualmente há discussões para novas alterações no seu texto, apresentadas em 2015, estando ambas versões - a atual e a que contém a "reforma parcial" do estatuto à disposição para consulta no site da entidade ${ }^{175}$. As alterações foram propostas por uma

\footnotetext{
${ }^{174}$ Ver http://www.museuBunkyo.org.br/, acesso em 14/08/2017.

${ }^{175}$ Ver em: http://www.Bunkyo.org.br/pt-BR/quem-somos/estatuto-social/149-noticias/2015/814-reformaparcial-do-estatuto-do-Bunkyo, acesso em 15/08/2017.
} 
comissão especial, criada pelo Conselho Deliberativo, com o objetivo de "consultar os associados quanto ao regime de eleição direta ou indireta para que possamos melhor identificar a causa do crescente desinteresse do quadro social nos últimos anos"176. Além da eleição direta, a nova proposta ainda sugere mudanças na duração do mandato (de dois para três anos) e o fim da reeleição. Conforme mencionado anteriormente, o Bunkyo teve uma única eleição direta para diretoria, em 2005, em obediência a uma mudança no código civil brasileiro, que foi depois revogado, sendo que essa eleição foi muito disputada. No texto de 2015 que apresenta novamente a reforma, houve uma ponderação de que a situação de 2005 pode ter sido atípica, já que em breve seria formada a comissão de planejamento do centenário da imigração, o que teria atraído o interesse de muitos associados. Ou seja, o retorno às eleições diretas, por si só, talvez "não reconquiste o interesse dos associados na escolha de seus dirigentes" $" 177$.

Um outro ponto levantado pela comissão de reforma ecoa preocupações similares às dos estudos de renovação de 2003: "promover atividades de interesse específico dos jovens e incentivar a adesão ao quadro social do maior número de pessoas que tenham afinidade com a cultura japonesa, independentemente de sua origem étnica"178. A Comissão de Jovens foi fundada em 1997, o que significa que há pelo menos vinte anos os jovens já têm espaço institucional no Bunkyo, e também o estatuto social não impede a associação de pessoas sem ascendência japonesa, muito menos sua participação nos eventos da entidade. A menção específica da proposta do novo estatuto a esses dois pontos sugere que, apesar das iniciativas já tomadas, permanece a percepção de que são estes dois públicos - os jovens e os não descendentes - que estão se afastando (ou não se aproximando em números significativos) do Bunkyo.

O Bunkyo foi fundado em 1955, mas a sua data de registro é de 1963, quando se tornou legalmente uma "associação de fins não econômicos, de atuação em âmbito nacional, constituída por número ilimitado de associados - pessoas físicas e jurídicas sem distinção de nacionalidade, religião, raça ou condição social" ${ }^{179}$. A manutenção da entidade é garantida pelas contribuições dos associados (empresas e pessoas físicas), doações, subvenções e aluguel das salas e demais espaços da sua sede. Embora tenha

\footnotetext{
${ }^{176}$ Idem.

177 Idem

178 Idem.

${ }^{179}$ Ver o "Estatuto social" em: http://www.Bunkyo.org.br/pt-BR/quem-somos/estatuto-social.
} 
um quadro de funcionários fixos para o trabalho administrativo e de manutenção, a direção da entidade e a organização dos eventos e solenidades são atribuições de associados-voluntários eleitos ou nomeados para cargos de diretoria, em conselhos e comissões temáticas. Embora a estrutura principal do Bunkyo esteja em São Paulo, a entidade mantém 30 representações regionais com o objetivo de atingir a comunidade nipo-brasileira que reside em outras partes do país.

O estatuto social do Bunkyo define as normas para a composição do corpo de associados e da direção, e a descrição de cada função. São considerados "órgãos sociais" da entidade: a assembleia geral (composta pelos associados, que elegem os membros do conselho deliberativo), o conselho deliberativo (que elege a diretoria e tem poder de decisão em circunstâncias de interesse da entidade), a diretoria (que exerce as funções de direção) e o conselho fiscal (que cuida da parte financeira da entidade). Há também dois outros conselhos: o consultivo (que é órgão superior de consulta direta do presidente) e o conselho superior de apoio e orientação (consultado pela diretoria, como forma de apoio institucional). Qualquer pessoa que queira fazer parte do corpo de associados do Bunkyo pode se inscrever, desde que seja indicado por alguém que já seja sócio. Os associados que queiram se candidatar ao conselho deliberativo podem fazê-lo desde que sejam sócios há pelo menos três anos e indicados por pelo menos cinco associados. O conselho deliberativo é formado por 100 membros e 50 suplentes, com mandato de quatro anos, podendo ser reeleitos.

Os dirigentes do Bunkyo, ou seja, o presidente, três vice-presidentes e três secretários, têm mandato de dois anos, sendo reelegíveis por duas vezes no máximo. Os demais diretores, com função administrativa, também têm mandato de dois anos, podendo ser reeleitos por duas vezes consecutivas no mesmo cargo. As diretorias se dividem por temas: Cultural, Social, de Comunicação, de Esportes, de Assistência Social e de Planejamento, além de cinco outros diretores sem área específica. $\mathrm{O}$ Conselho Consultivo, nomeado pela Diretoria, é composto por um número ilimitado de membros. A maneira de organizar as atividades de modo a manter o foco em uma variedade ampla de iniciativas - que é uma das características do Bunkyo - se dá por meio de comissões, que se responsabilizam pelo planejamento e execução dos eventos permanentes e temporários da entidade, da administração das suas unidades externas e internas, do patrimônio da entidade etc. 


\subsection{As comissões e a missão do Bunkyo}

Atualmente o Bunkyo tem 29 comissões permanentes, sendo que, eventualmente, a diretoria pode criar comissões especiais com alguma tarefa ou missão temporária, como é o caso da Comissão de Reforma do Estatuto, criada em 2015. Cada comissão tem um presidente, um vice-presidente (ou mais) e um número variado de membros. No final de cada ano, as comissões encaminham ao Conselho Deliberativo do Bunkyo seu planejamento para o ano seguinte. Embora todas as comissões sejam peças fundamentais na engrenagem do Bunkyo, cito a seguir alguns exemplos de comissões e suas atividades planejadas para o ano de 2017 que revelam o tipo de ação desenvolvida pelo Bunkyo para cumprir - da maneira que considera adequada - sua missão de representar a comunidade nipo-brasileira e de preservar o legado dos imigrantes japoneses no Brasil.

A comissão de administração geral e eventos acumula funções diversas de grande significado cultural e institucional. Embora cada uma das unidades mantidas pelo Bunkyo, externas (Pavilhão Japonês e Centro Kokushikan) e internas (o museu e o edifício-sede em si), tenha suas próprias comissões específicas, a comissão de administração geral e eventos tem como primeira função da lista "dar suporte" a todas elas. Essa comissão, portanto, proporciona o elo entre os espaços do Bunkyo, externos e internos, dando a eles uma unidade: por mais isolados que de fato estejam quanto ao espaço geográfico, possuem uma continuidade no ponto de vista do espaço institucional e discursivo do Bunkyo. Graças a este e a outros mecanismos de integração entre os seus espaços, a instituição Bunkyo pode exercer a sua função de "lugar de memória" e de ponto de referência da comunidade nipo-brasileira, pois em cada um deles acontecimentos diferentes se realizam, durante praticamente todos os meses do ano, evocando e atendendo aspectos diversos da lembrança do passado (a imigração e o percurso dos seus descendentes), das necessidades do presente (lazer, estudos, arte, pesquisa, trabalho, esportes e socialização) e dos planos de futuro (integração das associações, formação de novas lideranças e projetos de continuidade). 
Duas das cerimônias mais tradicionais mantidas pelo Bunkyo, de ligação com o Japão, também são de responsabilidade dessa comissão de administração geral e eventos: o Ano Novo e o aniversário do imperador. A cerimônia do Ano Novo, ou Oshôgatsu, é realizada geralmente no dia primeiro de janeiro, com a reunião das lideranças do Bunkyo, de várias outras entidades nipo-brasileiras e de autoridades japonesas, como o cônsul-geral do Japão. Embora seja uma alusão a um aspecto cultural valorizado há séculos no Japão, a cerimônia de Ano Novo do Bunkyo é um exemplo do que Hobsbawm (1992) chama de "tradições inventadas", não no sentido de criação falsa, mas por ser uma mistura de elementos antigos (como o oferecimento de refeições que trazem sorte ao novo ano, como a sopa ozôni e o bolinho de arroz moti) e novos, que refletem a adaptação dos imigrantes japoneses e seus descendentes à nova terra, e depois também ao meio urbano e às mudanças culturais.

Já o aniversário do imperador, comemorado em dezembro, é uma tradição também inventada, no sentido de Hobsbawm, que mobiliza os mais velhos da comunidade e as autoridades japonesas presentes na cidade. Além dos discursos e votos de vida longa ao imperador, o ritual inclui a entoação de todos do tradicional Banzai! (que nessa circunstância significa "Viva!") ${ }^{180}$, e o brinde de saquê com a aclamação de Kampai! (saúde!) diante dos retratos do imperador e da imperatriz. Para completar a construção do ambiente festivo à japonesa, a comemoração geralmente inclui canções tradicionais pelo Coral do Bunkyo e, por fim, um coquetel com iguarias da gastronomia japonesa. Estas duas cerimônias - o Ano Novo e o aniversário do imperador -, que reúnem as personalidades mais importantes da comunidade nipo-brasileira, renovam os laços com o Japão e a centralidade do Bunkyo como o espaço onde essa renovação se realiza.

180 "Banzai", em japonês, significa "dez mil anos", sendo que a expressão completa, "Tenno Heika Banzai", é usada no sentido de "longa vida ao imperador". Durante a Segunda Guerra, a expressão passou a ter uma conotação nacionalista, muitas vezes associada ao momento em que os aviadores suicidas (os kamikaze) arremessavam seus aviões contra alvos inimigos. 


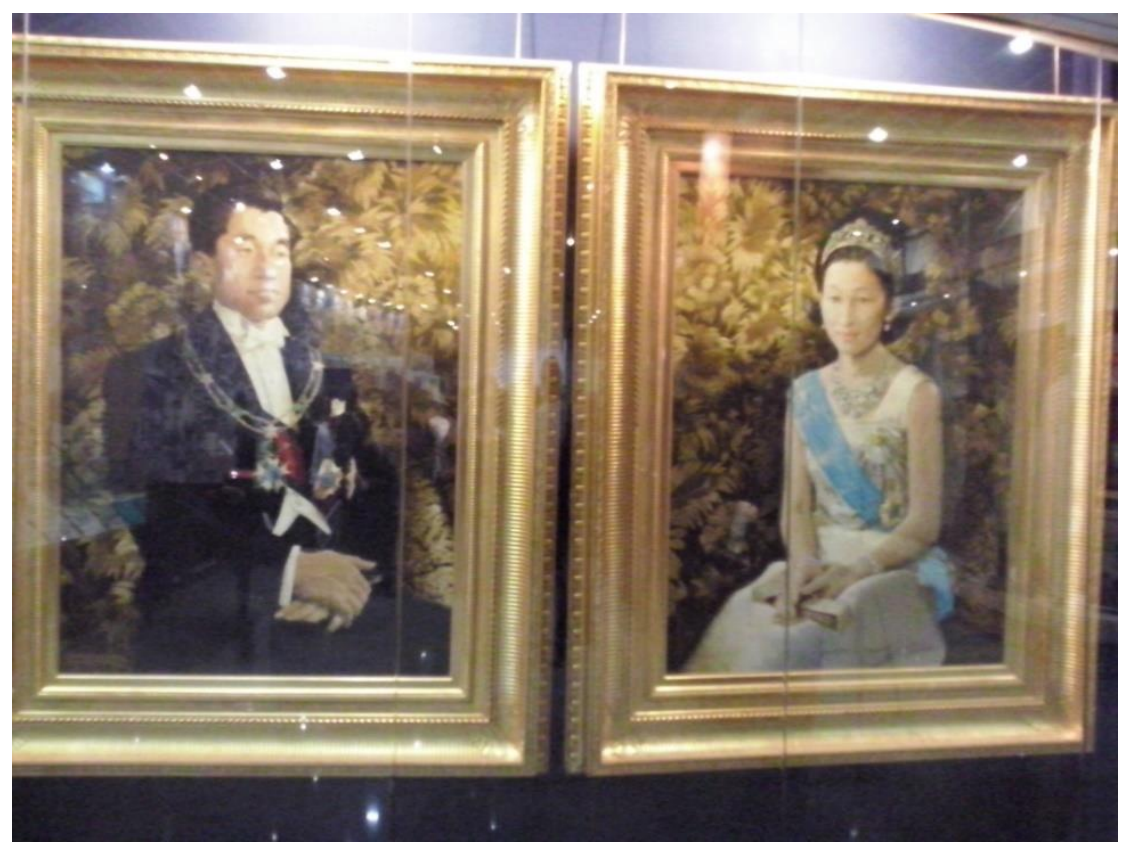

Foto 14: Retratos do Imperador Akihito e sua esposa, Imperatriz Michiko, no 9o andar do Museu Histórico da Imigração Japonesa, no Bunkyo. Fonte: fotografia da autora.

Outros elementos de grande significado para a preservação do legado da cultura japonesa no Brasil são de responsabilidade da comissão de administração geral e eventos, como o Hakujusha Hyôshô (homenagem aos imigrantes pioneiros com 99 anos de idade ou mais), as recepções de boas-vindas e de despedida das autoridades japonesas de partida ou chegando ao Brasil e o apoio ao prêmio concedido aos autores de haiku (poema tradicional japonês). A homenagem aos pioneiros idosos é a celebração do legado humano da imigração, um elo vivo com o passado da comunidade nipo-brasileira, que aliás tem sido objeto de um projeto de levantamento de história oral pelo museu do Bunkyo, como será descrito mais à frente. Em 2017, foram homenageadas 36 pessoas no Hakujusha, que receberam prêmios e diplomas em uma festa de confraternização na presença de lideranças da entidade, autoridades japonesas e seus familiares.

As recepções de boas-vindas e de despedida das autoridades japonesas são eventos de significado crucial na consolidação do Bunkyo como interlocutor do Japão no Brasil. A legitimidade do Bunkyo como entidade representativa da comunidade nipobrasileira resulta em boa medida dessa confirmação proporcionada pelo governo japonês e suas agências, como é o caso da JICA (Japan International Cooperation 
Agency), que subsidia projetos do Bunkyo elaborados por essa comissão de administração geral e eventos. Em junho de 2017, o Bunkyo organizou e sediou a despedida do cônsul Takahiro Nakamae, que permaneceu dois anos em São Paulo e prestigiou muitos dos eventos do Bunkyo.

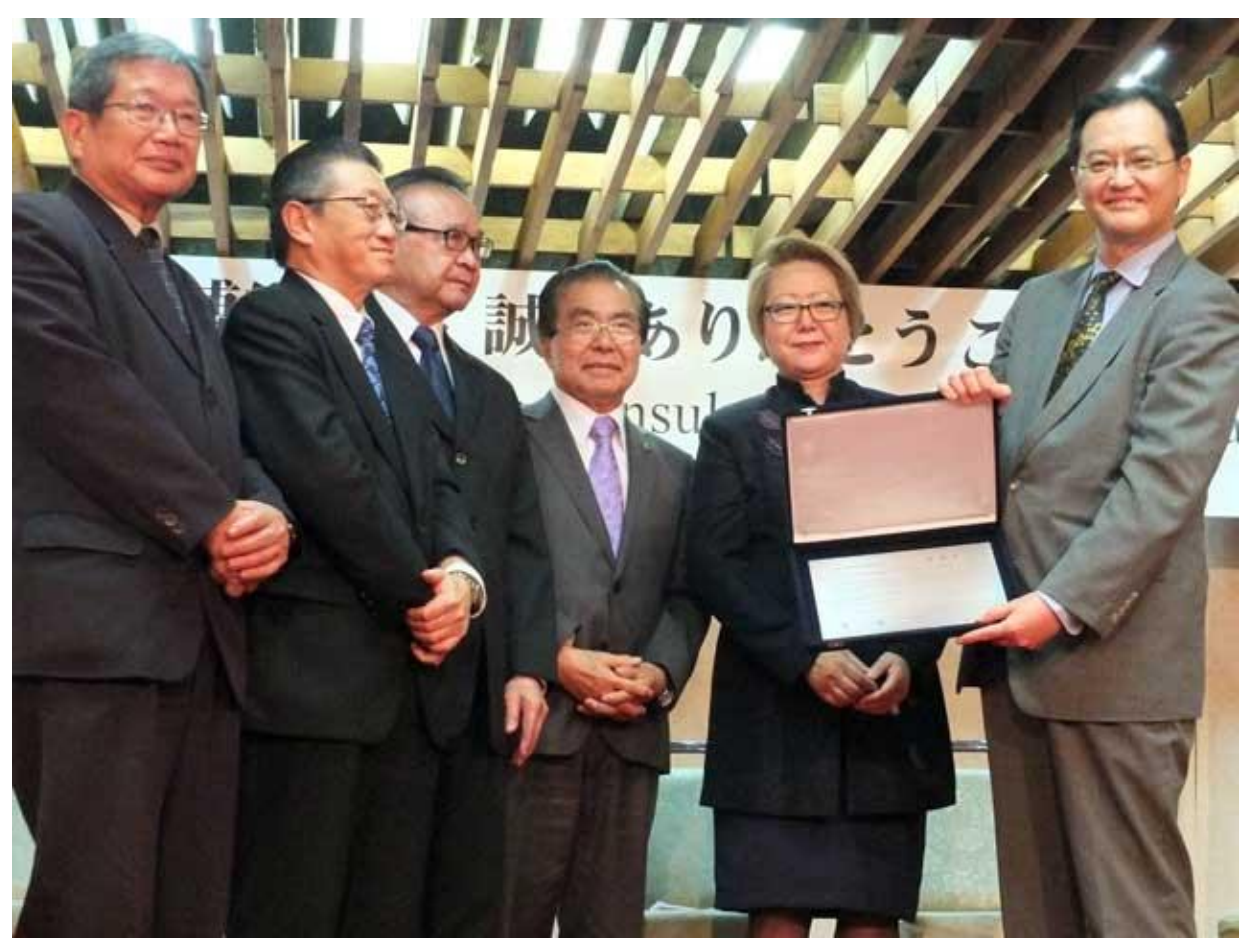

Foto 15: Takahiro Nakamae (à direita), na sua cerimônia de despedida no Bunkyo, ao lado da presidente da entidade, Harumi Goya. Fonte: fotografia de Aldo Shiguti, Jornal Nippak.

Em agosto, a entidade recebeu em seu salão nobre o novo embaixador do Japão, Akira Yamada, que veio receber as boas-vindas das associações nipo-brasileiras antes de seguir para Brasília. Além da reafirmação dos elos do Bunkyo com o governo japonês, as boas-vindas ao embaixador foram uma oportunidade de renovação dos laços entre a entidade e os demais membros da comunidade nipo-brasileira, já que 33 entidades participaram da homenagem.

A comissão de administração do Pavilhão Japonês tem atribuições igualmente cruciais quanto à manutenção e ao avanço da imagem institucional do Bunkyo como entidade central da comunidade nipo-brasileira e mantenedora do seu legado. Considerado um monumento de representação da amizade Brasil-Japão e "símbolo da 
gratidão do povo japonês" ${ }^{181}$, desde a sua construção na circunstância especialmente simbólica do IV Centenário, o Pavilhão é até hoje um ponto de referência dos valores tradicionais da cultura japonesa, conforme já mencionado anteriormente nesta tese. A comissão do Pavilhão, portanto, tem a missão de preservar sua estrutura e jardim - além do lago de carpas coloridas (nishiki-goi) - a partir de premissas arquitetônicas e paisagísticas superespecializadas, o que demanda uma ligação permanente com o Japão, por meio da assessoria de técnicos japoneses.

Também faz parte do planejamento da comissão do Pavilhão promover festivais tradicionais como o Hina Matsuri (festival das bonecas), o Kodomo no hi (dia das crianças) e o Bunka no hi (dia da cultura), o que proporciona um elo ainda mais dinâmico com o Japão, já que essas práticas tradicionais ainda são populares entre os japoneses atualmente (principalmente os dois primeiros). Ao mesmo tempo em que "preservam o legado" tradicional, esses festivais - de grande apelo visual e lúdico atraem não somente os visitantes da comunidade nipo-brasileira, assegurando para o Bunkyo (além, claro, de vários de seus outros eventos e iniciativas) uma projeção institucional mais ampla no panorama cultural paulistano, principalmente pela localização do Pavilhão, no parque mais frequentado da cidade.

Outra comissão de expressão equivalente é a de administração do museu da imigração. Como já argumentei anteriormente neste capítulo, considero o museu um "lugar de memória" especialmente significativo para o Bunkyo e seus representados, por ter se tornado um ponto de convergência de objetos, imagens e documentos que compõem uma narrativa estruturada - na perspectiva da construção cronológica e discursiva - da imigração japonesa no Brasil. Entre os projetos dessa comissão para o ano de 2017 - muitos deles já participando de um planejamento de maior alcance, com vistas às comemorações dos 110 anos da imigração, em 2018 -, há um projeto já em andamento de "história oral", com a gravação de depoimentos de imigrantes idosos e posterior formação de uma videoteca com essas histórias de vida, que poderão ser consultadas por pesquisadores e pelo público em geral. Esses rostos e vozes de pessoas reais, ao se juntarem ao acervo material - coletado, produzido e organizado pelo museu -, completarão o fio da narrativa, dando a ela sua expressão mais humana.

\footnotetext{
${ }^{181}$ Apresentação de Kokei Uehara, então presidente do Bunkyo. Em: BUNKYO, Sociedade Brasileira de Cultura Japonesa e Assistência Social. Pavilhão Japonês. Tradição e Modernidade. São Paulo: 2007.
} 
Uma exposição especial sobre um famoso personagem da história da imigração japonesa no Brasil está nos planos da comissão do museu para 2017, ano que marca o centenário da chegada ao país de Tomoo Handa, que veio do Japão aos onze anos de idade, e se tornaria ele próprio um dos mais importantes narradores do cotidiano dos imigrantes, como pintor e escritor. O museu já possui em seu acervo vários quadros de Handa, sobretudo óleos e aquarelas em que o artista retrata pessoas, paisagens e cenas da vida dos imigrantes na cidade e na lavoura, que ele conheceu bem nos anos em que trabalhou como agricultor com a família em fazendas de café, no interior de São Paulo, até se mudar para a capital, onde estudou na Escola de Belas Artes. Como já mencionado no capítulo anterior, Handa foi um dos fundadores do grupo Seibi, que revelou outros pintores importantes, como Manabu Mabe e Tomie Ohtake.

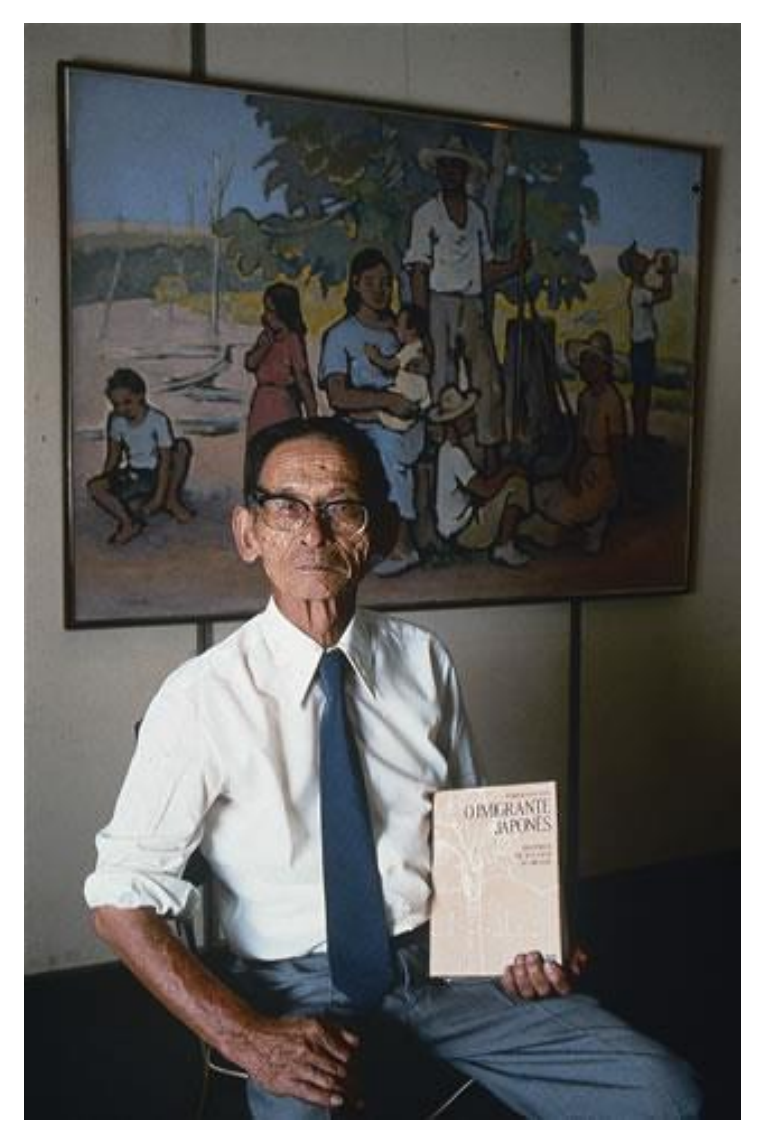

Foto 16: Tomoo Handa.

Fonte: fotografia de Raul Junior, em Japão100 ${ }^{182}$

\footnotetext{
${ }^{182}$ Ver em http://www.japao100.com.br/arquivo/saga-do-trabalho/ Acesso em 16/08/2017
} 
Como escritor, sua obra mais importante foi $O$ imigrante japonês, história de sua vida no Brasil, escrita originalmente em japonês e traduzida para o português por uma equipe de 11 tradutores. Sua versão em português tem 828 páginas, incluindo glossário de palavras usadas em japonês e um guia de leitura da pronúncia da grafia romanizada a partir dos ideogramas e kanás do original em japonês. Ao aproveitar a data comemorativa trazendo para o centro das atenções o nome e a obra de um de seus narradores mais conhecidos, o museu reforça novamente seu papel de "lugar de memória", ao mesmo tempo em que dissemina sua visão dos acontecimentos quanto à história da imigração.

Um outro projeto do museu para 2017 é a publicação de um catálogo sobre quimonos, aproveitando os dados já compilados por uma especialista vinda do Japão com o patrocínio da JICA, e, logo em seguida, um show para demonstrar a variedade de quimonos do acervo do museu e para ilustrar, ao vivo, o conteúdo do catálogo. Mas, sendo este um museu histórico da imigração japonesa, pode-se até questionar qual seria, dentro dele, o lugar dos quimonos, já que esse tipo tradicional de vestimenta japonesa especialmente os mais luxuosos, que fazem parte do acervo - praticamente não fazia parte do cotidiano dos imigrantes no Brasil, não só por causa do tipo de trabalho na agricultura, mas porque já se usava na época as roupas ocidentais, desde as primeiras levas de imigrantes, como atesta a maioria das fotografias do próprio acervo do museu.

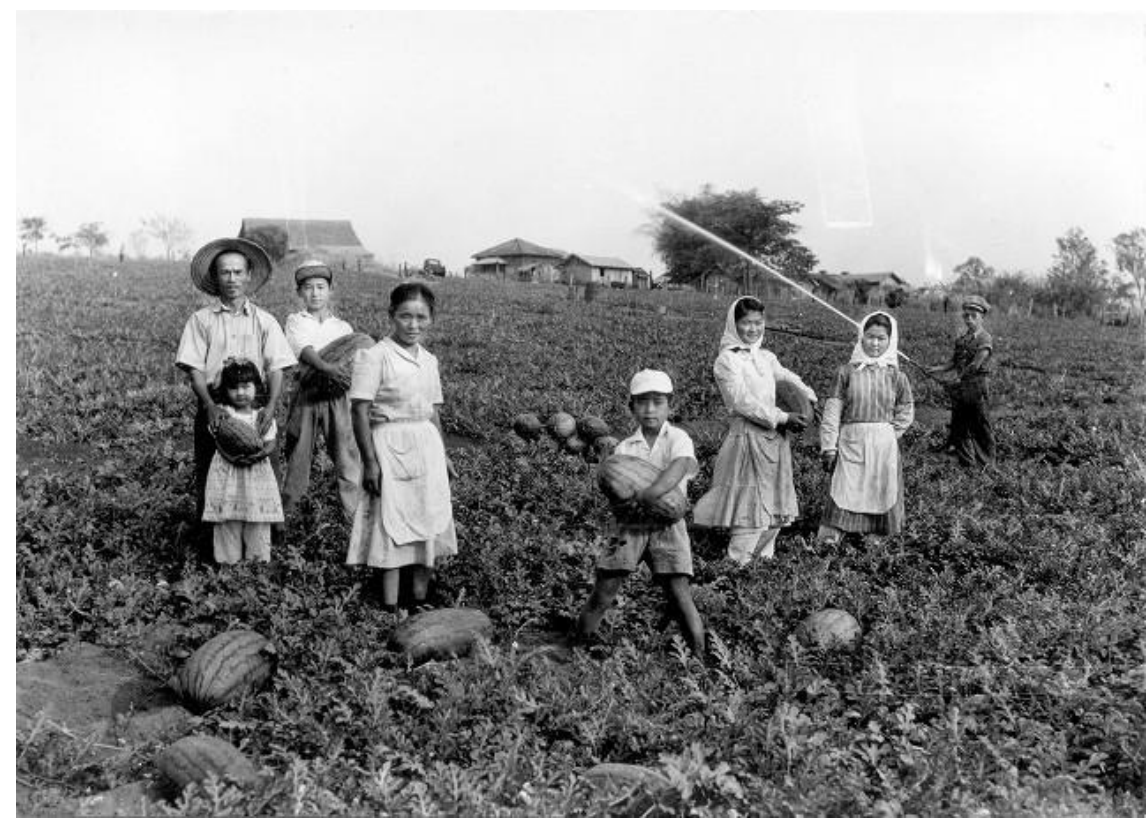

Foto 17: Agricultores japoneses no Brasil.

Fonte: Imigração Japonesa Blogspot 


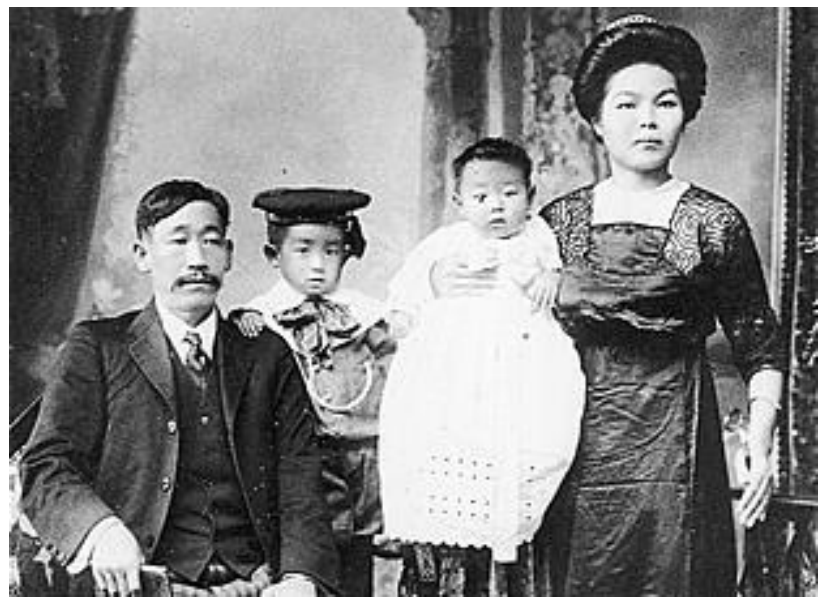

Foto 18: Família de imigrantes.

Fonte: Museu Histórico da Imigração Japonesa no Brasil

Na verdade, embora não estivessem mais presentes no cotidiano dos imigrantes no Brasil (a não ser em ocasiões festivas), os quimonos fizeram parte da vida dos japoneses até pouco antes de deixarem a terra natal, para onde a maioria deles pretendia voltar; além disso, o quimono foi e ainda é um dos elementos visuais mais distintivos da sociedade japonesa, o que sem dúvida teve o seu papel na construção da colônia japonesa no Brasil como "comunidade imaginada". Esse imaginário foi (e de certa forma continua sendo) alimentado pelos contos, histórias, imagens e filmes japoneses vistos, ouvidos, lidos e narrados no Brasil, nos quais o quimono quase sempre está presente, e por isso, por décadas, continuou a fazer parte das referências icônicas de identidade dos imigrantes e seus descendentes no país, graças à sua associação direta com a terra dos seus ancestrais.

Mesmo com os deslocamentos referenciais dos conteúdos tradicionais para as imagens do Japão moderno, o quimono ainda faz parte das imagens que distinguem a comunidade nipo-brasileira como segmento da sociedade brasileira, como pode ser constatado no cartaz de divulgação do Festival do Japão, em que uma figura feminina veste quimono tradicional japonês (vermelho como uma das cores da bandeira do Japão, mas com figuras tropicais) com o $o b i^{183}$ estampado com as cores e símbolos da bandeira brasileira. Dedicado a atrair tanto o público mais jovem como o mais idoso, o Festival do Japão produz nesse cartaz uma síntese do que é hoje essa "comunidade imaginada":

\footnotetext{
${ }^{183}$ Faixa usada na cintura sobre o quimono. É um acessório tradicional que também obedece a regras sociais de uso e quanto às maneiras de ser colocado, podendo ser de vários tipos de tecido, com cores, estampas, larguras e comprimentos também diversos.
} 
a menina de quimono e de sombrinha (o Japão tradicional) tem as feições típicas de uma personagem de mangá (o Japão Pop), tendo na vestimenta os símbolos combinados de ambas as nacionalidades (o "nipo" e o brasileiro).

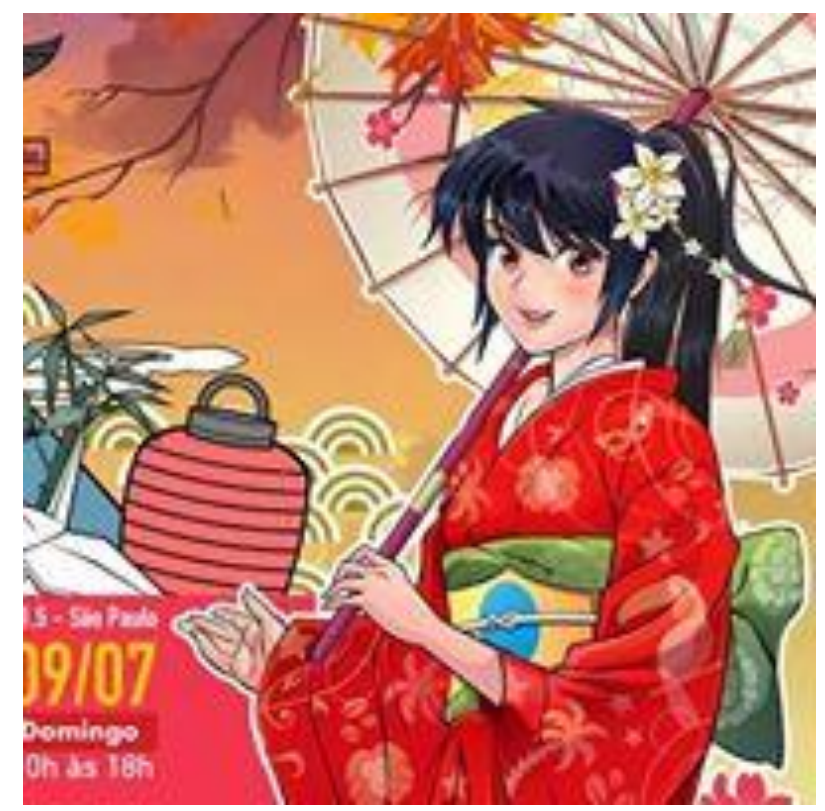

Figura 5: Parte do cartaz de divulgação do Festival do Japão, 2017

Também nos festivais de música e dança e nas práticas tradicionais como a cerimônia do chá, promovidos e apresentados há décadas pelo Bunkyo, o quimono está presente nos palcos, no auditório e até nas bancas que vendem produtos japoneses durante os intervalos das apresentações. Tema de exposições por vários anos consecutivos - sendo que uma delas, em 2013, foi no Palácio Bandeirantes, sede do governo estadual paulista -, os quimonos foram objeto de um desfile especial no Bunka Matsuri de 2017, promovido pelo Bunkyo, em que se pretendeu mostrar a complexidade de significados e de possibilidades estéticas dessa vestimenta, cuja variedade imensa de modelos, cores, estampas e tecidos reflete a posição social, a ocupação, o sexo, a condição civil e a faixa etária das pessoas que a usam, bem como as circunstâncias de seu uso (solenes, festivas ou informais). Assim, ao catalogar essa vasta e diversa obra de arte tradicional japonesa expressa no vestuário, o Museu Histórico da Imigração Japonesa vai além da narrativa da imigração em si mesma, incluindo um aspecto crucial do legado cultural japonês e uma das figuras mais recorrentes do imaginário que compõe e distingue o lado "nipo" da comunidade nipo-brasileira. 


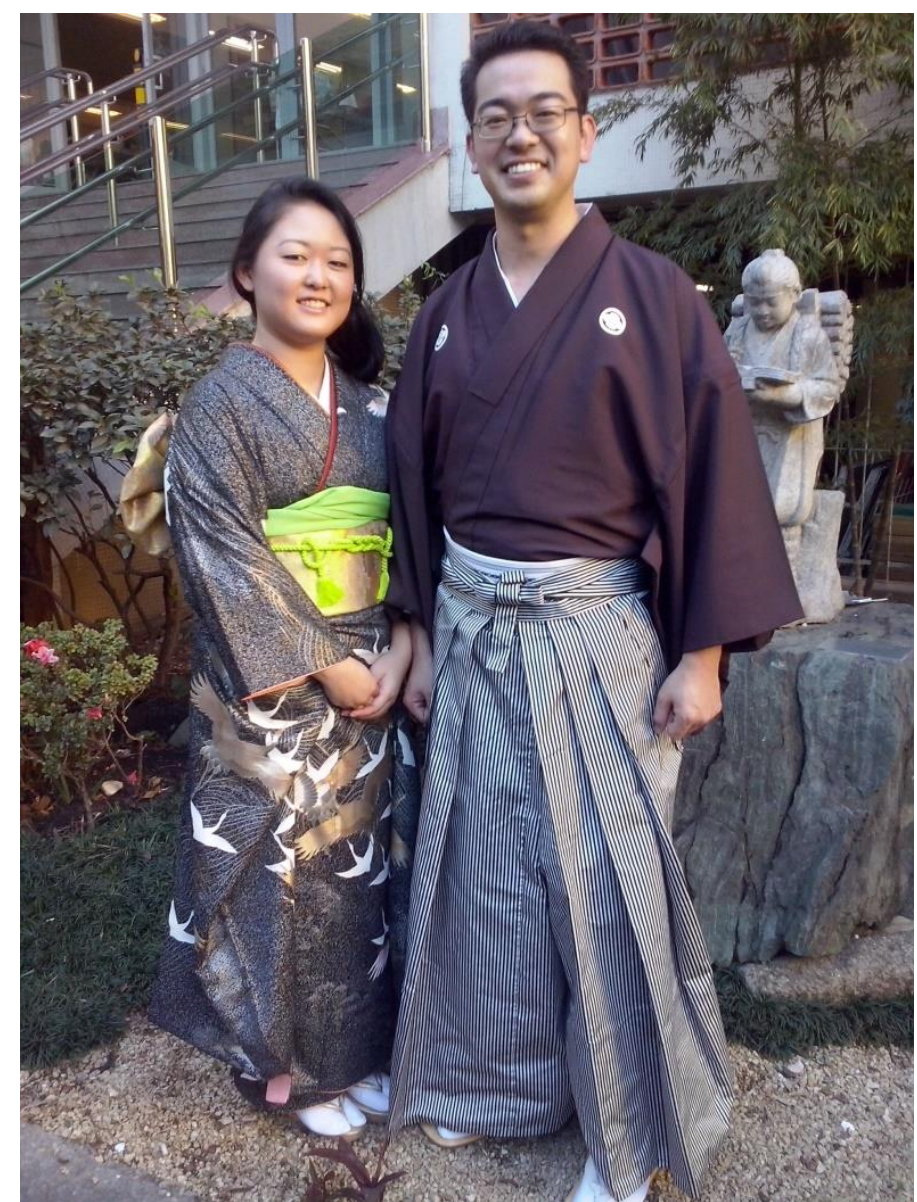

Foto 19: Casal de músicos, Gueinosai 2015.

Fonte: fotografia da autora.

Outro exemplo é a comissão de atividades literárias, cujo papel na narrativa da imigração é manter vivos e dinâmicos os elos com um dos gêneros mais apreciados e praticados pelos imigrantes desde os primeiros tempos de sua presença no Brasil: o haiku. Mais do que simplesmente uma atividade de lazer, o haiku foi uma das principais formas de expressão dos imigrantes, que mantinham por meio dos poemas sua ligação com o Japão e a prática da língua japonesa. Conforme já mencionado no capítulo anterior, o haiku era e ainda é praticado por pessoas comuns, e não só por intelectuais, motivo pelo qual teve grande importância na preservação dos valores culturais japoneses, sobretudo no início da imigração, quando os japoneses ainda acalentavam o sonho de voltar à terra natal, e também na época das restrições aos direitos dos imigrantes, durante a Segunda Guerra, quando a sua prática foi um símbolo de resistência às tentativas de assimilação forçada do governo nacionalista de Getúlio Vargas. 
Chamado no Brasil de haicai, teve no poeta Guilherme de Almeida um de seus entusiastas e difusores. O incentivo ao haiku é tema de um concurso anual, promovido por essa comissão, que também promove um concurso de contos, em português e em japonês, e um de mangá (atraindo com esse gênero também os mais jovens). Na cerimônia de entrega de prêmios do "Concurso Literário Nikkei" de $2016^{184}$, o vicepresidente do Bunkyo, Jorge Yamashita, ressaltou a "base educacional literária" que sempre fez parte da vida dos imigrantes japoneses no Brasil e o papel desse evento na preservação da cultura dos ancestrais entre as novas gerações.

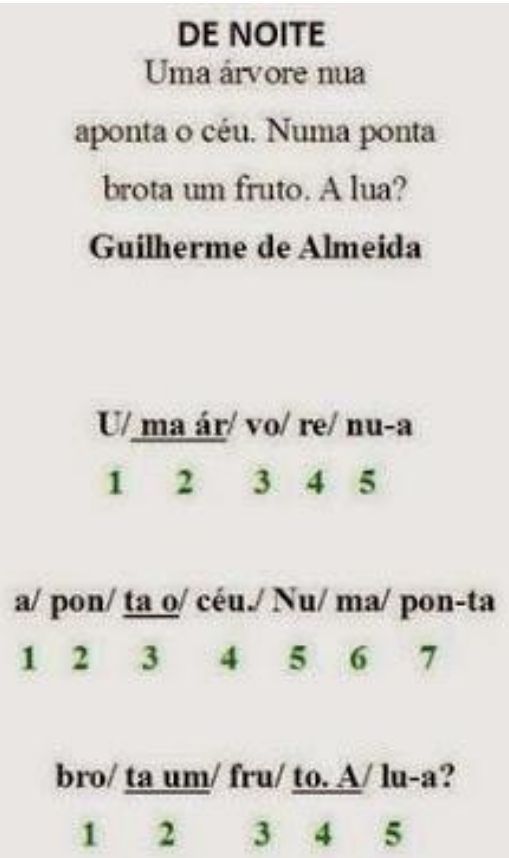

Figura 6: Haicai de Guilherme de Almeida (do livro Poesia Vária, de 1947). Fonte: Clube do Livro e Amigos

Outras comissões também promovem cursos, exposições, apresentações e palestras periódicas ou eventuais sobre aspectos tradicionais da cultura japonesa, como o ikebana, a gastronomia e o kendô, e uma variedade de práticas apresentadas no Bunka Matsuri, o mais completo festival japonês organizado pelo Bunkyo, e no Gueinosai, a festa mais abrangente da música e da dança tradicional do Japão. Outras comissões têm foco nas relações sociais e institucionais, como as comissões de jovens, do Fórum de Integração Bunkyo (FIB) e dos setores rural e empresarial. E outras ainda se dedicam às

184 Ver em http://www.Bunkyo.org.br/pt-BR/noticias/154-2016/1134-a-cerimonia-de-premiacao-dacomissao-de-atividades-literarias. Acesso em 20/08/2017 
relações com os governos do Brasil e do Japão, fechando assim o círculo de atuação do Bunkyo, que tenta abraçar da forma mais ampla possível os aspectos sociais, culturais e políticos que dizem respeito à comunidade nipo-brasileira, traçando dessa maneira - a partir de sua visão específica - os limites dessa comunidade e os repertórios que lhe dizem respeito.

\subsection{Publicações do Bunkyo}

O Bunkyo promove a produção de diversos guias, livros, catálogos, folhetos e DVDs, geralmente em situações festivas e com apoio de outras entidades e instituições nipo-brasileiras ou japonesas, que são distribuídos entre associados, autoridades e visitantes. São exemplos dessas publicações a antologia de contos premiados do Concurso de Atividades Literárias, o Guia do Museu Histórico de Imigração Japonesa, o catálogo O Olhar Japonês no Brasil, sobre exposição apresentada no Pavilhão Japonês em 2016, e a revista comemorativa dos 20 anos do Sakura Matsuri, também de 2016. No formato DVD, são exemplos a produção de uma coletânea de reportagens dos principais eventos referentes aos 120 anos do tratado Brasil-Japão, celebrado em 2015, e de um vídeo institucional sobre os aspectos históricos e técnicos da construção e revitalização do Pavilhão Japonês, também como parte das comemorações dos 120 anos. Ainda em 2015, ano em que o Bunkyo celebrou seus 60 anos de fundação, foram publicados o catálogo fotográfico bilíngue (português e japonês) Bunkyo 60 anos, sua trajetória e o livro 60 anos de Bunkyo: passado, presente e futuro, com 335 páginas, somente em português. 


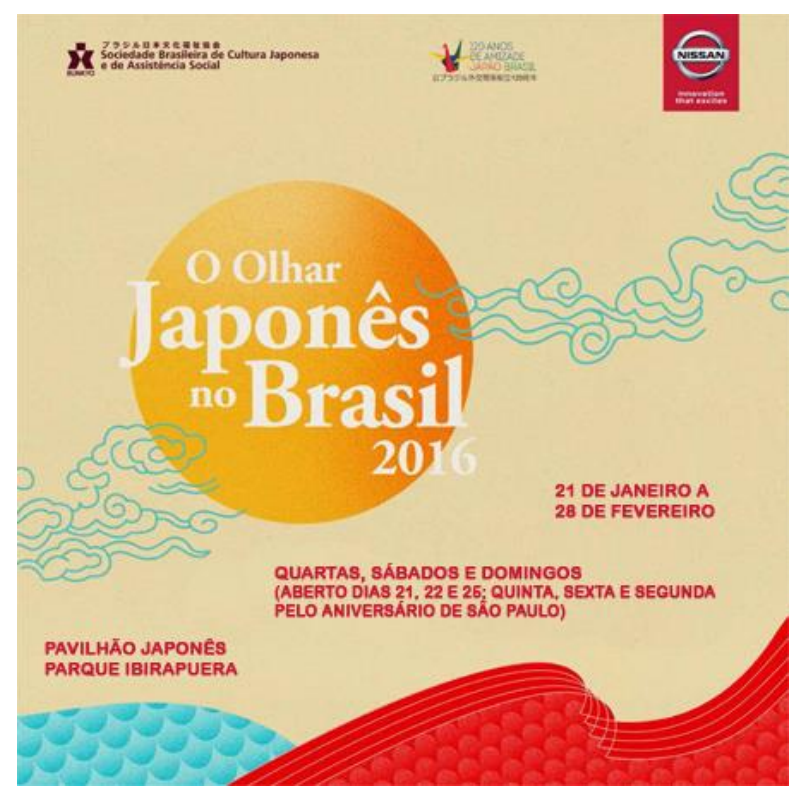

Figura 7: Cartaz de divulgação da exposição. A capa da publicação é praticamente igual. Fonte: Bunkyo

O livro 60 anos de Bunkyo: passado, presente e futuro é uma produção de fôlego que reflete o grande esforço da entidade em reunir as lideranças em torno da narrativa da sua fundação e de sua inserção na narrativa maior, que é a história da imigração japonesa no Brasil. Esse tipo de livro comemorativo é reescrito a cada dez anos, com análises e comentários sobre as ações e os avanços do Bunkyo na década anterior. Tratase de um recurso precioso para se conhecer o percurso da entidade, os personagens que fizeram parte dela, suas lutas internas e transformações, e também para se ouvir as vozes dessas lideranças e suas perspectivas particulares dos eventos, já que cada capítulo é assinado por uma pessoa diferente.

As categorias temáticas dos textos apresentam algumas características mais ou menos bem delineadas, como se vê no sumário dos doze capítulos do livro, mas a leitura dos textos revela que as falas agrupadas em uma categoria atravessam os temas de outras, o que indica a liberdade dos autores em construir suas falas. As apresentações e os capítulos se dividem em cinco tipos de textos: mensagens oficiais; narrativas históricas; estrutura e finalidades dos órgãos, unidades e comissões; história e funcionamento das demais entidades que funcionam no prédio do Bunkyo; e reflexões sobre o presente com projeções para o futuro. As mensagens oficiais são assinadas pelo presidente do Bunkyo, pelo embaixador japonês, pelo cônsul-geral em São Paulo e pelo coordenador do livro, que, de certa forma, antecipam alguns dos temas principais que serão desenvolvidos com mais detalhes nos capítulos subsequentes. 
Na apresentação, a fala de Kihatiro Kita, então presidente do Bunkyo, ressalta as mudanças que ocorreram no mundo e na sociedade brasileira, conclamando as lideranças do Bunkyo a se adaptarem aos novos tempos, abrindo mais espaços aos jovens sem reduzir o dos da "terceira idade", e a mudarem seus hábitos, abarcando "a sociedade em sua totalidade", sem deixar de lado a "essência do legado dos nossos pioneiros". Com essa fala, o presidente Kita resume o desafio da entidade, que é o mesmo há décadas e continua a ser, em pleno século XXI, indicando um caminho de abertura da comunidade nipo-brasileira, sem que esta perca as marcas do passado que a diferencia.

O texto de Kumio Umeda, embaixador do Japão no Brasil, traduz em palavras a mais típica das expressões corporais japonesas ao expressar "sinceras reverências" aos voluntários do Bunkyo que têm "preservado a cultura do Japão" e os "documentos históricos relativos à imigração". Embora a reverência já tenha se tornado um gesto mecânico entre os japoneses, a sua menção em um texto escrito revela a recuperação do seu sentido simbólico, que é o de tornar menor o homem (que reverencia) diante do outro, a maior demonstração de respeito e reconhecimento que alguém pode ostentar. $\mathrm{O}$ embaixador também ratifica a importância institucional do Bunkyo, ao lembrar as visitas do primeiro-ministro Shinzo Abe e do Grão-Mestre de cerimônia do chá Genshitsu à entidade.

O cônsul Noriteru Fukushima, em sua fala, sintetiza - e também referenda - o que o Bunkyo tem pretendido ser desde sua fundação: "a terra natal no coração da comunidade nipo-brasileira", através de atitudes que mantêm esses laços, como a celebração de eventos alegres, como o Festival das Cerejeiras, e também dos tristes, como a homenagem às vítimas do grande terremoto de 2011. Com essa fala, o cônsul sugere que, embora os descendentes dos imigrantes sejam brasileiros, o país de seus ancestrais deve continuar sendo a "terra natal" em seus corações, e que o Bunkyo representa esse lugar. Kiyoshi Harada, coordenador do livro, fecha as apresentações mas fará muitas outras intervenções, em vários outros capítulos - evocando, "com justiça", o lugar do Bunkyo como "entidade central da sociedade nipo-brasileira". 

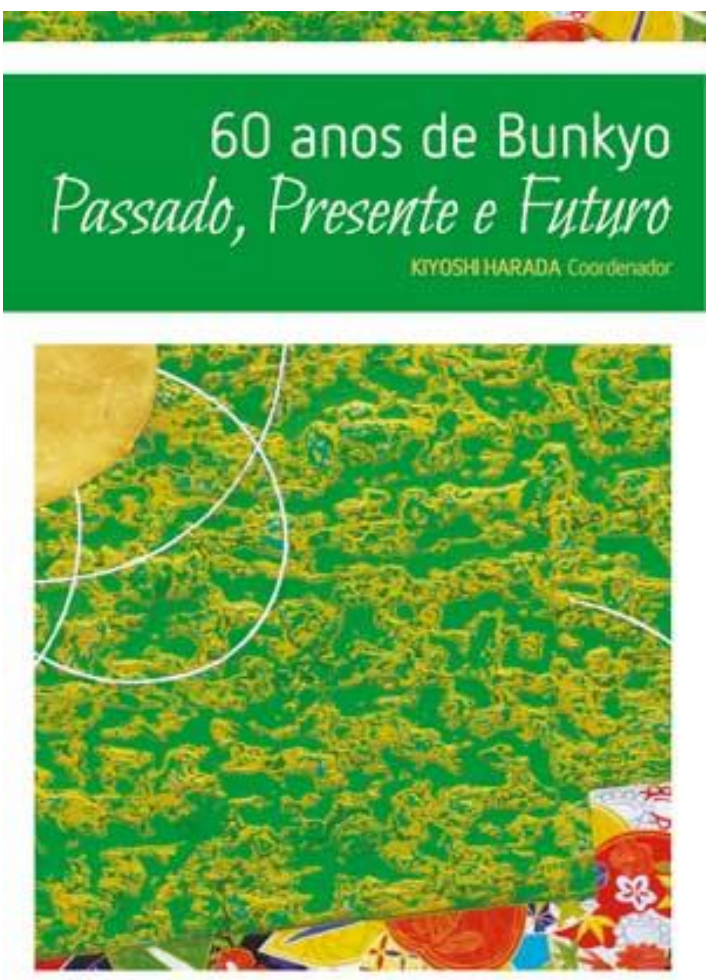

Figura 7: Capa do livro, projeto do artista plástico Kazuo Wakabayashi

\section{Fonte: Bunkyo}

Pode-se dizer que as mensagens oficiais que abrem o livro conferem autoridade à obra como um todo, por serem as vozes de representantes que se destacam na liderança do Bunkyo e dos dois representantes mais graduados do governo japonês no Brasil. Sendo a hierarquia um traço comumente atribuído à sociedade japonesa (BEFU, 2001, p. 66), e tendo verificado em minha observação de campo que esse traço se reproduz na entidade, talvez por ser gerida por descendentes das gerações mais idosas (issei e nissei: primeira e segunda geração de imigrantes ${ }^{185}$ ), concluo que as falas dessas mensagens oficiais na abertura do livro têm a função de conferir legitimidade tanto ao livro, como projeto de avaliação histórica, quanto ao Bunkyo, como entidade representativa da comunidade nipo-brasileira.

\subsection{A mídia do Bunkyo}

\footnotetext{
${ }^{185}$ Os imigrantes de primeira e segunda gerações (imin e nissei) são geralmente mais idosos, mas não necessariamente, lembrando que houve imigração japonesa para o Brasil até a década de 1970, e neste caso os nisseis evidentemente não são idosos. Refiro-me aqui aos imin e nisseis das levas imigratórias anteriores, que são mais numerosas que as recentes e mais representadas na direção do Bunkyo.
} 
A comissão de marketing e comunicação do Bunkyo tem a responsabilidade de produzir e manter a revista Colônia, o Bunkyonews (impresso e eletrônico), o site da entidade e as mídias sociais (Facebook, Twitter e Instagram), além de outras atividades voltadas à divulgação da marca, das notícias internas e das relações com a imprensa. Quanto à produção de notícias e comentários sobre eventos referentes à entidade e outras instituições afins, o público-alvo é constituído principalmente por seus associados, os demais membros da comunidade nipo-brasileira e as pessoas em geral que se interessam pelos seus eventos e estão na sua lista de e-mails. Na prática, a maior parte do material de comunicação é produzida por uma pequena equipe chefiada pela jornalista Célia Abe Oi, que também já foi diretora do museu da imigração e é considerada grande conhecedora da história do Bunkyo - onde trabalha desde 1998 - e da imigração japonesa no Brasil. Além das notícias e comentários que alimentam a mídia da entidade, Abe Oi é responsável pela organização e redação de grande parte dos discursos e textos publicados em livros, guias e catálogos, assumindo muitas vezes também o papel de relações-públicas em eventos dentro e fora da entidade e nas ocasiões em que o Bunkyo é procurado por jornalistas brasileiros ou estrangeiros em busca de informações sobre a comunidade nipo-brasileira.

\subsubsection{A página do Bunkyo na Internet (mapa do site)}

O website do Bunkyo é a mais ampla, atualizada e completa fonte de notícias e de informação da entidade. Uma seleção do material de divulgação do site é reproduzida nas páginas das redes sociais (com as devidas adaptações a cada linguagem) e também no Bunkyoe-news (o boletim eletrônico mensal). Disponível nos idiomas português e japonês (que o usuário escolhe clicando na bandeirinha do Brasil ou na do Japão, localizadas no centro superior da página), o site ainda tem link de acesso às redes sociais (Twitter, Instagram e Facebook, além do Trip Advisor) e a um campo de busca, que leva a uma seleção de notícias e artigos referentes ao assunto procurado. Construído na forma de hipertexto, a homepage do site traz várias notícias, anúncios, informações, fotos e imagens, além de barras e links que proporcionam acesso a outras seções do 
mesmo site, ao restante das notícias e informações resumidas na homepage (inclusive as divulgadas em dias e meses anteriores) e a vídeos no YouTube.

A homepage do Bunkyo traz ainda links para vários outros sites de entidades, fundações e agências governamentais, constituindo assim um universo japonês e nipobrasileiro conectado. Quando esse levantamento foi realizado, constavam na homepage os seguintes links: lado esquerdo parte superior, 110 Anos da Imigração Japonesa no Brasil e Fundação Kunito Miyasaka; lado esquerdo parte inferior, Beneficência NipoBrasileira de São Paulo, Kenren - Federação das Associações de Províncias do Japão no Brasil, Aliança Cultural Brasil-Japão, Associação Kaigai Nikkeijin Kyokai, Discover Nikkei - Japanese Migrants and Their Descendants, Associação Central NipoBrasileira, Associação Nipo-Brasileira; lado direito inferior, Consulado Geral do Japão em São Paulo, Governo do Estado de São Paulo, Prefeitura de São Paulo, JICA - Japan International Cooperation Agency, Japan Foundation, MAM - Museu de Arte Moderna de São Paulo, Instituto Paulo Kobayashi, CIATE - Centro de Apoio ao Trabalhador no Exterior, Urasenke Brasil - Centro de Chadô.

O projeto original de comunicação on-line do Bunkyo, utilizado de forma regular desde 2006 - chamado de Bunkyonet -, pretendia ajudar a estabelecer e incluir os links de todas as entidades nipo-brasileiras da capital, do interior e de outros estados, o que acabou não acontecendo pelas dificuldades de infraestrutura de grande parte dessas entidades. Descrevo a seguir o mapa do site.

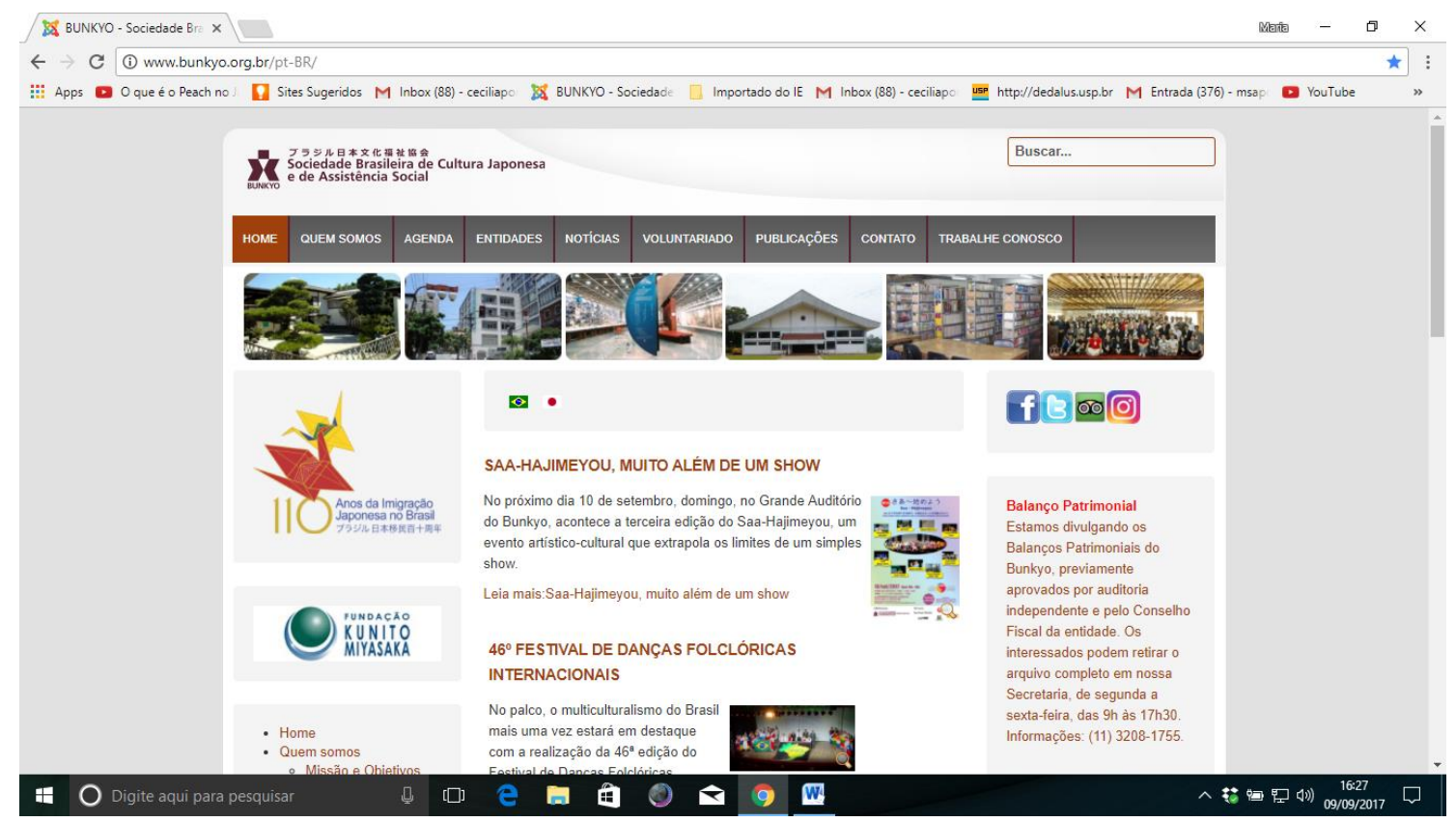




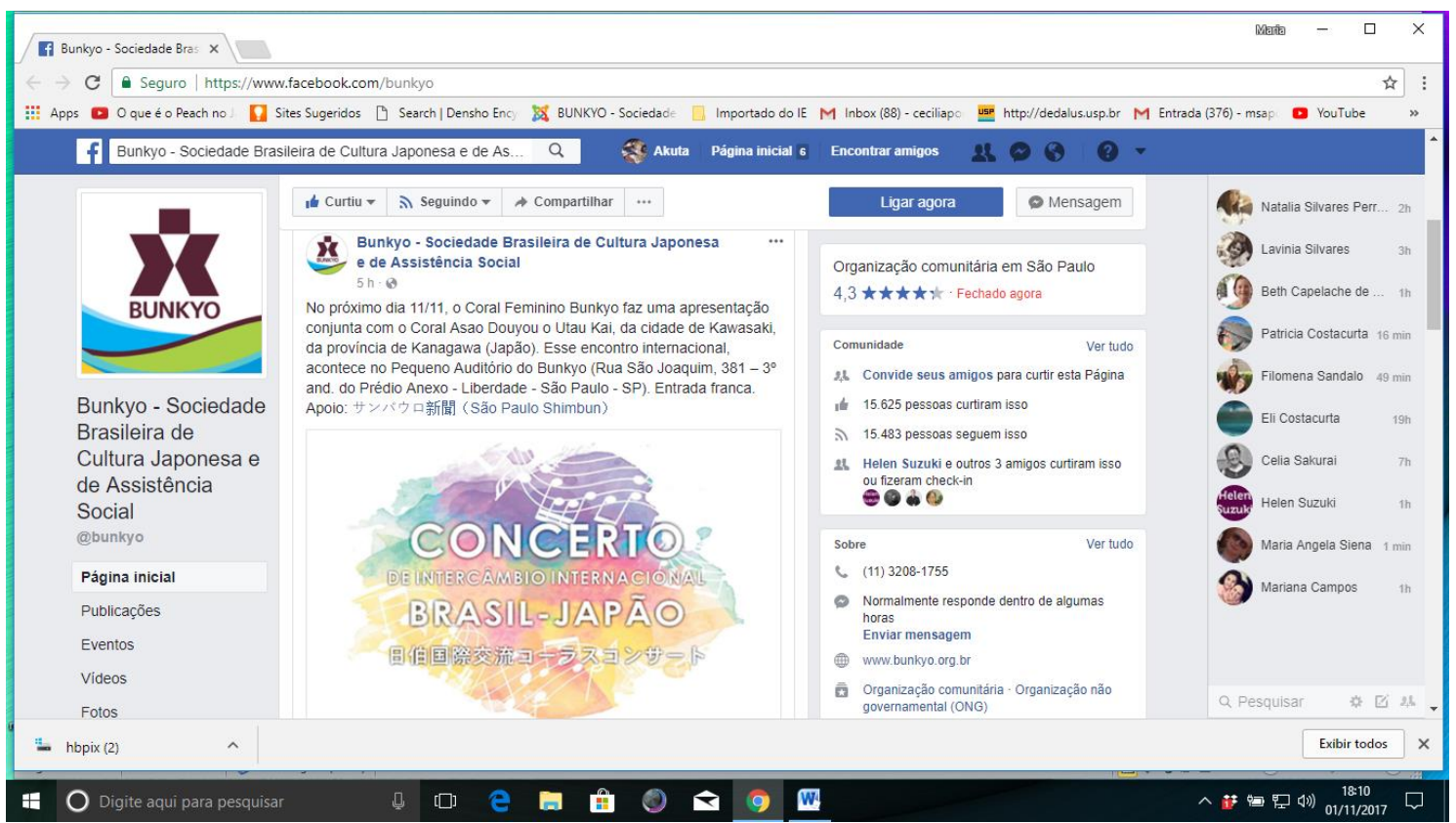

Página do Facebook do Bunkyo, em 1 de novembro de 2017

A página inicial (homepage) do site do Bunkyo tem uma barra principal horizontal na parte superior da página que indica: home, quem somos, agenda, entidades, notícias, voluntariado, publicações, contato e trabalhe conosco. Como já foi descrito acima, a "home" é a página principal, que traz notícias e informações mais recentes, além dos links para redes sociais e outras seções do site e demais entidades nipo-brasileiras. O "quem somos" traz um histórico da entidade, uma cronologia com fatos selecionados e resumidos, datados de 1954 a 2008, e, por último, vários vídeos do YouTube com uma relação de reportagens intitulada "TV Bunkyo", sendo que a primeira delas, de 5:42 minutos, produzida em 2012, começa com o texto da missão do Bunkyo e em seguida relata alguns dos eventos considerados mais significativos da história da entidade, com imagens antigas de arquivo, tais como a parada do IV Centenário, de 1954, e a visita do príncipe Mikasa, de 1958, terminando com o centenário da imigração, em 2008. As outras reportagens descrevem momentos de algumas eleições, eventos, discursos de políticos nikkeis, festas etc.

A "agenda" traz a programação diária - a partir do dia em que se faz o acesso a ela, com possibilidade de acesso também aos eventos anteriores - com um link que leva às informações referentes a cada uma dessas atividades. As "entidades", intituladas "comunidade nipo-brasileira", têm o link das principais agências governamentais e 
fundações japonesas e uma seleção de entidades nipo-brasileiras, todas com link que leva aos seus respectivos websites, e a maior parte delas com um breve resumo de seu ramo de atividades. São elas: a Embaixada do Japão no Brasil; o Consulado Geral do Japão em São Paulo; a JICA (Japan International Cooperation Agency); a JETRO (Japan External Trade and Research Organization), a Fundação Japão, a Enkyo (Beneficência Nipo-Brasileira de São Paulo), a KENREN (Federação das Associações de Províncias do Japão no Brasil); a Câmara de Comércio e Indústria Japonesa do Brasil; a Aliança Cultural Brasil-Japão; o Hospital Santa Cruz; o CIATE; o Ikoi-noSono (Assistência Social Dom José Gaspar); o Kodomo-no-Sono (Associação PróExcepcionais); o Kibô-no-Iê (Sociedade Beneficente Casa da Esperança); a JCI BrasilJapão (Câmara Junior Brasil-Japão); a ASEBEX (Associação Brasileira de Ex-Bolsistas no Japão); e a ABEUNI (Aliança Beneficente Universitária de São Paulo).

"Notícias" é uma lista de links para os anos de 2011 a 2017, em que as informações e comentários de cada ano estão agrupados por data, além dos links específicos para as eleições de 2015 e de 2017, para o terremoto de 2011, para o FIB e para as comemorações dos 110 anos, programadas para o ano de 2018. O "voluntariado" traz um cadastro para os voluntários que querem trabalhar no Bunkyo, com uma lista de opções de áreas de interesse (como auxílio na biblioteca, tradução de textos etc.). As "publicações" trazem um pequeno resumo de três periódicos produzidos pelo Bunkyo: a Revista Colônia, o Boletim Relações Empresariais e o Bunkyo News, com links que levam aos exemplares digitalizados e que podem ser lidos on-line. $\mathrm{O}$ "contato" traz os endereços postal, eletrônico e URL do Bunkyo, os números de telefone e de fax, e link para formulário de contato direto por e-mail. E o "trabalhe conosco" oferece um e-mail específico para envio de currículo e local para entregá-lo pessoalmente na entidade.

Do lado esquerdo, há uma barra vertical com 24 marcadores, sendo que alguns deles são os mesmos da barra horizontal (home, quem somos, agenda, trabalhe conosco e entidades). Sob o "quem somos" da barra vertical há dois outros marcadores que não constam na horizontal: missão e objetivos e estatuto social. Os demais são: associe-se, associados, diretoria, conselho deliberativo, conselho fiscal, conselho consultivo, conselho superior de apoio e orientação, representantes regionais, ex-presidentes, planejamento de comissões, instalações, secretaria, biblioteca (e acervo), Pavilhão japonês, museu histórico da imigração japonesa no Brasil, centro esportivo kokushikan 
daigaku, locação de espaços, cursos e atividades. O marcador "Missão e Objetivos" leva o visitante aos propósitos e à razão de ser do Bunkyo, ou seja, a mais importante declaração de princípios gerais que norteiam as decisões e ações da entidade. Logo abaixo, no link "Estatuto Geral", estão os regulamentos que tratam de direitos e deveres dos associados, regras para adesão, levantamento de recursos, eleições etc.

Em “Associe-se”, há um convite para o visitante conhecer as regras de adesão ao quadro social da entidade, com um link que leva ao estatuto social e outros links para fichas cadastrais de pessoa física e jurídica e para uma tabela de valores de várias categorias de sócios. Em "Associados", há uma série de anúncios para bolsas e descontos em uma faculdade paulistana aos quais os sócios do Bunkyo podem concorrer. Em "Diretoria" estão os nomes de todas as pessoas que ocupam cargos de direção no presente mandato. Em "Conselhos", também há a relação de pessoas e entidades que ocupam cargos ou são membros em cada um deles. Em "Representantes Regionais" estão os nomes de líderes locais que representam o Bunkyo em suas regiões no atual mandato: Santo Amaro, Suzano, Mogi das Cruzes, Vale do Paraíba, Santo André, São Bernardo, Campinas, Noroeste, Alta Paulista, Alta Sorocabana, Alta Araraquarense, Litoral Paulista, Bragantina, Sudoeste, Vale do Ribeira, Alta Mogiana, Rio de Janeiro, Minas Gerais, Norte do Paraná, Curitiba, Dourados, Campo Grande, Centro Oeste, Pará, Amazonas, Santa Catarina, Mato Grosso, São Paulo Norte, São Paulo Leste, São Paulo Sul, São Paulo Oeste, Bahia e Rio Grande do Sul.

Em "Ex-presidentes", há uma pequena introdução histórica da fundação do Bunkyo, a apresentação da atual presidente da entidade, Harumi Arashiro Goya (12음 dirigente e primeira mulher a ocupar o cargo), e de seus antecessores, em ordem decrescente (do nono ao primeiro ex-presidente, há uma foto e minibiografia de cada um). Em "Planejamento Comissões", como já foi descrito no item 2.3 deste capítulo, há uma lista de 29 comissões permanentes com a descrição de cada uma, seu presidente, vice-presidente e membros, e o planejamento de suas atividades aprovadas para o ano em curso. Ligadas ao "Comitê Administrativo", são elas: Comissão de Administração Geral/Eventos, Comissão Patrimonial, Comissão de Administração do Pavilhão Japonês, Comissão de Administração do Museu Histórico da Imigração Japonesa no Brasil, Comissão de Administração do Centro Esportivo Kokushikan Daigaku, Comissão Jurídica, Comissão de Planejamento Estratégico, e Comissão de Marketing e Comunicação. 
Ligadas ao "Comitê Cultural/Social”, são: Comissão de Biblioteca, Comissão de Artes Plásticas, Comissão de Arte Craft, Comissão de Música e Dança Folclórica, Comissão de Música, Comissão de Incremento Social, Comissão do Bunka Matsuri, Comissão de Ikebana, Comissão de Coral, Comissão de Atividades Literárias, Comissão de Divulgação da Gastronomia Japonesa. Ligadas ao "Comitê de Relacionamento", são elas: Comissão de Assistência Social, Comissão de Esportes, Comissão de Relacionamento com as Associações, Comissão do Fórum de Integração Bunkyo, Comissão Bunkyo Rural, Comissão do Prêmio Kiyoshi Yamamoto, Comissão de Jovens, Comissão de Relacionamento Institucional com o Japão, Comissão de Relações Governamentais e Comissão de Relações Empresariais.

Em "Instalações", há uma foto e um pequeno histórico da construção do edifício-sede do Bunkyo, desde a pedra fundamental lançada pelo príncipe Mikasa, em 1958, até as etapas das adições subsequentes e as reformas mais recentes, com uma descrição também do total de área construída e sua forma de ocupação. Logo abaixo do texto, um quadro indica os departamentos do Bunkyo e as outras entidades que ocupam cada andar do edifício-sede e do edifício anexo, além dos estacionamentos. Em "Secretaria", há uma pequena descrição de sua função, localização e os horários de expediente. Em "Biblioteca", há uma foto e um pequeno texto que descreve a quantidade e gêneros de livros, em japonês e português, disponíveis para os sócios (visitantes não podem fazer empréstimos), além de jornais, revistas, mangás e DVDs. No link "Acervo", tem-se acesso a um campo de consultas do acervo por idioma, categoria, título, autor e editora, e também às revistas e boletins digitalizados (Revista Colônia, Bunkyo News e Bunkyo Rural).

Em "Pavilhão Japonês", há três páginas com fotos, vídeo e texto sobre a história da sua construção, em 1954, as técnicas tradicionais utilizadas, o jardim zen e o lago de carpas, a sala de chá, o salão de exposições, os eventos que acontecem ali, a localização (com mapa) e informações sobre dias e horários de funcionamento e preço da entrada. Em "Museu Histórico da Imigração Japonesa no Brasil", fotos e texto contam um pouco da história de fundação do museu e oferecem informações sobre localização, dias e horários de funcionamento (do próprio museu e da sua biblioteca), regulamento para utilizar o áudio guia, visitas monitoradas e preços das entradas, além de um link para o site do museu, inaugurado em 2012. Em "Centro Esportivo Kokushikan Daigaku”, uma 
foto ilustra um texto curto que descreve a localização e formas de utilização dessa unidade do Bunkyo, doada à entidade em 1997.

Em "Locação de espaços", há fotos e descrições de salas, auditórios, cozinha, salão nobre e ginásios do edifício sede, e também do Pavilhão e do Centro Kokushikan, que podem ser alugados para eventos, cursos, palestras e aulas, e os preços, que variam de acordo com o espaço, o número de horas de utilização e se é para sócios ou não sócios. Em “Cursos”, há uma breve descrição de cursos oferecidos pelo Bunkyo, com informações sobre horários, preços (alguns são gratuitos) e como se inscrever. São eles: curso "Iki iki Issô" (ginástica para terceira idade), oficina de Ikebana, cuidador de idosos, dança de salão, dança sênior, coral feminino, pintura para adultos e crianças. Em "Atividades", há uma relação das atividades programadas para cada mês, até o final do ano, e, no fim da página, a relação das atividades que já aconteceram nos meses anteriores.

\subsubsection{Revistas e boletins}

O primeiro boletim informativo do Bunkyo, chamado Kaiho (literalmente “avisos da associação"), foi fundado em 1956 com o objetivo de tornar-se "uma publicação de caráter cultural, que visa a informação das nossas atividades e intercâmbio cultural entre aqueles que o leem" ${ }^{186}$. Publicado somente em japonês, o boletim era enviado gratuitamente aos associados do Bunkyo e também a entidades oficiais japonesas e associações nikkeis da América Latina, dos Estados Unidos e do Havaí. A partir de 1960, o boletim passou por modificações no formato e ganhou um novo nome, que permaneceu pelas décadas seguintes: Coronia (Colônia). A revista tornou-se um anuário, em edição bilíngue, com informações e comentários das atividades e eventos de destaque realizados naquele ano no Bunkyo, e também com os demonstrativos financeiros da entidade. As duas primeiras edições da Colônia - de outubro e de novembro/dezembro de 1956 - foram digitalizadas e podem ser lidas on-

\footnotetext{
${ }^{186}$ Sociedade Paulista de Cultura Japonesa, Comissão Pró Construção do Centro Cultural Brasil-Japão, $O$ Porquê do centro cultural Brasil-Japão, São Paulo [1961].
} 
line no site do Bunkyo, no link "Publicações". A última edição de Colônia é a de 2013, cuja capa faz alusão à comemoração dos 105 anos da imigração japonesa.

O boletim impresso mensal Bunkyonews (bilíngue) e sua versão on-line Bunkyo e-news (somente em português) foram criados no ano seguinte às comemorações do Centenário da Imigração Japonesa, em decorrência do clima de entusiasmo gerado pelas festividades e, sobretudo, pelo estabelecimento de relações mais próximas com as entidades e os associados, o que os boletins tinham por missão reforçar. Na primeira página do boletim número 1, aparentemente preocupados por estarem divulgando suas próprias obras, os editores justificam: “a discrição pode ser uma qualidade característica da atuação dos nipo-brasileiros. No entanto, algumas vezes é preciso falar de nossas realizações para trazer mais colaboradores, e assim transformar nossas iniciativas em empreendimentos sociais de longo alcance" ${ }^{, 187}$.

Além das notícias e comentários sobre eventos do Bunkyo, fazem parte das temáticas dos boletins assuntos referentes a outras entidades nipo-brasileiras e ao Japão. Segundo o site do Bunkyo, esse boletim é enviado por correio aos associados, colocado em pontos estratégicos da entidade e distribuído em eventos. A partir de 2013, porém, somente a versão eletrônica do boletim - Bunkyo e-news - continuou a ser editada, e mesmo assim com periodicidade irregular. Todas as edições do Bunkyonews - números 1 a 13 - foram digitalizadas e estão acessíveis no site da entidade (em Publicações).

${ }^{187}$ Ver em: http://www.Bunkyo.org.br/pt-BR/publicacoes/249-Bunkyonews? showall=\&start=2 


\section{Bunkyonews}

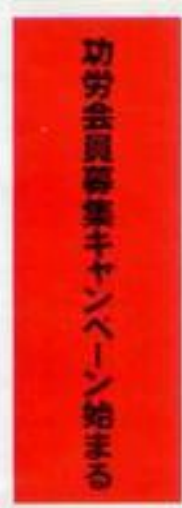

O Bunkyo lança a Campanha Associado Benemérito

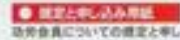

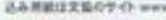

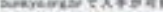

$7 \pi$

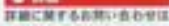

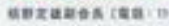

mir-wee Resxian

aewownorims oph

owishert

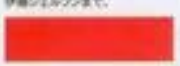

iniming

-

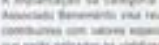

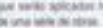

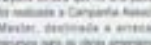

cons

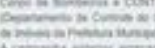

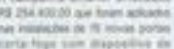

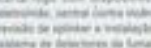

$-2+\cos =0$

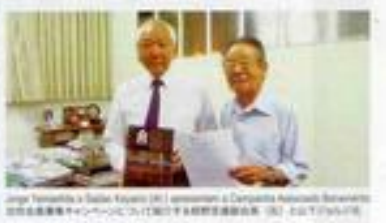

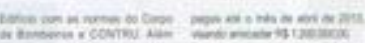

cis onis

nowevin

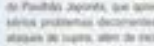

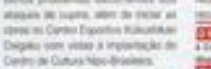

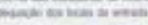

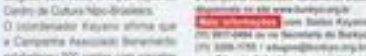

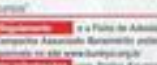

- + wamia

iming

singer
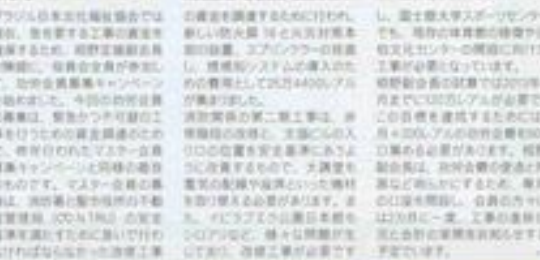

Eez:ain

minnecing

Uma fundarbo dedicoda a arte

de volocizar a culturo e as pessoce.

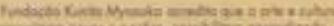

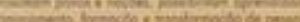

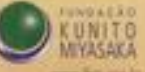

Figura 8: Bunkyonews, edição de março de 2012.

Fonte: Bunkyo

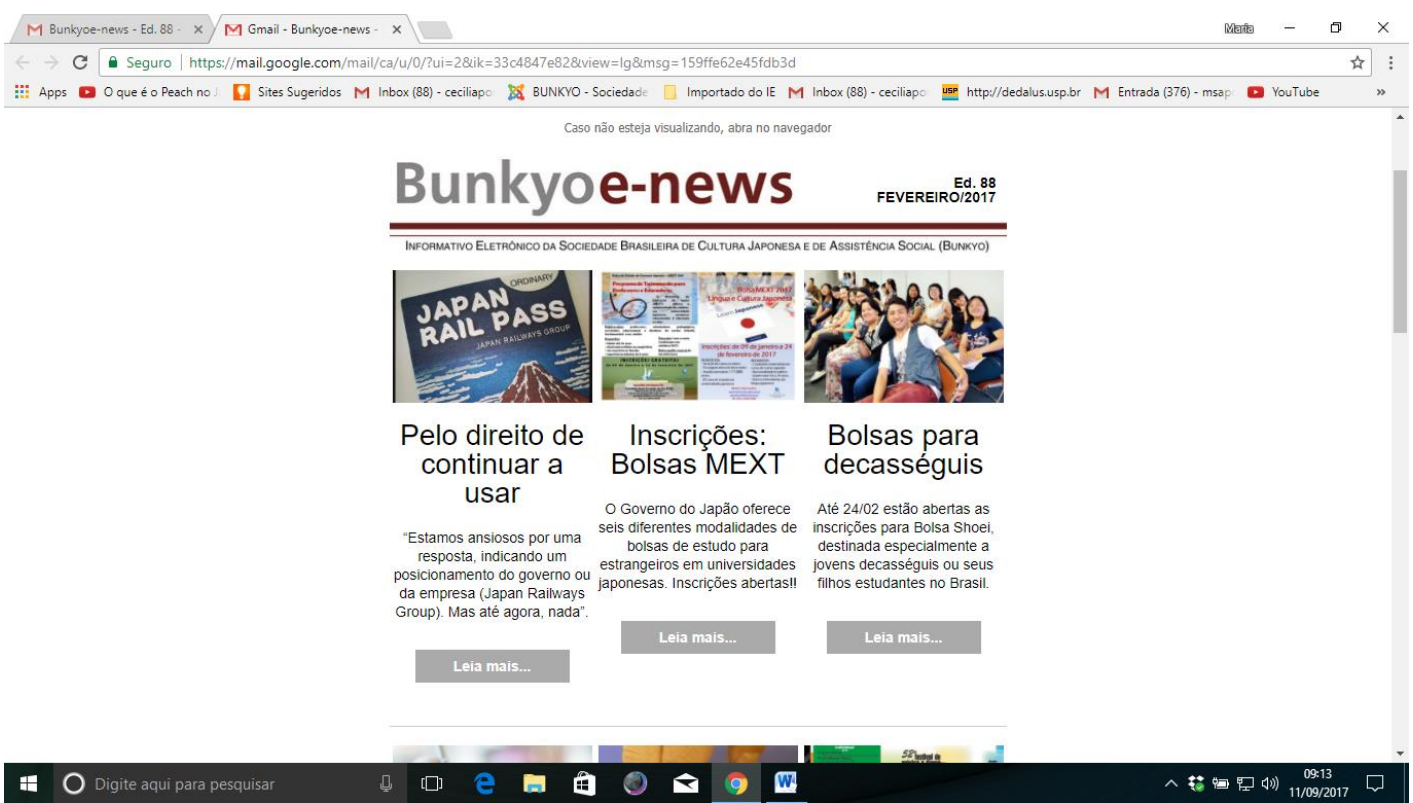

Edição de fevereiro de 2017 do Bunkyoe-news, enviada aos assinantes por e-mail 
A publicação mais recente do Bunkyo é o boletim trimestral on-line Bunkyo Empresarial, produzido pela Comissão de Relações Empresariais, criada em 2015. Segundo seus editores, a ideia da criação desse boletim surgiu em agosto desse mesmo ano, com a criação da comissão, cujo objetivo é aproximar-se das empresas, em especial das que promovem o intercâmbio Brasil-Japão, propiciando o surgimento de novos voluntários para a entidade. Essa aproximação sinaliza o retorno (pelo menos na intenção) a um relacionamento antigo do Bunkyo com as empresas japonesas e nipobrasileiras, que marcou o início e o desenvolvimento da entidade, sobretudo nas quatro primeiras décadas, quando aquelas empresas eram a principal fonte de lideranças e de recursos da entidade. Com a mudança do panorama econômico mundial e seu impacto sobre o perfil das empresas, o número de voluntários do Bunkyo decresceu, assim como sua autonomia financeira, embora os motivos desse decréscimo não se restrinjam às mudanças econômicas e seus reflexos sobre as entidades.

Os organizadores também querem proporcionar informações às pequenas empresas japonesas que estão instaladas ou que queiram se instalar no Brasil, como forma de ampliar a cooperação entre os dois países, que é uma das prioridades do Bunkyo. Os assuntos dos artigos, porém, não parecem focalizar temas que possam interessar certos nichos ou áreas específicas de atividade econômica, financeira e empresarial. Os artigos publicados nos últimos dois anos têm uma temática bastante variada, abordando desde o pioneirismo das atividades agrícolas dos imigrantes (como o reflorestamento, as plantações de chá no vale do Ribeira e da pimenta do reino e a criação do cooperativismo agrícola), em uma perspectiva histórica, até as questões energéticas no panorama atual e mundial, a situação educacional e previdenciária no Brasil e as mudanças econômicas vividas pelo Japão desde o final da Segunda Guerra. 


\section{Capítulo 4 - O Bunkyo e as narrativas da imigração japonesa e da comunidade nipo-brasileira}

Neste capítulo, procedo à análise de narrativa do corpus selecionado conforme a fundamentação teórica e métodos apresentados na introdução, de modo a explorar aspectos do projeto comunicacional (textos, falas, espaços e performances) do Bunkyo. Com isso, procuro seguir os objetivos da tese e discutir as hipóteses formuladas no início do trabalho. Foram selecionados para análise, em primeiro lugar, o IX FIB (Fórum de Integração Bunkyo), um evento anual de intensas trocas simbólicas, em que são ritualizadas várias das relações hierárquicas, políticas e afetivas entre os membros do Bunkyo e de outras entidades nipo-brasileiras, configurando-se assim em significativas "situações de comunicação" (CHARAUDEAU, 2012, p.67); em segundo lugar, os espaços, imagens e objetos que participam das montagens de ambientes no edifício-sede do Bunkyo, participando de forma concreta das narrativas da entidade; e, em terceiro, as mídias do Bunkyo, em especial uma página do seu site, em que analiso os textos e seus significados, além do impacto que a tecnologia digital exerce sobre os formatos e conteúdos das narrativas.

Conforme explicado na introdução, a finalidade dessa seleção é apresentar uma amostra representativa da dinâmica de construção e compartilhamento da narrativa da imigração japonesa e de outras histórias por meio das quais o Bunkyo procura manter a hegemonia dos significados, enquanto constrói o seu representado (a comunidade nipobrasileira) e seu legado (a cultura japonesa trazida pelos imigrantes). Assim, teremos o primeiro cenário narrativo: o cenário discursivo e performático do IX FIB; o segundo cenário narrativo: o cenário espacial-visual do edifício-sede do Bunkyo; e o terceiro cenário narrativo: o discurso midiático do Bunkyo na Internet.

\section{Primeiro cenário narrativo: o cenário discursivo e performático do IX FIB:}

Quem passasse em frente daquele edifício discreto, na esquina da Rua Galvão Bueno com a São Joaquim, naquele sábado chuvoso, não faria a menor ideia de que um 
acontecimento ali dentro reunia personagens de idades, interesses e ocupações tão variadas, vindas de Norte a Sul e de Leste a Oeste do país, e até do outro lado do planeta, para discutir um tema com certeza nunca discutido antes em nenhum lugar: "como japonesar em sua entidade". Como disse Anacleto Hanashiro, secretário-geral do Bunkyo e um dos anfitriões do evento, "japonesar é um neologismo inventado no Bunkyo, estamos aqui criando o conteúdo desta palavra". Na verdade, ela já havia sido usada dois anos antes, em edição anterior do mesmo evento, mas com uma pergunta diferente: “o que é japonesar para você?”.

Em 2015, o VII FIB (Fórum de Integração Bunkyo) queria, com essa pergunta, discutir as questões referentes à "cultura nipo-brasileira atual". Já no IX $F I B$, que ocorreu nos dias 7 e 8 de outubro de 2017, os organizadores trouxeram de volta a proposta de "japonesar", só que dessa vez a partir de uma perspectiva prática, aplicando $\mathrm{o}$ conceito às entidades nipo-brasileiras representadas no evento. $\mathrm{O}$ coordenador do fórum esse ano foi Fernando Matsumoto, que esclareceu que "japonesar é o ato de viver e vivenciar a cultura japonesa, e cada um e cada entidade tem seu modo de fazer isso" "188. Assim, a ideia do FIB é investir na integração das entidades dispersas pelo estado e pelo país, convidando representantes dessas entidades a passarem o fim de semana em São Paulo ouvindo apresentações, participando de atividades culturais e trocando ideias para que possam melhorar o desempenho de suas entidades.

O desempenho, porém, não tem a ver com as questões gerais de qualquer entidade, mas com algo que somente as associações nipo-brasileiras têm em comum: o compromisso de manter viva a cultura japonesa no Brasil. Embora a missão pareça simples, as entidades representadas no FIB relatam todo tipo de problema, desde a falta de recursos (humanos e materiais) até a falta de rumo, pois todos já passaram, em algum momento, por crises de desinteresse dos associados, de descrédito dos companheiros e até de definição sobre "quem" é o nipo-brasileiro (o mestiço conta? e o não descendente que gosta da cultura japonesa?) e "qual" é, concretamente, a missão das entidades (preservar a cultura do imigrante? do nikkei? do Japão tradicional? do Japão contemporâneo? do JPop? de tudo isso junto?)

No IX FIB, entretanto, assim como nos demais eventos promovidos pelo Bunkyo - e em quase todos os encontros humanos -, muitas coisas acontecem além do que está

\footnotetext{
${ }^{188}$ Ver em: http://www.Bunkyo.org.br/pt-BR/noticias/157-2017/1297-como-japonesar-em-sua-entidade-eo-tema-do-FIB-2017, acesso em 14/10/2017.
} 
na agenda e nos propósitos originais dos organizadores. Em uma reflexão sobre o “interacionismo simbólico”, Girardi Jr. (2016) relaciona a experiência da comunicação a uma "complexa rede de jogos e ritualizações socialmente situadas" (2016, p. 224). Esses encontros do Bunkyo são, de fato, dramatizações que expõem e reforçam papéis e lugares sociais, em uma dinâmica de "trocas simbólicas" - como diz o autor - que marca a proeminência de certos personagens, as hierarquias e os significados dos gestos, das palavras e das maneiras como são utilizados os espaços e os objetos.

O FIB é, portanto, um ritual comunicacional em que as falas e performances dramatizam a relação entre seus membros, sendo que o que está sendo ritualizado, entre outras coisas, é a relação entre a autoridade dos mais velhos - cujo poder está simbolicamente representado nos cargos que exercem, nos espaços privilegiados que ocupam no auditório, na prioridade das falas e nas reverências prestadas por seus interlocutores de idade ou posição inferior - e o soft power da juventude, que é o seu poder inerente sobre o futuro e sobre a continuidade do projeto do Bunkyo. Outro aspecto essencial dessa ritualização é a relação entre Brasil e Japão: logo na abertura do evento, as autoridades - entre elas, a cônsul-adjunta do Japão e a presidente do Bunkyo - no palco, à frente das bandeiras dos dois países, e os demais na plateia, todos de pé, ouvem o hino nacional do Japão (Kimi ga yo) e o do Brasil.

As formas diversas de "japonesar" também são performances ou dramatizações do que vem a ser "japonês no Brasil hoje", como as atividades de "taissô" (condicionamento corporal, ou ginástica), de haicai e de grupos circulantes em que os participantes conversam com pessoas diferentes sobre como têm "japonesado" em suas entidades. E, além destas, houve ainda as performances fora das atividades programadas, com as trocas de telefones e endereços, de ideias e de planos para futuros encontros.

Esta pesquisa de campo, realizada por meio de "observação participante”, ilustra um momento especial em que o Bunkyo, como anfitrião, comanda mais um desses rituais de trocas simbólicas, em que reforça seu papel de liderança entre as comunidades nipo-brasileiras, seu orgulho pelos filhos bem sucedidos, seu compromisso com os antepassados e seus laços oficiais com o Japão. Conforme explicitado na metodologia, o material colhido nesta pesquisa de campo - as performances, falas e rituais praticados pelos participantes do IX $F I B$ - é analisado como parte integrante da narrativa difundida 
pelo Bunkyo sobre a imigração japonesa no Brasil e a missão de transmitir o seu legado aos descendentes e à sociedade brasileira como um todo.

\subsection{Pioneiros e "virtudes japonesas"}

Um porteiro discreto, na entrada do edifício, apontava para o elevador enquanto informava aos que chegavam que o $F I B$ acontecia no "salão nobre", no segundo andar. Lá, os participantes eram recepcionados por funcionários e voluntários que distribuíam crachás e pastas com logotipo do IX FIB contendo bloco de papel, caneta e material de divulgação dos eventos do Bunkyo e entidades parceiras. O formato do salão é de palco em plano levemente mais elevado em relação aos assentos da plateia, com áreas livres em ambos os lados (onde ficavam, do lado direito, as mesas dos organizadores e, do esquerdo, o espaço do coffee break). Os participantes ocupavam as cadeiras ou ficavam atrás da plateia, de pé ou sentados em bancos improvisados que na verdade não eram bancos, mas caixas de madeira cuidadosamente polida em tamanhos diferentes onde são expostos, em outras ocasiões, arranjos de Ikebana e objetos de arte.
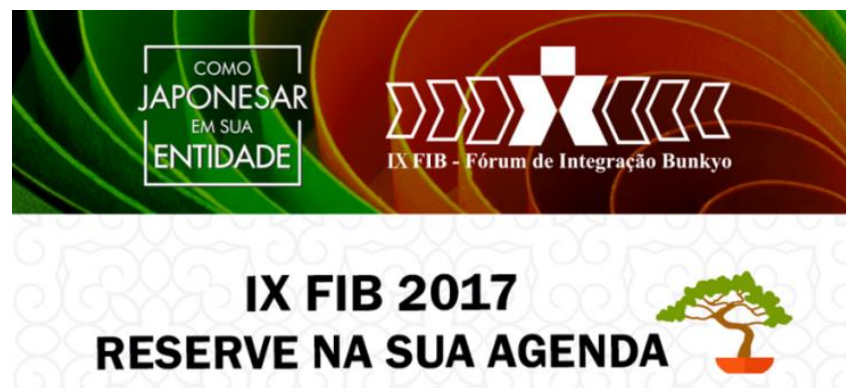

\section{EVENTO FIB}

Data: 7 e 8 de outubro de 2017

Local: Bunkyo - São Paulo

Aguarde para mais informações

REALIZAÇÃO:

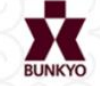

Figura 1: Mensagem de divulgação do evento FIB na sua página de Facebook. 
A primeira fileira de assentos tinha um aviso de "reservado", onde se acomodaram a presidente e a diretoria do Bunkyo, a convidada mais ilustre, a cônsuladjunta do Japão em São Paulo, representantes dos patrocinadores e outros convidados. Atrás deles, nas demais cadeiras, sentava-se quem quisesse, mas, assim como nas edições anteriores do $F I B$, a maioria dos mais jovens se aglomerava no fundo, ficando nas cadeiras, geralmente, os mais velhos. A diversidade dos participantes era visível: “jovens de todas as idades”, como diziam os apresentadores, de 17 anos (a mais jovem) às cabecinhas brancas (de idade não revelada), a maioria descendente de japoneses, mas também muitos não descendentes, interessados em diferentes aspectos da cultura ou da história do Japão.

Essas pessoas vinham de Campo Grande, Belo Horizonte, Florianópolis, Rio de Janeiro, Porto Alegre, Salvador e vários municípios paulistas, como os da "Alta Sorocabana" $" 189$, entre outros lugares. No palco, revezavam-se os palestrantes e os representes de entidades que eram chamados a dar seu testemunho. Segundo revelou um dos palestrantes do evento, aquele palco foi projetado nas medidas do teatro kabuki, uma modalidade tradicional de arte cênica japonesa que se desenvolveu no período Edo (1600-1868) ${ }^{190}$. Naquele palco também acontecem apresentações da cerimônia do chá, em dias de festividade especial, como o Bunka Matsuri (festival cultural), e solenidades de homenagem a autoridades, como as boas-vindas ao primeiro-ministro Shinzo Abe, que visitou o Bunkyo em 2014, e ao novo embaixador Akira Yamada, que chegou ao Brasil em agosto de 2017.

\footnotetext{
${ }^{189}$ Região oeste do estado de São Paulo que se desenvolveu a partir da década de 1920, em torno da Estrada de Ferro Sorocabana. Abrange municípios como Presidente Prudente, Álvares Machado, Presidente Epitácio, Assis e Rancharia. Teve grande presença de imigrantes japoneses na implantação das culturas de algodão, café e amendoim.

${ }^{190}$ Fonte: Embaixada do Japão no Brasil. Ver em: http://www.br.emb-japan.go.jp/cultura/kabuki.html
} 


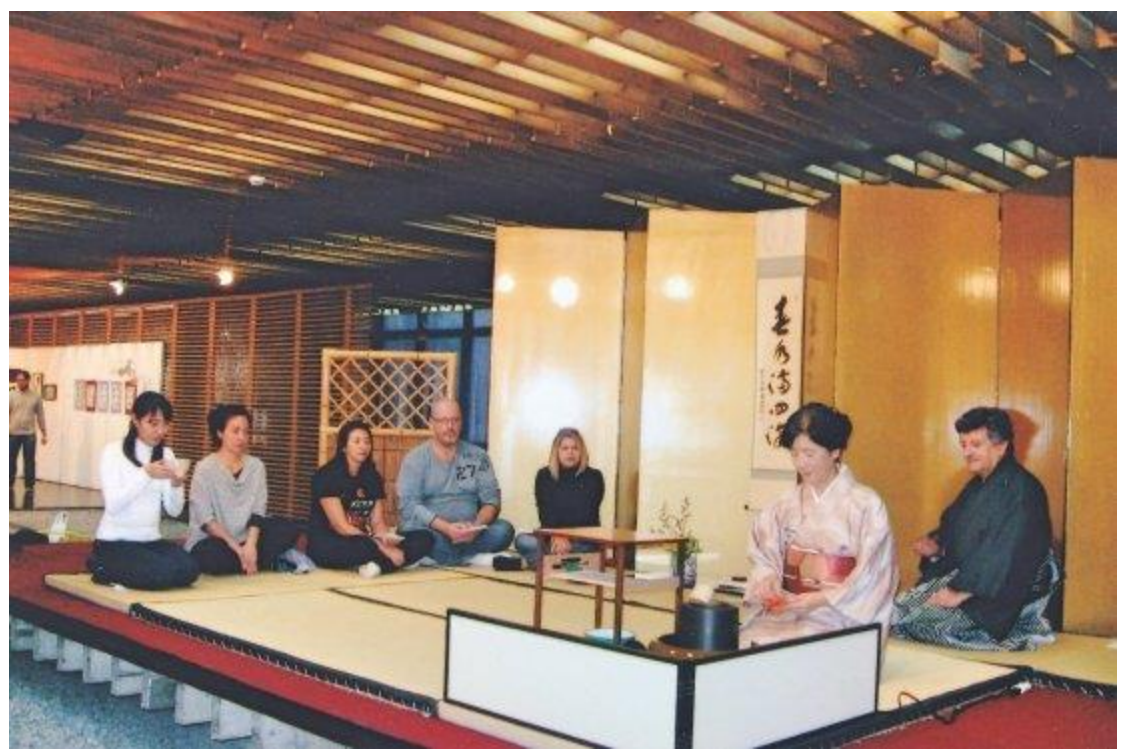

Foto 1: Cerimônia do chá no Bunka Matsuri, no palco do salão nobre. Fonte: Chado Urasenke Brasil

A presença de representantes do governo japonês nos eventos do Bunkyo não é exceção, mas regra. Não há evento de médio ou grande porte em que pelo menos algum representante ou o próprio titular do consulado não esteja presente. Nesse IX $F I B$ não foi diferente. Depois das palavras de abertura, proferidas pela presidente e pelos diretores do Bunkyo, a cônsul-adjunta Hitomi Sekiguchi, representando o governo do Japão, foi chamada a fazer a primeira palestra do fórum. Diferente dos outros representantes do governo japonês, a cônsul-adjunta, embora japonesa também, fala português sem sotaque, como uma brasileira. Ela explicou que viveu no Brasil durante alguns anos da infância e que em seguida fez faculdade no país, tendo assimilado a fluência e a sonoridade da língua.

Em sua fala, ela exaltou a atitude dos organizadores e participantes do encontro, que estão levando adiante a cultura "dos pioneiros" às famílias que, depois de três ou quatro gerações, já vivem longe da tradição. Sugeriu, também, que "veteranos" e jovens possam "comer da mesma tigela", uma antiga expressão japonesa que significa, mais ou menos, "alimentarem-se juntos das ideias uns dos outros", para que se ajudem a encontrar maneiras de inspirar as novas gerações que estão distanciadas da comunidade a se interessarem pelo Japão e pela participação em associações nipo-brasileiras. Lembrou que os decasséguis que retornam são verdadeiros japoneses no Brasil, e que também eles, ao transmitir a cultura japonesa no país, estão “japonesando". 


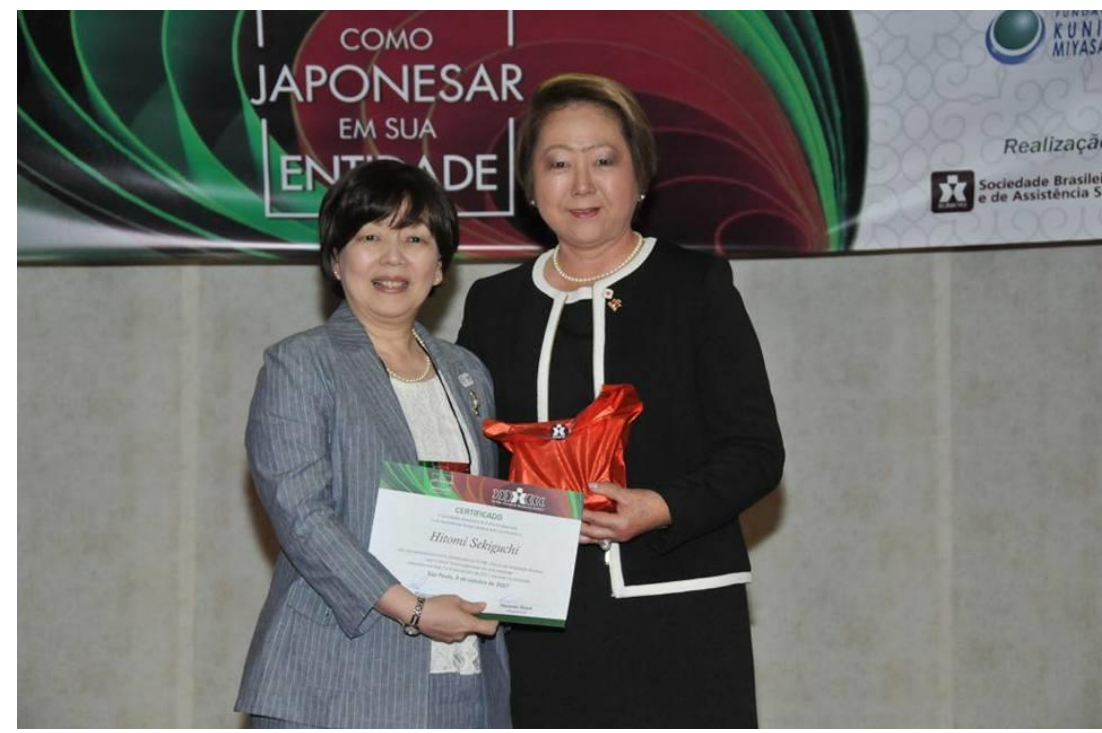

Foto 2: cônsul-adjunta Hitomi Sekiguchi (à esquerda) e a presidente do Bunkyo, Harumi Goya. Fonte: Aldo Shiguti/FIB

Quanto à participação do governo japonês nesse esforço conjunto, a cônsuladjunta citou as bolsas de estudo concedidas a jovens nikkeis para visitar ou fazer cursos no Japão. De mil candidatos que se inscreveram na edição mais recente do concurso de bolsas (2017), só 11 foram contemplados, o que ela reconhece que é muito pouco. Uma forma indireta de atingir essa grande maioria que ficou de fora, segundo ela, seria apoiar as atividades de suas entidades, favorecendo conexões e facilitando outras oportunidades de realização de projetos que disseminam a cultura japonesa no Brasil. Ela informou aos participantes que já estava disponível no site do Consulado Geral do Japão em São Paulo uma versão traduzida do relatório do "Painel de intelectuais sobre a colaboração com as comunidades nikkeis na América Latina e no Caribe", assinado em 9 de maio de 2017. O documento relata as considerações dos participantes do painel quanto às formas de apoio do governo às entidades, já que "a atuação dos nikkeis constitui um patrimônio material e imaterial para o Japão, sendo os nikkeis uma 'ponte' que liga o Japão com seus países"191.

Depois da entrega de presente e diploma de participação à cônsul-adjunta, e da sessão de fotos (ritual que se repetiu no final de todas as apresentações), foi chamado ao palco um outro frequentador assíduo dos eventos da entidade, embora resida no Japão. Reforçando a mensagem que já havia trazido em edições anteriores do FIB, Masayoshi

${ }^{191}$ Ver em: http://www.sp.br.emb-japan.go.jp/files/000296445.pdf, acesso em 12/10/2017. 
Morimoto conclamou mais uma vez os participantes do $F I B$ a disseminar as "virtudes japonesas" como forma de japonesar em suas vidas pessoais e em suas entidades. Como diretor-gerente da Kaigai Nikkeijin Kyokai (associação dos nikkeis e japoneses no exterior $)^{192}$, Morimoto tem trabalhado pelo intercâmbio entre o Japão e os países com populações de origem japonesa, com seminários, programas de treinamento, de ensino da língua japonesa e distribuição de material didático, como forma de manter e incentivar os elos entre os nikkeis e o país de seus ancestrais.

Palavras e expressões que, segundo Morimoto, se tornaram ao longo dos séculos símbolos da ética japonesa, como honestidade, diligência, devoção filial, seriedade, esforço, coragem e força de vontade, foram disseminadas pelo mundo através dos imigrantes, que, graças a essas virtudes, conseguiram vencer as adversidades e ser respeitados nos países que os receberam. O conselho de Morimoto, sobretudo aos jovens nikkeis, é que resgatem essas "virtudes japonesas" e as coloquem em uso, como forma de retribuição ao muito que receberam da cultura de seus ancestrais, e para continuar japonesando através de suas entidades.

Expressando-se em português misturado com espanhol, Morimoto é, ele próprio, um exemplo de encontros culturais: ele nasceu no Japão, sua esposa, na Argentina, e a filha, nos Estados Unidos. Suas viagens constantes ao Brasil, conta, já "abrasileiraram" sua estrutura mental. Quando está em Tóquio, tem que ir frequentemente a um café ou restaurante brasileiro, ou fazer algo que o faça sentir-se no Brasil. Vai mostrando, no Power Point, expressões em japonês como "majime ni yaru" (fazer com seriedade), "mottai nai" (não desperdiçar), "gambaru" (esforçar-se) e outros itens da lista das virtudes japonesas que deveriam inspirar os nikkeis, mas lembrando ao mesmo tempo que suas "virtudes brasileiras" - como flexibilidade e vivência multicultural - também podem ajudar o Japão - através deles - a vencer a sua dificuldade crônica para os negócios globais, por serem os japoneses "reservados" demais.

Prosseguindo na linha de buscar nos "valores japoneses" uma resposta para o que vem a ser "japonesar na sua entidade", o coordenador do IX FIB, Fernando Matsumoto, lançou, em sua palestra, um desafio: identificar "o que parece que é, mas é só casca", e o que é "conteúdo". Como exemplo, citou o caso de um brasileiro que

\footnotetext{
${ }^{192}$ O nome da entidade no site em português é Associação Kaigai Nikkeijin Kyokai. Em inglês, porém, é The Association of Nikkei and Japanese Abroad, motivo pelo qual traduzi por "Associação dos nikkeis e japoneses no exterior". Ver em: http://www.jadesas.or.jp/pt/, acesso em 14/10/2017.
} 
ganhou o primeiro lugar em um concurso de receitas, com a criação de um "udon à caponata", ou seja, introduzindo um elemento da culinária japonesa (o udon) na cultura gastronômica brasileira, que também inclui aspectos da tradição italiana (a caponata). Assim, embora a aparência do brasileiro (a "casca") demonstrasse que era $0 \%$ japonês, a sua prática (o "conteúdo") tinha “500\% de afinidade com o que é japonesar".

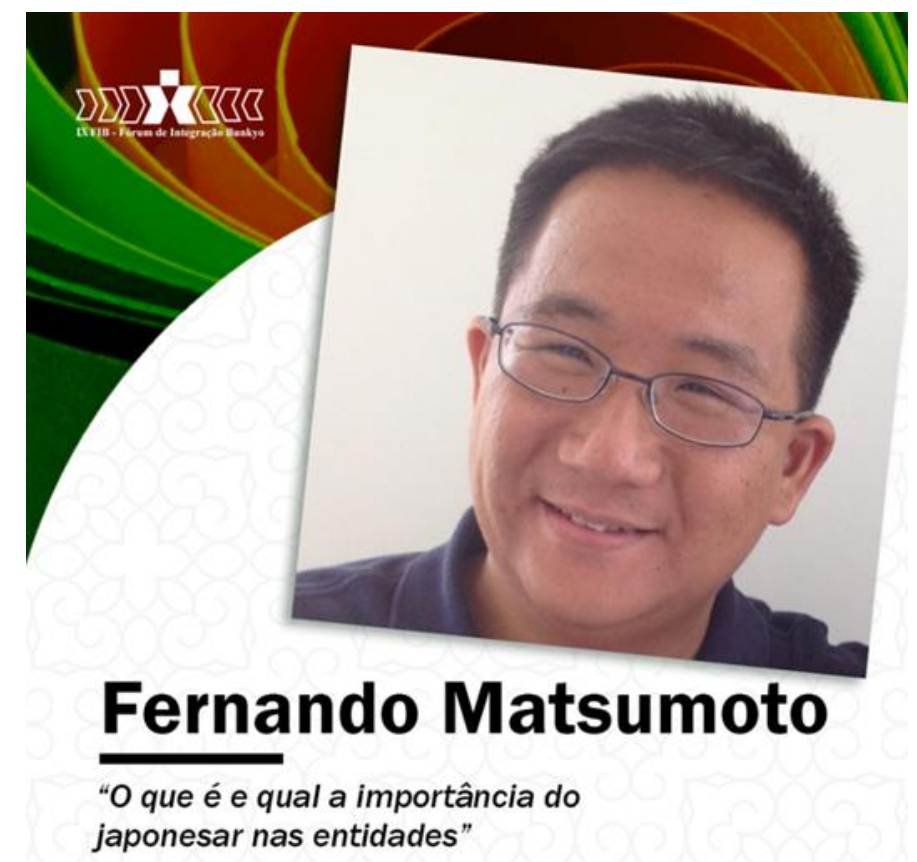

\section{Figura 2: palestra do coordenador do evento, Fernando Matsumoto}

Matsumoto conta que nunca estudou japonês nem praticou judô ou qualquer outro aspecto da cultura japonesa no Brasil, mas descobriu o quanto havia assimilado os valores japoneses assimilados pela sua educação familiar quando foi visitar o Japão e sentiu, "logo ao descer do avião que fazia parte daquele mundo". Mas ele lembra que, se para um descendente educado nos valores japoneses essa identificação costuma ser um processo natural, para o não descendente a identificação não é impossível, pois ele pode “criar estas referências". Assim, ele diz que a carga genética pode ser importante quando o assunto é “japonesar”, mas não é essencial, pois há descendentes que já cortaram os laços com sua ancestralidade, e há não descendentes que abraçaram aspectos da cultura japonesa como se fossem seus.

Já os conflitos geracionais estão, para Matsumoto, entre os problemas que mais dificultam o desempenho dos kaikans (entidades). As visões e os modos de agir dos mais velhos dificilmente correspondem às expectativas dos mais novos, e a esse impasse ele responde com uma sugestão bem diferente: que cada um descubra o que 
gosta e faz melhor e transforme essas habilidades em um "propósito" a ser aplicado na vida e na entidade, fazendo dessa oportunidade uma forma de japonesar, ou seja, de achar o Japão dentro de si. Assim, Matsumoto sugere que, em vez de focar nos problemas, os participantes devem fazer dos kaikans um lugar de realização de propósitos, seja na forma de palestras, de um Bunka Matsuri (festival cultural), ou qualquer outra atividade que os faça felizes, lembrando que “japonesar", muitas vezes, é plantar uma semente de algo que se vai colher muito depois.

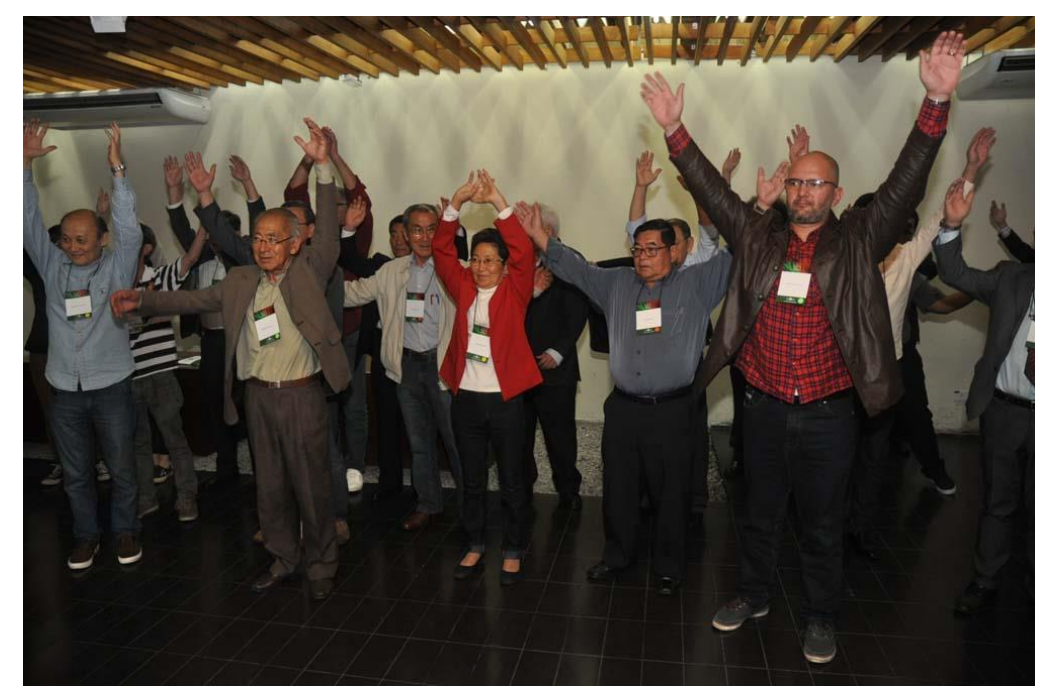

Foto 3: Taisô: momento para alongar os músculos.

\section{Fonte: Bunkyo}

Após a palestra de Matsumoto, os participantes foram convidados a se integrar a uma atividade de relaxamento com as técnicas do taisô, que nesse caso se resumia a alguns exercícios de respiração e alongamento, sob a liderança de duas jovens do Seinen. A atividade física era preparatória para o que vinha em seguida, uma dinâmica de grupos circulantes que começava com todos os participantes andando pela sala até um sinal, quando deveriam parar e formar grupos de cinco entre os mais próximos, para cada um se apresentar e dizer o nome da entidade que representa e o que veio buscar no FIB. Ao ouvir novamente o sinal, os grupos deveriam desfazer-se, e as pessoas, voltar a circular. E assim por diante, até que todos tivessem conversado, sempre de cinco em cinco, com o maior número de pessoas.

Os participantes vinham de vários municípios do estado de São Paulo e de outros estados do país; tinham idades variadas; alguns eram membros da diretoria ou de alguma comissão do Bunkyo e estavam ali para prestigiar o evento. Um rapaz carioca era adepto do haicai e veio ao FIB para difundir a poética japonesa em uma "atividade 
cultural" que se realizaria naquele mesmo dia, no final da tarde. Outro carioca era professor universitário, especializado em História das Guerras e em História do Japão, e mudara o foco de sua pesquisa sobre samurais para um estudo do rearmamento do Japão no pós-guerra; veio ao fórum para conhecer o Bunkyo e acabou descobrindo que um pesquisador de Belo Horizonte, também participante do FIB, trabalhava com o mesmo tema que ele. Uma jovem do município de Álvares Machado, onde existe o único cemitério exclusivamente japonês do país ${ }^{193}$, é filha de decasséguis que foram trabalhar no Japão quando ela era criança e retornaram há poucos anos. Apesar de ter se formado em Arquitetura, tornou-se professora de japonês e tinha acabado de ganhar da JICA uma bolsa de três meses no Japão.

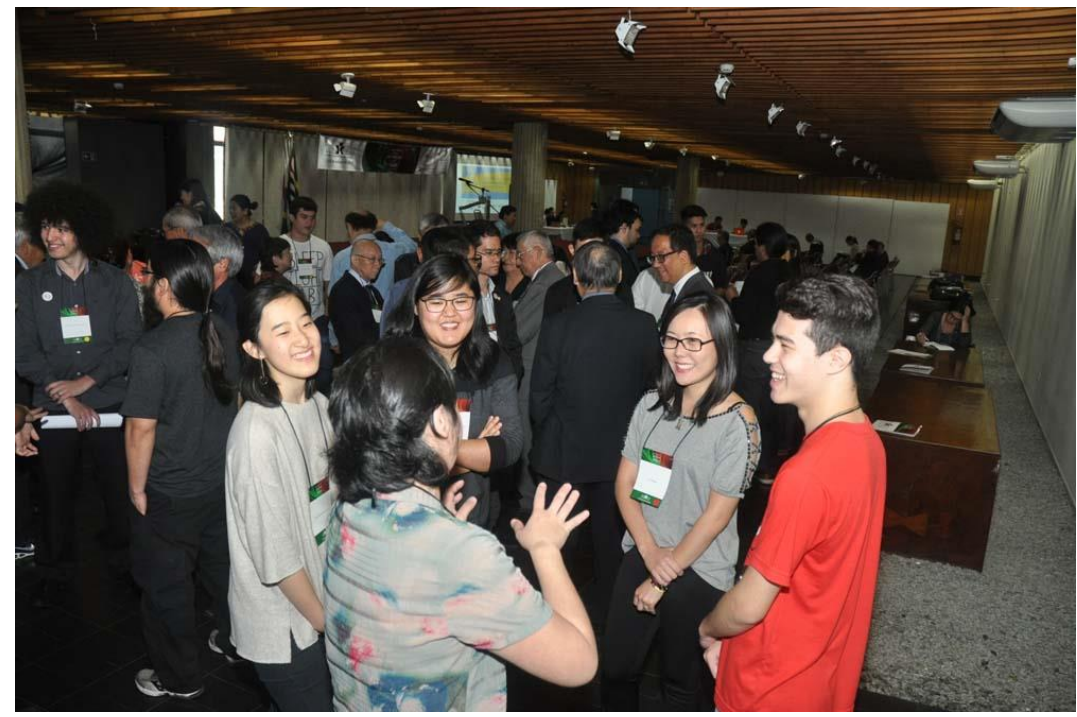

Foto 3: atividade de integração: conversas em grupo.

\section{Fonte: Bunkyo}

Uma estudante de Presidente Prudente veio ao FIB para trocar ideias com gente de outras entidades e, também, para buscar material sobre o Bunkyo para o seu TCC (Trabalho de Conclusão de Curso). Um professor aposentado de Campo Grande veio, a convite do Bunkyo, com a esperança de levar ideias para a revitalização da associação nipo-brasileira de sua cidade, onde, segundo ele, a participação de jovens está cada vez menor. Uma senhora de Salvador veio para o FIB para pedir sugestões de como integrar as entidades nipo-brasileiras em seu estado, dispersas em áreas muito distantes entre si. Um senhor de Porto Alegre veio contar, todo feliz, que apesar da população de origem

193 O cemitério foi fundado por membros da colônia japonesa em 1918, quando houve uma epidemia de febre amarela na região. Foi fechado em 1943 por ordem do governo de Getúlio Vargas, sob a acusação de segregação racial. Fonte: Museu Histórico Municipal de Álvares Machado. Ver em: http://www.pmmachado.com.br/museu_machado/cemiteriojapones.html, acesso em 15/10/2017. 
japonesa ser relativamente pequena em seu estado, as associações locais são ativas e passaram a organizar um festival anual de cultura japonesa que, em 2017, teve sua sexta edição, reuniu milhares de visitantes e já consta do calendário oficial da capital gaúcha. Contou também que nesse mesmo ano, durante o festival, foi celebrado $o$ cinquentenário da "irmandade" entre Porto Alegre e a cidade japonesa de Kanazawa, capital da província de Ishikawa.

Informações como essas - e muitas outras que não pude obter, pois não deu tempo de ouvir todo mundo - eram trocadas rapidamente durante os minutos em que os grupos se alternavam, com desenvoltura e animação por parte de alguns, e com timidez e poucas palavras por parte de outros, mas todos visivelmente curiosos sobre os detalhes das histórias e felizes por conhecer pessoas ou reencontrar quem não viam desde o $F I B$ anterior. Quanto à minha participação, foi realmente um ritual de integração - o que era, afinal, o objetivo da observação participante -, pois, de mera observadora marginal, passei a ser uma personagem do evento, pois muitos dos que me ouviram (como todos, eu também tinha que dizer o que estava fazendo ali) se interessaram pela pesquisa de Doutorado, pelas minhas motivações pessoais, e queriam saber o que eu pretendia fazer com a tese, etc. Trocamos cartões - que são entregues com ambas as mãos e com uma leve reverência, em ritual típico de qualquer evento japonês, assimilado até por não descendentes - e continuamos as conversas durante o almoço, o coffee break, o tour que fizemos pelas dependências do Bunkyo e também, depois do encontro, por e-mail.

\subsection{Na "linha de frente"}

Depois da animação da atividade de integração, todos foram chamados de volta aos seus lugares para uma nova rodada de palestras e testemunhos, sob o tema "O resgate da cultura japonesa e os novos desafios da comunidade nikkei”. A primeira a falar foi Márcia Nakano, presidente recém-empossada da JCI Brasil-Japão ${ }^{194}$, que exortou os jovens nikkeis a buscarem o significado dos 110 anos da imigração japonesa,

\footnotetext{
194 A Câmara Júnior Brasil-Japão (atual JCI Brasil-Japão) foi fundada em 24 de junho de 1982, por iniciativa da Câmara de Comércio e Indústria Japonesa no Brasil. A JCI (Junior Chamber International) é uma organização sem fins lucrativos de pessoas entre 18 a 40 anos comprometidas com suas comunidades.

Fonte: http://jcibrasiljapao.org.br/, acesso em: 16/09/2017.
} 
a serem celebrados no ano de 2018, e o seu papel nessas celebrações. Para ela, os 110 anos estão refletidos no imenso legado deixado pelos imigrantes, cuja transmissão para as futuras gerações deve ser providenciada agora, pelas novas lideranças que devem ocupar seus lugares na "linha de frente", ou seja, assumir as rédeas dos trabalhos de recuperação do que já se perdeu e do que está sendo esquecido.

Criada sob os valores japoneses tradicionais, Márcia aprendeu que uma moça deve falar em voz baixa, que jamais deve olhar uma autoridade nos olhos e que, depois de casada, a mulher deve ser a primeira a acordar e a última a dormir, além de também obedecer ao marido. Ela diz que não poderia repassar esses mesmos ensinamentos à sua filha pequena, pois "os valores devem estar alinhados com a época e com a sociedade em que se vive". Mas acredita que "o que a cultura japonesa tem de mais rico são os valores de respeito e solidariedade ao ser humano", presentes em atitudes de gentileza e atenção para com os outros.

Logo em seguida, Rodolfo Wada - um dos mais jovens membros da diretoria do Bunkyo - relatou alguns dos pontos discutidos em agosto passado no fórum promovido pelo JCI Brasil-Japão durante a $10^{\text {a }}$ Semana da Cultura Japonesa de Lins, sobre o mesmo tema dessa palestra: o resgate da cultura japonesa e os desafios da comunidade nikkei. O ponto de partida é que todas as reflexões sobre resgates e desafios levem em conta o contexto dos 110 anos da imigração japonesa, isto é, em relação à história e à cultura da qual fazem parte. Portanto, a primeira deliberação do encontro foi pela construção de projetos que envolvam a todos, para que cada membro da comunidade se sinta parte deles e participe das operações de resgate da cultura.

A segunda foi pelo enfrentamento de todo conservadorismo "negativo", ou seja, que se oponha à inovação das estruturas da comunidade e das associações, ressaltando, porém, que existem aspectos do conservadorismo que podem ser positivos. O terceiro ponto refere-se aos "tesouros" da cultura japonesa (humanos e materiais), que não podem ficar fechados, mas sim acessíveis a toda a sociedade. E o quarto e último ponto - em sintonia com o anterior - é que a missão de cada associação da comunidade nipobrasileira sirva à sociedade como um todo, e não apenas a si própria.

Depois de Márcia e Rodolfo, foi a vez de Alexandre Kawase dar sua opinião sobre o tema do resgate da cultura japonesa e dos desafios da comunidade nikkei. Membro, ele também, da JCI, chegou à mesma conclusão, de que a entidade nipobrasileira deve servir à sociedade, e não apenas à comunidade de descendentes. Na sua 
experiência, viu que trazer pessoas para trabalharem como voluntários em ações de cunho social tem revitalizado as associações, e que o "japonesar" acaba sendo uma consequência dessa revitalização. Assim, sugere que cada associação convoque seus membros para refletirem juntos sobre o que podem fazer por seu bairro, por sua cidade e por sua região. Atrair pessoas, diz ele, não pode ser na base da obrigação. As associações têm que se voltar aos jovens, de modo que se tornem um lugar onde eles tenham prazer de estar.

Isto se consegue, segundo ele, mantendo atividades adequadas a essa faixa etária e criando espaços para que eles possam participar das decisões, e se sintam parceiros daquilo que está sendo construído. A parceria, ele diz, gera envolvimento, cria laços. Assim, a entidade não só atrai novos membros, mas os mantém. Kawase levantou ainda um outro aspecto pouco lembrado nas discussões sobre a eficiência e sobrevivência das associações nipo-brasileiras, que, no entanto, não são as únicas a precisarem se preocupar com isso: a importância de melhorar e regularizar a infraestrutura da entidade, de profissionalizar os seus membros, de ter estatuto e conduzir os processos de sucessão com transparência. Quanto às maneiras de japonesar, devem estar adaptadas ao país onde se vive, pegando-se o melhor de cada um. No Brasil, diz ele, pode-se juntar, por exemplo, a hospitalidade à japonesa com a receptividade à brasileira: "temos mais unindo os dois do que ficando só com um”.

Ao final dessa palestra, foi anunciada a hora do almoço, e todos desceram um andar até um dos salões, que foi transformado em restaurante, com grandes mesas coletivas, e cada lugar já contendo um obentô, um par de hashis ${ }^{195}$ e uma latinha de guaraná. Em uma mesa lateral havia opções de bebida: chá mate, água e café. E também foi anunciado que os vegetarianos podiam pedir a troca de seu obentô, o que poucos fizeram (eu entre eles). Como as mesas eram longas, as pessoas só conseguiam conversar com quem estava à sua frente e ao seu lado, mas a animação foi grande mesmo assim, com gente levantando o tempo todo ou comendo em pé para poder se encontrar com amigos em lugares distantes dos seus. Nesses momentos, a costumeira formalidade que impõe o distanciamento respeitoso entre jovens e mais velhos nos ambientes da comunidade nipo-brasileira diminui sensivelmente ou até desaparece.

\footnotetext{
195 Obentô: comida japonesa em pequenas porções arrumada cuidadosamente dentro de uma caixinha, que se come fria; hashis: palitinhos, ou varetas usadas em vez de talheres no Japão e em outros países da Ásia.
} 
É como se instalasse ali um espaço/tempo especial em que as regras mais rígidas da hierarquia japonesa (reproduzida entre os nipo-brasileiros educados na maneira tradicional, como é o caso dos mais velhos, e que acaba se impondo também entre os mais jovens nas situações formais) se tornassem temporariamente suspensas, e todos fossem iguais (como dizia Roberto Da Matta sobre o carnaval brasileiro ${ }^{196}$ ). Também os não descendentes (cerca de 30\% dos presentes), ao compartilhar um almoço à japonesa com gosto e sem dificuldade com os hashis, se tornavam um pouco mais "iguais". A refeição foi o momento em que todos "japonesaram” espontaneamente, mas de um jeito oposto ao que se viu e ouviu no "salão nobre" durante a parte "séria" do trabalho. Com exceção de um senhor de uma entidade nipo-brasileira de Campinas, todos em volta de mim eram bem jovens. E a conversa, predominantemente, também foi sobre comida japonesa e uma certa padaria da Liberdade, que vende doces especiais que, segundo dizem, não se encontra em nenhum outro lugar, e sobre os restaurantes das imediações, que recomendavam uns aos outros por servirem comida japonesa boa e barata.

Um tour pelas instalações do Bunkyo estava programado para as $13 \mathrm{~h} 30 \mathrm{~min}$, com saída dali mesmo, da sala de almoço. Após alguma insistência, por parte dos organizadores, para que os presentes retornassem de suas mesas ou dos grupinhos onde conversavam animadamente, os participantes do encontro se reuniram em grupos depois de descobrirem que em seus crachás havia um adesivo em forma de bola de uma certa cor. Cada cor formava um grupo de pessoas, com um líder (todos membros do Seinen) que as guiava no passeio pelos nove andares do edifício principal do Bunkyo (aliás, oito, pois a instalação do museu no nono andar estava fechada para manutenção), e também no prédio anexo. Os grupos tinham um roteiro e um tempo aproximado em cada lugar, de modo que as instalações fossem ocupadas por um grupo de cada vez. Meu grupo foi direto para o grande auditório, onde as pessoas eram informadas que ali aconteciam as apresentações do Gueinosai (artes de palco tradicionais) e de outros festivais de cultura japonesa, de recepção de membros da família imperial e do governo japonês e muitas outras cerimônias importantes para o Bunkyo.

Com orgulho, o guia contou que o auditório tem lugar para 1.300 pessoas e que seus assentos são únicos, feitos sob medida e colocados um a um, por isso não podem

\footnotetext{
196 Embora as situações sejam completamente diferentes, foi deste livro de Da Matta (Carnaval, malandros e heróis) que me lembrei quando refletia sobre a suspensão temporária das regras sociais, em que o mundo oficial e suas formalidades deixam de ser um modelo obrigatório para a autoexpressão, e outros modos de ser podem aflorar, ainda que por tempo contado.
} 
ser substituídos por outros, pois só eles próprios se encaixam em seus espaços. Dali, o grupo percorreu outros lugares, como o futuro espaço multicultural, que está sendo construído com a ajuda de empresas que se beneficiam da Lei Rouanet, e que atualmente é usado em ocasiões como o Bunka Matsuri, para montagem das oficinas de origami, oshibana, shodô, furoshiki ${ }^{197}$ etc. O grupo visitou também o pequeno auditório, onde acontecem cerimônias menores e sessões de filmes japoneses (que a partir de 2017 ano têm legendas em português, como forma de ampliar o número de frequentadores do "Cine Bunkyo"), o ginásio de esportes, onde no momento eram dadas aulas de tênis de mesa (o famoso pingue-pongue), a biblioteca, onde alguns senhores idosos liam jornais em japonês (e onde alguns dos participantes mais jovens do grupo foram correndo ver a coleção de mangás e animês), até que finalmente chegou ao local mais aguardado do tour: o museu.

Estávamos no sétimo andar, onde uma outra guia nos introduziu ao museu, montado na forma de corredores em curva, que conduz a visita em uma linha do tempo que vai narrando, em murais de imagens, objetos, instalações e textos, em ambos os lados, a história que começa em meados do século XIX, quando os japoneses começam a sua diáspora em direção primeiro ao Reino do Havaí e em seguida às Américas. Parte do grupo se dispersou, pois cada um queria ver alguma coisa em especial, ou se demorar mais em uma peça ou outra do acervo. As primeiras peças a fazer grande sucesso foram as maquetes do Kasato Maru e do Brasil Maru, em caixas de vidro. Os guias informavam que o navio dos pioneiros (o Kasato Maru) não era, na verdade, um navio adequado para os imigrantes, pois se tratava de um navio-hospital russo que fora adaptado depois que o exército imperial japonês se apropriou dele como parte da dívida de guerra ${ }^{198}$. Já o segundo (o Brasil Maru) era originalmente um navio de carga e de passageiros, e a partir de então a viagem dos imigrantes pôde ser mais bem organizada.

As instalações sobre a "Vida de colono na fazenda de café", inspiradas em um quadro de Tomoo Handa, e o "Desbravamento de terras virgens", com várias espécies de animais silvestres empalhados, foram sendo apresentadas aos visitantes, que se encantaram ainda mais com a "cabana do imigrante", uma réplica de moradia rústica, com paredes de troncos de árvores e chão batido, e cobertura de sapé, que, em alguns aspectos, é idêntica a uma casa da gente pobre do interior, com fogão à lenha, panela de

${ }^{197}$ Origami: dobradura em papel; oshibana: artesanato com folhas e flores secas; shodô: caligrafia de ideogramas japoneses com pincel; furoshiki: técnica de embrulho de presentes com tecido.

${ }^{198}$ Trata-se da guerra russo-japonesa (1904-1905), vencida pelo Japão. 
barro e cestas de vime, mas, em outros, reproduz a casa japonesa, como os tatames no quarto, os futons dobrados, as sandálias de palha e o retrato do imperador e da imperatriz na parede.

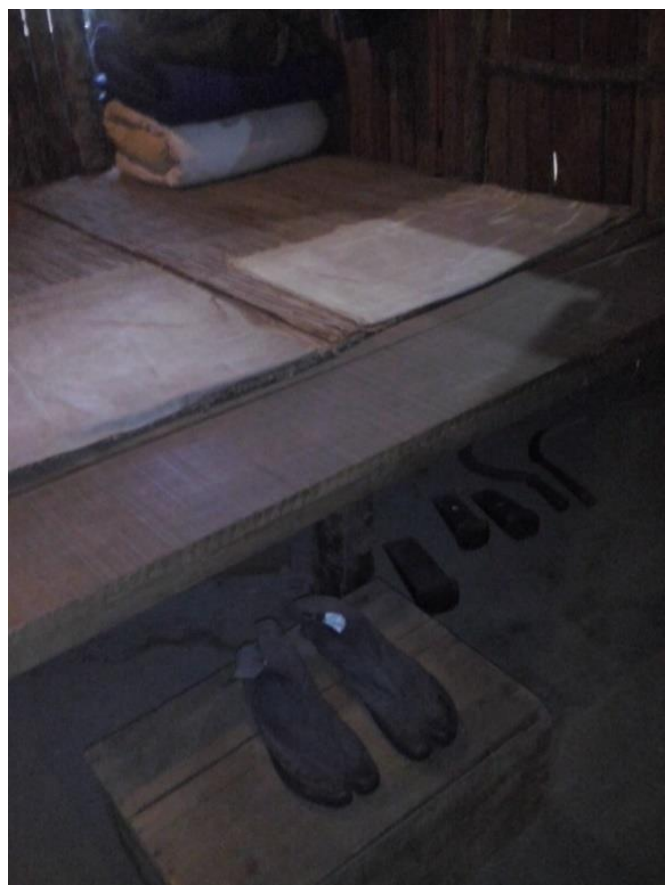

Foto 4: interior da cabana do imigrante.

Fonte: fotografia da autora.

No oitavo andar, as exposições narram o processo de adaptação do imigrante com novas formas de produção agrícola, a união em cooperativas e a mudança para as cidades. Em determinada altura, respondendo a uma pergunta de uma pessoa do grupo, o guia comentou que a "vida do imigrante japonês no Brasil não foi nada fácil", e que seus "sacrifícios teriam sido esquecidos" se os diretores e membros do Bunkyo não tivessem tomado a iniciativa de começar um grande projeto de reunir objetos e documentos que contassem essa história aos seus descendentes e ao povo do país que os acolheu. Ele contou, então, que as empresas transportadoras e cooperativas de membros da comunidade nipo-brasileira iam buscar as doações em várias partes do estado e do país, para constituir o acervo do museu, inaugurado em 1978 pelo então príncipeherdeiro Akihito.

Continuando com a narrativa que se desenrolava nos corredores, os visitantes se depararam com "o túnel chamado guerra", uma parte do corredor com teto rebaixado e paredes projetadas para frente, tudo em cor cinza metálica, de modo que os visitantes 
sentissem um pouco da sensação de "opressão" que foi vivida pelos imigrantes durante os anos da Segunda Guerra, quando foram proibidos de frequentar suas escolas, produzir jornais em japonês e até falar japonês em público. Essa parte da exposição tem diversas imagens, objetos e documentos sobre a guerra no Pacífico e na Europa, e sobre os conflitos entre derrotistas e vitoristas no Brasil. Ao sair do "túnel”, os visitantes puderam ver as imagens e objetos de uma nova era, o "amanhecer da sociedade japonesa do pós-guerra", quando a colônia pôde novamente ler jornais, falar publicamente em japonês e receber a visita de celebridades japonesas no Brasil.

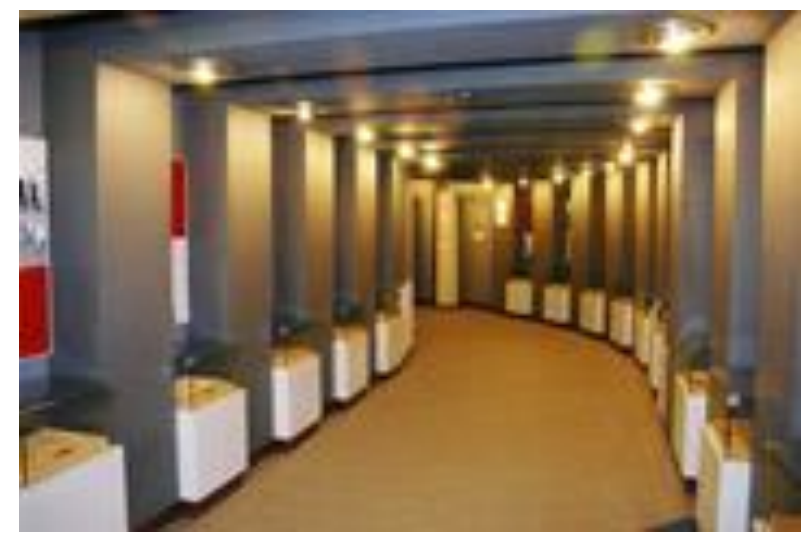

Foto 5: o "túnel chamado guerra".

\section{Fonte: Museu Histórico da Imigração Japonesa, Bunkyo.}

Finalizado o tour, e após um intervalo animado de trinta minutos em torno da mesa de bebidas, sanduíches, pães de queijo, biscoitos e bolos do coffee break, os participantes do IX $F I B$ foram convocados mais uma vez a voltar às suas cadeiras para participarem de uma "mesa-redonda". Na verdade, não havia mesa, nem os participantes sentavam-se em círculo (o que obrigaria alguns deles a ficarem de costas para as pessoas que os assistiam), mas, segundo um deles, o formato era de propósito um semicírculo para que a plateia se tornasse a outra metade do círculo, e assim sua participação nas conversas formaria a imaginária "mesa-redonda". No palco, jovens que atuam no Seinen, na organização do $\operatorname{REVI}^{199}$ e de associações nipo-brasileiras do interior foram apresentados em extensos currículos que ressaltavam sua formação educacional, títulos acadêmicos, atividades profissionais e experiência nas entidades nipo-brasileiras, o que, aliás, foi a regra em praticamente todas as apresentações, antes e depois desta.

\footnotetext{
199 "Revitalização - Fórum nacional de jovens líderes das entidades", ou REVI, promovido anualmente pela Comissão de Jovens do Bunkyo desde 1997.
} 
Os apresentadores dessa "mesa-redonda" falaram sobre o próximo fórum, do qual estariam participando dali a cinco dias, no Centro Esportivo Kokushikan Daigaku, no município de São Roque, e como os propósitos daquele fórum, em grande parte, coincidiam com os deste. Como o tema do REVI daquele ano seria "Diversidade cultural", um dos pontos ressaltados, mais uma vez, foi a participação dos não descendentes nas entidades de cultura japonesa e seu papel no futuro da comunidade nipo-brasileira. Já o pessoal do interior (de Presidente Prudente) tinha um problema específico: atrair mais jovens para a entidade, o que conseguiram criando um ambiente favorável à construção de novas amizades e de experiências divertidas e sem formalidades. Apesar da oposição e descrédito de membros das associações, tiveram sucesso na criação de um $F I B$ regional, atraindo cerca de 180 participantes de vários municípios vizinhos.

A questão de "como japonesar" foi explorada pelo grupo, e cada um contou alguma experiência já vivida nas entidades: um jogo de palavras em japonês que valia prêmio, apresentações de músicas e brincadeiras que alguém aprendeu no Japão, e até a prática do karaokê, que geralmente faz bastante sucesso com pessoas de todas as idades. Outra forma de "japonesar" é participar dos festivais de cultura japonesa, com apresentações de taikô, artes marciais e outros aspectos que atraem os jovens. No final das apresentações, Roberto Nishio, representante da fundação patrocinadora, pegou o microfone para elogiar o esforço e a capacidade de liderança de todos, animado com a perspectiva de que "a nossa cultura não vai morrer, pois jovens de valor como vocês estão à frente".

A última atividade do dia, sobre o haicai, foi apresentada por quatro rapazes do Rio de Janeiro, todos não descendentes, ligados ao Grupo de Estudos Japoneses da UFF (Universidade Federal Fluminense). Admiradores ou praticantes do haicai e estudiosos de diferentes aspectos da história e da cultura do Japão, eles começaram a exposição com um breve histórico do que vem a ser essa modalidade da poética japonesa, que teve como principal mestre o poeta Matsuô Bashô, que viveu no século XVII. Enquanto um dos membros do grupo ia explicando no palco as origens e as características desse tipo de poema, inspirado no zen budismo, os outros membros do grupo circulavam - cada um em um lugar da plateia - declamando haicais, em japonês e português: "uma cai/ duas caem/ ah, camélias"; "a flor morta/ no fim do inverno/ ressuscita"; "yuku haru ya/ 
tori naki uo nol me wa namida"200. Por ser muito curto, eles explicam, o haicai é como um flash, a percepção de um instante, por isso nos ensina a valorizar "os pequenos grandes momentos do cotidiano", e inspiram o autoconhecimento. "O que é japonesar?" - um dos jovens pergunta. “O haicai responde!” “É ver o que ele é, praticado ao mesmo tempo no Brasil e no Japão!"

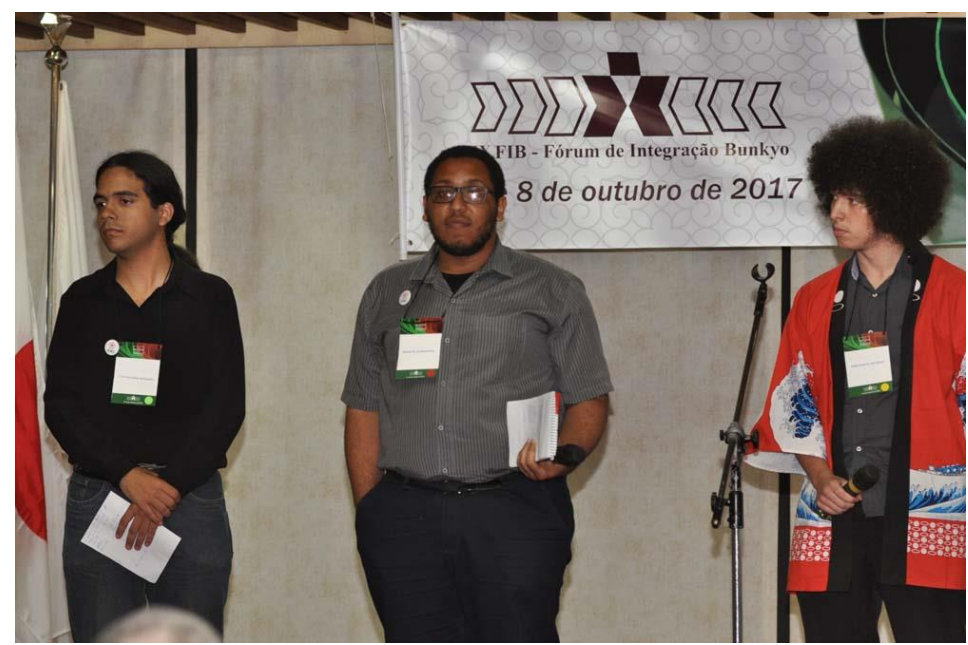

Foto 6: os haicaístas do Rio: Erick Ciqueira, Mateus Nascimento e Pedro Ribeiro.

\section{Fonte: Bunkyo}

O domingo começou cedo, com café da manhã animado e apresentação de Hideko Honma, ceramista nipo-brasileira famosa, que compartilhou alguns segredos da prática da cerâmica, alguns deles aprendidos no Japão. No final do encontro, ela doou ao Bunkyo algumas de suas peças, que foram sorteadas entre os presentes. Em seguida, foi apresentado o novo "pilar jovem"201 do Bunkyo, que, por meio de iniciativas e projetos recém-criados, promete ampliar o espaço e a participação das novas gerações no presente e no futuro da entidade. Uma dessas iniciativas é a criação de uma comissão de cursos e palestras que quer utilizar melhor o "capital intelectual" das 32 comissões do Bunkyo para divulgar seus conhecimentos sobre a cultura japonesa entre os membros da comunidade e a sociedade brasileira em geral. Já houve um curso-piloto, sobre o teatro kabuki, e vai haver mais um, sobre a história do decasségui, para testar os formatos. A ideia é difundir esses conhecimentos para as pessoas terem maior prazer,

\footnotetext{
200 Tradução de Meiko Shimon: "Vai-se a primavera!/ Pássaros cantam, e lágrimas/ nos olhos dos peixes". Este poema não foi declamado pelos rapazes, mas, como não consegui anotar nenhum dos que eles declamaram em japonês, incluí este, do livro de viagens de Bashô, publicado em 1694, para o leitor poder sentir a sonoridade (de 5, 7 e 5 sílabas cada) desse tipo de poema em japonês. Ver em: BASHÔ, M. Trilhas Longínquas de Oku, p. 19. São Paulo: Escrituras, 2016.

${ }^{201}$ Referência aos três Pilares da Entidade (Administrativo, Cultural/Social e Relacionamento), que com a adição do "Pilar Jovem", agora são quatro.
} 
compreensão e motivação ao assistirem uma apresentação de cultura japonesa, e também para usufruírem dos seus ensinamentos.

A presidente da Japan House, Angela Hirata, seria a próxima a falar, mas, como teve um impedimento de última hora, quem assumiu o microfone foi o seu diretor de operações, Cláudio Kurita, um dos filhos "da casa", como ele se referia ao Bunkyo por ter sido por vários anos um dos líderes do grupo de jovens e também seu presidente, e depois membro da diretoria da entidade. Depois da apresentação de seu extenso currículo, Kurita mostrou alguns vídeos institucionais da Japan House (disponíveis, conforme ele contou, no site da entidade e no YouTube) e comentou que era um "orgulho para a comunidade nipo-brasileira" que a primeira Japan House - que será construída posteriormente também em Los Angeles (esta com inauguração prevista para janeiro de 2018) e em Londres - tenha sido feita no Brasil.

Para ele, o fato de a comunidade nikkei do Brasil ser a maior do mundo, e também a mais engajada no avanço e no aprofundamento das relações do seu país com o Japão, teve um peso decisivo na escolha do Brasil como primeiro país a sediar uma Japan House. As conexões dessa instituição com a comunidade nipo-brasileira também se estendem em vários tipos de parcerias, diz Kurita, como, por exemplo, a realização conjunta da Japan House e do Centro de Chadô Urasenke do Brasil de uma cerimônia do chá, prática secular japonesa, em uma instalação de arte moderna - na exposição "Eterno efêmero", de Kengo Kuma -, sob um balão coberto por um tecido levíssimo, do qual é feito, segundo uma lenda japonesa, a túnica celestial dos anjos ${ }^{202}$.

\footnotetext{
202 Jornal Nippak. Ver em: http://www.portalnikkei.com.br/cultura-japan-house-sao-paulo-realizasessoes-de-cerimonia-do-cha-em-parceria-com-o-centro-de-chado-urasenke-do-brasil/, $\quad$ acesso em 20/10/2017.
} 


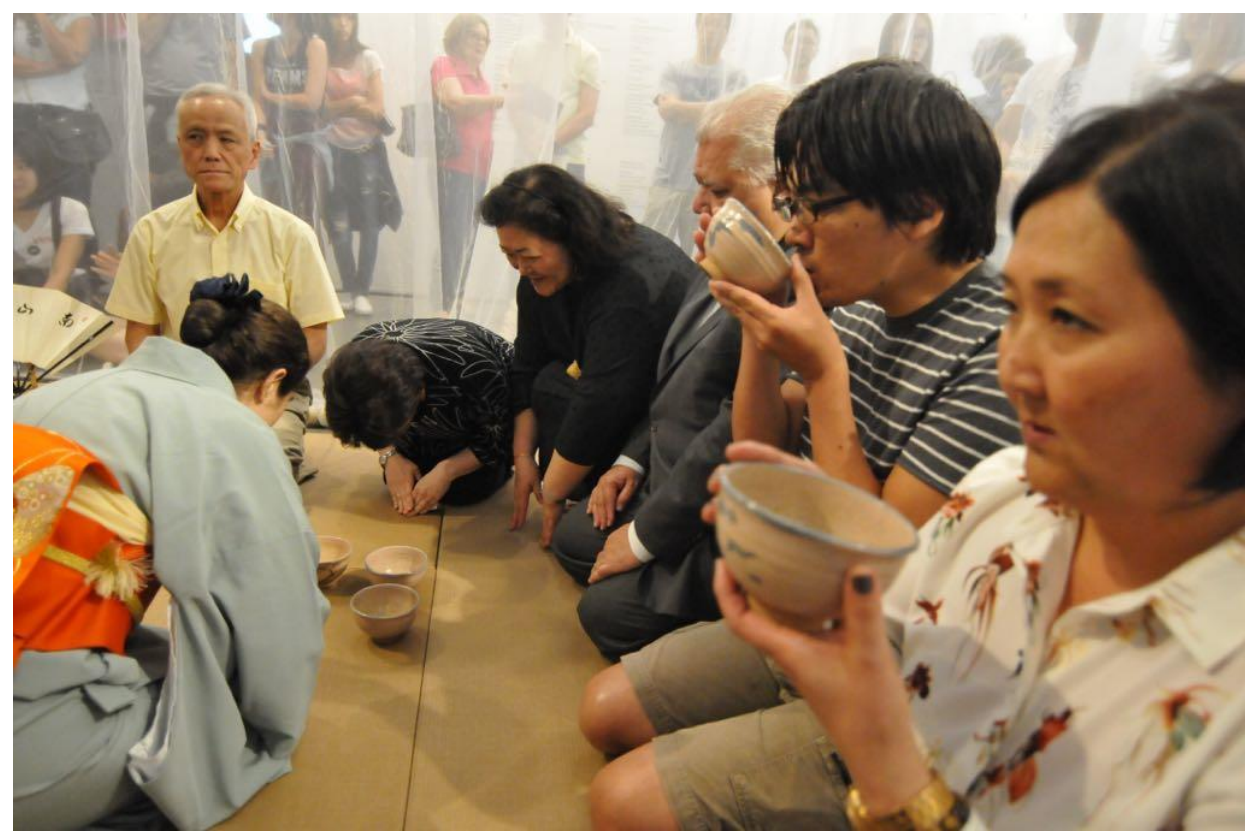

Foto 7: cerimônia do chá na instalação de Kengo Kuma, na Japan House. Fonte: Jornal Nippak

Outro exemplo é o convite às kenjinkais (associações de províncias do Japão) para que exponham e vendam seus produtos na casa (ele também chama a Japan House de "casa"), além dos trabalhos conjuntos com a comissão de comemoração dos 110 anos da imigração japonesa no Brasil. Segundo Kurita, a Japan House também se dedica, em suas práticas, a divulgar os valores japoneses, como o omotenashi, que significa "hospitalidade" com alto nível de respeito e dedicação ao hóspede ou visitante, e também a gentileza como forma de servir e de "espalhar beleza", como foi o caso da "intervenção itinerante" do artista japonês Makoto Azuma, famoso por suas criações florais. Com arranjos de flores no guidão e na parte traseira de bicicletas, ciclistas percorreram vários bairros da cidade de São Paulo distribuindo flores aos passantes. No final de sua apresentação, o presidente do Conselho Deliberativo do Bunkyo, Jorge Yamashita, subiu ao palco para cumprimentar Kurita e disse, com orgulho, que "não é a Japan House que tem que fazer alguma coisa por nós, nikkeis, mas somos nós que temos que fazer tudo o que for preciso pela Japan House, através de pessoas de valor da comunidade, como você".

Já se aproximando do final, o coordenador do evento, Fernando Matsumoto, liderou mais uma atividade, chamada de "motivacional" que ele, no entanto, já de início avisou que não poderia fazer, pois "ninguém motiva ninguém, cada um é que tem de encontrar a motivação dentro de si”. Ele reforçou sua proposta, lançada na palestra 
anterior, para que os membros das entidades nipo-brasileiras descubram os seus propósitos e consigam fazer coincidir a lista das suas "paixões" com a lista do que seus amigos dizem que eles "fazem melhor", e também com aquilo que de fato "fazem" na vida pessoal e na comunidade. Os depoimentos que vieram em seguida, de representantes de entidades de regiões distintas do país, ilustraram algumas dessas situações em que a "motivação" das lideranças jovens (de todas as idades) salvaram as entidades.

Um dos personagens mais idosos desse $F I B$, mas nem por isso menos ativo e animado, foi Tetsuo Koketsu, presidente da Hansoro - Associação Nipo-Brasileira da Alta Sorocabana, sediada em Presidente Prudente, e que abrange entidades de 17 municípios da região. Respeitado por todas as lideranças do Bunkyo e pelos demais frequentadores do $F I B$ que o conhecem por sua participação e entusiasmo, Koketsu revelou que foi a criação do Seinenbu (grupo de jovens da Hansoro) que injetou as novas energias que revitalizaram a associação. Mas, para isso, diz que peregrinou pelas cidades do interior, sugerindo eventos de esportes e karaokê - que ele achava que animariam os mais novos - e envolvendo os líderes com uma de suas frases preferidas em japonês (cuja tradução foi só o que pude anotar): “quem não busca o impossível, não consegue nem o possível”. Hoje, o Seinenbu Hansoro promove o FIB regional, que já está na quarta edição, com as bênçãos - e a presença constante - de Koketsu.

Também na cidade de Santos - porta de entrada da grande maioria de imigrantes japoneses no país, desde o início do século $\mathrm{XX}$-, a associação nipo-brasileira local tem entre seus diretores voluntários um jovem ativo, Matheus Misumoto, cujo empenho não passou despercebido pelas autoridades japonesas, que lhe concederam uma viagem para o Japão, juntamente com outros nove jovens latino-americanos de descendência japonesa, em um programa de fortalecimento dos laços entre a nova geração nikkei das Américas e o país de seus ancestrais. Frequentador assíduo do FIB, Misumoto começou seu depoimento mostrando uma foto, no telão, de uma pessoa sentada de costas sobre o tatame de uma sala, de frente para as shoji (portas de correr) abertas, contemplando um jardim zen, do lado de fora. 


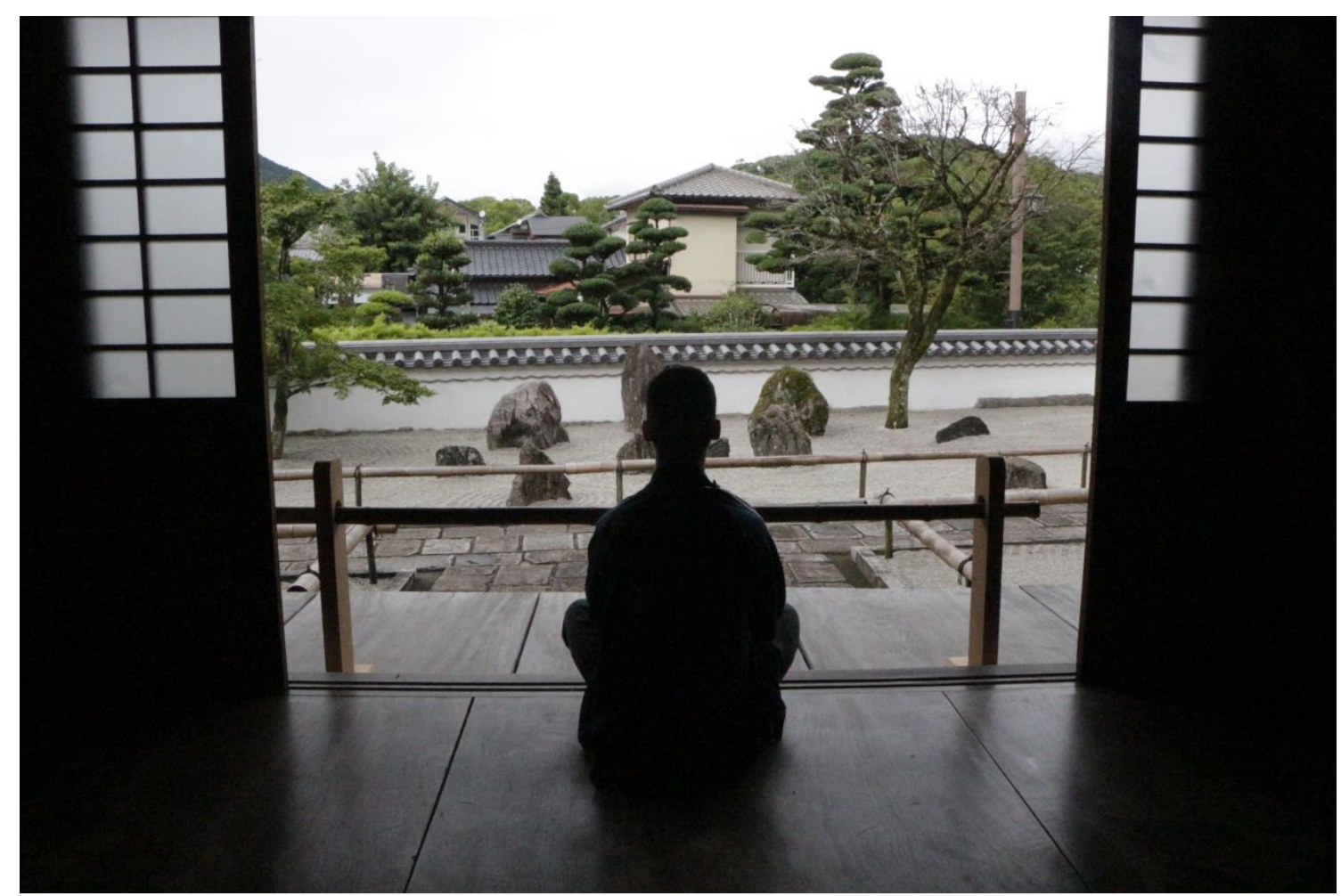

Foto 8: Matheus Misumoto em meditação no templo budista, em Dazaifu, província de Fuzuoka. Fonte: fotografia de Paula Ikeda

Como a luz era mais clara na parte exterior, não dava para identificar quem era a pessoa de costas, mas logo Misumoto revelou que era ele. Explicou que aquele foi o único momento em que pôde, ainda no Japão, parar para refletir sobre aquela viagem, que teve programação muito intensa. Mas foi também, de forma alegórica, uma representação da espiritualidade daquela jornada, em que visitava pela primeira vez o país que inclui parte de sua história (ele tem ascendência japonesa só por parte de pai), e da qual acabava de retornar. Nessa fase "pós-programa”, Misumoto diz que está ainda tentando "juntar os pontos" do que viu e sentiu no Japão, com as experiências e informações trocadas no FIB. Acredita que o desafio para os jovens nipo-brasileiros, hoje, é descobrir o que se espera de uma entidade no século XXI, em especial as entidades nipo-brasileiras. Ele avalia que as primeiras entidades, no passado, tiveram a função de agregar os imigrantes recém-chegados. E quando foram para as mãos dos descendentes, mudaram de finalidade, passando a ser um espaço para "honrar a história dos pais".

Misumoto acredita que, a partir da terceira geração, as entidades refletem um novo tipo de adesão dos descendentes à cultura japonesa, que é mais na base do "gosto 
pessoal" do que nas questões de identidade ou pertencimento. Misumoto também acha necessário repensar o conceito de "cultura Nikkei", cujos conteúdos têm refletido, predominantemente, a relação da comunidade com o Japão até os anos 1970 (quando cessou a imigração japonesa para o Brasil). Depois disso, ele diz, parece que houve um "congelamento cultural", como se os jovens tivessem a obrigação de continuar a "passar adiante um baú de relíquias". Mas a cultura "se move junto com as pessoas", pondera Misumoto, e por isso é preciso que as entidades coloquem "na prateleira" outras coisas além da cultura tradicional, para que mais pessoas - especialmente as mais jovens, inclusive as de fora da comunidade - se interessem pelo que elas têm a oferecer ${ }^{203}$.

Já as palavras de agradecimento de Anacleto Hanashiro, secretário-geral do Bunkyo, evocaram mais uma vez os valores tradicionais japoneses: "aqueles que aprendemos de nossos pais e estamos difundindo entre os brasileiros", e que, para ele, respondem à pergunta levantada pelo tema do FIB, "como japonesar em sua entidade". Ele contou aos presentes que, naquele mesmo dia, estava acontecendo, no pequeno auditório do edifício anexo, um simpósio internacional promovido pelo CIATE (Centro de Informação e Apoio ao Trabalhador no Exterior). Hanashiro contou que esteve lá mais cedo e assistira ao depoimento do padre Evaristo Veiga, que viveu 23 anos junto aos decasséguis brasileiros no Japão.

O padre relatou a situação difícil das famílias que não conseguem educar seus filhos nem em japonês, nem em português, citando o caso de "uma moça linda, de vinte anos, e que até hoje é analfabeta". Hanashiro propôs que "já que estamos aqui discutindo os valores japoneses", que seja incluída entre as nossas tarefas a ajuda na readaptação dos "retornados" do Japão como uma das formas de "japonesar no Brasill". Antes de encerrar seu agradecimento, Hanashiro pediu que todos, de pé, o acompanhassem em uma homenagem aos organizadores e participantes do evento, girando o corpo e ao mesmo tempo elevando o braço direito, junto com uma saudação na voz mais alta possível de "BRRRRRAVO!!!!".

As palavras de encerramento do evento couberam ao também entusiástico Roberto Nishio, presidente da Fundação Kunito Miyasaka, sempre presente e atuante nos FIBs, patrocinador da grande maioria dos eventos importantes da comunidade nipobrasileira e mesmo de eventos menores, de nível local. Nishio começou contando que o

\footnotetext{
${ }^{203}$ Parte das afirmações de Matheus Misumoto, no texto acima, foi feita durante sua apresentação, e parte diretamente a mim.
} 
trabalho da fundação que preside, criada em 1998, é a concretização do propósito de divulgação da cultura japonesa do próprio Miyasaka, que chegou ao Brasil em 1932, como diretor-executivo da Bratac (Sociedade Colonizadora do Brasil), criada para administrar três colônias japonesas no estado de São Paulo e uma no Paraná. Miyasaka foi um dos fundadores do Bunkyo e presidiu a entidade de 1965 a 1971; juntamente com outras lideranças da comunidade, ajudou na criação de entidades assistenciais voltadas à população nipo-brasileira, como o hospital Santa Cruz, o Kodomo-no-sono (para crianças deficientes) e Ikoi-no-sono (para idosos necessitados).

Nishio revelou que, no ano que vem (2018), quando a fundação comemora seu vigésimo aniversário, será inaugurado um de seus maiores projetos: o Parque Ecológico Imigrantes $^{204}$, localizado no quilômetro 33 da pista de descida da rodovia Imigrantes. A ideia do projeto foi criar um parque temático, sustentável e integrado na Mata Atlântica, para proporcionar convívio e conhecimento sobre a necessidade de preservação desse fragilíssimo ecossistema, já reduzido a pouco mais de $7 \%$ do que foi um dia. O projeto reflete um dos valores atribuídos à cultura japonesa, de proximidade e respeito à natureza.

Como exemplo, ele citou a visita do cônsul Takahiro Nakamae (que encerrou sua missão no Brasil em junho de 2017) às obras do parque, onde fotografou os manacás em flor. Ele contou que, além da inauguração do parque, a fundação já tem boa parte de seus recursos empenhada no patrocínio dos eventos de comemoração dos 110 anos da imigração japonesa, também celebrada no ano que vem, mas que continua à disposição das entidades de Mato Grosso, Bahia, Rio Grande do Sul "e de todos da comunidade que pedirem a nossa ajuda". Animado com a promessa generosa, o auditório bateu palmas com entusiasmo.

Como fazem em todas as edições do $F I B$, os organizadores prepararam um pequeno vídeo com uma montagem bem-humorada de fotos dos momentos em que preparavam o evento, e com depoimentos de vários deles em homenagem ao coordenador, que nesse ano foi Fernando Matsumoto. No final, fizeram uma surpresa para ele, que o levou às lágrimas: a presença da esposa Grace e da filhinha Mei, de quatro meses. Aos poucos, os participantes foram se levantando, abraçando os amigos, se reunindo em grupinhos para planejar o futuro próximo, uns se despedindo às pressas

\footnotetext{
204 Ver em: http://www.fkm.org.br/parque-ecologico-imigrantes/parque-ecologico-imigrantes-3/ acesso
} em $21 / 10 / 2017$. 
para pegar uma carona, um ônibus ou um avião de volta para casa, outros aglomerados perto da porta, ansiosos pela última convocação: "hora do almoço, gente!".

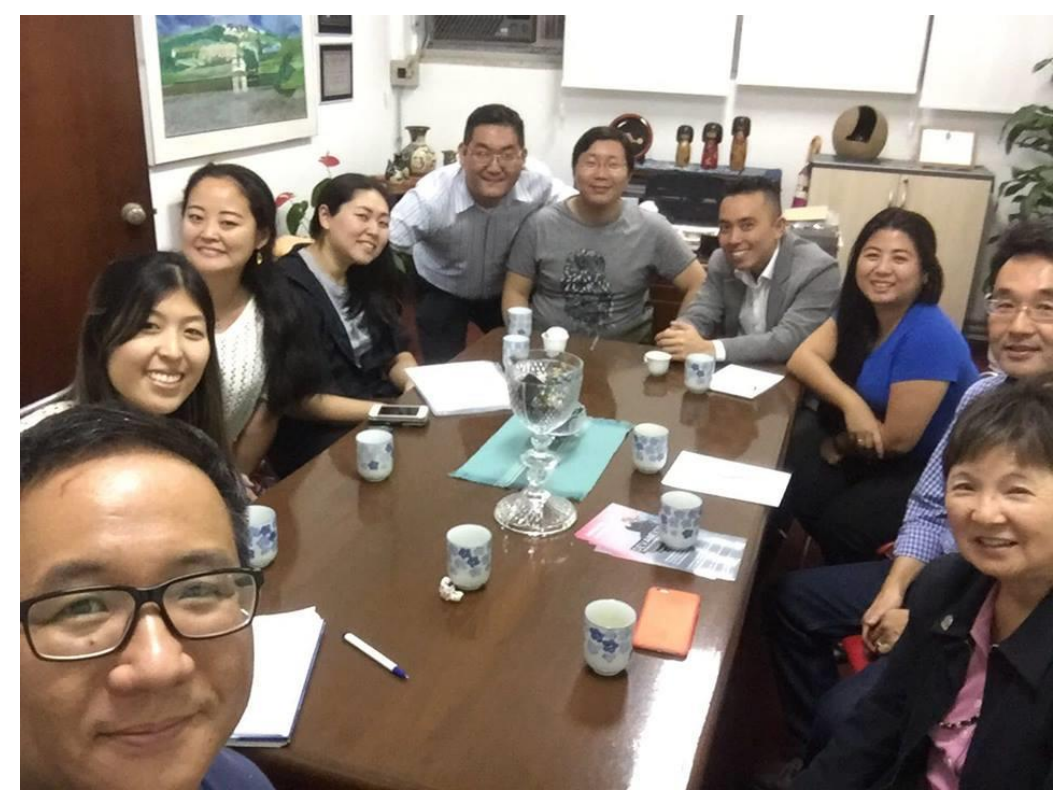

Foto 9: reunião de avaliação dos coordenadores do IX FIB.

Fonte: fotografia de Fernando Matsumoto/Bunkyo

\subsection{A narrativa da integração e da renovação}

A criação da expressão “japonesar” no $F I B$ de 2015 e sua retomada no de 2017 geraram mais uma nova narrativa sobre a identidade nipo-brasileira e a cultura japonesa no Brasil. Essa narrativa se reporta tanto a uma questão filosófica (as diferentes percepções do que vem a ser "japonesar" para cada um dos membros da comunidade nipo-brasileira, e os pontos de convergência dessas percepções) quanto a uma questão de ordem prática (como cada pessoa ou entidade vivencia, no seu cotidiano, esse “japonesar"). Essas novas narrativas, como vimos, remetem às velhas narrativas, confirmando a memória das antigas tradições. Mas também constroem novas memórias: os feitos recentes da comunidade (os acontecimentos, esforços e sacrifícios, alegrias e orgulhos daqueles que as viveram) que, ao serem compartilhados, passam a ser parte de uma narrativa comum, não só do $F I B$, como também da comunidade. 
O evento desse ano proporcionou um "ambiente narrativo", ou uma "situação de comunicação", como diz Charaudeau (2012, p.67), em que os personagens puderam compartilhar mais uma vez suas ideias e histórias, renovando os elementos simbólicos da sua cultura comunitária e reforçando os vínculos afetivos que os unem. Ao mesmo tempo, esse ambiente narrativo permitiu que antigas relações de respeito à hierarquia e aos símbolos tradicionais da comunidade fossem reafirmadas, com as solenidades, reverências, hinos e cores nacionais, presença de autoridades, etc. Esse ambiente narrativo é constituído pelo "tempo público" de um encontro entre pessoas que se sentem conectadas por uma variedade de laços (étnicos, culturais, afetivos e/ou de afinidade). Como diz Ricoeur (1980), o tempo público "não é o tempo anônimo da representação comum, mas o tempo da interação. Nesse sentido, o tempo da narrativa é, desde o princípio, o tempo de estar-com-os-outros"205 (1980, p.184).

A nova narrativa, construída ao longo de um "tempo público" em que se questiona o que é "japonesar" e as diferentes formas de viver esse japonesar, abre uma discussão sobre a diversidade dessa identidade nipo-brasileira e sobre a própria cultura japonesa, cujas referências foram sacudidas pela passagem do tempo e, portanto, já não são as mesmas de décadas atrás. Enquanto alguns participantes evocam as "virtudes japonesas" como sendo o diferencial que distingue a comunidade de origem japonesa sem deixar de incluir as "virtudes brasileiras" -, alguns ressaltam a necessidade de colocá-las em um novo contexto, como foi o caso de Marcia Nakano, que não vai ensinar à filha certos valores que aprendeu com os pais (quanto ao papel tradicional da mulher), e de Misumoto, que quer repensar a cultura nikkei em termos de uma relação mais atualizada com a cultura do Japão e com as expectativas das novas gerações.

Mas esses questionamentos não significam que os valores originais da cultura japonesa trazidos pelos imigrantes perderam sua validade como foco de referência, muito pelo contrário. As constantes alusões aos 110 anos da imigração, às histórias do museu (os navios que trouxeram os imigrantes, a adaptação nas fazendas, as doenças tropicais que dizimaram famílias inteiras, a perseguição e o sofrimento durante e após a Segunda Guerra etc.) e os testemunhos pessoais dos mais velhos (e até dos mais jovens, como Matsumoto, que, ao chegar ao Japão, descobre, antes mesmo de sair do aeroporto, que "faz parte daquele mundo"), são a prova de que a grande narrativa da imigração

\footnotetext{
${ }^{205}$ No original, em inglês: "This public time (...) is not the anonymous time of ordinary representation but the time of interaction. In this sense, narrative time is, from the outset, time of being-with-others". Tradução da autora.
} 
japonesa ainda é a base para todas as outras, até mesmo para aquelas que tentam superála (nos discursos sobre os "novos tempos", sobre a "nova cultura" do Japão contemporâneo etc.).

O IX FIB foi um daqueles contextos criados pelo Bunkyo em que as trocas simbólicas se dão por meio de performances que, segundo Zumthor (2000), têm como característica principal a "reiterabilidade", ou seja, uma repetição constante como forma, mas jamais redundante. Esse foi a nona vez que o FIB se reuniu, e, embora os objetivos temáticos, os convidados especiais e algumas atividades sejam sempre diferentes, a essência da forma permanece. Essa permanência, porém, não é casual: é ela que garante a continuidade dos preceitos fundamentais que estão por trás da sua criação e da sua manutenção enquanto evento relevante para o projeto do Bunkyo. Como diz o autor, "a performance, de qualquer jeito, modifica o conhecimento. Ela não é simplesmente um meio de comunicação: comunicando, ela o marca" (2000, p. 32).

Assim, vemos que o $F I B$, enquanto conjunto de performances conduzidas e patrocinadas pelos membros do Bunkyo - mas também de convidados e participantes que se desviam um pouco do padrão -, é principalmente uma forma de conhecimento, marcado pela performance em si. Assim, os encontros participam da construção do conhecimento sobre os significados da imigração (o seu passado), e do momento presente da comunidade, em que se compartilham histórias e ideias (o presente) para que a cultura japonesa sobreviva, prospere e encontre um lugar na vida dos descendentes dos imigrantes (o seu futuro). Por isso as vivências no museu, as palestras e as trocas de histórias são essenciais para a consolidação do (re)conhecimento do que é importante saber (sobre o passado), fazer (no presente) e planejar (para o futuro).

Também a dimensão do "espetáculo" é fundamental, quando se pensa na performance, que é a totalidade do que acontece junto com o ato em si: além da fala, os gestos, as expressões, as sonoridades e composições físicas do ambiente, e tudo o mais que liga (e faz interagir) o corpo e o espaço. Refletindo sobre o ato performático e a "disposição cenográfica" criada ao seu redor e a seu favor, Zumthor cita Josette Féral, para quem a "semiotização do espaço" permite que o "espectador perceba a teatralização da cena e a teatralidade do lugar" (apud ZUMTHOR, 2000, p. 40). Embora a autora tenha escrito sobre a encenação ficcional do teatro propriamente dito, essa reflexão ilumina a compreensão dos mecanismos de dramatização que acompanham qualquer tipo de performance. 
O IX FIB foi uma dessas encenações que, não por acaso, acontecem em um palco, em ambiente totalmente "semiotizado", como diz Féral. Os elementos que compõem o espaço, bem como o desempenho dos personagens - que, nesse caso, encenam a si próprios em uma história que não é "ficcional" (no sentido de "inventada") -, estão carregados de significados que têm no contexto do próprio FIB e do Bunkyo as chaves de sua decodificação. Essas referências decodificadoras, porém, são parte do conhecimento que é compartilhado neste e em todos os eventos do Bunkyo, um conhecimento que (assim como a identidade) não possui uma estabilidade definitiva, precisando por isso ser "reiterado", repetido, lembrado e (re)constituído constantemente.

Também o aspecto levantado por Austin (1979) sobre as "falas performativas" é aplicável às práticas do Bunkyo durante o IX FIB para a compreensão dos seus objetivos mais profundos. Se as narrativas compartilhadas durante os encontros se dedicam especificamente à disseminação de certo conhecimento sobre o passado, para orientar o presente com vistas ao futuro da comunidade nipo-brasileira, as falas performativas têm o papel de realizar esse compromisso, pois um compromisso não se ensina, se faz. A palavra performativa tem o dom de fazer, causar ou transformar, como no caso do exemplo de Austin (1979, p. 235), sobre a cerimônia de casamento em que, ao responder "eu aceito", a pessoa em questão não está simplesmente dizendo algo, mas transformando-se com aquele "ato falado" em uma pessoa casada.

O compromisso a ser assumido durante o IX FIB é, em várias ocasiões, reiterado concretamente nas falas de seus participantes, sendo que, em alguns momentos, a "fala performativa" está apenas sugerida, como no momento em que Nishio diz que "o futuro da cultura japonesa está garantido, pois jovens de valor como vocês estão à frente". A fala performativa direta, sugerida nesse caso, seria: "Eu prometo que o futuro da cultura japonesa está garantido, pois contamos com a liderança de jovens de valor como vocês”. Essa ação - o ato de prometer - é, ao mesmo tempo, um ato que consolida a aliança entre os velhos e os jovens nessa missão maior, que é de todos, e um recurso de formalização pública (ainda que de forma afetiva e aparentemente "informal") desse compromisso.

O enredo dessa narrativa começa com a percepção, anos atrás, de membros do Bunkyo de que as entidades estão se esvaziando e de que a reduzida presença de jovens nos eventos da entidade se deve à crescente falta de interesse das novas gerações pela cultura de seus ancestrais, o que ameaça o futuro da comunidade. Embora o tema da 
juventude como sinônimo de renovação e continuidade seja antigo nas narrativas do Bunkyo, é no relatório de $2003^{206}$ que a "atenção às novas gerações" se articula de forma mais clara como meta nos textos e nas falas dos líderes da entidade.

Premidos pelo dever de representar a comunidade nipo-brasileira e de preservar o legado dos imigrantes - como eles próprios definiram em sua missão -, os líderes do Bunkyo conceberam uma nova frente de ação (que espelhava, porém, práticas não tão novas), em que colocam no palco do salão nobre personagens cujos relatos e performances apresentam diferentes histórias. Estas acontecem em lugares distantes umas das outras, mas preservam um ponto em comum: a perspectiva de que suas trajetórias específicas possam contribuir para o fortalecimento dos laços da comunidade, para a integração de quem está disperso e para inspirar quem perdeu o interesse pela cultura dos ancestrais.

Assim, como se depreende das falas de seus organizadores e participantes, a estrutura da narrativa se apresenta em uma tríade: os problemas principais da comunidade (dispersão, esvaziamento, desinteresse), suas causas mais comuns (distâncias, conflitos, conservadorismo, novos interesses, falta de tempo, de apoio e de recursos) e os caminhos para sua superação (integração, revitalização, ajuda mútua, inovação, pilar jovem). As intervenções dos personagens, apesar da diversidade de suas histórias e estilos, tendem a repetir a sequência "problemas/causas/superação", em uma variedade de falas e de performances que evocam "a emoção" (vídeos e fotos com crianças, idosos, casais apaixonados, pais e filhos, cenas da natureza, frases poéticas, testemunhos comoventes, fundo musical que induz à sensibilização etc.) e "a razão" (demonstrações com dados, estatísticas, informações, argumentos e exemplos de projetos bem-sucedidos), muitas vezes combinando as duas coisas.

Apesar de a estrutura do evento dividir as participações em unidades com começo, meio e fim - como é o caso de cada palestra ou depoimento pessoal, que narra uma pequena história ou mensagem que é uma totalidade em si mesma -, o FIB costura todas as falas, imagens e performances em um acontecimento único, sobre "japonesar" na entidade e na vida, apontando os caminhos da integração e da revitalização para todos os que se sentem parte da cultura japonesa no Brasil, descendentes ou não. Essa narrativa se constrói a partir de um tipo de evento que corresponde ao que Victor Turner

\footnotetext{
${ }^{206}$ Conforme explicado no Capítulo 2, esse relatório foi produzido pela Comissão Provisória de Estudos de Renovação, constituída em outubro de 2002.
} 
(1980) chamou de "drama social", ou seja, os momentos especiais em que os valores mais essenciais de um grupo são vivenciados ritualmente, através de performances e um "script" que não só reafirmam esses valores como os questionam e recriam.

Os dramas sociais, segundo o autor, são fenômenos formadores e integradores de toda sociedade humana, e ocorrem dentro dos grupos que compartilham valores e interesses, e que se consideram parte de uma "história comum", real ou imaginada (1980, p.145). Por serem momentos especiais de troca, a dimensão comunicacional desses rituais inclui não somente as falas e os textos significativos, mas toda a dramaturgia: gestos, indumentária, etiqueta, cenografia, as dinâmicas e as performances, que participam da construção e negociação dos significados. Importante ressaltar também que, para Turner, os dramas sociais são, em grande medida, processos políticos, dominados pelo que ele chama de "grupo de estrelas", isto é, o grupo de protagonistas da narrativa social, os líderes a quem a comunidade devota "sua mais profunda lealdade" ou reconhece autoridade e legitimidade.

$\mathrm{O}$ autor ressalta que esses momentos especiais da existência de uma comunidade geram narrativas que condensam as experiências e atualizam seus significados. Levantando as raízes etimológicas das palavras "narrativa" (conhecimento) e "drama" (fazer ou agir), Turner conclui que "narrativa é conhecimento (e/ou gnose) que emerge da ação, isto é, conhecimento pela experiência"207 (1980, p. 163). A partir desse referencial, constato que as narrativas do IX FIB emergem de um "drama social" bem específico: um encontro em que personagens significativos da comunidade nipobrasileira procedem a uma série de performances em que os problemas da comunidade, suas causas e soluções são os temas principais das falas e das vivências, renovando, durante esses rituais, a relevância dos temas, dos objetivos e das pessoas envolvidas.

Os personagens desse drama são muitos, alguns assumindo o protagonismo em determinadas cenas, outros mantendo a função de coadjuvantes, mas ninguém é figurante: mesmo o mais calado espectador da plateia teve a sua oportunidade de contar ou perguntar algo, pelo menos nas atividades de integração, no tour pelo prédio ou nas mesas de refeições. A cônsul-adjunta Hitomi Sekiguchi e a presidente Harumi Goya são as protagonistas dos rituais iniciais, sinalizando com suas presenças a legitimidade do evento, ao mostrar que os que ali se reúnem contam com o apoio oficial do Bunkyo e do

\footnotetext{
${ }^{207}$ No original em inglês: "narrative is knowledge (and/or gnosis) emerging from action, that is, experiential knowledge". Tradução da autora.
} 
governo do Japão. Os hinos nacionais dos dois países, diante das respectivas bandeiras, marcam o espaço e o tempo do ritual: o espaço integrador em que Brasil e Japão se encontram, atualizando no presente o passado que constituiu os primeiros encontros.

Outros personagens assumem também papéis centrais na narrativa do $F I B$ pelos cargos que ocupam e pelo seu prestígio pessoal, em função de sua idade, de sua dedicação à causa nipo-brasileira e dos eventos que testemunharam em suas longas vidas, o que faz deles documentos vivos da história oral da comunidade. Esse é o caso, entre outros, de Roberto Nishio, presidente da maior fundação de apoio aos projetos e entidades nipo-brasileiras e membro do Bunkyo há décadas, de Masayoshi Morimoto, presidente de uma organização internacional de apoio aos nikkeis e à difusão da cultura japonesa no mundo, e de Tetsuo Koketsu, ao mesmo tempo o mais idoso e mais atuante (além de carismático, embora muito discreto) líder da comunidade no interior de São Paulo. A presença desses personagens é essencial à construção da narrativa, primeiro porque suas falas ajudam a dar um conteúdo honorável à ideia do que seja "japonesar", e segundo porque suas presenças e performances reafirmam a legitimidade do evento e de certos valores praticados no Bunkyo, como a proeminência dos mais velhos e daqueles que exercem cargos em instituições valorizadas pela comunidade.

Personagens mais jovens também exercem funções destacadas na narrativa, sobretudo quando sua performance é antecedida pela apresentação de um extenso currículo, que inclui algum cargo elevado em uma instituição importante, como foi o caso de Cláudio Kurita, diretor operacional da Japan House, e de Márcia Nakano, atual presidente do JCI Brasil-Japão. Claro que outros valores também estão presentes na narrativa, dando autoridade aos personagens, como é o caso da dedicação à causa nipobrasileira, a experiência em determinada atividade também valorizada pelos membros da comunidade, o talento pessoal em alguma área de formação profissional e a participação em algum evento ou viagem recente cujo relato tem algo a acrescentar às discussões. Embora o foco narrativo, de certa forma, se concentre em uma fala invisível, presente nos textos (produzidos antes e depois do evento) que unificam as histórias pessoais em uma narrativa única cujo tema principal é a integração e a revitalização da comunidade nipo-brasileira, o formato do IX $F I B$ é como um verdadeiro drama (no sentido de "ação" e "encenação") onde é possível ver e ouvir uma diversidade de vozes e de performances, e onde cada ator contribui, com seu toque pessoal, para a tessitura da narrativa final. 
Dessa forma, a ação desenvolve um enredo, a partir dos propósitos e finalidades dos organizadores do evento, que envolve personagens com diferentes funções e qualidades, e que se enquadra no que Assumpção (2010) chama de "tempo dramático", cuja "duração dinâmica" é subordinada ao "aqui e agora" cênico, mas principalmente no sentido de que o "presente" é função de um passado (ou futuro) a ser revelado durante a ação. Assim, quando Morimoto afirma que as "virtudes japonesas" devem servir de referência para "japonesar" na vida pessoal e na vida comunitária, e Wada diz que os "tesouros" da cultura japonesa não devem ser acessíveis apenas aos descendentes, mas a todos na sociedade, os espectadores entendem muito bem que ambos estão falando do legado deixado pelos imigrantes e que, portanto, se referem ao passado de sacrifícios e superações dos pioneiros que reafirmaram essas virtudes e acumularam esses tesouros.

Da mesma forma, o futuro está implícito no compromisso de todos os participantes em preservar a cultura dos ancestrais, ainda que transformando-a e adequando-a "à época e à sociedade em que se vive", como pondera Nakano. E torna-se explícito na fala de Nishio, para quem o futuro da cultura japonesa está garantido, "pois jovens de valor como vocês estão à frente". Ao colocar as gerações em diálogo, o FIB se torna o espaço de encontro simbólico entre passado, presente e futuro. Aqui, vale a pena lembrar as palavras de Ricoeur (1980, p. 184), para quem a narrativa rompe com a "obsessão da luta contra a morte" e redireciona a meditação sobre o tempo para o "problema da comunicação" não só entre os vivos, mas também entre "contemporâneos, antecessores e sucessores":

Afinal, não é o tempo da narrativa um tempo que continua além da morte de cada um de seus protagonistas? Não faz parte do enredo incluir a morte de cada herói em uma história que supera todo destino individual ${ }^{208}$

Assim, a narrativa do IX $F I B$, bem como todas as demais produzidas e disseminadas pelo Bunkyo, é parte de um projeto narrativo muito mais amplo do que seu próprio enredo, cuja temporalidade transcende o momento vivido, ao trazer do passado imemorial as raízes de suas identidades, e do passado mais recente, as memórias dos

\footnotetext{
${ }^{208}$ No original, em inglês: "After all, is not narrative time a time that continues beyond the death of each of its protagonists? Is it not part of the plot to include the death of each hero in a story that surpasses every individual fate? Tradução da autora.
} 
seus ancestrais, cultivados no tour ao museu, ao cantar de pé o Kimi ga yo, ao compartilhar suas histórias de família e como elas inspiram o presente e seus planos de futuro. E quanto à "fábula", ou moral da história, ela se encontra no "plano da estrutura profunda da narrativa", implícita em todas as falas e performances: por trás das homenagens e referências constantes à memória dos ancestrais está o on ("gratidão", em japonês, valor tradicional e com frequência mencionado pelos mais velhos), obrigação eterna, devida aos pioneiros que abriram caminho para seus descendentes, e em reconhecimento ao seu sacrifício pessoal e ao seu legado material, cultural e ético - o "tesouro" a que Wada se refere.

\section{O segundo cenário narrativo: o cenário espacial-visual do} edifício-sede do Bunkyo

Em uma reflexão sobre paisagem e memória, Taylor (2008) afirma que a identidade se relaciona diretamente com as experiências vividas no mundo, registradas nos símbolos, imagens e significados associados aos lugares e panoramas dessas vivências. A paisagem a que ele se refere, porém, não é a da natureza virgem, mas a do espaço humano, o registro histórico que comunica algo e, portanto, permite uma leitura e uma interpretação. Também Okano (2008), ao percorrer a Liberdade, o "bairro oriental" de São Paulo, se propõe a decifrar os significados da paisagem cultural, por meio de uma "leitura semiótica-visual" que distingue os ícones e índices, e os apliques e colagens $^{209}$ que evocam o contexto cultural japonês, apresentando o bairro como o lugar de memória dos descendentes dos imigrantes japoneses no Brasil.

Essa noção de espaço físico como sistema de comunicação cujos processos e significados remetem a um determinado contexto cultural associado à memória e à identidade das comunidades que o constroem, gerenciam e percorrem é o que inspira a minha análise dos espaços, objetos e imagens que compõem o mundo do Bunkyo. E também o conceito de "texto" de Lindlof (1995), conforme já citado na introdução da

\footnotetext{
${ }^{209}$ Ícone: "pertencente à classificação peirceana do signo em relação ao objeto, é aquele que representa o seu objeto através da similaridade" (Okano, 2008 p. 292); "apliques ou colagens são elementos estranhos ao texto base, que assimilado pelo contexto, não perdem os seus contornos originais dentro deste organismo onde foram de repente introduzidos" (Carone apud Okano, 2008 p. 294); índice é um signo que funciona indicando uma outra coisa não por similaridade, mas por contiguidade (proximidade).
} 
tese, que não se restringe às falas e aos textos escritos, mas inclui todos os elementos da cultura (um ritual, um objeto, uma canção, uma imagem etc.) que constituem "um conjunto coerente de significantes". Observei especificamente os aspectos da identidade e da memória da comunidade nipo-brasileira que estão registrados em objetos e imagens distribuídas em algumas das salas e corredores dos ambientes que ocupam o edifíciosede do Bunkyo, além do térreo, e ainda o jardim japonês, ao lado da escadaria externa que separa o universo nipo-brasileiro do mundo de fora ${ }^{210}$. Esses registros fazem parte das pequenas e grandes narrativas cujo tema principal é a imigração japonesa e seu legado no Brasil.

Além dos objetos, espaços e imagens que fazem parte das composições e instalações permanentes da entidade, há vários outros que são introduzidos em determinadas solenidades e eventos comemorativos que sinalizam espaços e tempos especiais, como é o caso de certos festivais - eventos que considero "totalizantes", no sentido descrito por Mauss (1974), por tentarem compor uma síntese do "ser japonês no Brasil”, com performances, exposições e atividades de expressiva amplitude simbólica, que inclui aspectos tradicionais e contemporâneos, clássicos e populares, sempre a partir de uma determinada perspectiva de seleção e elaboração.

\footnotetext{
${ }^{210} \mathrm{O}$ Bunkyo, porém, interage de forma ambígua com esse mundo externo, já que a rua é um lugar "de fora" do edifício-sede da comunidade nipo-brasileira, mas é também parte do bairro oriental da cidade, com o qual o Bunkyo está em permanente troca simbólica. Exemplos dessa troca são as lojas de produtos japoneses no seu entorno; as lanternas japonesas (suzuran-to) colocadas pela Prefeitura em toda a extensão do bairro da Liberdade, as festas de rua, como o festival das estrelas (tanabata matsuri) que acontece em julho, etc.
} 


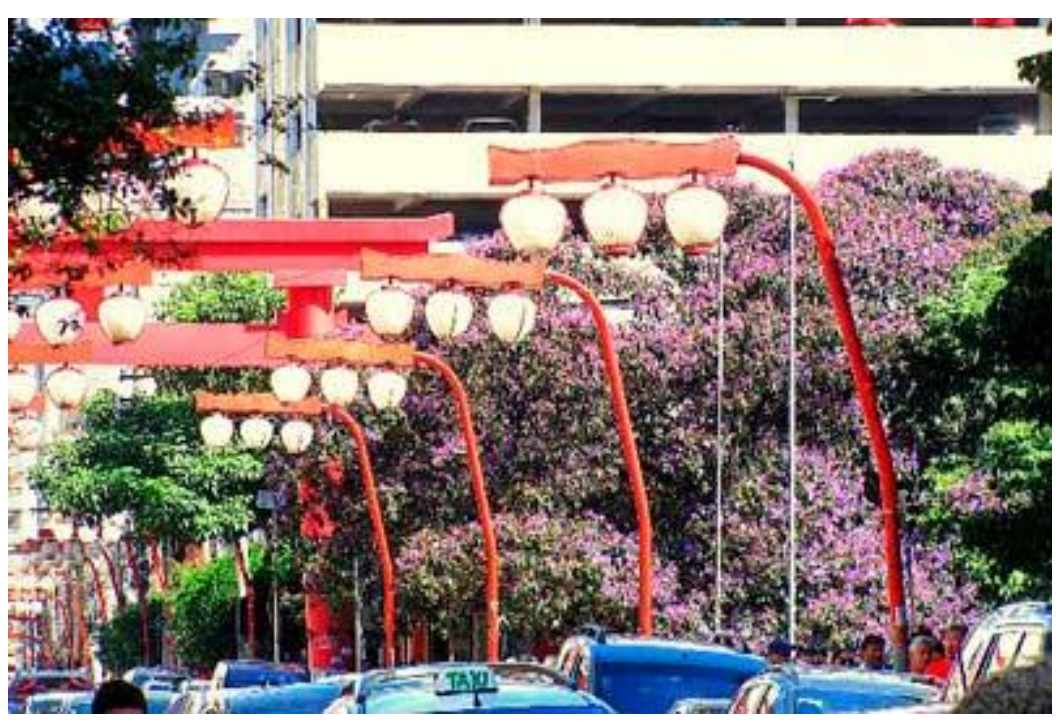

Foto 10: luminárias japonesas suzuran-to, bairro da Liberdade.

\section{Fonte: Jornal Nippak}

\subsection{Bunkyo: lugar de memória}

Em texto publicado no seu site sobre as circunstâncias da sua fundação, o Bunkyo é apresentado como o resultado de uma série de circunstâncias que começaram com a oportunidade de reconciliação da comunidade nipo-brasileira, dividida logo após a Segunda Guerra, durante a festa do IV Centenário da cidade de São Paulo, e pelo projeto de celebração do cinquentenário da imigração japonesa, que aconteceria dali a três anos e a cuja organização a entidade recém-criada se dedicaria. A criação do Bunkyo, portanto, foi um evento que deu início, de forma centralizada, à construção da memória da imigração japonesa no Brasil. Ou, pelo menos, esse foi o projeto principal do Bunkyo $^{211}$. A própria escolha do bairro da Liberdade - lugar simbólico por ter abrigado as primeiras moradias e comércios de imigrantes japoneses e que até hoje é referência cultural para seus descendentes - foi uma afirmação de identidade e de elaboração de um lugar de memória para a comunidade nipo-brasileira.

Os signos utilizados em placas de estabelecimentos comerciais, em ornamentos de casas, nas feiras de fim de semana, e em enfeites de rua, durante as festas

\footnotetext{
${ }^{211}$ A circunstância da fundação do Bunkyo é explorada em detalhes no Capítulo 2 desta tese.
} 
comunitárias, criaram uma espécie de "metáfora do Japão"212, um espaço simbólico por onde circulam pessoas entre pontos estratégicos que Okano chama de "pontos nodais" (2008, p. 295). O fato de a Liberdade ter deixado de ser o "bairro japonês" para se converter no "bairro oriental" da cidade, com a chegada de coreanos, chineses e imigrantes de outros países asiáticos, não ameaça o projeto de "lugar de memória" do Bunkyo para a comunidade nipo-brasileira, pois suas referências simbólicas e históricas continuam inscritas nos espaços e são constantemente atualizadas pelos atos memoriais e festivos da entidade e também de outras associações do bairro.

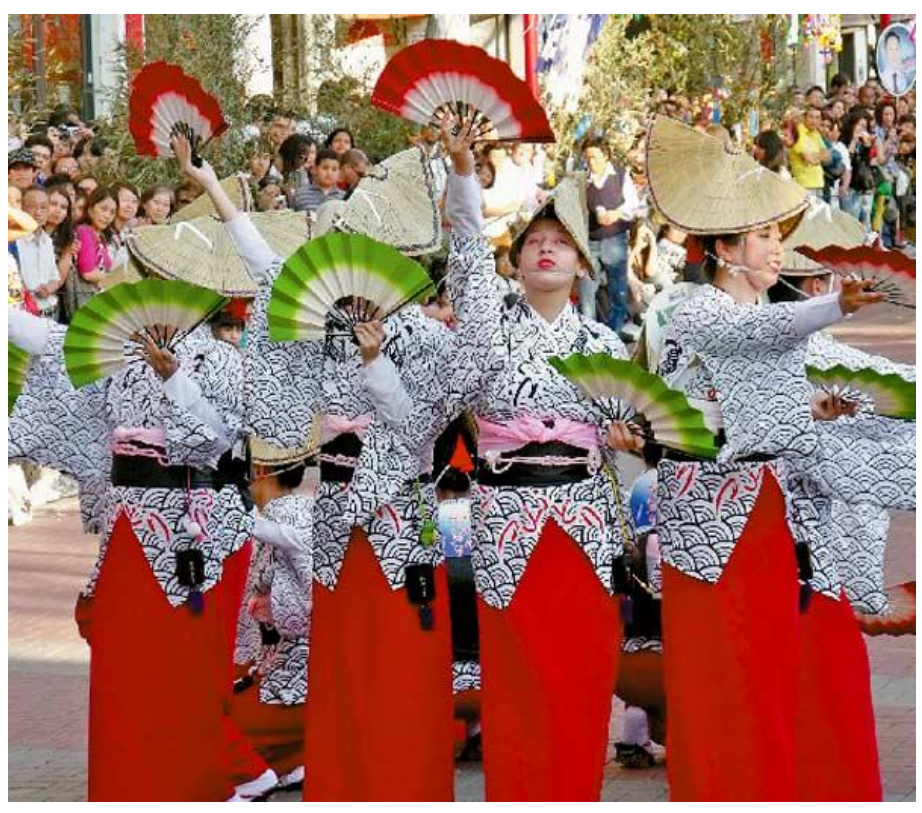

Foto 11: Odori (dança) no Tanabata Matsuri (festival das estrelas), no bairro da Liberdade. Fonte: Jornal Nippak

Um espaço qualquer se torna um "lugar de memória", segundo Nora (1993), quando a imaginação humana o investe de uma aura de recordação simbólica, motivada pelas necessidades do presente. Esse investimento na memória não tem nada a ver com nostalgia, mas é um "fenômeno sempre atual, um elo vivido no eterno presente" (1993, p. 9), refletindo também uma preocupação com o futuro. Por isso, as minorias defendem uma "memória refugiada sobre focos privilegiados e enciumadamente guardados" (1993, p. 13). E que "focos privilegiados seriam estes"? Em seu estudo sobre os lugares de memória, Nora cita os que "naturalmente" evocam lembranças, como é o caso

\footnotetext{
${ }^{212}$ Que Okano (2008) chama de mitate, um conceito que se refere, na cultura japonesa, ao "deslocamento semântico de um objeto para outro, localizado num contexto distinto", ou seja, é como se as pessoas visitassem esses espaços "fazendo de conta" que estão visitando o Japão (2008, p. 295).
} 
daqueles onde ocorreram guerras e batalhas, os edifícios onde personagens históricos residiram ou assinaram documentos que mudaram o rumo dos acontecimentos, os cemitérios onde esses personagens estão sepultados etc.

Mas, embora possam ser chamados de "naturais", não são os espaços em si que constroem suas histórias. A "vontade de memória" é a motivação que os transforma no lugar privilegiado das lembranças de um grupo, o que também "só se realiza se for objeto de um ritual", segundo Nora (1993, p. 21). Quanto aos espaços que o Bunkyo construiu - as instalações do seu edifício-sede, do Museu Histórico da Imigração Japonesa e do Centro Kokushikan, em São Roque -, pode-se dizer que foram palco de algum acontecimento histórico fundador da identidade e da memória nipo-brasileira? Pode-se considera-los verdadeiros "lugares de memória" como seriam, por exemplo, a moradia de um pioneiro, um cemitério de imigrantes, o local onde vitoristas e derrotistas se enfrentaram por discordarem quanto ao resultado da guerra? Vejamos.

Nas falas, textos e imagens em que é narrada a fundação da entidade durante seus primeiros anos, há um momento de grande importância histórica para seus membros e lideranças: a vinda do príncipe Mikasa (irmão caçula do imperador Hiroito) e sua esposa Yuriko para as comemorações do cinquentenário da imigração japonesa no Brasil, em 1958. Era a primeira vez que um membro da família imperial visitava o Brasil, e por isso sua presença causou grande impacto sobre a comunidade nipobrasileira, em pleno processo de superação dos traumas da Segunda Guerra, causados pela perseguição aos "súditos do eixo" no Brasil e pelos conflitos entre compatriotas no interior da comunidade.

Entre as muitas visitas oficiais do casal de príncipes, uma delas foi ao local em que o Bunkyo iniciava trabalhos de construção da sua sede, e onde ele lançou a pedra fundamental do edifício que seria inaugurado cinco anos depois. Esse gesto do príncipe teve a força simbólica de transformar um mero edifício em lugar de memória, pois a deposição de uma pedra fundamental no solo é análoga a uma semente que se planta na terra, a qual se espera que cresça, se torne uma grande árvore e produza frutos. Por isso, a presença de Mikasa é sempre evocada, para que ninguém se esqueça de que foi o gesto de um membro da família imperial, em pessoa, que "plantou" a primeira pedra sobre a qual se ergueu o que é hoje a sede do Bunkyo.

Também as visitas subsequentes de membros da família imperial sempre tiveram alguma parada na sede do Bunkyo, como foi o caso da primeira visita do então príncipe 
herdeiro Akihito ao Brasil, em 1967, quando foi homenageado no "salão-nobre" e plantou um pinheiro no jardim do Pavilhão Japonês, e também em 1978, quando inaugurou o museu da imigração japonesa. Assim, as narrativas do Bunkyo frequentemente enfatizam esses momentos em que seu edifício-sede ou seus outros espaços foram palco de eventos memoráveis, sobretudo no que diz respeito aos membros da família imperial, que têm grande força simbólica principalmente entre os imigrantes e descendentes mais velhos.

Entre os outros eventos que instituem o espaço do Bunkyo como "lugar de memória", sobressai-se a criação do museu, que hoje ocupa três andares do edifíciosede da entidade. Inaugurado 23 anos após a fundação do Bunkyo - com a presença legitimadora do príncipe-herdeiro Akihito -, o museu se tornou um foco convergente de lembranças e atos memoriais, juntando materiais dispersos, produzindo os que faltavam e criando um discurso unificador. Completamente independente do Museu da Imigração do Estado de São Paulo, criado em 1993, o museu do Bunkyo manteve sua autonomia em relação aos esforços do poder público em reconstruir a memória oficial da imigração.

Assumindo assim o "direito de narrar" as histórias dos imigrantes japoneses em nome da comunidade nipo-brasileira, o Bunkyo também assume o que Ferreira (2011) chama de "dever de memória", ou seja, o compromisso assumido de lutar contra o esquecimento a partir de mecanismos de produção e de compartilhamento de representações sobre o passado e a identidade coletiva. $\mathrm{O}$ dever de memória, no caso do Bunkyo, se refere à obrigação moral de reconhecimento dos esforços e sacrifícios dos ancestrais (o "on", mencionado anteriormente), o que não só motiva como justifica as formas de definição do que deve ser lembrado e do que deve ser esquecido. Ferreira pondera que memória e esquecimento são, na verdade, complementares e não opostos entre si, fazendo parte da "negociação de identidade do sujeito em relação a seu passado" (2011, p. 110).

\subsection{O que dizem os espaços, imagens e objetos}

Diversos autores apontam caminhos de abordagem das dimensões comunicacionais da paisagem cultural humana a partir da observação de seus 
componentes materiais e espaciais. Refletindo sobre a "política da memória”, Nasrallah (2005) trata da "retórica da paisagem", referindo-se a monumentos, edifícios e diversas outras construções (e também ruínas e "sítios" onde só restam marcas no chão, ou nem isso) que "falam" entre si e com os passantes que os visitam, e que têm muito mais a “dizer" (sobre o passado apropriado pelo presente) se, em vez de observados isoladamente, são analisados como um todo integrado. Também a sua localização, magnitude, tipos de materiais, imponência, emblemas e outras características daqueles elementos da paisagem cultural fazem parte do seu potencial retórico e, portanto, da "política da memória" que ergueu ou gerencia esse conjunto de construções monumentais.

Também Corrêa (2005) propõe uma leitura dos monumentos e espaços em função de sua capacidade de condensar significados complexos em torno de valores e práticas, que constituiriam um "exemplo de retórica", ou seja, uma técnica de argumentação e persuasão no espaço urbano a partir de signos visuais. Em outro estudo, sobre as formas simbólicas e o espaço, Corrêa (2007) lembra que, "mais do que uma estátua ou memorial, um prédio apresenta uma flexibilidade e permite uma refuncionalização simbólica", sendo assim um meio útil para a "política de significados" e para a "reconstrução do passado por meio de formas simbólicas", já que pode ser ocupado e utilizado de diversas formas, de acordo com as novas necessidades do presente.

Por sua vez, ao refletir sobre o papel central dos objetos materiais nos processos de rememoração, Meneses (1998) analisa a "natureza retórica" dos objetos que se tornam "documentos" em museus, e que, ao "falarem", revelam, na verdade, as falas daqueles cujos critérios os transformaram em objetos de memória. E Okano (2008), a partir de uma perspectiva "semiótica-visual", analisa as imagens e objetos do bairro da Liberdade que têm como referenciais aspectos da cultura japonesa, e que lá foram colocados com a finalidade de proporcionar uma associação daquele espaço com o Japão. Sua análise explora os processos de ressignificação dos objetos quando deslocados de seus contextos de origem para novos espaços e sobrepostos a novos elementos.

Quanto ao Bunkyo, a composição dos seus espaços revela uma estratégia de criação de itinerários, materialidades e visualidades que participam de uma narrativa mais ampla e onipresente da imigração japonesa e do mundo que seus descendentes 
construíram no Brasil. As continuidades, pontos de convergência e associações temáticas entre os elementos que fazem parte dos seus diversos ambientes sugerem que o edifício-sede do Bunkyo se constitui em uma unidade espacial de significados, apesar dos vários espaços que se poderia chamar de "neutros", como elevadores, escadas, banheiros, cômodos vazios e os que servem de depósito. Mas a maior parte dos ambientes tem pelo menos algum detalhe que participa da paisagem cultural, evocando diferentes partes do Japão, da vida do imigrante japonês e da comunidade nipobrasileira, em várias camadas de tempos históricos que coexistem entre si. Essa composição resulta de uma "colagem" de elementos, dispostos em locais variados, mas sempre com grande visibilidade, como, por exemplo, os arranjos de ikebana, os retratos de membros da família imperial, pinturas das cerejeiras em flor etc., que em seu próprio contexto têm um significado específico, mas que na paisagem do Bunkyo funcionam como índices do Japão.

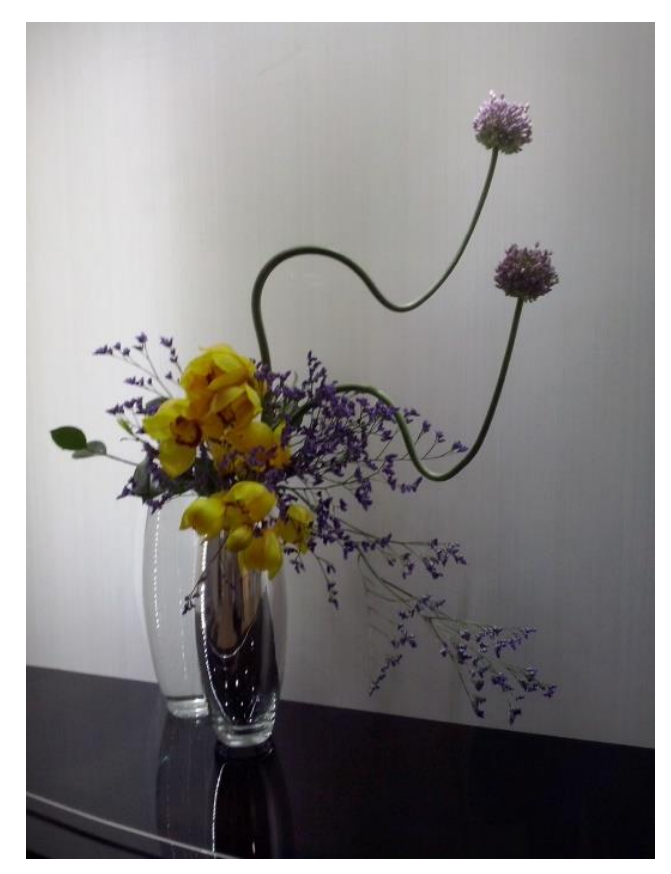

Foto 12: exemplar de ikebana no andar térreo do edifício.

Fonte: fotografia da autora.

A portaria do edifício-sede do Bunkyo, por onde entram os visitantes em dias comuns, dá acesso aos elevadores e a escadas internas. Nas paredes, murais exibem uma variedade de cartazes - a maioria em português e japonês - que não só informam os visitantes sobre os eventos relacionados ao mundo nipo-brasileiro (espetáculos de dança 
clássica japonesa, bolsas de estudos para descendentes, feira de livros na biblioteca, shows de cantores japoneses, cursos de japonês para futuros decasséguis, excursões para o Japão etc.) como já sinalizam, por meio de escritas em kanjis, hiraganás e katanás independentemente do conteúdo informativo de seus textos - a passagem para um universo semântico distinto da realidade brasileira.

Ainda no térreo, chega-se à secretaria, onde estão localizados o setor de comunicação, uma salinha de espera para as visitas e o acesso à sala da presidência e de reuniões da diretoria. $\mathrm{Na}$ parede da secretaria, contrastando com as referências icônicas variadas, um quadro só escrito, pendurado em local visível a todos os que se encontram no aposento, com um texto resumido da missão do Bunkyo. A transformação do texto em quadro modifica sua natureza comunicativa, ressaltando-a. No site da entidade, onde se pode ler o texto completo da missão, a mensagem permanece "invisível" até que alguém tome a iniciativa de acessá-la. Ao ser recortada, emoldurada em uma escala visual ampliada e alçada a um lugar de destaque em sala de grande confluência, a missão ganha materialidade e visibilidade. Assim, em vez do que acontece no site, o texto é que interpela o visitante, não apenas revelando a todos qual é a missão do Bunkyo, mas também sugerindo a sua importância para a entidade, e a importância da entidade na sua realização.

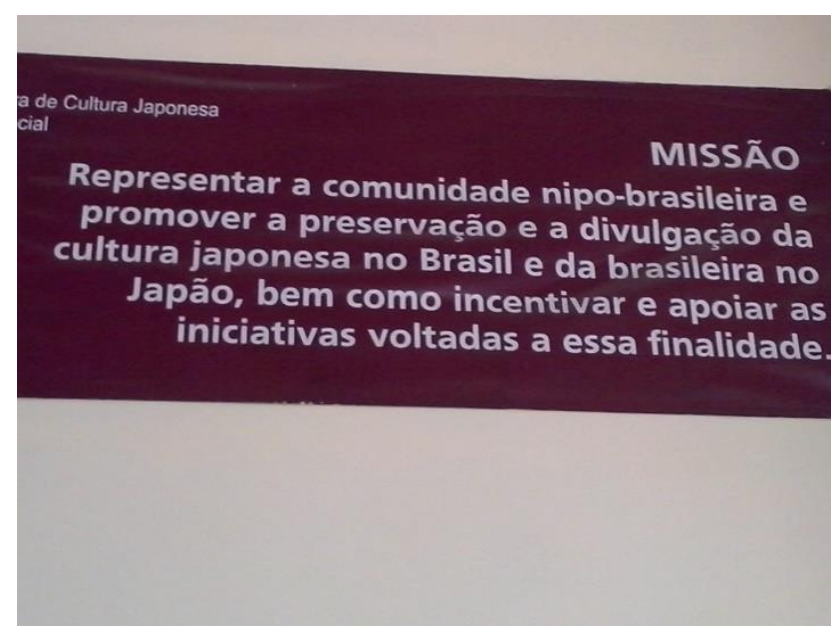

\section{Foto 13: missão do Bunkyo, em painel na parede da secretaria.}

\section{Fonte: fotografia da autora.}

Do lado de fora do edifício-sede, à direita da portaria, há uma larga escadaria que dá acesso ao saguão principal e ao grande auditório, onde acontecem importantes 
eventos sociais e culturais do Bunkyo. Nos dias de festas e cerimônias, os portões são abertos e as pessoas encarregadas da recepção ficam a postos no alto das escadarias, de modo que todos - autoridades, associados e visitantes - percebam que é por ali que devem subir. Nas ocasiões muito importantes, até mesmo os mais idosos preferem enfrentar os vários degraus dessa entrada principal, de aparência mais solene que a simplíssima entrada da portaria (por onde não é necessário subir degrau nenhum). Como essa entrada é usada somente nessas situações especiais, a escadaria assume o significado de passagem simbólica entre dois mundos: o de fora (a rua, a "indistinção") e o de dentro (a comunidade nipo-brasileira, singular e distinta do resto da sociedade brasileira). Nesse sentido, o papel da escadaria se assemelha ao de um elemento da cultura japonesa que também simboliza "transição entre dois mundos", mas em um sentido religioso: o torii, portal que, na tradição xintoísta, marca a passagem do terreno profano para o sagrado.

Em outro estudo sobre o espaço na cultura japonesa, Okano (2013/2014) compara diferentes apropriações do espaço das escadarias e suas semânticas: enquanto que em um lugar turístico do ocidente (como um museu ou uma catedral) elas podem se transformar em extensões da própria praça, ou calçada, onde as pessoas descansam, comem e conversam, a escadaria japonesa é um lugar tradicional de passagem para alcançar o divino, projetado para interagir com os sentidos do caminhante de formas variadas. Portanto, assim como o torii na tradição xintoísta, a escadaria, "presente na maioria dos templos budistas, é tradicionalmente considerada elemento de interconexão entre o território profano e o divino" (2013/2014, p. 160). Apesar das diferenças óbvias entre a escadaria de um templo japonês e a de uma entidade nipo-brasileira, essa ferramenta conceitual oferece uma possibilidade interessante de interpretação dos significados que certos elementos da paisagem cultural podem assumir, ainda que os atores envolvidos não tenham intenção de produzir esses efeitos, pelo simples fato de estarem inseridos em um contexto de trocas simbólicas que evocam determinadas referências culturais. 


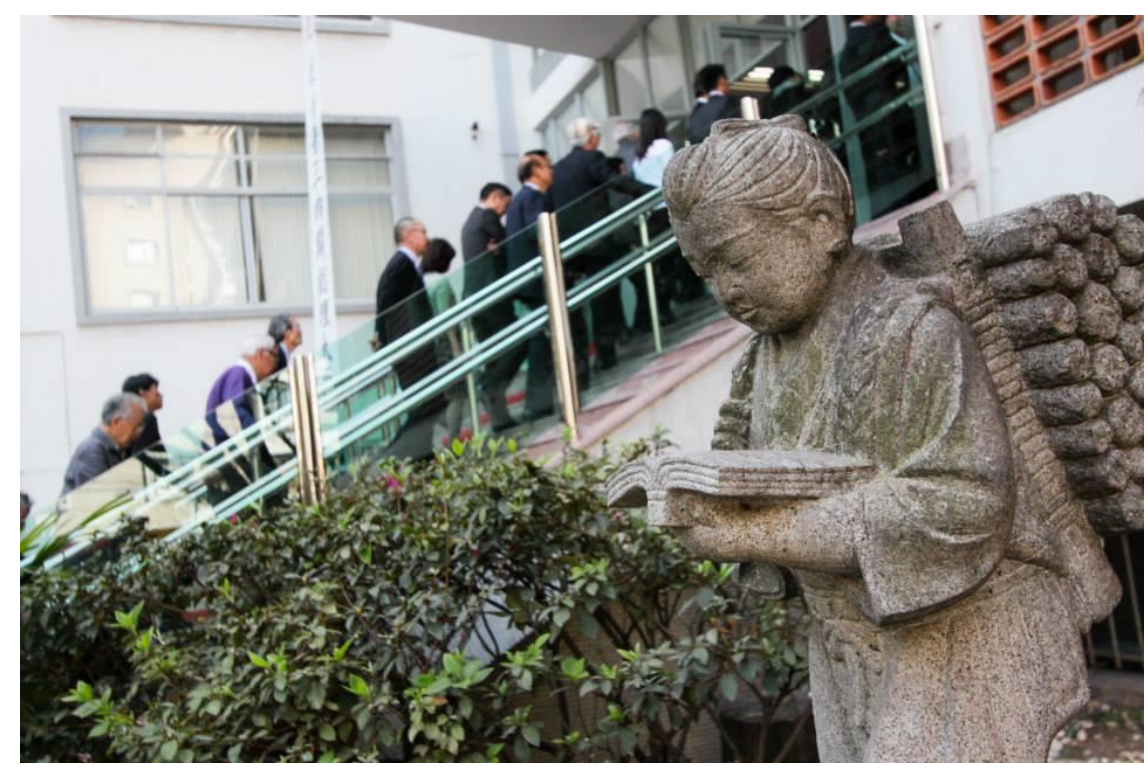

Foto 14: convidados à recepção ao primeiro-ministro Shinzo Abe sobem as escadas. Fonte: Bunkyo

O contexto principal, nesse caso, é o próprio evento que está acontecendo no interior do prédio - sempre ligado a algum tema da cultura japonesa ou a alguma circunstância oficial relacionada à comunidade nipo-brasileira ou ao governo do Japão , e outro referencial é o jardim zen, construído pelo Bunkyo no térreo, ao lado da escadaria. Embora o jardim esteja "fora" do edifício (em área externa), ele está também "dentro dele" (pode ser visto da rua, mas está dentro da área de grades que circundam parte do edifício-sede do Bunkyo), permitindo diferentes leituras, seja pelos passantes, que podem ver nele "algo de oriental", seja pelos participantes dos eventos, que possuem outras chaves de decodificação dos seus significados culturais.

Seu potencial semântico remete tanto à estética da jardinagem tradicional japonesa quanto à sua natureza religiosa, pois esse tipo de jardim tem origem na tradição zen budista, que atribui significados especiais e poderes meditativos à disposição e à forma das pedras, arbustos, pedaços de tronco, plantas, areia e pedregulhos no espaço do jardim. Construído ao lado da escadaria de acesso ao edifíciosede do Bunkyo, o jardim zen pode ser uma das mediações entre os indivíduos que o admiram ao entrar no prédio e os sentimentos de pertencimento à comunidade herdeira da cultura tradicional japonesa. 


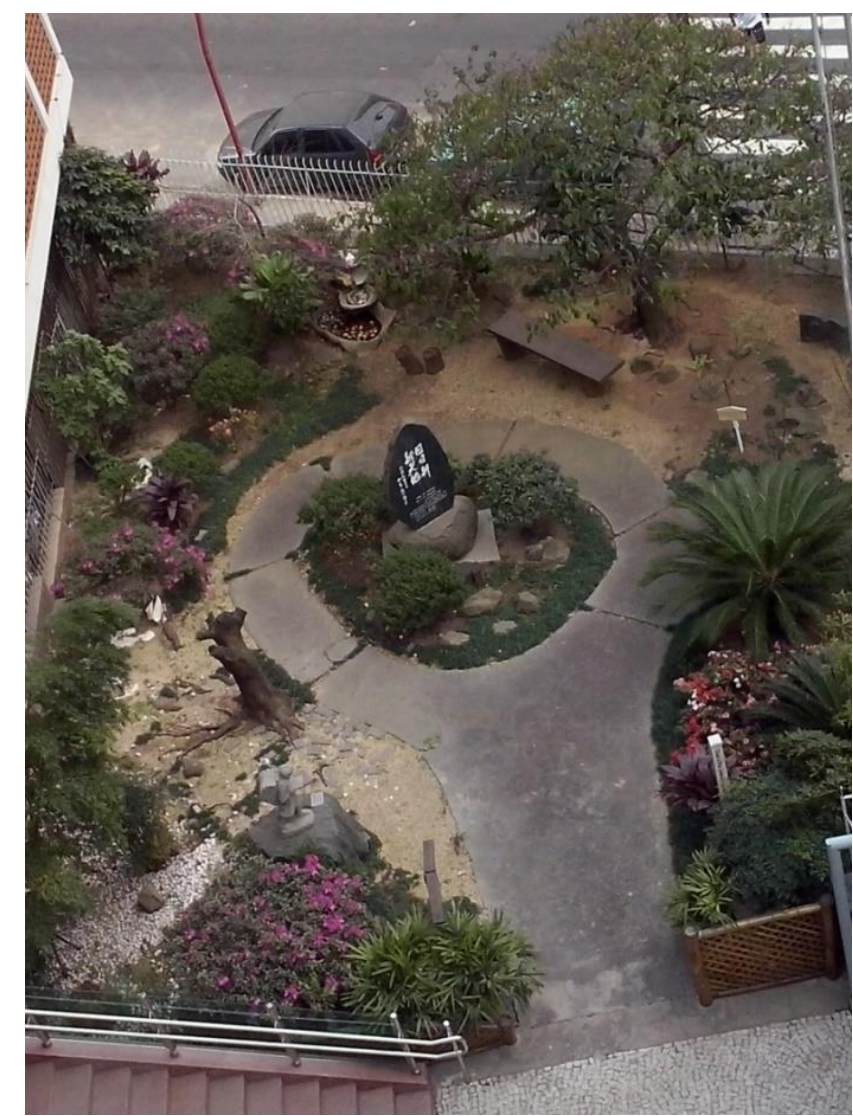

Foto 15: jardim japonês na entrada do Bunkyo, visto de cima.

Fonte: fotografia da autora.

\subsection{Festas e celebrações: ritos e performances}

Eventos importantes como os festivais anuais - Bunka Matsuri, festival das cerejeiras e Gueinosai $^{213}$-, as celebrações do ano novo, do aniversário do imperador e da imigração japonesa e o $F I B$ são momentos especiais na vida do Bunkyo, pelas possibilidades de dramatização das relações sociais e hierarquias entre os membros da comunidade, que atualizam nessas ocasiões os elos que os unem e os valores éticos e estéticos que consideram parte de seu legado e identidade. Mobilizando uma grande quantidade e diversidade de grupos de dança, música, teatro, arte visual, floral e marcial da cultura tradicional japonesa, além de monges e padres nas celebrações católicas e

213 O Bunka Matsuri (Festival da Cultura) e o Gueinosai (Festival de Música e Dança Folclórica Japonesa) acontecem anualmente em junho, ambos na sede do Bunkyo na Liberdade, como parte das celebrações do aniversário da Imigração Japonesa; o Sakura Matsuri (Festival das Cerejeiras) acontece sempre no início de julho, no Centro Kokushikan, em São Roque. 
budistas, comerciantes, autoridades e membros da comunidade nipo-brasileira, esses eventos são "situações de comunicação", no sentido de Charadeau (2012) e se aproximam do que Mauss (1974) chama de "fatos sociais totais", ou seja, os eventos que envolvem trocas cerimoniais materiais e simbólicas que acionam, ao mesmo tempo, planos comunicacionais de fundo religioso, econômico, político, estético e moral do grupo social, revalidando os compromissos e o reconhecimento mútuo entre seus membros.

Em seu estudo sobre as "mediações culturais da festa", Amaral (1998) pondera que as festividades de grande repercussão entre os membros de um grupo são um fundamento de comunicação, ou um "discurso social" em que a festa se torna uma "mediadora entre os anseios individuais e os coletivos, fantasia e realidade, passado e presente, e presente e futuro" (1998, p. 19). No caso do Bunkyo, observa-se que o anseio mais premente é pela preservação do espírito de "coletividade", na evocação de um passado (a memória da imigração e da cultura japonesa trazida pelos imigrantes) que é marca de identidade do grupo no presente. Durante o Bunka Matsuri e o Gueinosai, por exemplo, observa-se um desfile de signos cujas referências originais são substituídas pela lógica da festa, que é a de reconstituir a memória do imigrante japonês e da cultura que trouxe com ele.

No palco do auditório, sucedem-se a dança kabuki e das plantadoras de arroz, os concertos de shakuhachi, koto e shamisen, entre outros números de artes cênicas e musicais clássicas e folclóricas japonesas. Os quimonos estampados, vestidos por mulheres que, entre uma apresentação e outra, andam pelo saguão com seus passinhos curtos e apressados (como as gueixas e maikos do Japão), o aroma dos obentôs e das tigelas de $u d o n$, o rufar ensurdecedor dos taikô, o ruído surdo das espadas de bambu do $k e n d \hat{o}$, as oficinas de origami e oshibana ${ }^{214}$ e muitas outras cenas, sons e imagens que parecem saídas de um filme de Ozu transformam o cenário em uma síntese da paisagem cultural japonesa do Brasil. Tanto no palco como no saguão, praticamente não há atores, dançarinos ou músicos profissionais japoneses. São praticamente todos imigrantes ou seus descendentes, que trouxeram há décadas suas artes do Japão, ou as

\footnotetext{
${ }^{214}$ Kabuki: teatro popular japonês; koto e shamisen: instrumentos musicais de corda; maiko: aprendiz de gueixa, que é uma especialista em entretenimento nas artes tradicionais japonesas; obentô: refeições prontas, vendidas em caixas; udon: caldo com macarrão, carne e vegetais; taikô: tambores tradicionais japoneses; origami: dobradura em papel; oshibana: arte com colagem de flores secas; kendô: luta de espadas.
} 
aprenderam aqui com alguém, e reconstituem essas apresentações em grande estilo, com coreografias, cantos, penteados, maquiagem e vestuário rigorosamente "autênticos".

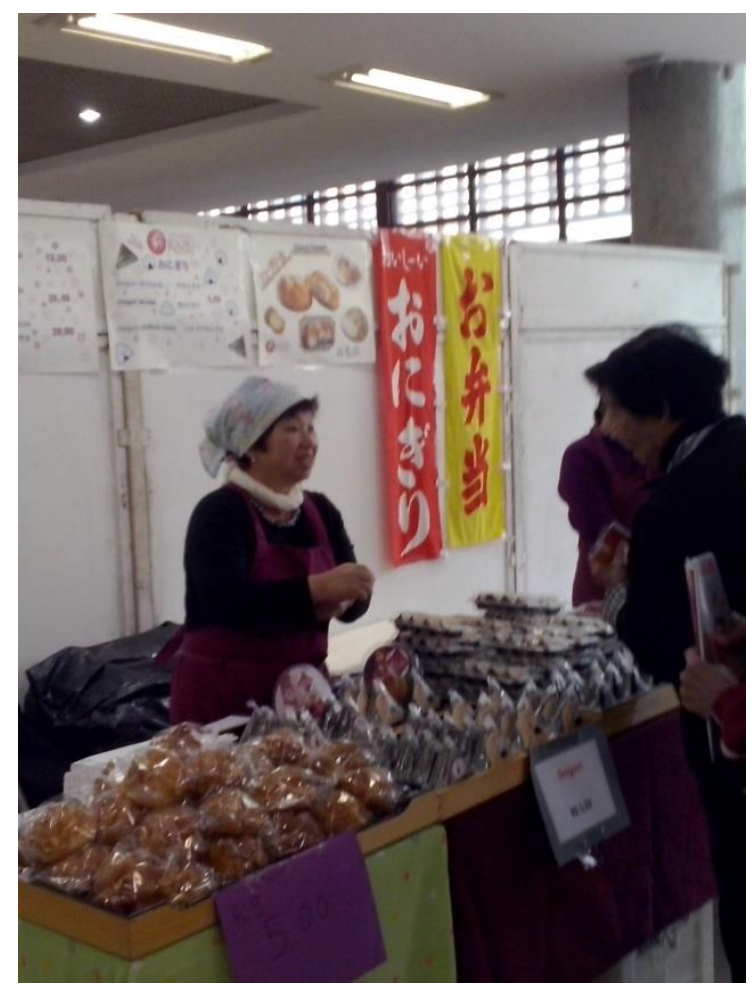

Foto 16: banca de comidas japonesas durante o Gueinosai. Fonte: fotografia da autora.

Quanto aos formatos e significados de cada apresentação, imagem, aroma, som ou objeto, suas referências culturais originais se inserem em algum lugar específico no tempo e no espaço (geográfico e social) do Japão. Mas, em boa parte, suas formas e significados já foram hibridizados por força das apropriações individuais e dos grupos, que, com o passar do tempo, os modificam com suas releituras, e pelo contato com práticas artísticas de diferentes origens. $\mathrm{O}$ verdadeiro significado do festival, porém, não é o resultado da soma dos significados de cada um dos elementos da festa, mas a sua totalidade transcendente e representativa do "espírito" do Japão, uma fonte sempre atualizada de distinção. Essas apresentações se repetem há anos no Bunkyo (o Gueinosai, que é anual, por exemplo, já está na sua $52^{\text {a }}$ edição), e a sua continuidade é como uma garantia de que a narrativa da imigração japonesa e do legado dos imigrantes seguirá sendo contada dessa forma. 


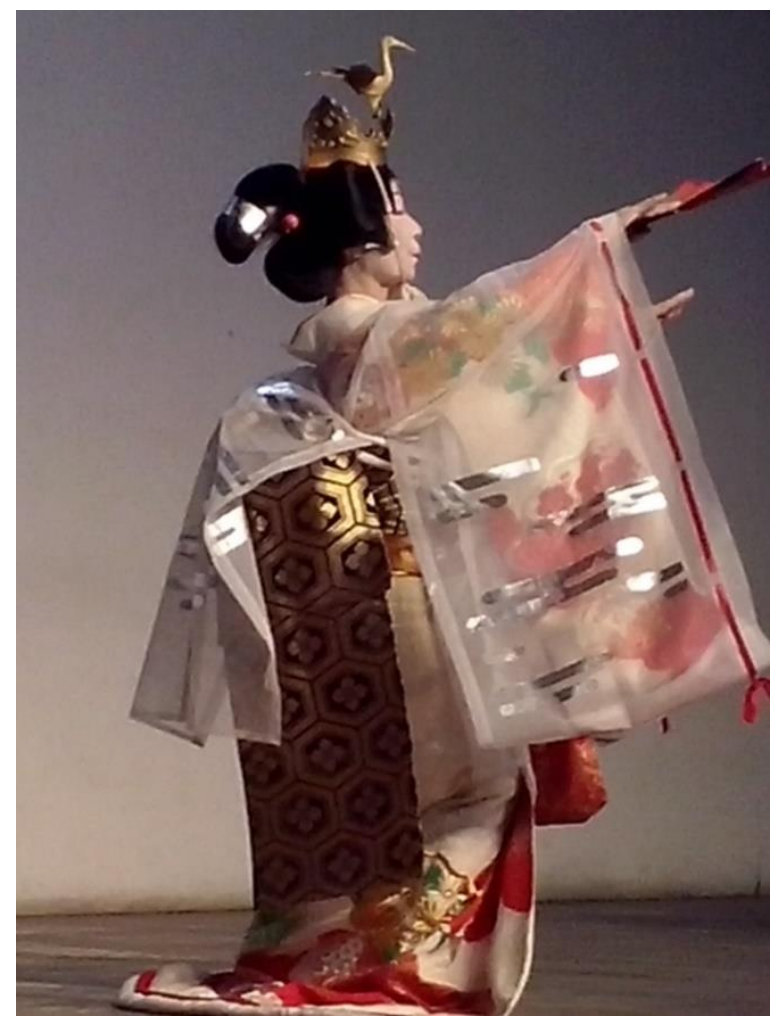

Foto 17: dança kabuki, no 50 Gueinosai.

Fonte: fotografia da autora.

\subsection{O poder evocativo do museu}

O Museu Histórico da Imigração Japonesa representa um momento especial no esforço de construção de um "lugar de memória" da comunidade nipo-brasileira. Inaugurado em 1978, ano do $70^{\circ}$ aniversário da imigração japonesa ao Brasil, seu compromisso parece se apoiar menos na "história aprendida" e mais na "história vivida", conforme distinção de Halbwachs (2013), que aponta as diferenças entre os métodos e motivações da historiografia oficial e dos registros de histórias de vida (2013, p. 79). Todos os ambientes, objetos, imagens e instalações do museu aproximam os grandes feitos, registros e "relíquias" ao homem comum, às histórias de vida que cada descendente dos imigrantes japoneses pode considerar parte de sua própria história familiar, e constroem um cenário que, ao abrigar os fragmentos materiais da memória, proporciona aos membros da comunidade "uma imagem de permanência e estabilidade" do que já se foi (2013, p. 157). 
Se desde a pintura rupestre a imagem faz parte do sistema de comunicação humano, a tecnologia exacerbou a sua presença no espaço público, transformando as maneiras de ver e representar o mundo (inclusive o do passado). Por isso, no espaço do museu, as instalações e a disposição do acervo não apenas organizam e conservam os objetos e documentos que mantêm viva a memória, mas também têm algo a "dizer" sobre o passado. Refletindo sobre o lugar da "teia de imagens" na linguagem - esse "fato social" que Saussure considerou "o mais determinante na formação de uma coletividade" -, Bucci (2016) afirma que "a linguagem pode se processar também na membrana da visualidade" (2016, p. 115-119). Diz o autor:

(...) as imagens funcionam como se compusessem uma língua: uma língua visual. Seus processos de significação também se revelarão análogos aos da língua feita só de palavras. Também no caso das imagens, os sujeitos (ou indivíduos, ou grupos, ou falantes, ou atores, como quisermos) interagem (ou dialogam) por meio do signo (2016, p. 122).

Também Mateus (2016), ao explorar o potencial "retórico" das imagens, lembra que elas "gozam de um poder evocativo que as palavras não alcançam", pela presumida autenticidade do visual ou de seu "valor de verdade". Muitas dessas imagens e objetos também têm autenticidade derivada de sua própria "biografia", como diz Meneses (1998), ou seja, de sua trajetória no tempo e no espaço e sua vinculação direta a "fatos memoráveis" (1998, p. 93).

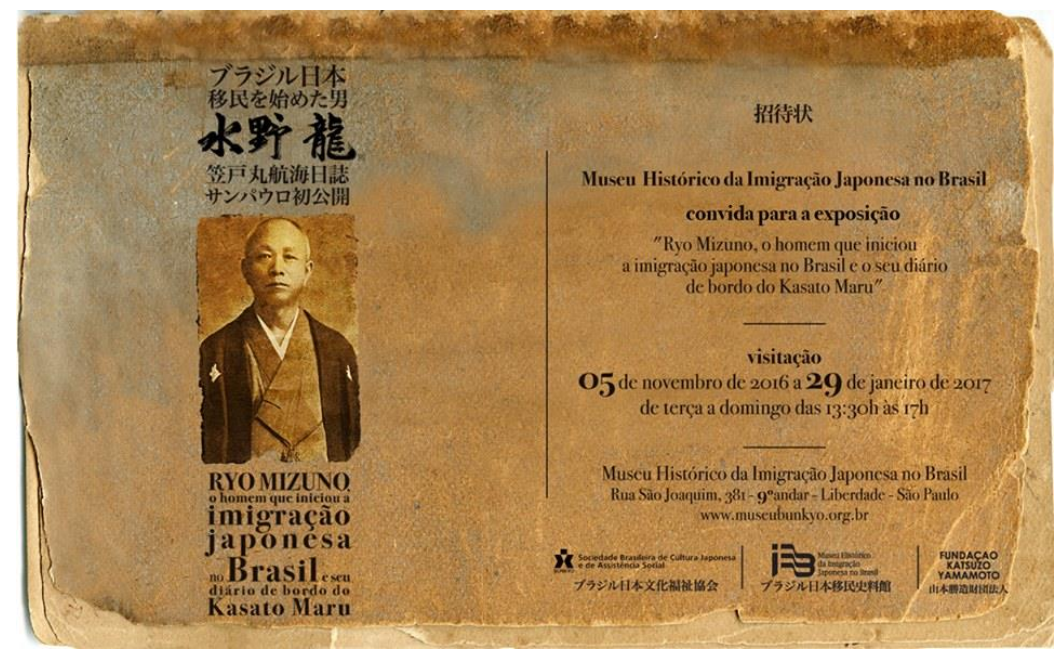

Foto 18: cartaz de exposição reproduz capa de diário de bordo de 1908.

Fonte: Bunkyo 
O poder comunicativo de cada elemento do museu - como no caso dos festivais - não está em seu valor individual, mas em sua relação com os outros objetos, isto é, na parte que desempenha no discurso sobre o passado, na narrativa da imigração. Uma enxada que pertenceu a um pioneiro, uma medalha conquistada por um artista nipobrasileiro em algum concurso importante ou a armadura de um antigo samurai, por exemplo, não "falam" só sobre si mesmos, mas também - em conjunto com outros objetos como bandeiras, emblemas e textos explicativos - sobre os valores atribuídos aos membros do grupo, como heroísmo, coragem, esforço e espírito de sacrifício, sejam eles simples agricultores, estudantes e profissionais bem-sucedidos ou os bravos guerreiros do passado.

Mas não só os objetos autênticos têm o poder de dizer coisas sobre o passado: as réplicas do navio Kasato Maru e da casa do imigrante agricultor, entre outras, embora não tenham, como o artefato real, o vínculo orgânico com o passado, ainda assim proporcionam uma associação simbólica capaz de evocar a coisa ou a situação que pretendem substituir. Em sua reflexão sobre a noção de autenticidade no campo do patrimônio cultural, Bauer (2012) afirma que cópias e reproduções têm a função de ajudar a compor o imaginário sobre o que é antigo: enquanto o objeto real tem "valor de matriz", a "verossimilhança, ao invés de alinhar-se imediatamente com o falso, localizase numa zona intermediária, onde uma determinada ideia de passado encontra lugar" (2012, p. 23).

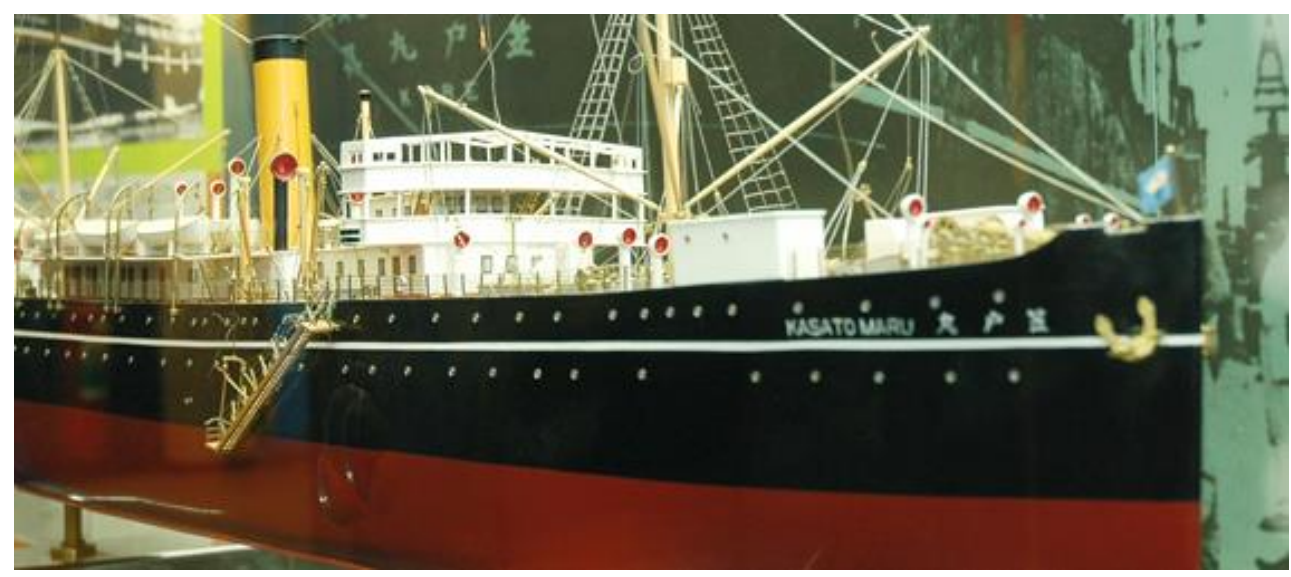

Foto 19: réplica do navio Kasato Maru.

Fonte: Museu Histórico de Imigração Japonesa 
Assim, a réplica do Kasato Maru assume o protagonismo de uma narrativa que tem início com a chegada do navio verdadeiro ao porto de Santos, há mais cem anos, trazendo a bordo a primeira leva de imigrantes japoneses. É como se a "vontade de memória" tivesse o poder de fazer ver, na réplica, a "alma" do verdadeiro Kasato Maru, que hoje está nas profundezas do mar, próximo à península de Kamchatka, afundado pelas forças russas no final da Segunda Guerra ${ }^{215}$.

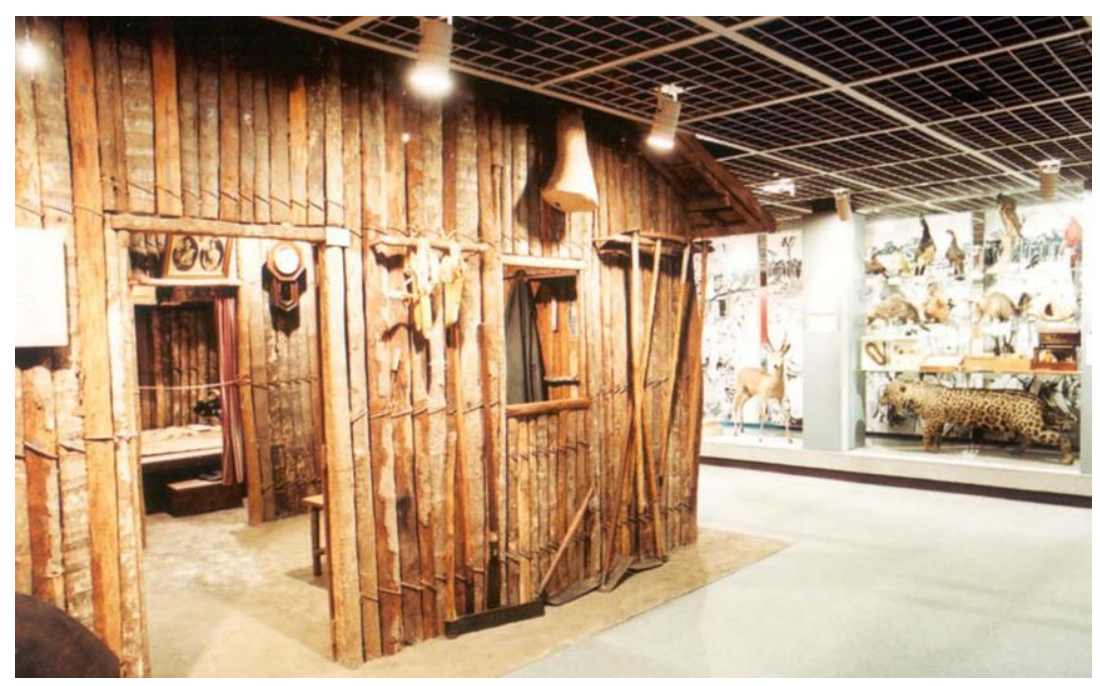

Foto 20: cabana do imigrante japonês.

\section{Fonte: Bunkyo}

A outra grande réplica do museu é a cabana do imigrante, composta por técnicas, materiais e objetos usados pelos primeiros agricultores japoneses. O potencial comunicativo dessa reprodução está em sua integridade, real e simbólica: no meio dos muitos fragmentos materiais dispersos no museu, a cabana reúne muitos daqueles objetos em uma narrativa única e concreta, cujos elementos de extrema simplicidade, em vez de evocar uma ideia de pobreza ou de falta, sugerem uma riqueza de recursos e de virtudes, em que os valores e costumes tradicionais da vida e da casa japonesa são conservados, apesar das adversidades, pelo esforço de adaptação, trabalho árduo e engenhosidade dos pioneiros.

\footnotetext{
${ }^{215}$ Ver em http://www.ndl.go.jp/brasil/pt/column/kasatomaru.html, acesso em 13/07/2017.
} 


\subsubsection{Um catálogo onde se visualizam as narrativas}

O catálogo do museu que, segundo seus apresentadores, foi um projeto esperado por longo tempo, tem por objetivo "inserir informações sobre algumas das principais peças do acervo". Essa publicação permite que se visualize, de modo resumido, como as narrativas da imigração e seus temas correlatos foram organizados no museu na forma de uma ampla narrativa que realiza três feitos importantes: primeiro, junta fatos e objetos em uma ordem cronológica que sugere o encadeamento entre os acontecimentos e suas relações de causa e efeito, promovendo ao mesmo tempo avaliações de juízo moral e atribuições de significado a cada história narrada; segundo, coloca lado a lado textos e suas representações materiais, o que potencializa o "efeito de verdade" e, portanto, a força da narrativa como versão dos acontecimentos; terceiro, reconfigura a experiência de pessoas separadas no tempo e no espaço em termos de uma história comum, humanizando os fatos e suas consequências econômicas e políticas que, afinal, não ocorrem em um mundo abstrato, mas em um mundo real, povoado por homens, mulheres e crianças que pagam o preço e assumem o fardo das grandes transformações.

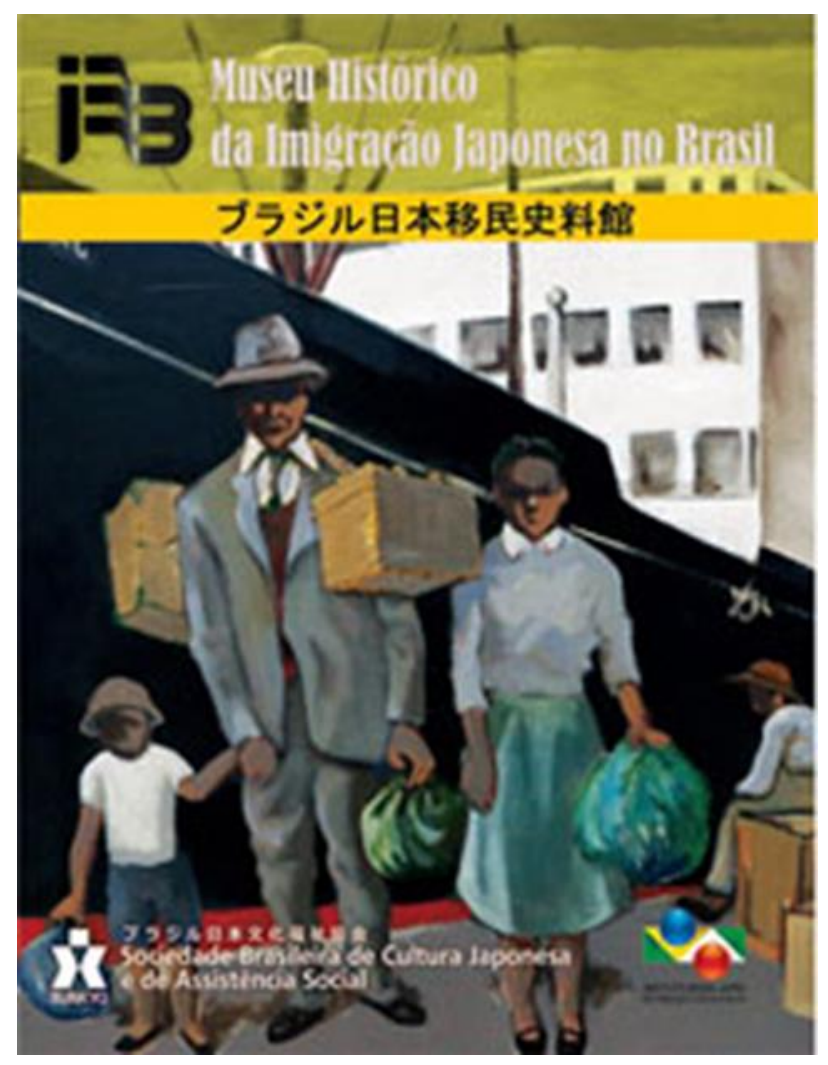

Foto 21: capa do catálogo. Foto: Museu Histórico de Imigração Japonesa. 
A descrição dos percursos expositivos do $7^{\underline{0}}, 8^{\underline{0}}$ e $9^{\underline{0}}$ andares no índice do catálogo, ilustra os pontos ressaltados acima. No "percurso expositivo do $7^{\underline{0}}$ andar", o primeiro tema, "Imigração japonesa no Brasil”, é seguido por "Kasato Maru - o navio da esperança", "Os pioneiros", e outros ainda como "Os desafios" e "A sabedoria". A imigração japonesa, que dá nome ao museu, é o grande tema e a "narrativa-mãe" da qual derivam todas as demais. $\mathrm{O}$ texto conta que já havia imigrantes japoneses no Brasil antes da vinda do Kasato Maru, em 1908, que passa, no entanto, a ser o "marco zero" da história por ter trazido a primeira leva mais numerosa e já organizada de imigrantes.

Intercalado por trechos de reportagens de época e por citações bibliográficas entre outros "efeitos de real" da narrativa -, o texto relata uma "história de superação e dificuldades", vivida por pessoas capazes de "muito esforço, dedicação e sacrifícios". Assim, o que dá intensidade à narrativa não é o fato histórico em si, mas os personagens reais, que, durante a travessia oceânica, "passavam frio", se "alimentavam precariamente", suportavam o "barulho ensurdecedor dos motores" e dormiam perto de um "grande depósito de carvão". Relatos desse tipo convidam à empatia por parte do visitante (ou leitor do catálogo), que pode assim imaginar a sensação de estar a bordo naquelas precárias condições e avaliar a real dimensão dramática dos acontecimentos. Em "Os pioneiros", o texto se dedica ao "reconhecimento e a saudação" a todos que contribuíram para que a imigração se concretizasse, começando por Ryo Mizuno, cujo busto ali no museu "simboliza a gratidão dos primeiros imigrantes que chegaram ao Brasil como consequência do seu trabalho e atuação".

No capítulo "Os desafios", a primeira fotografia do catálogo assusta: uma enorme onça empalhada que, de boca escancarada, mostra os dentes afiados àqueles que visitarem o museu e que poderão assim imaginar os riscos que os japoneses tiveram que enfrentar nas matas e florestas virgens que transformaram com suas próprias mãos em terras agricultáveis. Em "A sabedoria", vemos os imigrantes utilizando seus conhecimentos, inteligência e capacidade de adaptação para criar novas técnicas com as quais puderam não só sobreviver como também prosperar na "difícil realidade rural do Brasil".

Em "Hospital Santa Cruz", o leitor/visitante é informado sobre as doenças contraídas pelos imigrantes por desconhecerem seus fatores propagadores, como no caso da malária, que ceifou milhares de vidas, e cujo enfrentamento teve a ajuda do 
governo japonês, que, "sensibilizado com a situação de seus conterrâneos, enviou recursos de 36.000 ienes". O percurso do $7^{\circ}$ andar termina com a "Amazônia", onde os imigrantes foram mais "severamente castigados", pelo ambiente extremo e a terrível dificuldade de escoamento de suas produções, mas onde "se mantiveram firmes", deixando "muitos de seus descendentes" que permanecem por lá até os dias de hoje.

O percurso do $8^{\circ}$ andar começa com o "Cooperativismo", uma decorrência do hábito dos japoneses de se associarem "para tratar de assuntos comunitários", e que criou condições de aumentar a produtividade e de introduzir novas culturas no país. As "transformações" e a "vida na metrópole" focalizam as inovações técnicas e a mudança para os centros urbanos, onde muitos imigrantes - que não se deram bem na lavoura, ou, pelo contrário, prosperaram e quiseram partir para uma nova vida - foram se dedicar “às suas verdadeiras vocações e ofícios de origem". Em "Personalidades", são expostas pinturas e fotografias de homens que formaram a elite japonesa no Brasil, como empresários, diplomatas, médicos e engenheiros, mas também os mais humildes que lideraram empreitadas não menos desafiadoras, como os pioneiros da Amazônia e da colônia Hirano, quase inteira dizimada pela malária (inclusive seu fundador, Umpei Hirano).

O capítulo "Túnel chamado guerra" mostra uma grande fotografia dessa instalação do museu que termina em uma parede inteiramente coberta pela fotografia iluminada de um ipê amarelo, de importante significado para muitos imigrantes, que o consideravam o equivalente brasileiro da cerejeira japonesa. A área expositiva do $9^{\underline{0}}$ andar tem como destaques a homenagem ao presidente do Bunkyo em cuja gestão o museu foi construído e inaugurado e os imponentes retratos do imperador Akihito e da imperatriz Michiko. O catálogo quase nada diz sobre o casal, mas um poema da imperatriz, com sua imagem ao fundo, declara o reconhecimento da família imperial do sacrifício de seus súditos: "Ao longo daquela longínqua estrada/ percorrida por vocês, imigrantes/ no caminho difícil e vencido/ Oh! Quantas vezes até agora/ têm os ipês florescido?"216.

\footnotetext{
${ }^{216}$ Como explica Hashimoto (2012), o Japão é um dos raros países que reconhecem e praticam a poesia como instituição oficial, uma prática que se mantém até hoje. O imperador Meiji, por exemplo, era chamado de "divino poeta" (2012, p. 59).
} 
O pós-guerra, a aproximação do governo e das empresas japonesas com o Brasil, o movimento decasségui e o "novo Japão", entre outros temas, encerram a linha do tempo da narrativa. Nela, os fatos estão reunidos de modo a ter seus significados relacionados entre si e explicitar o lugar de cada um no contexto da grande narrativa da imigração. Oferecendo rostos, nomes e objetos que pertenceram a pessoas reais, a narrativa (textual e material) desenvolve - em um tom afetivo que só aqueles que assumem o "direito de narrar" suas próprias histórias se permitem utilizar - um enredo que expõe os problemas, conflitos e soluções que levam a acontecimentos transformadores, seus cenários, personagens-chave e a "moral da história", que mostra que a união e solidariedade entre os imigrantes os fortaleceram, que o esforço e o trabalho duro destruíram todas as barreiras e que a persistência acabou trazendo a todos o sucesso merecido. E da narrativa também faz parte a "declaração" de que os governantes japoneses, embora não tenham conseguido poupar o seu povo da diáspora, nunca o abandonaram, e que, por sua vez, os imigrantes japoneses, apesar das dificuldades, cumpriram seu papel de "pequenos embaixadores", ajudando a elevar a imagem do Japão no Brasil.

\subsection{Um itinerário com cinema e leituras}

Por fim, a biblioteca e o pequeno auditório (onde filmes japoneses são projetados uma vez por semana, entre outros eventos com públicos menores) também fazem parte do cenário narrativo espacial-visual do Bunkyo, tendo sido incorporados aos itinerários dos frequentadores e visitantes da entidade, embora estejam um pouco fora de mão, no edifício anexo. Esses espaços e os demais "falam entre si” e com os passantes principalmente nos eventos importantes, como o Bunka Matsuri, que obriga o público a circular de um lado para outro, indo do auditório, onde o ambiente é dominado por quimonos, danças, músicas e tambores japoneses tradicionais, até o espaço multiuso, onde por toda parte se veem oficinas de artes japonesas, passando pela área de bazares, onde são vendidos produtos japoneses, e pela praça de alimentação, onde os aromas de udon, missoshiru, tempurá e yakissoba se misturam, para o entusiasmo daqueles que vão buscar nesses festivais a variedade de pratos regionais do Japão. 


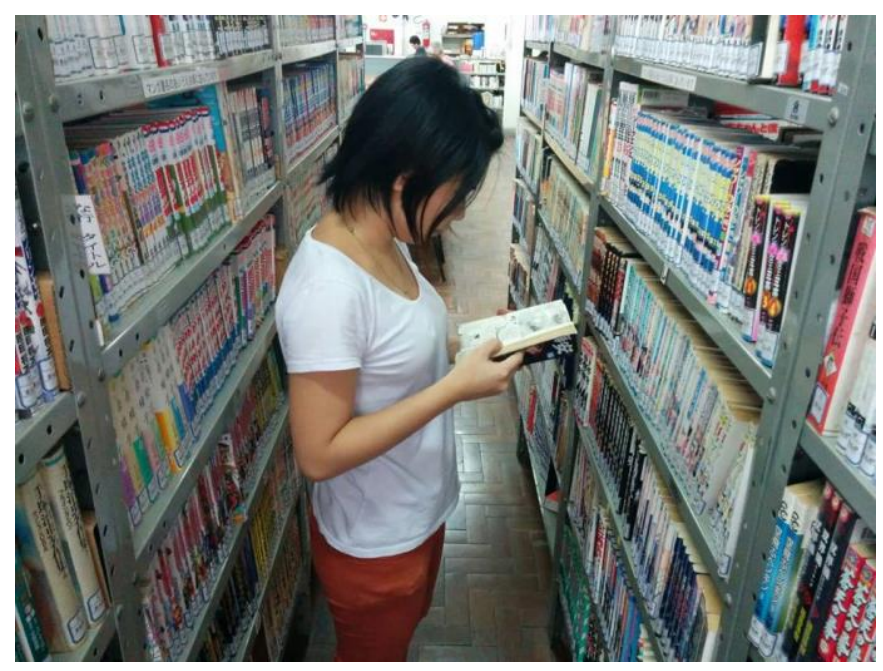

Foto 21: biblioteca.

Foto: Bunkyo

O clima agitado e barulhento dos espaços nesses dias de festa cessa bruscamente à porta da biblioteca, onde reinam o silêncio e as fisionomias sérias de leitores de jornais japoneses - geralmente senhores idosos - sentados em grandes mesas, em que alguns também folheiam revistas e livros em japonês. Sobre o balcão, atrás do qual alguns funcionários trabalham e falam em sussurros, muitos folhetos - em português e japonês - informam quando será a feira de livros usados, as regras para se concorrer a bolsas para o Japão, as datas para palestras no CIATE, entre outros assuntos. Mais para dentro, um labirinto de estantes expõe milhares de livros - cerca de 60 mil, segundo os organizadores da biblioteca - com títulos em português e em japonês (a grande maioria), sobre história da imigração, no Brasil e seus estados, biografias, livros de arte e literatura japonesa. Mais para o canto, uma outra seção é dedicada a livros infantis, desenhos animados (animê), histórias em quadrinhos (mangá) e DVDs de filmes japoneses. 


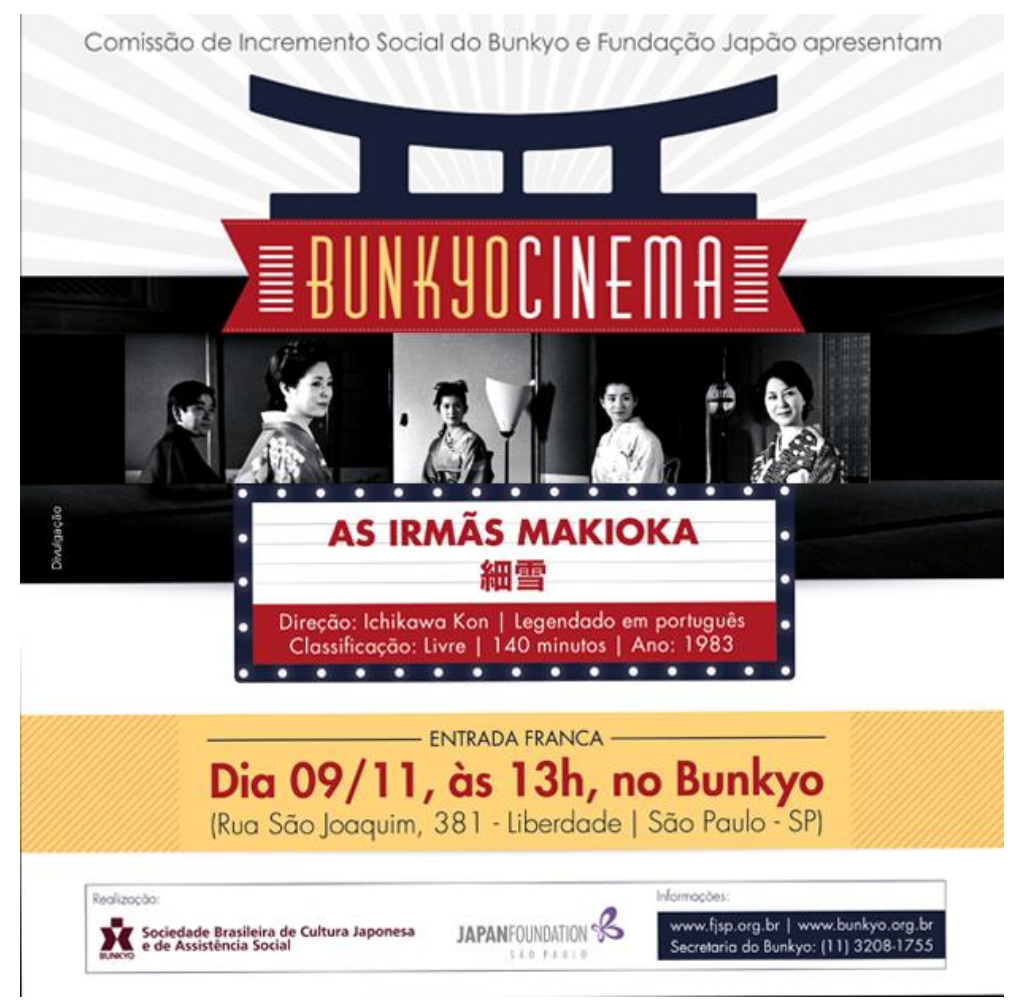

Figura 5: cartaz apresentando filme no pequeno auditório.

Fonte: Bunkyo

Os ambientes da biblioteca e do pequeno auditório, com os atores e ações que ali se desenvolvem, integram-se à narrativa do Bunkyo participando da completude do mundo proposto pela entidade, a despeito da dispersão inevitável de vários de seus fragmentos, como foi comentado acima. Quando se propôs, há mais de 60 anos, a ser a entidade central dos japoneses no Brasil, o Bunkyo optou por oferecer mais do que as associações da época já ofereciam. Assim, cada um dos seus espaços foi dedicado a uma parte de um mundo que deveria ser o mais amplo possível, abrangendo as dimensões políticas, religiosas, sociais e culturais da vida da comunidade. Nesse contexto, a biblioteca e o pequeno auditório (ao projetar filmes semanalmente) completam esse mundo nipo-brasileiro do Bunkyo com o cinema e a literatura, dois aspectos fundamentais na formação espiritual e na educação cultural dos associados de todas as idades. 


\subsection{As narrativas do espaço e da cultura material}

Os autores e reflexões apresentados acima indicam o caminho que trilhei na análise dos espaços físicos e da cultura material que compõem o ambiente do Bunkyo como elementos de um sistema comunicacional. Cada um desses elementos faz a mediação entre os sujeitos que gerenciam e/ou percorrem esses ambientes e a ampla narrativa que constrói e atualiza o universo identitário e cultural de um público imaginado. Assim como uma casa vai acumulando, com o passar dos anos, os objetos e imagens que contam histórias sobre seus moradores, e como um templo religioso é "decorado" também com imagens e objetos que ajudam a contar as histórias relatadas nos livros sagrados e nas falas de seus monges, padres ou pastores, o edifício do Bunkyo - que já foi chamado de "templo" e de "casa"217 -, com o tempo, também juntou objetos e imagens, e consagrou itinerários que têm algo a dizer sobre todos aqueles que participaram de cada etapa de sua construção e ampliação, e sobre as histórias que compartilham.

Como diz Nasrallah (2005), os prédios e monumentos "falam" entre si e com os passantes, por isso são mais eloquentes quando considerados em conjunto. Nesse sentido, o edifício do Bunkyo está inserido na narrativa da presença oriental na cidade de São Paulo, como também sugere Okano (2008). De fato, a escolha do local de construção da sede da entidade a inclui na narrativa da imigração japonesa por ter sido o bairro onde os primeiros imigrantes fixaram residência, no início do século $\mathrm{XX}$, ao deixarem as colônias agrícolas, e também o comércio, a primeira escola japonesa da cidade e as pensões onde se alojavam os filhos de agricultores que vinham do interior para estudar na capital.

Se, para a maioria dos passantes na calçada, o edifício que ostenta em letras "garrafais" o nome de "Sociedade Brasileira de Cultura Japonesa" e um jardim zen na lateral, em uma rua em que as luminárias lembram uma estética oriental, sinaliza apenas que aquele é o endereço de uma entidade relacionada ao Japão, para os seus

\footnotetext{
217 O slogan vencedor da campanha de construção da sede, em 1961, dizia: "Juntos construímos o nosso templo"; e também o primeiro presidente do Bunkyo, Kiyoshi Yamamoto, considerava essa sede como o "templo da cultura japonesa" e "refúgio espiritual da comunidade nipo-brasileira". Ver no Capítulo 2 e também em OI, C.A. A trajetória do Bunkyo e as comemorações da imigração japonesa no Brasil. Em: HARADA, K. (coord.) 60 anos de Bunkyo: Passado, Presente, Futuro. São Paulo: 2015, p. 54-58. Quanto à "casa", ver a apresentação de Cláudio Kurita no IX FIB, neste capítulo.
} 
frequentadores todos esses signos reportam a um contexto que eles conhecem bem melhor. Esses signos foram assimilados ao longo da vida, desde as primeiras experiências em família, e se mantiveram ou sumiram da memória segundo o nível de interesse de cada indivíduo pela cultura de seus ancestrais. Mas o que importa, nesta análise, é que os frequentadores do Bunkyo estão em contato com imagens cujas "narrativas" não só recontam as histórias que eles já conhecem, mas também ampliam essas histórias, renovando seus laços com a comunidade e o lugar que ocupam naquelas histórias, pois, como lembra Bucci (2016), "as imagens criam sentidos comuns. As imagens atam laços sociais" (2016, p.119).

Alguns objetos e imagens têm uma passagem rápida pelo espaço do Bunkyo, como é o caso dos arranjos de Ikebana (cujas flores e folhas logo murcham) e dos cartazes de shows, palestras e festivais sobre temas do Japão (colocados pouco antes e retirados logo após os eventos acontecerem). Porém, são sempre substituídos por outros, com função idêntica e mensagens mais ou menos do mesmo estilo. Outros também são passageiros, mas ficam por mais tempo, como as obras expostas no museu de arte (situado no primeiro andar) e os objetos e imagens que fazem parte de alguma exposição temporária do museu da imigração. Mas vários deles têm lugar permanente nos espaços onde "moram" pela força simbólica de suas presenças na história da imigração e do Bunkyo, como é o caso das fotografias de seus presidentes, que ficam na parede da sala da diretoria (no térreo), do painel com a "missão" na secretaria e da réplica do "navio da esperança", como é chamado o Kasato Maru, que fica no primeiro pavimento do museu da imigração (sétimo andar do edifício).

A permanência desses objetos e imagens e a frequente reposição de equivalentes daqueles que são passageiros evidenciam a vitalidade das narrativas que justificam sua presença e a necessidade de uma constante troca simbólica entre as histórias e sua representação material. Em sua reflexão sobre "a vida social das coisas”, Appadurai (2006) questiona o controle que as pessoas acham que têm sobre os significados "permanentes" dos objetos, que têm, na verdade, uma trajetória no tempo em que seus significados mudam (ou se esvaziam) à revelia das ações e relações humanas que atribuíram a eles essas representações. Diz o autor: 
A corrosão da História apenas sustenta e intensifica a tendência inerente das coisas de prosseguir em direção a algum novo estado em suas vidas sociais. E isto é verdade tanto para os objetos de arte quanto para as coisas em geral (2006, p. 16) $)^{218}$.

Não seria, então, justamente o papel da narrativa de se opor à impermanência da "vida social" desses objetos e imagens, validados - segundo seus defensores - pela experiência humana, impedindo assim os efeitos da corrosão da História não só sobre as coisas, mas também sobre a memória? Claro que a condição "ilusória" da permanência também não poupa as narrativas, nem mesmo aquelas que se agarram em fatos fundadores e em histórias consagradas. Cada 18 de junho reconta a história da imigração em diferentes palcos, por narradores diversos. Cada novo FIB entrega a novos portadores o "tesouro dos ancestrais", que por sua vez o imaginam um pouco diferente do que outros, antes deles, o imaginaram. Cada nova exposição do museu revoga algum tabu, silencia ou reverbera alguma voz, recupera dos arquivos (ou afunda dentro deles) alguma história que não (ou já) havia sido contada. Isto sem falar no público, cujas possibilidades ressignificadoras das narrativas são infinitas.

Mas uma coisa é ver a narrativa mudar, outra coisa é perdê-la para a "corrosão da história", ver os objetos e imagens (e as lembranças que representam) marchando em direção a algum novo estado em que nada mais pode ser reconhecido, e o passado já não pode atender as necessidades do presente. Esta é, a meu ver, a principal atribuição dos objetos, das imagens e dos espaços nas narrativas da imigração e do Bunkyo (e possivelmente de qualquer outra narrativa de relevância para alguma comunidade): reter, com a sua materialidade e promessa de permanência (ilusória ou não), a passagem do tempo, e intermediar as relações entre as pessoas que fazem parte de seu universo simbólico. Assim, as narrativas dão alma humana aos objetos e imagens, e estes lhes emprestam sua concretude.

A visibilidade e a eloquência da cultura material e dos espaços físicos, além de seu "valor de verdade", como diz Mateus (2016) - pois, ao contrário das palavras, eles mostram o que dizem - tornam imprescindível sua presença nas narrativas que devem

\footnotetext{
${ }^{218}$ No original em inglês: "The corrosion of history only supports and intensifies the inherent tendency of things to move on to some new state in their social lives. And this is as true of art objects as it is of things in general". Tradução da autora.
} 
perdurar. Eles interpelam os passantes nos momentos de silêncio e completam (ou corroboram) as falas nas circunstâncias de compartilhamento. Por sua "capacidade retórica", como diz Meneses (1998), eles persuadem as pessoas a associá-los com outras coisas, outros lugares e outros tempos, nem que para isso as pessoas tenham que se dispor a "fazer de conta", como no mitate, descrito por Okano (2008). E, para que proporcionem uma apreensão rápida, esses objetos e imagens não passam, muitas vezes, de meros estereótipos, que reduzem a complexidade das realidades que indicam, mas cuja força comunicativa reside justamente em seu enxugamento semântico. "Less is more", como diz o poema ${ }^{219}$. Kazuo Wakabayashi, criador da logomarca dos 110 anos da imigração, diz a mesma coisa de outra maneira: "precisava de uma forma que simbolizasse o Japão, e a melhor delas é a dobradura do grou, pois milhões de pessoas sentem que estão de frente para o país ao vê-la",220.

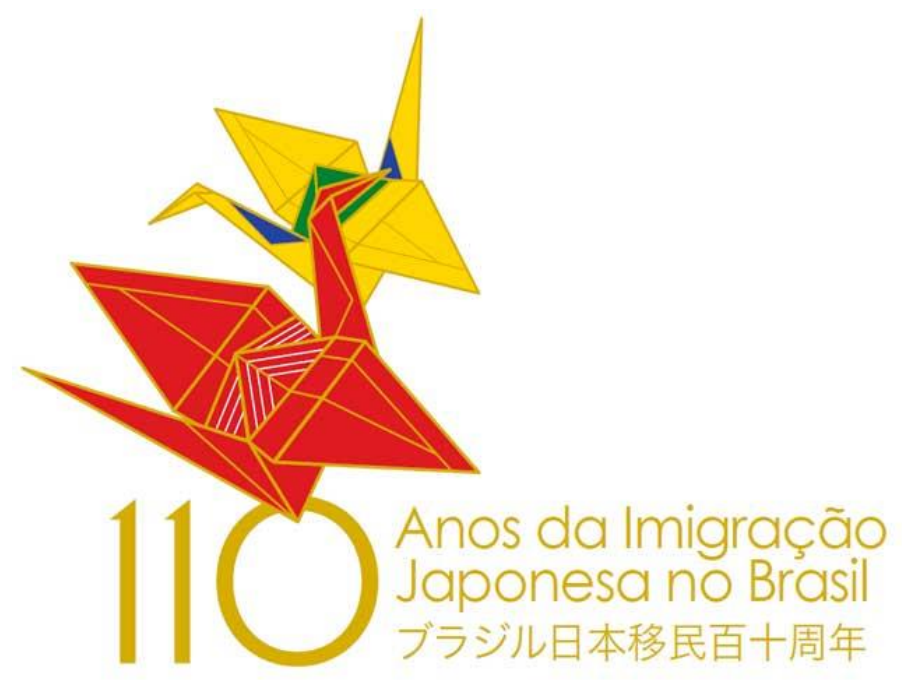

Figura 3: logomarca do $\mathbf{1 1 0}^{\circ}$ aniversário da imigração, com os dois tsuru (grous). Fonte: Bunkyo

Assim, as imagens do Monte Fuji, das gueixas, dos tsuru e das cerejeiras em flor ainda têm seu papel nas narrativas de uma entidade que já não se dirige apenas a seus frequentadores, mas a públicos mais amplos, como parte de um processo de adaptação aos novos tempos. Essas imagens esvaziadas de seus conteúdos originais, assim como

\footnotetext{
${ }^{219}$ Poema de Robert Browning, "The Faultless Painter", de 1855 (verso 75).

${ }^{220}$ Ver entrevista de Wakabayashi em: http://www.chadourasenke.org.br/especial/0014/, acesso em 14/11/2017. O texto do Bunkyo, porém, atribui a escolha do grou (o tsuru) ao fato de ser símbolo de gratidão no Japão. Ver em: http://www.Bunkyo.org.br/pt-BR/110-anos/1284-os-tsuru-e-o-simbolo-degratidao, acesso em 14/11/2017.
} 
outras menos estereotipadas, têm várias camadas de significações possíveis, como é o caso do jardim japonês e dos arranjos de Ikebana que comunicam menos ao público em geral e mais aos que conhecem sua história secular. E também dos retratos do imperador Akihito e de sua esposa Michiko - expostos no nono andar do museu -, que para uns são somente a imagem dos monarcas japoneses, e para outros, são objeto de veneração.

Os objetos, imagens e espaços físicos, em si mesmos, não podem ser considerados "narrativas", com algumas exceções como, por exemplo, as histórias ilustradas, como os antigos emakimono ${ }^{221}$ e as pinturas murais, que possuem um enredo completo (ou quase isso). Algumas colagens, como a que foi feita na capa do livro Prêmio Kiyoshi Yamamoto, do Bunkyo, que junta diversas pinturas de Tomoo Handa com cenas rurais de imigrantes japoneses, também conseguem contar uma história, ou boa parte dela, embora nesses casos a sequência dos fatos nem sempre faça parte da montagem. Os objetos e imagens são, na maior parte das vezes em que observei os espaços do Bunkyo, fragmentos de várias narrativas que estão à disposição dos passantes para que eles próprios os coloquem, conforme suas próprias combinações, em um "texto" que é sugerido de várias outras formas.

\footnotetext{
221 "Rolo de pintura", em japonês. "As narrativas de Genji”, ou "Genji Monogatari”, do século XII, é um
} dos mais famosos emakimono. 


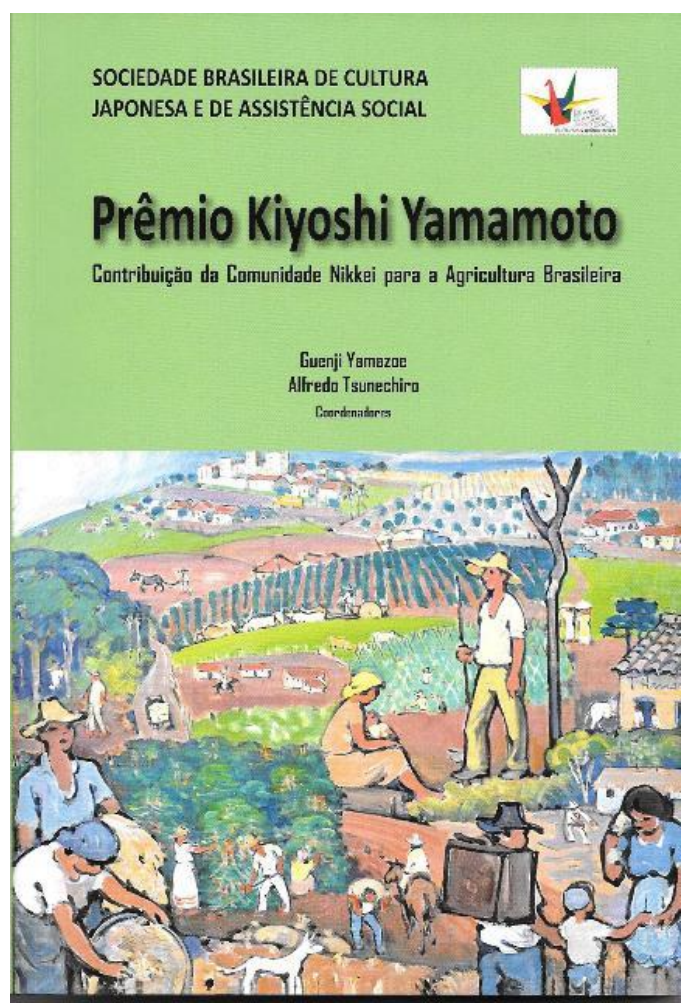

Figura 4: capa de livro do Bunkyo, com cenas de pinturas de Tomoo Handa. Fonte: Bunkyo

Assim, as narrativas discursivas (da imigração, do conflito e reconciliação dos imigrantes no pós-guerra, da fundação do Bunkyo, etc.) se apresentam nos textos, falas e performances em sua dimensão cronológica, mas, ao se juntarem às narrativas visuais (aos objetos, imagens e espaços do edifício do Bunkyo), podem adquirir finalmente uma dimensão "configuracional” como diz Ricoeur (1980), já que ali todas as histórias se encontram formando uma narrativa total. Sua dispersão em fragmentos materiais e em ecos do que se ouve, vê e lê no conjunto das falas, gestos e textos do Bunkyo, porém, é reorganizada - em uma infinidade de combinações - somente pela compreensão do público que faz parte, ou procura fazer, daquele universo simbólico.

No museu, entretanto, o esforço para organizar a dispersão é sua finalidade primordial e a tarefa mais importante de seus gestores. Nos seus três andares, os objetos e imagens, assim como a composição dos espaços, obedecem a uma lógica temática e/ou sequencial (no ponto de vista cronológico). Lá, os fragmentos das histórias encontraram o seu ponto de convergência mais bem definido, pois em nenhum outro lugar a narrativa da imigração japonesa no Brasil - como também as demais narrativas 
que dizem respeito à comunidade nipo-brasileira - é contada com tamanha diversidade de recursos, temas, personagens, cenários e atividades. Embora boa parte das histórias já houvesse sido contada em livros de memórias, pesquisas acadêmicas e até romances, um museu poderia contar a história inteira toda de uma vez, de uma forma mais dinâmica e da maneira que seus organizadores achavam que deveria ser contada.

E o museu seria, acima de tudo, um "lugar de memória", o local onde as pessoas poderiam se encontrar para celebrar as lembranças de sua família, de sua comunidade, ou do país deixado para trás - seu ou dos ancestrais. Este é o aspecto que transforma uma coleção de histórias em narrativa de fato: o ato de compartilhar, que faz com que o tempo de narrar seja o "tempo de estar com os outros", evocando novamente Ricoeur (1980). A ordenação daqueles objetos e imagens dispersos é marcada por uma narrativa de enredos instigantes, cenários inspiradores e sequências marcadas por acontecimentos transformadores: partidas dramáticas, chegadas desafiadoras, a tragédia da guerra, conflitos entre compatriotas e o "amanhecer" dos novos tempos. E há ainda o panteão dos grandes e pequenos heróis, os rostos que humanizam os relatos e dão uma dimensão épica às narrativas. Esse foi o grande feito dos organizadores do museu, cujas vozes narradoras aparecem (geralmente sem nome, exceto nas mensagens de apresentação) nas legendas, nos painéis e nos textos que explicam os fatos descritos, como é o caso do catálogo do museu, publicado em 2016 e comentado acima.

\section{O terceiro cenário narrativo: o discurso midiático do Bunkyo}

\section{na Internet}

Já no ano seguinte à sua fundação, o Bunkyo começou a investir na comunicação com seus associados por meio da revista mensal Kaiho, que publicava informações sobre a entidade e artigos sobre cultura japonesa, e que, a partir de 1960 passou a chamar-se Revista Colônia. Esse título já revela o que o projeto comunicacional do Bunkyo pretendia ser: uma forma de reunir a colônia japonesa (a "comunidade imaginada") em torno de si. A mídia do Bunkyo, então, se dirigiu por várias décadas a um público falante de japonês, com hábitos sociais bastante restritos às comunidades japonesas de suas cidades e bairros, e que, embora já tivesse se estabelecido 
definitivamente no Brasil, ainda via o Japão e os assuntos japoneses como a sua fonte primordial de identificação cultural e afetiva.

Esse era o público para o qual as narrativas da imigração e dos percursos da comunidade eram construídas, pois esse era o público que - de acordo com sua missão - o Bunkyo deveria "representar" e a quem pertencia o legado que a entidade se propunha a "preservar". As narrativas eram compartilhadas por meio da Revista Colônia, guias e catálogos, textos comemorativos e outros materiais de divulgação, que eram enviados pelo correio às casas dos associados ou distribuídos em locais-chave, frequentados pela comunidade. Enquanto isso, uma mudança no perfil do público começava a delinear-se. No final dos anos 1980, as mudanças já estavam aceleradas. Boa parte dos descendentes dos imigrantes, na terceira e na quarta geração, sem falar japonês e mais integrada ao Brasil, ao mundo e ao Japão Pop pelo cinema, histórias em quadrinhos e televisão, já via com pouco interesse as narrativas da imigração.

O Bunkyo demorou a reagir. Em 2003, como é mencionado no Capítulo 2, a "Comissão de renovação" da entidade apontava como omissões da entidade uma maior “atenção às novas gerações" e a "utilização de mecanismos modernos de comunicação". E, mesmo assim, foi só em 2006 que foi lançado o Bunkyonet, o projeto que utiliza uma ampla rede on-line que dá acesso ao site do Bunkyo e aos links das entidades associadas (embora muitas delas tenham ficando de fora por falta de recursos tecnológicos). A partir de 2009, com o sistema de internet mais elaborado e já contando com o Bunkyo News (impresso) e o Bunkyo e-news (enviado por e-mail), as narrativas da imigração e da comunidade nipo-brasileira passaram a se dirigir a um público mais amplo e diverso, que podia se conectar ao Bunkyo e, ao mesmo tempo, a diversas outras fontes de narrativas.

Da mesma forma que os edifícios e monumentos falam entre si, no contexto dos espaços descritos por Nasrallah, os textos e imagens também dialogam uns com os outros, no ambiente de intertextualidade da homepage do Bunkyo. Na página que será considerada para fins de análise de narrativa, com matérias dos dias 13 a 21 de junho de 2017, os temas apresentados se referiam à despedida do cônsul japonês, ao festival das cerejeiras, à apresentação do Gueinosai, às celebrações da memória do imigrante e à homenagem aos condecorados pelo governo do Japão.

Além dos resumos e pequenas fotos que remetem a cada um desses assuntos, o ambiente da página era composto pelas imagens permanentes do jardim zen do Pavilhão 
Japonês, do edifício do Bunkyo com uma luminária suzuran-to ("lâmpada em forma de lírio", em japonês) em primeiro plano, e do Centro Kokushikan, cujo telhado visto de frente lembra o de uma casa japonesa. Presentes também na página, entre outros, os dois tsuru coloridos dos 110 anos da imigração e mais dois logos que combinam as cores nacionais do Brasil e do Japão, além da rosa dos ventos do CIATE, da borboleta da Fundação Japão e da folhinha verde de chá (ou será um leque?) do Chado Urasenke.

A homepage do Bunkyo se constitui, portanto, em um ambiente narrativo estruturado como uma paisagem de variadas presenças, todas elas oferecendo, a um toque do mouse, desdobramentos em diferentes direções, com possibilidades de experiências narrativas diversas, quase todas, porém, tendo algo (ou tudo) a ver com o Japão e/ou com a comunidade nipo-brasileira (as três exceções são os links da Prefeitura de São Paulo, do Governo do Estado e do Museu de Arte Moderna, o MAM). Portanto, a homepage do Bunkyo se constitui em um "hipertexto" em que títulos de matérias, resumos de informações, nomes de entidades, ícones e outros tipos de signos estão agregados no espaço da página, proporcionando um encontro com o mundo narrativo nipo-brasileiro, cujo primeiro impacto comunicativo é causado pela presença de todos esses elementos juntos. Seus enredos, porém, são acessíveis apenas um de cada vez.

Nesse sentido, a mídia eletrônica do Bunkyo está em desvantagem em relação aos ambientes presenciais de comunicação da entidade. Um passeio pelo edifício-sede e, mais ainda, experiências no $F I B$, no museu e no Bunka Matsuri colocam o visitante em contato com narrativas variadas ao mesmo tempo, bastando apenas que se disponha a estar ali e a se deixar tocar pelo que vê e ouve. Na homepage do Bunkyo, por outro lado, é necessário que o visitante tome todas as iniciativas de, com o mouse na mão, acessar cada história e fazer a ponte entre elas. O ambiente virtual também está em desvantagem pela sua possibilidade limitada de se constituir em "espaço público" no sentido de palco de "compartilhamento". Uma coisa é ler ou escrever em casa comentários - ainda que em tempo real - sobre alguma história ou notícia nas páginas do Facebook, Instagram, Whatsapp ou Twitter do Bunkyo ou do Seinen; outra é estar de pé no auditório lotado do salão nobre, cercado pelos membros da comunidade, e gritar, junto com eles, "BRRRRRAVO!!!" no final de um evento em que narrativas inteiras foram compartilhadas.

Por outro lado, a mídia eletrônica proporciona o acesso universal aos interessados em conhecer ou se aprofundar no mundo narrativo do Bunkyo, estando eles 
em qualquer lugar do Brasil ou do mundo, desde que entendam o português ou o japonês. E, para os que só leem inglês ou espanhol, há o link do Discover Nikkei ${ }^{222}$, acessível nas quatro línguas, e que, embora não se restrinja ao mundo nipo-brasileiro, também o inclui, com narrativas oferecidas até por membros do próprio Bunkyo ${ }^{223}$. A flexibilidade e o baixo custo do meio digital também permitem que a entidade, mesmo nos períodos de dificuldades financeiras, mantenha a periodicidade e a variedade de suas mensagens e a abrangência de acesso. A vantagem da interatividade não é nada insignificante, levando-se em conta o feedback que proporciona para a entidade por meio das redes sociais e a possibilidade de pesquisas amplas como, por exemplo, a que foi realizada em 2014 sobre o perfil dos “jovens nikkeis", realizada pelo Bunkyo por encomenda do consulado-geral do Japão em São Paulo ${ }^{224}$.

\subsection{As histórias e o seu contexto}

Ao contrário das narrativas organizadas no museu, que buscam resgatar - ou constituir - a sequência de fatos que montam a cronologia da imigração e das histórias decorrentes dela, as narrativas organizadas pela mídia on-line do Bunkyo estão vinculadas à atualidade dos acontecimentos, como as notícias de um jornal. As notícias - cujos resumos constituem a parte central da homepage, e cada uma com um link "Leia mais" que leva ao texto completo - oferecem histórias com começo, meio e fim, sendo nesse sentido pequenas "narrativas integrais" em si mesmas. Em sua proposta de análise da narrativa jornalística, Motta (2005) propõe que se procure identificar "a serialidade temática e o encadeamento cronológico" entre as notícias fragmentadas e publicadas em determinado período de tempo para que se possa compreender "o tema como síntese".

Mas, à diferença da narrativa jornalística, a maior parte das notícias do Bunkyo está vinculada a celebrações e eventos previstos nos calendários, e mesmo aquelas que são novidades não chegam a ser surpreendentes como os crimes, acidentes, escândalos,

\footnotetext{
${ }^{222}$ Inaugurado em 2005, o Discover Nikkei é coordenado pelo Japanese American National Museum, com apoio da The Nippon Foundation. Ver em: http://www.discovernikkei.org/pt/about/, acesso em $10 / 11 / 2017$

${ }^{223}$ Ver, como exemplo, a narrativa de Eduardo Goo Nakashima, secretário-geral administrativo do Bunkyo em: http://www.discovernikkei.org/pt/journal/2013/10/7/a-vela-que-se-apaga/, acesso em $31 / 10 / 2017$.

${ }_{224}$ Ver em http://www.Bunkyo.org.br/pt-BR/noticias/86-2014/232-com-a-palavra-os-jovens-nikkeis, acesso em 17/11/2017.
} 
revelações e outros acontecimentos que alimentam as manchetes de jornais. Sendo todas referentes ao mundo do Bunkyo e da comunidade, as notícias estão relacionadas entre si, embora não estejam necessariamente encadeadas cronologicamente. As notícias, então, não formam uma "síntese", como no modelo de Motta, mas um "contexto" que integra as narrativas em um conjunto significativo que tem muito a dizer sobre o passado, o presente e o futuro da comunidade nipo-brasileira segundo o Bunkyo.

E que contexto seria esse? O que ele diz? Como chegar a ele? Na análise que faço da página do Bunkyo já mencionada ${ }^{225}$, me proponho a trilhar o seguinte caminho: primeiro, fazer a análise de cada notícia como uma história em si, de acordo com o modelo apresentado e aplicado anteriormente, demostrando as relações entre essas histórias e o "contexto" das narrativas mais amplas do Bunkyo; segundo, analisar como a presença das demais entidades na página do Bunkyo participa dessa narrativa; e terceiro, como os recursos digitais foram explorados e que marcas deixaram na linguagem da narrativa.

Um último ponto a considerar é o fato de que as matérias da homepage escolhida são todas assinadas pelas duas jornalistas do setor de Comunicações, embora em outras páginas haja matérias sem assinatura e atribuídas à "Divulgação", e até assinadas por outras pessoas de fora do setor. Quanto a isso, como não se trata de peças opinativas, considero as matérias como representativas da visão do Bunkyo, pelo simples fato de estarem no site da entidade, e também por não destoarem do conteúdo de outros textos e falas em que assuntos semelhantes são abordados.

\footnotetext{
${ }^{225}$ Com a passagem do tempo, ao ser acessada, a homepage já não aparece na configuração que era visualizada anteriormente, mas todas as matérias continuam acessíveis e os links de cada matéria seguem disponíveis, e serão mencionados à medida que as respectivas matérias forem analisadas.
} 

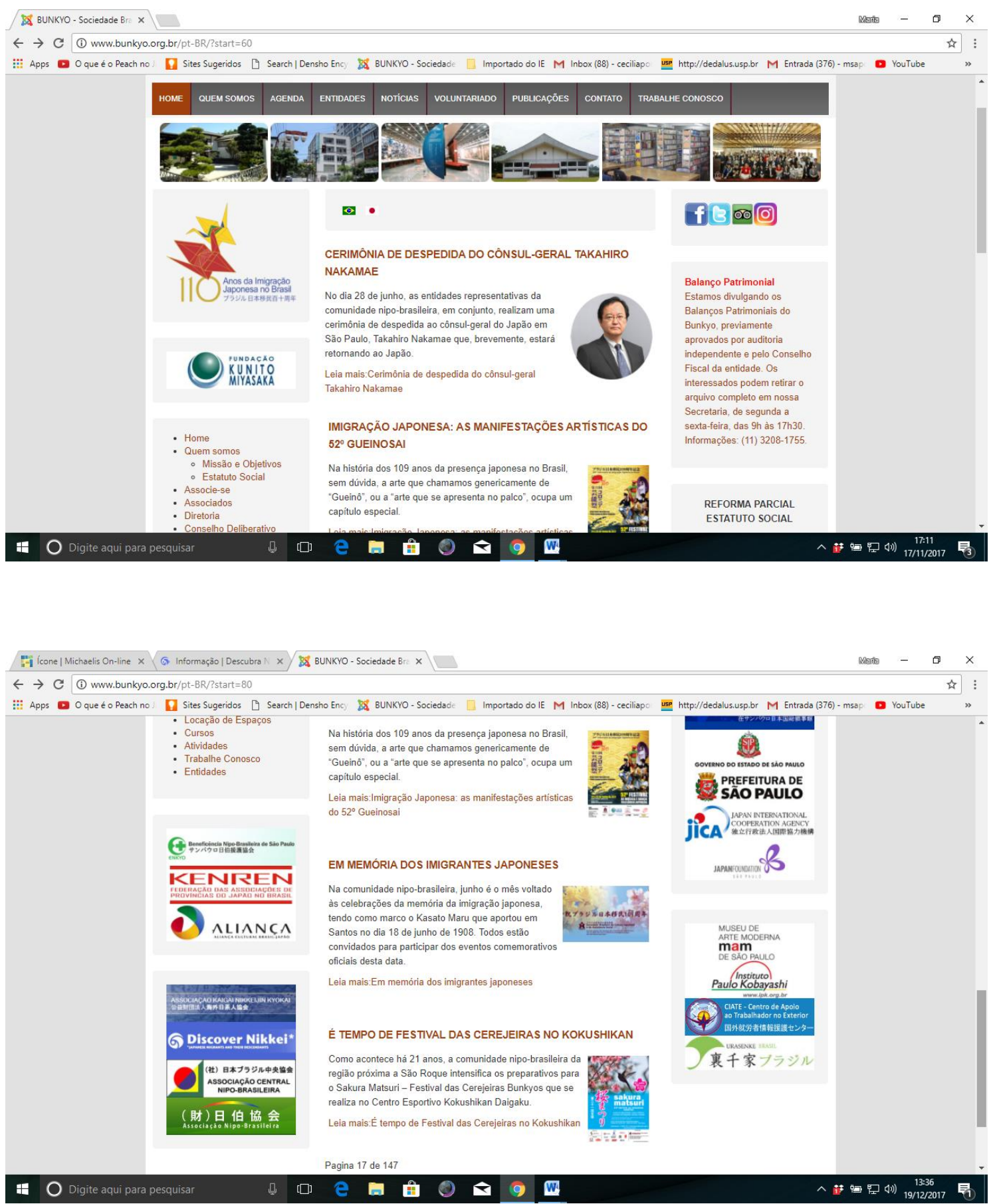

Duas metades da página do Bunkyo que é objeto de análise neste capítulo 


\subsection{1 "O cônsul Nakamae"}

A primeira matéria da homepage tem como título: "Cerimônia de despedida do cônsulgeral Takahiro Nakamae"226, com data de 21 de junho. O rosto da foto é bastante familiar aos frequentadores do Bunkyo, por sua presença constante nos eventos da entidade durante os dois anos que ficou em São Paulo (de junho de 2015 a junho de 2017), período em que muitas coisas importantes aconteceram na comunidade nipobrasileira: a celebração dos 120 anos do tratado de amizade entre Brasil e Japão, o sexagésimo aniversário do Bunkyo, o centenário do consulado em São Paulo, a inauguração da Japan House e a vinda do príncipe Akishino.

A homenagem de despedida ao cônsul, assim como sua festa de boas-vindas, dois anos antes, aconteceram no palco do salão nobre do Bunkyo, com a presença de representantes das go-dantai (cinco entidades) que estão sempre juntas na organização de eventos importantes da comunidade - Enkyo, Aliança, Câmara de Comércio, Kenren e o próprio Bunkyo -, além de outras 29 entidades nipo-brasileiras, cujos nomes são reproduzidos integralmente em uma lista no final da matéria. A matéria em si é curta e apenas informativa, mas a presença desse personagem na página do Bunkyo tem um grande efeito sinalizador.

Sendo o representante do governo japonês na cidade, o cônsul é muito mais do que sua própria pessoa: ele é a presença do Japão na comunidade nipo-brasileira e, sobretudo, na sede do Bunkyo, reforçando mais uma vez a centralidade política e institucional da entidade. Nakamae é uma figura "paternal" para a comunidade, apesar de jovem para o papel. Ele personifica a pátria dos ancestrais, que mostra seu apreço pelos filhos que se dispersaram ao emigrarem por força da necessidade, mas que não são esquecidos.

\footnotetext{
${ }^{226}$ Ver em: http://www.Bunkyo.org.br/pt-BR/noticias/157-2017/1249-cerimonia-de-despedida-do-consulgeral-takahiro-nakamae, acesso em 17/11/2017.
} 


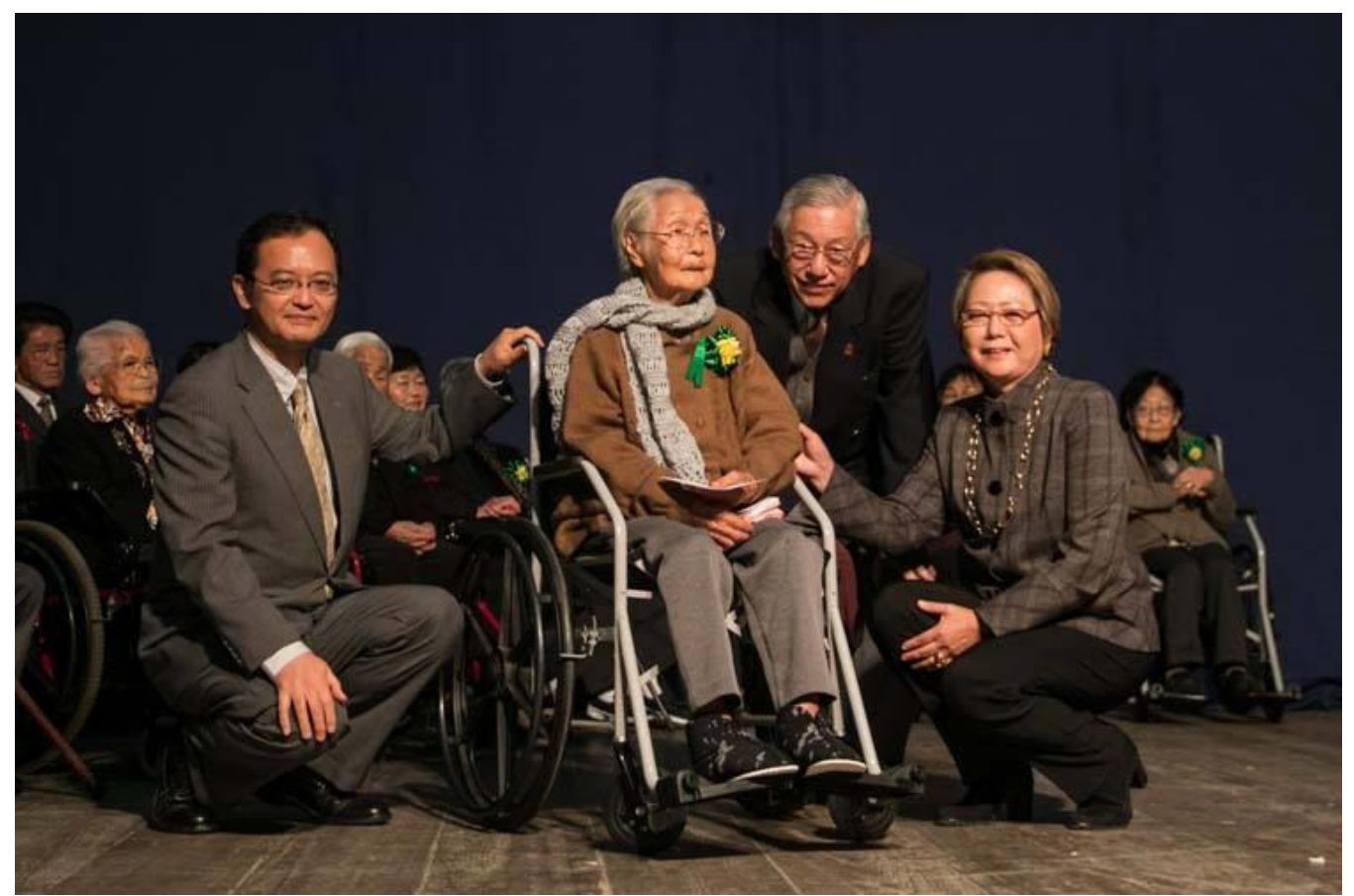

Foto 22: Nakamae (à esquerda) na Hakujusha Hyoushou ${ }^{227}$.

Fonte: Bunkyo

Claro que Nakamae é apenas uma figura circunstancial, pois antes e depois dele, outros fizeram - e ainda fazem - o mesmo papel. Mas, naquele momento, seu rosto é que personaliza as relações entre o Bunkyo, a comunidade e o Japão, já que a formação (ou reforço) dos vínculos só acontece em uma relação humana, por mais abstrata que seja sua significação. E, além do rosto, há ainda as palavras e os gestos. Uma rápida busca no site mostra que Nakamae proferiu discursos, deu palestras e participou de conversas informais em centenas de eventos no Bunkyo e em outros ambientes, em São Paulo e no interior do estado.

Nos municípios paulistas, o cônsul percorreu também diversas cidades para atualização do koseki tohon (registro civil) de cidadãos japoneses ou de dupla nacionalidade e suas famílias no país, o que permite que o governo japonês controle a cidadania japonesa no exterior. Assim, o idioma bem falado, a polidez, as regras e a hierarquia estão presentes na figura do cônsul, que mostra a face contemporânea e amistosa do Japão ao mesmo tempo em que reapresenta os valores do passado, em uma

\footnotetext{
227 "Homenagem aos imigrantes de 99 anos", evento analisado em seguida. Na foto, além dos homenageados e do cônsul, estão também a presidente do Bunkyo, Harumi Goya, e o presidente da Fundação Kunito Miyasaka, Roberto Nishio.
} 
síntese cultural e temporal que o próprio Bunkyo, de certa forma, também procura reproduzir no Brasil.

\subsection{2 "Gueinosai: a arte de palco"}

A segunda matéria da homepage tem como título "Imigração Japonesa: as manifestações artísticas do $52^{\circ}$ Gueinosai ${ }^{\text {"228 }}$, com data de 5 de junho. A matéria evoca, já de início, o aniversário de 109 anos da imigração japonesa, que é na verdade comemorado com diversos eventos durante todo o mês de junho. Evoca também o papel dessas formas de "arte de palco" - danças e cantos tradicionais e folclóricos - nos esforços de preservação da cultura japonesa e de "união entre os compatriotas". A história do Gueinosai quase se confunde com a do Bunkyo, pois a entidade tinha apenas dez anos de idade quando as apresentações tiveram início.

Com a inauguração do grande auditório, em 1970, o Gueinosai pôde ascender à condição de grande espetáculo, atraindo um público que costuma ocupar quase todos os mais de mil assentos do teatro. Os mestres que mantiveram essas técnicas vivas e seus discípulos - as novas gerações de cantores, instrumentistas e dançarinos - são a imagem e o som do Japão de tempos passados ainda vivos no Brasil, fazendo parte, portanto, das histórias sobre a cultura dos ancestrais. Mas, como tudo caminha com o tempo, também o Gueinosai teve que abrir a tradição e o folclore às novas "artes de palco", hibridizando assim algumas de suas partituras e coreografias que são a expressão, agora, de um passado atualizado.

Esse hibridismo se deve a trabalhos de mestres que tomaram a iniciativa de fazer a mistura de coreografias e cantos clássicos ou folclóricos com outros sons e formatos, resultando em novas expressões artísticas, como as do grupo Yuubi, que, segundo a matéria, conseguiu "transpor o tempo" e apresentar uma "dança de estilo cosmopolita, bela e contagiante". Há também as formas já trazidas híbridas do Japão, como a dança Yosakoi, surgida em 1954, que combina "a dança japonesa tradicional com música moderna".

\footnotetext{
228 Ver em: http://www.Bunkyo.org.br/pt-BR/noticias/157-2017/1245-imigracao-japonesa-asmanifestacoes-artisticas-do-52-Gueinosai, acesso em 17/11/2017.
} 
Isso não significa, porém, que formatos mais próximos do original não tenham sido preservados. Mostrando que o passado ainda tem prioridade no Gueinosai, a matéria cita o grupo de taishogoto, um instrumento de cordas que lembra o koto (tipo de harpa japonesa), “formado em sua maioria por músicos da terceira idade”. Mas não só de pessoas idosas vivem as artes do passado, como exemplifica o grupo Min, “formado em sua maioria por jovens", que apresenta canções folclóricas de agricultores e pescadores, entre outras, ao som de instrumentos tradicionais como o shamisen (corda), o shakuhachi (sopro) e o taiko (percussão).

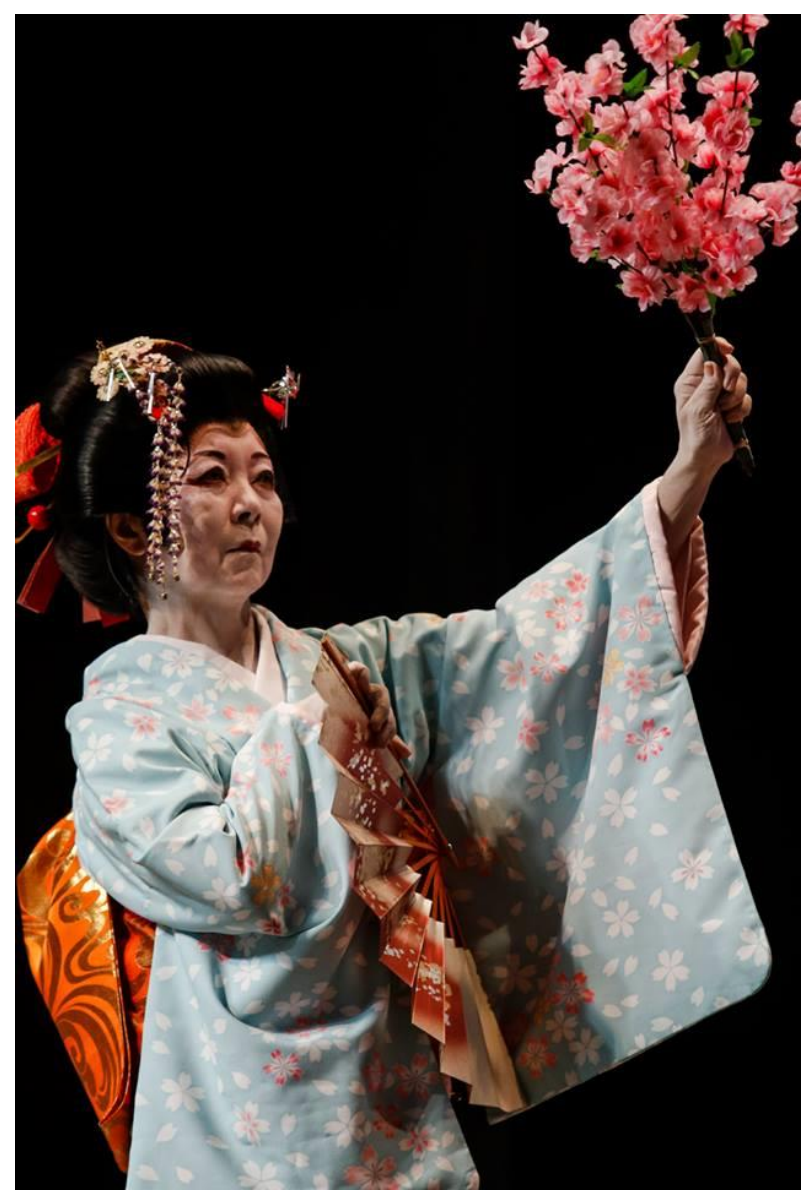

Foto 23: dançarina no $51^{\circ}$ Gueinosai.

\section{Fonte: fotografia de Gabriel Inamine/Bunkyo}

O espetáculo como um todo é um conjunto de eventos artísticos sem relação direta uns com os outros, uma colagem de tradições de várias origens e uma justaposição de camadas temporais distintas. Mas o significado atribuído a ele pela matéria - um "capítulo especial" na "história dos 109 anos da presença japonesa no Brasil" - costura com um fio invisível essas performances, sons e cenários, formando 
uma história de travessias no tempo e no espaço, e de linguagens híbridas que juntam gerações, técnicas e signos audiovisuais de referências culturais variadas (ainda que todas japonesas).

O Gueinosai é um repositório de símbolos que povoam as narrativas, provendo personagens, imagens, cenários, figurinos e musicalidades que dão vida a um mundo japonês imaginado. É como se esse mundo, que só sobreviveu nos livros, nos filmes e nas histórias da obaatian (avó), de repente se materializasse no palco, dando vida a samurais, nobres, gueixas e camponeses, cujas danças e canções proporcionam uma experiência de encontro entre artistas, público e mundo representado, renovando, assim, os significados do que foi compartilhado.

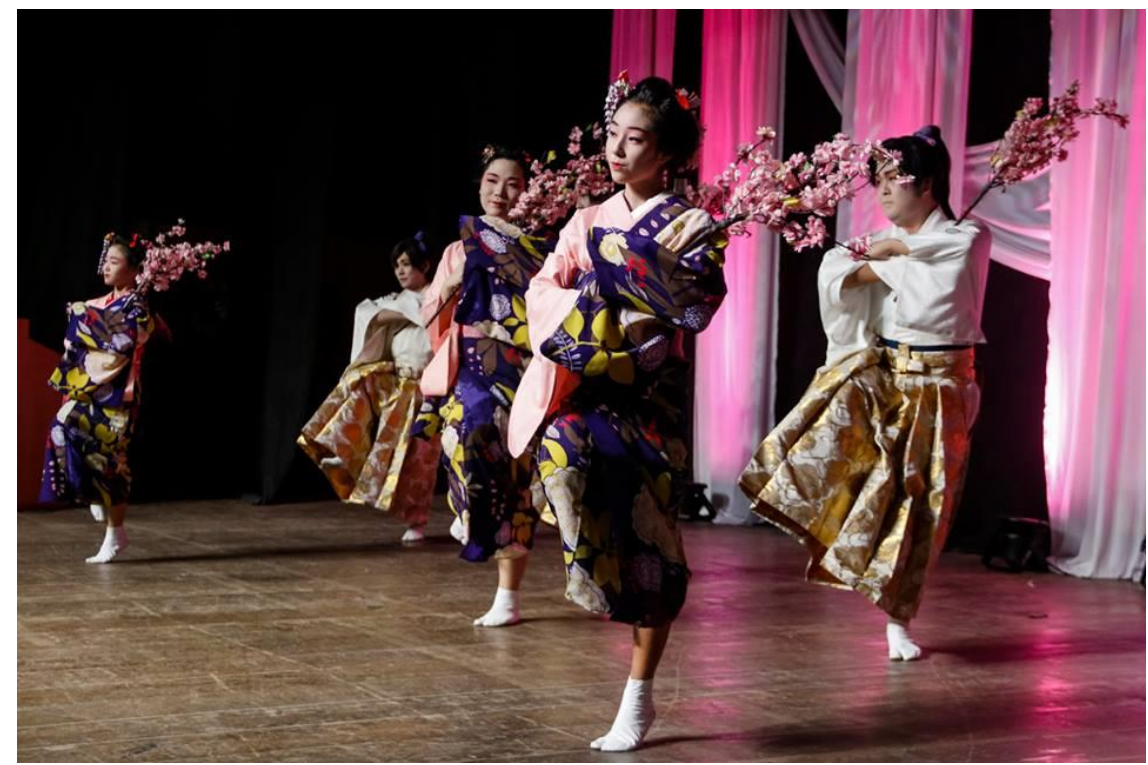

Foto 24: dança no $51^{\circ}$ Gueinosai.

Fonte: fotografia de Gabriel Inamine/Bunkyo

O festival consegue ainda juntar as gerações de descendentes, que, na vida real, vivem em tempos diferentes, mas no palco são personagens de um mesmo tempo imaginado: das lendas de um passado mítico. Numérica e visualmente grandioso, o Gueinosai ilustra a narrativa da imigração bem-sucedida, da comunidade unida e orgulhosa do seu passado e da cultura dos ancestrais. É um momento de reafirmação do que é considerado a "memória coletiva" da comunidade, e também do protagonismo do Bunkyo nesse processo, já que sua realização, por mais de meio século, tem sido sempre no palco da entidade. 


\subsubsection{Junho, tempo de lembrar}

A terceira matéria da página tem como título "Em memória dos imigrantes japoneses" ${ }^{, 29}$, com data de 5 de junho, e apresenta a lista dos eventos do mês, dedicado à memória dos imigrantes devido à data de chegada do navio Kasato Maru ao porto de Santos, em 18 de junho de 1908, com a primeira leva planejada de imigrantes japoneses para o Brasil. O primeiro evento da lista - no dia 11 de junho - é um concerto de piano a quatro mãos, sem qualquer relação direta com o espírito da comemoração, já que as duas concertistas não são nikkeis e o repertório é de clássicos ocidentais (como Dvórak e Mozart), a não ser por dois detalhes: primeiro, das seis peças do programa, uma era do compositor japonês Yoshinao Nakada (parte de "Outono", da suíte "As Quatro Estações do Japão") - o que foi citado mas não ressaltado na matéria -; segundo, o concerto era em benefício da Yassuragui Home, entidade vinculada ao Enkyo (parceiro do Bunkyo e uma das go-dantai).

Dedicar um concerto beneficente à memória da imigração evoca, de certa forma, o espírito comunitário que prevaleceu nos tempos das colônias agrícolas, quando os imigrantes ajudavam uns aos outros em redes solidárias que foram substituídas - com a mudança para as cidades - pelas entidades assistenciais da comunidade (como é o caso do Yassuragui Home), conforme argumentado no Capítulo 2. E a presença do compositor japonês no programa do concerto não chega a fazer uma diferença muito significativa no que se refere ao tema do evento, já que ele não é muito conhecido, a peça em questão faz referência ao Japão, mas não à imigração, e a matéria nem dá destaque a ele ou à sua obra. Mas, no contexto da homepage do Bunkyo, a simples presença do seu nome (e das estações do ano, um tema recorrente na cultura japonesa, como menciono mais à frente) não deixa de ser uma marca sinalizadora de um mundo que está em sintonia com as demais presenças: o mundo que se identifica com o Japão, de ontem ou de hoje.

Embora esses eventos sejam chamados de "Concertos Bunkyo aos Domingos", o que pode sugerir que acontecem toda semana, na verdade eles não são regulares. No ano

229 Ver em: http://www.Bunkyo.org.br/pt-BR/noticias/157-2017/1244-em-memoria-dos-imigrantesjaponeses Acesso em 18/11/2017 
de 2017, foram apresentados quatro deles: em abril, junho, outubro e novembro, e nem sempre fazem alusão, pela biografia dos músicos ou dos compositores, ao mundo nipobrasileiro ou ao Japão. Ligado à Comissão de Música do Bunkyo, o concerto, sempre gratuito, é apenas uma oportunidade de proporcionar aos associados e frequentadores em geral um encontro com a música clássica. Embora os concertos não sejam pagos, o público é convidado a contribuir com alimentos não-perecíveis, para serem doados a alguma entidade assistencial nipo-brasileira.

O segundo evento da lista são as "cerimônias religiosas" do dia 18 de junho: uma missa em igreja católica, um culto budista no grande auditório do Bunkyo e um ritual com presença de pessoas de todas as religiões no Memorial em Homenagem aos Imigrantes Falecidos, no Parque Ibirapuera. Essa parte da matéria remete diretamente à narrativa da imigração, com a homenagem do Butsuren (Federação das Escolas Budistas do Brasil):

“...àqueles que atravessaram o mundo cheio de sonhos e esperança de uma vida melhor. Mesmo diante de tantas adversidades em terras estrangeiras, com muito sacrifício, coragem e persistência, eles abriram caminhos para que muitos de nós, geração após geração, estejamos aqui e agora. Essa cerimônia é realizada para cultuar as almas dos imigrantes falecidos, para transmitirmos o nosso respeito e renovarmos o nosso sentimento de gratidão aos antepassados." (Texto do folheto entregue aos presentes antes do ritual no memorial, produzido pelo Butsuren).

O texto retoma, assim, o enredo que tem início com a viagem dos imigrantes do Japão para o Brasil e prossegue com os relatos de sacrifício e superação até os tempos de hoje, lembrados com a gratidão pelas pessoas que trabalham para que essa história não se perca. Reforçando a ponte entre as gerações, os rituais de junho não apenas mantêm essa união das pessoas através do tempo, mas estabelecem uma relação de reciprocidade entre os que "abriram caminhos" e os que agora, em retribuição, preservam a sua memória. Essa relação de reciprocidade entre vivos e mortos, através do culto aos ancestrais, remete às tradições da cultura familiar japonesa, em especial o gimu (dever, obrigação), o respeito e reverência que se deve aos pais e aos antepassados, e o on, que é o dever especial de gratidão, que se estende a todos a quem se deve um favor. 


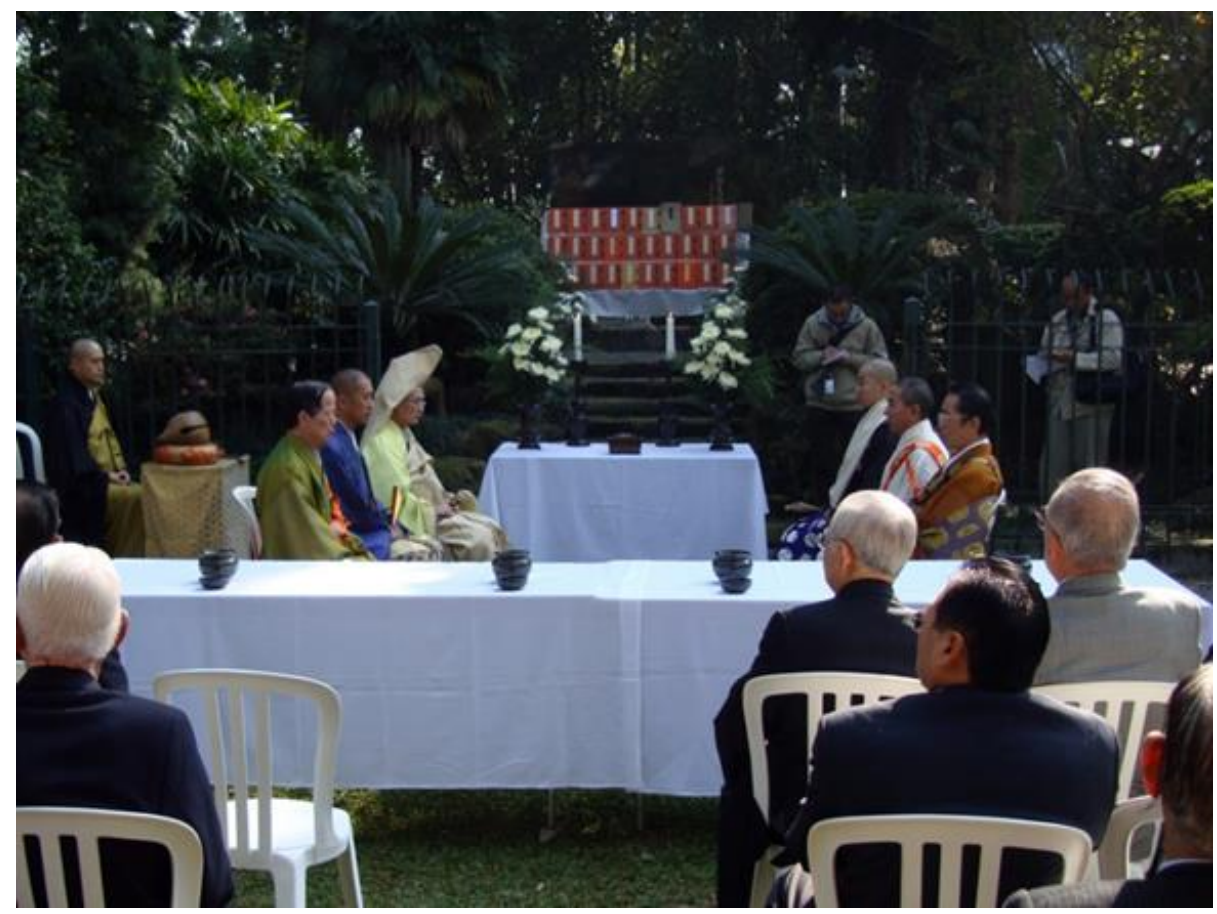

Foto 25: culto ecumênico no Memorial em Homenagem aos Imigrantes Falecidos, no Parque Ibirapuera. Fonte: Bunkyo

Dessa forma, os rituais em memória dos imigrantes japoneses se dirigem aos descendentes como a uma "grande família", já que os pioneiros falecidos são considerados os ancestrais de todos os nipo-brasileiros que estão vivos hoje. Esse vínculo de "parentesco" - que não se baseia na consanguinidade direta, mas no passado comum imaginado - é reforçado a cada ano, com esses textos, falas e rituais que evocam os sacrifícios dos que partiram para que os descendentes possam usufruir do seu legado. Além desse aspecto de cultura familiar, a dívida de gratidão também está fundamentada nas relações sociais de um modo geral, como salienta Benedict (2007) em seu estudo sobre a sociedade japonesa: "A probidade no Japão repousa no reconhecimento do próprio lugar dentro da grande rede de mútuo débito, abarcando tanto os antepassados quanto os contemporâneos" (2007, p. 88).

Embora a maioria dos membros da comunidade nipo-brasileira já tenha nascido no Brasil, a sobrevivência de certos preceitos éticos tradicionais do Japão (pelo menos entre alguns desses membros) é confirmada pelos rituais de culto aos imigrantes, que impelem cada um a "reconhecer" o seu lugar dentro dessa rede inquebrantável de débito dos vivos em relação aos mortos, e também em relação à fonte de toda autoridade: a família imperial, que representa a ancestralidade japonesa desde o início dos tempos. 
O terceiro evento da lista é o Gueinosai, que já foi comentado aqui. O quarto evento da lista é a Hakujusha Hyoushou ${ }^{230}$, homenagem aos imigrantes de 99 anos de idade ou mais. No ano de 2017, foram homenageadas 36 pessoas que atingiram essa idade, em uma solenidade de entrega de diploma de honra ao mérito e saudações de autoridades do Bunkyo, do consulado e de outras entidades nipo-brasileiras. Para localizar esses quase centenários, o Bunkyo envia mensagens a entidades nipobrasileiras do país pedindo a indicação de nomes e o contato com as famílias. Esse evento é mais um exemplo de cultivo de certos hábitos tradicionais do Japão, onde não se comemora o aniversário todos os anos, mas em determinadas idades consideradas especiais, como é o caso dos 99 anos de idade.

Celebrada junto às comemorações da imigração, no mês de junho, a Hakujusha Hyoushou é mais uma forma de louvar os pioneiros, só que, nesse caso, os que ainda estão vivos. O diploma de "honra ao mérito" é o reconhecimento da sua condição de pioneiros $^{231}$ e, portanto, de desbravadores e sobreviventes das duras condições enfrentadas pelos imigrantes nas primeiras décadas no Brasil, o que coloca esses anciãos na condição de credores quanto à dívida geral de gratidão que os nipobrasileiros têm em relação aos seus antecessores. O lugar desse evento na narrativa da imigração é importante de várias formas: ele permite que se visualize a temporalidade da história, já que a vida dessas pessoas tem sido longa o suficiente para que suas biografias possam ilustrar a narrativa, em suas diversas fases e episódios.

Ele mostra, também, que as "rupturas" e os "desequilíbrios" foram todos superados, graças ao protagonismo de pessoas reais como aquelas que estão no palco, em suas cadeiras de rodas, sendo documentos vivos de cada parte dessas histórias de enfrentamento e sucesso. E é importante, ainda, como ritual comunitário, pois o dever de expressar reconhecimento pelos sacrifícios e conquistas dos pioneiros não é apenas de seus parentes, mas de toda a comunidade - a "grande família japonesa do Brasil" -, representada nesse evento pelas lideranças do Bunkyo e outras entidades nipobrasileiras, e pelo cônsul, que ocupa o papel mais do que fundamental, conforme

\footnotetext{
230 Ver em: http://www.Bunkyo.org.br/pt-BR/noticias/157-2017/1178-homenagem-aos-idosos-2017, acesso em: 18/11/2017.

${ }^{231}$ Tendo nascido em 1918, os homenageados de 99 anos (em 2017), mesmo que já nascidos no Brasil, se tornaram adultos em uma época em que as condições de vida ainda eram difíceis para boa parte dos imigrantes. Viveram, também, os anos da guerra e do pós-guerra, quando os japoneses e suas famílias sofreram fortes restrições por parte do governo Vargas.
} 
exposto acima, de mostrar que também o Japão reconhece o sacrifício e as glórias dos pioneiros.

O quinto evento da lista é o $21^{\circ}$ Festival das Cerejeiras, ou Sakura Matsuri ${ }^{232}$, que, no ano de 2017, foi apresentado nos dias 1 e 2 de julho, no Centro Esportivo Kokushikan Daigaku, em São Roque. O ponto alto do festival é o hanami (contemplação das flores), uma tradição japonesa que leva milhões de pessoas, todo início de primavera, aos parques, jardins públicos e templos quando as cerejeiras desabrocham. As cerejeiras do Kokushikan não têm a variedade daquelas que crescem nas diversas regiões do Japão, que diferem quanto à coloração, ao tamanho e ao formato das flores, e também quanto aos tipos de árvores, sendo que algumas florescem em longos cachos que pendem quase até o chão.

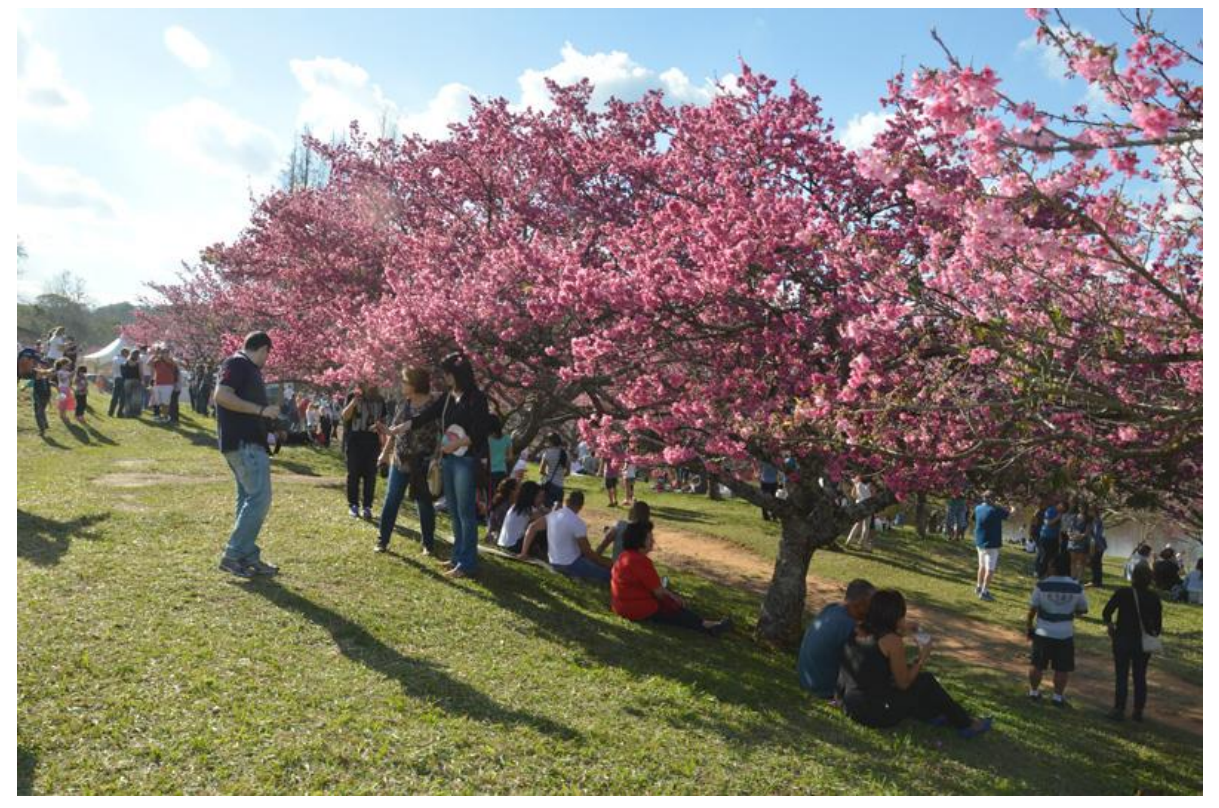

Foto 26: Sakura Matsuri no Centro Kokushikan.

\section{Foto: Bunkyo}

Mas, ainda que não sejam tão espetaculares quanto as japonesas, o que importa é o significado simbólico das cerejeiras do Bunkyo, plantadas ao redor de um lago, e que atraem durante o festival um grande número de pessoas, que caminham ou se sentam sob as árvores, comendo, bebendo e tocando música, como se faz no Japão há séculos.

\footnotetext{
${ }^{232}$ Ver em: http://www.Bunkyo.org.br/pt-BR/noticias/157-2017/1243-e-tempo-de-festival-das-cerejeirasno-kokushikan, acesso em 18/11/2017.
} 
As cerejeiras encontraram no centro esportivo, doado pela universidade Kokushikan em 1997, um lugar perfeito, pelo espaço amplo e rodeado de árvores, pela presença do lago, por guardar certa distância do barulho da cidade e ainda assim não ficar muito longe de São Paulo, onde está o edifício-sede do Bunkyo. Já no seu início, a matéria integra o festival nas "comemorações alusivas à imigração", o que confirma o papel das cerejeiras - e especialmente do hanami - no projeto memorial do Bunkyo.

Ao ler a matéria e observar as fotos, o leitor fica sabendo que, além do hanami, o festival oferece várias atividades inspiradas no Japão, como oficinas de artes, apresentação de danças e de tambores, culinária, peças de decoração como o koinobori (bandeira com desenho de carpa) do "dia dos meninos", bonsais e mudas de cerejeiras, tudo sob o comando de entidades, voluntários e artistas nipo-brasileiros. Ao ver essas montagens e cenários, conclui-se que esta é uma festa japonesa, com certeza. Mas não exclusivamente: o Sakura Matsuri divide seu espaço com a gastronomia e as apresentações folclóricas de países como Alemanha, Itália e Portugal. Embora a hegemonia da ambiência japonesa esteja garantida na maioria dos espaços e atividades do festival, ela diminui consideravelmente na área bazarista, onde se vende de tudo, de DVDs e eletrônicos japoneses a cosméticos, panelas e roupas de várias marcas do mercado, e também na área de diversão infantil, onde só há brinquedos de plástico colorido que lembram as brinquedotecas dos shoppings. 


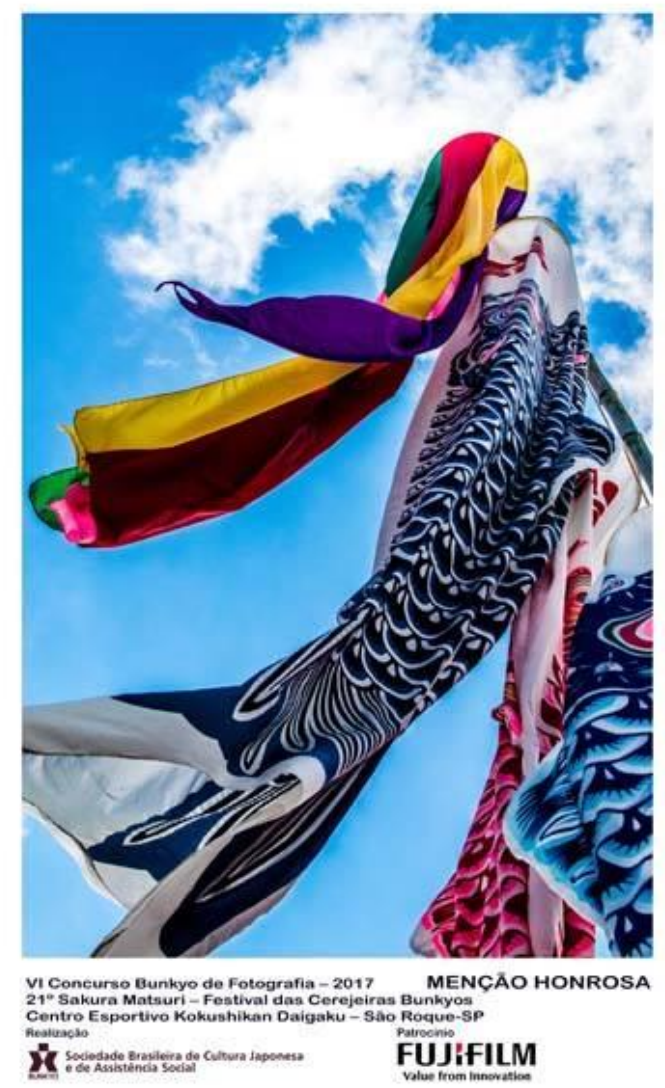

Foto 27: Fotografia de koinobori premiada no Sakura Matsuri.

\section{Fonte: Bunkyo}

O Sakura Matsuri faz parte da narrativa da imigração enquanto esforço de continuidade de um mundo que ficou para trás no tempo e no espaço. Atualiza os cenários, os repertórios e os valores estéticos da comunidade imaginada, misturando, assim como em outros eventos, os sabores e aromas, as artes e as atividades de origens regionais diversas do Japão (e até de outros países) em torno de um evento principal - o hanami - de forte significação simbólica. Com a grande afluência de público não nikkei, a multiculturalidade das bancas de alimentação, vendas e diversão e a reduzida quantidade e variedade das próprias cerejeiras, o festival não chega a ser uma versão sequer próxima do verdadeiro hanami japonês.

E nem é necessário que seja, pois a narrativa da imigração japonesa é uma história de deslocamentos e adaptação, de encontros culturais e de preservação a partir de matrizes muito diversas. A continuidade do mundo na "história vivida", como dizia Halbwachs (2013), não é uma tentativa de memória pela imitação do passado, até 
porque o passado coletivo de uma comunidade imaginada comporta incontáveis memórias, de uma diversidade sem fim de paisagens e experiências, motivo pelo qual as lembranças conseguem se adequar a um presente nivelador, em que todos conseguem reconhecer pelo menos uma pequena parte de sua própria história.

O sexto e último evento da lista é o Festival do Japão ${ }^{233}$, organizado pelo Kenren (federação das associações das províncias japonesas) desde 1998 e que acontece - desde 2005 - no gigantesco centro de convenções da Rodovia dos Imigrantes, sempre no mês de julho. O Bunkyo tem participado desde o início com estandes de atividades, na divulgação e com voluntários na montagem, antes e durante o evento. A matéria fala pouco sobre o festival em si, mas traz o link do site, onde se lê que "atualmente é considerado o maior evento de cultura japonesa do mundo". A matéria do Bunkyo se limita a informar que o "carro-chefe" do evento é a culinária das diferentes províncias do Japão, citando também o concurso de Miss Nikkey do Brasil, os espaços dedicados às crianças e à "terceira idade" e as atividades de Cosplay do Akibaspace ${ }^{234}$, um site de cultura pop inspirado no estilo praticado na cidade japonesa de Akibahara.

Ao contrário do Sakura Matsuri, que é uma alusão direta a um equivalente japonês, em especial ao hanami, o Festival do Japão não remete a nenhum evento ou aspecto simbólico específico do Japão de ontem ou de hoje. No entanto, propõe-se a apresentar o repertório cultural clássico, folclórico e contemporâneo japonês, promovendo uma colagem de referências do passado e do presente, a partir de uma seleção de elementos que reflete as propostas dos grupos envolvidos nas apresentações, os produtos e técnicas a que têm acesso e sua adaptação ao público visitante, majoritariamente não descendente e diverso. Os organizadores do festival, então, prometem oferecer, durante três dias, a máxima concentração possível de experiências gustativas, olfativas, auditivas e visuais desse "Japão no Brasil".

Apesar da forte presença, em todos os lugares, de signos pertencentes ao acervo simbólico da população nipo-brasileira, o Festival do Japão, no entanto, passa uma inegável impressão de "Japão-espetáculo", um enorme desfile de variedades que, para fazer caber tudo em um único, gigantesco, evento, acabando transformando as músicas, sons, barulhos e vozes simultâneas em cacofonia, e o resto - aromas, sabores e imagens - em uma feira de percepções misturadas e quase indistintas. Despojados de um

\footnotetext{
${ }^{233}$ Ver em www.festivaldojapao.com.br, acesso em 18/11/2017.

${ }^{234}$ Ver em https://akibaspace.com.br/, acesso em 18/11/2017.
} 
contexto espacial sugestivo, e esvaziados drasticamente do seu sentido original para se aglomerarem na estrutura do espetáculo, os elementos culturais japoneses e nipobrasileiros do Festival do Japão participam da narrativa da imigração apenas através do significado totalizador do evento, que, segundo sugere o título da matéria, é o de celebrar, no ponto de vista de seus organizadores, a "memória dos imigrantes japoneses".

Esses organizadores prometem retomar - nesse mesmo tipo de estrutura, pelo que tudo indica - as grandes celebrações no ano que vem (2018), quando o Festival do Japão vai sediar o aniversário de 110 anos da imigração japonesa, que desde já estão representados no logo do festival, no site do evento. O logo sintetiza em um painel de cinco quadros o enredo da narrativa da imigração (ou a sequência cronológica dos principais acontecimentos dessa história): a chegada das primeiras famílias japonesas ao Brasil, o trabalho no campo, a ascensão social e profissional dos nikkeis, a consolidação da sua presença no bairro da Liberdade, em São Paulo, e o "retorno" dos decasséguis ao Japão (que também pode ser interpretado como a possibilidade de visita - já de avião, e não mais de navio, como viajaram os imigrantes - dos nikkeis ao país dos seus ancestrais), traçando assim um ciclo de pelo menos cinco gerações.

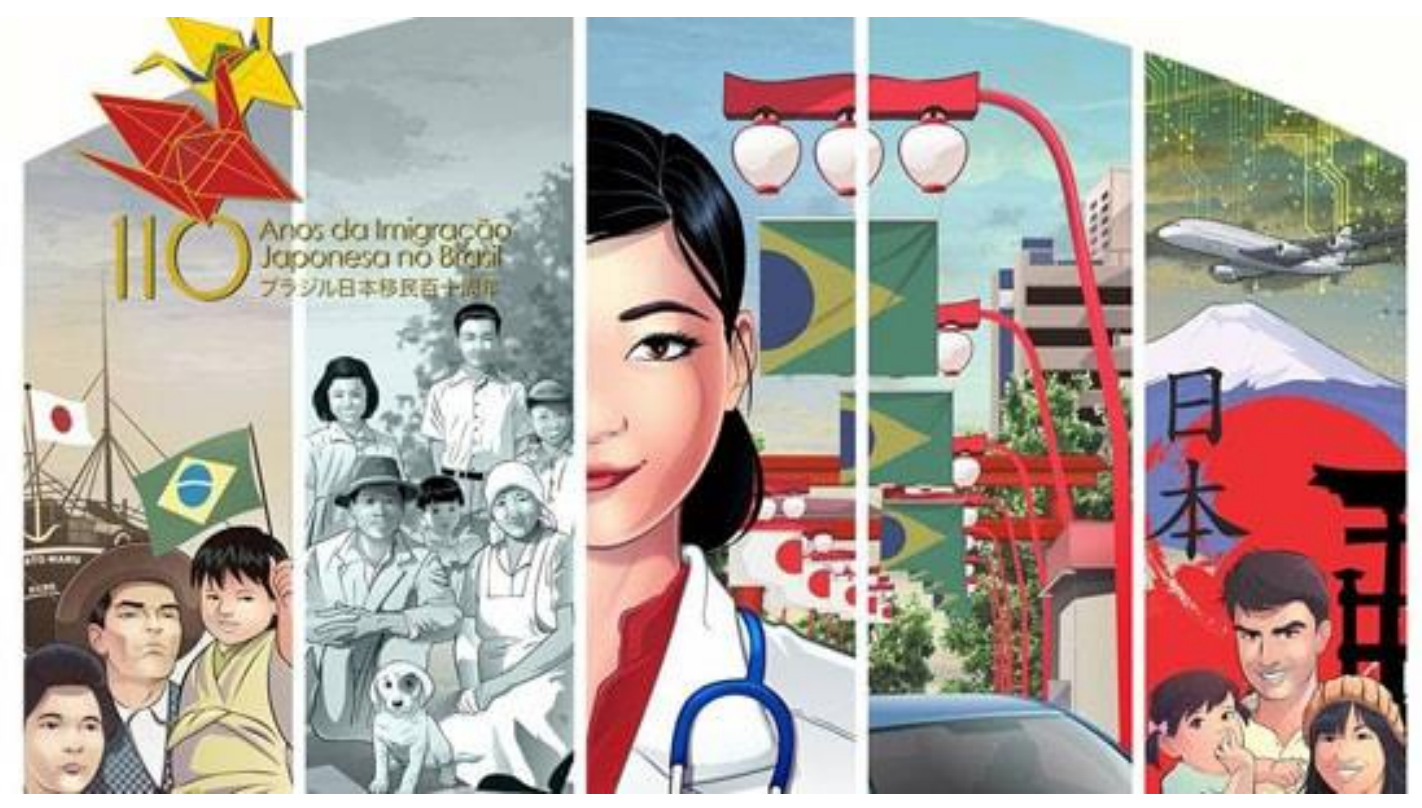

Figura 6: logo do Festival do Japão 2018.

Fonte: site oficial do evento 


\subsection{4 "Condecorados da primavera"}

A quinta e última matéria da página tem como título "Amanhã, 14/06, acontece a

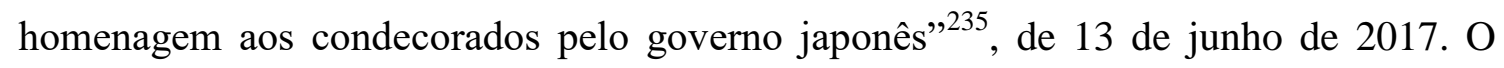
texto remete diretamente à narrativa da comunidade nipo-brasileira ao revelar que é ela (a comunidade) que "se reúne para homenagear os cinco Condecorados de Primavera 2017 pelo governo japonês”. De fato, há uma reunião de 37 entidades nipo-brasileiras (o Bunkyo entre elas) que organizam o evento - e cujos nomes são todos citados no final da matéria - e apontam as personalidades a serem homenageadas ${ }^{236}$. Embora as entidades sejam as organizadoras do evento, seu promotor é, na verdade, o governo do Japão, por meio do seu consulado geral em São Paulo, que destaca e agradece, com essa condecoração, os nikkeis que trabalharam em prol do intercâmbio Brasil-Japão e do "progresso da comunidade".

Essa narrativa, portanto, também tematiza a relação dos descendentes de japoneses com o país dos seus ancestrais, cujo governo não só se faz representar em praticamente todos os eventos significativos da comunidade, como também investe de forma proativa nessa relação. A narrativa também atualiza a demarcação dos contornos da comunidade nipo-brasileira, apontando quem faz parte dela (as entidades que organizam o evento e indicam nomes a serem condecorados) e quais os modelos de virtude e os tipos de contribuição que são apreciados por aqueles que concedem as comendas, ou seja, os feitos que são dignos de reconhecimento e honrarias ${ }^{237}$.

A matéria em si revela alguns aspectos importantes do contexto da narrativa, que não por acaso ocorre no mês das grandes comemorações da imigração. Os personagens dessa história, segundo a própria matéria informa, são os “dirigentes das entidades nipobrasileiras", os condecorados e seus amigos e familiares, podendo também haver a “adesão do público", já que a cerimônia é aberta a quem quiser assistir. Os protagonistas, além daqueles que concedem as honrarias e os líderes das 37 entidades

\footnotetext{
235 Ver em: http://www.Bunkyo.org.br/pt-BR/noticias/157-2017/1247-amanha-14-06-acontece-ahomenagem-aos-condecorados-pelo-governo-japones, acesso em 18/11/2017.

${ }^{236}$ Essa homenagem tem duas versões anuais: os Condecorados de Primavera e os Condecorados de Outono.

${ }^{237}$ Não afirmo que esse critério de demarcação de contornos e de definição de modelos seja único nem o mais importante, mas vale apenas para essa narrativa que estou analisando. Existem, é claro, narrativas alternativas que definem e avaliam a comunidade nipo-brasileira a partir de outros critérios, conforme mencionado aqui antes.
} 
organizadoras, são, obviamente, os próprios condecorados. Eles são cinco ao todo, quatro homens e uma mulher, todos na faixa dos 79 a 88 anos de idade. Como se pode depreender tanto da matéria do Bunkyo quanto da do Consulado ${ }^{238}$, os cinco homenageados são merecedores da "honraria" porque prestaram serviços relevantes à comunidade. A relevância desses serviços, porém, é julgada e classificada de acordo com algum critério hierárquico de valor, pois as comendas não são todas iguais (especialmente pela menção a "ouro" e "prata", que têm valor real e simbólico reconhecidamente maior e menor).

Assim, o desembargador aposentado Jo Tatsumi, ex-presidente da Aliança Brasil-Japão e membro atuante do Instituto de Direito Comparado Brasil-Japão, recebeu a mais elevada - e até mesmo "invejável" - Ordem do Sol Nascente "Raios de Ouro com Roseta" por ter contribuído tanto na difusão da língua japonesa quanto na área de Direito entre os dois países. Já o ex-presidente da Associação Cultural e Esportiva Nipo-Brasileira de Atibaia, Masasuke Kuroki (o único japonês do grupo, os demais são brasileiros), e o engenheiro agrônomo Guenji Yamazoe receberam a de "Raios de Ouro e Prata", o primeiro por ter sido "protagonista junto à comunidade local para promover o ensino da língua japonesa e a difusão da cultura japonesa na sociedade brasileira", e o segundo por sua dedicação à pesquisa no Instituto Florestal da Secretaria do Meio Ambiente, do qual foi diretor, e à comissão do prêmio Kiyoshi Yamamoto, da qual foi presidente. A assistente social Sonoko Yoshiyasu, que serviu aos idosos por quase 60 anos e chegou à presidência de sua entidade, a Ikoi-no-sono, e o ex-presidente do Instituto Cultural Nipo-Brasileiro de Campinas Nituo Tsukada, que dedicou seu esforço a melhorias na sua entidade e à divulgação da língua e cultura japonesa na região, receberam ambos a Ordem do Sol Nascente "Raios de Prata".

Não há nenhuma fonte em português que ofereça uma explicação sobre a classificação de valor das comendas oferecidas ${ }^{239}$, mas um dos meus informantes revelou que o sistema classificatório passou por uma reformulação em 2003 justamente para não dar a impressão de que os méritos das pessoas têm valores maiores e menores. $\mathrm{O}$ fato de serem diferentes, porém, sugere que a hierarquia (no sistema de classes)

\footnotetext{
${ }^{238}$ Ver em http://www.sp.br.emb-japan.go.jp/itpr_pt/not_17_06_haru-jokun.html, acesso 18/11/2017. 239 Para uma explicação $\quad$ sintética, http://nikkeypedia.org.br/index.php?title=Ordem_do_Sol_Nascente, acesso em 19/11/2017.
} 
permanece, ainda que não declarada ${ }^{240}$. A matéria em si é enxuta em termos de indícios dos significados desse evento para a comunidade e para o Bunkyo. Mas uma busca no site da entidade leva a outras matérias que dão mais informações e revelam que a Ordem do Sol Nascente - concedida em nome do imperador - é a maior honraria que um Nikkei pode receber.

Portanto, entre aqueles que têm apreço pela tradição, ser um condecorado é uma fonte de orgulho como poucas. No ritual da solenidade da entrega das comendas, formase um círculo imaginário em torno da comunidade ali reunida, em cujo centro as falas e performances dos personagens destacados reforçam os valores considerados essenciais e distintivos da comunidade. $\mathrm{O}$ respeito às formalidades, à hierarquia $\mathrm{e}$ às etiquetas sociais é o primeiro deles, já que, mais uma vez, os ritos das condecorações se repetem, sempre na primavera e no outono, reproduzindo o mesmo cerimonial dos anos anteriores, que, por sua vez, revivem certos modelos de ritos e condecoração que há mais de um século já eram observados no Japão.

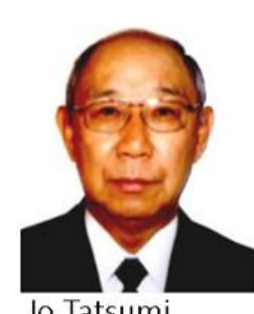

Jo Tatsumi

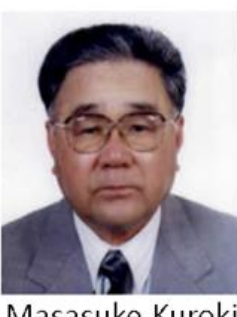

Masasuke Kuroki Guenji Yamazoe

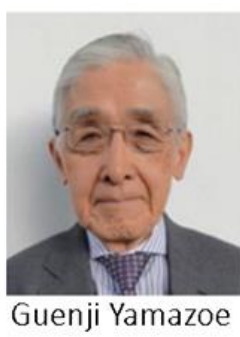

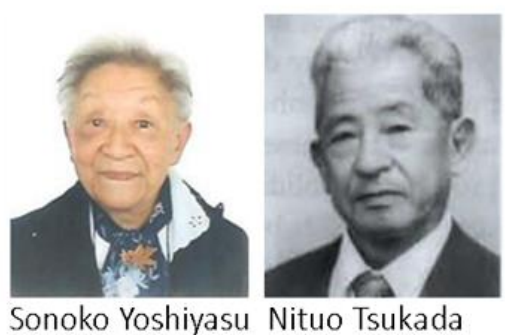

\title{
Condecorados de Primavera 2017 pelo governo japonês
}

Homenagem aos condecorados da regional de São Paulo do Consulado Geral do Japão

Figura 8: fotos dos condecorados e título da matéria.

\author{
Fonte: Bunkyo
}

\footnotetext{
${ }^{240}$ Uma explicação sobre as comendas oferecidas pelo governo japonês foi elaborada pelos professores da Aliança Cultural Brasil-Japão, segundo o Portal NippoBrasil. Há uma alusão, de passagem, sobre certos cidadãos que se opõem ao "sistema de classes" das condecorações. Ver em: http://www.nippobrasil.com.br/culturatradicional/n079.php, acesso em 19/11/2017.
} 
O reconhecimento público do governo japonês à contribuição dos imigrantes e de seus descendentes também se faz presente no centro do círculo, representado nas palavras e atitudes do cônsul-geral, que - ao entregar as comendas - procede mais uma vez à renovação simbólica dos laços que unem o Japão aos filhos, netos e bisnetos dos seus cidadãos que um dia tiveram que deixar a pátria, mas que não se desgarraram, nem foram esquecidos. Um a um, os condecorados passam a ocupar o centro do círculo, contando momentos de sua história pessoal, que assim proporcionam - como em outras ocasiões - os nomes e rostos da narrativa principal sobre as pessoas que dedicaram suas vidas a um projeto que é, ao mesmo tempo, individual e comunitário, já que o sucesso de um tem que ser o orgulho de todos. Assim, cada relato conta uma história de lutas pessoais e conjuntas, de retribuição àqueles que "lutaram ombro a ombro", de oportunidades que fazem lembrar que "a gratidão é a memória do coração", de esforços para desempenhar bem cada "missão" e para continuar sendo um "servo da sociedade" mesmo depois da aposentadoria ${ }^{241}$.

Os rituais da entrega das comendas, sendo uma situação de compartilhamento de histórias, instituem o ambiente narrativo que, como diz Martino (2016), cria ou reforça os vínculos entre aqueles que contam e que ouvem uma história. Os aspectos temporais da narrativa são definidos no decorrer das histórias, que é a dimensão do tempo da vida dos condecorados, individualmente, e do tempo coletivo da história da comunidade nipo-brasileira, além do tempo do encontro em si (este sim, com começo, meio e fim), que inicia com os discursos de apresentação e, em seguida, com a concessão das honrarias, continua com o compartilhamento de cada história dos homenageados e, por fim, prossegue para a confraternização, quando todos se encontram para um brinde, abraços, reverências e conversas informais. O tempo da narrativa também está presente na referência às estações do ano, em uma inversão que remete à localização geográfica japonesa, já que a Condecoração da Primavera é concedida em junho, quando no Brasil é outono, e a Condecoração de Outono é concedida em dezembro, quando no Brasil é primavera.

A menção às estações do ano não alude apenas ao fator temporal e geográfico, mas também ao cultural, pois as estações do ano estão muito presentes na cultura japonesa como reguladoras das atividades produtivas que, por sua vez, inspiraram a

\footnotetext{
${ }^{241}$ Incluí trechos das declarações dos condecorados de outono de 2016 para ilustrar os tipos de relato compartilhados nessa ocasião. Ver mais em: http://www.Bunkyo.org.br/pt-BR/noticias/154-2016/1151concorrida-homenagem-aos-condecorados-de-outono, acesso em 19/11/2017.
} 
poética, a estética e a mística japonesas, como é o caso do haiku ${ }^{242}$ e outros tipos de poema $^{243}$, e também certas festividades e ritos mágico-religiosos, como o setsubun ${ }^{244}$, as estampas, cores e regras de uso de quimonos - ou o wafuku em geral - de acordo com cada estação $^{245}$. Assim, a incorporação desse traço cultural japonês nas práticas da comunidade - ainda que por iniciativa do governo do Japão, no caso da comenda - não deixa de ser mais uma evidência de que a ligação simbólica com o Japão é um dos fatores constituintes e renovadores da identidade do grupo, e de que é nas narrativas da comunidade que se observa a dinâmica dessa constituição e renovação.

Por fim, vale mencionar o cenário da entrega das honrarias, que mais uma vez tem o "salão nobre" do Bunkyo como espaço distintivo das performances e textos da história narrada, um espaço que marca, com sua "nobreza", a formalidade e o caráter oficial do evento, e também a importância do Bunkyo, que mais uma vez se estabelece como anfitrião de um encontro significativo da comunidade. O cenário das comendas, portanto, não é mero espaço físico - como qualquer outro poderia ser -, mas a elaboração de um lugar que participa da troca simbólica do evento, nesse caso dando a ele solenidade e recebendo dele a confirmação da legitimidade que o Bunkyo necessita para atualizar-se como representante da comunidade nipo-brasileira e guardião do seu legado.

\subsection{A mídia digital do Bunkyo e a narrativa nipo-brasileira}

Apesar de uma utilização bastante econômica dos recursos tecnológicos e de um texto e paginação semelhantes à de suas publicações impressas, as notícias e

\footnotetext{
${ }^{242}$ No haiku, a referência às estações do ano está indicada pelo kigo, a palavra ou expressão que alude direta ou simbolicamente à estação do ano. Neste conhecido haiku de Bashô, por exemplo, o "sapo" é o kigo, significando a primavera: "Furuike ya/ kawazu tobikomu/ mizu no oto". Tradução de Paulo Leminski: "Velha lagoa/ o sapo salta/ o som da água". Ver em: BENTO, Sérgio. "Mallarmé Bashô": a tradução-apropriação como via para o silêncio. Cadernos de Literatura em Tradução, Revistas USP, n. 9, 2008.

${ }^{243}$ Veja-se, como exemplo, este poema de Fujiwara no Ietaka: "Kaze soyogu nara no ogawa no yugure wa/ misoguizo natsu no shirushi narikeru". Tradução: "O vento sussurra entre as folhas do carvalho/ E, ao entardecer, os peregrinos se purificam na beira do riacho./ Sinal da chegada do verão!" Em: http://www.chadourasenke.org.br/estacoes/nagoshi-no-harae/, acesso em 20/11/2017.

${ }^{244}$ Setsubun, significa "dividir as estações". Ver em: http://web-japan.org/kidsweb/explore/calendar/february/setsubun.html, acesso em 20/11/2017.

245 A palavra wafuku se refere à vestimenta tradicional japonesa. Ver em: https://wafuku.wordpress.com/2011/05/15/japanese-colour-names-seasonal-combinations/, acesso em 20/11/2017.
} 
comentários da homepage do Bunkyo já mostram as marcas da mudança de forma e linguagem do ambiente digital, que Longhi (2009) chama de "narrativas intermídia", em função da convergência de formatos e expressividades que a tecnologia proporciona. Para a autora, essa convergência - nas formas de linguagem sonora, visual e textual, e também na interatividade - não resulta em uma simples mistura, mas em uma "interrelação orgânica" que cria novas formas de expressão e de relações de produção e consumo. Assim, as narrativas "intermídia” seriam:

[...] histórias contadas com uma combinação de meios, que vão da imagem em movimento, ou parada, ao som, passando pelo tratamento da imagem em terceira dimensão, possibilitado por softwares cada vez mais poderosos do ponto de vista da manipulação digital da informação. Reunindo conteúdo e forma, tratam-se de narrativas poderosas para a informação. (2009, p. 192)

Esse enorme - e sempre crescente - potencial de combinações possíveis tem criado, segundo a autora, "novos ambientes digitais" que "vêm desenvolvendo seus próprios formatos narrativos" (2009, p. 194). Os novos formatos remetem não apenas aos textos em si e às linguagens utilizadas (incluindo imagens e sons), mas também às relações com outras fontes que fazem parte do "ecossistema digital" como um todo, e de certas fontes de referência em particular que têm afinidades entre si. Também os hábitos de recepção - que vão do leitor/espectador/ouvinte passivo dos meios tradicionais para o "usuário ativo, que navega em uma rede hipertextual e produz conteúdos", como diz Scolari (2008, p. 77) - determinam os novos formatos narrativos que surgem na ambiência digital.

Em seu estudo sobre a narrativa das novas mídias, Ryan (2004) afirma que o advento dos meios digitais afetou a narrativa de todas as formas:

Uma gramática completa da linguagem abrange três elementos: semântica, sintaxe e pragmática. Na teoria da narrativa, a semântica se torna o estudo do enredo, ou história; sintaxe se torna o estudo do discurso, ou as técnicas narrativas; e a pragmática se torna o estudo da narração de histórias e o modo de participação dos agentes humanos na 
performance da narrativa. As mídias digitais afetam a narrativa nos três modos. (2004, p. 354$)^{246}$

A autora pondera que, no nível da pragmática, os meios digitais passaram a oferecer múltiplas maneiras de participação ao usuário, que pode explorar as variadas possibilidades dos recursos colocados à sua disposição, desde a escolha dos links, a ordem em que o faz, até o enveredar-se pelas fontes externas que se abrem a partir das explorações iniciais. Nesse ponto, a narrativa sai quase completamente do controle daqueles que a produzem e a "gerenciam", e um de seus principais desafios seria a "manutenção de uma lógica coerente" que consiga preservar pelo menos alguns de seus significados essenciais. No que se refere às narrativas on-line do Bunkyo, a seleção prévia das presenças na sua homepage é uma das maneiras não só de manter certa coerência dos enredos, mas também de proporcionar adições relevantes - no ponto de vista de quem produz e "gerencia" as narrativas -, já que todas as entidades "parceiras" presentes na sua página inicial contribuem de alguma forma para a história da imigração ou da comunidade nipo-brasileira, incluindo assim a sua "marca" na narrativa, endossando-a e acrescentando detalhes especiais.

No nível do discurso, Ryan (2004) afirma que, ao produzir novas maneiras de apresentar as histórias, as mídias digitais obrigam os usuários a desenvolver novas estratégias de interpretação, porque os textos aparecem na tela em forma de "fragmentos" que devem ser colocados mentalmente em ordem, como num quebracabeça, para que se recupere a história mais ampla. Quanto às narrativas do Bunkyo, embora a sua homepage seja organizada de forma austera, que praticamente reproduz o estilo de linguagem e composição dos textos e ilustrações do seu material impresso, só o fato de serem acessíveis somente por meio de links, marcadores e outros tags já requer ações do usuário que determinam uma forma de experiência com a narrativa que exclui leitores não proficientes nas tecnologias digitais, como é o caso de boa parte dos membros idosos da comunidade.

\footnotetext{
${ }^{246}$ Em inglês, no original: "A complete grammar of language comprises three elements: semantics, syntax, and pragmatics. In narrative theory semantics becomes the study of the plot, or story; syntax becomes the study of discourse, or narrative techniques; and pragmatics becomes the study of the uses of storytelling and of the mode of participation of human agents in the narrative performance. Digital media affect narrative in three ways". Tradução da autora.
} 
E esse quebra-cabeça, que, de fato, tem que ser operado mentalmente pelo leitor/visitante para que uma história mais completa se apresente, não chega a ser uma experiência totalmente nova para os frequentadores do Bunkyo. Estes têm sido desde sempre expostos a fragmentos da narrativa da imigração em suas vivências nos espaços da entidade (edifício-sede, pavilhão, centro Kokushikan e museu), nos eventos solenes, nos festivais e exposições variadas. Embora presenciais, esses fragmentos também exigem um esforço do visitante em recuperar da memória outros pedaços da narrativa para que o sentido seja colocado "mentalmente em ordem", como num quebra-cabeça.

Por fim, no nível semântico, a autora pondera que o impacto da mídia digital na narrativa não é uma questão de "nova lógica" que precisaria ser desenvolvida, mas sim de uma combinação correta entre a mídia e o tipo de narrativa (sua forma e substância). A autora quer dizer com isto que as melhores narrativas para os meios digitais são aquelas cujos temas e enredos mais se beneficiam de seus recursos tecnológicos, ou seja, aqueles que têm maior "afinidade" com a mídia on-line. Nesse ponto, a maior dificuldade, segundo ela, é a adaptação da "linearidade inerente das estruturas narrativas" aos protocolos interativos das mídias digitais (RYAN, 2004 p. 356).

Quanto a isto, não creio que as narrativas se atrapalhem muito pela falta de linearidade no ambiente digital. Assim como a memória pode prescindir das sequências cronológicas sem prejuízo da lógica temporal dos fatos (como lembrava Ricoeur), também as narrativas podem se apresentar de formas não-lineares e fragmentadas sem que se perca sua dimensão configuracional, ou seja, a totalidade que lhe dá sentido. $\mathrm{O}$ Bunkyo tem produzido narrativas que foram recontadas por décadas através da sua mídia impressa, das performances dos seus diversos personagens e das montagens de seus espaços, em uma ordem e em formatos que nem sempre reproduziam as cronologias das histórias narradas. Portanto, embora a recente fragmentação da narrativa na era digital tenha exacerbado essa tendência, ela não tem exclusividade sobre isso.

Um exemplo interessante é o Boletim Bunkyo Empresarial"247, presente no marcador "Publicações" da homepage do Bunkyo. O formato e a linguagem são austeros e se assemelham aos artigos de uma revista impressa, praticamente sem utilização de recursos de interatividade nos textos, gráficos e imagens. Inaugurado em 2015, o boletim tem um objetivo específico, como o título sugere, mas suas matérias - que

\footnotetext{
${ }^{247}$ Ver as publicações on-line em http://www.Bunkyo.org.br/pt-BR/publicacoes/902-boletim-Bunkyorelacoes-empresariais, acesso em 20/11/2017.
} 
podem ser lidas inteiras on-line por meio da plataforma de publicação digital "Issuu" também exploram temas relacionados à imigração, sem conexão cronológica ou temática com os demais artigos da publicação. Este é o caso do boletim número 8, de julho de 2017, que, no meio de diversos artigos sobre economia brasileira e mundial, conta uma história sobre os problemas de saúde enfrentados pelos imigrantes (esta pequena história, sim, sob uma perspectiva cronológica) e a fundação das primeiras clínicas e hospitais por iniciativa da comunidade e do governo japonês.

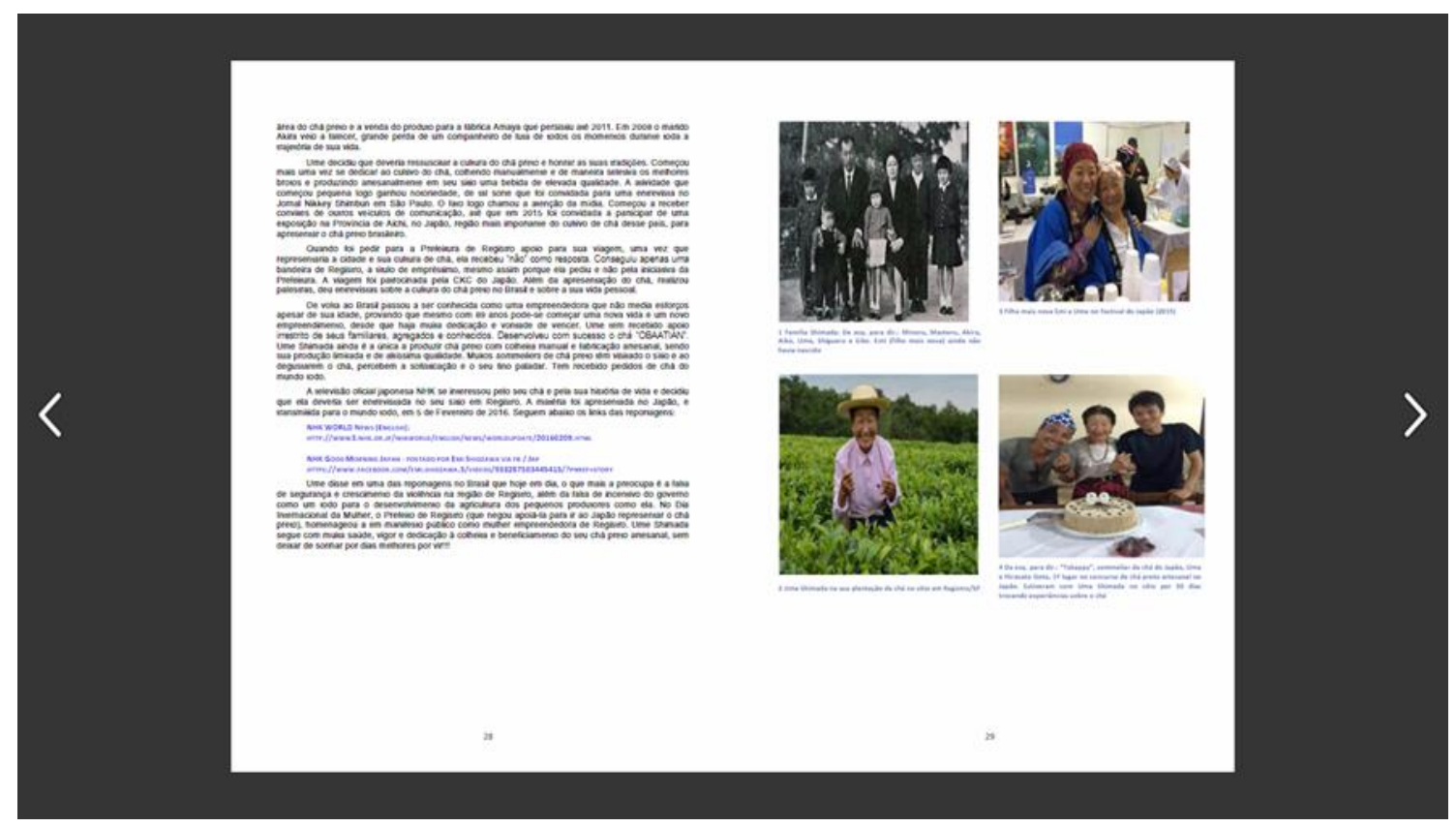

Páginas 28 e 29 da edição número 5, de outubro de 2016, do Boletim Empresarial

Outro artigo semelhante, na edição de número 3, de abril de 2016, relata histórias de desbravamento de matas virgens pelos imigrantes e de um projeto pioneiro de reflorestamento, do final dos anos 1960. E na edição de número 1 do boletim, de outubro de 2015, a primeira matéria fala sobre as contribuições dos nikkeis na agricultura, desde a chegada dos imigrantes, no início do século $\mathrm{XX}$, até recentemente. Além dos textos, o boletim usa amplamente gráficos, tabelas, reproduções de pinturas (como uma de Tomoo Handa que ilustra o artigo da primeira edição) e fotografias, como partes da informação e do enredo. Dessa forma, o Boletim Bunkyo Empresarial participa das narrativas da imigração à medida que evoca momentos especiais da história dos japoneses e de suas atividades produtivas no Brasil, ainda que esses momentos se apresentem na forma de fragmentos fora de sequência e sem ligação direta com as demais matérias da publicação. 
Também as entidades parceiras presentes na homepage do Bunkyo oferecem mais histórias, como, por exemplo, a da fundação do Kenren, da Associação Kaigai Nikkeijin Kyokai e do Enkyo, todas recheadas com relatos de episódios curiosos e emocionantes, que se referem a momentos, lugares e situações diversas em que os imigrantes se juntavam para criar uma associação de pessoas de uma mesma província, para construir uma clínica ou ambulatório em locais sem assistência médica ou para enviar ajuda às vítimas da guerra no Japão. Histórias como essas, assim como as notícias do Bunkyo, participam da homepage da entidade na forma de hipertexto, portanto não-linear, em que a ordem de acesso a cada uma delas quem escolhe é o leitor visitante da página. Cada uma das histórias narradas nos sites tem uma inteireza em si mesma, mas, em relação à grande narrativa da imigração e da comunidade nipobrasileira, é apenas um fragmento que precisa ser juntado a outros no ato da leitura/exploração para adquirir o seu sentido integral, ou sua totalidade. E será que isso quer dizer que os significados das narrativas digitais já saíram completamente do controle das suas fontes de produção - no nosso caso, do Bunkyo?

Por um lado, há que se levar em conta o fato de que o "usuário pode eleger entre diferentes conteúdos, manipulá-los, reproduzi-los, retransmiti-los e regular seu tempo de consumo" (SCOLARI, 2008, p. 77), o que indica que a produção de sentido está na esfera da recepção. Por outro lado, a construção e gerência do site do Bunkyo reflete o investimento da entidade na atualização (em seus próprios termos) do universo nipobrasileiro, cujo marco inaugural é definido pela chegada dos primeiros imigrantes japoneses ao Brasil, e cuja continuidade busca-se preservar por meio dos elos uns com os outros e com o Japão. Quanto a isto, observa-se que a homepage do Bunkyo participa de um projeto comunicacional que tenta manter o controle sobre a produção de sentido da narrativa.

Assim, todas as suas histórias reproduzem alguma parte do enredo principal, e cada entidade parceira só está ali porque representa um daqueles elos e porque adiciona outras histórias consideradas relevantes, garantindo a lógica temática da narrativa e uma visão panorâmica de sua extensibilidade. O sentido que o próprio Bunkyo atribui à totalidade da narrativa feita de textos e de materialidades está presente na seleção de tudo o que publica, inclusive na presença das entidades parceiras. E está também na forma como tudo acontece, das rotinas aos eventos extraordinários. Se essas narrativas construídas e disseminadas pelo Bunkyo produzem ou não os ecos esperados nas formas 
de representação do mundo de seu público é uma outra história, que só uma análise de recepção pode contar. 


\section{Considerações finais}

Esta tese dedicou-se à dinâmica de representação de um segmento da sociedade brasileira - a população de origem japonesa - a partir dos seus esforços de investimento na distinção cultural que, no entanto, preservam os vínculos com a sua "brasilidade". Essa distinção cultural não é um fato em si, mas a percepção que o grupo constrói sobre si mesmo, a partir de um trabalho de seleção de aspectos culturais e de seu compartilhamento, motivo pelo qual a distinção (ou o que diferencia a comunidade nipo-brasileira dos demais brasileiros) reflete os esforços específicos que são feitos neste sentido. A pesquisa explorou o trabalho de uma entidade, em especial - o Bunkyo - que procura garantir e manter, de várias maneiras, a hegemonia dos significados da identidade, do pertencimento e da memória da comunidade nipo-brasileira.

A pesquisa explorou, especialmente, a mediação da comunicação no processo de construção desses significados, sobretudo em um contexto de inserção desses sujeitos no mundo globalizado, em que a hibridização desestabiliza toda diferenciação fundamentada em culturas originais. Os resultados da pesquisa demonstram que o projeto comunicacional do Bunkyo dedicou-se justamente a atuar na contramão desses processos comunicativos globalizantes (percebidos como diluidores), investindo no que a comunidade tem de particular, tendo o passado como referência e a construção do futuro como um lugar onde o legado tem que caber.

Pelos motivos que descrevi na Introdução e nos capítulos subsequentes, escolhi o Bunkyo, entidade que, desde 1955, se propõe a representar a comunidade nipobrasileira e preservar o seu legado, como foco deste trabalho. Com base na premissa de que as "identidades coletivas são sistemas de reconhecimento e diferenciação simbólicos que ocorrem no espaço-chave da comunicação" (LOPES, 2004), estabeleci como hipótese central que o projeto comunicacional do Bunkyo é o espaço e o tempo em que são construídas e compartilhadas narrativas para que a comunidade nipobrasileira veja a si própria no presente como um segmento distinto da sociedade nacional, tendo o passado (imaginado) como referência de diferenciação.

Os discursos que justificam tanto a relevância dessa tarefa como a legitimidade do Bunkyo para cumpri-la têm sido produzidos e modificados ao longo dos anos não apenas por meio de textos escritos e falados, mas também de performances, em que 
valores e papéis são ritualizados e compromissos são reiterados. E, além disso, cenários, montagens, imagens e objetos têm participado das narrativas como forma de materializar certas falas e histórias, resistindo assim à sua diluição com a passagem do tempo, e também endossando as narrativas, ao emprestar a elas sua concretude e um efeito de real.

O advento dos recursos digitais abriu a possibilidade de novos espaços públicos para o Bunkyo, com um potencial infinito de ampliação. Mas, como preço a pagar, impôs desafios quanto ao gerenciamento das formas de leitura e compartilhamento de seus conteúdos, e também a desestabilização dos tempos e espaços das histórias, cujas versões concorrentes se tornaram simultaneamente mais acessíveis aos leitores. Mas, se por um lado essas versões - e o resto do mundo - estão presentes no mesmo espaço cibernético, competindo pelo mouse do seu público, por outro o Bunkyo pode contar com as entidades parceiras, que, a apenas um link de distância, participam das trocas simbólicas que adicionam significados (de maneiras desejáveis, por isso foram selecionadas) às narrativas do Bunkyo.

Assim, defini o projeto comunicacional do Bunkyo como o conjunto de mídias produzidas e administradas diretamente pela entidade, juntamente com as situações de comunicação montadas e vivenciadas em seus diversos espaços, em eventos regulares e extraordinários que ritualizam as formas e valores da distinção nipo-brasileira. Como estratégia primordial da sua militância comunitária, por meio da qual o seu universo de significados procura sobreviver paralelamente - sem se opor, mas sem se dissolver nos significados hegemônicos das mídias nacional e internacional -, o projeto comunicacional do Bunkyo põe em prática uma política de identidade que tem no direito e no dever de memória sua fonte principal de legitimação. Os contornos da identidade nipo-brasileira e do legado deixado pelos imigrantes japoneses emergem daquele espaço-chave da comunicação, em função de um público previamente imaginado (os imigrantes e seus descendentes), mas que é, na verdade, construído e atualizado nesse processo de interpelação.

Conforme mencionado na fundamentação teórica da tese, as representações que as mídias produzem sobre seu público levam à definição do que "é preciso saber", ao mesmo tempo em que elas se apresentam como a instância competente "para informar", a partir da autoridade que esse saber lhes confere, como diz Charaudeau (2012). Embora o autor se referisse à grande mídia, a mesma dinâmica se reproduz na pequena estrutura 
comunicacional de uma entidade comunitária, pois o que proporciona a autoridade do saber e sua competência para disseminá-lo é a institucionalidade da tal instância que detém os meios, que, no caso desta pesquisa, é o Bunkyo.

Assim, independentemente das versões concorrentes e do que de fato ocorre na instância da recepção, o Bunkyo tem mantido a "hegemonia sobre os significados e significantes" (BUCCI, 2005) da produção do discurso sobre a identidade e o legado da imigração, graças às formas de legitimação que corroboram seu status de instituição representativa da população nipo-brasileira, como a presença do governo e da família imperial do Japão em sua sede, a gerência de espaços fundadores como o Pavilhão Japonês e de lugares de memória como o museu da imigração, e ainda a organização de eventos de repercussão nacional e internacional como o centenário da imigração.

A análise de narrativa se comprovou um método rico e fecundo na revelação das dinâmicas de construção e compartilhamento da memória, das práticas e dos valores éticos e estéticos que distinguem a comunidade, na visão do Bunkyo. Essas narrativas expõem o esforço do Bunkyo de selecionar notícias, fatos, objetos, histórias, comentários e testemunhos considerados de interesse da população nipo-brasileira no presente, além de verdadeiros e relevantes para a reconstituição do seu passado. Esse trabalho de seleção e compartilhamento de conteúdos, de mobilização de pessoas e entidades e de construção e gerenciamento da memória através das narrativas é o que configura a militância do Bunkyo a favor da distinção e contra o esquecimento. É também nessas narrativas que fica evidente a ligação simbólica com o Japão (de ontem e de hoje) como um dos principais fatores de distinção e renovação da identidade do grupo.

Assim como a comunidade nipo-brasileira é uma comunidade imaginada, no sentido de Anderson (2011), que a descreveu como um conjunto de pessoas que se imaginam parte de um todo, ou no de Wawzyniak (2008), que pensou a colônia japonesa como uma representação simbólica, também o Japão é nação "construída e mapeada pelo imaginário" dos japoneses no Brasil e seus descendentes. Este Japão redesenhado pelas narrativas, portanto, não se confunde com o país das cartografias geográficas ou dos livros de História, nem mesmo com o das crônicas contemporâneas, mas se refere ao ponto de "origem" e aos primeiros "acontecimentos" que proporcionam a "ancoragem" da identidade e um lugar de "circulação de lembranças", como diz Candau (2002). O autor lembra o papel de "pedagogia acerca das origens" que as 
narrativas desempenham, e seu "efeito performativo" sobre a memória, plantando "sementes de recordação", e unindo assim a comunidade em torno de uma determinada versão do passado imaginado.

A memória coletiva da comunidade nipo-brasileira e a sua identidade cultural produzem e são produzidas por essas narrativas, compartilhadas nos espaços públicos em que esses indivíduos transitam, como aqueles criados e mantidos pelo Bunkyo no seu edifício-sede, no Pavilhão Japonês, no Centro Kokushikan, no museu da imigração e no seu website. A performance da identidade e da memória, então, é parte da narrativa que evoca lembranças, valores e tudo o mais que se constituiu no acervo a ser revivido e preservado através dos anos. Os rituais que celebram aniversários, passagem do ano, falecimentos e condecorações são as "tradições inventadas" de que falava Hobsbawm (1992), pois passaram a existir a partir da colagem de fragmentos de práticas consagradas no Japão e adaptadas à realidade dos japoneses e seus descendentes no Brasil.

Ainda como parte das tradições adaptadas e recriadas, as tradições budistas japonesas - celebradas nos ritos ecumênicos do aniversário da imigração, nas festas de ano novo, no jardim zen do edifício do Bunkyo e do Pavilhão, entre outros - aparecem também como fundamento dos ritos e das narrativas da memória, como forma de gratidão e reconhecimento dos vivos aos antepassados. Embora essas práticas tenham a sua função religiosa original de manter os vínculos entre vivos e mortos, acabaram por servir também à luta contra o esquecimento, ou seja, a favor da preservação de uma seleção de lembranças que são - segundo a percepção do Bunkyo - a fonte de distinção da comunidade nipo-brasileira. Essa luta contra o esquecimento do que "deve" ser lembrado, porém, não impede o esquecimento deliberado, que faz parte da negociação da identidade e dos aspectos políticos de apropriação da memória.

As estruturas de preservação dessas versões da memória e da identidade produzidas e disseminadas pelo Bunkyo nunca impediram, também, que críticas - como as que geraram o relatório de 2003 - e questionamentos, como os que presenciei durante o IX FIB, tenham introduzido modificações nas narrativas, ou tenham, pelo menos, balançado um pouco mais forte sua aparente estabilidade. Não impediram tampouco que 
práticas alternativas, fora do Bunkyo, produzissem narrativas radicalmente diferentes da sua, como foi o caso do projeto Travessias em Conflito ${ }^{248}$.

Sem interesse por disputas abertas, o Bunkyo empreende - com algumas (grandes) vantagens - sua luta pela hegemonia dos significados da memória e da identidade nipo-brasileira, uma luta que, a cada nova geração, se torna mais difícil, com as discussões - que até já se instalaram no interior do próprio Bunkyo - sobre se ainda faz sentido falar em identidade nikkei no Brasil. E, de todo modo, qualquer que seja o rumo que essas discussões venham a tomar, os indivíduos para quem o significado da identidade nipo-brasileira pode fazer sentido serão sempre participantes desse processo de construção de significado, lembrando ainda, como diz Lesser (apud MACHADO, 2011, p. 10), que a identidade nipo-brasileira é "uma peça em transformação dentro de um mosaico de identidades mais amplo". Assim, a força das narrativas da imigração e da comunidade nipo-brasileira é medida pela sua capacidade de reverberar em um universo identitário que inclui os ecos simultâneos de muitas outras narrativas, em cujos tempos e espaços paralelos transitam, também como personagens, esses mesmos nikkeis, membros que são das sociedades contemporâneas, no contexto da globalização.

É difícil dizer, sem uma pesquisa de recepção, em que medida a chamada comunidade nipo-brasileira corresponde ao público imaginado pelo Bunkyo quando este constrói o seu representado no espaço de seu projeto comunicacional. Também uma abordagem quantitativa e comparativa da sua participação nos eventos e apresentações do Bunkyo e nas promoções de outras entidades (parceiras ou não) seria necessária para a avaliação da real ressonância das narrativas da imigração e da comunidade nipobrasileira sobre os indivíduos que supostamente fazem parte dela. Outra questão igualmente importante que também não ficou resolvida nesta pesquisa é a da persistência da etnicidade - que no passado foi condição suficiente (e necessária) de pertencimento à colônia japonesa - como fator essencial da identidade. Embora tenha ficado claro, pelo menos no que diz respeito ao Bunkyo, que as narrativas não indicam a

\footnotetext{
${ }^{248}$ Conforme já explicado anteriormente, o Projeto Travessias em Conflito, do Núcleo Hana de Pesquisa e Criação Teatral, dedicou-se, a partir de 2012, a uma dramaturgia focada no "lado B da imigração japonesa do Brasil", com relatos de vida de imigrantes japoneses e seus descendentes no país, apresentados pelos próprios protagonistas das histórias, sob a direção de Alice Kiyomi Yagyu.
} 
importância da etnicidade para a identidade, é inegável que a presença insignificante de não descendentes no quadro dirigente da entidade sugere o contrário.

O contexto das narrativas do Bunkyo leva a crer que a definição do seu "representado" continua sendo condição estratégica para a manutenção da sua condição de entidade representativa da comunidade, o que ficou claro no importante relatório de 2003. Desde então, a questão da representação tem enfatizado a inclusão de todos os indivíduos da população nipo-brasileira com pouca participação nos quadros e temas de palestras da entidade, como os imigrantes pós-guerra, os decasséguis, os nikkeis da terceira geração em diante, os jovens, as mulheres e também os não descendentes. Os textos de certos líderes do Bunkyo no livro dos 60 anos mostram, se não uma preocupação, pelo menos o registro da inevitabilidade do desaparecimento gradual do fenótipo nipônico no Brasil com o crescimento dos casamentos interétnicos.

Quanto a isto, as narrativas colhidas por mim no IX FIB indicam que um dos caminhos escolhidos foi passar aos nikkeis a missão de "resgatar o tesouro" deixado pelos imigrantes, sobretudo no que diz respeito às "virtudes japonesas", e disseminá-lo entre os brasileiros, permitindo assim que sobrevivam não mais como patrimônio da comunidade, mas da sociedade nacional como um todo. A visão do que venham a ser esse tesouro e essas virtudes, porém, está aberta a discussões, como demonstra o ponto levantado por Matheus Misumoto durante o encontro.

Tudo indica também que os jovens são parte fundamental da estratégia de sobrevivência do Bunkyo como instituição, qualquer que seja a direção dos ventos de mudança que sopram sobre o seu representado. Eu diria até que já existe uma nova narrativa, especificamente sobre e para os jovens (e outra, ainda em construção, "pelos" jovens), que vem se formando há tempos nas falas, performances e textos do Bunkyo. Essa narrativa promete se expandir com a criação do "quarto pilar", ou "Pilar Jovem", uma expressão de forte conotação simbólica que, no entanto, foi exposta em detalhes apenas na palestra de Ricardo Nishimura e Maurício Miyasaki, respectivamente presidente e vice-presidente do Comitê Jovem, durante o IX FIB. O livro dos 60 anos e outras publicações mais recentes não falam nada ainda sobre o que vem (ou virá) a ser esse "pilar jovem". 


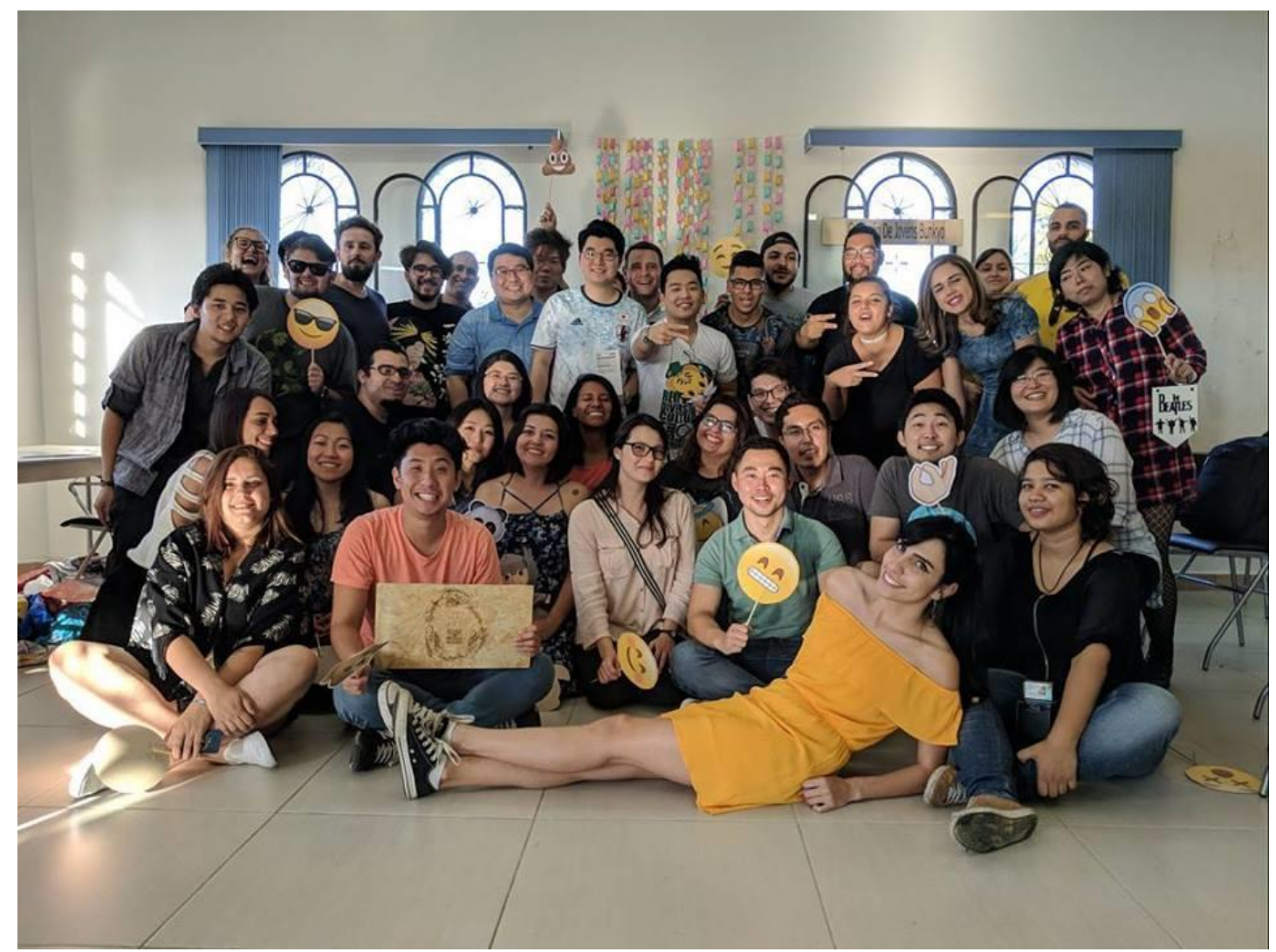

Bônenkai (encontro de fim de ano) do Seinen, 2017.

Fonte: facebook.com/cjb.seinenbunkyo

A comemoração dos 20 anos do Seinen, em 2017, foi a circunstância ideal para a produção e o compartilhamento dessa nova narrativa, que reforça os papéis já difundidos antes e eleva os jovens à condição de quarto pilar da entidade ${ }^{249}$. Apesar de não haver grandes novidades quanto às funções e cargos oferecidos aos jovens, e às estruturas de participação ativa na organização de eventos, além das de que eles já dispõem (como o REVI, o FIB e o próprio Seinen), a simples menção ao "quarto pilar" já indica que, para os líderes da entidade, um aumento efetivo da participação dos jovens - ou seja, a base sólida que esse pilar pode adicionar à estrutura - é providência necessária para impedir que o edifício simbólico do Bunkyo venha a ruir. E, a respeito das questões da etnicidade e do futuro para o qual o Seinen deverá conduzir o Bunkyo (posto que os jovens ali reunidos são os herdeiros da entidade), a fotografia acima tem

249 Conforme já relatado no Capítulo 3, os outros três são: Administrativo, Cultural/Social e Relacionamento. 
algo a revelar: em nenhum outro ambiente interno do Bunkyo há tantos rostos de não descendentes!

\section{Mais uma palavra sobre o Bunkyo}

Quando se propôs, há 62 anos, a ser a entidade central dos japoneses no Brasil, o Bunkyo teria que oferecer mais do que já ofereciam as associações da época. Assim, preparou-se para abarcar as dimensões política, religiosa, educacional, social e cultural da vida da comunidade nipo-brasileira, e assumiu o papel de seu porta-voz. Propôs-se a juntar o que se dispersou após a guerra, a criar a unidade a partir da diversidade interna e a assumir o direito e o dever de narrar a história da imigração. Tornou-se anfitrião das autoridades japonesas no país, fomentador das relações Brasil-Japão e criador/administrador de lugares de memória.

Com a passagem das décadas, o Bunkyo viu a comunidade nipo-brasileira se dispersar cada vez mais pela metrópole paulistana e por outras cidades do Brasil e do mundo, inclusive do Japão (principalmente nos anos do "fenômeno decasségui"). Empunhando as mesmas bandeiras há mais de seis décadas - de ser a entidade central, a espinha dorsal e o refúgio espiritual da população de origem japonesa no Brasil -, o Bunkyo se vê hoje às voltas com a difícil tarefa de manter a distinção cultural de um segmento da sociedade brasileira, sendo que ela mesma vem se transformando intensamente, sobretudo desde os anos 1990, quando a expansão (e maior acessibilidade) da Internet acentuou a hibridização de praticamente todas as culturas no mundo, marcando o início do apogeu da era da globalização.

Como manter, em um mundo cada vez mais tecnológico e mutante, a ressonância de narrativas fundadas na memória? Como evitar que os discursos, as falas, as performances e as montagens que têm o passado como referência dos seus "tesouros" soem saudosistas, nostálgicos, tradicionalistas, ou simplesmente "coisa de velhos"? Os críticos do Bunkyo o acusam de apego a uma visão conservadora da cultura japonesa e da comunidade nipo-brasileira, mantida por uma estrutura pouco aberta à alternância do poder, dificultando assim a ascensão de lideranças com visões inovadoras. Apego ao prestígio social e político dos cargos, elitismo e incapacidade de compreender parte da comunidade, por ter representado no passado somente a visão dos makegumi 
(“derrotistas”), são algumas das outras acusações já emitidas contra o Bunkyo que, por seu lado, prefere enfrentar suas disputas nos bastidores, com discrição e sem confrontos abertos.

Desde a criação da Revista Colônia, logo após a sua fundação, o Bunkyo demonstrava a importância que sempre deu a um projeto comunicacional que fizesse avançar suas narrativas e versões dos acontecimentos. A noção de projeto comunicacional utilizada nesta tese, entretanto, teve que ser ampla para abarcar as práticas comunicativas que vão além das mídias propriamente ditas. Isto porque a estratégia de comunicação do Bunkyo não era competir com os grandes jornais e redes de tevê e rádio, nem mesmo com a mídia nikkei, mas ocupar os espaços que essas mídias não alcançavam (ou não se interessavam em ocupar), além de criar os seus próprios espaços. Ou seja, o Bunkyo criou um projeto comunicacional que atuou paralelamente à grande mídia e à mídia nikkei - ocupando, vez por outra, alguns de seus espaços (nos eventos que tiveram cobertura ou inspiraram comentários) - e sobre o qual manteve total controle, tanto quanto às formas de produção quanto ao conteúdo das mensagens, em função do perfil de um público que não só imaginou, mas também ajudou a construir.

Assim, já no documento "O Porquê do Centro Cultural Brasil-Japão", de 1961, o Bunkyo se propunha a tornar-se "a fonte de informações do Japão em relação ao Brasil e ao Continente Sul-Americano", a "tornar cada vez mais eficiente a divulgação da Cultura Japonesa no Brasil”, promovendo a publicação de revistas, conferências, mesasredondas, sessões de cinema, eventos variados etc. E, entre os muitos espaços de comunicação criados pela entidade, destacam-se o seu próprio edifício-sede - que, como diz Okano (2008), tornou-se um dos "pontos nodais" da Liberdade, ou seja, um ponto de referência da comunidade -, o museu da imigração e o Centro Kokushikan, onde eventos, performances e montagens, além de inúmeras publicações, vêm atualizando e disseminando as narrativas do Bunkyo. De todos os seus feitos, porém, o que lhe tem garantido os melhores resultados foi ter criado e consolidado, através das décadas, um discurso que o torna uma entidade transcendente, uma instituição em si mesma, maior e mais longeva que as palavras e as pessoas de seus membros e líderes. 


\section{Mais uma palavra sobre o método}

Tendo definido que as narrativas são formas de organização do pensamento e de conhecimento do mundo que se refletem nos relatos e histórias que contamos - o que também pode ser postulado ao contrário, ou seja, são relatos e histórias que contamos que se projetam em formas de pensamento e de conhecimento do mundo -, Bruner (2001) conclui que a compreensão dos seus significados é "irremediavelmente" hermenêutica. Ele lembra, porém, que a interpretação das narrativas não promete mais do que uma explicação “convincente e não contraditória”, já que não existe um método empírico que comprove a sua correção. Assim, as interpretações apresentadas nesta tese foram cuidadosamente pensadas em relação a vários aspectos daquelas histórias: seus pontos de cruzamento com outras histórias, sua correspondência com situações semelhantes, a persistência de certos elementos no tempo e em diferentes espaços, as coincidências de relatos dos entrevistados e outras evidências que eu pude acumular durante as sessões de levantamento etnográfico e nas leituras de textos, catálogos, livros, folhetos e notícias produzidas pelo Bunkyo em diversas fases da sua existência.

Apesar de todos os cuidados, não há como não lembrar também as palavras de Geertz (1973), para quem a busca pela "teia dos significados" não deixa de ser, na verdade, uma sucessão de "adivinhações", "um traçar de conclusões explanatórias a partir das melhores conjeturas e não a descoberta do Continente dos Significados e o mapeamento de sua paisagem incorpórea”. Ao reler as minhas próprias interpretações, concordo com ele que são "ficções no sentido de que são 'algo construído', 'algo modelado' - o sentido original de fictio - não que sejam falsas, não-fatuais ou apenas experimentos do pensamento" (1973, pp. 25-31).

Entendendo as técnicas, mas também o investimento humano envolvido na tarefa de interpretar, Geertz lembra que a análise dos significados não se parece com a “tarefa de um decifrador de códigos”, mas sim “com a do crítico literário” (1973, p. 19). A meu ver, essa semelhança decorre da empatia que desenvolvemos com nosso objeto, este envolvimento que faz parte de qualquer trabalho de compreensão de uma obra também humana. E não se trata, claro, de uma obra humana como os encanamentos de esgoto ou as torres de transmissão de eletricidade, mas de um trabalho escrito, falado, gestual e icônico carregado de afetividade e experiência do mundo, como sempre são as histórias referentes à memória e à identidade. 
Uma tese de Doutorado inicia com um desejo de conhecer, uma curiosidade sobre algo em especial, e o atrevimento de achar que isso possa vir a ser um trabalho relevante. Mas a falta de humildade que caracteriza o início dessa empreitada logo se transforma em excesso, pois os caminhos a trilhar são tantos e a busca é tão interminável, que logo desconfiamos da nossa capacidade de dar conta do projeto que nós mesmos criamos. E, antes que essa desconfiança se transforme em certeza, devemos terminar a tese, dando por encerrado não o trabalho relevante que sonhamos, mas a tarefa a que humildemente nos encarregamos de executar, já transformada em algo bem mais "realista" 250 .

De qualquer forma, fica aqui registrado o meu desejo de que esta tese possa inspirar outros pesquisadores que também trabalham a partir da premissa de que as Ciências da Comunicação têm "papel central na compreensão das configurações socioculturais do mundo", e que a Comunicação é o "espaço-chave" da construção das identidades coletivas. E que também possa sugerir caminhos àqueles que, como eu, veem na análise de narrativa uma inesgotável possibilidade de acesso aos significados da memória e do pertencimento comunitário, e ainda às dinâmicas de constituição dos espaços públicos, onde os cenários não são apenas um lugar físico, mas parte das trocas simbólicas entre membros de uma coletividade. Espero que esta tese tenha trazido também alguma contribuição aos estudos da diáspora japonesa no Brasil, da comunidade nipo-brasileira e do papel do Bunkyo nesse contexto.

\footnotetext{
250 Expressão que o pesquisador costuma usar para consolar a si mesmo quando percebe que é necessário redimensionar o seu trabalho, nada tendo a ver, portanto, com a intraduzível "realidade" da vida e do conhecimento.
} 


\section{Referências}

ADACHI, N. (ed.) Japanese Diasporas. Unsung pasts, conflicting presents and uncertain futures. London, New York: Routledge, 2006

ALBUQUERQUE, L.M.B. Comunidade e sociedade: conceito e utopia. Raízes, Ano XVIII, N.20, novembro, pp. 50-53, 1999

AMARAL, R. As mediações da festa. Revista Mediações, Londrina, v. 3, n. 1, p. 13-22, jan/jun.1998

ANDERSON, B., Comunidades Imaginadas, São Paulo, Companhia das Letras, 1991

ASSUMPÇÃO, M.E.O.O. Teatro X Narrativa: gêneros intercambiáveis? Linha D’água, setembro 2010. Disponível em: < http://www.revistas.usp.br/linhadaqua/article/view/62341 > Acesso em: 7 nov. 2017

AUSTIN, J.L. Performative Utterances (Chapter 10). In: Philosophical Papers. 3rd Edition. J.O. Urmson and G.J. (editors.), Oxford: Clarendon Press, 1979

BAUER, L. Uma 'verdadeira réplica': considerações acerca da noção de autenticidade no campo do patrimônio cultural. Esboços - Revista do Programa de Pós-Graduação em História da UFSC, Florianópolis, v. 18, n. 26, p. 14-28, mar. 2012. Disponível em: <https://periodicos.ufsc.br/index.php/esbocos/article/view/2175-7976.2011v18n26p14>. Acesso em: 10 jul. 2016

BAUMAN, Z. Identidade - entrevista a Benedetto Vecchi. Rio de Janeiro: ZAHAR, 2004

BEFU, H. Hegemony of homogeneity. Melbourne: Trans Pacific Press, 2001

BENEDICT, R. O crisântemo e a espada. São Paulo: Perspectiva, 2007

BENJAMIN, W. O narrador. Considerações sobre a obra de Nikolai Leskov. Em: Magia e técnica, arte e política. Obras escolhidas. São Paulo: Brasiliense, 1987.

BERGER, A.A. Media analysis techniques. Beverly Hills: SAGE, 1982

BLANCO, Victor F. Sampedro. Identidades mediáticas e identificaciones mediatizadas. Revista CIDOB d'Afers Internacionals, N. 66-67, p.135-149. Barcelona, 2004

BOURDIEU, P., O poder simbólico, Lisboa, Difel, 1989

BRAGA, J.L., LOPES, M.I.V.L., MARTINO, L.C. (Orgs.) Pesquisa empírica em comunicação. São Paulo: Paulus, 2010 
BRUNER, J. A Cultura da Educação. Capítulo 7: “A Interpretação Narrativa da Realidade. pp. 127-143. Porto Alegre: Artmed, 2001

BUCCI, Eugênio. Hegemonia do significado e hegemonia do significante. Revista Rio de Janeiro, n.15, jan-abr 2005

A forma bruta dos protestos. São Paulo: Companhia das Letras, 2016

BUNKYO - SOCIEDADE BRASILEIRA DE CULTURA JAPONESA E ASSISTÊNCIA SOCIAL Pavilhão Japonês - Tradição e Modernidade. São Paulo, 2007.

Guia do Museu Histórico da Imigração Japonesa no Brasil São Paulo,

2008

Bunkyo: 60 anos. Sua Trajetória. São Paulo, 2015.

BUTLER, J., Gender Trouble, New York, Routledge, Chapman and Hall Inc., 1990

CAMARGO, Luís Soares de. O Pavilhão Japonês no Ibirapuera: um marco entre dois povos. Informativo Arquivo Histórico Municipal, 3 (18): maio-jun. 2008. Disponível em: http://www.arquiamigos.org.br/info/info18/i-manu.htm Acesso em: 23/06/2017

CANDAU, J. Memória e identidade. São Paulo: Contexto, 2002

CARDOSO, R. O. Identidade, etnia e estrutura social, São Paulo, Livraria Pioneira Editora, 1976.

CARNEIRO, M.L.T. e TAKEUCHI, M.Y (orgs.), Imigrantes japoneses no Brasil trajetórias, imaginário e memória. São Paulo: Edusp, 2010

CHARAUDEAU, P. Discurso das Mídias. São Paulo: Contexto, 2012

COLMEIRO, J.F. Memoria histórica e idendidad cultural - de la postguerra a la postmodernidad. Barcelona: Anthropos, 2005

CORRÊA, R. L. Monumentos, política e espaço. Geo Crítica / Scripta Nova. Revista electrónica de geografía y ciencias sociales. Barcelona: Universidad de Barcelona, 15 de febrero de 2005, vol. IX, núm. 183. 〈http://www.ub.es/geocrit/sn/sn-183.htm> Acesso em: 6.Jun.2016

Formas Simbólicas e espaço - algumas considerações. Em: GEOgraphia, ano IX, N.17, pp. 7-17, Niterói, UFF 2007

CULLER, Jonathan. Teoria Literária: uma introdução. São Paulo: Beca Produções Culturais, 1999. 
DAMAZIO, R. E PEREIRA D. A., "Cultura sem fronteiras". Entrevista com Néstor García Canclini, Caderno de Leitura, No. 2, Edusp, janeiro/fevereiro 2008. Disponível em: http://www.edusp.com.br/cadleitura/cadleitura_0802_8.asp Acesso em 25 de dezembro de 2015

DEZEM, R. Matizes do "amarelo" - a gênese do discurso sobre os orientais no Brasil (1878-1908). São Paulo: Humanitas, 2005

Um exemplo singular de política imigratória: subsídios para compreender o processo de formação dos núcleos pioneiros de colonização japonesa no estado de São Paulo (1910- 1930). Proin, Arquivo Público do Estado e Universidade de São Paulo, 2011 Disponível em: http://usp.br/proin/download/artigo/artigo_politica_imigratoria.pdf Acesso em 3 de março de 2017.

"Bravos Nipões" ou embaixadores do Mikado? O período pré-imigratório e a questão da identidade (1890-1909). Revista de Estudos Brasileiros. Osaka Universidade de Estudos Estrangeiros. Vol.11. 2015 pp.1-33

FERREIRA, M.L.M. Políticas da memória e políticas do esquecimento. In: In: Revista Aurora, PUC-SP, n. 10, 2011 pp. 102-116

GARCÍA CANCLINI, N., Culturas híbridas: estratégias para entrar e sair da modernidade, São Paulo, Edusp, 2008

, "Não há um relato compartilhado que articule a nossa sociedade", MATRIZes, Ano 6, No. 1, jul/dez. de 2012

GEERTZ, C., A interpretação das culturas, Rio de Janeiro, Zahar, 1978

HALBWACHS, M. A memória coletiva. São Paulo: Centauro Editora, 2013

HALL, Stuart, A identidade cultural na pós-modernidade, Rio de Janeiro, DP\&A, 2004

Pensando a Diáspora (Reflexões Sobre a Terra no Exterior). Em: $D a$ diáspora, identidades e mediações culturais, Org. de Liv Sovik; Belo Horizonte, Editora UFMG, 2006

, Diasporas, or the logics of cultural translation. Em: MATRIZes, São

Paulo, v.10, n.3, set/dez , pp 47-58, 2016

HANDA, T. O imigrante japonês - história de sua vida no Brasil. São Paulo: T.A.Queiroz, 1987

HARADA, K. (coord.). 60 anos de Bunkyo - passado, presente e futuro. São Paulo: Cadaris Comunicação, 2015 
HASHIMOTO, S.L.I. As representações dos japoneses nos textos modernistas brasileiros: Mário de Andrade, Oswald de Andrade e Juó Bananère. Tese de Doutorado. Versão corrigida. FFLCH/USP, São Paulo, 2012

HATUGAI, E. R. Parentesco, conflito e identificações entre famílias interétnicas de descendentes de japoneses e não descendentes. Comunicação. I Seminário Internacional de Pós-Graduação em Ciências Sociais. Marília, UNESP, 2015

HINE, C. Virtual Ethnography. London: Sage Publications, 2000

HIRABAYASHI, L. (ed.) New Worlds, New Lives - globalization and people of Japanese descent in the Americas and from Latin America in Japan. Stanford: Stanford University Press, 2002

HOBSBAWM, E. e RANGER, T. (eds.), The invention of tradition, Cambridge, Cambridge University Press, 1992

IWABUCHI, K. Recentering globalization - popular culture and Japanese transnationalism. Durham: Duke University Press, 2002

JACKS, N. Comunicação, Cultura e identidade: "relações íntimas, profundas e delicadas". Antares, vol. 5, No. 9, jan/jun. 2013

JENSEN, K.B. e JANKOWSKI, N.W. Metodologías cualitativas de investigación en comunicación de masas. Barcelona: Bausch, 1993

JUSTO, Carolina Raquel. Fundos para conter conflitos do pós-guerra na colônia japonesa beneficiaram física. Ciência e Cultura. SBPC - Sociedade Brasileira para Progresso da Ciência. V. 60, No. 2, p. 14-15, São Paulo, 2008 .

Disponível em: http://cienciaecultura.bvs.br/pdf/cic/v60n2/a07v60n2.pdf. Acesso em 30 de junho de 2017.

KINJÔ, CELSO. Cem anos de imigração (18 de junho de 1908 a 18 de junho de 2008). In: Jornalistas \& Cia On line. 2008. Disponível em: http://www.jornalistasecia.com.br/edicaoespecial09.htm Acesso em 10 de abril de 2017 KISHIMOTO, A. Cinema Japonês na Liberdade. São Paulo: Estação Liberdade, 2013

KITAHARA, M. Commodore Perry and the Japanese: a study in the dramaturgy of power. In: Symbolic Interactions. Vol. 9 No. 1 New Jersey: Wiley, 1986 pp. 53-65.

KOSHIYAMA, A.M. A construção de novas identidades na revista Made in Japan (1998-2002). Anais da Intercom. XXVI Congresso Brasileiro de Ciências da Comunicação. Belo Horizonte, 2003

KUSANO, D. Mishima no Brasil. Retrato do escritor quando jovem. Passagens. Fórum de Ciência e Cultura. Rio de Janeiro: UFRJ, dez. 2009, pp 7-27. 
LESSER, J. A negociação da identidade nacional: imigrantes, minorias e a luta pela etnicidade no Brasil, São Paulo: Unesp, 2001

Japanese, Brazilians, Nikkei: a short history of identity building and homemaking. In: LESSER, J. (ed.) Searching for home abroad. Durham: Duke University Press, 2003

Reflexões sobre (codi)nomes e etnicidade em São Paulo. Em: Revista de Antropologia, SP, USP, 2008, v.51, no. 1 pp. 267-281

LÉVI-STRAUSS, C. A outra face da lua - escritos sobre o Japão. São Paulo: Companhia das Letras, 2012

LINDLOF, T. R., Qualitative communication research methods, Thousand Oaks, Sage, 1995

LONGHI, R. R. Infografia on-line: narrativa intermídia. Estudos em Jornalismo e Mídia, UFSC, Ano VI - n. 1, pp.187-196 jan/jun 2009

LOPES, L. C.. Hermenêutica, teorias da representação e da argumentação no campo da Comunicação. Em: LOPES, M.I.V. (org.) Epistemologia da Comunicação. São Paulo: Loyola, 2003.

LOPES, M.I.V., Sobre o estatuto disciplinar do campo da Comunicação. In: LOPES, M. I.V. de (Org.) Epistemologia da Comunicação. São Paulo: Loyola, p. 277 a 293, 2003.

Para uma revisão das identidades coletivas m tempo de globalização. In: LOPES, M.I.V de (org.) Telenovela: internacionalização e interculturalidade. SP: Loyola, 2004

Pesquisa em Comunicação, São Paulo: Edições Loyola, 2009

Reflexividade e relacionismo como questões epistemológicas na pesquisa empírica em Comunicação, in Braga, J.L.; Lopes, M.I.V.; Martino, L.C. (orgs.), Pesquisa empírica em comunicação, São Paulo, Paulus, p.27 a 49, 2010

LUYTEN, S.B. Mangá e animê. Ícones da cultura pop japonesa. São Paulo: Fundação Japão, 2014 disponível em< http://fjsp.org.br/artigo/manga_anime_sonia_luyten/_> Acesso em 19 de fevereiro de 2016

MACHADO, I.J.R. Japonesidades Multiplicadas - Novos estudos sobre a presença japonesa no Brasil. São Carlos: EDUFSCar, 2011

MAEYAMA, T. Ethnicity, secret societies, and associations: the Japanese. In: Brazil. Comparative Studies in Society and History, Cambridge University. V.21, Issue 4. Oct. 1979, pp.589-610. Disponível em: https://doi.org/10.1017/S0010417500013207 Acesso em: 6 de março de 2017 
MALINOWSKI, B. Argonautas do Pacifico Ocidental: um relato do empreendimento e da aventura dos nativos nos arquipélagos da Nova Guiné, Melanesia, São Paulo, Abril Cultural, 1976 [1922].

MANZINI, E.J. A entrevista na pesquisa social. Didática, São Paulo, v. 26/27, p.149158. $1990 / 1991$

MARTÍN-BARBERO, J. Uma aventura epistemológica, entrevista a Maria Immacolata Vassalo de Lopes, MATRIZes, Ano 2, No. 2, 2009

hegemonia. $5^{\mathrm{a}}$. ed. Rio de Janeiro: UFRJ, 2008.

MARTINO, L. M. S. De um eu ao outro: narrativa, identidade e comunicação com a alteridade. Parágrafo, V. 4, N.1, pp. 40-49, Jan/Jun 2016

MASTERSON, D.M.; FUNADA-CLASSEN, S. The Japanese in Latin America. Chicago: University of Illinois Press, 2004

MATEUS, S. Pode uma imagem ser um argumento? Revista Famecos, Porto Alegre, v.23, n.2, maio, junho, julho e agosto de 2016

MAUSS, M. Sociologia e antropologia. São Paulo: EPU/EDUSP, 1974

MATSAGANIS, M.; KATZ, V.; BALL-ROKEACH, S. Understanding Ethnic Mediaproducers, consumers and societies. Los Angeles: Sage, 2011

MENESES, U. T. B. Memória e cultura material: documentos pessoais no espaço público. Revista Estudos Históricos, [S.1.], v. 11, n. 21, p. 89-104, jul. 1998. Disponível em: 〈http://bibliotecadigital.fgv.br/ojs/index.php/reh/article/view/2067>. Acesso em 26 maio, 2016

MENEZES, P. R. A., Grupo Seibi: o nascimento da pintura nipo-brasileira. Revista USP, No. 27, São Paulo: set/nov de 1995 pp. 102-115 Disponível em: http://www.revistas.usp.br/revusp/article/view/28346 Acesso em 11 de julho de 2017

MIYAO, S. Nipo-brasileiros - processo de assimilação. São Paulo: Centro de Estudos Nipo-Brasileiros, [2006] $]^{251}$

MIZUMURA, C. M. S.. Mulheres no jornalismo nipo-brasileiro. Tese de Doutorado. ECA/USP, 2011

MORIN, E. Ensinar a viver - manifesto para mudar a educação. Porto Alegre: Sulina, 2015

\footnotetext{
${ }^{251}$ Embora o ano de publicação desta edição em português não apareça no livro, a data de 2006 foi confirmada pelo Centro de Estudos Nipo-Brasileiros, editor da obra. Uma versão anterior (sem os últimos artigos), em japonês, foi publicada em 2002.
} 
MOTOYAMA, S., Sob o signo do sol levante, uma história da imigração japonesa no Brasil, Volume 1 (1908-1941), São Paulo, Paulo's, 2011

MOTTA, L.G., Jornalismo e configuração narrativa da história do presente. E-Compós, edição 1, Dez. 2004. Disponível em: http://compos.org.br/seer/index.php/ecompos/article/viewFile/8/9 Acesso em 19 set. 2017

A análise pragmática da narrativa jornalística, in $28^{\circ}$. Congresso Brasileiro de Ciências da Comunicação, RJ, 2005. Anais [cd-rom]. SP: Intercom/Portcom, 2005. Disponível em:

http://www.portcom.intercom.org.br/pdfs/1057680528427387408285905017265231424 62.pdf Acesso em 21 dez. 2015

NAMEKATA, M. H. O conto japonês Urashima Tarô: uma análise sob o prisma do mito. Revista Cerrados v.7, n.8 pp. 71-80, Brasília, UnB, 1998

NAKAMURA, M. T., e CRIPPA, G. Memória e identidades nipo-brasileiras: cultura pop, tecnologias e mediações. Revista Tendências da Pesquisa Brasileira em Ciências da Informação, v.7, n.2., jul./dez. 2014 Disponível em:

http://inseer.ibict.br/ancib/index.php/tpbci/article/view/170/214 Acesso em 5 maio 2017

NASRALLAH, L. The politics of memory. Harvard Divinity Bulletin. Vol. 33, No 2. Autumn 2005. Disponível em:

http://bulletin.hds.harvard.edu/articles/autumn2005/politics-memory Acesso: 5 jan 2015.

NIMURA, J. Daughters of the samurai. New York: W.W.Norton \& Company Publishers, 2015

NORA, P. Les Lieux de mémoire I. La Republique, Paris: Gallimard, 1984. Tradução de Yara Aun Khoury. Projeto História, PUC-SP, Vol, 10. Jul/Dez pp.7-28 1993

ODA, T. Canção da Terra Natal (Furusato no uta). Em: Hashimoto, F., Tanno, J.L., Okamoto, M.S (orgs.). Cem anos da imigração japonesa. História, memória e arte. São Paulo: UNESP, 2008.

OKAMOTO, M. s. e NAGAMURA, Y., Burajiru Jihô (Notícias do Brasil) e Nippak Shimbun (Jornal Nipo-brasileiro): os primeiros tempos dos jornais japoneses no Brasil (1916-1941), Revista Escritos Ano 9, No. 9, Rio de Janeiro, Fundação Casa de Rui Barbosa, 2015 pp 147-179.

OKANO, M. A leitura semiótica-visual: da visualidade à visibilidade - orientalização e orientalidade. Em: HASHIMOTO, F., LEIKO, J., OKAMOTO, M.O. Cem Anos da Imigração Japonesa. São Paulo: UNESP, 2008 
Ma - a estética do 'entre', Revista USP. São Paulo, No.100, pp.150-

$164,2013 / 2014$

OLIVEIRA, R.C. Identidade étnica, identificação e manipulação. Sociedade e Cultura, v.6, n.2, jul/dez. 2003, p.117-131.

PAYER, M.O. Entre a língua nacional e a língua materna, Anais, II SEAD, Seminário de Estudos em Análise do Discurso, Porto Alegre, UFRGS 2005. Disponível em: http://www.ufrgs.br/analisedodiscurso/anaisdosead/2SEAD/SIMPOSIOS/MariaOnicePa yer.pdf Acesso em 2 jan. 2016

Escuta, 2006

Memória da Língua. Imigração e nacionalidade. São Paulo: Edição

PERAZZO, P. F. Prisioneiros de Guerra - os súditos do Eixo nos campos de concentração brasileiros. São Paulo: Imprensa Oficial, 2009

POUPART et al., A pesquisa qualitativa, enfoques epistemológicos e metodológicos, Petrópolis, Vozes, 2008

RICOEUR, P. Narrative Time. In: Mitchell, W.J.T. On Narrative. Chicago: The University of Chicago Press, 1980 pp. 165-186

A memória, a história, o esquecimento. Campinas, SP: Editora da Unicamp, 2007

Tempo e Narrativa, Volume 3. São Paulo: Martins Fontes, 2016

ROCHA, D.; DEUSDARÁ, B. Análise de conteúdo e análise de discurso: aproximações e afastamentos na (re)construção de uma trajetória. Rio de Janeiro, UFRJ. ALEA Vol.7, No. 2, pp. 305-322, Jul-Dez 2005

RONSINI, V. M.; OLIVEIRA, V. Política de identidade e mídia. In: Revista da Associação Nacional dos Programas de Pós-Graduação em Comunicação - COMPÓS. Vol.10, 2007.

RYAN, M. L. (ed). Narrative across media. The Language of storytelling. Lincoln, London: University of Nebraska Press, 2004

SAKURAI, C. Romanceiro da imigração japonesa. São Paulo: IDESP, Editora Sumaré, 1993

A fase romântica da política: os primeiros deputados nikkeis no Brasil. Em: Fausto, B., Truzzi, O., Grün, R., Sakurai, C. Imigração e Política em São Paulo. São Paulo, Editora Sumaré, 1995 
Imigração japonesa para o Brasil. Um exemplo de imigração tutelada: 1908-1941. Em Anais, XXII Encontro Nacional da ANPOCS. GT 9 Migrações internacionais. Caxambu, MG 1998

Os Japoneses. São Paulo: Contexto, 2007

SANADA, H. (coord.) Do Japão ao Brasil... Retornando à origem. CIATE - Vinte Anos de História. São Paulo: CIATE, 2012.

SATO, C.M. Os jornais para comunidades estrangeiras no contexto da globalização: processos de desenraizamento, exclusão e construção de novas identidades. Revista Rumores ECA/USP Vol.3 No.5 2009

SCOLARI, C. Hipermediaciones. Elementos para uma teoria de la comunicación digital interactiva. Barcelona: Gedisa, 2008

SETTON, M. G. J. As religiões como agentes da socialização. Cadernos CERU, série 2, v. 19, n. 2, USP, dezembro de 2008

SODRÉ, M., Sobre a epistemé comunicacional, In: MATRIZes, São Paulo, ECA-USP, Vol.1, n. 1, 2007, pp.15-26

SONG, J. Fighting for Foreigners: Immigration and Its Impact on Japanese Democracy, de Apichai W. Shipper. Em Journal of East Asian Studies, Vol. 10, No. 2 (MAYAUGUST 2010), Cambridge University Press p. 353-355. Resenha

SOUZA, M. Imagem urbana e identidade cultural: expressões midiáticas na comunicação bilíngue do bairro da Liberdade. Em: ABEJ PAPERS, Associação Brasileira de Estudos Japoneses, Abril 2008. Disponível em: <http://www.estudosjaponeses.com.br/antigo/downloads/Papers_Marco_Souza_2008_A br.pdf $>$ Acesso em 28 jan. 2015

TADA, M. A cultura gestual japonesa. São Paulo: Martins Fontes, 2009

TAYLOR, K. Landscape and Memory: cultural landscapes, intangible values and some thoughts on Asia. 3rd International Memory of the World Conference, UNESCO: Canberra, Australia, pp. 19-22 February, 2008 Disponível em: $<$ http://www.unesco.org/new/en/communication-and-information/flagship-projectactivities/memory-of-the-world/resources/meeting-documents/3rd-international-memory-ofthe-world-conference/ > Acesso em 12 ago 2015

THIOLlENT, M. Crítica metodológica, investigação social e enquete operária, São Paulo: Polis, 1980

TURNER, V. Social Dramas and Stories about Them. Em: MITCHELL, W.J.T. On Narrative. Chicago e Londres: The University of Chicago Press, 1980 pp. 137-164. 
VALDETTARO, S. "Epistemología de la Comunicación: un estado de la cuestión en el contexto actual de la mediatización", In: Questões Transversais: Revista de Epistemologia da Comunicação, Vol.1, No. 1, Jan-julho 2013

WAWZYNIAK, S.M. Território nipo-brasileiro: a constituinte da colônia japonesa no Brasil.; Anais do XXIV Simpósio Nacional de História - História e multidisciplinaridade. São Leopoldo, Unisinos, 2007

A 'colônia' como representação: imigração japonesa no Brasil. In: HASHIMOTO, F.; TANNO, J.L.; OKAMOTO, M.S. (orgs.) Cem anos da imigração japonesa. São Paulo: UNESP, 2008

Contornos e representações familiares: a constituição da família japonesa no Brasil. Nuevo Mundo 30/03/2008, Disponível em: https://nuevomundo.revues.org/29302 Acesso em 4 de março de 2017

WILLIAMS, R. Marxismo e Literatura, Rio de Janeiro, Zahar, 1979

WOITOWICZ, K.J. Mídia étnica nas fronteiras da folkcomunicação. Multiplicidade, construção de identidades e resistência cultural no cenário midiático. XII Conferência Brasileira de Folkcomunicação, Taubaté, SP. Anais do Congresso. 2009

WOORTMANN, E. F. Japoneses no Brasil/ Brasileiros no Japão. Revista de Antropologia, USP, 1995, v.38, no. 2

YAMASHIRO, J. Japão - passado e presente. São Paulo: IBRASA, 1977

ZUMTHOR, P. Performance, Recepção, Leitura. São Paulo: Educ, 2000

\section{Fontes primárias:}

BUNKYO - SOCIEDADE PAULISTA DE CULTURA JAPONESA, Comissão Pró Construção do Centro Cultural Brasil-Japão. "O Porquê do Centro Cultural BrasilJapão" [1961]

BUNKYO - SOCIEDADE BRASILEIRA DE CULTURA JAPONESA, Comissão Provisória dos Estudos de Renovação, Relatório Final, 19 de março de 2003

\section{Sites:}

Biblioteca Nacional do Parlamento (National Diet Library), Departamento de História Política. Imigração Japonesa no Brasil, Tóquio: Japão. Disponível em: http://www.ndl.go.jp/brasil/pt/ Acesso em: 23/02/2017

Bunkyo: http://www.bunkyo.org.br/pt-BR/ Acesso em: 23/02/2017 
CIATE: http://www.ciate.org.br/ Acesso em: 23/02/2017

Ministério das Relações Exteriores do Japão:

http://www.mofa.go.jp/region/latin/brazil/centenary.html Acesso em: 23/02/2017

Museu Histórico da Imigração Japonesa: http://www.museubunkyo.org.br/index.htm Acesso em: 23/02/2017 


\section{Anexo}

\section{Entrevistas}

As entrevistas incluídas neste anexo foram selecionadas a partir de um critério que passou por diferentes estágios durante os quatro anos em que me dediquei a esta pesquisa de Doutorado (de 2014 a 2018). A princípio, procurei conversar com o maior número possível de pessoas, dentro e fora do Bunkyo, pois muita gente tinha coisas interessantes para contar e as pessoas, em geral, gostam de contar as suas histórias. Aos poucos fui identificando alguns interlocutores com quem poderia reconstituir mais detalhadamente os aspectos das histórias que precisava conhecer melhor.

E por fim, defini alguns poucos nomes para publicar suas entrevistas inteiras pois não teria tempo de fazer isto com um número maior de entrevistados, como eu desejava - para que suas "vozes" participassem do meu trabalho, permitindo assim que o leitor pudesse "ouvi-los" diretamente, com a menor interferência possível da minha parte. A seleção destes nomes se deu em função do critério de que cada uma destas pessoas era como um "informante-chave", que Poupart (2008) descreve como alguém capaz “de 'informar' não só suas próprias práticas e as suas próprias maneiras de pensar, mas também - na medida em que ele é considerado como 'representativo' de seu grupo ou de uma fração dele - sobre os diversos componentes de sua sociedade e sobre seus diferentes meios de pertencimento" (2008, p.222).

O método de entrevista utilizado foi do tipo "semiestruturado", em que as entrevistas são conduzidas a partir de "um roteiro com perguntas principais, complementadas por outras questões inerentes às circunstâncias momentâneas da entrevista" (MANZINI, 1990-1991). Diferente do questionário fechado e da entrevista estruturada, em que tudo o que o pesquisador deseja conhecer já está previamente definido, este método consiste em se levantar um tema amplo, por meio de algumas perguntas, e permitir que a entrevista assuma o seu próprio fluxo, sem que o entrevistador conduza o rumo das rememorações e/ou reflexões do entrevistado, e sem impedir que ele introduza pontos novos, que não estavam no roteiro. Na pesquisa acadêmica, porém, existe sempre um limite à abertura da entrevista. Citando Palmer e Bourdieu, Poupart (2008) menciona o equilíbrio que se deve buscar, ao "estabelecer um 
compromisso entre a não-diretividade e uma certa orientação a dar à entrevista, em função do objeto pesquisado" (2008, p.226).

Além da liberdade de conduzir os rumos de sua própria entrevista, cada entrevistado também foi convidado a editar o texto final. A ideia era atingir um equilíbrio, como aponta Poupart, para que o material conseguido fosse "uma coconstrução, da qual tomam parte tanto o entrevistador quanto o entrevistado" (2008, p. 247). Em outras palavras, as entrevistas foram concebidas de modo a proporcionar ao leitor um contato bem próximo com alguns dos personagens da história apresentada nos capítulos da tese. Embora esses relatos tenham informado, em momentos diferentes, a minha compreensão do que ocorre nos bastidores do Bunkyo, algumas das partes mais interessantes de suas histórias não aparecem em nenhum outro lugar da tese, apenas aqui.

Os entrevistados são cinco: Eduardo Goo Nakashima, secretário-geral administrativo; Célia Abe Oi, coordenadora de Comunicação; Masato Ninomiya, presidente do CIATE; Andrew Hideo Kajiyama, presidente do Seinen; e Harumi Goya, presidente do Bunkyo. Suas entrevistas são intituladas "Fragmentos de uma conversa" porque todas elas foram muito mais longas do que foi editado. O que não aparece no texto final foi retirado ou porque não coube, ou porque o próprio entrevistado decidiu manter em "off". 


\section{Fragmentos de uma conversa 1}

Eduardo Goo Nakashima ${ }^{252}$

Entrevistas realizadas em 16/06/2017 e em 30/10/2017.

O Bunkyo foi fundado por três grupos minoritários da comunidade japonesa no Brasil: "esclarecidos" (ou derrotistas), originários da província de Okinawa e católicos. Okinawa foi um reino independente que foi incorporado pelo Japão e por isso seus habitantes eram discriminados. Os católicos eram pouco expressivos no Japão, ${ }^{253}$ sofriam o preconceito da proibição de sua crença no Japão por mais de dois séculos, mas no Brasil, de população de maioria católica, foram privilegiados. Somados, estes três grupos (derrotistas, opinava-nos e católicos) representavam menos de dez por cento da comunidade de imigrantes japoneses.

Depois de tentativas mal sucedidas de unificação dos imigrantes, no pós-guerra, tudo começou a dar certo com a construção do Pavilhão Japonês do parque Ibirapuera, em que a liderança "esclarecida" obteve o consenso para a adesão massiva da colônia japonesa e do governo japonês para sua viabilização, e que foi doado à cidade de São Paulo em retribuição ao acolhimento dos imigrantes no Brasil. Foi essa realização que deu impulso ao projeto de fundação do Bunkyo.

A legitimidade do Bunkyo como representante central da comunidade nipobrasileira foi afirmada pela primeira vez em 1958, quando o príncipe Mikasa (irmão do então imperador Showa) veio lançar a pedra fundamental do edifício-sede. Foi consolidada com a vinda do príncipe herdeiro Akihito em 1967 e depois em todas as vezes que algum membro da família imperial do Japão veio ao Brasil. O Bunkyo e a

\footnotetext{
252 Eduardo Goo Nakashima é nissei (filho de japoneses), nascido em Mogi das Cruzes, Estado de São Paulo. Formou-se na Faculdade de Arquitetura e Urbanismo da USP, e tem título de Mestre em História da Arquitetura pela Universidade de Hiroshima, Japão. Trabalhou em empresas japonesas antes de assumir o cargo de Secretário-Geral Administrativo do Bunkyo, em maio de 2003.

253 A igreja de São Gonçalo - santo que foi mártir no Japão, onde morreu crucificado pelas forças do xogunato em 1579 - situa-se na Praça João Mendes, em São Paulo, próximo ao bairro da Liberdade. Tornou-se paróquia dos japoneses em 1966, sob a coordenação dos jesuítas, para atender a uma população de imigrantes nipônicos católicos, estimada, à época, em cerca de 60 mil pessoas. Todo ano, no dia 18 de junho, há missa às 8 horas nessa igreja, em comemoração ao aniversário da imigração japonesa. E todos os domingos, também às 8 horas, as missas são celebradas em japonês. Fonte: Arquidiocese de São Paulo.
} 
Aliança Cultural Brasil-Japão nasceram como irmãos, na verdade como Caim e $\mathrm{Abel}^{254}$. Depois de idas e vindas, alternando períodos de "convivência pacífica" e de "guerra fria", o Bunkyo criou, na década de 90, um curso de japonês no edifico-sede, o que causou um confronto com o curso tradicional da Aliança instalado no edifício do Bunkyo desde a sua inauguração em 1964, o que causou uma mágoa prolongada. Hoje as duas entidades se dão bem, mas os "criadores" projetaram uma fusão futura delas, para preservar a "alma" do projeto original de uma entidade central.

O Bunkyo, segundo sua carta de fundação, foi criado para exercer a prática da cultura, por isso foi importante o projeto de construção do auditório, onde seriam apresentados aspectos diversos da cultura japonesa. Também deveria ser um lugar para aprender, e para isso foi feita a biblioteca e oferecidas bolsas de estudo. Sobre a preservação do legado, que também faz parte da missão do Bunkyo, o museu da imigração japonesa, recentemente, quebrou três tabus: o primeiro, é a exposição da bandeira do Japão que Tokuichi Hidaka segurava no momento em que participava do assassinato do coronel Jinsaku Wakiyama, em 1946, um fato que até recentemente tocava num ponto extremamente sensível da história da colônia ${ }^{255}$; o segundo foi a exposição sobre Ryo Mizuno, que para muitos não foi um pioneiro, mas alguém que lucrou às custas dos imigrantes; e o terceiro, é a exposição do retrato do imperador Akihito e da imperatriz Michiko no meio de uma sala onde os visitantes, ao passarem pelo quadro, dão as costas às figuras retratadas, o que é considerado desrespeito pelos japoneses que veneram o imperador.

E ainda quanto a tabus, há outra história da qual não se fala muito, que é a imigração de japoneses para a Amazônia brasileira. Com o fim da guerra, os cidadãos japoneses que moravam na Manchúria, na Coréia e em outros territórios asiáticos ocupados, tiveram que voltar para o Japão, todos de uma vez, o que gerou um excedente populacional imenso, que num país pequeno e assolado pela guerra, não tinha como ser absorvido nem acomodado. O Brasil era um dos poucos países que aceitaram receber os imigrantes, mas como não havia lugar para todos nas regiões de melhor clima, muitos

\footnotetext{
${ }^{254}$ O foco da analogia com a história bíblica de Caim e Abel, aqui, é na sobrevivência de apenas um dos dois irmãos, e não, evidentemente, no assassinato.

${ }^{255}$ Hidaka, que na época tinha 19 anos, fazia parte de um grupo de militantes "vitoristas" que não só acreditavam que a derrota do Japão era uma mentira inventada pelos Aliados, como também consideravam seus conterrâneos "derrotistas" (os que reconheciam a derrota do Japão) traidores da pátria. Wakiyama foi um dos "derrotistas" da colônia assassinados pelos militantes "vitoristas". Esta história é tema do documentário "Yami no Ichinichi - O Crime que abalou a Colônia Japonesa no Brasil", de Mário Jun Okuhara, de 2012.
} 
foram levados para a Amazônia, sem planejamento nem ajuda. Como o ambiente era muito inóspito, acabou havendo muitas mortes. Foi uma verdadeira tragédia.

O período mais interessante vivido pelo Bunkyo foi dos seus primeiros anos até o final da década de 1970, quando o ambiente era mais "arejado", sendo frequentado tanto pelos imigrantes em geral, como também pela elite paulistana. Artistas, professores da USP e intelectuais em geral, encontravam aqui um clima favorável às discussões e à troca de ideias sobre cultura japonesa, inclusive os não descendentes. Foi neste período que foi construído o Museu da Imigração Japonesa, acrescendo quatro andares ao Edifício Bunkyo, o que realizou um dos principais objetivos da fundação do Bunkyo. Depois, o gás dos ideais da fundação do Bunkyo se esgotou, e a burocracia ${ }^{256}$ teve de assegurar sua continuidade.

A participação de jovens no Bunkyo tem sido apontada com frequência como a grande medida eficaz para atrair novas ideias e formar lideranças para garantir o futuro da entidade. Há quase uma mística em torno dos poderes transformadores da juventude, mas a sua participação não é necessariamente inovadora, pois os jovens, por sua imaturidade inerente, podem ser manipulados para finalidades conservadoras, como foi - em um exemplo extremo - o caso da juventude nazista e fascista, na Europa préguerra. Sem excluir os jovens, claro, deveríamos atentar também que há muita gente experiente, na faixa dos 40 a 60 anos, ou até mais, que está afastada do Bunkyo e poderia dar uma grande contribuição inovadora à entidade. Infelizmente, não há projetos de caráter abrangente voltadas a atrair a participação destas pessoas.

O primeiro presidente do Bunkyo a ter começado a atuar na entidade em sua juventude (no ano de 1957) foi Atushi Yamauchi ${ }^{257}$, que foi também o primeiro nissei a assumir a presidência do Bunkyo. Acredito que sua nomeação teve maior impacto, por ser nissei, do que a de Harumi Goya, nossa atual presidente, por ser mulher. Embora a presença feminina no cargo máximo de uma entidade de tradição japonesa ser um acontecimento importante, a escolha de um nissei no início dos anos 1990 foi verdadeiramente a quebra de um tabu, pois o Bunkyo ainda era uma entidade totalmente dominada pela visão de mundo dos isseis.

\footnotetext{
${ }^{256}$ A burocracia - como forma de organização estruturada, normativa e hierárquica - faz parte da cultura japonesa, não sendo necessariamente um problema. $O$ termo é utilizado aqui no sentido neutro, de trabalho rotineiro e repetitivo, despojado das ideias e entusiasmo que o moviam anteriormente, em que as regras se tornam, como diz Jacques Maritain, um fim em si mesmas, e não mais um meio para se atingir determinado fim.

${ }^{257}$ Atushi Yamauchi foi o oitavo presidente do Bunkyo, de 1991 a 1999.
} 
Muitos problemas que aconteceram na comunidade, e por extensão também no Bunkyo, foram atribuídos aos nisseis, por já não serem mais verdadeiros "japoneses", por isso surgiu o mito de que quando os nisseis assumem tudo cai, apontando-se como exemplo a decadência das cooperativas, das empresas e bancos fundados pelos imigrantes no país e assumidos posteriormente por nisseis. Até o terrível impacto destruidor que a moratória do governo José Sarney teve sobre as empresas japonesas no Brasil, em 1987, foi atribuído pelo menos em parte aos nisseis, que não as ajudaram a perceber que a situação econômica caminhava para este desfecho, embora muitos fossem pagos para oferecer consultoria. Alegava-se na época que as outras empresas estrangeiras de alguma maneira se prepararam para acontecimentos deste tipo, só as japonesas foram pegas de surpresa.

A gestão de Yamauchi teve muitos méritos, mas também teve problemas que alimentaram o mito, como foi o exemplo da criação do curso de japonês, que se por um lado tornou-se o "feijão com arroz" do Bunkyo (no sentido de que era uma fonte estável de recursos, que ajudava a pagar as contas), por outro gerou um atrito sério com a Aliança, como já mencionei anteriormente. Foi por causa do curso, também, que teve início uma pendência com a Previdência Social, que até hoje dá muita dor de cabeça à entidade.

Yamauchi não foi o único a quebrar tabus. Antes dele, Masuichi Omi (cuja gestão se estendeu de 1983 a 1991) também foi, em certo sentido, pioneiro: foi o primeiro presidente, digamos assim, de "sangue vermelho" do Bunkyo, ou seja, o primeiro a ter trajetória iniciada como imigrante colono, nas fazendas de café. Todos os que o antecederam tinham "sangue azul": eram a elite dos imigrantes, que tinham educação superior e/ou ocupavam cargos elevados em empresas ou instituições importantes, antes de assumirem a presidência no Bunkyo. ${ }^{258}$

\section{O lento declínio}

\footnotetext{
${ }^{258}$ Outro ponto em comum entre Omi e Yamauchi foi a longa gestão à frente da entidade. Ambos ficaram oito anos na presidência, ao contrário de seus seis antecessores, que ficaram de quatro a seis anos, com exceção do segundo presidente, que ficou apenas dois anos (Kumaki Nakao), e do primeiro, que ficou sete anos e meio (Kiyoshi Yamamoto).
} 
Assim como o xogunato Tokugawa, que dominou o Japão por 260 anos, teve uma ascensão e queda, o Bunkyo cresceu positivamente até a inauguração do museu em 1978. Conseguiu ostentar a liderança da comunidade até o octogésimo aniversário da imigração, em 1988, e começou a lenta decadência na virada dos anos 90, com o início do movimento decasségui e o consequente esvaziamento das associações, e o final de sua base econômica, com o fechamento das cooperativas Cotia e Sul-Brasil e do Banco América do Sul, em 1997. Em 1998, o Bunkyo apresentou uma limitada atividade nos 90 anos da imigração, sendo superado pelo Paraná, que teve a presença do presidente Fernando Henrique Cardoso. E aí foi inventada a UNEN (União Nacional das Entidades Nikkeis), uma "aventura macabra" com o objetivo de criar uma entidade para superar o Bunkyo, e ainda por cima comandada por nisseis! ${ }^{259}$ Neste ano de 2017, as federações e entidades do interior criaram a União das Entidades Nikkeis do Estado de São Paulo, que tentará tomar o lugar do Bunkyo no Estado. Enfim, essa história vai longe!

Também os eventos de integração, cujos formatos lembravam os do FIB atual, sofreram desgaste com o esvaziamento das entidades nikkeis desde a diáspora decasségui. A construção do ginásio de esportes e do prédio anexo comprovava a crise já instalada, reafirmando uma tese equivocada de que os jovens seriam atraídos à entidade simplesmente pela existência de um lugar para prática de esportes. Durante os anos 1990, bons trabalhos como o exame unificado das bolsas de estudo e estágios técnicos para o Japão (abrangendo as patrocinadas pelas províncias, JICA e AOTS), e que era aplicado centralizadamente pelo Bunkyo, foi cedido para outra entidade, que em seguida deixou de realizá-lo, uma clara falta de visão de que era celeiro para o surgimento e formação das futuras lideranças da comunidade.

A burocracia que não era a causa da falta de novos projetos, passou a ser enfim o único fio condutor da continuidade da entidade. Os anos 1990 tiveram apenas duas boas realizações: a criação do CIATE e as obras do terceiro pavimento do museu, no nono andar do nosso prédio. De resto, a entidade foi definhando a ponto de não ter mais força agregadora para celebrar os 90 anos da imigração com a grandeza das décadas passadas, conforme expliquei acima.

Além de assumir, em 1999, a presidência da entidade que ajudou a fundar em clima tão desfavorável, Hideo Iwasaki ainda iria enfrentar uma situação muito mais grave, sem precedentes na história do Bunkyo. Enfurecido com a atitude de um superior

\footnotetext{
${ }^{259}$ Embora a UNEN ainda exista formalmente, ela nunca conseguiu um número significativo de adesões.
} 
que considerara injusta, um funcionário coletou secretamente documentos que comprovariam "procedimentos indevidos", supostamente praticados em gestões passadas ou até recentes. Sendo sempre voluntários, os diretores e presidentes da entidade não raro delegavam a terceiros, boa parte das tarefas administrativas, inclusive as da parte contábil, o que indica que os tais procedimentos provavelmente eram feitos sem seu conhecimento. De posse dos documentos, este funcionário, com a ajuda de um segundo desafeto do Bunkyo, fez chegar aos proprietários dos jornais uma mala com cópias destes papeis.

Se tivessem chegado às páginas dos jornais, os documentos poderiam ter causado danos à imagem da entidade, o que foi evitado graças à mediação de pessoas de grande prestígio dentro da comunidade, chamadas a intervir e a conduzir, juntamente com lideranças do Bunkyo, um amplo processo de renovação, que resultou, entre outras coisas, no anúncio por parte dos membros da direção, inclusive do presidente, de que não se recandidatariam às próximas eleições, que ocorreriam dali a poucos meses ${ }^{260}$. A ideia era que o exemplo da mudança viesse de cima, criando maior transparência nos processos internos e abrindo espaços para que novos líderes se encarregassem das tarefas da renovação. Foi difícil encontrar quem aceitasse esta tarefa, mas no final ficou acertado que Kokei Uehara, professor emérito e livre-docente da Escola Politécnica da USP, e ex-representante do Brasil na UNESCO, seria a pessoa que lideraria o Bunkyo naquele momento delicado da sua existência, e ocupava na ocasião da presidência da Aliança Cultural Brasil-Japão, circunstância especialíssima que abriu a janela para a conclusão do projeto dos "criadores" da formação da entidade central Bunkyo-Aliança.

O ano de 2002 foi um divisor de águas para o Bunkyo, que poderia ter acabado aí. Foi a nossa "Era Meiji" ${ }^{261}$ : mudar para continuar a existir. Como temos o DNA japonês, o Bunkyo "imitou” o Japão e se abriu ${ }^{262}$.

Neste mesmo ano em que o relatório da renovação foi assinado (2003), o secretário-geral administrativo Senichi Adachi, meu antecessor, anunciou a sua

\footnotetext{
${ }^{260}$ Para isso, foi criada em outubro de 2002 a Comissão Provisória dos Estudos de Renovação, que teve como coordenador Kazuo Watanabe, desembargador aposentado do Tribunal de Justiça de São Paulo.

${ }^{261}$ Era Meiji se refere ao período de governo do Imperador Meiji, de 1868 a 1912. Foi nessa época que o Japão pôs em prática um grande projeto de modernização, que incluiu abertura comercial com o Ocidente e influência cultural, tecnológica e científica dos Estados Unidos e países europeus.

${ }^{262}$ Segundo documento produzido na época, pessoas ligadas à própria direção do Bunkyo detectaram a necessidade da entidade se reformular profundamente. Uma "comissão provisória dos estudos de renovação" elaborou um projeto de mudanças cujo relatório final foi assinado no dia 19 de março de 2003.
} 
aposentadoria, depois de 33 anos no cargo. Adachi foi funcionário e colaborador do Bunkyo desde 1957 - portanto dois anos após sua fundação - e havia participado das decisões que mudavam o regulamento interno quanto à permanência dos profissionais na entidade. Foi definido que os homens deveriam se aposentar aos 70 anos e as mulheres aos 65, assim toda a sua chefia entregaria seus cargos. Com a saída de Adachi, houve uma pressão para que alguns veteranos permanecessem, mas prevaleceu o entendimento de que o regulamento criado por eles próprios deveria ser respeitado. Assim, saíram todos, o que foi o encerramento de um ciclo.

A celebração dos 100 anos da imigração japonesa, em 2008, foi um acontecimento grandioso, até surpreendente para a comunidade que já não via esta pujança desde as comemorações de 1988. Isto demonstrou que os japoneses e seus descendentes são bem quistos no Brasil como em nenhum outro lugar no mundo. Uma coisa interessante pode ser observada na nossa feira anual de livros usados, que são praticamente todos em japonês: um número cada vez maior de brasileiros não descendentes tem vindo à feira para comprar livros, que eles conseguem ler com fluência. Antigamente, os brasileiros vinham somente atrás de mangá e de almanaques de empresa, como da Toyota, por exemplo. Hoje há muitos que conseguem ler até Kawabata $^{263}$ no original, e querem saber mais sobre o Japão.

A ajuda às vítimas do terremoto de 2011 no Japão foi um marco recente na afirmação da legitimidade do Bunkyo. Recebemos mais de três milhões de reais e decidimos enviar direto para o Japão. A confiança da comunidade nipo-brasileira no Bunkyo ficou muito clara, pois gente do Brasil inteiro veio trazer doações em dinheiro pessoalmente ou enviava suas doações por banco.

No ano de 2013 o projeto de renovação completou dez anos, o que incluiu a saída de Adachi e minha contratação para a secretaria-geral administrativa. Teria sido importante fazer uma ampla reflexão sobre os resultados das medidas que foram tomadas, se atingiram ou não seus objetivos. Dez anos é um bom período para se medir a mudança de mentalidade que deve ocorrer para que uma verdadeira renovação se realize. Por exemplo, a mudança da língua corrente da entidade, do japonês para o português, foi drástica e rápida, e hoje se produz poucos documentos na língua pátria dos isseis. Não se questiona se algo essencial se perdeu nesta passagem.

${ }^{263}$ Yasunari Kawabata (1899-1972), escritor japonês que ganhou o Prêmio Nobel em 1968. 
Quanto à secretaria-geral administrativa (a porção profissional da entidade, a sua burocracia), suas prerrogativas não constam do estatuto, por uma postura ainda claramente issei $^{264}$, mas como se diz aos nisseis, "deve-se explicitar as questões, pois hoje somos todos brasileiros" ${ }^{\text {265 }}$. Penso que a secretaria-administrativa deveria voltar a ter um papel relevante no processo contínuo da renovação, e um papel efetivo no diálogo com a diretoria e as comissões de voluntários, como foi nos primórdios até a fase áurea da entidade.

Para que isto possa acontecer, precisamos superar alguns preconceitos da "corte dirigente" como, por exemplo, quanto à capacidade de dedicação e lealdade de voluntários e funcionários, como se uns fossem mais ou menos capazes, só porque uns são pagos e outros não. Todos nós queremos a mesma coisa, ou seja, melhorar a organicidade entre as funções, atrair mais participantes pensantes, com potencial real de inovação, melhorar o diálogo e o ambiente para que novos voluntários e profissionais queiram se juntar a nós, em vez de se sentirem perdidos e mal aproveitados.

Hoje, além do Pavilhão Japonês e da nossa sede principal, temos também o Centro Esportivo Universidade Kokushikan ${ }^{266}$, que após 20 anos de sua doação não encontrou um destino de uso. Poderá ser um lugar como o Nippon Country Club ${ }^{267}$, cuja "verdade", como lugar representativo da comunidade nipo-brasileira, é demonstrada pelo fato de que tem hoje um quadro de vinte e cinco mil associados, oferece atividades variadas e ainda conta com voluntariado ativo em todas as faixas etárias e de gênero.

O Pavilhão Japonês, que é administrado pelo Bunkyo, foi o primeiro lugar de divulgação da cultura japonesa no Brasil em um lugar público. Agora, tem também a Japan House, que se dedica à mesma missão, entre outros. Teria sido bom que a Japan House também fosse vinculada ao Bunkyo. Na verdade, ao saber de que havia a intenção de construí-la em São Paulo, o Bunkyo tentou trazê-la para a nossa sede. Seria melhor que fosse abrigada pela comunidade nipo-brasileira do que pagar aluguel a uma empresa privada. Mas a localização, na Avenida Paulista - de grande visibilidade e

\footnotetext{
${ }^{264}$ Segundo a tradição japonesa, que veio com os isseis, o trabalho burocrático é um trabalho de bastidores, isto é, de "cozinha".

${ }^{265}$ Ou seja, as atribuições do trabalho administrativo deveriam estar explícitas no estatuto da entidade, em vez de permanecer como trabalho de "cozinha", como faziam os antigos japoneses.

${ }^{266}$ Centro Esportivo Kokushikan Daigaku, área de 23 alqueires doada ao Bunkyo em 1997, em São Roque, onde se realizam eventos e campeonatos, e todos os anos, no mês de julho, é realizado o Sakura Matsuri (Festival das Cerejeiras).

${ }^{267}$ Clube de campo fundado por nipo-brasileiros em Arujá, no ano de 1960, com atividades da tradição cultural japonesa e outras brasileiras.
} 
maior facilidade de acesso ao público - deve ter sido um fator decisivo na escolha daquele lugar para sediar a Japan House.

O futuro do Bunkyo enquanto entidade central da comunidade é indefinido, com o envelhecimento e a morte dos isseis e nisseis. Não é muito claro o que as gerações seguintes querem realizar com a entidade. Por isso, as festas do tipo Gueinosai ${ }^{268}$ hoje estão em decadência, há menos comparecimento de público, de grupos atuantes e de organizadores. Muitos aspectos da cultura japonesa podem ser transmitidos, ensinados, e têm sido assimilados e apreciados, como os matsuri ${ }^{269}$, que os jovens adoram, mesmo os não descendentes. Mas vejo que houve incapacidade em transmitir a leitura e escrita em japonês. Nesse sentido, de forma radical, pode-se dizer que a transmissão da cultura japonesa está se operando de forma "analfabeta". Mas existe a exceção citada, dos não descendentes fluentes em língua japonesa em busca de livros na língua original. Será que eles vão querer gerir esta entidade?

Outro contingente populacional importante são os decasséguis retornados. O Bunkyo tem que achar um jeito de assimilar os filhos dos decasséguis retornados ${ }^{270}$.

Estes filhos dos retornados foram ainda crianças para o Japão ou nasceram lá. Voltaram (ou vieram) para o Brasil antes de se profissionalizarem e aqui não conseguem passar no vestibular porque não sabem português o suficiente. Eles são japoneses, se identificam com o Japão, têm a cultura japonesa na pele. Eles são os novos imigrantes japoneses no Brasil. Há aqui um número expressivo deles, mais de 100 mil pessoas. Eles podem dar um novo sentido, uma nova "alma" para o Bunkyo, um novo rumo. Mas do jeito que o Bunkyo está estruturado hoje, não temos nada a oferecer para eles, pois não se identificam com o nosso ambiente. Eles não "colam” em nenhum lugar, no país, nem mesmo aqui.

A única coisa que não tem como os mais velhos transmitir aos jovens é a reverência ao imperador. No Japão, a instituição do imperador permanece, para as novas gerações, como nos países europeus, ou seja, com novos significados. Já no Brasil, não vejo como o conceito possa ser legado aos sucessores da comunidade. O Bunkyo é uma

\footnotetext{
${ }^{268}$ Gueinosai é o Festival de Música e Dança Folclórica Japonesa, promovido todo mês de junho pelo Bunkyo.

${ }^{269}$ Matsuri: festival, festividade ou festa em japonês. Geralmente, os matsuri têm grande variedade de atividades culturais e de entretenimento. (N. da A.)

${ }^{270}$ Os retornados são os decasséguis e suas famílias que permaneceram por anos no Japão e retornaram definitivamente para o Brasil.
} 
instituição "símbolo", tem aura. Mas a entidade vive um dilema hoje, que é o de reencontrar a sua "alma".

Outro aspecto frágil é que no Bunkyo não temos mais debates, como nos velhos tempos, quando os isseis estavam no comando. Nos anos de 2005, 2007, 2009 e 2011 houve chapas de oposição, nas eleições da entidade, e com isso tivemos um pouco de debate, já à moda "nissei" - que os isseis consideram "à brasileira", que é do enfrentamento de partes contrárias, ao invés da busca abnegada do consenso. Talvez a raiz da questão tenha sido semeada lá atrás pelos próprios isseis, com a divisão de "vitoristas" e "derrotistas". Hoje, em vez de debates, só temos palestras. Esse é o legado da geração nissei, da qual eu mesmo faço parte.

Mas é necessário reconhecer que "se não tudo são flores", o Bunkyo tem tentado reagir, e a eleição de Harumi Goya para a presidência da entidade não deixa de ser uma prova disto. Afinal, foram quebrados três paradigmas quando ela foi eleita: primeiro, por ser uma mulher no comando; segundo, por ser de Okinawa, e terceiro, por ser imigrante pós-guerra. Há uma divisão entre os imigrantes que vieram antes e depois da guerra, estes últimos vistos como menos representativos dos valores japoneses do período antigo. Passada mais de uma década desde o início do processo de renovação, o Bunkyo deu um passo claro em direção à revitalização, ao elegê-la. Ela permitiu que os jovens atuantes do Bunkyo, forjados nas organizações de "matsuris" (festas de cultura japonesa que se alastraram nacionalmente nos anos 2000) nos últimos 20 anos, passassem a assumir posições de destaque na organização. Considero que se esses jovens valores tiverem a consciência e a humildade de acolher os dois outros extratos da juventude de hoje vinculada com a cultura japonesa, os não descendentes intelectuais e os filhos de decasséguis (os novos nisseis), ambos fluentes em língua japonesa, um novo equilíbrio geracional para a gestão futura da entidade poderá emergir. 


\section{Fragmentos de uma conversa 2}

Célia Abe $\mathrm{Oi}^{271}$

\section{Entrevista realizada em 01/08/2017}

Em 1955, quando o Bunkyo foi fundado, a comunidade nipo-brasileira vivia um momento crucial de sua trajetória neste país. Podemos afirmar que nas primeiras décadas da imigração japonesa ao Brasil, iniciada em 1908, a grande parte desses imigrantes nutria o sonho de retorno à terra natal - eram os compatriotas que, circunstancialmente, viviam fora do Japão. A Segunda Guerra, juntamente com as inúmeras sequelas, trouxe uma nova atitude das famílias: a conscientização de que tinham criado raízes em terras brasileiras e a derrota impossibilitava, pelo menos em curto prazo, o retorno ao Japão.

A partir dos anos 1930 e durante a Guerra, o cotidiano dos estrangeiros passou a sofrer uma série de restrições - entre elas, o direito de continuar com suas entidades, culminando com o fechamento da representação consular. Para os imigrantes japoneses, essa ruptura foi um choque terrível tanto no seu relacionamento intergrupal quanto à presença "física" de sua terra natal.

Fato é que a reorganização pós-guerra da comunidade nipo-brasileira ocorreu em bases diferentes, até porque, a expansão da zona urbana representava novas oportunidades também para os imigrantes japoneses e seus descendentes. Assim, os núcleos de colonização foram pouco a pouco perdendo suas forças - não parava de crescer o número de famílias que decidiam mudar-se da zuna rural para as cidades ou para a zona periférica dos centros urbanos.

O Bunkyo nasce nesse clima de mudanças e da necessidade de se constituir uma organização capaz de estabelecer uma interlocução nacional e internacional com diferentes setores de atividades, ou seja, de representar a comunidade japonesa no Brasil. Antes da Segunda Guerra, os japoneses no Brasil viam uns aos outros como "patrícios", ou "conterrâneos"(japoneses que, temporariamente, viviam fora do Japão). Depois da Guerra, passaram a constituir a "colônia nikkei", ou seja, um grupo de

\footnotetext{
${ }^{271}$ Coordenadora de Comunicação do Bunkyo. Formada em História e Jornalismo, começou a carreira no final dos anos 1970 na Revista Arigatô (publicada pelo Jornal Paulista) indo para o Diário Nippak (atuou na editoria em português e também do suplemento Página Um) e finalmente para o Notícias do Japão. Foi admitida no Bunkyo em 1998 como diretora do Museu Histórico de Imigração Japonesa, onde ficou até 2007, quando assumiu o setor de Comunicação da entidade.
} 
japoneses e descendentes que moram fora do Japão, que se radicou no Brasil e cortou o vínculo de cidadania japonesa.

Líderes como Kiyoshi Yamamoto (que foi o primeiro presidente do Bunkyo), acreditavam que a melhor maneira de enfrentar a discriminação contra os japoneses no Brasil seria difundir a cultura japonesa junto à sociedade brasileira, que mal a conhecia. Acreditavam também que as novas gerações de descendentes, apesar de não falarem mais o japonês e estarem cada vez mais integradas à sociedade nacional, poderiam ter interesse em conhecer a cultura do país de seus ancestrais. Nesse sentido, buscaram organizar entidades com esse enfoque, envolvendo em sua diretoria, também, interessados de diferentes etnias.

Nesse aspecto, o Bunkyo esteve focado em atuar como entidade representativa dessa comunidade, que não era mais exclusivamente japonesa, mas que ainda mantinha laços afetivos muito fortes com o Japão. Assim, a entidade se tornou o principal interlocutor do governo japonês, como também do brasileiro em assuntos relativos ao mundo nipo-brasileiro. Passou a incrementar uma série de eventos culturais voltados prioritariamente ao público conhecedor da língua japonesa. Além disso, tornou-se referência em comemorações e eventos significativos, tais como as visitas da família imperial e autoridades japonesas, o centenário da imigração, os 120 anos do Tratado de Amizade Brasil-Japão, entre outros.

O desafio da representatividade - o Bunkyo, aos 60 anos, tem pela frente o crescente desafio de desempenhar seu papel de representante da comunidade nikkei. De lá para cá ocorreram grandes mudanças nas relações entre os imigrantes e descendentes e suas associações, que antes eram motivadas por necessidades concretas e que hoje já não existem. A geração "cúmplice" que o fundou, e se sentia comprometida com sua manutenção, foi lentamente desaparecendo, como também as empresas e instituições provedoras dos recursos.

Certamente, esse desafio de "atualizar" sua estrutura e missão não é exclusivo do Bunkyo, mas é comum à maioria das entidades nipo-brasileiras. É chegado o momento de o olhar não só para os jovens descendentes, como também para mestiços e não descendentes, que muitas vezes têm mais admiração, interesse e conhecimento da cultura japonesa do que os próprios nikkeis, ou seja, a condição étnica (sangue japonês) já não é garantia, nem determinante, para essa identificação com as premissas das 
entidades nipo-brasileiras. Incorporar esses novos personagens poderá representar uma mudança radical na vida de muitas das entidades, não só do Brasil.

E no ponto de vista da atividade cultural japonesa, uma das novidades são os grupos de taik $\hat{o}^{272}$, que, sem dúvida, mais atraem os jovens, não só por causa da alegria e energia que envolvem, mas porque utilizam uma linguagem universal: ninguém precisa saber japonês para se expressar no taikô.

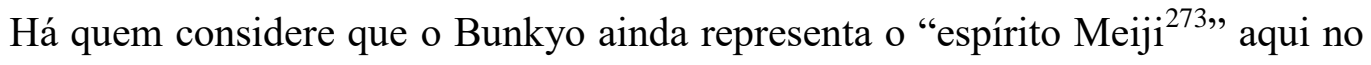
Brasil, porque a maioria dos imigrantes que fundaram a entidade nasceu no período préguerra, e que isto teria, de certa forma, resultado no tipo de missão abraçada pelo Bunkyo e seu modo de atuação, até os dias hoje.

Mas, seja como for, o que se tem pela frente é a incorporação, pela comunidade, dos interesses da quarta e da quinta gerações de descendentes, e também dos gaijins $^{274}$, ou seja, essa turma do mangá, do "temaki", e do "sushi com cream cheese" - um pessoal animado que participa de oficinas e cursos relâmpagos (como de cerimônia do chá e de ikebana) e possui um conhecimento superficial sobre tudo, mas curte a cultura japonesa. Além deles, há a necessidade de integrar os mestiços. Discriminação implícita ou explícita contra estes grupos não tem sido registrada, mas se percebe uma indisfarçável dificuldade de assimilá-los com naturalidade aos quadros dirigentes da entidade.

Uma estratégia essencial para a sobrevivência dessas entidades culturais será a de procurar e estabelecer os "pontos em comum" entre elas, para que se fortaleçam mutuamente, isto é, para que se ajudem na tarefa de manter viva a cultura japonesa no Brasil e o intercâmbio com o Japão. Além do papel dessas entidades de origem japonesa junto à comunidade, é interessante incluir também as igrejas, como Seicho-No-Ie, Messiânica, Perfect Liberty, Soka Gakkai, etc.

\footnotetext{
${ }^{272}$ Grupos que reúnem uma variedade de instrumentos de percussão, tocados apenas entre si, ou com outros instrumentos de corda ou sopro. Eram usados desde a antiguidade em paradas militares, festivais populares ou cerimônias religiosas.

${ }^{273}$ Período Meiji (1868-1912) é uma fase de intensas mudanças com o fortalecimento do governo centralizado no poder imperial, da abertura dos portos aos estrangeiros e da crescente industrialização no país. Além da política expansionista, o governo se empenhou na formação educacional popular baseada em rígidos preceitos éticos e morais. Nos dias atuais, a referência ao "espírito Meiji" é usada como conotação ao comportamento baseado em posturas do "século passado", ou seja, de mentalidade anterior à Segunda Guerra que foi superada pelas mudanças do Período Showa.

${ }^{274}$ Como são chamadas, no idioma japonês, as pessoas que não têm ascendência japonesa.
} 
O papel exercido pelas chamadas novas religiões do Japão têm a particularidade de serem muito acolhedoras, por estarem mais adaptadas às necessidades concretas das pessoas. As igrejas de origem japonesa muitas vezes têm uma atividade sincrética, misturando cristãos e budistas, e difundem um discurso e ritual unido com cultura e filosofia japonesas.

O projeto de Comunicação - buscando ampliar e fortalecer seu relacionamento com as entidades nikkeis, em 2006, o Bunkyo estabeleceu um projeto de comunicação baseado na criação do "Bunkyonet", que visava a montagem de um portal com links de todas as outras entidades nipo-brasileiras, de São Paulo e de várias cidades e Estados brasileiros. A efetividade do Bunkyonet esbarrou no despreparo dessas entidades para manter seus próprios sites e, em muitos casos, na dificuldade local de acesso à internet. Além disso, as entidades só contavam com a disponibilidade de voluntários que, não raro, desconheciam essas ferramentas.

Nos últimos anos, as atividades da secretaria do Bunkyo estão cada vez mais baseadas na ferramenta digital buscando dar mais agilidade às decisões da diretoria e andamento das questões burocráticas. Vale dizer que somente alguns dos diretores são convocados "via telefone" para as reuniões.

O fato é que a internet tem sido a forte aliada para ampliar e consolidar a comunidade com os associados e as entidades, auxiliando em sua atuação como entidade nacional a despeito de algumas dificuldades de acesso à rede digital de algumas entidades do interior.

Como parte da estratégia de comunicação, além do site da entidade (www.bunkyo.org.br), quinzenalmente, é veiculado o "Bunkyo e-news" com as informações mais relevantes que são enviadas para os mais de 30 mil e-mails cadastrados. Além dos endereços eletrônicos dos diretores e associados, eles têm sido colhidos em ação contínua nos eventos do Bunkyo no seu edifício-sede, no Pavilhão Japonês, no Museu Histórico da Imigração Japonesa no Brasil e em outras festas da cultura japonesa em que a entidade participa, tendo como meta atingir não somente a população nipo-brasileira como também os não descendentes. Além desses boletins, em casos excepcionais, são enviados comunicados avulsos por meio desse mailing.

Atualmente, os dirigentes do Bunkyo costumam atribuir o sucesso dos eventos e a grande afluência de público ao bom trabalho do departamento de Comunicação (diante 
do insucesso, a culpa também recai sobre a performance da Comunicação!). Certamente, esta é uma maneira muito simplista de analisar o resultado de uma atividade, principalmente pelo fato de que, cada vez mais, as entidades têm buscado promover determinados eventos de interesse comum em bloco, em parcerias.

Podemos citar, como exemplo, os preparativos para as comemorações dos 110 anos da imigração japonesa que estão sendo desenvolvidos por um Comitê que reúne representantes das cinco maiores entidades (go-dantai, em japonês) - o Bunkyo, a Beneficência Nipo-Brasileira de São Paulo, Federação das Associações de Províncias do Japão no Brasil, Aliança Cultural Brasil-Japão e Câmara de Comércio e Indústria Japonesa do Brasil. Em outros eventos, tal como uma cerimônia de boas-vindas ao novo embaixador do Japão, um total de 39 entidades parceiras (incluindo as go-dantai) participa com seus representantes (em geral, presidente), sendo que cada um arca com determinado custo da recepção. Trata-se de uma homenagem coletiva, em que todos têm a oportunidade de apresentar-se à nova autoridade como também de confraternizar-se com outros dirigentes - e cabe ao Bunkyo, enquanto entidade representativa, liderar e organizar esses eventos.

As matérias, em geral, tanto do site como das páginas das redes sociais, são notícias referentes a eventos e acontecimentos promovidos pelo Bunkyo ou relacionados a alguma área considerada de interesse do público nipo-brasileiro. A mídia nikkei, tanto impressa como online, também tem ajudado a conectar as entidades e a avançar o nosso propósito comum, que é a divulgação da cultura japonesa.

A cultura do voluntariado - Talvez não seja exagero dizer que um dos traços marcantes das entidades nipo-brasileiras é o trabalho voluntário. Este é um costume que vem desde a formação dos núcleos coloniais dos imigrantes japoneses onde ajuda mútua e atividade coletiva eram imprescindíveis para enfrentar as condições locais adversas e desconhecidas.

São procedimentos trazidos de sua terra natal - nas antigas aldeias (murá) os moradores se ajudavam uns aos outros, tanto em trabalhos sazonais como em imprevistos decorrentes das frequentes catástrofes naturais. Essa mentalidade do trabalho coletivo no Japão tem sido encorajada em dias atuais, até por grandes empresas e em situação de convívio no bairro ou núcleo de moradores. 
Largamente praticada nos primórdios da imigração japonesa, a cultura do voluntariado foi um elemento básico na estruturação das associações nipo-brasileiras em geral. Assim, certos tipos de atividades, principalmente aquelas relacionadas à cultura, não podem ser remuneradas, muito menos envolver lucro sob a pena de cair na artificialidade.

Nesse contexto, entidades como o Bunkyo, voltadas à difusão da cultura, estão intrinsecamente ligadas ao esforço de preservação do patrimônio coletivo, que não devem ser considerado uma atividade meramente profissional. Qualquer atividade de difusão e preservação da cultura tem de ser alguma coisa do tipo "dedicação de vida". Assim, no Bunkyo, todos (à exceção dos funcionários da secretaria) são voluntários (diretoria e integrantes das Comissões, somando mais de 300 pessoas). Assim, eventos como o Gueinosai ${ }^{275}$ reúnem não somente artistas como também staff e outras pessoas (exceto os funcionários da empresa contratada para iluminação e som) na condição de voluntários.

Nessas apresentações junto às entidades, os artistas (professores e alunos) arcam com os custos - tudo fica por conta do "sacrifício pessoal" para garantir o legado dos ancestrais. Em determinados casos, as entidades oferecem uma quantia em dinheiro (que varia conforme a situação) a título de ressarcimento de parte das despesas, mas não é um cachê, ou seja, um pagamento ao profissional.

Outro exemplo é o Festival do Japão, que cresceu a ponto de se tornar o maior da América Latina, e está estruturado na mão de obra voluntária. De uma parte estão as empresas que, com seu patrocínio, arcam com os custos da infraestrutura. De outra, está um batalhão de voluntários reunido pelas entidades participantes para viabilizar as atrações do Festival. Certamente, se não houvesse essa dedicação dos voluntários, esse evento (e outros dessa natureza, que têm sido replicados pelo país afora) não teria alcançado esse tamanho gigantesco (anualmente, em três dias de eventos, são cerca de 250 mil visitantes).

É interessante ressaltar que também há, por parte do governo japonês, uma preocupação em valorizar o voluntariado - duas vezes ao ano, tendo como critério de escolha do homenageado os trabalhos dedicados em prol da cultura japonesa e/ou

\footnotetext{
${ }^{275}$ Gueinosai - Festival de Música e Dança Folclórica Japonesa, apresentado anualmente, no mês de junho, no Grande Auditório do Bunkyo (gueino tem o significado de "artes de palco").
} 
assistência ao Japão, são condecoradas pessoas (descendentes de japoneses ou não, do mundo todo).

Hoje há a percepção de que a profissionalização de certas funções poderia trazer mais eficiência à atuação do Bunkyo e das entidades em geral, ajudando a cumprir melhor sua missão e a se preparar para enfrentar os desafios do presente e do futuro. Em diversos momentos, principalmente na organização de grandes eventos, essa questão volta à pauta e, em alguns casos, admite-se a renumeração de determinadas atividades, mas, na essência, a cultura do voluntariado, por enquanto, prevalece sobre qualquer consideração.

Mudanças e caminho futuro - a mudança de uma entidade como o Bunkyo, ancorado numa diretoria executiva formada por mais de 30 membros (sendo 10 deles eleitos a cada dois anos) e apoiada por cerca de 32 diferentes comissões, é um processo moroso. Talvez não fosse exagero afirmar que a mudança acontece mais por impossibilidade de continuar com os mesmos procedimentos do que por ser resultado de uma necessidade propriamente dita.

A diretoria da entidade, em sua maioria, sempre foi um mundo dos homens, embora as mulheres, reunidas no Fujinkai (Departamento de Senhoras) exercessem um papel preponderante na organização e manutenção dos eventos (atividades que ainda hoje são exclusividade das senhoras, já que poucas associações recorrem aos serviços de bufês).

Vale dizer que no Bunkyo, em sua fundação, não foi criado um departamento de senhoras. Ao longo de sua trajetória, a entidade teve a predominância masculina no exercício de sua direção, bem como, na frequência dos eventos. É interessante que esse reflexo se evidenciava até na construção do espaço físico - somente nas duas últimas décadas que se aumentou o numero de banheiros femininos.

Os últimos anos, como em todos os setores, a presença feminina tem crescido no Bunkyo e a eleição, em 2015, de Harumi Arashiro Goya, a primeira mulher para exercer a presidência, foi simbólica e teve repercussão na comunidade nikkei e no Japão.

O futuro do Bunkyo e das demais entidades de cultura japonesa no Brasil dependem acima de tudo de uma integração dos jovens de forma efetiva, ampla e duradoura. Uma frente de trabalho com o envolvimento da geração dos "cabelos pretos" 
e dos mais jovens é o $\mathrm{FIB}^{276}$ que tem reunido lideranças de diferentes entidades (incluindo de outros Estados) para tratar sobre o hoje e o amanhã - além de também ter incentivado as atividades do próprio Seinen ${ }^{277}$.

No outro extremo, têm sido desenvolvidas as atividades voltadas para a terceira idade. Além do curso gratuito de cuidadores de idosos (reúne interessados em cuidados próprios ou como alternativa profissional), também promove atividades físicas e de lazer com foco em técnicas japonesas ${ }^{278}$. Funciona também o grupo de Dança Sênior e outro de Dança Social (com bailes periódicos).

Para os leitores de língua japonesa, funciona a biblioteca circulante, com um acervo de cerca de 60 mil livros e um setor de mangá. Realiza periodicamente a Feira de Livros Usados que, nos últimos anos, registra um aumento considerável da clientela de não descendentes de japoneses e de pessoas do interior. Na Feira são vendidos os livros doados e a renda é destinada à manutenção da biblioteca.

\footnotetext{
${ }^{276}$ Fórum de Integração Bunkyo, realizado desde 2007 uma vez por ano (exceto 2010 e 2012), geralmente no mês de outubro.

277 "Jovens", em japonês - termo usado nas entidades para se referir ao Seinenkai, ou departamento que reúne os Jovens

${ }^{278} \mathrm{Um}$ exemplo é o grupo de ginástica voltado para a terceira idade, chamado Iki-lki-Taissô, dirigido por professora japonesa. Outro numeroso grupo pratica o Kenko Taissô, semelhantes a ginástica rítmica.
} 


\section{Fragmentos de uma conversa 3}

Masato Ninomiya ${ }^{279}$

\section{Entrevista realizada 26/08/2017}

A educação é uma tradição japonesa secular, praticada nos templos budistas, no passado feudal, de forma até democrática, pois não só os filhos da classe samurai podiam frequentar as aulas, mas também os filhos de comerciantes e de agricultores, que aprendiam a fazer cálculos com o ábaco ${ }^{280}$, e a ler os ideogramas japoneses, que são derivados dos chineses. Com a restauração Meiji, um edito imperial determinou a educação básica obrigatória de um mínimo de quatro anos, que com o tempo foi ampliado para um número maior de anos. De modo que quando os imigrantes japoneses vieram ao Brasil já tinham boa escolaridade e tentaram manter isso aqui, mesmo nas condições precárias em que viviam.

Muitas vezes, suas casas eram pobres, mas as escolas que construíam para os filhos tinham que ter boa aparência. Isto também porque os japoneses têm como traço marcante a "cultura da vergonha", que é a importância que dão ao que os outros pensam deles. Assim, as escolas tinham que demonstrar que os habitantes daquela colônia valorizavam a educação, e que seus filhos não eram ignorantes. Também os esportes eram valorizados como forma de manter um espírito saudável de competitividade e por isso promoviam os undokai, as gincanas esportivas que mobilizavam os moradores de cada colônia. As escolas em língua japonesa e as gincanas, assim como os jornais em japonês e o rádio de ondas curtas, que alguns imigrantes tinham para ouvir notícias do Japão eram uma forma de manter os laços com a cultura japonesa, já que a imensa maioria tinha intenção de voltar para o Japão assim que juntasse algum dinheiro.

\footnotetext{
279 Masato Ninomiya chegou ao Brasil em 1954, aos 5 anos de idade. Seus pais imigraram para o Brasil com uma carta de chamada enviada pelos tios, que já moravam na cidade de São Paulo. É formado em Direito e Letras, ambos pela Universidade de São Paulo, Mestre e Doutor pela Universidade de Tóquio. É um dos fundadores e presidente (desde a fundação) do CIATE. Teve cargos de direção no Bunkyo e é atualmente um dos membros efetivos do conselho deliberativo da entidade e presidente da comissão de relacionamento institucional com o Japão. Desde 1978 vem acompanhando as visitas de membros da família imperial ao Brasil, como tradutor e assessor.

${ }^{280} \mathrm{O}$ ábaco, ou soroban em japonês, é um instrumento de calcular, inventado na China há cerca de 3 mil anos, formado por uma estrutura geralmente quadrada ou retangular com fios paralelos e contas, ou arruelas deslizantes, que de acordo com sua posição representam a quantidade a ser trabalhada; em cada fio há dois conjuntos de contas: 5 contas no conjunto das unidades e duas contas que representam 5 unidades. (Fonte: Brasil Escola).
} 
A impossibilidade de prosseguir com a escola em língua japonesa, durante a guerra, e de voltar ao Japão, após a guerra, fez com que os imigrantes buscassem outras formas de educar os filhos, agora nas escolas brasileiras. Para acompanhá-los, muitas famílias saíram do campo e se estabeleceram nas cidades, onde se integraram ao pequeno comércio e prestação de serviços, ou ao redor da capital e se especializaram na produção de verduras, legumes, frutas e ovos, em pequenos sítios que, juntos, abasteciam a grande São Paulo.

Os filhos dos imigrantes puderam estudar graças às oportunidades que o Brasil ofereceu, pois era possível trabalhar de dia e frequentar os cursos noturnos. Aqui não havia quotas nem discriminação contra os alunos que estudam à noite. No Japão, quem faz curso noturno não consegue entrar nas boas faculdades. No Brasil é uma questão de esforço: quem estuda, consegue. Desde a década de 1930, os filhos de japoneses conseguiram entrar nas faculdades de Direito, Medicina, Odontologia, entre outras.

Apesar da integração cada vez maior dos filhos de imigrantes na sociedade brasileira, graças aos estudos e ao trabalho, durante muito tempo o casamento interétnico foi incomum. Claro que sempre houve casos, mas o fato é que de modo geral, os japoneses já tinham tendência à endogamia desde muito antes da imigração, pois os casamentos quase sempre aconteciam dentro do mesmo feudo, sendo que os de outras regiões do Japão eram considerados quase como "estrangeiros". Por isso era muito comum casamentos entre primos, e a prevalência dos mesmos nomes de família dentro de determinada localidade. Ao chegarem ao Brasil, este hábito sofreu uma grande mudança, pois a partir de então, mesmo que os noivos e suas famílias fossem originários de províncias diferentes, a única exigência, para o casamento ser aceito, é que fossem todos japoneses. Com os imigrantes de Okinawa, porém, havia de fato um preconceito, pois durante muito tempo este foi um reino independente, e muitos não os consideravam japoneses de verdade.

Diante deste quadro de dispersão dos imigrantes em colônias distantes entre si e também nas cidades - além do problema da divisão entre kachigumi e makegumi ${ }^{281}$ - o Bunkyo surgiu (em 1955) como única iniciativa da colônia capaz de congregar a todos em uma grande entidade representativa, tentando superar os problemas do pós-guerra e

\footnotetext{
${ }^{281}$ Kachigumi (ou vitoristas) eram os imigrantes japoneses que não acreditavam que o Japão havia perdido a guerra, e makegumi (ou derrotistas) eram aqueles que reconheciam a derrota e foram, por isso, acusados de traição pelo grupo adversário.
} 
aproveitando o momento de otimismo gerado pela festa do IV Centenário da cidade de São Paulo. Pouco depois foi fundado o Enkyo ${ }^{282}$ para oferecer cuidados médicos aos imigrantes, que na grande maioria eram pobres e não tinham recursos para cuidar da saúde. Desde o seu início, com campanhas de arrecadação junto a pequenas entidades, o Enkyo foi crescendo e hoje - com cerca de 10 mil associados - é economicamente muito mais forte que o Bunkyo, que deve ter mais ou menos 2.500 sócios. Porém, o Enkyo não tem a força política que o Bunkyo ainda tem como entidade representativa da comunidade nipo-brasileira, sobretudo junto ao governo japonês.

Uma entidade que também tem crescido em força política é o Kenren ${ }^{283}$, que foi no passado chamado de "clube de velhinhos", e hoje promove o Festival do Japão, o maior festival de cultura japonesa do país, mobilizando a cada ano mais de 200 mil pessoas, entre visitantes e voluntários. Para se ter uma ideia da importância deste festival, pela primeira vez a solenidade oficial de comemoração da imigração japonesa não será no dia 18 de junho, que é a data da chegada da primeira leva de imigrantes japoneses em Santos, no navio Kasato Maru, mas sim no mês de julho, durante o Festival do Japão ${ }^{284}$. O poder político do Kenren decorre do fato de os dirigentes de associações de províncias terem acesso direto ao Japão, por meio de prefeitos e governadores provinciais que vêm ao Brasil em visitas oficiais, ou que os recebem lá, nas visitas destes dirigentes às províncias de origem.

Outra entidade de importância significativa é a Aliança Cultural Brasil-Japão, fundada um ano após o Bunkyo (em 1956), que foi a primeira entidade nipo-brasileira no sentido literal da palavra. Desde o começo, seus dirigentes eram japoneses e brasileiros para enfatizar a sua finalidade de intermediação cultural entre o Brasil e o Japão. Sua missão principal é a difusão da cultura japonesa no Brasil, incluindo o ensino da língua, que tem sido um dos focos principais da sua atividade. A entidade tem

\footnotetext{
${ }^{282}$ A Beneficência Nipo-Brasileira de São Paulo, também chamada de Enkyo, foi fundada em 1959 com o nome de Associação de Assistência aos Imigrantes Japoneses, com foco principal naqueles que chegavam do Japão após a guerra. Com o tempo, diversificou sua área de atuação prestando hoje serviços em todas as áreas médicas, e também de assistência social. Fonte: http://www.enkyo.org.br/

${ }^{283}$ A história da Federação das Associações de Províncias do Japão no Brasil, ou Kenren, começa com a criação de uma entidade japonesa de familiares de emigrantes que partiram para o Brasil após a guerra, e que em 1962 se tornou uma entidade de âmbito nacional chamada Federação Japonesa das Famílias de Emigrantes Ultramarinos, com o intuito de prestar assistência aos emigrados e promover o encontro daqueles que haviam perdido contato com seus parentes, entre outras iniciativas. Em 1966 foi fundada a Kenren, para fazer do lado brasileiro os mesmos esforços da federação japonesa. Hoje promove o intercâmbio entre bolsistas e técnicos, visitas de membros do governo das províncias, e aspectos das culturas locais. Fonte: http://www.kenren.org.br/

${ }^{284}$ Trata-se da celebração dos 110 anos da imigração japonesa ao Brasil, a ser comemorada em 2018.
} 
crescido, com a inauguração recente de uma nova unidade e centro cultural, no bairro de Pinheiros. Mas o fato é que o interesse, no Brasil, pela língua japonesa já foi ultrapassado pelo estudo do chinês. Este tem tido uma procura enorme graças, entre outros motivos, à impressionante estrutura do Instituto Confúcio, que inclusive fez uma parceria importante com a Unesp (Universidade Estadual Paulista) para o ensino da língua chinesa no Brasil e promover o intercâmbio entre os dois países.

Outra entidade importante no contexto nipo-brasileiro é a Câmara de Comércio e Indústria Japonesa do Brasil ${ }^{285}$, que cresceu com a consolidação dos negócios bilaterais e a vinda de empresas japonesas para o país, a partir das décadas de 1950 e 1960. Mas a situação já não é tão boa como foi no passado. Várias empresas japonesas foram embora após perderem dinheiro na prospecção do pré-sal, e outras por causa do peso da carga tributária e trabalhista no Brasil, que desencoraja os investimentos. Para se ter uma ideia, há cerca de 30 mil empresas japonesas na China, mais ou menos mil empresas na Coréia do Sul, na Tailândia e na Indonésia. No Brasil, deve ter umas 700, já contando as filiais de uma mesma empresa em locais diferentes do país. As empresas que estão bem, economicamente, fazem doações regulares a eventos e promoções de entidades nipobrasileiras, mas um dirigente de empresa japonesa no país tem um limite de poder de decisão, de modo que na necessidade de recursos maiores, as entidades têm que ir ao Japão diretamente.

Quanto ao futuro da comunidade nipo-brasileira, é importante que o Bunkyo consiga formar e proporcionar, de fato, oportunidades para novas lideranças. Para isso, acho que voltar para o esquema de eleições diretas para direção da entidade, experiência que tivemos apenas uma vez, em 2005, seria uma ideia interessante. Novas lideranças que tenham verdadeiro interesse em manter vivos os laços entre Brasil e Japão podem estar se formando entre aqueles filhos de brasileiros que vivem há anos no Japão e estão tendo a oportunidade de cursar faculdade e superar a condição de cidadãos de segunda classe. E também os decasséguis e seus filhos que voltaram ao Brasil e estão podendo estudar aqui tendo a chance de se tornarem profissionais qualificados. Há centenas de jovens nestas condições hoje, com este vínculo duplo com os dois países. A comunidade nipo-brasileira não tem uma finalidade em si mesma. Sua finalidade primordial e razão

\footnotetext{
${ }^{285}$ A Câmara de Comércio e Indústria Japonesa do Brasil tem origem na fundação da Cooperativa de Comércio Japonesa, em 1926, para desenvolver os negócios entre o Brasil e o Japão. Após a guerra, com a vinda crescente de bancos e empresas japonesas para o Brasil, passou a chamar-se Câmara de Comércio Japonesa do Brasil, adotando seu nome atual a partir de 1962.
} 
de existir é a manutenção da ponte entre o Brasil e o Japão, tanto no ponto de vista econômico, quanto no cultural. 


\section{Fragmentos de uma conversa 4}

Andrew Hideo Kajiyama ${ }^{286}$

Entrevista realizada em 2/09/2017

O perfil do Seinen do Bunkyo, atualmente, é de pessoas entre 26 e 28 anos, o mais velho deve ter uns 33 anos. São quase todos recém-formados, já empregados e bastante ocupados em suas vidas pessoais. Temos na nossa base de dados cerca de 100 pessoas inscritas, mas os mais atuantes - que frequentam os eventos com regularidade são aproximadamente 35 membros. A comissão de jovens costumava ter caráter operacional, tipo "carregadores de cadeira" nos eventos, sem envolvimento na parte estratégica. Mas o Bunkyo hoje oferece oportunidades para os jovens participarem de reuniões importantes de diretoria, dando abertura para críticas e ideias. Isso tem a ver com a perspectiva de sucessão da entidade, com a preparação de futuros líderes, então nos sentimos agora mais participantes, e não como algo deslocado do centro de decisões. Nas reuniões de diretoria do Bunkyo, a Comissão de Jovens é convidada a participar não somente através de seu presidente, mas de seus diretores, o que nos permite participar das decisões da Bunkyo de forma mais democrática e não apenas centralizada no presidente da Comissão. Isto é parte de uma estratégia de preparação das lideranças jovens, por isso ocupamos a presidência por apenas um ano, para dar oportunidade ao maior número de pessoas de exercer esta liderança.

A palavra do momento é "inovação". A comunidade japonesa já foi muito fechada em si mesma, mas hoje o próprio Bunkyo e as autoridades japonesas do consulado, em suas palestras, enfatizam que a comunidade Nikkei não é só formada por descendentes, mas por todos os brasileiros que se identificam com a cultura japonesa. Na comissão de jovens, a abertura é total e real, todos que querem participar são bem vindos. Eu diria que houve um aumento de cerca de $30 \%$ na participação de mestiços e não descendentes de japoneses desde o ano passado, sendo um dos nossos objetivos aumentar cada vez mais a heterogeneidade do grupo e mostrar abertura a qualquer pessoa interessada em cultura japonesa.

\footnotetext{
${ }^{286}$ Andrew Hideo Kajiyama, presidente da Comissão de Jovens do Bunkyo (Seinenkai, ou simplesmente Seinen), tem 27 anos, é sansei (terceira geração). Formado em Engenharia Elétrica pela USP, trabalha atualmente como assessor de planejamento em uma empresa da área médica. Começou a frequentar na adolescência o Seinen de sua cidade natal, Santo André, e mais tarde o Seinen da universidade, no campus de São Carlos. Entrou no Seinen do Bunkyo há dois anos, e assumiu a presidência em março de 2017.
} 
A ação da presidência e da diretoria do Seinen é focada em metodologias de gestão, para fazer as coisas darem certo, mas tomamos cuidado para que o nosso grupo não pareça com uma empresa, pois nem todas as pessoas gostam de relacionar o trabalho voluntário com a vida profissional. O ponto mais essencial nesta estratégia de gestão do Seinen é preparar sucessores, deixando claro que aqueles que saem para dar lugar aos novos líderes, não saem de cena, não desaparecem, mas continuam ali, dando apoio aos que assumiram a liderança.

Parte dos nossos projetos não pode ser implementada dentro da vigência de nossa gestão, que é de um ano, por isso temos sempre que pensar na continuidade dos trabalhos e na sucessão para que os projetos tenham resultados efetivos. Assim, vamos sondando, procurando potenciais, observando os perfis individuais, as preferências e habilidades, e ajudando as pessoas a perceberem que são raras as oportunidades de exercitar a liderança em uma entidade de relevância como o Bunkyo.

A nossa geração tem se esforçado para superar a hierarquia, que é típica da cultura japonesa, começando por conquistar uma maior flexibilidade no modo de desenvolver as atividades do Seinen, delegando ao maior número possível de pessoas as tarefas que envolvem tomadas de decisão, e encorajando a sua participação nas reuniões com os dirigentes do Bunkyo. Às vezes as pessoas ficam inseguras, mas é importante que elas não tenham medo de errar no Seinen, pois é um ambiente controlado, com pessoas de confiança e que dá abertura para que possamos errar e consequentemente aprender mais com nossos erros e sem grandes consequências e impacto, como seria num ambiente de trabalho remunerado.

Nossos encontros na REVI (Revitalização - Fórum Nacional das Jovens Lideranças das Entidades) são as mais esperadas oportunidades para estarmos juntos de líderes de seinens e grupos jovens do Brasil inteiro e discutir as nossas questões específicas. Como se trata de um fórum nacional, tem gente que vem de associações nipo-brasileiras de vários Estados para discutir as estratégias de revitalização de suas entidades, e falamos de tudo que tem dado certo, e o que precisa ser mudado. Também ficamos conhecendo as particularidades dos Seinens de outras regiões, como é o caso do Paraná, que é bem apegado às tradições japonesas, e o do Rio de Janeiro, em que grupos específicos se especializaram na prática do haicai e tem maioria de não descendentes. Os encontros da REVI sempre acontecem no Centro Esportivo Kokushikan Daigaku, e são uma verdadeira experiência de imersão, pois ficamos lá dentro por três dias inteiros, 
dormimos nos alojamentos, tomamos café, almoçamos e jantamos lá, todos juntos. Este ano, o tema do fórum será "Diversidade cultural e suas infinitas possibilidades", ou seja, como promover o encontro entre culturas na perspectiva das entidades nipo-brasileiras.

Quanto à nossa maneira de divulgar nossos eventos e chamar novos interessados em participar do Seinen, usamos no primeiro momento nossas páginas de Facebook e Instagram, ambas refletindo o mesmo material. Mas num segundo momento, quando vamos conversar com mais detalhes e para um contato mais pessoal, preferimos o Whatsapp, que é mais eficiente. Temos também um site independente do Bunkyo, mas está em reforma no momento. Os nossos diretores de recursos humanos e de marketing é que cuidam da comunicação em geral. Não temos realizado reuniões regulares do Seinen, pois estamos sempre envolvidos na organização e realização de eventos do Bunkyo ou propriamente nossos como é o caso, agora do "Vamos Falar Japonês"287, porém estamos nos planejando para que estas aconteçam.

De março a outubro, a agenda do Bunkyo é muito cheia e temos participação em quase todos os eventos, por isso não há distanciamento entre nós, pois estamos juntos quase todos os fins de semana. Reuniões em dia de semana presenciais são mais difíceis de acontecerem porque praticamente todo mundo trabalha, ou mora longe, ou faz pósgraduação, ou tudo isso junto. Por isso, fazemos muitas vezes reuniões à distância, por meio do Discord, um aplicativo de game que tem sala de chat. Mesmo no caso destas reuniões online, redigimos pautas, e depois as atas, registrando tudo o que foi discutido, e que ficam à disposição de todos pelo Google Docs. Assim, não temos que contar com a memória, todas as conversas estão lá, na forma de uma "comunicação tangível”, o que garante também a transparência da nossa atuação.

Temos uma campanha de captação de novos membros uma vez por ano, no Festival do Japão. A maioria dos nossos membros atuais entrou para o Seinen desta forma. Temos um espaço no stand do Bunkyo, onde fazemos panfletagem divulgando a atuação e atividades da comissão de jovens, e conversamos com as pessoas que se aproximam de nós. Não temos um público-alvo - o que é em si uma decisão política e

\footnotetext{
${ }^{287}$ A primeira edição do "Vamos Falar Japonês? \#話しましょう!" aconteceu em 14 de julho de 2017 e como o interesse foi grande, o Seinen decidiu realizar uma segunda edição em 3 de setembro do mesmo ano. O objetivo do evento foi a troca de experiências e o aprendizado da língua e cultura em formato de roda de conversa. Para os organizadores, o mais importante não é o conhecimento da língua, mas conhecer as tradições do Japão, e entender a sua origem e seus significados.
} 
estratégica do Seinen - por isso quem se interessar pelo nosso grupo é convidado a aparecer em uma das atividades.

Fazemos esta campanha durante o Festival do Japão por ter um público muito variado e também porque as pessoas que estão ali já estão predispostas a gostar de cultura japonesa. Os panfletos que distribuímos têm o link da nossa página no Facebook e fazemos um evento de bate-papo com estas pessoas depois do Festival. Neste ano, mais de 50 pessoas entraram no bate-papo querendo conhecer melhor o Seinen. Muitos destes novos contatos já eram voluntários em outras entidades, durante o Festival, e ficaram sabendo da existência do Seinen por meio da nossa campanha.

Participar do Seinen é uma oportunidade de criar laços, principalmente na situação que eu vivi em São Carlos, na época da universidade. Praticamente todos nós estávamos longe de casa, então o Seinen era a nossa família, e era bem heterogêneo, tinha jovens de vários lugares e não apenas descendentes de japoneses. A cultura do Japão é uma referência, sempre, mas na perspectiva das pessoas jovens como, por exemplo, a prática da Matsuri Dance, que é uma adaptação do bon odori ${ }^{288}$, mas neste formato atual, é totalmente inspirada no J-Pop. Esse gênero de dança coletiva surgiu entre os jovens da comunidade Nikkei do Paraná, e acabou se espalhando. A Comissão de Jovens já promoveu quatro workshops de Matsuri Dance, todos com muita receptividade e interesse pelos participantes.

O interesse das novas gerações pelo Japão geralmente começa pelo mangá e animê, e também pelas músicas e demais aspectos da cultura pop japonesa, embora atualmente exista um interesse até maior pelo K-Pop, principalmente pelas bandas coreanas. $\mathrm{O}$ interesse pela língua japonesa tem diminuído entre os jovens, que acabam preferindo investir seu pouco tempo livre no inglês e no espanhol, que é mais útil para suas carreiras. As bolsas de estudos para o Japão seriam um bom recurso para despertar o interesse dos jovens no aprendizado da língua, mas estes programas não são muito bem divulgados quanto poderiam ser, atingindo poucas pessoas que poderiam se interessar por tal.

É importante encontrar uma maneira de divulgar a tradição japonesa de modo que seja atraente às novas gerações, e o Bunkyo tem procurado se renovar. De modo geral, os jovens apreciam shows, festivais, a comida japonesa, mas o que eles gostam

\footnotetext{
${ }^{288}$ Dança folclórica japonesa de participação coletiva e popular em que se homenageia o espírito das pessoas falecidas. Fonte: Portal NippoBrasil.
} 
mesmo é de estarem juntos e conhecerem novos amigos com o mesmo interesse: a cultura japonesa. O Seinen também está numa fase de coleta de dados, para dar sugestões e ajudar o Bunkyo a repensar a sua programação. A comissão de jovens, inclusive, foi convidada a fazer um tour pelo Bunkyo, para conhecer cada setor e seu funcionamento, e também o museu, e seu acervo. Estamos conhecendo melhor a instituição para podermos nos envolver melhor neste processo de renovação.

A ideia da Comissão de Reforma do Estatuto Social do Bunkyo, constituída em 2015, de reestabelecer as eleições diretas para a diretoria e comissões, pode ser interessante neste momento que estamos vivendo, pois possibilitaria maior transformação. Se mais pessoas de fora tiverem acesso ao centro de decisões da entidade, o processo de inovação pode ser mais efetivo. O próprio Seinen, de acordo com seu regulamento interno, deveria promover eleições diretas para a presidência, mas isso não tem acontecido pela dificuldade de se formarem chapas para a disputa: as pessoas têm receio de assumir responsabilidades, com o excesso de trabalho e compromissos que estão enfrentando nesta fase da vida.

Mas uma das nossas prioridades é incentivar as discussões e debates, e criar condições para que o Seinen retome seu compromisso com as eleições diretas. Atualmente, temos um presidente e dois vices, que dividem as tarefas com o presidente, e mais cinco diretorias: de projetos e eventos culturais, de marketing e comunicação, de recursos humanos e integração, de infraestrutura e tecnologia, e a de finanças. Muitos dos nossos eventos implicam gastos de locomoção e com materiais, e geralmente pagamos boa parte disso do nosso bolso, pois o Bunkyo tem condições limitadas de nos ajudar. Mas temos nossas fontes fixas de captação de recursos como, por exemplo, no Bunka Matsuri, toda a venda de bebidas é por nossa conta, o que pudermos ganhar vai para o caixa do Seinen.

Os nikkeis do mundo, mesmo tendo suas diferentes culturas locais, têm o Japão como ponto em comum. Claro que os jovens descendentes não ignoram o legado dos seus ancestrais, mas o Japão que é referência para as novas gerações é o Japão moderno, a música, o entretenimento, a tecnologia, os filmes, os doramas ${ }^{289}$. Acho que a maioria dos jovens nikkeis de hoje não vê o Japão como uma possibilidade de emprego, mas

\footnotetext{
${ }^{289}$ Doramas (ドラマ) - adaptação da palavra inglesa "drama" - são novelas de televisão japonesas que fizeram grande sucesso na década de 1990 e que até hoje têm um público cativo no mundo inteiro, embora tenham inspirado a criação de ficção televisiva em outros países asiáticos que em alguns casos fazem atualmente mais sucesso que os equivalentes japoneses.
} 
sim de consumo cultural. O aspecto étnico do "ser Nikkei” tende a mudar. Não acho que irá se dissolver de uma hora para a outra, mas vai ser diferente do que é hoje, por incorporar cada vez mais pessoas sem laços hereditários com o Japão.

Em minha visão, houve um aumento significativo de relacionamentos interétnicos entre descendentes de japoneses e não descendentes, embora a maioria dos relacionamentos ainda seja entre descendentes. A escolha do parceiro tem mais a ver com a afetividade e com preferências individuais, até porque a pressão da família, que era forte no passado, hoje não está tão presente nas famílias descendentes de japoneses. Tenho visto também descendentes de japoneses que até preferem sair da comunidade, chegando inclusive a renegar a sua ascendência. Mas o que a gente vê mais é o não descendente se aproximando dos nikkeis porque gosta da cultura japonesa, e acaba estendendo este interesse para a questão pessoal. Acho que a tendência é que um dia a cultura japonesa não terá mais um rosto. E nem por isso será menos japonesa. O futuro da cultura japonesa no Brasil não depende do fator étnico, mas do interesse que vamos conseguir - ou não - manter vivo por esta cultura entre as novas gerações, dentro e fora da comunidade nipo-brasileira. 


\section{Fragmentos de uma conversa 5}

Harumi Arashiro Goya ${ }^{290}$

Entrevistas realizadas em 15/03/2016 e 5/09/2017

Uma vez ao ano, costumo visitar Okinawa, onde nasci e ainda tenho alguns parentes. Cada vez que vou para lá, percebo que quase ninguém mais fala o dialeto da região, a não ser os mais idosos, embora alguns aspectos das artes tradicionais locais, como o teatro, a música e a dança ainda sejam praticados, e tenha até um movimento de resgate da língua okinawana. Muito da cultura japonesa tradicional do Japão, em geral, está se perdendo, com a modernização do país, mas aqui no Brasil ainda sobrevive, pelo esforço de preservação do legado dos imigrantes. Um dos exemplos é a prática da ikebana, que aqui no Brasil é mais clássica e muito mais bonita do que no Japão. Claro que os descendentes dos imigrantes japoneses também já passaram por um longo processo de mudança, mas a comunidade nipo-brasileira é muito resistente. Aqueles que ainda falam ou pelo menos entendem japonês, querem se atualizar e fazem isso lendo jornais e assistindo a NHK, mas não querem perder a tradição, não querem deixá-la morrer.

O fato de ser a primeira mulher a ocupar o cargo de presidente em uma entidade cuja diretoria é formada praticamente só por homens é um desafio, claro. Mas embora isso seja novo para o Bunkyo, não é totalmente novo para mim. Quando trabalhava na Secretaria da Fazenda, durante o governo Mário Covas, tive que aprender a assumir a liderança, a chefiar mudanças, a trabalhar com homens. Também tive experiências anteriores em entidades nipo-brasileiras, como membro da diretoria da Associação Okinawa e presidente da associação brasileira dos ex-bolsistas da JICA (Japan International Cooperation Agency). Tenho a impressão de que em nossas reuniões, os diretores acabam esquecendo de que sou mulher, e para dizer a verdade, até eu mesma

\footnotetext{
290 Harumi Arashiro Goya é presidente do Bunkyo, já no segundo termo. Foi eleita pelo Conselho Deliberativo da entidade pela primeira vez em 2015, sendo que seu mandato atual termina em 2019. É a primeira mulher a assumir a presidência do Bunkyo. Nasceu na província de Okinawa e emigrou para a cidade de Cambará, no Estado do Paraná em 1958, juntamente com a família, que emigrou para trabalhar na colheita de café. Foi alfabetizada em português e japonês (oficial), em escola bilíngue, mas o idioma falado em casa era o dialeto de Okinawa, no qual também é fluente. Formou-se em Engenharia Civil e foi funcionária pública, tendo chefiado a implantação de projetos na Secretaria da Fazenda do governo estadual de São Paulo.
} 
às vezes esqueço que sou a única mulher em uma mesa de reuniões cheia de homens. Mas acho que eu tenho, por ser mulher, uma percepção diferente, um modo de ver as coisas que me ajuda a antecipar as situações que vão dar certo e as que não vão, e a tomar decisões delicadas.

Muitas vezes tenho que falar em público, para autoridades brasileiras e japonesas, diante de auditórios lotados. O que acabou me ajudando, neste sentido, é que eu gosto de cantar e graças à minha prática de karaokê fui obrigada a enfrentar o microfone e a perder o medo dele. Um dos desafios mais difíceis é ter que manter a conversa, às vezes, com visitantes japoneses que não são de falar muito e eu é que tenho de levantar os assuntos e manter o fluxo da conversa. Com frequência tem pessoas na mesa que falam japonês muito melhor que eu e poderiam me ajudar, mas por uma questão de protocolo e respeito à hierarquia, ficam calados e eu tenho que dar asas à imaginação.

Minha fluência do japonês padrão foi adquirida sem que eu sentisse, pois a minha primeira língua foi o dialeto de Okinawa, que se falava em casa e na comunidade. Minha base do japonês padrão resume-se aos quatro anos de escola primária e o hábito de ler revistas e mangá. Fui bolsista no Japão por três meses e meio, mas a língua falada nos cursos e interações com colegas era só o inglês. Se eu pudesse adivinhar que um dia seria presidente do Bunkyo, teria estudado mais. De qualquer modo, os visitantes japoneses compreendem que somos brasileiros, e por isso eles não têm a expectativa de que nosso domínio da língua seja perfeito.

O Bunkyo é o pai de todas as grandes entidades nipo-brasileiras, a mais antiga. Conseguiu unir a comunidade dividida e tornou-se o contato oficial do governo japonês no Brasil. Hoje, muitas associações estão realizando tarefas específicas que antes eram do Bunkyo. Nossa missão é representar a comunidade nipo-brasileira em todo o território nacional, mas outras regiões também têm suas próprias associações, e em muitos casos trabalham junto conosco. Um dos Estados que tem realizado seus eventos separadamente é o Paraná, onde há uma grande concentração de nipo-brasileiros, sobretudo na área de Maringá, Londrina e Curitiba. Apesar da dificuldade de manter o contato com as regiões mais distantes, temos nos esforçado para manter o apoio das associações e também do consulado japonês, senão perdemos a representatividade. As atividades mais importantes da comunidade são organizadas, sobretudo, pelas chamadas 
“go-dantai” (cinco entidades): Bunkyo, Enkyo ${ }^{291}$, Kenren ${ }^{292}$, Aliança Cultural BrasilJapão e Câmara de Comércio e Indústria Japonesa do Brasil. Mas precisamos incluir outras, como o Hospital Santa Cruz, que assim como o Enkyo, representa a área de saúde da comunidade.

Hoje em dia está bem mais difícil manter as atividades do Bunkyo do que era no passado, pois as empresas japonesas já não fazem doações como antes, a mentalidade empresarial agora é outra. Antigamente, as pessoas físicas também doavam sem pedir nada em troca, seu único interesse era preservar a cultura japonesa no Brasil, e por isso faziam o seu kifu (simples doação). Também os valores arrecadados com as anuidades estão decrescendo, com o envelhecimento dos associados, que se tornam remidos, e com o desligamento de outros, que vão perdendo o interesse. Até mesmo a captação de recursos via Lei Rouanet, para construção de um espaço multicultural no andar térreo, está difícil de conseguir, com a crise econômica que o país está enfrentando e o seu reflexo sobre as empresas nacionais. Nosso prédio já tem mais de 50 anos e precisa de obras de renovação, e também de adequação a alguns regulamentos do Corpo de Bombeiros. Temos várias salas alugadas, mas mesmo assim cerca de $90 \%$ do edifício é nosso, e temos que arcar com despesas de condomínio, limpeza e manutenção. E além disso, ainda temos as despesas especiais do museu, do Pavilhão Japonês e do Centro Kokushikan. Por isso tudo, teremos que mudar a forma de administrar a entidade, tornála autossustentável, por meio de eventos pagos e locações.

Quanto às formas de sucessão e participação, há uma comissão que analisa mudanças no estatuto social, e o retorno às eleições diretas é uma das sugestões apresentadas. Não vejo muito entusiasmo quanto a esta ideia, até porque nossa única experiência com eleições diretas, em 2005, não foi positiva, pois o único candidato de oposição inscreveu novos sócios na última hora para manipular a votação. Mas há uma outra sugestão da comissão, quanto ao mandato do presidente, que passaria a ser de três anos, e não de dois, como é hoje, mas sem direito à reeleição consecutiva. Esta é uma sugestão com maior probabilidade de ser acatada.

Também a participação dos jovens na diretoria tem sido uma prioridade. Além do espaço que se abriu ao Seinen (Comissão de Jovens), temos dois vice-presidentes jovens. O problema é que as pessoas, nesta fase da vida, tem problemas de tempo,

\footnotetext{
${ }^{291}$ Beneficência Nipo-Brasileira de São Paulo.

${ }^{292}$ Federação das Associações de Províncias Japonesas no Brasil.
} 
famílias dependentes, e ainda não atingiram sua estabilidade financeira. Este é um aspecto importante porque nós pedimos doações, e quem pede tem que doar primeiro, é uma questão de respeito àquele que pedimos ajuda. Dificilmente estas pessoas mais jovens, que trabalham tempo integral, poderiam assumir uma função como voluntários no nível de dedicação que o Bunkyo necessita, inclusive para viajar com frequência, até para o Japão. É por isso que a maioria dos cargos é ocupada por pessoas mais velhas, que já se aposentaram e já têm uma situação financeira estável. E é por isso também que os voluntários, na maioria, são homens. Mesmo as mulheres aposentadas, que assumiram suas carreiras e tiveram autonomia financeira, muitas vezes têm compromissos familiares com netos, pais idosos, etc.

Apesar de estar ocupando um cargo que dá prestígio, não tenho ambições pessoais. Todos nós, na diretoria e nas comissões do Bunkyo, como eu disse, somos voluntários. Usamos nossos próprios carros, viajamos por nossa conta, pagamos todas as nossas despesas. No meu caso, como sou espírita, considero o meu papel no Bunkyo como uma missão que devo cumprir. Como diz a cantora japonesa Mariko Nakahira, que faz todo ano um show beneficente de captação de recursos para o Bunkyo, quem tem coragem de olhar para o céu e "dizer" para os nossos ancestrais que não temos nenhuma responsabilidade de preservar o legado que eles trouxeram para o Brasil?

$\mathrm{Na}$ verdade, este trabalho é uma forma de agradecer aos imigrantes os caminhos que eles abriram para nós, os bons valores que nos ensinaram, e a reputação de honestidade e eficiência que os japoneses desfrutam no Brasil. Pena que boa parte dos nikkeis não valoriza este legado. Quanto a mim, além desta consciência de que temos algo a preservar, e que esta é a nossa obrigação, o que me motiva a realizar este trabalho voluntário é também o fato de ter sido bolsista da JICA, e sinto que tenho esta dívida com o Japão. Isto é o que nós, japoneses chamamos de on, ou seja, o vínculo de gratidão que nunca se rompe com aqueles que nos prestaram um favor. 